UNIVERSIDADE DE SÃO PAULO

FACULDADE DE FILOSOFIA, LETRAS E CIÊNCIAS HUMANAS

DEPARTAMENTO DE SOCIOLOGIA

PROGRAMA DE PÓS-GRADUAÇÃO EM SOCIOLOGIA

ANA TERCIA SANCHES

\title{
A grande corporação bancária e os meandros do processo de trabalho
}

Versão corrigida

São Paulo

2016 
UNIVERSIDADE DE SÃO PAULO

FACULDADE DE FILOSOFIA, LETRAS E CIÊNCIAS HUMANAS

PROGRAMA DE PÓS-GRADUAÇÃO EM SOCIOLOGIA

ANA TERCIA SANCHES

\section{A grande corporação bancária e os meandros do processo de trabalho}

Tese apresentada ao Programa de Pós-Graduação em Sociologia do Departamento de Sociologia da Faculdade de Filosofia, Letras e Ciências Humanas da Universidade de São Paulo, para obtenção do título de Doutora em Sociologia.

Orientador: Prof ${ }^{\mathrm{o}}$. Drº . Iram Jácome Rodrigues

Versão corrigida

De acordo:

Prof $^{\mathrm{o}}$. Dr ${ }^{\circ}$. Iram Jácome Rodrigues

São Paulo

2016 
A Gabriela, Giovana e Guilherme, meus filhos, por compartilharem comigo a rica e complexa experiência da vida e torná-la algo ainda mais interessante. 


\section{AGRADECIMENTOS}

Agradeço, antes de tudo, ao meu estimado orientador Prof. Dr. Iram Jácome Rodrigues pela atenção e paciência. Estivemos ao longo desses últimos anos reunidos em torno dos compromissos e preocupações acadêmicas. Tive por decorrência destes episódios a oportunidade, não menos relevante, de conhecê-lo como pessoa. Sua capacidade intelectual, postura e generosidade são marcantes. Fica aqui meu muito, muito, obrigada.

Desejo, nesta ocasião, agradecer à Prof ${ }^{\mathrm{a}}$. Dr ${ }^{\mathrm{a}}$. Cecília Carmen Pontes Rodrigues, pessoa importantíssima nesta trajetória. Talvez ela nem imagine quanto, mas seus sábios conselhos e apoio foram fundamentais para conseguir chegar até o final da minha pesquisa.

Aos professores que estiveram em minha banca de qualificação, Prof. Dr. José Ricardo Ramalho e Prof ${ }^{a}$. Dr ${ }^{a}$. Heloísa Helena Teixeira de Souza Martins, também direciono meus agradecimentos, afinal, tiveram acesso a um material bruto e pouco amadurecido, sobre o qual fizeram críticas e observações muito pertinentes. Ainda que eu não tenha conseguido ter a capacidade de absorvê-las completamente neste trabalho, com certeza povoam minhas referências sobre o ato de pesquisar e em especial sobre como pensar o tema trabalho.

Às bancárias e bancários entrevistados, obrigada pelo tempo, confiança e atenção dedicada.

Às diretoras e diretores do Sindicato dos Bancários de São Paulo, Osasco e região, na pessoa da primeira mulher presidenta desta entidade, Juvândia Moreira, registro meu profundo agradecimento. $\mathrm{O}$ apoio a mim concedido foi determinante para o começo, $\mathrm{o}$ meio e o fim desta pesquisa. 
À diretora geral da Faculdade 28 de Agosto, Neiva Ribeiro, que lidera a primeira experiência em curso superior organizada por trabalhadores bancários em nosso país, agradeço o apoio e as oportunidades de aprendizado recebidas neste importante espaço.

Aos companheiros do Centro de Pesquisa 28 de Agosto, Cidinha, Moisés Marques, André Accorsi, Silvio Almeida, Camilo Onoda e Alessandra Devulsky por contribuírem e servirem de inspiração à produção científica.

Aos companheiros do DIEESE-Rede Bancários, Gustavo Cavarzan e Catia Uehara, muito obrigada por nossas conversas, pela troca de informações, elas foram profícuas para poder materializar este conjunto chamado Tese.

Aos profissionais do CEDOC - Centro de Documentação e Memória do Sindicato dos Bancários de São Paulo, Osasco e região e a Mercês, obrigada por proporcionarem o acesso aos diversos materiais sobre o mundo do trabalho bancário.

Aos amigos que me ajudaram em diversas ocasiões e são ao mesmo tempo referência profissional pela sua competência e seriedade: Sidney Jard, Jaime Santos, Dari Krein, Carla Diéguez, Jonas Bicev, Mario Ladosky e Regina Padovan.

Aos amigos que me ajudaram, incentivaram, ouviram e literalmente me ampararam nas horas em que o sentimento, o carinho ou até mesmo a conversa franca, de quem a gente confia ou admira, é o que faz a diferença. Obrigada por estarem de algum modo na minha vida: Alemão, Jânio, Deise Recoaro, Julio Santos, Ana Lúcia, Gilmar Carneiro, Flávio Monteiro, Mauro Dias, Edvaldo Borges, Adriana Magalhães, Rodrigo Pires, Serginho, Marcia Basqueira, Daniel Reis, Carlos Damarindo, Paulo Salvador, Jô Portilho e Renato Lima.

Aos familiares, em especial meus pais, que ouviram inúmeras vezes eu falar de uma coisa que fazia pouco sentido para eles: uma tal "tese". Obrigada por compreender minhas ausências.

E, por fim, não posso deixar de citar a inestimável colaboração dos meus filhos, Gabriela, Giovana e Guilherme, durante todo o percurso que envolveu esta pesquisa. 
Desde a seleção no programa de Pós-Graduação em Sociologia da USP e nos anos subsequentes, até chegar a este momento eles foram meus incentivadores e me ofertaram gentilmente diversas formas de auxílio que se refletiu no leva e trás de livros nas bibliotecas, na confecção de listas, tabelas e gráficos, na organização dos materiais de pesquisa e ainda contribuíram nos cuidados com a casa, compras... comidinha... tanta coisa que ficaria cansativo escrever. Mas, fundamentalmente, foram meu esteio, pois o amor e o carinho que compartilhamos animaram os dias solitários e cansativos que envolvem a análise dos conteúdos de pesquisa e a escrita. Sou muito grata pela compreensão e companheirismo de vocês. Se isso tudo valeu a pena, com certeza valeu porque amamos essencialmente pessoas e não coisas. 
"Eu não quero dizer que cada um é conforme nasce - não vou a esse ponto. Mas, talvez devêssemos ponderar por que algumas pessoas resistem ao comportamento digamos universal o modo de comportasse mais geral - e outras não? Por que algumas pessoas mantêm uma atitude crítica em relação às coisas? Por que algumas pessoas acham que não é por fato das coisas serem novas ou modernas que elas são necessariamente boas? Isto não é defender o antigo... é simplesmente considerar que não tem nenhuma razão para acreditar que no momento em que estou a viver é o momento em que todas as coisas que se estão a fazer - as de agora e as que vão ter efeitos no futuro - são as únicas e as melhores que poderiam estar a ser feitas e a ser pensadas, imaginadas e aplicadas. Não tenho qualquer razão para isso, pelo contrário, tenho muitas razões que me dizem que nós tomamos por um caminho errado." 


\section{RESUMO}

O objetivo desta tese é analisar o processo de trabalho no setor bancário a partir da experiência de uma grande corporação de capital privado que negocia suas ações em âmbito internacional. A questão central que norteia esta pesquisa consiste em verificar como as pressões competitivas contemporâneas, marcadas pela lógica do curto prazo dos mercados financeiros, ou de um capitalismo financeirizado, reverberam no cotidiano dos trabalhadores. A maximização do retorno ao acionista em tempos cada vez mais comprimidos leva a novas formas de racionalizar o trabalho que influencia diretamente o modo de se inserir nesses ambientes. Nesse contexto, o papel atribuído às tecnologias da informação é fundamental para estabelecer novas formas de controle e intensificar o ritmo de trabalho. A "gestão por resultados" ou os "programas de metas" são a expressão mais acabada da lógica do curto prazo no ambiente corporativo bancário. Eles representam a espinha dorsal do sistema meritocrático que desconsidera as realizações dos trabalhadores no médio e longo prazo influenciando diretamente as formas de interação social, afetando o bem-estar físico e mental dos trabalhadores, assim como a relação com os clientes.

Palavras-chave: trabalho bancário; cultura organizacional; gestão do trabalho; inovações tecnológicas; curto prazo; capitalismo financeirizado. 


\begin{abstract}
The objective of this thesis is to analyze the work process in the banking sector from the point of the experience of a large private capital corporation which negotiates its shares on an international level. The central question which orients this research consists in verifying how the contemporary competitive pressures, marked by the short term logic of the financial markets, or of a finance capitalism, reverberate in the day to day of the workers. The maximization of return to the shareholders in increasingly tighter times brings one to new forms of rationalizing the work which directly influence the means of insertion into this environment. In this context the role attributed to information technology is fundamental in establishing new forms of control and intensifying the rhythm of work. "Management by result" or "goal programs" are a more worn out expression of short term logic in the corporative banking environment. They represent the dorsal spine of the meritocratic system which fails to consider the achievements of workers in the medium to long term, directly influencing the forms of social interaction, affecting the physical and mental well-being of the workers, and even relations with clients.
\end{abstract}

Keywords: bank work, organizational culture, work management, technological innovations, short term, finance capitalism. 


\section{LISTA DE ABREVIATURAS E SIGLAS}

ABECS - Associação Brasileira das Empresas de Cartões de Crédito e Serviços AIDS - Síndrome da Imunodeficiência Adquirida ANATEL- Agência Nacional de Telecomunicações

ANBIMA- Associação Brasileira das Entidades dos Mercados Financeiro e de Capitais ATM - Automatic Teller Machine

ATS - Adicional por Tempo de Serviço

BACEN - Banco Central

BB - Banco do Brasil

BSC - Balanced Scorecard

CAT - Comunicado de Acidente de Trabalho

CBN - Central Brasileira de Notícias

CBO - Código Brasileiro de Ocupações

CCT - Convenção Coletiva de Trabalho

CEA - Certificação de Especialistas em Investimentos

CEDOC - Centro de Documentação e Memória

CEERT - Centro de Estudos das Relações do Trabalho

CEF - Caixa Econômica Federal

CIAB - Congresso Internacional de Automação Bancária

CIPA - Comissão Interna de Prevenção de Acidentes

CLT - Consolidação das Leis do Trabalho

CLT FLEX - Consolidação das Leis do Trabalho Flexível

CONTRAF - Confederação Nacional dos Trabalhadores do Ramo Financeiro

CPA - Certificado Profissional ANBIMA

CPDs - Centros de Processamentos de Dados

CPF - Cadastro de Pessoa Física

CPU - Unidade Central de Processamento

CUT - Central Única dos Trabalhadores

DIEESE - Departamento Intersindical de Estatística e Estudos Socioeconômicos

DJSI - Dow Jones Sustainability World Index

DORT - Doenças Osteomusculares Relacionadas ao Trabalho

DUT - Declaração do Último Dia Trabalhado 
DVD - Digital Versatile Disc

FEBRABAN - Federação Brasileira de Bancos

FENABAN - Federação Nacional dos Bancos

FGTS - Fundo de Garantia por Tempo de Serviço

FGV - Fundação Getúlio Vargas

HPV - Human Papiloma Vírus

HSBC - Hong Kong and Shanghai Banking Corporation

IBGE - Instituto Brasileiro de Geografia e Estatística

IBGC - Instituto Brasileiro de Governança Corporativa

IDEC - Instituto Brasileiro de Defesa do Consumidor

INSS - Instituto Nacional do Seguro Social

IP - Internet Protocol

IPEA - Instituto de Pesquisa Econômica Aplicada

IR - Imposto de Renda

IRPF - Imposto de Renda Pessoa Física

ISO - International Organization for Standardization

LER - Lesões por Esforços Repetitivos

MBA - Master of Business Administration

MD - Medida Provisória

MOC - Microsoft Office Communicator

MPT - Ministério Público do Trabalho

MSN - Microsoft Service Network

MTE - Ministério do Trabalho e Emprego

NYSE - Bolsa de Valores de Nova Iorque

ONG - Organização Não Governamental

PC - Personal Computer

PCR - Parcela Complementar de Resultados

PJ - Pessoa Jurídica

PL - Projeto de Lei

PLR - Participações nos Lucros e Resultados

POS - Ponto de Serviço

PROCON - Fundação de Proteção e Defesa do Consumidor 
PROER Programa de Estímulo à Reestruturação e ao Fortalecimento do Sistema Financeiro Nacional

PROES Programa de Incentivo à Redução da Presença do Estado Atividade Bancária PUC Pontifícia Universidade Católica

RAIS Relação Anual de Informações Sociais

RH Recursos Humanos

SA - Sociedade Anônima

SAC - Serviço de Atendimento ao Consumidor

SEEB - Sindicato dos Empregados dos Estabelecimentos Bancários

SELIC - Sistema Especial de Liquidação e de Custódia

SMS - Short Message Service

TI - Tecnologia da Informação

TMA - Tempo Médio de Atendimento

TPM - Tensão Pré-Menstrual

TST - Tribunal Superior do Trabalho

TVM - Títulos e Valores Mobiliários

UNCTAD - United Nations Conference on Trade and Development (Conferência das Nações Unidas sobre Comércio e Desenvolvimento)

UNI - United Networks International

USP - Universidade de São Paulo 


\section{LISTA DE GRÁFICOS}

Gráfico 1 - Concentração do sistema bancário brasileiro em ativos totais (2014) .........36

Gráfico 2 - Evolução das despesas com serviços de terceiros dos maiores bancos no

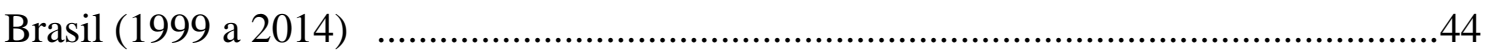

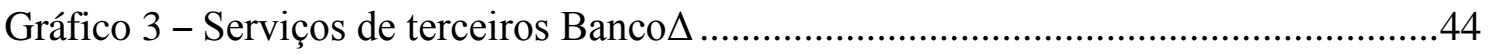

Gráfico 4 - Evolução do número de Correspondentes Bancários no Brasil (2000-2014)

Gráfico 5 - Evolução participação por tipo de vínculo empregatício ..............................51

Gráfico 6 - Vínculo empregatício preferido pelos profissionais ....................................52

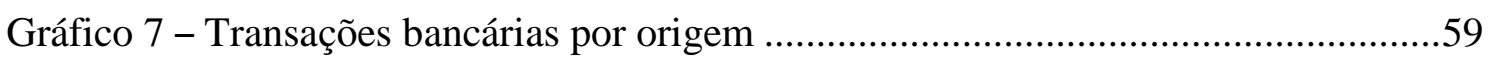

Gráfico 8 - Comportamento dos usuários nos canais de atendimento ...........................60

Gráfico 9 - Economias típicas potenciais em transformações fim a fim .......................63

Gráfico 10 - Participação dos cargos no back office câmbio .......................................69

Gráfico 11 - Grupos de trabalhadores nos bancos por hierarquia funcional ...................70

Gráfico 12 - Evolução lucro líquido dos maiores bancos no Brasil (1994-2014).........120

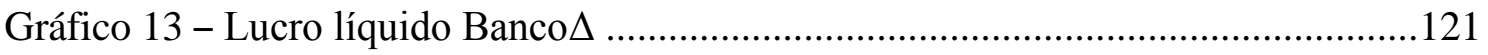

Gráfico 14 - Número de empregados Banco $\Delta$...........................................................122

Gráfico 15 - Carteira de crédito por empregado $\operatorname{Banco} \Delta$..........................................123

Gráfico 16 - Distribuição dos(as) bancários(as), escolaridade atual ............................205

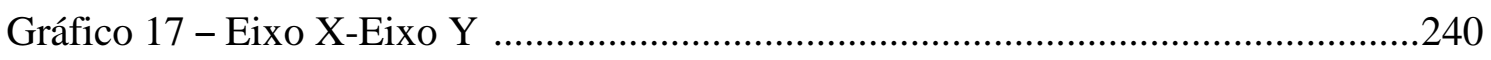

Gráfico 18 - Conhecimento da vaga se deu por qual meio? .......................................243

Gráfico 19 - Motivo do afastamento dos bancários do trabalho em 2013 ...................268

\section{LISTA DE TABELAS}

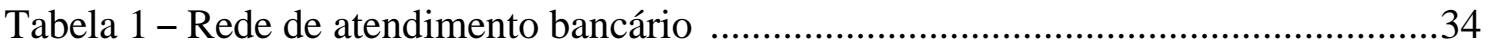

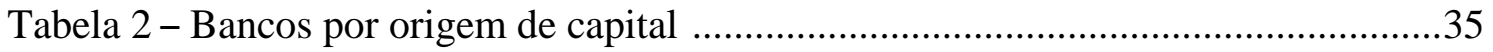

Tabela 3 - Remuneração mensal cargo caixa .........................................................155

Tabela 4 - Remuneração anual cargo caixa ……....................................................156

Tabela 5 - Gerações de trabalhadores Banco $\Delta$...........................................................194

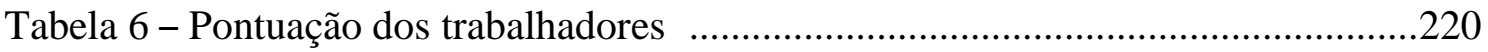




\section{LISTA DE QUADROS}

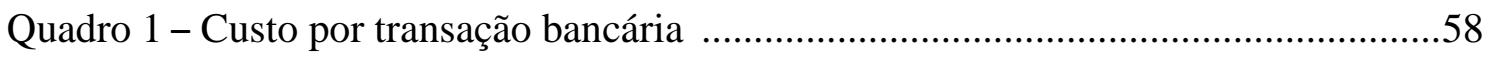

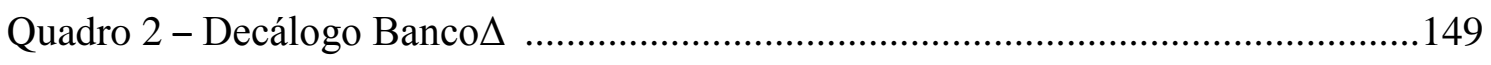

Quadro 3 - Benefícios exclusivos aos trabalhadores ...............................................159

Quadro 4 - Benefícios para os trabalhadores e extensivos à família ............................162

Quadro 5 - Benefícios exclusivos aos trabalhadores dos polos administrativos...........162

Quadro 6 - Benefícios extensivos à comunidade .....................................................165

Quadro 7 - Pesquisa “O impacto da organização e do ambiente de trabalho bancário na saúde física e mental da categoria" - Grupo respondente: Bancos privados ...............225

Quadro 8 - Distribuição total dos trabalhadores avaliados ......................................239

Quadro 9 - Quadro síntese dos principais requisitos para admissão no Banco $\Delta$.........251

Quadro 10 - Pesquisa: "Perfil do bancário e as condições de trabalho no setor financeiro

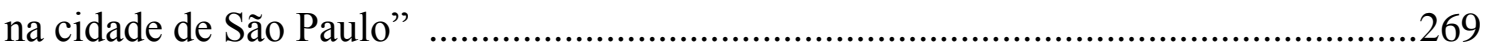

Quadro 11 - Pesquisa: “O impacto da organização e do ambiente de trabalho bancário na saúde física e mental da categoria" - Grupo respondente: Trabalhadores Banco $\Delta .269$

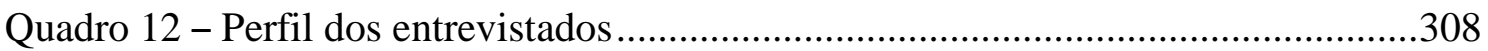

\section{LISTA DE FIGURAS}

Figura 1 - Organograma holding financeira

Figura 2 - Exemplo de processo de trabalho tipicamente encontrado no setor bancário

Figura 3 - Exemplo mesmo processo de trabalho em estágio digitalizado ....................62

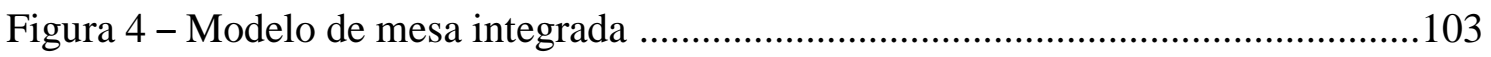

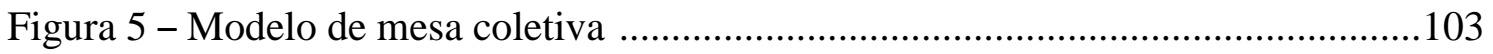

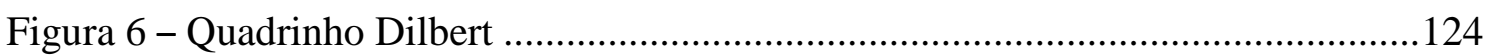

Figura 7 - Esquema gráfico: Convenção coletiva de trabalho e acordo celebrado por

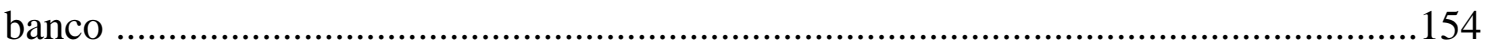

Figura 8 - Esquema gráfico: Direitos e benefícios Banco $\Delta$........................................158

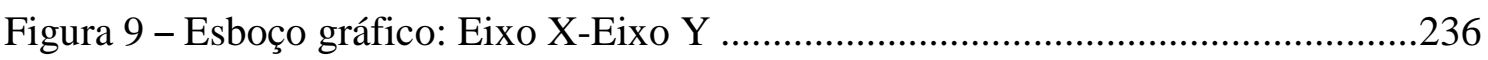




\section{LISTA DE IMAGENS}

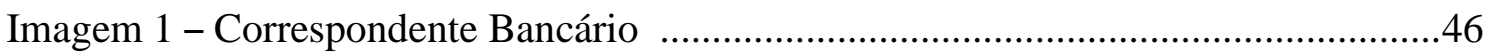

Imagem 2 - Vista da entrada de agência bancária (1986) ...........................................65

Imagem 3 - Vista da entrada de agência bancária (2007) ............................................65

Imagem 4 - Passeata dos bancários na Av. Paulista, durante campanha salarial em

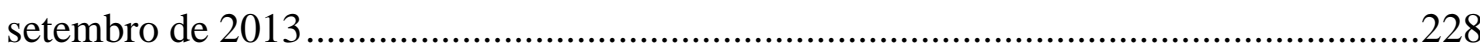




\section{SUMÁRIO}

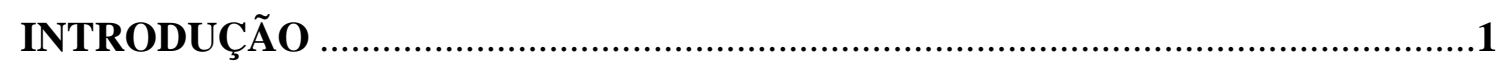

PARTE I - O SETOR BANCÁRIO DIANTE DAS PRESSÕES COMPETITIVAS E A LÓGICA DO CURTO PRAZO

Capítulo 1 - Breves considerações sobre a transição do paradigma fordistakeynesiano para a acumulação flexível.................................................................16

$1.1 \mathrm{O}$ campo das finanças: dominância política e cultural.........................................22

Capítulo 2 - A reestruturação produtiva bancária na virada do século .................28

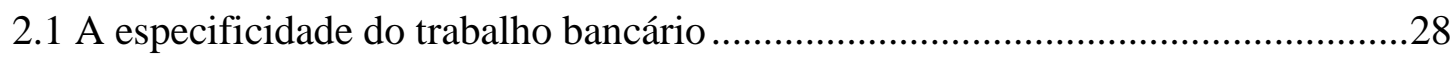

2.2 Estratégias corporativas bancárias no contexto brasileiro .....................................32

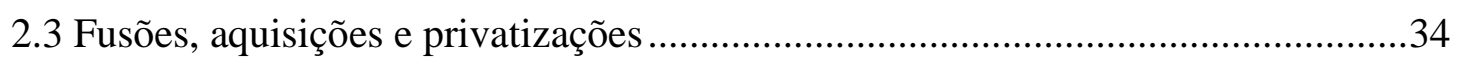

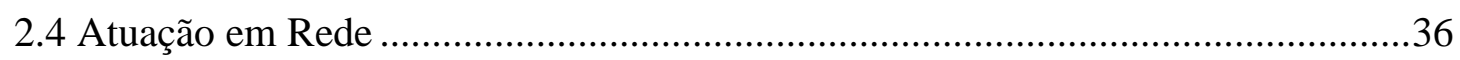

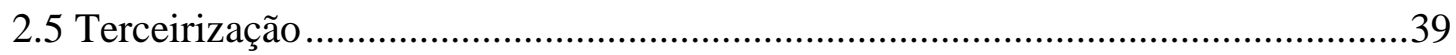

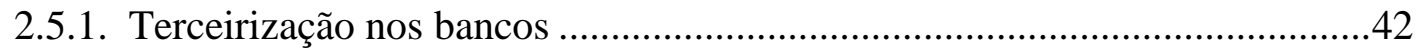

2.5.2. Terceirização e o acirramento da fragmentação dos trabalhadores ...............47

2.6. Difusão tecnológica e as perspectivas sobre o futuro do trabalho nos bancos ....54

2.6.1 As novas formas de interação social diante das inovações tecnológicas .........54

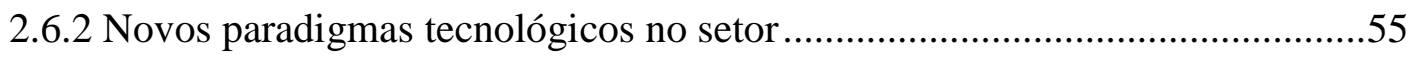

2.6.3 TI no trabalho bancário e a recomposição de cargos e funções .......................60

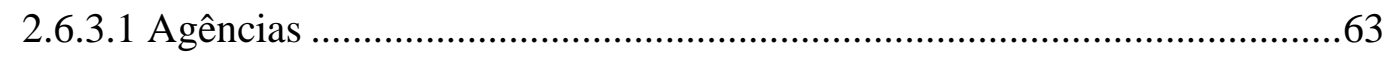

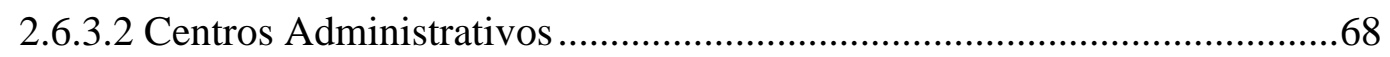

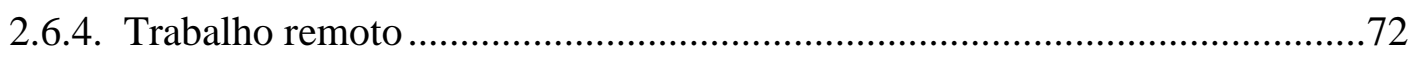

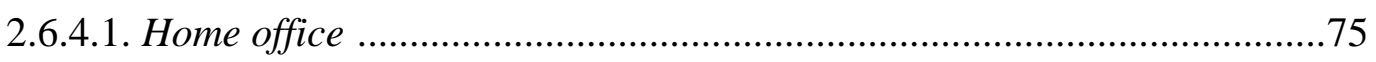

2.6.5. O conceito empresarial de "banco do futuro" .............................................77

\section{Parte II - RACIONALIZAÇÃO DO PROCESSO DE TRABALHO NA GRANDE CORPORAÇÃO BANCÁRIA}

Capítulo 3 - Modelos e referências de organização do trabalho................................79

3.1 Novas tecnologias e as diversas formas de controle ............................................84

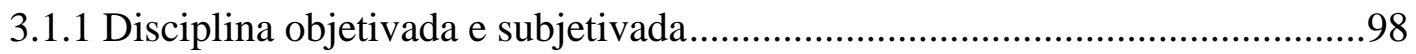

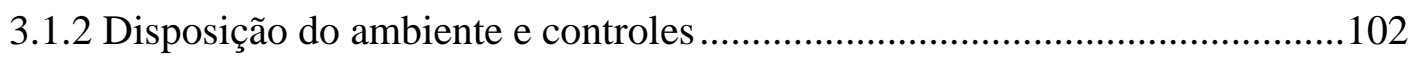

3.1.3 Autonomia e criatividade diante das diversas formas de controle ................106 
3.1.4 Significados da jornada flexível............................................................110

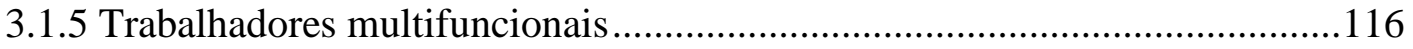

3.1.6 Autosserviço: o cliente como parte da racionalização do trabalho ...............118

3.2. Produtividade e ritmo de trabalho bancário .......................................................119

Capítulo 4 - Dinâmica organizacional na grande corporação bancária .................128

4.1 Quando a gestão empresarial incorpora o bem comum ......................................128

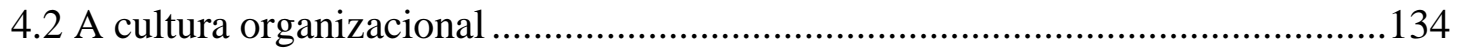

4.3 Um amontoado de relativas inovações ........................................................137

4.4 O papel do RH e a da cultura organizacional ...................................................146

4.5 Direitos, benefícios e socialização corporativa...................................................152

4.5.1 Outras políticas de integração social .......................................................... 164

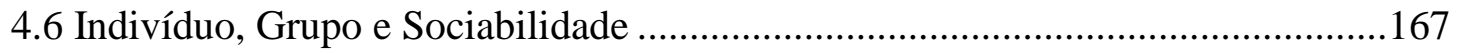

4.6.1 A tensão: indivíduo versus grupo na gestão contemporânea ........................167

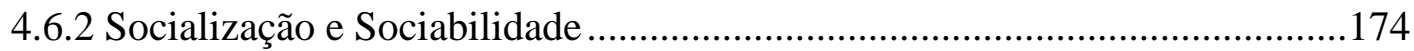

4.6.3 Status e sociabilidade a partir do emprego bancário ....................................179

4.6.4 Ambiguidades no ambiente de trabalho e perspectivas dos trabalhadores ...184

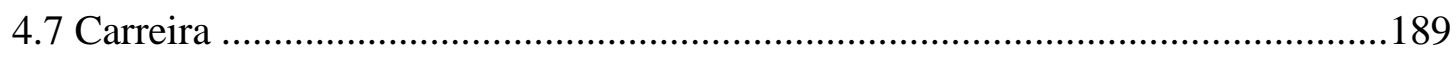

4.7.1 As novas gerações e as percepções sobre carreira ........................................194

4.7.2 Retóricas acerca da carreira e do emprego..................................................198

Capítulo 5 - A política da meritocracia e a face pragmática da grande corporação

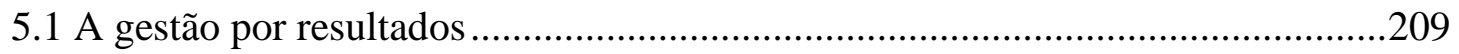

5.1.1 Os programas de resultados relacionados à remuneração variável ..............212

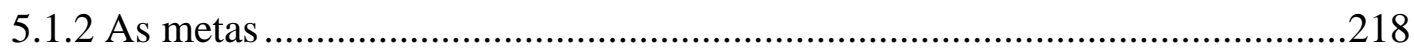

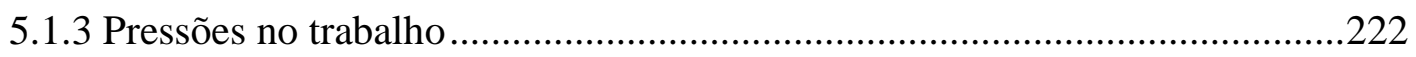

5.1.4 A superação no ambiente corporativo e a metáfora do atleta ......................225

5.1.5 Metas são um convite ao vale-tudo .........................................................22

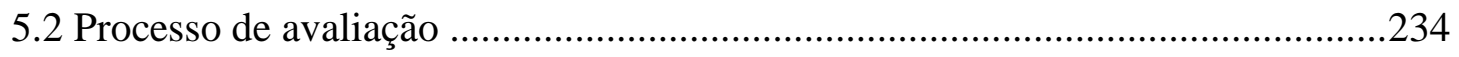

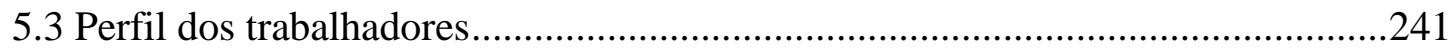

5.3.1 Como as vagas são disponibilizadas .......................................................242

5.3.2 Elementos definidores dos perfis dos trabalhadores .................................245

5.3.3 Comportamento, o principal diferencial ..................................................252

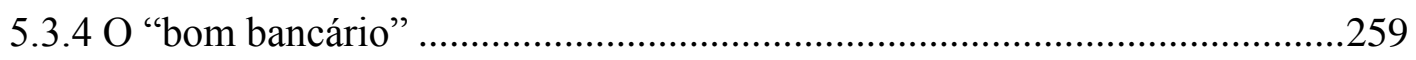


5.4 Quando o trabalho na grande corporação bancária se torna um risco à saúde dos trabalhadores.

5.5 Formas de enfrentamento às pressões no ambiente de trabalho .272

Considerações finais 280

Referências bibliográficas 293

Anexos .307

Perfil dos entrevistados 308

Roteiro de entrevista com bancários .310

Roteiro de entrevista com consultores 312 


\section{Introdução}

O cenário de transformações pelas quais tem passado o setor bancário ao longo das últimas décadas reconfigurou a interação entre trabalhadores bancários ${ }^{1}$, terceirizados e clientes. Com o acirramento da competitividade intercapitalista, os executivos do setor adotaram estratégias administrativas e financeiras que influenciaram diretamente o processo de trabalho bancário alterando o modo pelo qual a oferta de produtos e serviços se viabiliza.

Os trabalhadores nesse cenário têm atuado em meio às novas exigências de produtividade e flexibilização em um mercado de trabalho influenciado pela visão de curto prazo que se relaciona diretamente com os modelos de produção no capitalismo contemporâneo (HARVEY, 1992; SENNETT, 2002).

A relação entre a financeirização e a organização do trabalho foi pouco explorada, segundo Dias e Zilbovicius (2009). A maximização do retorno ao acionista em tempos cada vez mais comprimidos leva a novos meios de racionalizar o trabalho de tal forma que a "gestão por resultados" tornou-se a tônica do modo de agir dos trabalhadores e passou a reorientar, por decorrência, as interações sociais, interferindo no bem-estar dos trabalhadores do setor, seja ele físico ou mental e também na relação estabelecida com os clientes.

A questão central desta tese consiste em verificar como as pressões competitivas contemporâneas, marcadas pela lógica do curto prazo dos mercados financeiros, ou de um capitalismo financeirizado, reverberam no cotidiano dos trabalhadores que atuam em uma grande corporação bancária.

A partir do conhecimento das várias dimensões do setor bancário relacionadas ao trabalho e aos trabalhadores, procuraremos apurar os elementos discernidores da realidade empírica que dá sustentação ao novo arranjo flexível nas grandes corporações, indagando sobre as suas influências em cenários plasticamente impecáveis como parecem ser aqueles propagados pelas próprias empresas; consultorias de recrutamento e seleção; revistas e outros meios de comunicação especializados em carreira e recursos humanos.

\footnotetext{
${ }^{1}$ Usaremos nesta tese a definição genérica "trabalhadores", mas frisamos que a categoria profissional que será analisada é composta por $51 \%$ homens e $49 \%$ mulheres (RAIS - MTE, 2014). O banco que será alvo do detalhamento deste estudo mantém os seguintes percentuais: $60 \%$ mulheres e $40 \%$ homens (Relatório Gerencial Banco $\Delta 2014$ ).
} 
Deste modo, nos propomos a estudar as mudanças ocorridas no setor nas últimas décadas considerando, sobretudo, o processo de trabalho bancário e as interações sociais decorrentes dele.

O discurso e prática que giram em torno do modelo de produção flexível se articulam no chamado "mundo corporativo", estabelecendo características que estabelecem um tipo de perfil de trabalhador, fazendo-o triunfar no senso comum à medida que determinados valores, princípios e normas são amplamente reproduzidos e inculcam um modo de ser do trabalhador contemporâneo.

A organização de grandes bancos do setor em rede se perfila na estrutura denominada holding financeira. Nesse desenho há uma empresa principal que controla as demais empresas subsidiárias. Por meio dessa forma jurídica e econômica de atuar, é possível concentrar mais poder econômico, político e cultural. Em nosso estudo adotamos a expressão "grande corporação", por compreender que ela simboliza a grande empresa capitalista contemporânea, uma empresa principal associada a outras empresas por meio de controle acionário, com atuação internacional, orientada pela valorização de suas ações no mercado financeiro.

A grande corporação bancária é constituída por um conjunto complexo e interativo permeado por estratégias internas e externas, em tempos nos quais o valor da marca é essencial para o estabelecimento do valor das ações no mercado financeiro. Assim, sua imagem está diretamente associada a um tipo de ética - a "ética corporativa" - e às "boas" práticas de gestão que passam a estruturar o campo das subjetividades nas relações sociais, tanto estabelecidas internamente como perante a sociedade. Dessa construção simbólica, feita com o suporte das consultorias e dos meios de comunicação e marketing, são forjados nexos explicativos que alinhavam a aceitação, adaptação e submissão dos trabalhadores a um novo modo de trabalho e vida que busca se firmar em um cenário hostil, marcado pela alta concentração de renda e poder das corporações, em detrimento de interesses de âmbito mais geral das sociedades.

Diversos autores retrataram, direta ou indiretamente, as mudanças que ocorreram nas instituições financeiras quando estas buscaram acompanhar os movimentos de crise e expansão do sistema capitalista local e internacionalmente. As abordagens, em geral, vindas de áreas próximas do conhecimento, são múltiplas e não se esgotam nos estudos retratados na revisão bibliográfica realizada para esta pesquisa.

As contribuições de autores, como os que apontamos a seguir, são referências importantes para mapear, em um plano histórico mais amplo, a configuração do setor. 
Canêdo $(1978,1986)$ realizou duas pesquisas que descreveram o processo de formação do sindicato da categoria e resgataram elementos fundamentais para compreendermos o processo de trabalho nos bancos desde a década de 1920 à década de 1970. Romanelli (1978) analisou modelos de orientação cultural a partir da estrutura de classe e poder vivida por trabalhadores bancários na década de 1970. Já Accorsi (1990) realizou um estudo referência sobre a automação bancária no período da década de 1960 até o final dos anos 1980.

Pesquisas realizadas por Segnini (1988, 1997, 1998); Rodrigues, I. e Rodrigues, L. (1988); Blass (1992); Larangeira (1997); Jinkings (1996, 2002) abordaram períodos que compreendem desde a década de 1980 até o final dos anos 1990. Os conteúdos abordados tratam das reestruturações produtivas no setor bancário observando suas implicações sociais. Nesse sentido, os autores destacaram aspectos relacionados às mudanças na organização, automação, racionalização e divisão do trabalho, feminização da categoria, privatização, desemprego, terceirização, qualificação, organização sindical, formas de resistência, relações de poder nas instituições bancárias, dentre outros.

A bibliografia sobre o trabalho bancário e os trabalhadores ligados ao setor mostra ainda um conjunto de outros autores que apresentaram seus estudos na década de 2000, sendo eles: Penella (2000); Venco (2003); Rodrigues (2004); Chaves (2005); Sanches (2006). Esses autores pesquisaram temas diversos circunscritos ao contexto bancário, como doenças ocupacionais, trabalho à distância, tecnologia, plano de demissões voluntárias, dimensões culturais e valores no ambiente de trabalho, ação sindical e terceirização, buscando em alguma medida recuperar elementos que compusessem a reestruturação econômica e reorganização do trabalho.

Das produções concluídas na década corrente tivemos contato com o estudo de Soares (2013) sobre a mobilização bancária; de Oliveira (2014) sobre a terceirização e ação sindical no trabalho bancário; de Dulci (2015) sobre a automação bancária; de Nogueira (2015) sobre as transformações do setor e o sentido do trabalho bancário; e de Ostronoff (2015), que analisou a ação sindical bancária e suas novas estratégias de luta articuladas à pauta de saúde e condições de trabalho.

Entretanto, apesar das expressivas contribuições à compreensão das relações sociais vivenciadas nos bancos, a realidade do setor é muito dinâmica e conta com um conjunto de especificidades vinculadas às mudanças recentes, sobretudo vividas nas últimas décadas, que comportam atualizações e novas abordagens. 
Ressalta-se que a maioria dos estudos citados reporta-se a pesquisas de campo realizadas na década de 1990, para recompor o quadro de análise sobre o setor, e reproduz as estratégias e acontecimentos que são relacionados a este período, que em grande medida se perpetuam, considerando que no capitalismo não existem muitas maneiras inovadoras de obter mais valia que não seja pela busca de produtividade no trabalho e suas respectivas medidas para alcançá-la. Contudo, consideramos que uma parte de nossa contribuição neste estudo se estabelece na possibilidade de trazer à tona novos elementos que possam atualizar os acontecimentos mais relevantes no setor, analisando suas influências tanto para trabalhadores como para outros agentes que interagem no contexto bancário.

Outra parcela de nossa contribuição visa captar e analisar a percepção dos trabalhadores sob determinadas variáveis associadas ao processo de trabalho como: controle, autonomia, participação, trabalho em grupo, sociabilidade, perspectiva de carreira, avaliação, perfil, ritmo e pressão vividos dentro do ambiente corporativo e que nos possibilitam tornar mais compreensivo o modo de ser e estar nesses ambientes.

Assim, para atingir tais objetivos, serão observados os meandros dos processos de trabalho, observando como as formas de interação no cotidiano corporativo estão permanentemente mediadas pelas estratégias de negócios e pela ação dos agentes envolvidos.

As estratégias de negócios respondem às constantes transformações no setor baseadas em rearranjo de capitais e poderes controladores das instituições; na implementação de novas tecnologias; em novos modos de organização do trabalho que passam inclusive pela alteração da composição da força de trabalho contratada diretamente.

A ação dos agentes envolvidos se orienta por múltiplos sentidos, alguns inclusive contraditórios. O trabalho marcado pela forte pressão e controle, fonte de insatisfação e sofrimento, convive com a percepção de que por meio do exercício da profissão o trabalhador encontra reconhecimento e reciprocidade.

Para auxiliar esta trajetória investigativa se tornou relevante recuperar as características básicas do trabalho bancário que, operando como um típico escritório, está submetido a amplos processos burocráticos com etapas de trabalho prescritas. Ainda que tenha sob si o traço essencial da relação de serviço, intermediada pela figura do cliente, este processo de trabalho é marcado pelo forte controle de tempos e até 
mesmo de quantidades, o que o relaciona diretamente ao modelo taylorista-fordista de produção.

As inovações tecnológicas, sobretudo o papel atribuído às tecnologias da informação (TIs) nas últimas décadas, possibilitaram uma readequação de grande magnitude nos processos de trabalho bancário. Por meio delas foi possível ampliar e sofisticar os controles tornando-os on-line ou real time, eliminar ou automatizar etapas de trabalho, redividir trabalhos, rearranjar funções, permitir o acesso remoto ao trabalho e popularizar o autosserviço para os clientes.

Considerando que o processo de trabalho bancário é marcado pelo hibridismo dos modelos de gestão e organização do trabalho, observamos as influências das novas formas de gestão conhecidas por "organização flexível” ou "toyotismo". Elas estão presentes na flexibilidade de horários e funções, nos programas de gestão por resultados, no aprofundamento da apropriação dos saberes dos trabalhadores, na diversidade de formas de contratação e contidas na retórica que organiza a "cultura corporativa".

Por meio da disseminação de uma determinada "cultura organizacional" ou "cultura corporativa", tanto as empresas como as respectivas consultorias de RH desmobilizaram o conceito de valorização dos trabalhadores por tempo de casa e de referenciais de emprego de longo prazo, passando a dar ênfase à meritocracia e ao empreendedorismo.

O estabelecimento de uma relação de emprego marcada pelo curto prazo está diretamente associada ao uso de força de trabalho contingente - terceirizada - e aos resultados de produtividade dos trabalhadores efetivos - contratados diretamente -, monitorados em ciclos reduzidos de tempo que visam atender às expectativas dos investidores.

Os trabalhadores terceirizados representam além de um custo menor sobre o insumo força de trabalho, um custo variável no ciclo de expansão e retração do negócio que pode ser ajustado a qualquer tempo. Os trabalhadores contratados diretamente pelas instituições financeiras são submetidos a avaliações constantes de resultados que se tornam na prática a principal medida de sua vulnerabilidade. A permanência no emprego, na empresa privada, é condicionada ao desempenho individual medido e monitorado em ciclos curtos. 
As grandes corporações, por terem ações negociadas em bolsas de valores internacionais, reproduzem em efeito cascata as pressões para atingir rentabilidades comparadas àquelas obtidas pelo resultado do rentismo no mercado financeiro.

A aposta da "gestão por resultados" está fundada na absorção de melhores níveis de produtividade em menor tempo possível utilizando várias ferramentas informatizadas de gerenciamento da força de trabalho. Sem limites, o paradigma rentista coloca os trabalhadores em posição mais vulnerável, pois os processos produtivos buscam responder à competição intercapitalista pautada no resultado financeiro de curto prazo.

Fortemente identificada com os chamados "programas de metas", a "gestão por resultados" vem orientando os processos de trabalho no interior da grande corporação bancária. Os "programas de metas", ainda "primitivos" na década de 1990, se sofisticaram e ganharam ampla visibilidade e aplicabilidade nos anos 2000 e nos anos subsequentes, aliando controle da gestão do trabalho a outras práticas institucionalizadas, como a avaliação individual periódica.

Jinkings (2002) já apontava a existência de "programas de metas" ligados à remuneração variável nos bancos desde 1992. Sobre esses, concluiu que se "criava um complexo sistema de controle dos níveis de produtividade dos funcionários e, simultaneamente, estimulava a intensificação do trabalho, via remuneração". No entanto, a autora, que já tinha avançado muito em suas análises, não se propôs a aprofundar o modo pelo qual os programas existentes no interior das instituições se transformaram em instrumentos de gestão do trabalho.

As metas e avaliações de performance já estavam presentes na década de 1990 no setor bancário, como estamos apontando, mas se tratavam de práticas incipientes, com força e expressão delimitadas a alguns grupos de trabalhadores. Com o desenvolvimento tecnológico foi possível ampliar para todos os espaços da grande corporação bancária tais dispositivos de gestão.

Nos anos 2010, as pesquisas de Colombi (2014), e ainda mais especificamente as de Santos (2012), abordaram os "programas de metas" relacionados à remuneração variável ou à Participação nos Lucros e Resultados (PLR) no setor bancário. Além de os autores identificá-los como a forma encontrada pelas empresas para flexibilizar a remuneração dos trabalhadores, eles também analisaram que esses programas são formas de ideologização, submissão, reforço ao individualismo e controle gerencial.

Mantemos concordância com as análises acima mencionadas. Contudo, o ponto que pretendemos chamar a atenção está embasado na perspectiva de os "programas de 
metas" serem a versão mais acabada da "gestão orientada por resultados", que se traduz efetivamente na lógica de curto prazo, aplicada no processo produtivo do setor bancário.

As métricas de produtividade desses programas são exigidas dos trabalhadores em períodos curtos que acompanham a publicação dos balanços para os investidores. Os resultados apurados são submetidos a comparações internacionais de rentabilidade, o que coloca, constantemente, sob o ambiente corporativo estudado, múltiplas formas de pressão sobre os trabalhadores.

O resultado da produtividade individual é igualmente submetido à comparação entre os próprios trabalhadores, possibilitando que rapidamente possam ser percebidas oscilações no desempenho obtido por cada um, apontando aqueles considerados melhores e piores. Além do aprofundamento das formas de controle e monitoramento existentes, observa-se que é por meio da retórica que envolve a "cultura corporativa", que se enfatiza a ideia de superação constante, tornando previsível que os sinais de estagnação ou retração da produtividade sejam impulsionadores da troca dos trabalhadores no curto prazo.

A questão relativa às pressões para atingir metas "abusivas", segundo adjetivação do sindicato dos trabalhadores bancários em São Paulo, expressa uma das principais reclamações sobre o ambiente de trabalho nos últimos anos ${ }^{2}$. Assim, a "performance", "entrega de resultados" ou o "cumprimento de metas de produtividade" se tornam para os trabalhadores a tônica da vida corporativa contemporânea e influenciam diretamente o perfil exigido dos profissionais nos bancos em tempos que tudo pode ser medido e controlado on-line e em real time.

Concordando com Boltanski e Chiapello (2009), que analisaram criticamente as novas formas de gestão, os gerenciadores dos modelos pós-fordistas de organização do trabalho apresentaram um conjunto de promessas que não foram cumpridas. As contradições do discurso empresarial bancário relacionado à autonomia, criatividade, participação, horizontalização, valorização do trabalho em grupo e até mesmo sobre a qualidade dos serviços, emergem quando o processo de trabalho aponta para o pragmatismo dos resultados, limitando a ação dos trabalhadores que, em que pese se chamarem "colaboradores", são aquilo que nunca deixaram de ser: indivíduos subordinados às normas, controles e prescrições do empregador.

As transformações que aconteceram e acontecem no interior das instalações dos bancos brasileiros, reconhecendo aqui seu caráter heterogêneo e disperso

\footnotetext{
${ }^{2}$ Folha Bancária (várias edições); SEEB, 2011.
} 
geograficamente, perpassam por inúmeros locais de trabalho, como as agências e os centros administrativos. Em 2014, o Banco Central divulgou que existiam 23.126 agências e 153 instituições bancárias públicas e privadas atuando no país ${ }^{3}$.

A categoria bancária é formada por 512 mil trabalhadores bancários no Brasil, destes $51 \%$ são homens e $49 \%$, mulheres ${ }^{4}$. Outros segmentos de trabalhadores atuam para o setor e estão vinculados por formas de contratação diferenciadas. Esses segmentos são denominados terceirizados e constituem parte da força de trabalho necessária para efetivação dos produtos e serviços bancários. A respeito deste contingente, não é possível mensurar quantidades seguras devido ao caráter disperso da própria atividade, que reúne diversas empresas, com enquadramentos sobre a natureza econômica e sindical igualmente heterogêneas. Por exemplo, no maior banco privado nacional, citamos o caso dos trabalhadores que atuam em atividades de teleatendimento, segundo o relatório gerencial divulgado pela instituição apenas $35 \%$ do total de trabalhadores são contratados diretamente, sendo os demais terceirizados para exercer esta função ${ }^{5}$. Entretanto, este parâmetro não pode ser tomado como referência para toda e qualquer atividade dentro das instituições financeiras, ou seja, não se pode supor que em todas as demais áreas existam $65 \%$ de participação de força de trabalho terceirizada.

O escopo desta investigação, no que tange ao aprofundamento da análise sobre o processo de trabalho em si, se ancora na experiência de uma grande corporação do setor financeiro, mais especificamente, um banco de grande porte com controle privado nacional, com atuação em outros países, denominado doravante de Banco $\Delta$. Sob seu controle atuam no Brasil 86.192 trabalhadores, sendo que destes $60 \%$ são mulheres e $40 \%$ são homens ${ }^{6}$.

Consideramos que o significado deste estudo extrapola o universo do banco destacado à medida que as instituições financeiras mimetizam suas estratégias de atuação na cena nacional tanto no âmbito privado como público, ocorrendo poucas oscilações significativas.

É importante ressaltar que diversos bancários da instituição pesquisada tiveram experiências de trabalho em outros bancos, fato que foi mencionado nas entrevistas realizadas. Essa condição, somada à visão que temos sobre as estratégias do setor, nos leva a crer que os procedimentos internos se assemelham, haja vista as orientações

\footnotetext{
${ }^{3}$ Dados disponíveis no site BACEN: www.bcb.gov.br. Acesso em: abr. 2014.

${ }^{4}$ Dados RAIS 2014

${ }^{5}$ CATARINO BRASILEIRO, Anuário Brasileiro de Bancos, 2015.

${ }^{6}$ Fonte: Relatório gerencial Banco $\Delta, 2014$.
} 
padronizadas de atuação veiculadas pela principal entidade de representação dos banqueiros: a FENABAN - Federação Nacional dos Bancos e ao papel atribuído às consultorias empresariais no sentido de delinear as diretrizes sobre organização e gestão implementadas nas instituições financeiras.

Ainda vale dizer que as análises contidas na literatura especializada consultada abordam aspectos relacionados aos processos de trabalho nos bancos em geral, sejam eles privados ou públicos, nacionais ou estrangeiros, nos apontando práticas muito semelhantes. Mesmo considerando que parte relevante de nossa investigação ficará restrita a um estudo de caso, inferimos que ela pode ser significativa à medida que reflete a experiência do maior banco privado no país, posicionado na lista dos vinte maiores bancos do mundo, exercendo, portanto, forte influência sobre os demais concorrentes no ambiente competitivo do mercado financeiro.

Um estudo de caso no âmbito das ciências sociais, como observou Becker (1999), visa uma análise detalhada de tal forma que possa evidenciar a dinâmica das relações sociais existentes em determinadas organizações ou comunidades. $\mathrm{O}$ pesquisador nesta modalidade busca compreender em profundidade a organização, ao mesmo tempo em que tenta desenvolver "declarações teóricas mais gerais" sobre as regularidades observadas.

\section{Detalhamento dos procedimentos de pesquisa}

A maneira como conduzimos esta investigação teve como ponto de partida a escolha de elementos que pudessem contribuir para elucidar os objetivos propostos e responder as questões que orientam nossa trajetória analítica. Foram acessadas diversas fontes de dados e informações, enfatizando neste percurso o método qualitativo. Conforme assinala Martins (2004, p. 292):

as chamadas metodologias qualitativas privilegiam, de modo geral,
a análise de microprocessos através do estudo das ações sociais
individuais e grupais. Realizando um exame intensivo dos dados,
tanto em amplitude quanto em profundidade, os métodos
qualitativos tratam as unidades sociais investigadas como
totalidades que desafiam o pesquisador.

Para este estudo foi realizado trabalho de campo por meio de observação direta em período prolongado, equivalendo a todos os anos que compreendeu esta pesquisa de doutorado (2012-2015). As anotações que derivam da observação in loco foram 
relevantes para compor o quadro compreensivo desta pesquisa. Entenda-se que o "caderno de campo", neste caso, trata-se de qualquer possibilidade de registro daquilo que caracteriza e configura o ambiente de trabalho. Ele aglutina ainda anotações coletadas em conversas informais, fotos e documentos institucionais possíveis de serem recolhidos ao longo desta jornada.

Como observou Becker (1999, p. 123), “os documentos não podem ser aceitos pelo seu valor de face, mas têm de ser interpretados" considerando como foram criados, por quem e para que propósitos foram criados. Com base nesta orientação, buscamos analisar o conjunto de documentos e publicações institucionais do Banco $\Delta$, das consultorias de RH e também do sindicato que tivemos acesso.

Foram realizadas 18 entrevistas estruturadas ${ }^{7}$, que tiveram a seguinte distribuição: 15 entrevistas com trabalhadores e 03 entrevistas com consultores de RH que prestam serviços aos bancos. Do total de trabalhadores, participaram 07 mulheres e 08 homens, situados em cargos distintos dentro da instituição escolhida. No tocante à área de atuação dos trabalhadores, atingimos respectivamente as seguintes participações: 07 trabalhadores de agências e 08 de departamentos situados em áreas administrativas.

A distribuição das entrevistas buscou ainda levar em consideração que invariavelmente os trabalhadores submetidos ao regime de cumprimento de metas conhecem bem a tarefa que realizam diretamente, mas não dominam o processo de trabalho de modo mais abrangente, por isso se tornou relevante ouvir os gestores, que pela especificidade de suas atribuições dominam melhor as diversas etapas e conexões que estruturam o fazer bancário dentro da grande corporação analisada.

A triagem para escolha dos entrevistados considerou preferencialmente trabalhadores que não mantivessem contato direto com a pesquisadora. Isso totalizou mais de $70 \%$ do grupo. Assim, era solicitado ao intermediador, que fazia o contato com o trabalhador a ser entrevistado, que apenas registrasse que se tratava de uma pesquisa acadêmica e que tudo que fosse dito estava posto sob sigilo, não identificando a fonte.

Ainda, para tentar se desviar de possíveis ruídos que atrapalhassem o conteúdo das respostas, ao abrir a entrevista, foi apresentada uma carta assinada pelo orientador desta pesquisa, reafirmando o caráter acadêmico e a preservação de sigilo. Temos a compreensão de que isso não garante nenhum "resultado melhor" ou "mais realista", mas consideramos que poderia ajudar em nosso processo investigativo.

\footnotetext{
${ }^{7}$ Ver ao final desta tese, em “Anexos", os roteiros das entrevistas e outras informações sobre o perfil dos entrevistados.
} 
Percebemos em nossa leitura sobre as metodologias usadas nas pesquisas mencionadas em nossa revisão bibliográfica que é recorrente entrevistar trabalhadores que a instituição sindical apresenta, ou ainda, atingir um recorte mais específico dentro deste grupo de influência, como entrevistar apenas trabalhadores afastados em função de tratamento de saúde. Essas são perspectivas que podem trazer um viés à amostra que precisa ser ponderada.

Não que se pretenda desmerecer, os tipos de amostra citadas, contudo visamos chamar a atenção de que é preciso estabelecer mediações para que não se tome automaticamente a parte pelo todo, como é o caso da percepção dos "militantes sindicais", afinal, eles representam as menores frações de trabalhadores no interior das organizações bancárias e são permeados pela ideologia sindical. Portanto, é melhor do ponto de vista da investigação ouvir mais atores da cena do mundo do trabalho tentando, porque certamente é uma tentativa, agrupar as diferentes visões, ainda que em uma pequena mostra qualitativa.

Assim, em nosso caso, ouvir só aqueles que sabidamente eram críticos da grande corporação pesquisada talvez nos impusesse pouca criatividade no trabalho acadêmico, que a nosso ver visa desvendar e analisar aquilo que ultrapassa o campo da aparência.

Os questionários, diferentes para trabalhadores e consultores, buscaram apreender as percepções dos entrevistados acerca de nossos objetivos específicos. As entrevistas realizadas entre 2013 e 2015 foram gravadas sempre com a permissão dos participantes. As exceções ocorreram com 02 consultoras de RH, que aceitaram a entrevista, mas não a gravação, e, ainda 02 gestores do Banco $\Delta$. A duração média de cada entrevista gravada foi de 1 hora e 30 minutos e foram realizadas em diversos locais: na residência dos entrevistados, no Centro de Formação Profissional do sindicato, na sede das consultorias e também na própria universidade na qual a autora é aluna.

O conteúdo recolhido pelo entrevistador, tenha ele qualquer posição, sempre sofrerá as mediações do próprio entrevistado, que poderá, ou não, reforçar ou omitir algo. Ter o gravador como uma prova das informações repassadas ou mesmo como uma chance para denunciar as opressões que sofre pode rearranjar o tipo de narrativa do entrevistado conforme seu juízo e sua própria escolha naquele momento.

Pode-se, ainda, afirmar que muitos bancários deixaram de conceder a entrevista expressando direta ou indiretamente sua preocupação em tratar de assuntos "privados" publicamente. Essa postura, a nosso ver, está ligada a constante divulgação de normas 
internas para que nenhuma informação do banco seja compartilhada fora do ambiente corporativo.

As entrevistas foram analisadas e destacadas nos capítulos desta tese conforme o tema de cada tópico analisado. De acordo com Queiroz (1983, p. 91):

os depoimentos pessoais, a partir do momento em que foram gerados, passam a constituir documentos como quaisquer outros, isto é, se definem em função das informações, indicações, esclarecimentos escritos ou registrados, que levam a elucidações de determinadas questões.

Os dados quantitativos disponibilizados pela Febraban, por meio de seus relatórios gerenciais, publicações institucionais, somados aos dados sistematizados pelo Banco Central, DIEESE e Ministério do Trabalho e Emprego (MTE), foram utilizados para compreender o quadro no qual se insere o objeto de nossa pesquisa, no sentido de estabelecer determinados parâmetros.

Foram observados, ainda, os dados secundários de outras pesquisas disponíveis, que contribuíam com os nossos objetivos de análise. Citamos por exemplo a pesquisa coordenada por Iram Jácome Rodrigues "Perfil do Bancário e as Condições de Trabalho no setor Financeiro na cidade de São Paulo", que se inseriu dentro do Projeto "Transformações do trabalho e ação sindical no setor financeiro", no qual a autora deste estudo também foi participante.

A pesquisa contou com a leitura e análise de diversos tipos de materiais de comunicação institucional disponíveis, tanto impressos como virtuais, do $\operatorname{Banco} \Delta$.

O sindicato profissional da categoria, sediado em São Paulo, se constituiu como outra fonte de pesquisa. Além do site disponível na internet, a entidade possui um acervo documental, o CEDOC - Centro de Documentação e Memória, nele há diversas publicações disponíveis, dentre elas: Folhas Bancárias, boletins sindicais específicos do banco pesquisado, fotos e materiais de campanhas diversas.

A revisão bibliográfica também se constituiu como parte deste processo de investigação. Ela abrangeu uma seleção das produções que envolvem as análises sobre bancos e bancários.

Nesta sistematização, que envolveu diversas abordagens, foram relacionados aspectos do processo social em seu âmbito micro e macro, pois como defende Mills (1969b), as questões levantadas pelo pesquisador podem transcender a vivência do indivíduo e de sua vida particular. Por meio da imaginação sociológica, deve-se buscar 
aquilo que possa ser "assunto público", compreendendo o cenário histórico mais amplo em termos de seu significado na vida dos indivíduos.

Para Mills (1969b) a principal tarefa do cientista social é deixar claro os elementos de inquietação e indiferença contemporâneos. Sobre esse espírito, investigaremos o universo da grande corporação escolhida.

A estrutura desta tese se divide em duas partes. A primeira parte visa situar o macro contexto econômico, político e cultural no qual o objeto deste estudo se insere e é influenciado. Serão posteriormente destacados os principais pilares que sustentam as reestruturações produtivas que aconteceram de modo contínuo ao longo das últimas décadas. Buscaremos, desta forma, contribuir com uma visão mais atualizada das estratégias de negócio e respectiva configuração do setor bancário brasileiro. A segunda parte, a qual reservaremos maior empenho, se concentrará nos resultados do estudo sobre o refinamento das formas de racionalização do processo de trabalho, dando ênfase às influências das novas tecnologias e os respectivos meios de controle. Os elementos que estruturam o modelo de gestão na grande corporação bancária e sua relação direta com o cotidiano de trabalho serão analisados a partir da cultura organizacional e da implantação de políticas internas calcadas na gestão de resultados no curto prazo.

Os capítulos desta tese se dividem da seguinte forma:

Parte I

O primeiro capítulo traz à tona considerações sobre o contexto mais amplo onde se insere nosso objeto de análise. Busca-se situar os significados do capitalismo contemporâneo hegemonizado pelas finanças e como isso colocou em questão o padrão fordista-keynesiano, fazendo emergir um novo padrão que não apenas se consolida pelo viés econômico, mas é essencialmente cultural, construído pela ação dos principais agentes articulados na cena internacional. Partindo deste contexto, tentaremos relacionar um conjunto de significados políticos, econômicos e culturais que dão sustentação à lógica do curto prazo e consequentemente ao paradigma flexível.

O segundo capítulo busca primeiramente conceituar o trabalho bancário. $\mathrm{Na}$ sequência são reunidos dados e informações que nos permitem ter uma cartografia do setor em nosso país nas últimas décadas. Destacamos aspectos relevantes de sua estratégia operacional e consequentemente das reestruturações produtivas mais recentes. Para tanto, são apontados os pilares que compõem o alicerce destas mudanças, a saber: 
a) fusões, aquisições e privatizações; b) formação de rede; c) terceirização; d) difusão tecnológica. Em maior profundidade, serão analisados os dois últimos aspectos pela possibilidade de relacioná-los mais diretamente ao cotidiano do trabalho, pelo papel que exercem na reconfiguração das relações sociais, econômicas e políticas do setor.

\section{Parte II}

O terceiro capítulo recupera e analisa elementos do processo produtivo bancário, que nos ajudam a situar como tem se configurado o refinamento das formas de racionalização do trabalho no setor. Nesse sentido, inicialmente, faremos uma breve abordagem sobre a influência dos modelos de organização do trabalho no setor bancário. Nosso estudo se aprofundará no papel atribuído às inovações tecnológicas e na relação direta que exercem sobre as novas formas de controle no ambiente laboral, mas ainda buscamos demonstrar como outras formas diretas e indiretas de controle estão presentes neste cotidiano. Diante disso, será analisada a perspectiva de atuar com autonomia e criatividade nessas circunstâncias. Destacaremos, também, como os novos dispositivos tecnológicos aprofundaram os controles proporcionando a elevação de indicadores de produtividade.

O quarto capítulo abrange uma análise sobre a dinâmica organizacional, trazendo para o centro do debate os principais eixos que estruturam a vida de mulheres e homens no ambiente corporativo. Inicialmente, fazemos uma abordagem sobre a própria cultura organizacional, observando como é estruturado o discurso institucional, conectando micro e macro espaço. As diretrizes que compõem a ação política da área de Recursos Humanos, responsável pela regularidade da vida social no interior do banco estudado e pela "educação corporativa", são analisadas tendo como ponto de partida a verificação das políticas de participação e adesão dos trabalhadores. Posteriormente nosso interesse se concentra na apreensão da relação que alinhava indivíduo, grupo e sociabilidade, dentro desse contexto. Por fim, abordamos as perspectivas dos trabalhadores quanto à carreira.

O quinto capítulo explicita como o principal viés do paradigma flexível no universo bancário, a lógica do curto prazo, se expressa na pressão direta exercida sobre os trabalhadores quando submetidos a programas de gestão por resultados e a processos de avaliação contínuos na instituição pesquisada. Apresentamos qual o perfil requerido pelas grandes corporações, estabelecendo uma mediação com a percepção dos trabalhadores sobre o que na prática define o "bom bancário". Finalizamos apontando 
alguns dos reflexos indesejáveis à saúde dos trabalhadores, provocados a partir das disjuntivas vividas no ambiente corporativo e quais as respostas que têm sido construídas nesse cenário. 


\section{PARTE I - O SETOR BANCÁRIO DIANTE DAS PRESSÕES COMPETITIVAS E A LÓGICA DO CURTO PRAZO}

\section{Capítulo 1 - Breves considerações sobre a transição do paradigma fordista- keynesiano para a acumulação flexível}

A transição do padrão de acumulação capitalista fordista-keynesiano para acumulação flexível, de acordo com Harvey (1992), mudou os usos e significados do espaço e do tempo, sendo estes submetidos a um efeito de compressão que se refletiu sobre as práticas político-econômicas, o equilíbrio do poder de classes, bem como sobre a vida sociocultural.

O modelo de produção flexível ${ }^{8}$ se deu como caminho para superar a crise dos anos 1970 nos países de capitalismo desenvolvido. A implementação de novas formas de produção, aliada às inovações tecnológicas, possibilitaram a aceleração do tempo de giro do capital em qualquer local do globo e no menor tempo possível, restabelecendo margens de lucro esperadas pelos investidores.

Harvey (1992) buscou ainda retratar as mudanças de paradigma de acumulação do capital destacando que não se trata apenas de um processo econômico, mas também de um processo culturalmente orientado. O novo modo de produzir conduz a uma nova forma de consumir, igualmente mais acelerada, com base em necessidades criadas, de acordo com expectativas pré-concebidas. Esta produção cultural, orientada por símbolos, foi impulsionada e mantida pelo conjunto de agentes da mídia no qual a publicidade passa a assumir um papel integrador. Para o autor, o consumo de massa ultrapassou os bens físicos, materiais, e avançou para os serviços mais diversos, sendo que ambos passaram a ter prazos de uso menores e mais efêmeros.

Os horizontes temporais e espaciais das corporações em termos de implementação de estratégias e relação com o mercado se estreitaram, sobretudo diante das facilidades da comunicação via satélite. O sistema bancário, por exemplo, criou condições para que o dinheiro circulasse com mais rapidez, haja vista os avanços tecnológicos que possibilitam seu trâmite em múltiplas formas por meio da difusão do uso de cartões de crédito e débito e dos bancos eletrônicos operando on-line e real time, ou seja, colocou-se a possibilidade de realizar transações financeiras em qualquer lugar

\footnotetext{
${ }^{8}$ Harvey (1992) chamou de "acumulação flexível” a reestruturação do capitalismo que ocorreu na década de 1970 nos países desenvolvidos. A noção de flexível se contrapõe àquilo que na análise do autor se traduzia pela rigidez na forma de gerir os capitais, as mercadorias e a própria força de trabalho do período em que predominou o regime fordista concomitantemente às inovações que surgiram no campo da organização do trabalho e novas tecnologias.
} 
do mundo a partir dos sofisticados sistemas de informações e telecomunicações já disponíveis desde o final do século XX.

Na cena mundial, durante os anos 1980 e 1990, diversos países passaram por processos de reestruturação produtiva, alterando substancialmente as relações de trabalho, enquanto paralelamente se ajustava a forma de o Estado intervir na sociedade, fazendo emergir no campo da política-econômica aquilo que se definiu por neoliberalismo (ANDERSON, 1995).

Em termos simplificados, neoliberalismo significa uma releitura contemporânea do chamado liberalismo, forma política em que o paradigma econômico capitalista é menos regulado permitindo que o mercado atue mais livremente a exemplo do que predominou entre o final do século XIX e o início do século XX. Período em que essa doutrina econômica, marcada pela expressão laissez-faire, assegurou ao capital operar em regime de livre concorrência, com o mínimo de restrições por parte do Estado e demais agentes.

Keynes em 1926, ao analisar a economia baseada na livre concorrência e pouco regulada, afirmava que os interesses privados e sociais não eram harmoniosos (SZMRECSÁNYI, 1984). O autor criticou a ausência de contrapontos fortes sobre a tese do laissez-faire defendida pelos economistas de sua época, e apesar de reconhecer as teses dissonantes existentes, vinculadas ao protecionismo e ao socialismo marxista, tratava-as como inconsistentes. $\mathrm{O}$ economista foi o arquiteto das ideias que levaram ao Welfare State, o Estado de Bem-Estar Social, nos países capitalistas desenvolvidos.

De acordo com Hobsbawm (1995), a revisão do modelo liberal foi influenciada por um conjunto de fatores. Tal revisão tornou-se producente e foi conduzida desde as primeiras décadas do século $\mathrm{XX}$ por aqueles que queriam preservar o próprio sistema capitalista, uma vez que rondava a inspiração ameaçadora vinculada à revolução de 1917 na Rússia.

Após duas guerras mundiais e o crash da Bolsa de Nova York, forjou-se um consenso em torno da criação e sustentação do Welfare State. Nessa ocasião, o papel do Estado foi fundamental para implementar políticas de longo prazo com o objetivo de manter pleno emprego, buscar soluções para modernizar as economias dos países e, ainda que não fosse declarado, conter o avanço do comunismo. A adoção de tais diretrizes fez ruir a dominância do pensamento econômico vinculado à velha ortodoxia inspirada no laissez faire (HOBSBAWM, 1995). 
Ressalva-se, como apontou Pochmann (2004), que a presença dos elementos que caracterizavam o Estado de Bem-Estar Social foi uma excepcionalidade das economias que constituem o centro do capitalismo mundial, ou seja, uma minoria de nações. A motivação de natureza socialdemocrata não apenas disponibilizou serviços sociais como educação e saúde, além de promover distribuição de renda, mas fundamentalmente "retirou das forças de mercado a determinação exclusiva da expansão econômica e da gestão sobre a força de trabalho" (POCHMANN, 2004, p. 4).

Os "anos dourados", nome pelo qual ficou conhecido o período do Welfare State, começaram a ruir juntamente ao fim do Acordo de Bretton Woods, em 1971 (HOBSBAWM,1995). Tal acordo, assinado no ano de 1944 à época do fim da segunda guerra, previa um gerenciamento econômico internacional. Tratava-se de um marco regulatório que visava controlar as relações comerciais e financeiras.

Com a liberalização das taxas de câmbio em 1973, reflexo direto do fím do Acordo de Bretton Woods, a globalização financeira deu um salto. Os movimentos especulativos de capital ganharam força, e em diversos países foram adotadas medidas liberalizantes e de desregulamentação do sistema financeiro que desencadearam movimentos abruptos de capitais (CARNEIRO, 2007; BRESSER-PEREIRA, 2010).

Entretanto, diante das chamadas "falhas de mercado", os economistas do mainstream, vinculados ao FMI - Fundo Monetário Internacional, reconheciam que era preciso haver algum controle. Assim, em 1975, surge o Comitê da Basileia que, visando dar confiabilidade ao sistema financeiro, orientou as nações a adotarem um conjunto de regras de supervisão bancária para atuar no mercado (FREITAS; PRATES, 2002). Em 1988, surgia o primeiro acordo, o chamado Basileia I. Contudo, tornou-se amplamente criticado por não tratar com rigor necessário o crédito interbancário internacional de curto prazo, um dos motivos principais das crises vivenciadas nos próximos anos.

Diversas crises financeiras ${ }^{9}$ compuseram o cenário econômico da década de 1990 e dos anos posteriores. Elas estão relacionadas ao desmantelamento de mecanismos de proteção, antes existentes nos mercados, para que as finanças mundiais pudessem operar com mais liberdade (GONZALEZ, 2007).

O sistema financeiro internacional passou a se ancorar em novos instrumentos de rentabilidade, dentre eles destacamos aqueles que proporcionam alta liquidez: a

\footnotetext{
${ }^{9}$ Gonzalez (2007) menciona as seguintes crises: crise econômica do México (1994-1995); crise financeira asiática, que atingiu diversos países como Tailândia, Indonésia e Coreia do Sul (1997-1998); crise financeira da Rússia (1998); crise econômica da Argentina (2001-2002).
} 
securitização de fundos de recebíveis ${ }^{10}$ e as operações com derivativos. ${ }^{11}$ Operados sob elevados riscos, ambos servem a lógica do curto prazo (GRÜN, 2004a, 2004b; CARNEIRO; MARCOLINO, 2010).

Os fundos de recebíveis permitem que os títulos sejam "securitizados" e repassados em lote para particulares ou empresas, devendo aceitar um risco que se torna uma espécie de média de riscos desse gênero de operação. Em contrapartida, farão jus a um rendimento maior. (GRÜN, 2004b, p. 18)

Como explica Carneiro (2007, p. 12), o "custo de oportunidade", basicamente associado as em atrativas taxas de juros das novas operações financeiras, favorece o capital de tipo rentista em detrimento do capital produtivo, confirmando a predominante plutocracia financeira no capitalismo contemporâneo.

A predominância da esfera financeira em um capitalismo menos regulado, quando comparado ao período fordista-keynesiano, influencia diretamente o processo de acumulação via produção, impondo sobre esta uma nova forma de organização e valorização do capital que passa a ter como função objetiva a maximização do valor acionário das empresas paralelamente à busca de maior liquidez (CARNEIRO, 2010; LAPYDA, 2011). Estas características buscam aproximar as duas formas de investimento, a financeira e a produtiva, reduzindo-as "a um fluxo de caixa peculiar" com padrões de rentabilidade semelhantes, o que nem sempre pode se concretizar (CARNEIRO, 2010, p. 39).

A internacionalização financeira acompanhou a transnacionalização de empresas do setor produtivo, com sede nos países desenvolvidos, que buscavam alternativas à crise que se instalava nos anos 1980. Em meio a mercados menos regulados, o capital financeiro imprimiu um novo ritmo à dinâmica econômica dos países por meio do alto retorno e da rentabilidade de suas operações, as quais chegaram a ofuscar diversos setores produtivos.

A perspectiva de aplicar em ações de empresas de capital aberto ganhou novo impulso quando houve a valorização do poder dos administradores profissionalizados. Para dar mais segurança aos investidores e acionistas, era preciso retirar a exclusividade

\footnotetext{
${ }^{10}$ Grün (2004b) cita o exemplo de títulos de dívidas diversas transformados em fundos de aplicação de risco, que consistem em vantagens aparentes para quem recebe o crédito - o dinheiro antecipado das dívidas que formaram o fundo - como para quem compra as cotas do fundo por meio de sua remuneração.

${ }^{11}$ Segundo Sandroni (1999), "derivativos são operações financeiras cujo valor de negociação deriva (daí o nome derivativos) de outros ativos, denominados ativos-objeto, com a finalidade de assumir, limitar ou transferir riscos [...]. A utilização ampliada dos derivativos no mundo todo tem gerado uma preocupação crescente por parte dos bancos centrais, autoridades monetárias e de supervisão bancária e técnica, dada a dificuldade de avaliação de sua dimensão e suas consequências em termos de riscos, já que as atividades financeiras se tornam cada vez mais globalizadas".
} 
do poder administrativo e financeiro dos proprietários. O esquema operativo reconhecido pela forma holding serviu para fortalecer a perspectiva de governabilidade e transparência do negócio, influenciando diretamente a difusão da cultura das "boas" práticas corporativas associadas a um maior controle e proteção dos investidores que almejavam receber seus dividendos.

Esta expectativa de retorno dos investidores influenciou diretamente a administração interna nas empresas de capital aberto, sobretudo aquelas com atuação internacional, pressionando-as para atingir um índice de eficiência - relação entre despesas e receitas - que demonstrasse a otimização de resultados financeiros das instituições, tornando-as atraente aos olhos dos acionistas.

Como analisam Dias e Zilbovicius (2009), estas alterações de âmbito macro levaram a uma "financeirização da produção", a qual não se constituiu em avanços às condições de trabalho, ao contrário, fizeram emergir novos elementos de constrangimento aos trabalhadores. As novas maneiras de organizar e se relacionar com o trabalho foram forjadas em oposição ao paradigma fordista-keynesiano, sendo enaltecidas por determinados atores sociais pelas qualidades que supostamente engendravam associadas à noção de flexibilização; autonomia; multifuncionalidade; fim da estabilidade, para citar alguns exemplos.

Os administradores e consequentemente os trabalhadores foram submetidos aos interesses dos acionistas que ditam, principalmente por meios dos investidores institucionais, detentores de grande capitais, as normas de funcionamento das empresas, garantindo o retorno e a rentabilidade esperada. Assim, desta orientação políticaeconômica revertem-se pressões diretas sobre os trabalhadores em termos de busca por maior produtividade, rebaixamento de salários e flexibilização dos contratos (LAPYTA, 2011).

Superadas as barreiras espaciais, com ajuda das novas tecnologias, é a efemeridade do tempo juntamente com os seus significados práticos que nos parece uma das vertentes mais fortes do novo estilo de vida contemporâneo. A flexibilidade, que está na financeirização da economia e nos modos de trabalho, torna-se uma característica cultural marcante em nossas sociedades e é válida para todas as esferas da vida.

Bauman (2009) em sua abordagem sobre o modo de ser na vida moderna usa a expressão "vida líquida". Para o autor, os membros de uma sociedade agem sob condições que envelhecem rapidamente e se tornam obsoletas, trata-se de uma vida em 
constante incerteza e com uma sucessão de reinícios. A lógica do curto prazo está presente nas corporações, nos modos de operar economicamente, na escola, no amor, ou seja, está na vida cotidiana. A análise crítica e pessimista do autor sobre o modo de ser nas sociedades modernas se expressa ainda na seguinte passagem:

A vida da sociedade líquido-moderna é uma versão perniciosa da dança das cadeiras jogada para valer. $\mathrm{O}$ verdadeiro prêmio nessa competição é a garantia (temporária) de ser excluído das fileiras dos destruídos e evitar ser jogado no lixo. E como a competição se torna global, a corrida agora se dá em uma pista também global. (BAUMAN, 2009, p. 10)

A cultura do novo capitalismo, segundo Sennett (2011), se estrutura em contraste com a cultura do capitalismo social. $\mathrm{O}$ modelo integrador que caracterizava o período anterior aos anos 1970 nas grandes empresas dos países considerados desenvolvidos perde espaço juntamente à queda do poder gerencial para o acionário que implicou em decisões e resultados a curto prazo.

Naturalmente, não há nada de novo nesta busca de abrigo ou lucro fáceis para o dinheiro. Mas o efeito cumulativo de tão grande liberação de capitais e da pressão por resultados de curto prazo transformou a estrutura das instituições mais atrativas para os investidores recém-investidos de poder. Enormes pressões foram exercidas sobre as empresas, para que se fizessem belas aos olhos do primeiro voyeur que passasse; a beleza institucional consistia em demonstrar sinais de mudança e flexibilidade internas, dando pinta de empresa dinâmica, ainda que tivesse funcionado perfeitamente bem na época da estabilidade. (SENNET, 2011, p. 44, grifo do original)

Sennett (2011), tomando como ponto de partida as comparações entre as burocracias de dois tempos marcados na história do capitalismo, antes e pós anos 1970, quando houve a crise do modelo fordista-keynesiano, explica que as corporações trataram de se reformular para atender a uma nova clientela internacional de investidores que estavam mais preocupados em obter lucros a curto prazo, derivados dos preços de ações, do que lucros a longo prazo obtidos com dividendos vindos do setor produtivo.

O modelo fordista foi retratado como um modelo de inclusão social, fruto do acordo tácito entre capital produtivo e trabalho. Nesse contexto, o tempo racionalizado no longo prazo organizava a vida social, pois por meio dele as narrativas de vida dos indivíduos podiam se estruturar. Segundo Sennett (2011), podia-se definir como seriam as etapas de uma carreira ou como seria o planejamento financeiro pessoal com finalidade de adquirir segurança e conforto material. Esse modo de ser, orientado a 
partir da vivência no interior de uma organização, dava sentido a um tipo de "capitalismo social" que requeria, paralelamente, outra subjetividade diferente da que emerge no paradigma flexível. Como aponta o autor, no novo estilo de vida a insegurança não apenas é uma consequência, é também uma diretriz ativada.

Assim, no novo capitalismo os indivíduos enfrentam a perspectiva de ficar à deriva. A linha divisória entre o velho e o novo paradigma cultural fica explicitada pelas relações menos estáveis, ou seja, mais incertas.

As grandes corporações do setor bancário e respectivamente os trabalhadores a elas vinculados, seja por qual laço for, não escapam às pressões competitivas derivadas da financeirização que se situam politica, social e culturalmente imbricadas em âmbito nacional e internacional.

\subsection{O campo das finanças: dominância política e cultural}

Para Grün (2004b), que se apoiou no pensamento de Bourdieu (1989), ${ }^{12}$ o espaço das finanças é um campo de poder, e este é o lócus social no qual determinado polo ou polos dominantes geram formas ou até regras de convivência. Um exemplo claro seria o léxico das finanças e como ele se constitui em uma espécie de língua franca das elites contemporâneas. $\mathrm{O}$ autor aponta como o mundo das finanças interfere na construção social da realidade, sobretudo interferindo e disputando o campo simbólico, que em outras palavras pode ser pensado como campo cultural.

$\mathrm{Na}$ cena mundial, os operadores do sistema financeiro, dada as facilidades tecnológicas da virtualização e da comunicação em rede, conseguem mimetizar seus procedimentos. As agências de avaliação de risco se tornaram corporações internacionais influentes e são porta vozes, juntamente com outras organizações igualmente de âmbito internacional, da padronização das diretrizes e posições que o "mercado" considera adequado, interferindo claramente na cena política, como se pode citar a elevação do "risco Brasil" na ocasião da eleição presidencial em 2002 em virtude da projeção de vitória do candidato Lula. Posições como esta atingem diretamente a expectativa econômica dos atores sociais, podendo alterar a disposição de investimentos e levar à perda de confiança generalizada.

\footnotetext{
${ }^{12}$ BOURDIEU, P. La noblesse d'état: grandes écoles et esprit de corps. Paris: Les Éditions de Minuit, 1989.
} 
O "mercado" é representado como um ente que possui sentimentos até mesmo por aqueles que pretensamente defendem a razão e objetividade em suas análises como os fazem os analistas econômicos e os atuais "engenheiros das finanças".

Os bancos brasileiros recrutam com facilidade pessoas que tenham formação acadêmica em engenharia, dada a reconhecida capacidade de abstração no desenvolvimento de cálculos complexos. Entretanto, termos com conotação emocional são largamente utilizados por economistas, consultores, dirigentes do setor financeiro, acadêmicos e mídia em geral, para tornar compreensível a visão hegemônica das finanças sobre aquilo que se define genericamente de "mercado". Não à toa, nos deparamos comumente com as expressões: "nervosismo no mercado"; "alterações de humor no mercado financeiro"; "euforia no mercado". ${ }^{3}$

De acordo com Grün (2010, p. 270):

a "racionalidade econômica" é um produto intelectual engendrado pelas disputas sociais e se altera no mesmo sentido que suas linhas de força, produzindo enquadramentos cognitivos específicos, nos conduzindo a conferir racionalidade a determinadas proposições e condutas e a refutar outras.

Diante desta tendência de produção de clima cultural ressaltada por Grün (2005), a sociedade tem reverenciado o "mercado" e teme os "efeitos sistêmicos" de uma eventual crise financeira sair do controle, consentindo em contribuir com as operações de salvamento para os problemas derivados das engenharias financeiras de alto risco praticadas no modelo neoliberal, visto como mais competitivo e produtivo, em contraposição ao modelo de fundamento keynesiano com papel mais decisivo do Estado na regulação socioeconômica.

Os preceitos da chamada "governança corporativa" surgiram para amparar as políticas-econômicas no contexto histórico marcado pela reorganização capitalista póscrise dos anos 1970, em um cenário que por si só se apresentava instável, relacionado à volatilidade dos capitais, elevados riscos de crises e quebras econômicas.

De acordo com Grün (2004a), a "boa" governança corporativa foi a solução apresentada para resolver o problema da capitalização das empresas e reencontrar o caminho da virtude do capitalismo na crise dos anos 1970 em países desenvolvidos. As "boas" práticas visaram criar ambiente de maior segurança por meio da instauração de transparência das informações e do respeito aos acionistas minoritários.

\footnotetext{
${ }^{13}$ Expressões retiradas de manchetes de matérias do jornal $O$ Estado de S. Paulo respectivamente em tais datas: 23-07-2002; 23-092002; 06-04-2003.
} 
Ainda neste mesmo propósito, Grinblatt e Titman (2005) defendem que havia uma preocupação para afastar os interesses oportunistas dos administradores ou interesses particulares das famílias controladoras de grandes empresas. As medidas de "boa" governança visavam diminuir a exposição ao risco do negócio e levavam a valorização dos ativos das empresas, melhorando assim sua imagem.

Freitas e Prates (2002), ao tratar das crises financeiras vivenciadas na década de 1990, estabelecem um contraponto mencionando que as "boas" práticas, amplamente difundidas à época, focadas na transparência das informações, não são suficientes para atingir as causas dos desastres econômicos relacionados à "arquitetura financeira internacional" que segue em vigor, cujas fragilidades são expostas pela excessiva liberdade do fluxo de capitais e em função dos altos riscos assumidos.

A doutrina econômica que tem predominado no ambiente das finanças, professada por seus representantes diretos e indiretos, é embasada em teses estruturantes, como austeridade e autorregulação. Assim, por exemplo, quando se observa a elevação do déficit público, são defendidas políticas rigorosas de controle de gastos, que normalmente recaem sobre os serviços públicos usados pelos trabalhadores, enquanto a defesa de autorregulação do mercado financeiro se faz com base na premissa da transparência e fortalecimento da livre concorrência que, a princípio abriria espaço para formas de acompanhamento e controle das "partes envolvidas".

No jargão administrativo, as "partes envolvidas" e interessadas nas operações de uma empresa são denominadas stakeholders. ${ }^{14} \mathrm{O}$ conceito inclui acionistas, investidores, empregados, fornecedores, clientes, governos, ONGs e comunidade. O conjunto de ideias que visam estabelecer artificialmente uma simetria de representação entre as partes e, sobretudo, dar mais controle ao capitalismo menos regulado é denominado "governança corporativa".

$\mathrm{Na}$ tentativa de dissimular o conflito, trabalhadores foram denominados de "colaboradores" e, ainda que aconteça em menor grau, puderam se transformar em acionistas ao receberem cotas como prêmios por desempenho, substituindo parte dos pagamentos diretos em forma de dinheiro. A relação com os stakeholders é marcada pelo alto teor propagandístico e está aliada habitualmente às noções de responsabilidade social e sustentabilidade, amplamente divulgadas pelas instituições do sistema financeiro.

\footnotetext{
${ }^{14}$ Conforme informações disponíveis em: www.ibgc.org.br. Acesso em: dez. 2013.
} 
Como observou Grün (2010), a doxa ${ }^{15}$ econômica é propagada pelos agentes defensores do mainstream. As agências de rating, economistas e comentaristas das academias e da mídia em diversos casos emprestam sua legitimidade social apontando a força da disputa simbólica. O desenvolvimento do arcabouço teórico visto sobre os temas da governança corporativa, responsabilidade social, sustentabilidade, autorregulação e regras de austeridade iluminam a "hegemonia cultural das finanças" à medida que "produzem e reforçam convenções cognitivas que dão consistência à dominação" (GRÜN, 2010:264) das grandes corporações no cenário internacional, cada vez mais representadas pelo poder da marca e de seu capital financeiro.

Harvey (1992) aponta que a volatilidade e a efemeridade que circunda todos os aspectos do modo de vida das pessoas no capitalismo nas últimas décadas implica, em última análise, na mudança mental de como as pessoas veem o mundo e como se inserem nele. A partir disso, ajustando-se a esta transformação, elas reorganizam os próprios valores. A "condição pós-moderna", para o autor, significa amiúde as mudanças culturais vivenciadas no capitalismo flexível que se refletem na modificação no próprio modo de vida das pessoas com a generalização de novas práticas igualmente mais flexíveis. Trata-se de uma lógica cultural que tem de lidar com o desafio da aceleração do tempo de giro do capital, concomitantemente ao cancelamento de valores tradicionais e historicamente definidos no período pós-guerra.

A hegemonia das finanças se traduz no cotidiano pela capacidade de conferir sentido a suas práticas, mesmo quando estas são contraditórias. Trata-se de dominância produzida culturalmente à medida que consegue embutir pressupostos comportamentais, tornando tácito o acordo sobre o funcionamento econômico das sociedades.

As grandes corporações bancárias criam e padronizam valores e comportamentos que extrapolam seus muros, influenciando a sociedade de várias formas. Algumas das "partes envolvidas" no processo de interação com as grandes corporações são expostas ou mesmo forçadas indiretamente a adotar o "padrão ético corporativo". Os trabalhadores e fornecedores - empresas terceirizadas - são obrigados a assinar e concordar com o Código de Ética construído pelas grandes corporações. Os clientes recebem informações, por meio dos veículos de comunicação institucional, sobre os propósitos da instituição e tomam contato com seus valores e princípios. Os

\footnotetext{
${ }^{15}$ De acordo com Bourdieu (2001, p. 25), doxa trata-se de um "conjunto de crenças fundamentais que nem sequer precisam se afirmar sob a forma de um dogma explícito e consciente em si mesmo". Para o autor "cada universo erudito possui sua doxa específica, conjunto de pressupostos inseparavelmente cognitivos e avaliativos cuja aceitação é inerente à própria pertinência" (ibid. p. 122). É, ainda como explica, uma posição, um conhecimento construído por pares, que arbitrariamente tem o potencial de se arraigar profundamente nas estruturas das sociedades.
} 
acionistas, por meio das ações de governança corporativa, exigem e reforçam a difusão de tais valores, ao mesmo tempo que esperam que as práticas de "boa" governança se traduzam em indicadores de resultados positivos.

Este ambiente cultural gera "externalidades", ou seja, na visão dos executivos do setor, trata-se da criação de valor não apenas para a própria empresa, mas para a sociedade, pois abrange feitos que diferem da sua atividade econômica tradicional. Nessa perspectiva, tais executivos visam demonstrar propósitos maiores que os interesses diretamente relacionados à obtenção de lucro, construindo um sentido universal às suas ações para justificar sua relevância social e alavancar o valor de sua imagem que se tornou um ativo intangível ${ }^{16}$ negociado a preços elevados no mercado graças ao seu potencial multiplicador de negócios.

Segundo Milone (2004), o valor das empresas no mercado financeiro está cada vez menos influenciado pelos ativos tangíveis ${ }^{17}$ que ela possui. $\mathrm{O}$ valor da marca, como um ativo intangível, é responsável pela geração de valor adicionado que coloca as grandes empresas em posição de liderança na disputa internacional capitalista contemporânea. As empresas com marcas fortes obtiveram performances superiores no mercado acionário. Os consumidores simpatizantes da marca e do status dela decorrente perpetuam os resultados financeiros dos acionistas.

Kayo (et al. 2006) reforçam a posição de Milone (2004) e destacam em sua pesquisa que o valor de mercado de uma empresa, medido pelo preço de suas ações nas Bolsas de Valores, cresceu seis vezes mais do que o valor contábil entre a década de 1980 e 2000

Em nível micro, a "cultura corporativa" cumpre o papel de orientar comportamentos e tornar aceitáveis as relações sociais que derivam do processo de trabalho marcado pelas inúmeras pressões que recaem sobre os trabalhadores, mas que também acabam atingindo os clientes das instituições.

As mudanças ocorridas no sistema financeiro brasileiro, desde a década de 1990, e mantidas nas décadas subsequentes, influenciadas pelo padrão de acumulação capitalista internacional financeirizado, refletiram decisões e prioridades que se fizeram orientadas sob o princípio da maior criação de valor e retorno aos seus acionistas no menor prazo.

\footnotetext{
16 Segundo Sandroni (1999), os ativos intangíveis designam valores que não têm uma representação física imediata. São "intangíveis" do ponto de vista contábil, por exemplo, as patentes, as franquias, as marcas, os direitos autorais etc.

${ }^{17}$ Segundo Sandroni (ibid,), os ativos tangíveis são aqueles representados pela propriedade de edifícios, máquinas, equipamentos e estoques.
} 
Nesse sentido, os bancos ampliaram a atuação em rede; realizaram fusões e aquisições; terceirizaram atividades; expandiram-se no mercado nacional e internacional; adotaram estratégias de segmentação de clientes e mantiveram elevados investimentos em tecnologia. A busca por maior produtividade levou ainda à implementação de ajustes nas formas de organizar e gerir a força de trabalho. Os trabalhadores foram, por consequência, submetidos a exigências e controles mais rigorosos, quando não diretamente precarizados em sua relação de emprego. É o que propomos apurar no próximo capítulo. 


\section{Capítulo 2 - A REESTRUTURAÇÃo PRODUTIVA BANCÁRIA NA VIRADA DO SÉCULO}

\subsection{A especificidade do trabalho bancário}

O trabalho bancário se insere no macro setor de serviços e mantêm pela natureza da atividade uma inter-relação direta com clientes. O papel social de um banco é realizar a intermediação financeira entre diferentes agentes na sociedade. Por se tratar de um serviço de interesse público, os bancos que não são públicos recebem a autorização de órgão atrelado ao Governo Federal, o Banco Central, para operar no mercado. O principal insumo do setor, o dinheiro, dada todas as inovações tecnológicas possíveis na atualidade, tem sua forma em papel, moedas ou cheques cada vez menos utilizada, ao passo que o meio virtual, que opera por transmissão de dados, é amplamente utilizado.

Assim, o fazer bancário se ancora no papel atribuído aos bancos na sociedade. Um banco é uma instituição que se insere em um sistema mais amplo denominado Sistema Financeiro Nacional, devendo cumprir as seguintes funções: a) rentabilizar as economias e poupanças das pessoas e empresas por meio do pagamento de juros; b) financiar o consumo e o investimento das pessoas e empresas cobrando para isso juros e comissões; c) realizar serviços de pagamentos e recebimentos também para seus clientes Pessoa Física ou Jurídica. Em síntese, uma instituição bancária atua como agente intermediário de recursos financeiros disponíveis na sociedade entre as esferas da produção, distribuição e consumo abrangendo dessa forma pessoas físicas e jurídicas. ${ }^{18}$

A manipulação e o controle, direto ou indireto, do dinheiro captado e emprestado pelos bancos é central no trabalho bancário. Ao final de cada expediente, determinadas posições contábeis se transformam em documentos que retratam todas as operações financeiras realizadas pelas instituições (ROMANELLI, 1978; BLASS, 1992).

Em pesquisa realizada em 1980, sobre o setor bancário, o Dieese (1980, p. 17) observava que

todo o produto a ser trabalhado, ou produto resultante do trabalho, nas empresas bancárias, se resume em papéis e números, ou melhor, papéis com números. Podemos dizer que essa é a sua "matériaprima". Para operar tal "matéria-prima", o processo de trabalho se

\footnotetext{
${ }^{18}$ Conforme informações disponibilizadas no site do BACEN: www.bcb.gov.br. Acesso em: nov. 2012.
} 
estrutura de acordo com as regras determinadas, havendo controle do desempenho dos trabalhadores envolvidos nesse processo, em vários pontos seguidos pelo fluxo de papéis.

Segnini (1988) explicou que no trabalho bancário a contabilidade, o registro numérico, ou ainda aquilo que era definido como modo escritural, eram realizados por milhares de pessoas, expressando assim, a forma da produção no setor.

Ainda sobre a compreensão e significado do trabalho bancário retratou Jinkings (1996):

A força de trabalho bancária realiza as operações necessárias à agilização do fluxo de capital em seu cotidiano. Manipulando símbolos de valor e efetuando registros contábeis, em um contexto de trabalho fragmentado, os bancários dificilmente apreendem em sua totalidade o significado de sua atividade [...] é a contabilidade, a transferência e a redistribuição desses valores e cifras (de propriedade alheia) que se dedica o bancário em sua rotina de trabalho (JINKINGS, 1996, p. 81).

As caracterizações do trabalho bancário, acima sintetizadas, guardam relação com o presente, mas será necessário ponderar as transformações que ocorreram permanentemente no setor, sobretudo aquelas vinculadas às TIs - Tecnologias da Informação.

Como Jinkings (1996, p. 18) apontava, com as mudanças organizacionais e tecnológicas implementadas na década de 1990, “a tradicional matéria-prima do trabalho bancário, o papel, vai sendo substituída cada vez mais rapidamente pelos dados armazenados e manipulados em sistemas eletrônicos, baseados em redes de computadores".

Essas mudanças atenderam às necessidades locais marcadas pela funcionalidade operacional em um país com amplas dimensões e foram relevantes para lidar com as novas diretrizes econômicas em voga no início da década de 1990, mas também responderam à conveniência de um modelo de sistema financeiro cada vez mais internacionalizado, com base na presença de bancos estrangeiros atuando no país e bancos nacionais atuando no exterior (MINELLA, 1988; ANGELO, 2007).

A composição do setor bancário no Brasil é demarcada pela participação de entes públicos, que do ponto de vista do volume de ativos representam 34\%, e dos bancos privados, 66\% em 2011 (BACEN, 2011). No interior dos bancos a divisão do trabalho ainda obedece a subdivisões entre as áreas administrativas e comerciais, sendo que esta última ganhou maior peso após a estratégia direcionada para venda de produtos 
e serviços ter sido priorizada, extrapolando a atividade de pagamentos e recebimentos que caracterizava fortemente o setor nos anos 1970 e 1980.

Os trabalhadores bancários, a exemplo dos trabalhadores de escritório, realizam atividades abstratas e racionalizadas submetidos ao controle de uma estrutura burocrática bastante rígida. A rotina diária conta com operações fragmentadas, sendo que o trabalho só se completa considerando a noção de "cadeia produtiva", ou seja, depois de cumpridas as diferentes etapas contidas em um longo processo integrado.

O processo de trabalho no interior das instituições bancárias é descentralizado, sendo distribuído pelas redes de agências e centros administrativos. As diversas etapas de trabalho contidas no fazer bancário perpassam por estas duas esferas. Trata-se de um trabalho realizado em cadeia, portador de muitas tarefas parceladas, no qual um completa o trabalho do outro.

Tomando por base os dados relativos ao $\operatorname{Banco} \Delta$, situamos que uma unidade de agência bancária pode, nos dias atuais, reunir de 5 a 50 bancários, a depender de seu porte. As de grande porte, caracterizadas por conter as diversas segmentações de clientes reunidas em um mesmo espaço físico, representam a minoria. Os centros administrativos concentram diversas áreas operacionais e, em menor grau, áreas comerciais do banco, nestes locais se encontram grandes volumes de trabalhadores, podendo aproximadamente reunir de 100 a 8.000. ${ }^{19}$ Para se ter como base o Banco $\Delta$, que atua como holding financeira, em nível nacional emprega 86 mil trabalhadores, destes aproximadamente $60 \%$ estão distribuídos pelas 3.967 agências, e 40\%, em 70 centros administrativos. ${ }^{20}$

O fluxo de trabalho nas agências tem dias de "pico", demarcados pelo calendário social diretamente relacionado à atividade econômica e comercial, sendo, por exemplo, do início do mês até o dia 10 e também os dias em que o movimento é maior no final do mês. Entretanto, se durante a década de 1980 a rotina de trabalho era marcada por momentos "intensos" e de "tranquilidade" espalhados no período do fluxo de trabalho mensal, durante a década de 1990 e, principalmente, a partir dos anos 2000, percebeu-se a intensificação do trabalho no cotidiano destes trabalhadores devido às políticas de cumprimento de metas.

As metas de produtividade nestes ambientes não dependem ou oscilam em função da sazonalidade da atividade econômica mensal, marcada por esses dias de

\footnotetext{
${ }^{19}$ Relatório de Gerencial Banco $\Delta 2014$

${ }^{20}$ Relatório de Gerencial Banco $\Delta 2014$.
} 
"pico". Elas são mensuradas pelo volume de atendimentos, venda de produtos e serviços, dentre outros itens que podem estar relacionados inclusive a indicadores de qualidade do atendimento.

Nas áreas administrativas, os dias ou horários de "pico" são determinados em função dos prazos diários, semanais e mensais ditados pelo Banco Central e outros prazos delimitados por outros agentes, como aqueles relacionados à cobrança de títulos a vencer ou fechamento de contrato para concessão de um empréstimo.

O processo de trabalho em uma empresa bancária não encerra seu ciclo nas agências, unidades menores e descentralizadas abertas ao público. Há um conjunto de outras tarefas que incluem planejamento, operacionalização, execução e controle, conformando em síntese uma imensa burocracia que viabiliza ações que abrangem o universo de clientes, agentes públicos e privados, pessoas físicas e jurídicas espalhados não apenas no Brasil, mas também no mundo financeiro, o qual está cada vez mais conectado e interligado.

Por certo, a atividade de vendas ganhou preponderância nos ambientes que mantêm contato com o público, incluindo, neste caso, unidades de trabalho como as centrais de teleatendimento, que além de darem suporte a uma série de burocracias antes realizadas nas próprias unidades físicas, agora realizam o atendimento remotamente, via telefone, acompanhando uma tendência que se observa em diversos ramos da economia. Nessas unidades, pode-se encontrar tantos serviços ativos, neste caso o trabalhador tem a iniciativa de ligar para o cliente, quanto serviços receptivos, pelos quais a relação se estabelece a partir da demanda do cliente que buscou atendimento por essa via. Em ambos os casos, há oferta de produtos, ou seja, busca-se efetivar vendas, a diferença fundamental é que a primeira modalidade é exclusiva enquanto a segunda, a venda, já se torna consequência do contato estabelecido, da oportunidade criada.

O crédito, atividade essencial de uma instituição financeira, é emblemático para expressar como podem ser ofertados os serviços na atualidade. Diante das facilidades tecnológicas e dos limites pré-aprovados, a efetivação da operação de contratação pode ser feita por caixa eletrônico ou internet (PC e smartphones). Também são populares os créditos disponíveis nos cartões de crédito e empréstimos consignados pelos quais não é necessário ser correntista de banco para obtê-los.

Os produtos e serviços bancários, inseridos na estratégia de expansão dos negócios, tornam-se cada vez mais interligados a outros ramos da economia como o 
comércio e telecomunicações, alterando a própria organização e divisão do trabalho bancário como veremos mais adiante com as práticas de subcontratação.

\subsection{Estratégias corporativas bancárias no contexto brasileiro}

A política econômica do setor bancário no Brasil atua em sintonia com as demais políticas financeiras implementadas em escala global. Os efeitos locais derivados dessas políticas remontam a aspectos da lógica do curto prazo (GRÜN, 2004a, 2004b; SENNETT, 2011), marcada exemplarmente pela reestruturação das grandes corporações que objetivavam garantir retorno financeiro aos seus acionistas e, por isso, promoveram alterações nas relações entre trabalhadores, empresas e clientes.

As empresas, para conviverem com as "pressões do capital impaciente" (SENNETT, 2011, p. 44), promoveram reengenharias e buscaram se reinventar para se manter no mercado. As inovações tecnológicas, sobretudo vinculadas à comunicação e informação, tiveram papel crucial na mudança dos procedimentos internos, no ajuste de normas e orientações nas organizações.

Seria inadequado afirmar que houve ou há "uma" reestruturação produtiva bancária. Em verdade, são vários processos contínuos e somados que constituem esta ideia abrangente de reestruturação produtiva. Em outras palavras, referem-se às mudanças mais gerais que o setor vem passando ao longo de sua trajetória.

A história dos bancos no país demonstra que eles obtiveram altos lucros derivados das expressivas taxas de inflação, observadas desde a década de 1980 até a implantação do Plano Real, em 1994. Tendo por base a experiência administrativa vivenciada neste período após a aplicação de diversos Planos Econômicos - Cruzado I e II, Bresser e Verão -, que tinham como objetivo dar resposta à estagnação econômica, forte desemprego e hiperinflação, o setor promoveu rearranjos internos para lidar com as mudanças na política econômica doméstica.

As mudanças no cenário econômico nacional, impulsionadas também por outro fator, não menos expressivo, como a abertura econômico-financeira do início dos anos 1990, impeliram as instituições a reorganizar suas estruturas operacionais e a reformular estratégias comerciais consolidando uma nova fase na gestão de seus ativos (DIEESE, 1994; RODRIGUES, 1999). 
Uma onda de reestruturações incentivadas pelo governo aconteceu no setor durante a década de 1990, influenciada pela concentração do capital e pelas novas orientações aos mercados financeiros internacionais, como os Acordos de Basileia.

A atuação no setor durante as décadas de 1990 e 2000 foi redirecionada contabilizando ganhos de escala e escopo (FARIA; PAULA; MARINHO, 2006). A ampliação e a diversificação da cesta de produtos e serviços proporcionaram a redução do custo administrativo unitário médio por transação e foram responsáveis pela geração de uma nova e potencial fonte de receitas que viria substituir parte expressiva dos ganhos obtidos em anos de inflação alta no país. Além disso, os administradores dos bancos optaram pelo financiamento da dívida pública focando deliberadamente grande volume de seus recursos nas operações de tesouraria em função das atrativas taxas de juros (RODRIGUES, 1999).

Os ganhos derivados da venda de produtos e serviços financeiros conquistaram grande importância nos resultados dos bancos. Progressivamente houve uma série de investimentos voltados para a diversificação e segmentação desses produtos para clientes e posteriormente não clientes (não-correntistas) das instituições bancárias.

A dinâmica concorrencial do setor financeiro consolidou e ampliou o leque de segmentação do atendimento entre pessoas físicas e jurídicas e, ainda sob essas classificações, surgiram novas divisões de acordo com a faixa de rendimentos e porte da empresa. Em 1999, contribuindo para aprofundar a estratégia de segmentação das instituições financeiras, é autorizada aos bancos, por meio da Resolução do Banco Central $n^{\circ} 2.640$, a contratação de empresas de diversos ramos de atividade econômica para prestar serviços bancários. Trata-se do chamado Correspondente Bancário. Tal medida fundamentada na expansão do atendimento para a população com menor renda se configurou como uma das formas mais agressivas de terceirização no setor, dado que se espalhou com velocidade por todo território nacional devido ao seu baixo custo de implantação (ANGELO, 2007; BACEN - Disponível em: www.bcb.gov.br. Acesso em: nov. 2012).

Para operar no mercado, os bancos contam com uma estrutura amplamente descentralizada. Em 2010, foram registradas 428.847 dependências que compõem a rede de atendimento (ver quadro a seguir) pela qual os clientes realizam milhões de operações bancárias. 
Tabela 1 - Rede de Atendimento Bancário

\begin{tabular}{|c|c|c|c|c|c|c|c|c|c|}
\hline Período & $\mathbf{2 0 0 0}$ & $\mathbf{2 0 0 2}$ & $\mathbf{2 0 0 4}$ & $\mathbf{2 0 0 6}$ & $\mathbf{2 0 0 8}$ & $\mathbf{2 0 1 0}$ & $\mathbf{2 0 1 2}$ & $\mathbf{2 0 1 4}$ & $\mathbf{0 0 / 1 4}$ \\
\hline $\begin{array}{c}\text { Número de } \\
\text { Agências }\end{array}$ & 16.396 & 17.049 & 17.260 & 18.087 & 19.142 & 19.813 & 22.218 & 23.126 & $41 \%$ \\
\hline $\begin{array}{c}\text { Postos } \\
\text { Tradicionais (1) }\end{array}$ & 9.495 & 10.148 & 9.856 & 10.220 & 11.661 & 12.670 & 14.322 & 14.698 & $54 \%$ \\
\hline $\begin{array}{c}\text { Postos } \\
\text { Eletrônicos (2) }\end{array}$ & 14.453 & 22.428 & 25.595 & 32.776 & 38.710 & 45.087 & 37.665 & 40.521 & $180 \%$ \\
\hline $\begin{array}{c}\text { Correspondentes } \\
\text { Bancários }\end{array}$ & 13.731 & 32.511 & 46.035 & 73.031 & 108.074 & 165.228 & 354.927 & 346.502 & $2.423 \%$ \\
\hline $\begin{array}{c}\text { Total de } \\
\text { Dependências }\end{array}$ & 54.075 & 82.136 & 98.746 & 134.114 & 177.587 & 242.798 & 429.132 & 428.847 & $693 \%$ \\
\hline
\end{tabular}

Fonte: Banco Central. Relatório Anual FEBRABAN 2010 e 2014. Elaboração da autora.

1. Inclui Postos de Atendimento Bancário (PAB), Postos de Arrecadação e Pagamentos (PAP), Postos Avançados de Atendimento (PAA), Postos de Atendimento Cooperativo (PAC), Postos de Atendimento ao Microcrédito e Postos Avançados de Crédito Rural (PACRE).

2. Dados de 2011, 2012 e 2013 foram revisados em 2014 pelo Banco Central.

O setor bancário, ao longo de sua estratégia expansionista, tem buscado constantemente melhorar sua produtividade e reduzir seus custos operacionais com a meta de atingir margens elevadas de rentabilidade e lucratividade. Para alcançar tais objetivos, o setor também tem implementado políticas de concentração de capital, inovação tecnológica e novas formas de organização da produção, como analisaremos a seguir.

\subsection{Fusões, aquisições e privatizações}

As estruturas do sistema financeiro brasileiro, articuladas em rede ou ainda mais especificamente operadas em grandes conglomerados, foram consolidadas pela estratégia de aquisições de outras instituições utilizada tanto para o aumento da base de ativos, de clientes e de negócios bancários, como para ampliar a oferta de serviços agregados dentro do sistema financeiro.

Os processos de fusões e aquisições são parte das estratégias empresariais do setor e se coadunam com movimentos semelhantes que ocorrem no âmbito nacional e internacional em diversos setores da economia.

Na década de 1990, no período do mandato de Fernando Henrique Cardoso, o setor presenciou um novo ciclo de fusões e aquisições, sobretudo para aplacar a própria crise financeira bancária brasileira pós-Plano Real, que levou o governo a implementar ações de salvamento às instituições financeiras destacadamente por meio do PROER Programa de Estímulo à Reestruturação e ao Fortalecimento do Sistema Financeiro 
Nacional $^{21}$ e do PROES - Programa de Incentivo à Redução da Presença do Estado Atividade Bancária. $^{22}$

A ocorrência das privatizações, estimuladas pelo PROES, levou a uma nova configuração que culminou com a diminuição dos bancos públicos, sobretudo estaduais, e com a ampliação da participação do capital estrangeiro, gerando maior concentração no setor, como demonstram as informações da tabela a seguir:

Tabela 2 -Bancos por origem de capital

\begin{tabular}{lcccccc}
\hline & 1990 & $\mathbf{1 9 9 4}$ & $\mathbf{1 9 9 9}$ & $\mathbf{2 0 0 3}$ & $\mathbf{2 0 0 7}$ & $\mathbf{2 0 1 4}$ \\
\hline Privados Nacionais com ou sem participação estrangeira & 174 & 176 & 108 & 88 & 87 & 79 \\
Privados Estrangeiros e com controle estrangeiro & 18 & 38 & 67 & 62 & 56 & 64 \\
Públicos Federais e Estaduais & 34 & 32 & 19 & 15 & 13 & 10 \\
\hline Número de Bancos & $\mathbf{2 2 6}$ & $\mathbf{2 4 6}$ & $\mathbf{1 9 4}$ & $\mathbf{1 6 5}$ & $\mathbf{1 5 6}$ & $\mathbf{1 5 3}$ \\
\hline
\end{tabular}

Fonte: Banco Central do Brasil - Departamento de Organização do Sistema Financeiro.

Elaboração: DIEESE Subseção SESE/SEEB-SP.

Pelos dados acima, observamos que houve a diminuição de aproximadamente 49\% do número total de bancos privados nacionais existentes no país entre 1990 e 2014. Paralelamente, ocorreu o crescimento de $71 \%$ da participação estrangeira e a redução de $74 \%$ dos bancos públicos brasileiros no mesmo período.

Os processos de fusões, aquisições e privatizações que ocorreram nas últimas décadas explicam a grande concentração de $82 \%$ dos ativos, créditos e depósitos sob o controle de apenas seis bancos no Brasil, a saber: Itaú-Unibanco, Bradesco, HSBC, Banco do Brasil, Caixa Econômica Federal e Santander. Para termos dimensão, apesar da concentração dos ativos nesse número reduzido de instituições, vale registrar que em 2014, no Brasil, operavam 153 bancos, representados pelo capital privado - nacional e estrangeiro - e pelos bancos públicos.

\footnotetext{
${ }^{21}$ A Medida Provisória no 1.179 e a Resolução n ${ }^{\circ} 2.208$, ambas de 1995, implantaram o PROER, que serviu para ordenar a fusão e incorporação de bancos a partir de regras ditadas pelo Banco Central. Disponível em: www.bcb.gov.br. Acesso em: fev. 2012.

${ }^{22}$ Em 1996, a Medida Provisória ${ }^{\circ} 1.514$, implantou o PROES com o objetivo explícito de induzir os governos estaduais a privatizarem os bancos regionais, possibilitando por meio de financiamento da União 100\% dos ajustes internos necessários para tal. Disponível em: www.bcb.gov.br. Acesso em: fev. 2012.
} 
- 6 maiores outros bancos

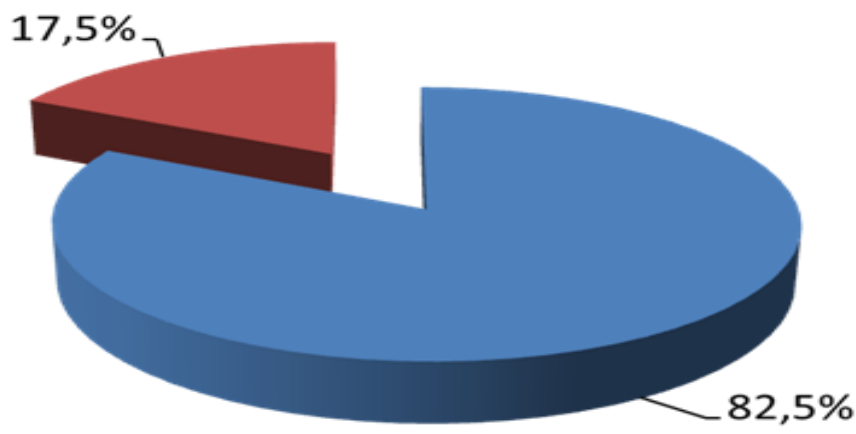

Fonte: Banco Central do Brasil. Elaboração: DIEESE - Rede Bancários

As fusões e aquisições são permeadas por complexos processos de integração das instituições que envolvem novas redes e sistemas de gestão que serão rearranjados quanto ao tratamento das informações, recursos humanos, contabilidade, cultura organizacional, entre outros aspectos.

\subsection{Atuação em rede}

As grandes corporações se estruturam por meio de redes que operam entre subunidades de negócios representadas por pequenas e médias empresas atuando de forma sinérgica ao longo de vários processos, sendo que uma pode reforçar e criar condições mais favoráveis à outra.

A flexibilidade de atuação possível à grande empresa, ao passo que esta redistribui todo o peso dos processos produtivos entre outras empresas parceiras, fornecedoras ou subcontratadas, confere, na visão empresarial, melhor condição de competição no mercado, pois são combinados interesses pontuais, projetos específicos e contratos por prazo determinados.

A noção de rede abordada por Castells (2005) dá conta de posicionar a empresa, controladora da marca, como a unidade legal concentradora de capital, enquanto a unidade operacional se dissolve na rede de negócios com papel definido de produzir. A rede é permeada pelo uso intensivo das tecnologias da informação e telecomunicações, que proporcionam facilidades de gestão à distância e, sobretudo, conferem maior 
dinamismo econômico, com condições mais favoráveis de produtividade, circulação e troca.

Para Boltanski e Chiapello (2009), o modelo de organização em rede se sustenta em um acúmulo de vínculos contratuais que apontam para a manutenção do poder da grande empresa capitalista - a empresa líder. Sob ela orbita um número crescente de pequenas e médias empresas. E é ainda, pelo ganho de escala e escopo, fruto do esforço de coordenação deste conjunto econômico flexível, que ela mantém sua forte posição nos mercados nacionais e internacionais.

Das múltiplas conexões contidas no esquema-rede resulta a formação de oligopólios, ou seja, um número reduzido de empresas com muito poder de atuação no mercado, como ocorre no setor financeiro brasileiro.

A existência de conglomerados e holdings favorecem a formação de oligopólios. Em meados dos anos 2000, grandes bancos nacionais tradicionalmente organizados em conglomerados incorporaram a forma de holdings financeiras. A estrutura em holding permite que uma empresa escolhida tenha como atividade principal a gestão de outras empresas do mesmo grupo, sob as quais se mantém participação acionária compartilhada, com objetivo de conferir a racionalização de procedimentos em busca de mais eficiência operacional e financeira (LODI, J.; LODI, E., 2004).

No setor financeiro, as redes, observadas em suas diversas formas conglomerados ou holdings -, possibilitaram reduzir o tempo de circulação de informação e distribuição de seus produtos e serviços.

O principal canal de distribuição dos produtos e serviços que foram desenvolvidos pelas empresas subsidiárias das redes financeiras são as agências bancárias. Isso tem redimensionado o negócio bancário e contribuído para elevar as margens de lucro do setor.

Os bancos brasileiros, estruturados em conglomerados, já no final dos anos 1990, diante do avanço da internacionalização de suas operações, passaram a negociar ações na Bolsa de Valores de Nova York, o que lhes conferiu mais visibilidade e facilidade em captar recursos no exterior. Tal participação se condiciona à obrigatoriedade de as instituições de capital estrangeiro privado emitir e dar transparência, por meio de relatórios gerenciais, a informações financeiras e gerais da empresa. Os relatórios, escritos em três idiomas, contêm centenas de páginas e ofertam uma visão ampla do negócio, servindo de apoio às decisões dos investidores. 
Nos anos 2000, as empresas brasileiras de capital aberto, dentre elas os bancos estruturados em grande parte no esquema holdings, se mostraram preocupadas em adotar as práticas da "boa" governança corporativa, motivadas pela necessidade de os acionistas garantirem seus interesses diante dos riscos que o mercado financeiro apresentava.

As vantagens avaliadas para as empresas operarem em holding são descritas nos seguintes aspectos: facilidades para lidar com problemas de herança nas famílias detentoras das ações majoritárias; e melhores condições de realizar o planejamento sucessório e os ganhos com a economia de impostos e tributos. Pelo modelo de gestão, é possível deslocar trabalhadores de uma empresa à outra sem extinguir os respectivos vínculos trabalhistas, o que geraria custos adicionais. É permitida a prestação de serviços entre as diversas empresas que compõem sua rede obtendo benefícios tributários. E, ainda, estima-se que os pagamentos a título de imposto de renda podem ser minorados em aproximadamente metade dos valores a serem pagos. ${ }^{23}$

No organograma reproduzido a seguir é possível dimensionar a abrangência de uma holding financeira:

${ }^{23}$ Disponível em: http://www.fiscosoft.com.br/a/3gw6/holding-familiar-tipo-societario-e-seu-regime-tributario-joao-alberto-borgesteixeira. Acesso em: fev. 2015. 
Figura 1

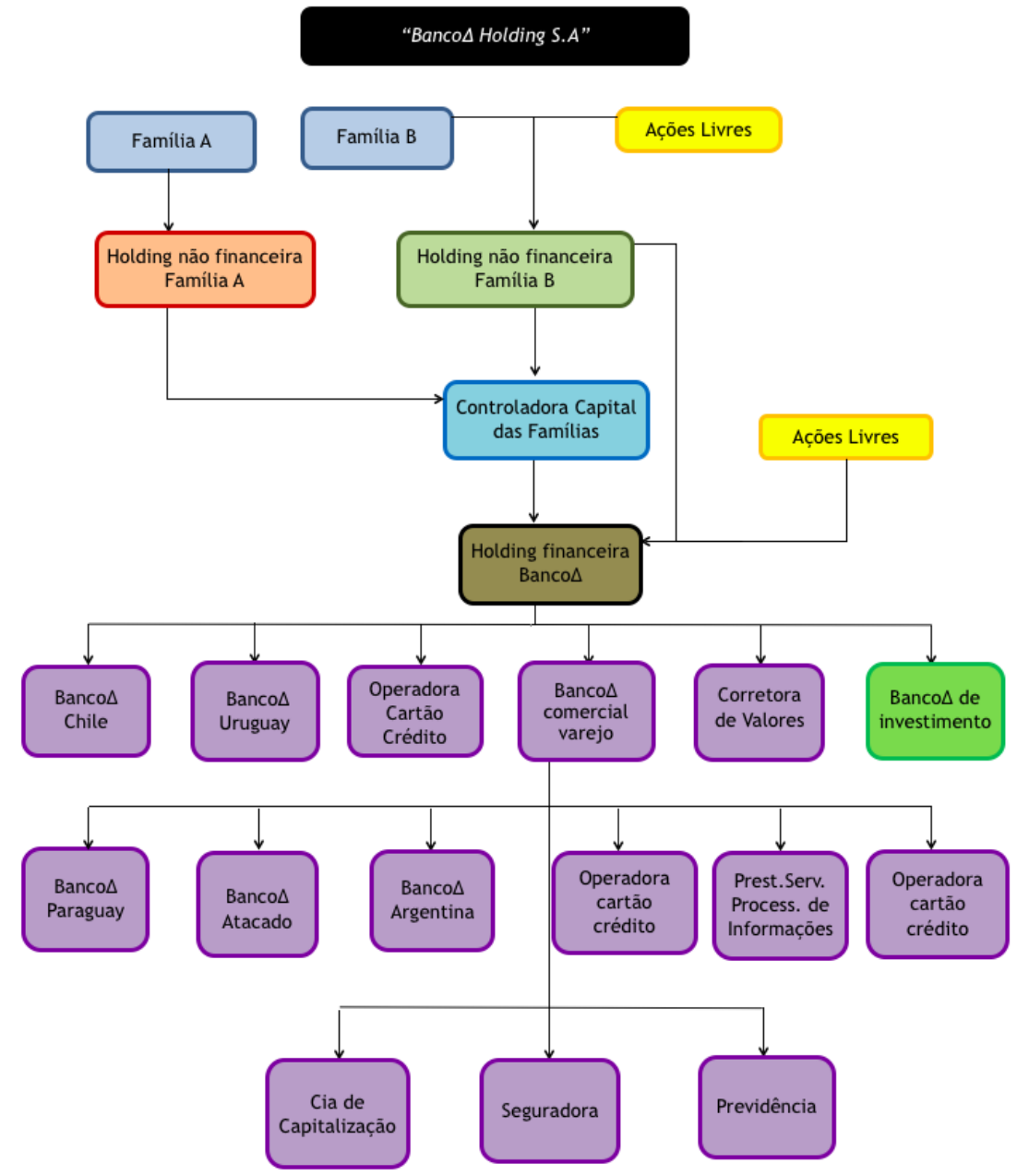

Fonte: Relatório Gerencial Banco $\Delta 2013$.

O Banco $\Delta$, que é uma holding, apresentou em 2014 o maior lucro líquido do sistema financeiro brasileiro, obtendo um incremento de $30,2 \%$ em seu resultado comparado com o ano anterior (DIEESE, 2014).

\subsection{Terceirização}

As novas estratégias de gestão das grandes empresas têm sido marcadas pela ampliação de mercados de atuação enquanto paralelamente verifica-se, como tendência, a redução do escopo de produção direta. Busca-se desta forma dividir a operacionalização de etapas de trabalho subcontratado-as por meio de outras empresas.

Sob o argumento de atuar cada vez mais naquilo que se definiu arbitrariamente e unilateralmente por "atividade-fim" ou "coração do negócio", as empresas brasileiras 
promovem um forte movimento de redivisão do trabalho. As expressões citadas são pouco precisas e servem, antes de mais nada, a uma escolha política e econômica dos administradores.

Diversos autores (HARVEY, 1992; SENNETT, 2002; BOLTANSKI e CHIAPELLO, 2009) apontam a existência de um modelo de organizar o processo produtivo nas grandes corporações marcado pela interação entre o núcleo central e a periferia. O núcleo é formado por atividades consideradas estratégicas, com grupo reduzido de trabalhadores contratados diretamente e mais valorizados pela empresa líder. A periferia contém todas as demais atividades que podem mais facilmente ser padronizadas e realizadas à distância, de acordo com as necessidades e interesses do principal agente econômico na relação estabelecida. Os trabalhadores situados na periferia são aqueles que observam condições mais precárias de trabalho.

Deriva desses processos, como sugere Antunes (2002, p. 52), uma “desconcentração produtiva" em que as empresas se tornam mais enxutas tanto pelas estratégias organizativas implementadas como pela modernização tecnológica. Nesse escopo ganha espaço na cena do mundo do trabalho a terceirização, fortemente ancorada no recrutamento baseado no curto prazo e no frágil vínculo, como é o trabalho temporário ou o trabalho por tempo indeterminado de baixa qualidade.

A terceirização consiste no repasse de atividades, antes exercidas por trabalhadores contratados diretamente, para trabalhadores contratados pela empresa interposta. Esta medida relacionada ao gerenciamento e organização do processo de trabalho gera uma triangulação na relação entre capital-trabalho, que ao invés de envolver dois agentes diretamente envolvidos, os trabalhadores e administradores do capital, passa a contar com um terceiro agente, a empresa subcontratada.

A CUT - Central Única dos Trabalhadores, em outubro de 2011, entregou um dossiê ao TST - Tribunal Superior do Trabalho na ocasião da Audiência Pública convocada por este órgão para tratar do tema da terceirização. No documento chamado "Terceirização e desenvolvimento: uma conta que não fecha", foram apresentados dados que estimam a existência de aproximadamente 11 milhões de trabalhadores terceirizados no país que recebem remunerações $27 \%$, em média, menor que os trabalhadores contratados diretamente; possuem taxa de permanência no emprego 55\% menores e jornadas inversamente maiores em 7\% quando contabilizadas na semana (CUT NACIONAL, 2011). 
O dossiê ainda aponta que os trabalhadores submetidos a um ritmo de produção intenso e à insuficiência nos processos de treinamento estão mais expostos ao adoecimento e tem sido inclusive penalizados com a própria vida, uma vez que entre os terceirizados o volume de mortes em decorrência do trabalho é mais elevado quando comparado com os trabalhadores efetivos. Os casos mais graves a esse respeito se concentram em categorias profissionais como a dos petroleiros e eletricitários.

A contratação ou renovação de contratos entre empresas, tanto na iniciativa privada como no setor público, obedecem prioritariamente o critério do menor preço. Desse modo, as empresas subcontratadas, com menor poder de barganha, aceitam propostas que comprometem o respeito aos direitos dos trabalhadores e afetam diretamente a qualidade dos serviços.

$\mathrm{O}$ crescimento do número de ações na Justiça do Trabalho ${ }^{24}$ contribui para nos indicar sobre as irregularidades que permeiam as práticas de terceirização no país. Apesar de muitos trabalhadores manterem contrato formal de trabalho, estão submetidos a situações comuns de atraso ou não pagamento de salários, descumprimento da programação de férias, horas extras não pagas, dentre outros tantos problemas decorrentes da típica relação triangular: empresa tomadora-trabalhador-empresa prestadora.

A insegurança jurídica é o principal entrave para implantar mais e novos processos de terceirização em todos os setores da economia. O risco de aumentar os passivos trabalhistas das empresas tomadoras tem motivado os empresários a apoiarem projetos de lei de caráter liberalizante, ou seja, que desobstruam qualquer obstáculo à terceirização e que a torne permitida em qualquer etapa do processo produtivo, esterilizando qualquer limite hoje circunscrito na Súmula 331 do TST. $^{25}$

Por não haver lei que regulamente a terceirização no país e ainda pelo fato de a Súmula 331 ter um caráter restritivo à prática, diversos julgamentos acabam favorecendo aqueles trabalhadores que questionam a responsabilidade da empresa tomadora pelos direitos não respeitados. As ações movidas na Justiça do Trabalho invariavelmente também solicitam o direto de enquadramento na categoria profissional que se relaciona à atividade econômica da empresa tomadora do serviço.

Desta disputa social e economicamente situada ganhou força o PL 4330, que tramitava desde 2004 na Câmara dos Deputados Federais em Brasília, sendo que em

\footnotetext{
${ }^{24}$ A "Pesquisa Brasileira em Gestão do Capital Humano" divulgada no jornal Valor Econômico aponta que entre os anos 2000 e 2009 as reclamações judiciais impetradas na Justiça do Trabalho por empregados terceirizados cresceram $71 \%$.

${ }^{25}$ A Súmula proíbe a terceirização nas atividades-fim das empresas.
} 
2013 chegou às últimas instancias de aprovação. Nesta ocasião, o movimento sindical, sobretudo vinculado à CUT, juntamente das associações dos magistrados do trabalho, pesquisadores e outras entidades de representação da sociedade civil conseguiram barrar sua aprovação temporariamente por meio do forte processo de mobilização social. No ano de 2015, sob um cenário político e econômico adverso na cena brasileira, o mesmo projeto foi recolocado em votação e teve aprovação na Câmara dos Deputados, avançando para tramitação no Senado, desencadeando forte reação dos movimentos sociais.

A pressão para diminuir os custos relacionados à força de trabalho no país passa pela disputa em torno de projetos de lei com características de flexibilização de direitos, haja vista o Brasil não ter feito uma reforma trabalhista ampla neste sentido.

Como Krein (2004) observou, nos anos 1990, o Estado teve um papel central na determinação da agenda de flexibilização do trabalho, promovendo alterações fragmentadas que passaram a regulamentar: banco de horas; Participação nos Lucros e Resultados - PLR; trabalho aos domingos e contratos parciais com encargos menores, para citarmos alguns exemplos.

Contudo, estas medidas não foram suficientes, sobretudo, para as grandes empresas que enxergavam na terceirização o principal meio pelo qual poderiam reduzir o custo com a força de trabalho, transformando-o em prestação de serviços adaptável às oscilações de demanda no mercado.

\subsubsection{Terceirização nos bancos}

Os bancos repassavam, já na década de 1980, as atividades de limpeza e segurança para empresas contratadas ou subsidiárias. Durante a década de 1990, diante das novas estratégias de negócios implementadas, as terceirizações se ampliaram para demais áreas, tornando-se generalizadas.

As facilidades de conexão entre bancos e empresas terceirizadas ampliaram as possibilidades de transferir etapas de trabalho. As empresas tomadoras de serviços, os bancos, mesmo tendo parte de seu trabalho realizado à distância, mantiveram o controle total das operações, haja vista a velocidade com que as informações sobre a produtividade estão disponibilizadas por meio dos softwares e rede de comunicações.

A possibilidade de ter trabalhadores atuando à distância foi conveniente aos bancos considerando a ameaça, que pesava e ainda pesa sobre eles, em ter que 
responder às possíveis ações trabalhistas. Afinal, ao colocar trabalhadores lado a lado, com estatutos diferentes, se expõe a olho nu as situações de desigualdade, ampliando dessa forma o risco jurídico.

A lista ${ }^{26}$ de etapas de trabalho que foram terceirizadas, realizadas em grande parte fora do ambiente de trabalho bancário, oscila de acordo com o banco pesquisado, podendo abranger: compensação bancária; procedimentos vinculados ao caixa eletrônico (classificação do cheque, validação, autenticação, lançamento e pesquisa na conta do cliente); retaguarda das agências; teleatendimento (receptivo e ativo); oferta, análise, preparação e monitoramento do contrato de crédito (imobiliário, veículos, crédito direto ao consumidor, consignado, microcrédito); processamento cartão de crédito; cobrança e recuperação de saldo devedor com clientes; digitação de cadastro de clientes; digitalização de documentos; captação de clientes/abertura de contas; tesouraria (numerário); suporte à internet; serviços envolvidos com tecnologia da informação; telecomunicações; custódia de cheques e documentos bancários; pagamentos, transferências, saques e depósitos por meio de Correspondentes Bancários; dentre outros.

Ainda, no sentido de apurar a difusão da terceirização no setor, destacamos no gráfico a seguir os dados da conta relativa à "Prestação com Serviços de Terceiros", incluída nas despesas operacionais dos bancos que apontam um relevante e contínuo crescimento ao longo dos últimos anos.

${ }^{26}$ A lista apresentada é feita com base na pesquisa de campo, consulta aos materiais sindicais e site TST. 


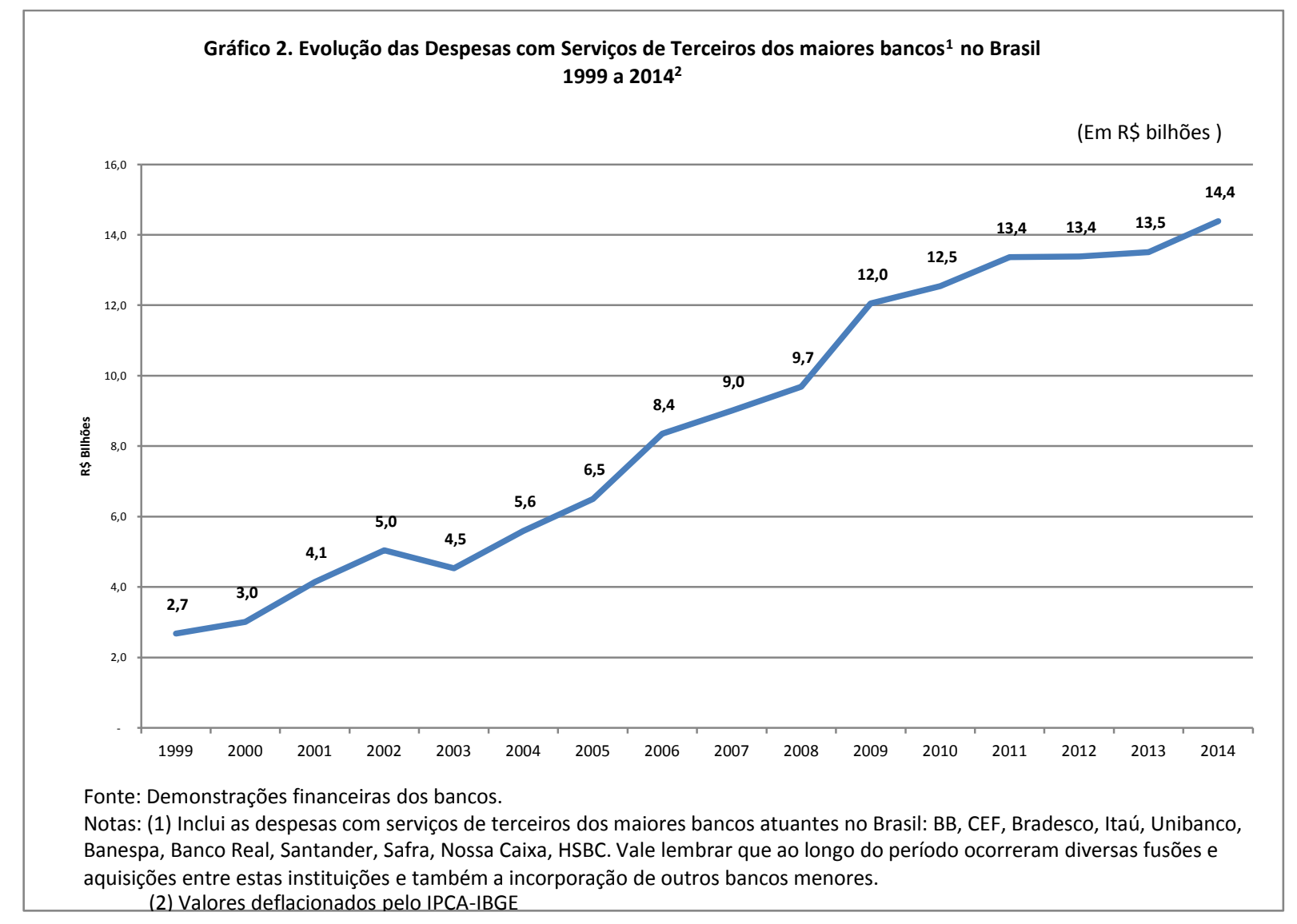

Elaboração: Rede Bancários - DIEESE

O gráfico a seguir apresenta a evolução das despesas com serviços terceirizados no Banco $\Delta$ e reitera o que se passa no setor apontando a tendência de crescimento da terceirização.

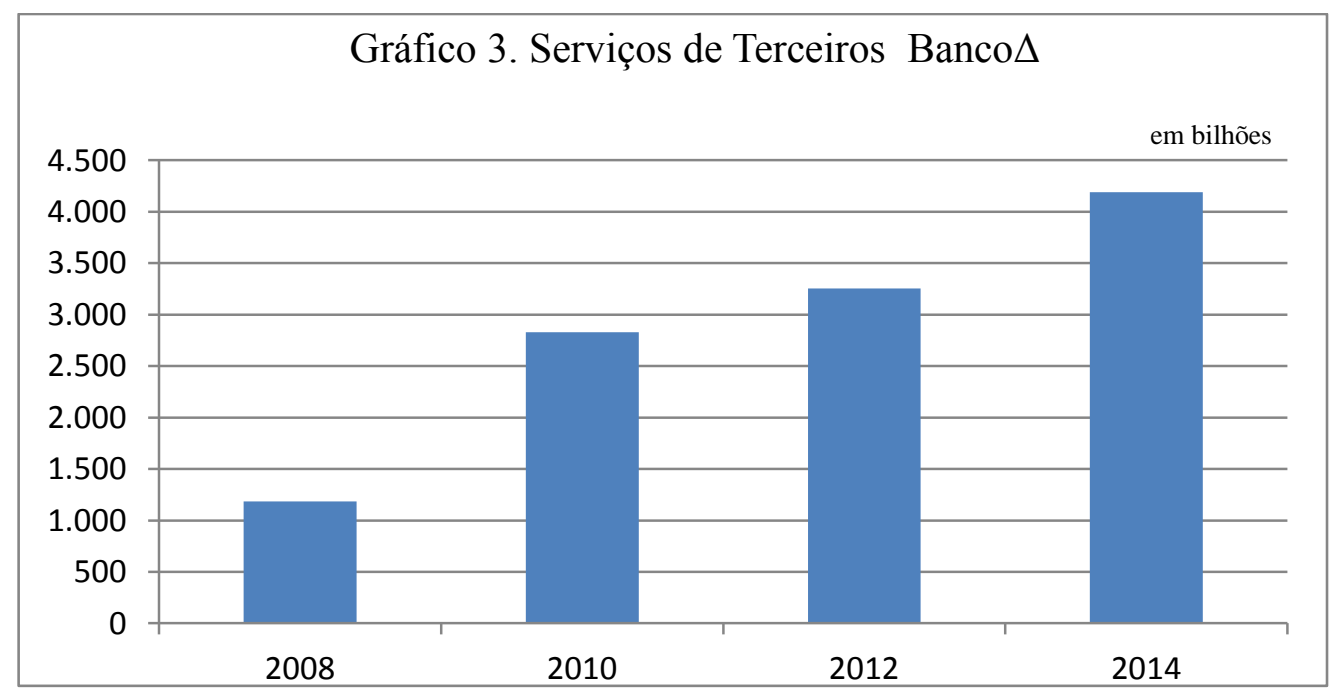

Fonte: Relatórios Gerenciais Banco $\Delta$ (anos selecionados). Elaboração da autora. 
A ampliação dos postos de Correspondentes Bancários merece destaque, pois é possível observar um aumento significativo nos últimos anos, consolidando-se como um canal de atendimento terceirizado para os clientes e usuários do sistema, conforme demonstra o gráfico a seguir:

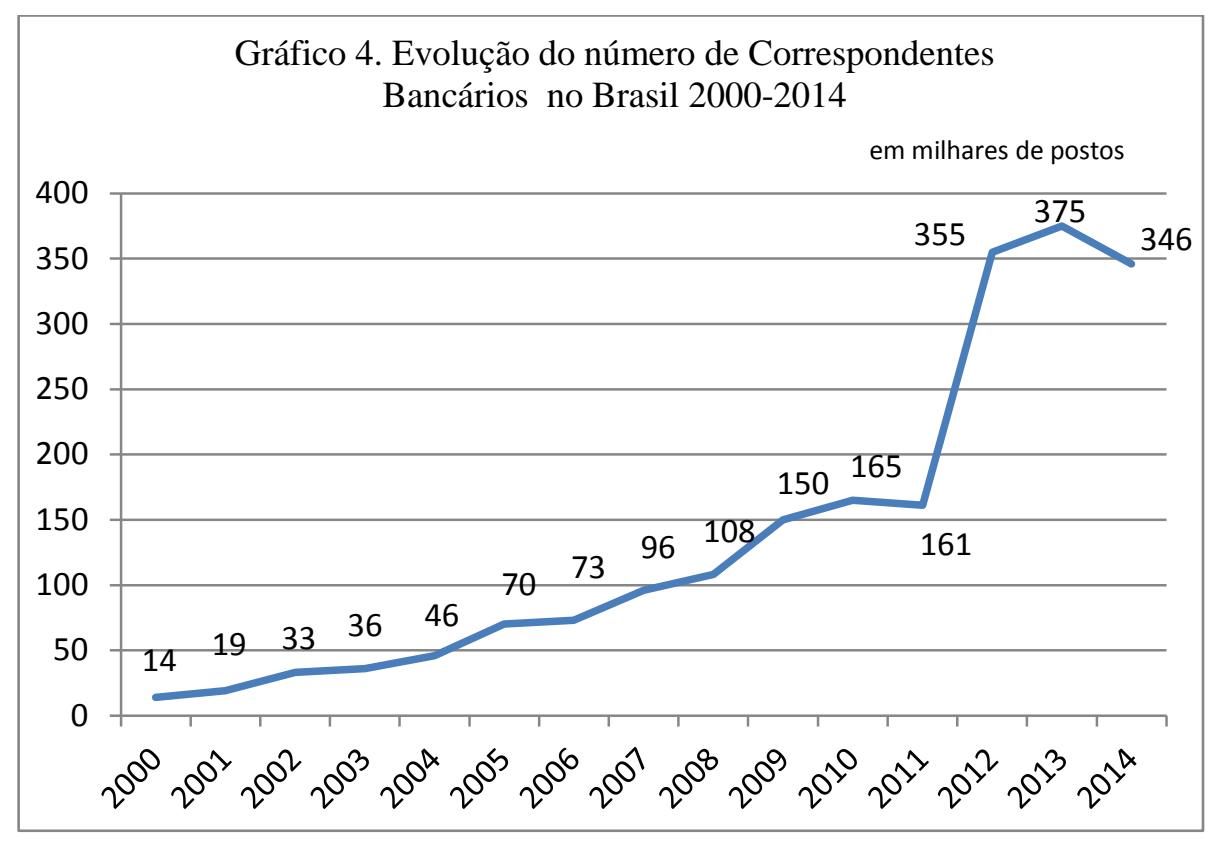

Fonte: Relatório Anual FEBRABAN (anos selecionados). Elaboração da autora

Os dados do Gráfico 4 apontam um salto desproporcional na curva de crescimento do número de correspondentes bancários no ano de 2012. De acordo com Vasquez e Carvarzan (2015), este acontecimento deve-se ao fato do BACEN ter editado duas novas regulamentações que ampliaram o rol de serviços que podem ser oferecidos à população, permitiram que os próprios bancos pudessem atuar como correspondentes bancários, e, ainda autorizavam que o estabelecimento pudesse ter objeto social único, ou seja, o correspondente poderia ser a atividade principal e exclusiva, não necessariamente um serviço acessório e complementar de outra atividade do comércio ou serviço. Os autores advertem que de acordo com explicação da FEBRABAN a queda no número de Correspondentes deve-se à mudança na metodologia da contagem realizada pelo BACEN.

Os pontos de atendimento dos Correspondentes Bancários estão espalhados pelos mais diferentes estabelecimentos comerciais e de serviços, tais como: supermercados, correios, casas lotéricas, lojas de material de construção etc. Dessa forma, permitem aos clientes o acesso a um horário de atendimento expandido, se 
comparado à agência bancária tradicional. Contudo, apesar de funcionarem com estrutura física independente, são diretamente ligados aos bancos, que se mantêm como os responsáveis diante da autoridade monetária, o Banco Central do Brasil, na medida em que manipulam valores e documentos bancários da população (SANCHES, 2006).

Imagem 1

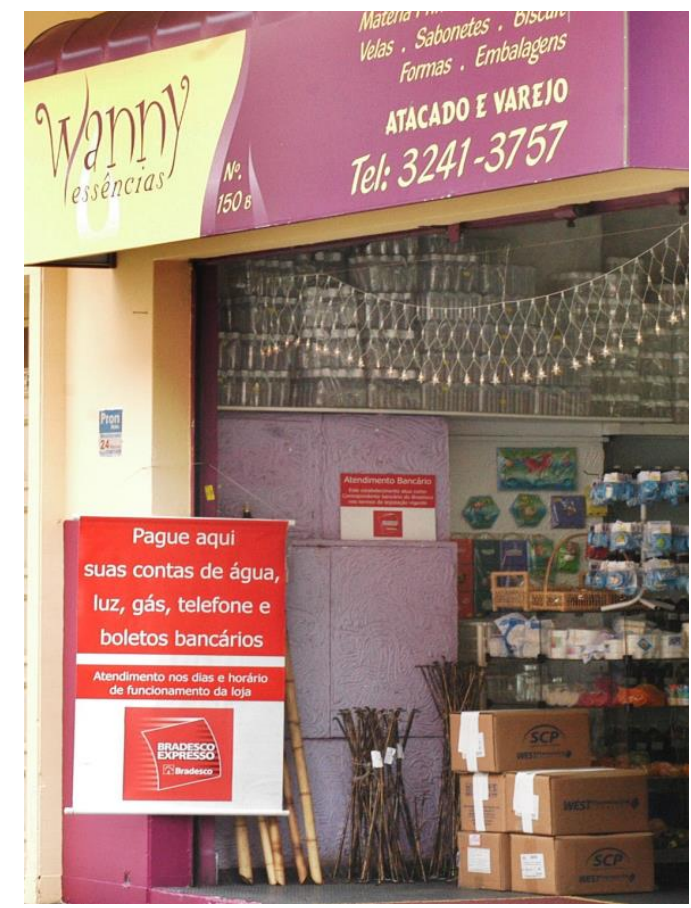

Correspondente Bancário, situado no centro da cidade de São Paulo, contratado por um banco privado nacional de grande porte. Foto: Maurício Morais/SEEB-SP.

Concordando com Oliveira (2014), a estratégia organizacional aplicada aos Correspondentes Bancários possibilitou a transferência de postos de trabalho dos bancos para outras empresas, reduzindo o custo com a força de trabalho ao mesmo tempo que retirou das agências os clientes indesejáveis, de baixa renda, com pouco ou nenhum potencial de negócios.

Os Correspondentes Bancários, pela sua abrangência nacional e volume de pessoas envolvidas, configuram a vertente de terceirização mais agressiva, implementada nos últimos anos. Por um lado, percebemos que a segmentação dos trabalhadores e clientes leva a uma condição inferior de trabalho quando comparada aos bancários e ainda implica queda da qualidade do atendimento, quando se sabe que nestes ambientes não é obrigatório, por exemplo, seguir o "plano de segurança" que vale para as agências dos bancos, apesar de manipularem mais dinheiro. Por outro lado, registramos que os Correspondentes Bancários ampliaram na prática o horário de 
atendimento à população, favorecendo aqueles que tinham dificuldades de acessar os bancos dentro dos limites estabelecidos para a agência tradicional funcionar. ${ }^{27}$

Cabe esclarecer que a FENABAN em diversos materiais de publicação institucional, visando minorar futuros problemas trabalhistas, incluiu o aposto "não" para tentar afirmar sua posição quanto à relação empregatícia dos trabalhadores vinculados aos Correspondentes. Ficando assim, visível a denominação "Correspondente não Bancário" (grifo nosso) em diversos materiais de divulgação e relatórios gerenciais emitidos pela entidade, entretanto, em que pese o uso do recurso linguístico, trata-se da mesma coisa.

A FENABAN por meio de seus representantes acompanhou o trâmite do PL 4330 na Câmara dos Deputados Federais ao longo dos últimos anos, demonstrando total interesse na sua aprovação. ${ }^{28} \mathrm{O}$ projeto dá garantias aos empregadores, na medida em que legaliza toda e qualquer possibilidade de terceirização. De seu detalhamento consta a exigência de que a empresa terceirizada contratada tenha objeto social único, o que caracterizaria a sua especialização. Contudo, o artigo 18 permite uma exceção que favorece o setor financeiro. ${ }^{29}$ Ao conferir a possibilidade de terceirizar a prestação de serviços bancários, mesmo que a instituição contratada não seja especializada e não tenha objeto social único, favorece o funcionamento dos Correspondentes Bancários nos mesmos moldes que têm atuado nos últimos anos, ou seja, operam em quaisquer estabelecimentos comercias e de serviços sem ofertar com exclusividade apenas serviços bancários.

\subsubsection{Terceirização e acirramento da fragmentação dos trabalhadores}

Empresas terceirizadas, mesmo operando à distância, interagem com o ciclo de trabalho de diversas áreas nos bancos. O trabalho realizado pelos trabalhadores

\footnotetext{
${ }^{27}$ Os bancos, nos últimos anos, têm experimentado abrir e fechar as agências bancárias em horários diferenciados. Entretanto, tal situação não se confunde com a ampliação de horário de pagamentos e recebimentos para qualquer um indiscriminadamente. São atendidos apenas alguns serviços, dentre eles renegociação de dívidas e ou atendimento a clientes com maior renda, visando fechar negócio. Os sindicatos são contra a medida, pois ela altera a jornada de trabalho e tem levado os trabalhadores a manifestarem seu descontentamento realizando diversas paralisações nestes locais. Conforme consta nos sites dos principais bancos nacionais e site do Sindicato dos Bancários de SP, Osasco e região.

${ }^{28} \mathrm{Na}$ ocasião da votação do PL 4330, em março de 2015, os representantes das confederações patronais de diversos setores, dentre eles a FEBRABAN, estiveram reunidos com Eduardo Cunha, presidente da Câmara dos Deputados em Brasília, manifestando apoio à aprovação do projeto de terceirização. Ao longo dos últimos anos, como pode ser observado em site oficial da Câmara http://www2.camara.leg.br, foi possível verificar a participação ativa de representantes da FEBRABAN nas diversas comissões por onde tramitam os projetos de lei que disciplinam o processo de organização do trabalho.

${ }^{29}$ Artigo 18: "As exigências de especialização e de objeto social único, previstas no art. $2^{\circ}$ desta lei, não se aplicam às atividades de prestação de serviços realizadas por correspondentes contratados por instituições financeiras e demais instituições autorizadas a funcionar pelo Banco Central do Brasil, nos termos da regulamentação do Conselho Monetário Nacional, enquanto não for editada lei específica acerca da matéria".
} 
bancários está totalmente atrelado ao trabalho realizado pelos terceirizados. Apesar de estarem cindidos por uma divisão política, social, jurídica e também espacial, podemos inferir que os terceirizados se constituem como parte do "trabalhador coletivo" no sentido atribuído por Marx (1985). Esta condição aponta para o fato de os esforços de ambos - seja bancário ou terceirizado - serem decisivos para gerar o lucro esperado pelas grandes corporações bancárias.

A subcontratação de trabalhadores afeta as relações trabalhistas e interfere na correlação de forças no confronto entre capital e trabalho, enfraquecendo as categorias profissionais com tradição de organização no Brasil. Pode-se dizer que indiretamente conduz à flexibilização da Convenção Coletiva de Trabalho (CCT), válida para todos os bancários que atuam nos bancos públicos e privados.

O processo de terceirização cria fissuras no pacto social e econômico firmado após anos de luta dos trabalhadores, desmontando na prática o caráter universalizante dos direitos aplicados aos bancários. Os subcontratados pelas empresas terceirizadas não se "enquadram" na mesma categoria profissional dos bancários, por esta ser uma definição que está atrelada à classificação econômica em que atua o empregador. ${ }^{30}$ Isso significa que os terceirizados ficam, portanto, alijados das conquistas históricas que compuseram o cenário de lutas e organização sindical relacionadas às empresas tomadoras dos serviços, os bancos.

Com a terceirização, verifica-se o rebaixamento das condições de trabalho quando feita a comparação entre trabalhadores contratados diretamente pelos bancos e trabalhadores terceirizados (SANCHES, 2006). Os funcionários das empresas prestadoras de serviços, os terceirizados, recebem salários que chegam a ser $43 \%$ da remuneração recebida pelos bancários; não têm acesso à PLR da empresa tomadora; e em diversos itens observam-se prejuízos monetários (SANCHES, 2015). Além disso, não tem acesso ao treinamento adequado e às mesmas possibilidades de sociabilidade que marcam a relação de emprego com as grandes empresas do setor bancário.

Os trabalhadores terceirizados executam as mesmas funções que antes eram realizadas pelos bancários em jornadas ampliadas, sobretudo quando são analisadas as ocupações que compõem a base da pirâmide de cargos e salários, como é o caso daqueles que exercem as funções de teleatendimento, retaguarda e compensação (SANCHES, 2006, 2015). Os acordos coletivos de trabalho apresentam,

\footnotetext{
${ }^{30} \mathrm{O}$ enquadramento sindical está previsto na CLT, é por meio dele que se definem as classificações para categorias profissionais e econômicas que possibilitam a formação de sindicatos, tanto de empregados como de empregadores. Pela regra vigente no país não é possível criar mais do que um sindicato na mesma base territorial, garantindo-se assim a unicidade sindical.
} 
comparativamente, significativas discrepâncias nos direitos recebidos que se expressam nas diversas cláusulas socioeconômicas.

Mediante os processos de terceirização, tem havido o acirramento da fragmentação nos grupos de trabalhadores que atuam para as grandes corporações que, invariavelmente, mantinham uma cultura de organização sindical estruturada (JINKINGS, 2002; DRUCK, 1999; RAMALHO; RODRIGUES, 2009). Em condições diferenciadas, os trabalhadores, terceirizados e aqueles contratados diretamente pelas grandes corporações, vivenciam experiências que se traduzem na consolidação de uma base social profundamente dividida e heterogênea, a qual leva a uma maior dificuldade de organização.

$\mathrm{O}$ aprofundamento da segmentação cria obstáculos à integração dos trabalhadores terceirizados e bancários. Os administradores buscam manter a relação de trabalho terceirizada tanto invisível quanto for possível no interior das grandes corporações. A característica da impessoalidade torna-se em muitas ocasiões uma das marcas dos processos de terceirização. Os trabalhadores terceirizados não são em geral conhecidos pelo nome, uma vez que sequer são apresentados aos demais bancários.

Desta relação deficitária são observados pequenos conflitos entre os próprios trabalhadores que os distanciam ainda mais. As diferenças de inserção dos terceirizados no ambiente corporativo são observadas a olho nu, pelo local em que fazem suas refeições diárias, uso de crachás, acesso a cursos e treinamentos, acesso a políticas de RH, informação sindical, dentre outros exemplos. Tais diferenças geram sentimentos ambíguos entre os trabalhadores bancários, uma mescla de discriminação e solidariedade (SANCHES, 2015).

A seguir, a percepção do entrevistado contribui para ilustrar um pouco essa ambiguidade:

eu sou uma pessoa que é livre de qualquer preconceito. Mas, eu vou te falar, existe um preconceito dentro do próprio terceiro. $\mathrm{O}$ Coordenador do próprio terceiro fala que não é para falar com o bancário, então o preconceito já vem de lá. Eu falo com todo mundo. Mas, tinha uma colega minha que dizia que qualquer coisa era culpa do terceiro... sabe o jeito de falar com a pessoa, com agressividade, desprezo, então você percebe o preconceito no modo de tratar a pessoa. A gente percebe que o terceiro hoje é visto como coitadinho. Em relação a trabalho é desonesto. Ele faz a mesma coisa que eu e ganha bem menos, então é desonesto, tem uma empresa que está ganhando para isso, ele trabalha, a empresa ganha. Mas, ele é bancário. Se ele não fizesse o serviço, eu faria. É um serviço bancário. A empresa terceirizada não quer funcionário dela na mesa de bancário, mesmo que seja para trabalhar, se tiver que 
falar com bancário não pode, tem que chamar o Coordenador e ele vai. Eu acho absurdo isso. (Bancário, Analista Júnior, 42 anos, 12 de banco)

Não é ocasional ou uma decisão individual do Coordenador dos trabalhadores terceirizados não permitir o diálogo com os bancários. Há uma orientação do próprio banco, apoiada em uma visão jurídica e política, que estrategicamente objetiva evitar o contato entre os trabalhadores, inviabilizando o diálogo e preservando a separação que já é visível, feita pelas divisórias ou paredes de vidro que envolvem os terceirizados dentro das áreas no interior do $\operatorname{Banco} \Delta$, como se fosse um aquário, isolando-os para que evitem criar laços, comprometimento e solidariedade, sobretudo quando há o risco de comparar em detalhes as condições e o tipo de trabalho, podendo servir de base para uma ação trabalhista no futuro.

Logo, como vem sendo apontado pelas autoras (JINKINGS, 2002; DRUCK, 1999; SANCHES, 2006), politicamente a terceirização também se torna vantajosa para o empregador. Sindicatos com tradição de luta e organização perdem força com o esvaziamento do Contrato Coletivo de Trabalho negociado na medida em que este deixa de representar parcelas importantes de trabalhadores, que apesar de estarem inseridos no processo produtivo são excluídos do pertencimento de categoria profissional ficando à mercê do enquadramento que o setor patronal determinar, considerando a ausência de liberdade e autonomia sindical em vigor no país.

Ponderamos que os processos de terceirização incluem trabalhos com maior valor agregado ou maior requisito técnico. É o caso dos trabalhadores que atuam nas diversas frentes que envolvem as TIs.

Nesses casos, os trabalhadores se submetem a um leque variado de formas de vínculo com as empresas terceirizadas que prestam serviços aos bancos. A pesquisa feita em 2014 pelo site APinfo, ${ }^{31}$ especializado para profissionais dessa área, demonstra quais são as principais formas de vínculo e suas respectivas oscilações no tempo. Como é possível observar no gráfico a seguir, encontramos seis variações que somadas compõe a força de trabalho neste segmento: 1) autônomo; 2) cooperado; 3) estagiário; 4) CLT Flex; ${ }^{32}$ 5) PJ - Pessoa Jurídica; e 6) CLT.

\footnotetext{
31 Pesquisa disponível em www.apinfo.com. Realizada pela internet durante os meses de maio a agosto de 2014, com 22.233 participantes de todo o Brasil, obteve maior concentração de respondentes provenientes dos estados do Sudeste e Sul.

${ }^{32}$ Essa modalidade que significa uma abreviação da CLT Flexível surgiu em 2006, implica no pagamento diferenciado da remuneração que o trabalhador tem a receber dividindo-a entre parte fixada, via regras da CLT, e parte "paga por fora". A parte CLT pode chegar, conforme o acerto, entre $40 \%$ a $60 \%$, sendo que sobre esse valor recairão os recolhimentos a título de Férias, $13^{\circ}$ Salário, INSS, FGTS e IRPF. Já na "parte paga por fora", são lançados nos comprovantes de recebimento itens como: Ajuda de Custo, Assistência Médica, Educação, Previdência Privada, Seguros Pessoais ou mesmo Reembolso de Despesas. Tais pagamentos
} 


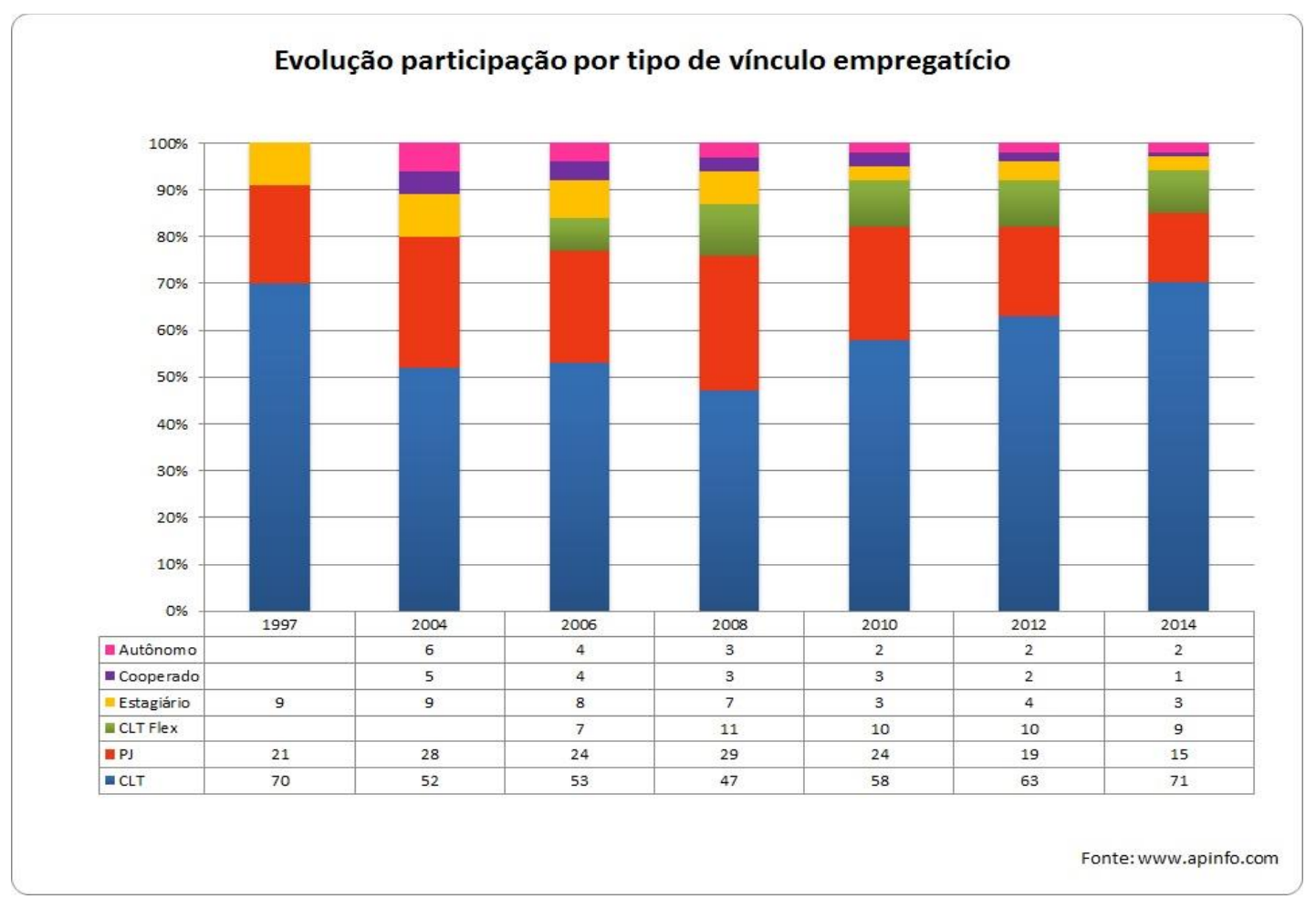

Como se pode observar, o padrão CLT percebeu sua maior queda no ano de 2008, voltando a crescer nos anos subsequentes. Enquanto esse tipo de vínculo perdia espaço, o padrão de contratação via PJ é aquele que mais ocupava seu lugar no leque de opções para compor a força de trabalho.

Esta diversidade ou flexibilidade que se estabelece, com relativa naturalidade entre os profissionais de TI, aponta para formas distintas de relações de trabalho constituídas entre as partes envolvidas - prestador de serviço e contratante - que coloca novas nuances para a construção de referenciais em torno de categorias profissionais.

As variações nas formas de vínculo para trabalhadores de TI, a depender das circunstâncias, em médio ou longo prazo, podem refletir tensões sociais decorrentes da falsa relação de independência ou autonomia, quando na prática as características da relação assalariada e subordinada prevalecem no cotidiano de trabalho. O setor bancário convive com situações em que o trabalhador é considerado um "consultor", inserido nesse mercado de trabalho pela modalidade PJ - Pessoa Jurídica, mas ainda assim

não sofrem descontos de tributos, que em última instância beneficiam os próprios empregados por meio do retorno em serviços públicos e seguridade social. Já para o IR, devido o salário declarado ser menor, a retenção será proporcionalmente menor. 
precisa ser contratado por outra empresa terceirizada, prestadora de serviços, para depois poder atuar de fato em um banco, em outras palavras, é um "quarteirizado"33.

A pesquisa da APinfo divulgou que o vínculo empregatício preferido pelos profissionais de TI era a CLT (ver gráfico 6). Os dados apresentam como a preferência cresceu nos últimos anos e se tornou predominante, o que pode ser interpretado como um sinal de que condições mais convenientes aos trabalhadores são garantidas nesse formato.

Contudo, é pertinente destacar que há um número, não desprezível, de pessoas que são indiferentes ao tipo de vínculo. Esta posição pode ser explicada pela valorização de determinados profissionais no mercado de trabalho mediante a especialização e atualização exigidas pela área de TI. As especificações técnicas envolvidas nos processos que mantêm uso intensivo de novas tecnologias se tornam obsoletas com rapidez, alterando as práticas e habilidades em curso, explicando assim maiores remunerações pagas a determinados consultores terceirizados.

\section{Gráfico 6}

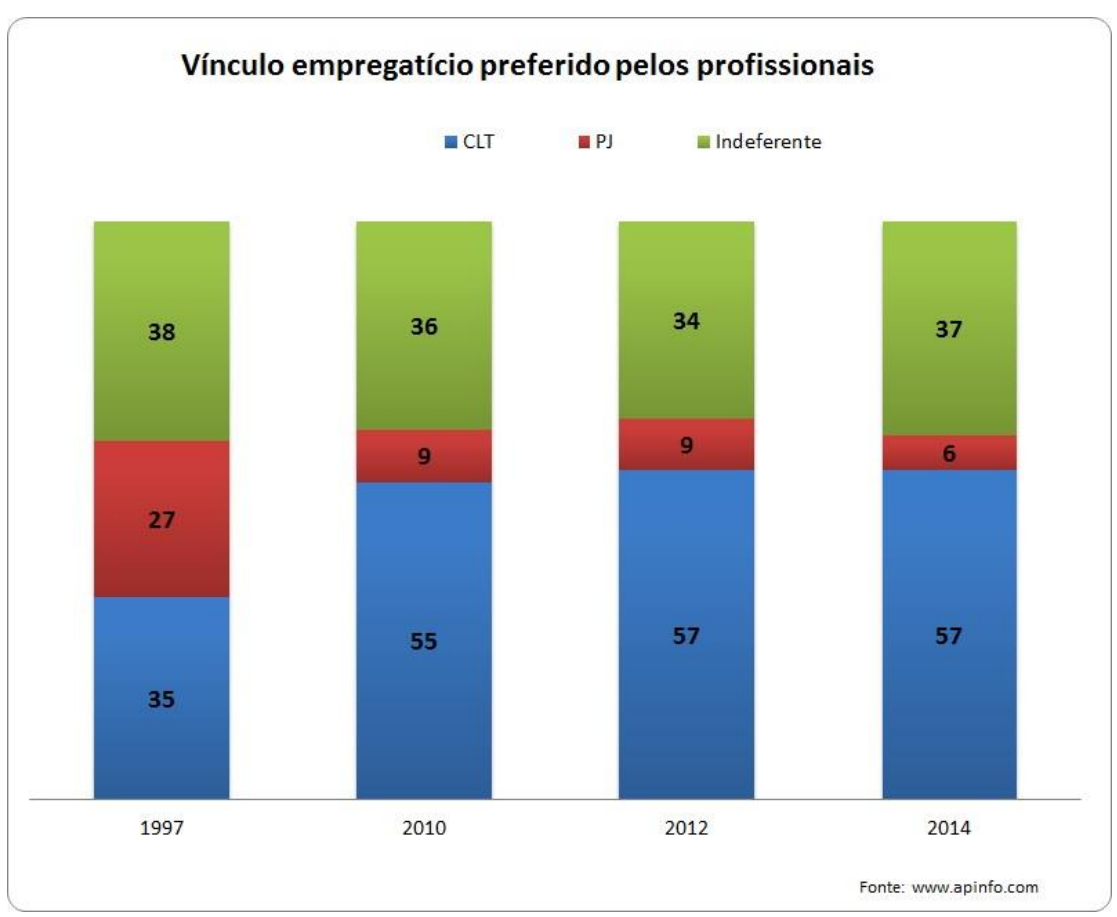

Há um tensionamento entre a forma CLT e as demais fora desse padrão. Nos anos 1990 e subsequentes, tanto nos bancos como em outros setores da economia, com

\footnotetext{
33 A denominação "quarteirização", invariavelmente associada aos processos de terceirização, refere-se: ora à empresa intermediadora, aquela que se coloca entre a empresa tomadora do serviço e a empresa terceirizada, ou seja, aquela que tem como função central gerenciar os contratos com as prestadoras de serviços; ora se trata de um desdobramento da terceirização, representada pelo momento em que a prestadora de serviços contratada repassa para outra empresa ou prestador serviços individual (Pessoa Jurídica- PJ) as atividades a serem realizadas (SANCHES, 2006).
} 
a onda das reestruturações e suas incertezas, muitos profissionais foram incentivados a despender das garantias oriundas da legislação trabalhista via CLT e daquelas relacionadas aos acordos específicos de determinada categoria profissional para aceitar um novo tipo de contratação como: autônomo, PJ ou cooperado.

Os recrutadores dos profissionais que atuavam em TI divulgavam a aparente desvantagem do padrão CLT comparando-o com um relativo aumento da remuneração direta oferecido pelas novas formas de vínculo. As empresas tomadoras do serviço, como os bancos, divulgavam que uma vez sem descontos e recolhimentos de encargos sociais poderiam remunerar o trabalho individual como "prestador de serviço" com valores superiores aos habitualmente praticados aos trabalhadores contratados diretamente.

Entretanto, os efeitos destas modalidades de terceirização são tardios e com o tempo surgem ações trabalhistas reivindicando vínculos empregatícios com as empresas contratantes, usuárias do serviço, haja vista que diversos itens apontam ilegalidades e desvantagens, sobretudo no longo prazo.

Diversos trabalhadores de TI, nomeados de autônomos, PJs, CLT Flex ou cooperados, mantêm na prática uma relação de subordinação com as grandes corporações bancárias na medida em que preservam em sua relação de trabalho características de um contrato de tipo "regular", ou seja, obedecem ao comando e a orientações dos bancos tomadores do serviço, cumprem horários e normas internas de convivência, são desprovidos de autonomia, e, além disso, atuam diretamente no sistema operacional do banco acessando informações restritas ao seu negócio.

Essas formas de contratação que se encontram fora do padrão CLT excluem direitos básicos do trabalhador brasileiro, como férias, $13^{\circ}$ salário, seguro-desemprego, licença saúde e maternidade, FGTS e respectiva multa em caso de desligamento, mas não apenas. No caso do setor bancário, o trabalhador deixa de receber os direitos estabelecidos na Convenção Coletiva de Trabalho, que inclui dentre outros itens: vale restaurante, vale alimentação, auxílio creche, auxílio transporte, convênio médico subsidiado, auxílio educação, cursos de aperfeiçoamento e a PLR. 


\subsection{Difusão tecnológica e as perspectivas sobre o futuro do trabalho nos bancos ${ }^{34}$}

\subsubsection{As novas formas de interação social diante das inovações tecnológicas}

A tecnologia, como observado por Castells (2002), pode expressar condições sociais específicas e introduzir novas trajetórias históricas. Os acontecimentos no setor bancário têm muito a nos contar sobre as mudanças que a própria sociedade vivencia.

A virtualização do dinheiro e as alterações nos hábitos de pagamentos que ocorreram nas últimas décadas nos possibilitam perceber a permeabilidade das TIs no cotidiano dos clientes e trabalhadores. Os bancos, por representarem um dos setores mais avançados tecnologicamente no Brasil, têm estado à frente na propagação e difusão de determinados usos tecnológicos, como foi o caso da senha eletrônica e, posteriormente, da biometria. ${ }^{35}$

As operações em rede, derivadas dos usos de padrões tecnológicos de procedimento comum, adotadas dentro do setor bancário, facilitaram as comunicações e alinharam processos entre as instituições participantes.

As instituições financeiras, visando alcançar maior produtividade e competitividade, integraram plataformas de sistemas de informação que viabilizam o fechamento das mais diversas operações entre bancos, unidades administrativas, agências e demais empresas terceirizadas vinculadas à cadeia produtiva do setor. As parcerias com setores do comércio e outros serviços, sobretudo no tocante a facilidades de pagamento via cartão de débito, somadas à ideia de self-service (FERREIRA, 2008), vinda da disponibilização dos produtos e serviços bancários aos clientes, com o mínimo de intermediação humana presencial, formaram um ambiente favorável à disseminação dos diversos usos das novas tecnologias, as quais alteraram a rotina tanto de clientes como de trabalhadores.

Os altos investimentos apontam a relevância que a TI assumiu tanto para quem vê as instituições de fora como para quem está dentro dela. A redistribuição de partes significativas dos processos de trabalho e a reconfiguração da interação entre trabalhadores bancários, empresas terceirizadas e clientes ao longo das três últimas décadas, fizeram parte do mesmo cenário em que houve o aprofundamento da informatização e automação nas instituições financeiras.

\footnotetext{
${ }^{34}$ Algumas reflexões contidas neste tópico foram abordadas no artigo escrito pela autora no curso da pesquisa de doutorado. Ver SANCHES (2012)

${ }^{35}$ Identificação pessoal feita por meio de parte do corpo. De acordo com dados da Pesquisa FEBRABAN (2014), foram coletadas mais de 45 milhões de amostras biométricas em 2014
} 
Diversos elementos que serão abordados ao longo do desenvolvimento desta tese buscarão identificar como as novas tecnologias alteraram a rotina dos agentes envolvidos.

\subsubsection{Novos paradigmas tecnológicos no setor}

A automação e a informatização no setor bancário têm suas origens na década de 1960. Nos anos subsequentes, viu-se gradativamente ampliar suas possibilidades de interação no ambiente de trabalho e na relação que se estabelece com os clientes.

Segundo Accorsi (1990), os acontecimentos que estruturaram a base tecnológica do setor se tornaram mais expressivos desde 1964, ocasião em que surgiram os centros de processamentos de dados - CPDs. O autor apontou as principais evoluções neste campo até a introdução do sistema on-line, em 1980.

Em 1980 existiam três agências on-line no país e, em 1987, o número saltou para 3 mil (ACCORSI, 1990). A moeda eletrônica ${ }^{36}$ foi introduzida na mesma década, sendo que, por meio dela operações de crédito e débito passaram a ser efetuadas em real time (FREITAS, 1998). Mas foi na década de 1990 que a automação bancária ganhou maior visibilidade, especialmente se consideramos a relação direta estabelecida com os clientes e o fato de que já era significativa nas operações de uso contínuo realizadas pelos trabalhadores.

Segnini (1998) havia retratado a automação dos serviços bancários no Brasil como uma referência mundial desde a década de 1990. A declaração do presidente da FEBRABAN ajuda a sustentar essa mesma visão da autora após terem se passado diversos anos.

[...] investimentos constantes em Tecnologia da Informação (TI) da mais alta qualidade, em torno de $\mathrm{R} \$ 4$ bilhões de reais por ano, embutidos em algo como $\mathrm{R} \$ 12$ bilhões por ano de despesas com o item TI, que fazem do parque tecnológico bancário brasileiro um dos maiores, mais bem aparelhados e mais sofisticados do mundo (Márcio Cypriano, Presidente da FEBRABAN em 22 set. 2005, Folha de S.Paulo).

O progresso tecnológico na história do capitalismo é analisado por Marx (1985) como algo endógeno ao sistema. O detentor dos meios de produção mantém como um dos seus objetivos a expansão dos negócios por meio dos meios tecnológicos que

\footnotetext{
${ }^{36}$ A expressão moeda eletrônica designa um conjunto variado de mecanismos de pagamentos e tecnologias, dentre as quais se podem citar cartões e softwares que propiciam a transferências de recursos pela internet e telefones (Freitas, 1998).
} 
dispõe. Com esse viés, os empresários do setor financeiro têm se beneficiado dos novos paradigmas tecnológicos, que possibilitam a confecção de computadores mais rápidos para gerar informações e realizar cálculos operados por microprocessadores igualmente mais ágeis, os quais pelas possibilidades das telecomunicações podem trocar informações para áreas remotas (ABECS, 2009).

Com o avanço das novas tecnologias (hardware, software, componentes eletrônicos e redes de comunicação de dados), em meados da década de 1990, foram amplamente massificadas inovações tanto nas agências como nos departamentos dos bancos. Destacam-se a popularização do uso dos caixas eletrônicos (ATMs - Automatic Teller Machine), largamente difundidos dentro e fora das instalações das agências bancárias, e o início das operações via internet para clientes (JINKINGS, 2002).

A disseminação dos usos de caixas eletrônicos com funcionalidades avançadas demonstra um dos aspectos que destacam a posição do Brasil com relação aos demais países. De acordo com as informações disponibilizadas no Congresso Internacional de Automação Bancária (CIAB) 2015, em nosso país os caixas eletrônicos disponibilizam mais de 400 tipos de transações. Nos demais países pesquisados pela FEBRABAN, predominam apenas as funções de saque e retirada de extrato. Os dados internacionais comparativamente ainda mostram que o número de caixas eletrônicos por população adulta no Brasil é um dos mais altos do mundo, sendo 249 unidades por 100 mil adultos bancarizados, enquanto a relação em outros países cai para 139 na Alemanha, 131 no Reino Unido e 106 no México.

As inovações são contínuas e a cada ano surgem novos projetos com potencial de alterar as relações entre bancos e sociedade. Um grande banco privado nacional, que já havia testado um novo modelo de caixa eletrônico em 2014, passará de acordo com informações divulgadas no CIAB 2015 a expandir a experiência que prevê a dispensa de uso de envelopes para depósitos em dinheiro e cheque, fazendo os valores em espécie serem transferidos em real time e as notas depositadas serem recicladas, ou seja, reutilizadas pelo próximo cliente a operar na máquina. Procedimentos como esse eliminam parte do trabalho manual em relação ao abastecimento da máquina com insumos (envelopes e dinheiro) e no processamento dos envelopes nela inseridos, que incluem: abertura manual, classificação dos tipos de cheque e digitalização, conferência dos valores e ainda sistematização de informações para cada unidade de caixa eletrônico derivadas de coletas realizadas em mais de uma vez ao dia. 
Os investimentos em TI, que em 1992 era da ordem de 2,7 bilhões de reais, em 2005 passaram a 4,6 bilhões, e em 2014 perfizeram 7,7 bilhões. ${ }^{37}$ Os clientes passaram a contar cada vez mais com as formas alternativas ao atendimento presencial na agência. Os terminais de autoatendimento ainda contaram com o compartilhamento de estruturas interbancos, que potencializaram ainda mais seu uso, isso significa dizer, por exemplo, que determinado banco, além de seus próprios caixas eletrônicos, pode fazer parcerias com outros bancos, e por meio de plataformas comuns, como é a rede Banco 24 Horas, permitir o acesso dos clientes para realizar determinadas operações ampliando suas possibilidades de interação (FEBRABAN, 2012).

Um marco nessa trajetória de inovações foi o caso do Sistema Brasileiro de Pagamentos, que em 2002 passou por uma completa reestruturação para se alinhar a outros países que já realizavam transferências interbancárias liquidadas em real time. As razões anunciadas para esta mudança, segundo o operador do sistema, o Banco Central, fundavam-se na agilidade e na redução do risco sistêmico, uma vez que por meio dele é possível fazer o monitoramento, em real time, do saldo das contas transacionadas e ainda reduzir o número de cheques e outras formas de pagamento menos seguras por meio das transferências eletrônicas de fundos entre bancos.

As novas formas dos clientes se relacionarem com o sistema bancário foram se cristalizando à medida que o atendimento na agência tradicional foi perdendo espaço para os demais canais que se expandiam, como foi o caso dos caixas eletrônicos, telefone, internet (PCs, tablets e smartphones) e Correspondentes Bancários. Essa mudança no tipo de acesso ao serviço fez $67 \%$ das transações bancárias serem realizadas sem atendimento presencial. ${ }^{38}$

De acordo com Fortuna (2009), o custo médio por transação obedece a variações expressivas que indicaram, desde a década de 1990, como o setor financeiro daria ênfase às transações eletrônicas realizadas sem atendimento presencial em detrimento das operações efetuadas, por exemplo, diretamente nos caixas das agências convencionais, tendo como mediador da prestação de serviços um trabalhador.

\footnotetext{
${ }^{37}$ Relatórios FEBRABAN e Pesquisa CIAB (anos selecionados).

${ }^{38}$ Revista Financeiro, nov./dez. 2010.
} 
Quadro 1. Custo por transação bancária

\begin{tabular}{c|c}
\hline Canal de Distribuição & Custo por Transação (em US\$) \\
\hline Agências & 1,07 \\
\hline Telefone & 0,54 \\
\hline Autoatendimento (caixas eletrônicos) & 0,27 \\
\hline Internet Banking & 0,01 \\
\hline
\end{tabular}

No levantamento que fizemos, pudemos observar que o Banco $\Delta$ divulga em sua tabela geral de tarifas os custos por transação para os clientes. Tais custos oscilam conforme o canal escolhido. Na comparação dos valores é sempre melhor o preço que não inclui o atendimento presencial na agência bancária (Relatório Gerencial Banco $\Delta$ 2014).

As novas tecnologias da informação e as telecomunicações possibilitaram maneiras de comprimir a quantidade de tempo necessária para realização de trabalhos no setor bancário por meio do acesso ao sistema " 24 horas por 7 dias da semana", como ocorre com os caixas eletrônicos, atendimento telefônico e em operações via internet.

Em 2014, o canal de atendimento ao cliente que obteve maior volume de transações foi o Internet Banking, atingindo a marca dos 18 bilhões. ${ }^{39}$ Para efeito de mensuração, citamos que em 2003 o mesmo canal respondia por 2,6 bilhões de transações realizadas.

O avanço no uso da internet contribui para explicar o fenômeno que aponta para uma sociedade hiperconectada. No Brasil, segundo Barbosa (2014), os usuários da internet ultrapassam metade da população. A questão geracional aponta para o crescimento potencial do uso da rede. Entre indivíduos de 10 a 15 anos, a proporção de uso é de $75 \%$, e entre 16 a 24 anos, de $77 \%$. Demais idades observam uso menos intensivo, como pode-se citar: entre 35 a 44 anos, 47\% são usuários, e de 45 a 49 anos, é de $33 \%$.

O uso de internet pelo telefone celular abrangeu 33\% da população brasileira e as ações mais frequentes a partir deste meio são: acesso às redes sociais, 30\%; compartilhamento de fotos, vídeos ou textos, 26\%; acesso a e-mails $25 \%$ e baixar aplicativos, 23\% (Barbosa, 2014).

Para realizar uma transação bancária via telefone celular, é preciso estar conectado à internet e baixar um aplicativo que pode lançar as informações

\footnotetext{
${ }^{39}$ Fonte: Pesquisa FEBRABAN de tecnologia bancária 2014.
} 
remotamente. Ambas as possibilidades estão se expandindo e se tornando cada vez mais comuns no cotidiano brasileiro, alterando relações entre as pessoas e as instituições, e como não poderia deixar de ser, o próprio processo de trabalho nos bancos.

Segundo divulgação da ANATEL - Agência Nacional de Telecomunicações, em 2012, foram computados 261 milhões de linhas ativas na telefonia móvel no Brasil. Esse dado é fundamental para entender como e porque os telefones celulares, ou computadores de mão, serão a principal forma de relacionamento com as instituições financeiras.

O canal de atendimento bancário que mais cresce em termos proporcionais nos últimos anos é o chamado Mobile Banking. Caracterizado pelo uso de dispositivos eletrônicos portáteis como tablets e smartphones, é visto pelos executivos do setor como canal mais promissor para expansão dos negócios. O gráfico abaixo consegue nos dar uma visão completa de todos os canais e a participação deles na realização das transações bancárias ao longo dos últimos anos.

\section{Gráfico 7}

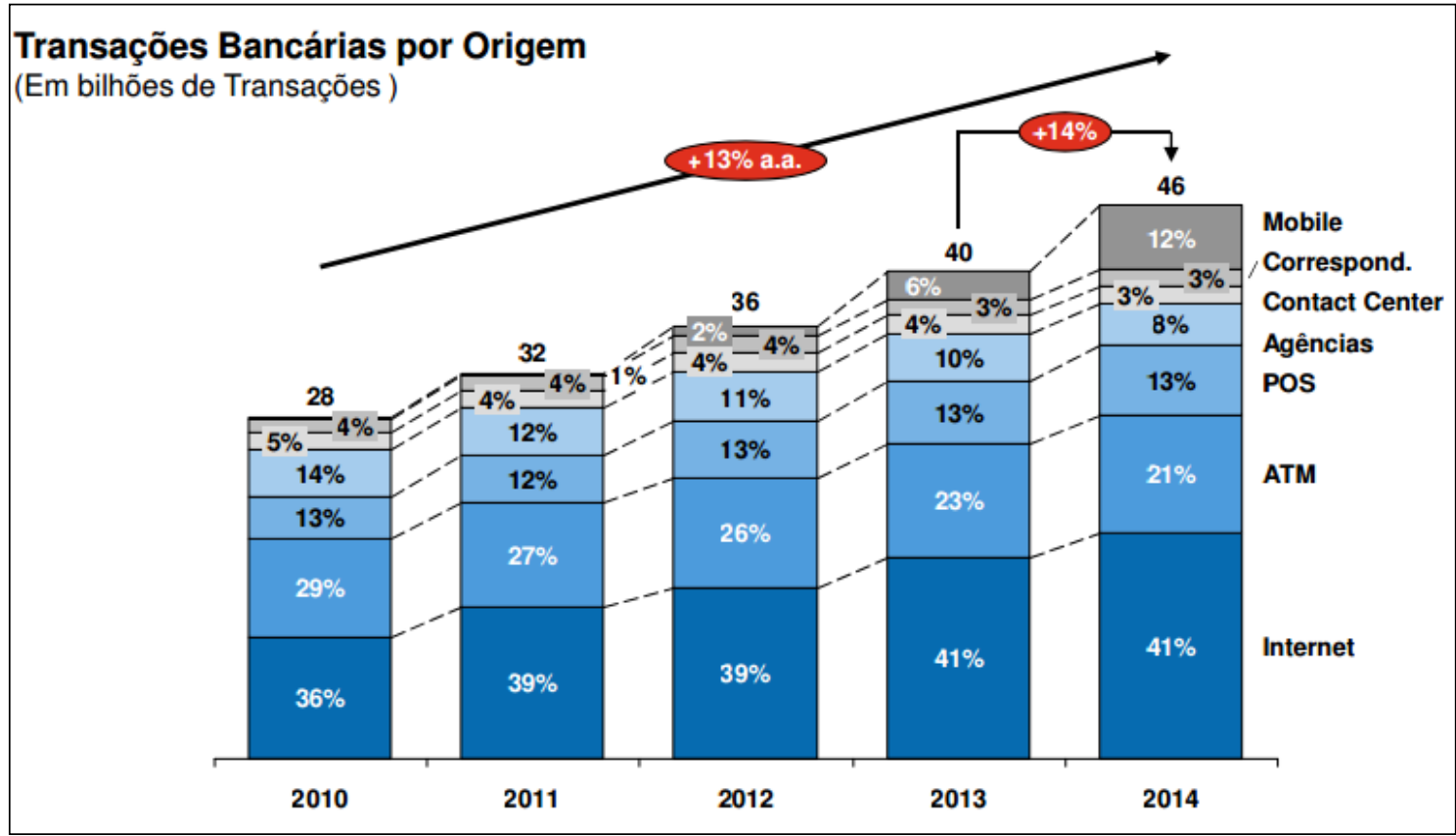

Fonte: Pesquisa FEBRABAN de Tecnologia Bancária 2014.

Notas: Mobile - serviços bancários disponíveis em dispositivos móveis como smartphones e tablets / Correspond - Correspondente Bancário / Contact Center - Teleatendimento / POS - Ponto de Serviço, popularmente designado "maquininha", que serve de base para transações de pagamento em estabelecimentos comerciais / ATM - Automated Teller Machine, no Brasil designado Caixa Eletrônico.

Ao observamos as transações bancárias por origem no Gráfico 7, é possível perceber que ao mesmo tempo em que houve a ampliação e diversificação dos canais de atendimento virtuais (mobile e internet), verificou-se a redução da participação dos 
canais com atendimento humano, com destaque nas agências que saíram de $14 \%$ para 8\% em apenas 4 anos, configurando a queda mais acentuada quando comparada aos demais.

O Gráfico 8 demonstra de outra forma o comportamento dos usuários nos canais de atendimento. Nessa visualização é perceptível a tendência de queda do grupo que reúne: agências bancárias, ATMs (caixas eletrônicos) e contact center (teleatendimento).

\section{Gráfico 8}

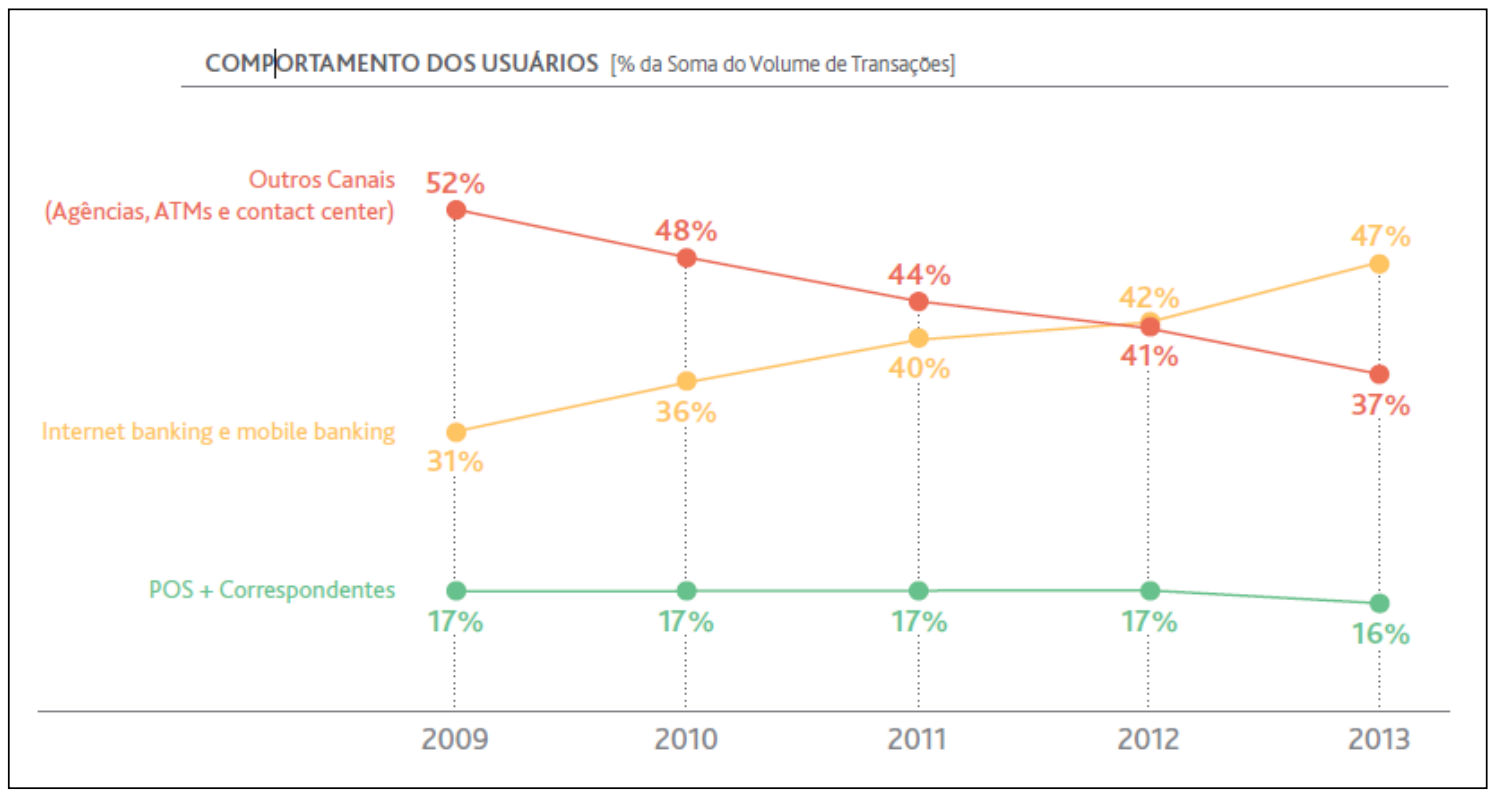

Fonte: Pesquisa FEBRABAN de Tecnologia Bancária 2013.

As tendências dos usos tecnológicos do setor se confirmam no Banco $\Delta$. Os canais digitais, internet e mobile, representavam $8 \%$ do resultado financeiro da instituição em 2012, sendo que apenas no terceiro trimestre de 2015 foram responsáveis por $37 \%$. Paralelamente, o atendimento presencial que era representado por $83 \% \mathrm{em}$ 2012 foi reduzido a $46 \%$ em $2015 .^{40}$

\subsubsection{TI no trabalho bancário e a recomposição de cargos e funções}

A área de TI atua em sinergia com todas as outras áreas de um banco e por meio dela a morfologia do trabalho tem sido redesenhada. ${ }^{41}$ Maçada e Becker (2001)

\footnotetext{
${ }^{40}$ Fonte: Relatório Gerencial 2015 Banco $\Delta$.

${ }^{41}$ No período anterior à década de 1990 , nos bancos, a principal área responsável pelo rearranjo dos processos internos de trabalho era chamada de Organização e Métodos.
} 
ressaltam a importância dos impactos da TI sobre as variáveis estratégicas organizacionais. Para os autores, os executivos dos bancos focaram seu uso para transformar e substituir atividades internas realizadas manualmente por processos eletrônicos.

As inovações tecnológicas, possibilitadas pelas TIs e Telecomunicações, trouxeram novas formas de organizar e dividir o trabalho alterando rotinas, eliminando etapas de trabalho e diminuindo os custos que envolvem insumos variados como papéis, arquivos físicos, postagem, transporte e a própria força de trabalho.

A digitalização de imagens dos mais diversos tipos de documentos bancários tem sido uma das principais vias para automatizar e proporcionar agilidade nos processos. Uma vez digitalizado, o documento pode tramitar por diversas áreas do banco ou nas empresas terceirizadas sem limites impeditivos de tempo e de espaço geográfico. Os arquivos físicos que, em outros tempos, eram reproduzidos em lugares diferentes dentro da mesma instituição, agora podem ser até eliminados.

De acordo com pesquisa recente da FEBRABAN (2014, p. 64), "o estágio atual das interações banco-cliente é fragmentado, ineficiente e exige múltiplos pontos de contato", ou seja, há ainda muito espaço para avançar na modelagem de processos, com base na automatização, que eliminem etapas de trabalho, conforme ilustram os dois gráficos a seguir:

Figura 2. Exemplo de processo de trabalho tipicamente encontrado no setor bancário:

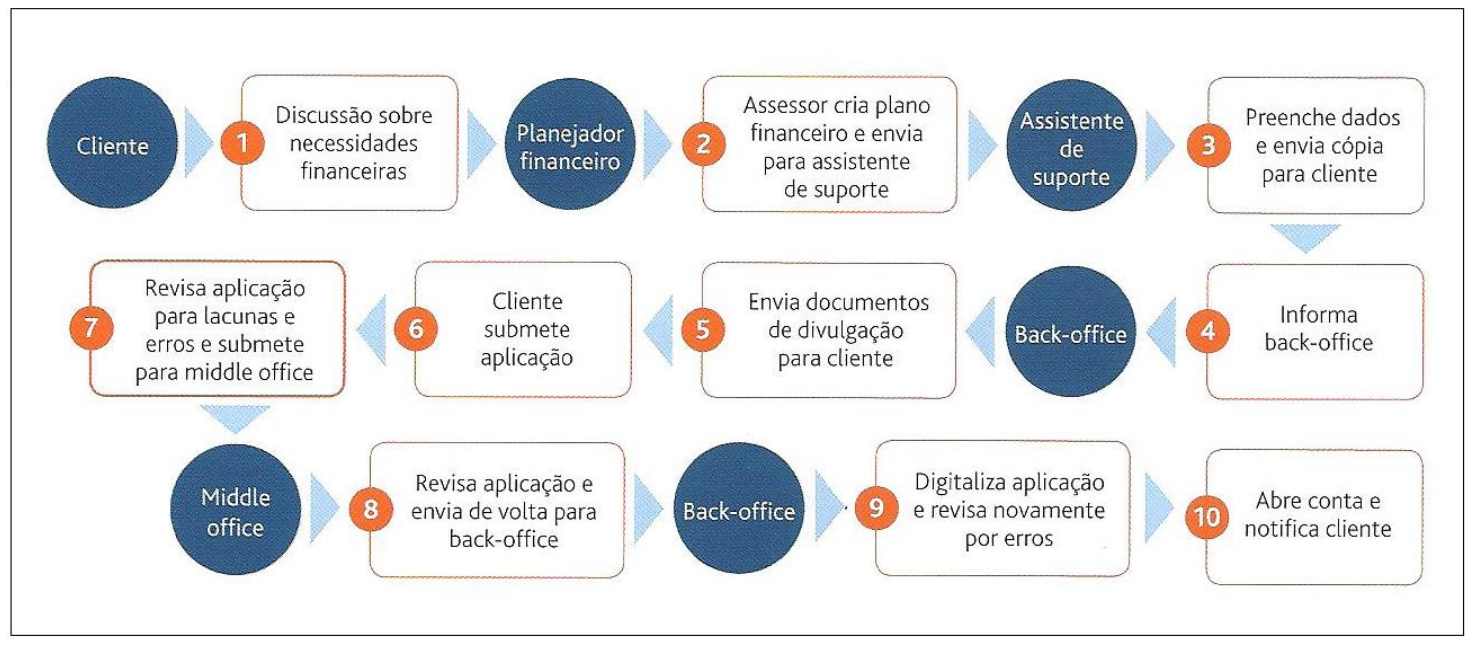

Fonte: Pesquisa FEBRABAN de Tecnologia Bancária 2014. 
Figura 3. Exemplo de processo de trabalho em estágio digitalizado:

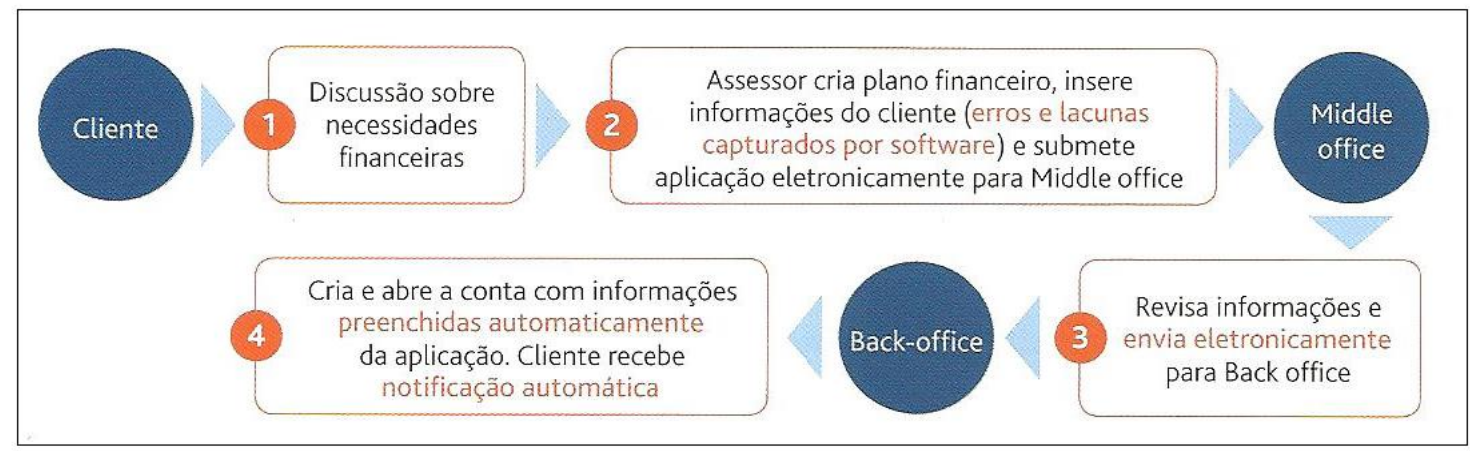

Fonte: Pesquisa FEBRABAN de Tecnologia Bancária 2014.

Ao comparar o "estágio típico encontrado no setor bancário" (Figura 2) com o “estágio digitalizado" (figura 3), é possível ver claramente a subtração de 06 etapas do processo de trabalho escolhido para exemplo.

No Banco $\Delta$, a digitalização relacionada ao serviço de desconto de cheque é um exemplo marcante. Até 2012, o processo envolvia 14 etapas de trabalho, realizados em dois dias, mas considerando a dinâmica oferecida pela digitalização e demais tecnologias disponíveis, passou a contar com apenas 03 etapas e ser realizado on-line, atingindo $96 \%$ do volume de operações desta natureza. ${ }^{42}$

Os executivos do setor, apoiados nas orientações das consultorias de TI, deixam claro que as transformações que ocorrem no setor, já visíveis na relação com os clientes, devem vir acompanhadas da intensificação de mudanças internas, sobretudo em áreas intermediárias como aquelas designadas middle e back office. As razões de ordem econômica que embasam a orientação são demonstradas no gráfico a seguir. A redução de custos operacionais pode ser de até $50 \%$ se houver migração do modo tradicional de realizar transações bancárias para o modo digitalizado:

\footnotetext{
${ }^{42}$ Fonte: Relatório Gerencial 2015 Banco $\Delta$.
} 
Gráfico 9

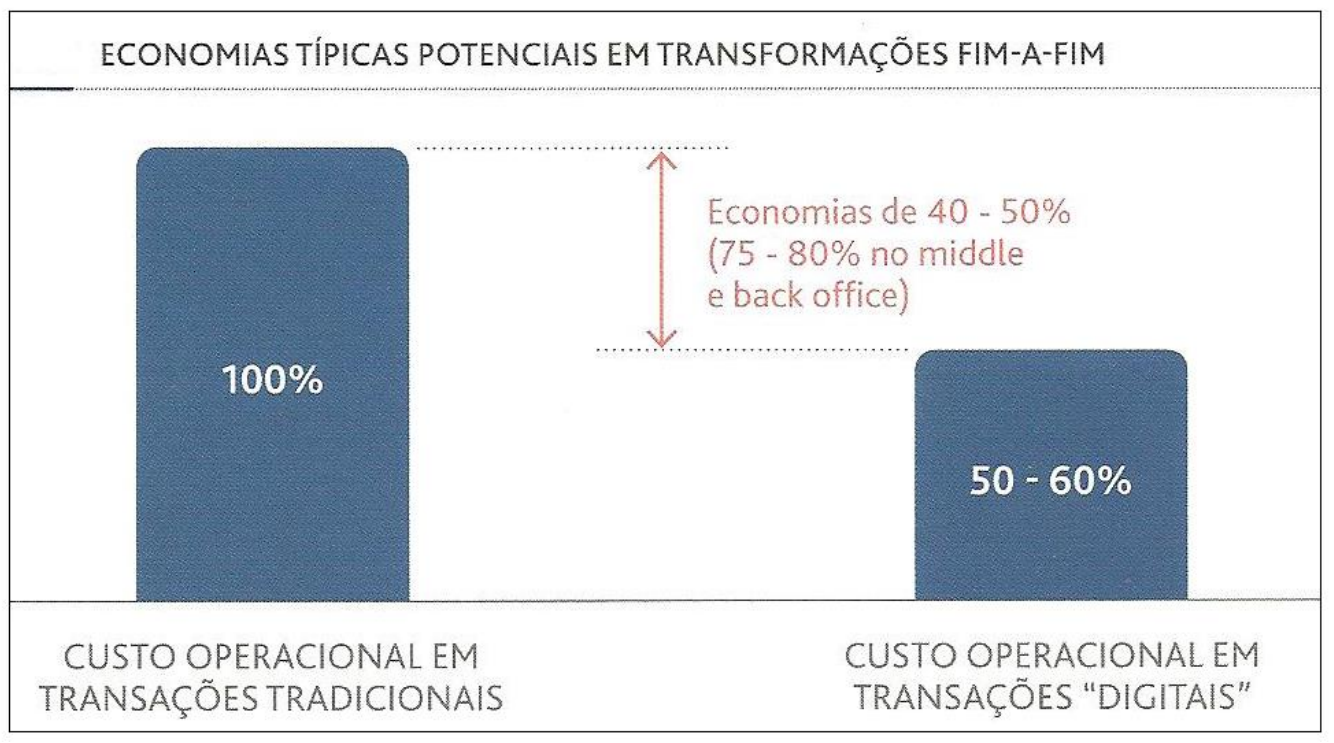

Fonte: Pesquisa FEBRABAN de Tecnologia Bancária 2014.

\subsubsection{Agências}

As agências concentram aproximadamente $60 \%$ de todo trabalho realizado em um banco de grande porte. São locais públicos, amplamente descentralizados, nos quais se comercializam os produtos e serviços bancários. O papel atribuído à agência vem sofrendo alterações substanciais ao longo das últimas décadas. Se outrora significou a única porta de entrada para se relacionar com a instituição, hoje é um dos canais menos acessados pelos clientes, como apontou o Gráfico 7. Contudo, ainda é um espaço importante para a estratégia de negócios bancários, dada a proximidade para se relacionar com os clientes que favorece a compra de produtos e serviços.

Na segunda metade da década de 1990, o ambiente de trabalho bancário já contava com a presença de computadores individuais em todas as mesas de trabalho. É nessa década que o trabalho da Retaguarda das agências foi reorganizado.

Os serviços relacionados à Retaguarda, denominada no jargão corporativo de back office, também estão espalhados pelos centros administrativos dos bancos. Em síntese, representam os serviços internos que processam todas as transações, produtos e serviços demandados pelos clientes.

O rearranjo da retaguarda das agências contou primeiramente com um processo de centralização das suas operações e posteriormente passou por intensa automatização das etapas de trabalho. As tarefas remanescentes, ainda simplificadas e rotinizadas, que 
não haviam sido informatizadas e automatizadas, em grande parte foram repassadas para empresas terceirizadas.

A agência, como um ponto de convergência entre banco e clientes, mudou sua atuação, assumindo cada vez mais a função de vitrine para venda de produtos e serviços. As inovações tecnológicas implementadas disponibilizaram gradualmente outros canais que possibilitavam realizar as operações bancárias - pagamentos, saques, depósitos, aplicações, transferências, recebimentos de talões de cheques - fora deste espaço físico.

Nos terminais de caixa das agências, com atendimento presencial ao público, foram instalados programas integrados ao sistema de informações do banco, permitindo a atuação em real time. Também foram introduzidos equipamentos que realizam a leitura ótica de cheques. Tal inovação possibilitou a captura de dados dos documentos na "boca do caixa", eliminando parte do trabalho manual de digitação de dados.

A ficha digitalizada de assinaturas dos clientes foi outra ferramenta que propiciou, por exemplo, que a conferência de assinatura do cheque fosse feita de forma direta, isto é, sem que o trabalhador deixasse seu lugar, dinamizando o processamento operacional. Antes o bancário saía de seu posto de trabalho para procurar no arquivo a ficha cadastral do cliente, a fim de verificar sua autenticidade, tarefa que passou a fazer diretamente no computador disponível em cada guichê de caixa. Esse é um exemplo singular dentre tantos outros que poderíamos citar.

A automatização do processo de trabalho nas agências também levou a mudanças na disposição física do ambiente que, para citar a década de 1980 em efeito comparativo, mantinha logo na entrada um espaço destacado para a bateria de caixas que realizavam o atendimento presencial dos clientes. Bancos de grande porte mantinham nas agências maiores, aproximadamente, vinte guichês de caixa com trabalhadores bancários processando as operações. Nos dias atuais, em detrimento do atendimento presencial, ao entrar na agência, o cliente depara-se com um volume numeroso de caixas eletrônicos naquilo que se convencionou chamar de antessala, espaço muitas vezes separado por uma porta de vidro do resto da agência, que funciona em horário expandido ao horário comercial bancário.

As fotos a seguir podem nos dar uma visão da disposição física das agências bancárias, observando um intervalo temporal de 21 anos. Na Imagem 2, a foto foi feita de dentro da agência no sentido da porta de entrada, o que consegue nos dizer o quão relevante era o papel do bancário que tinha a função de Caixa. Na Imagem 3, a foto foi feita na entrada da agência, o ângulo destacado privilegiou os caixas eletrônicos, o que 
nos dá a dimensão da sua abrangência, haja vista que estes passaram a substituir a função de Caixa operada por trabalhadores que, apesar de ainda existirem, têm a cada dia diminuído suas proporções na carreira bancária.

Imagem 2

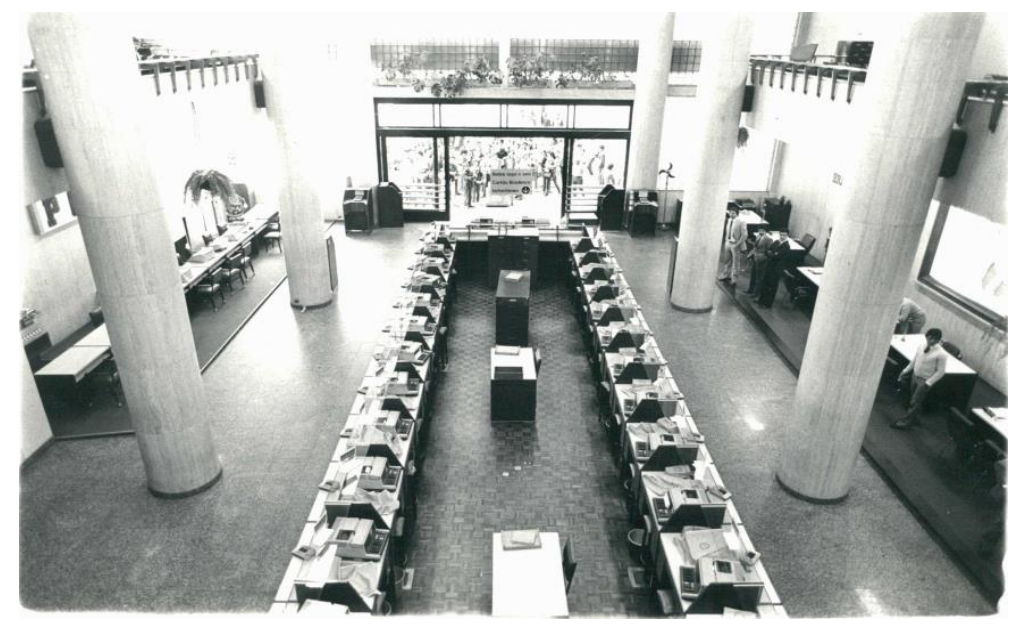

Vista da entrada de agência bancária, 1986.

Imagem 3

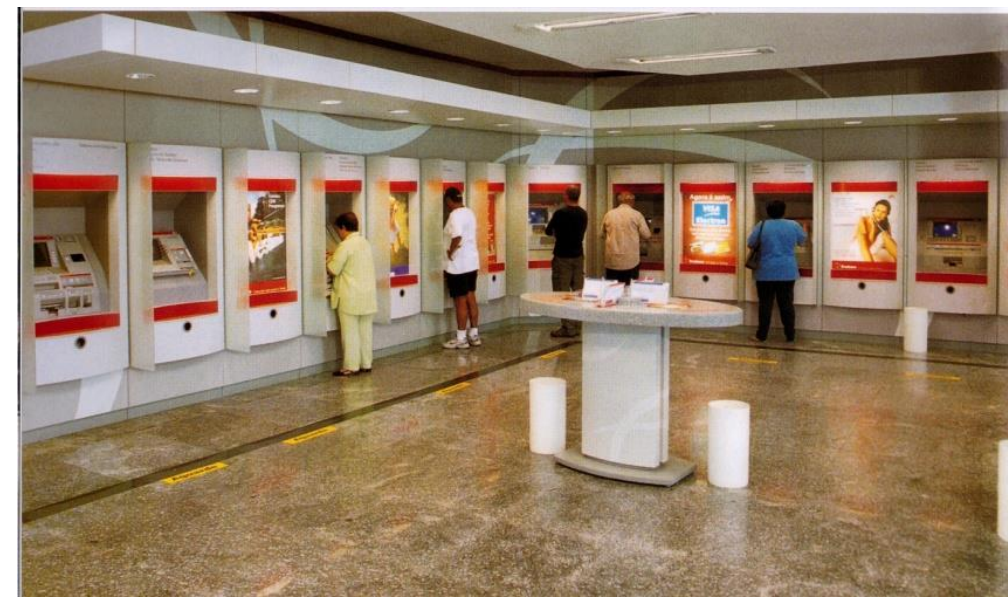

Vista da entrada de agência bancária, 2007.

Os bancos se empenharam em reduzir a presença dos clientes nas agências. Os funcionários desses estabelecimentos foram orientados a direcioná-los para o atendimento nos caixas eletrônicos e demais canais do banco, como telefone, internet e, posteriormente, já nos anos 2000, aos Correspondentes Bancários, sobretudo para realizar operações bancárias mais simplificadas, como pagamento de contas, saques, depósitos, transferências, dentre outras. 
$\mathrm{O}$ atendimento remoto foi intensificado substituindo o que antes era presencial. Funções como a das Telefonistas das agências sofreram alterações, à medida que estas passaram a figurar como Operadoras de Teleatendimento nas Centrais Telefônicas, que se tornavam cada vez mais disseminadas. A centralização dos telefones de diversas agências nas Centrais de Atendimento Telefônico buscou reduzir o fluxo de chamadas locais. O cliente passou a ser atendido pela Central, e caso ali não conseguisse resolver sua demanda, ele era retransmitido para a agência local para tirar uma dúvida ou falar com o seu gerente.

Como resultado das mudanças na interação entre clientes e bancos, novas ocupações surgiram, ${ }^{43}$ em que pese haver oscilações na nomenclatura entre bancos, preservam-se conteúdo similares. A cena do trabalho bancário passou a incluir a figura do Auxiliar do Autoatendimento, funcionário designado para facilitar e viabilizar o atendimento dos clientes nas operações realizadas nos caixas eletrônicos localizados nas antessalas das agências. Essa função, por requerer atribuições com menor grau de complexidade, na maior parte dos bancos, foi e tem sido repassada para estagiários, trabalhadores terceirizados ou, ainda, a jovens participantes de programas sociais do governo que recebem uma ajuda de custo pelo trabalho desempenhado.

No âmbito das mudanças operacionais impulsionadas pelas novas tecnologias é relevante o crescimento da função dos Operadores de Teleatendimento, ${ }^{44}$ segmento que atua nas Centrais de Atendimento Telefônico ${ }^{45}$ ao longo dos anos 1990 e anos subsequentes. Sua origem na estrutura das instituições bancárias, além de observar a migração da função da antiga telefonista, é marcada pela substituição do papel antes exercido pela antiga função do Escriturário, ${ }^{46}$ no atendimento, até então presencial, realizado nas agências bancárias.

\footnotetext{
${ }^{43}$ A autora esclarece que os dados da RAIS, por trazerem informações sobre as ocupações/cargos atrelados ao que a CBO permite declarar, não possibilitam que seja feita uma mensuração adequada no sentido de acompanhar a evolução das novas ocupações, pois cada banco pode a critério próprio dar a designação que bem entende e consequentemente adotar a nomenclatura que achar mais adequada, dificultando nossa análise com base em dados estatísticos ao longo do tempo. Nossas afirmações são calcadas no trabalho de campo, sobretudo no $\operatorname{Banco} \Delta$, e na verificação da literatura sobre o setor que passou a citar algumas das ocupações aqui mencionadas.

44 Para maior aprofundamento sobre a ocupação "operadores de teleatendimento" ou trabalhadores em call centers, consultar VENCO (2006) e ANTUNES e BRAGA (2009).

${ }^{45}$ É habitual que as Centrais de Atendimento Telefônico sejam reconhecidas por outras designações, como podemos citar: central de chamadas, call center, telemarketing, e ainda outros nomes escolhidos pelas instituições. Há uma variável relevante que se determina pelo tipo de atuação "ativa" ou "receptiva". Quando a Central de Atendimento Telefônico recebe ligações no jargão do meio corporativo, se traduz pela função "receptiva". Já é considerada "ativa" quando os trabalhadores do banco ou empresas terceirizadas contratadas pelo banco entram em contato com clientes e potenciais consumidores para divulgar e comercializar produtos e serviços bancários.

${ }^{46} \mathrm{O}$ cargo do Escriturário ainda pode ser encontrado em números expressivos nos bancos públicos, mas advertimos que se trata de nomenclatura referência, porquanto hoje predominam formas de comissionamento que nada tem a ver com a função nos moldes que tinha nos anos de 1980 ou 1990.
} 
Concomitantemente, derivado da ênfase à política de vendas de produtos, houve o crescimento do número de funcionários vinculados aos cargos de Gerentes de Contas e Assistentes de Gerência, que dão suporte ao atendimento realizado pelos Gerentes nas agências. $\mathrm{O}$ trabalho caracterizado pelo atendimento direto ao cliente, front office, foi também redimensionado em função das inovações tecnológicas. Por meio delas, foi possível ganhar agilidade e ter acesso a um amplo leque de operacionalidades.

A rotina de prestação do serviço bancário leva os trabalhadores a manipularem informações que estão integradas por sistemas complexos, que contam com o auxílio de softwares sofisticados, como são aqueles chamados de "intuitivos".

De acordo com Cossalter e Venco (2012, p. 79):

A tecnologia aplicada evolui direcionada à comunicação, na qual a informação circula por redes e é tratada sucessivamente em diversos níveis. Essa multiplicidade de tratamentos permite seu enriquecimento. Passa-se de simples procedimentos contábeis a uma complexa gestão e valorização da informação.

As possibilidades geradas a partir daquilo que a indústria de TI define como "interface intuitiva dos softwares" potencializa a ação do trabalhador. O perfil de determinado cliente, considerando a facilidade para acessar suas informações sobre renda, movimentação financeira e investimentos, serve para orientar a venda de novos produtos e serviços. Mas não apenas essas informações alimentam os bancos de dados das instituições que se tornam a cada tempo mais complexos, a conduta, os hábitos e até mesmo os potenciais interesses manifestos pelos clientes podem ser monitorados. Por meio da "navegação" que um cliente faz no site do banco, um software pode rastrear suas ações e reunir informações que se tornem alavancas para novos negócios das instituições financeiras.

Ele [o cliente] fez na internet uma simulação de crédito, então o sistema coloca: esse cliente fez uma simulação, ele pode ter interesse, liga para ele, para falar com ele sobre isso. É um big brother. Ele [o sistema] consegue na internet e em todos os meios eletrônicos. Mas, o que é dito para gente é para a gente não falar que tem conhecimento disso. É o que chamamos gatilho. (Bancária, Gerente de Contas, 35 anos, 08 de banco)

Situação similar se reproduz em diversas esferas do processo de trabalho nas instituições financeiras. Nos últimos congressos internacionais de automação bancária ${ }^{47}$ que ocorreram no país tem sido discutidas a implementação e relevância do Big Data. O

${ }^{47}$ CIAB, São Paulo, SP. 2013 e 2014. 
nome é uma referência ao grande volume de dados que circulam dentro e fora das empresas, operados em alta velocidade e oriundos de fontes variadas.

O Big Data estabelece conexões em tempo real a partir de dados estruturados, vindos da própria instituição, ou, de dados não estruturados, como são aqueles disponíveis nas redes sociais. Diariamente são disponibilizados, por meio dos diversos dispositivos e conexões, bilhões de informações, sendo que a maior parte advém dos dados não estruturados, que se transformam em informações que vão potencializar novas frentes de vendas direcionadas para produtos e serviços bancários (revista $C I A B$, 2014).

A facilidade de obter os dados é apenas uma etapa anterior à análise e ao cruzamento de bases que possam na ponta ser transformadas em "vantagens" no negócio. O monitoramento de informações sobre os hábitos dos clientes em outros locais, que não o próprio banco, indica as possibilidades de consumo e a relação que isso pode ter com a instituição que fará uso do Big Data. Então, se o cliente de determinado banco faz uma viagem internacional, ele poderá se interessar em ampliar o limite de seu cartão internacional, fazer saque em rede mais próxima, acessar informações sobre a conversão da moeda e ainda receber dicas de conveniência com base nos dados de seu histórico de consumo no Brasil observados no cartão de crédito. Assim, se por acaso no Brasil ele gosta do café de uma rede internacional, poderá também encontrar a loja mais próxima da mesma rede onde quer que ele esteja, o banco poderá the informar via SMS, mantendo a partir desta relação um canal em que a aparente cordialidade poderá ser sinônimo de fidelidade entre ele e a instituição.

O cliente passou a ter sua vida mapeada pelo uso que faz do meio digital, sendo este submetido a uma situação de monitoramento constante, sem que ele mesmo tenha a dimensão deste fato. Um "big brother", de acordo com a metáfora utilizada pela bancária, fica, portanto, adequado à situação.

\subsubsection{Centros Administrativos}

Por meio do trabalho burocrático caracterizado pela análise, suporte e validação de inúmeras variáveis contidas nos processos cotidianos bancários que relacionam clientes, agências, departamentos, governo e Banco Central é possível viabilizar a 
prestação de serviços financeiros. Esse conjunto de tarefas se situa nos chamados Centros Administrativos.

As atividades burocráticas necessárias ao funcionamento das instituições financeiras após todas as mudanças de cunho tecnológico no setor levaram à ampliação significativa do cargo que é hoje um dos mais frequentes dentro das áreas administrativas dos bancos: os Analistas de Processos, os quais são designados genericamente apenas Analistas. Nesse caso, explicamos que o uso do termo não deve ser confundido com Analistas de Sistemas, apesar de esta função também estar mais presente nas instituições.

Para efeito demonstrativo, nossa pesquisa apurou que na área de Câmbio de um grande banco privado nacional situam-se 219 pessoas distribuídas nos seguintes cargos:

\section{Gráfico 10}

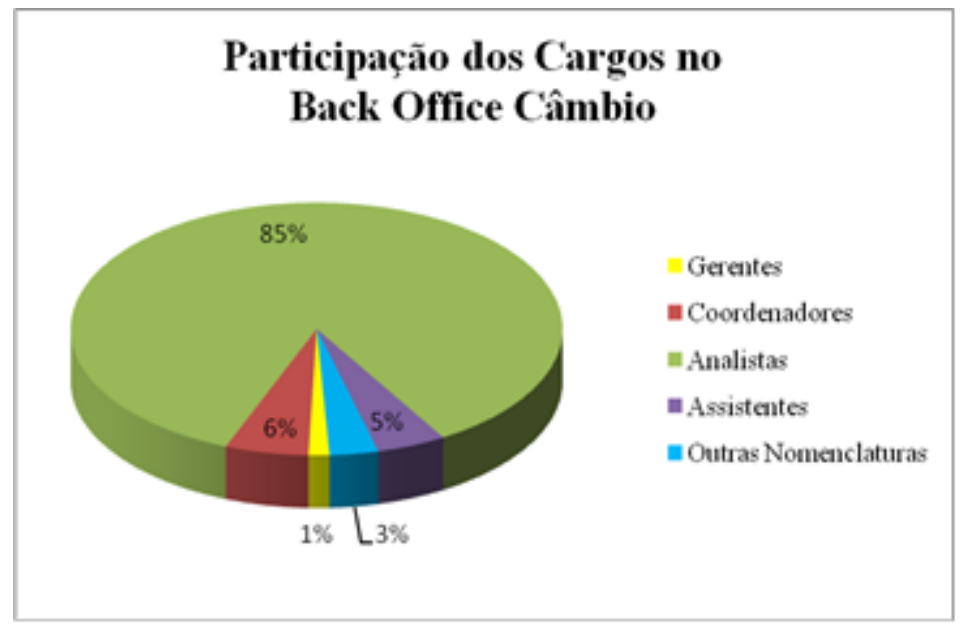

Fonte: Documento institucional de um grande banco privado nacional, 2014. Elaboração da autora.

Nas áreas administrativas dos bancos tornaram-se comuns a atuação de Técnicos, Analistas de Sistemas ou Especialistas em Tecnologia da Informação. A função deles, muitas vezes terceirizados, é dar assistência na área assim que surgir determinado problema, porém, mais do que isso, é poder, em todo momento, perceber e ajudar a automatizar determinada tarefa.

A pirâmide ocupacional ${ }^{48}$ (Gráfico 11), além de expressar a hierarquia dos cargos, demonstra o quanto a categoria bancária é heterogênea e reúne trabalhadores

\footnotetext{
${ }^{48}$ Os nomes dos cargos usados nos bancos, em grande parte dos casos, não correspondem à CBO - Código Brasileiro de Ocupações, portanto, o que é declarado para o Ministério do Trabalho e Emprego para compor sua base de dados não espelha o que acontece nas mudanças das carreiras. Os bancos fazem aproximações de seus cargos à descrição da CBO. O que buscamos retratar é fruto das experiências relacionadas ao trabalho de campo, que inclui observação direta e juntada de documentos. Também nos apoiamos nas entrevistas realizadas.
} 
que atuam tanto em funções simplificadas quanto em funções analíticas, técnicas ou de gestão.

Essa situação se refletirá na composição do quadro de carreira das instituições financeiras bancárias que se apresenta bem estratificado. Assim, apesar de serem submetidos em grande medida às mesmas regras, controles e sob o mesmo clima organizacional, é preciso considerar que convivem nestes ambientes trabalhadores com funções altamente especializadas, valorizadas monetariamente e com alto prestígio social junto daqueles que possuem funções menos especializadas e correlativamente menos valorizadas monetariamente, onde se situa a maior parte da força de trabalho.

\section{Gráfico 11. Grupos de trabalhadores nos bancos por hierarquia funcional}

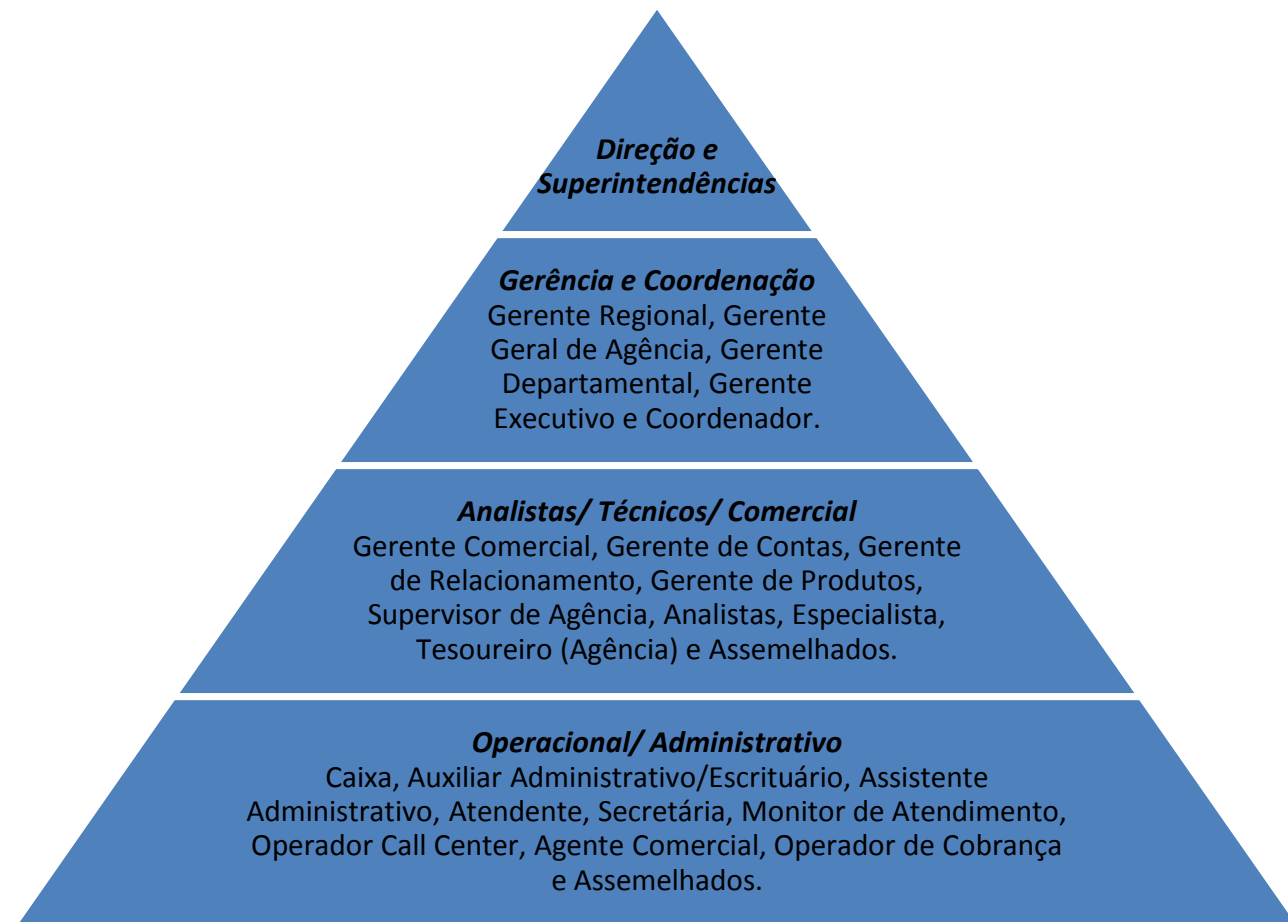

Fonte: A classificação acima foi inspirada na divisão por grupo operacional contida no questionário padrão da pesquisa promovida pela FEBRABAN "Censo da Diversidade - 2014”. Disponível no site www.febraban.org.br. Acesso em: fev.2015 Foi feita uma livre adaptação por conferir melhor sentido e compreensão dos grupos. Elaboração da autora.

Notas: a) Os cargos designados "Gerentes" obedecem a variações importantes, a saber: podem conter cargos vinculados ao gerenciamento de setores, de grupos, projetos ou podem se referir à função comercial de gerenciar "carteira de clientes". Os níveis salariais nestes casos observaram distâncias consideráveis, por isso o mesmo cargo aparece em dois grupos distintos; b) Os cargos de Analistas não devem ser interpretados como analistas de um tipo estrito, como Analista de Sistema. No interior das instituições este é um dos cargos com maior volume de trabalhadores atualmente. Seu papel nesse caso é relativo à análise de procedimentos burocráticos internos que na ponta viabiliza os mais variados produtos financeiros.

Este é o retrato mais atualizado que dispomos; entretanto, considerando a tendência da ampliação das terceirizações e contínuas inovações tecnológicas, somadas às declarações dos executivos dos bancos sobre aquilo que eles próprios definem de 
"agência do futuro", parte das funções consideradas repetitivas e simplificadas, que hoje compõe a base da pirâmide, tende à rigorosa diminuição.

Cargos que tradicionalmente compunham esta base na década de 1980, como os de Portaria (ascensorista, recepção, serviços de contínuos) e Escriturário, são praticamente residuais dentro dos bancos privados, e quando a função existe, ela é terceirizada. Outro grupo de cargos que reúne os Caixas, Tesoureiros e Chefes de Serviço das agências tem sido constantemente reduzido, os motivos derivam dos processos de terceirização, das novas estratégias de negócios implementadas nas agências e ainda, como temos tentado demonstrar, das inovações tecnológicas. Entretanto, mesmo que outro grupo de cargos, composto pelos Gerentes de Contas, Analistas, Técnicos e Coordenadores, cresça, percebe-se que comparativamente representa um número menor de pessoas envolvidas. $^{49}$

Os Coordenadores assumem em grande medida o antigo papel do Chefe de Setor, que predominava nos Centros Administrativos, compondo o primeiro nível de cargos com atribuição de gestão que envolve o fluxo de trabalho e trabalhadores.

O movimento de redução de níveis hierárquicos, downsizing, perpassou pelos anos 1980 e 1990, e permaneceu nos anos posteriores. De acordo com Donadone (2009), tal movimento fez parte das mudanças organizacionais que não foram exclusivas do setor bancário, achatando a pirâmide de posições, com o respectivo corte de cargos. Em alguns casos eliminando setores ou departamentos inteiros que no rearranjo se tornaram terceirizados.

Os processos de automação têm sido associados à redução de postos específicos de trabalho que se situam na base da pirâmide de cargos e salários dos bancos, pois é inequívoca a passagem de parte do trabalho efetivamente executado para a forma automatizada, o que torna supérflua parte da força de trabalho. Caso exemplar é a função atribuída à função de Caixa (atendimento presencial) versus o caixa eletrônico.

Diversos autores mencionaram o caráter poupador de força de trabalho das inovações tecnológicas no setor bancário (SEGNINI, 1998; JINKINGS, 2002; CHAVES, 2005; SOARES, 2013). O debate que envolve redução de empregos e

\footnotetext{
${ }^{49}$ Reforçamos nossa percepção sobre as mudanças que envolvem as funções dentro dos bancos no setor privado, trazendo à tona a análise feita por VASQUEZ E CAVARZAN (2015) que ao observarem o saldo de empregos por ocupações nos bancos privados, pela RAIS 2013, verificaram "a família ocupacional mais atingida foi a de "escriturários de serviços bancários" com redução de 7.722 postos de trabalho, passando de 68.860 trabalhadores para 61.138 , uma queda de $11,2 \%$ em apenas um ano. De acordo com a Classificação Brasileira de Ocupações (CBO), desenvolvida pelo Ministério do Trabalho e Emprego tal família ocupacional engloba as seguintes ocupações: atendente de agência, caixa de banco, compensador de banco, conferente de serviços bancários, escriturário de banco e operador de cobrança bancária”. Os autores ainda apontaram que a família ocupacional com maior aumento no número de postos de trabalho nos bancos privados entre 2012 e 2013 foi "Especialistas em promoção de produtos e vendas", com elevação de 2.710 vínculos, passando de 1.188 bancários para 3.898 bancários, cujas atividades estão relacionadas à venda de produtos e serviços aos clientes, dentre outras funções.
} 
tecnologia tem sido permeado por controvérsias e uma análise cuidadosa sobre esta relação pede a observância de outras variáveis que envolvem as diversas mudanças que ocorrem no setor bancário, como é o caso das fusões, privatizações, terceirizações e inevitavelmente o cenário econômico em que se situa a instituição.

Ademais, também vale considerar que o investimento tecnológico pode potencializar o negócio e fazer surgir novas ocupações dentro dos bancos, ainda que não no mesmo lugar e com as mesmas funções. Oliveira (2014) frisa que a tecnologia é um meio pelo qual os administradores reorganizam o processo de trabalho e ajustam as estratégias de negócios, obtendo, por exemplo, mais facilidade para terceirizar. O autor destaca que esse processo possibilitou que migrassem empregos de uma base para outra, o que relativizaria, portanto, a caracterização intrínseca entre avanços tecnológicos e desemprego, na medida em que observou a correlação com o aumento dos Correspondentes Bancários. Dulci (2015) também aborda a questão dos impactos da tecnologia no mercado de trabalho bancário levando em consideração que esta relação reconfigurou as formas de inserção no mercado financeiro, ou seja, a autora reforça a ideia de que empregos tanto no setor bancário como nos outras instituições que prestam serviço aos bancos puderam observar crescimento quando em especial a própria economia do país se desenvolvia entre os anos 2000 e 2010.

Registramos esses elementos no sentido de levantar as preocupações que emergem sobre as perspectivas de emprego no setor. Para haver uma apuração, talvez uma "conta de chegada", estimamos que todas essas variáveis citadas deveriam ser levadas em consideração. Mas, ainda assim, pode não haver uma contabilidade de fácil manejo, uma vez que empregos podem ser gerados ou subtraídos em outras pontas nos diversos processos de trabalho, ou seja, tornar-se algo imponderável. De toda forma, nenhum dos autores citados despreza o fato de os processos de automação eliminarem

funções e etapas de trabalho, sobretudo, quando se observa isoladamente determinada unidade, o que torna essa variável um forte ponto de partida para qualquer análise.

\subsubsection{Trabalho remoto}

Diversos arranjos são possíveis quando falamos em trabalho remoto. $\mathrm{O}$ teletrabalho é, por exemplo, uma dessas modalidades. Pode ser entendido por aquele tipo de trabalho que se realiza nas Centrais de Atendimento Telefônico, ou seja, feito à distância do cliente e que habitualmente concentra trabalhadores lado a lado, em uma 
base física definida. Mas, para além dessa noção, temos percebido que é possível querer designar o trabalho que se realiza na própria residência do trabalhador, podendo atender a clientes ou áreas internas das instituições.

No survey "Tecnologia e terceirização no setor bancário", ${ }^{50} 46 \%$ dos bancários participantes disseram ter desconhecimento do trabalho remoto, seguido de $38 \%$ que percebem que esta realidade já faz parte do cotidiano de trabalhadores de diversas áreas do banco. Do ponto de vista das empresas, as maiores ressalvas no que concerne este tipo de trabalho se aplicam a problemas de segurança no acesso à rede da instituição remotamente e ainda dúvidas sobre as relações trabalhistas, uma vez que o trabalhador pode se conectar em qualquer tempo.

$\mathrm{Na}$ última década tem sido frequente no $\operatorname{Banco} \Delta$ o uso do trabalho remoto para além das Centrais de Atendimento Telefônico. Estamos nos referindo àquele tipo de trabalho pelo qual o trabalhador pode acessar de sua residência o sistema do banco para realizar suas atividades, bastando usar a senha que lhe é disponibilizada. Nossa percepção é de que esta modalidade, antes apenas utilizada pelos profissionais de TI, tornou-se usual para outras funções, como é o caso dos gestores em seus diversos níveis: Coordenadores, Gerentes, Superintendentes e Diretores.

Em entrevista, a trabalhadora da área de crédito menciona como reconhece o trabalho remoto em seu ambiente de trabalho:

O pessoal da gerência e coordenação tem notebook... e o serviço precisa de uma alçada. No sábado e domingo pode não ter ninguém lá, então cai direto para esse pessoal autorizar direto da casa deles. (Bancária, Analista Sênior, 30 anos, 11 de banco)

Esse tipo de autorização que os cargos de gestão possuem é necessário para viabilizar a continuidade de etapas de trabalho que são realizadas nos Centros Administrativos, nas áreas de back office. Quando há trabalho em finais de semana, e os gestores não estão no ambiente físico onde o trabalho se realiza, é por meio do acesso remoto que eles autorizam procedimentos e podem controlar toda a produção. Porém, isso está fora das suas jornadas estabelecidas nos contratos de trabalho e não há pagamento de horas extras.

\footnotetext{
${ }^{50}$ Levantamento de opinião por meio de questionário de múltipla escolha elaborado pela autora a um grupo de 120 bancários de bancos públicos e privados em evento promovido pelo Sindicato dos Bancários de São Paulo, no município de Boraceia-São Sebastião, em novembro de 2010. O questionário contemplava 07 questões para identificar o perfil dos respondentes e 21 sobre aspectos relacionados a tecnologia, processo de trabalho e terceirização.
} 
Diante das mutações estabelecidas na sociedade, em 2011, a Presidência da República $^{51}$ sancionou lei que trata do uso das inovações tecnológicas e sua relação com o trabalho à distância. Constam nos termos da referida lei que "os meios telemáticos e informatizados de comando, controle e supervisão se equiparam, para fins de subordinação jurídica, aos meios pessoais e diretos de comando, controle e supervisão do trabalho alheio". Busca-se, a partir dela, estabelecer parâmetros de convivência quando trabalhadores se submetem à nova modalidade de cumprimento de tarefas, considerando que o cotidiano do trabalho assalariado tem se tornado cada vez mais poroso à vida privada.

De acordo com pesquisa citada em matéria veiculada no jornal diário paulista, ${ }^{52}$ constata-se que: "e-mail e celular estendem a jornada de trabalho para casa e até nas férias". Na pesquisa, a combinação entre crescimento mais intenso da economia brasileira e o avanço nas tecnologias resultaram no aumento de horas trabalhadas, sendo que $80 \%$ dos entrevistados afirmaram que são acionados nos momentos de lazer e descanso via mensagens de celular e $50 \%$ respondem a e-mails nas férias. A elevação do cansaço e estresse é apontada como consequência dessa relação on-line entre trabalhadores e as empresas em tempo integral.

A virtualização permite que funcionários façam reuniões on-line, compartilhem arquivos e acessem base de dados das instituições independente da localização. Esse aspecto reflete na organização sindical dos trabalhadores do setor.

Em ocasiões onde o movimento sindical bancário realiza paralisações em função de protestos ou greves, grandes grupos de trabalhadores têm permissão de acessar remotamente seu computador com a base de dados e as ferramentas informáticas necessárias para poder trabalhar à distância. Uma vez conectado ao sistema do banco, o trabalhador registra o início da sua jornada de trabalho, pausas e encerramento, como se estivesse no próprio ambiente de trabalho. A trabalhadora a seguir explica como o acesso remoto funciona nos dias em que o sindicato paralisa o Centro Administrativo do $\operatorname{Banco\Delta :}$

Eles dão a senha de acesso. Quem não tem acesso remoto tem que ir para o banco e ficar esperando abrir ou vai para outro lugar trabalhar. Tem a contingência... Eu sempre tive acesso remoto, porque eu respondo muito e-mail para outras áreas. $\mathrm{Na}$ área tem 18 pessoas, umas 7 ou 8 tem acesso remoto (Bancária, Analista Sênior, 30 anos, 11 de banco).

\footnotetext{
${ }^{51}$ Lei $\mathrm{n}^{\mathrm{o}} 12.551$, de 16 de dezembro de 2011.

${ }^{52}$ Jornal Folha de S.Paulo, 28 de novembro de 2011. Pesquisa encomendada pelo jornal à agência de recrutamento ASAP aplicada em 1.090 participantes com renda mensal entre $\mathrm{R} \$ 5.000$ e $\mathrm{R} \$ 15$ mil.
} 


\subsubsection{Home office}

O trabalho em domicílios, conforme analisou Krein (2007), passou a ser mais uma estratégia da gestão flexível da força de trabalho que toma por base a redução de custos operacionais para o capital. Pode estar associado a um maior nível de informalidade, mas também estar associado a um contrato regular, haja vista que são mantidas todas as formas de subordinação e controle on-line.

A expressão home office a princípio designa escritório em casa. Pode ser apreendida como uma forma de trabalho remoto à medida que o trabalho é realizado longe da base física da empresa. Contudo, para tentar ajustar o uso dos termos, quando tratamos de home office, queremos situar determinadas práticas de caráter não eventual, ou seja, que estão inseridas no contexto dos processos de trabalho, ainda que à distância, nos domicílios e marcadamente disciplinadas pela gestão das empresas.

A experiência das grandes corporações bancárias em manter trabalhadores assalariados realizando atividades em suas residências tem ganhado espaço nos últimos anos no Brasil. No CIAB 2015, foram registradas duas experiências em curso, uma relativa a um banco estrangeiro e outra relativa a um banco público.

O banco estrangeiro demonstrou possuir a experiência mais desenvolvida no setor. Desde 2008 adota o uso de home office no Brasil. De acordo com dados disponibilizados por Fris (2015, informação verbal), ${ }^{53} 9 \%$ do total de trabalhadores atuam nessa modalidade. São, portanto, 579 bancários, sendo que destes $70 \%$ são homens.

O processo que envolve a decisão de tornar o trabalho remoto um home office passa pela escolha de quais os tipos de trabalho e áreas que podem ou não adotar a modalidade. O banco estrangeiro homologou 13 áreas, mas ainda assim submete a decisão a uma avaliação individualizada que verificará as condições em que o trabalhador atuará, considerando a estrutura que dispõe que vão desde instalações físicas à composição familiar. Se aprovada a adesão ao programa, é celebrado um aditivo contratual para estabelecer as novas regras de interação no processo produtivo. $\mathrm{O}$ trabalhador passa por curso de treinamento que descreve em mínimos detalhes como fazer para não perder o foco no trabalho, diminuir os ruídos do ambiente interno, como se comportar em casa para não misturar hora de trabalho com outras tarefas pessoais e

\footnotetext{
${ }^{53}$ Dados apresentados por Patricia Fris, representante do Citibank, no CIAB realizado em São Paulo dos dias 21 a 23 de junho de 2015 .
} 
ainda como se programar para otimizar trabalho presencial, sobretudo considerando que sua presença física na empresa é menor.

$\mathrm{Na}$ experiência descrita, os administradores do banco estrangeiro perceberam que houve uma redução de $10 \%$ nas ações trabalhistas ${ }^{54}$ e em dois anos obtiveram retorno do investimento.

Os consultores orientam que os programas de home office não devem adotar a semana cheia, ou seja, é importante garantir ao menos 02 dias no local de trabalho da empresa, considerando a necessidade de reuniões, participações em treinamento e as próprias trocas de informações entre trabalhadores, o que reconhecidamente tornam o processo de trabalho melhor. Ainda a esse respeito, vale dizer que os consultores preocupados com a sociabilidade dos trabalhadores reiteram a manutenção da relação com os colegas de trabalho que devem ser mantidas por sessões de happy hour e outros eventos para confraternizar.

As ferramentas básicas para atuar em home office são: computadores, acesso à internet, comunicadores instantâneos via texto ou vídeo e ramal da empresa no local. A princípio, estes são custos de instalação assumidos pelas empresas,as quais passam a economizar com vale transporte e custos de infraestrutura: aluguel, energia, água, limpeza, manutenção e até impostos.

Inicialmente, o grupo de trabalhadores mais envolvido nesse tipo de trabalho é o que atua em TI. De acordo com os resultados da pesquisa de uma empresa multinacional de TI, divulgada por Cammer (2015, informação verbal) ${ }^{55}$ no CIAB, os funcionários que trabalham em casa, por pelo menos um dia na semana e são usuários das novas tecnologias mobile, são mais produtivos. Além disso, outras vantagens tanto para empresa e trabalhadores são citadas, como sintetizamos abaixo:

- Aumento de produtividade dos trabalhadores de $15 \%$ a $20 \%$.

- $\quad$ Redução de $30 \%$ no espaço de escritórios.

- Redução de $50 \%$ em chargeback $^{56}$ por empregado.

- Melhorias na comunicação são admitidas por $82 \%$ dos trabalhadores.

- Aumento de $80 \%$ na satisfação dos funcionários.

\footnotetext{
${ }^{54} \mathrm{O}$ risco jurídico é uma das maiores preocupações em torno da prática do home office. Sob esse aspecto, os consultores afirmam que é um risco reduzido, haja vista todos os controles sob o trabalho poderem ser registrados à distância, eliminando a possibilidade de questionamento quanto à jornada trabalhada. Usam inclusive a favor de seu argumento o fato de o TST adotar o home office em seus expedientes internos desde 2013.

${ }^{55}$ Dados apresentados por Andrew Cammer, representante da Cisco, no CIAB realizado em São Paulo dos dias 21 a 23 de junho de 2015.

${ }^{56}$ Chargeback é o cancelamento de uma venda feita com cartão de débito ou crédito.
} 
Assim, a defesa pela adoção do home office considera as vantagens para ambos envolvidos. É ainda frequentemente explorada a possibilidade de ganho em qualidade de vida, sobretudo para aqueles que trabalham nos grandes centros e sofrem com a falta de mobilidade. Sob apelos de reduzir o estresse dos trabalhadores e ainda poder contribuir com a redução da emissão de gazes poluentes, os programas de trabalho em domicílio buscam se tornar atraentes.

Desconhecemos um balanço mais apurado sobre a prática, sobretudo que possa dimensionar os reais efeitos para os trabalhadores. Mas, deve-se destacar que não é desprezível considerar de partida que os custos antes circunscritos às empresas são dissolvidos e repassados para os trabalhadores nessas experiências. Ademais, a ampliação da produtividade pode implicar na intensificação do ritmo de trabalho, quando os próprios administradores reconhecem que é possível ter mais foco.

\subsubsection{O conceito empresarial de "banco do futuro"}

A difusão do uso de notebooks, tablets, smartphones e outros dispositivos móveis favoreceram a lógica de compressão espaço-tempo nas sociedades contemporâneas. As corporações tem um peso considerável na propagação destes novos modos de ser e acessar serviços financeiros, pois massificam e doutrinam clientes a adotar práticas mais modernas. Por meio do investimento feito pelas grandes corporações em novas tecnologias se proporcionou rapidez na execução das tarefas diárias dentro de uma margem de confiabilidade elevada, em harmonia com os sistemas operacionais e suas complexas operações bancárias interligadas, suprimindo cada vez mais barreiras relativas às distâncias geográficas e às respectivas dificuldades de locomoção.

Assim, com a banalização da telefonia móvel e o uso de novas mídias digitais presentes no cotidiano dos clientes, o acesso aos bancos se darão cada vez mais pelos canais que não contam com atendimento presencial. Contudo, ainda não está posto em perspectiva a total ausência de contato direto com o cliente, haja vista ser esta a maneira por ele reconhecida como preferencial para fechamento de negócios (FEBRABAN, CIAB 2014).

$\mathrm{O}$ Banco $\Delta$ lançou sua nova versão de agência digital em 2013. Em 2015 anunciou ter 125 mil clientes nesta base. A proposta consiste em realizar o atendimento remoto possibilitando uma nova forma de interagir com os clientes. Com horários 
ampliados em relação à agência física, das sete à meia-noite, é possível acessar o gerente da conta, consultores de investimento e outros especialistas. $\mathrm{O}$ formato propicia o acesso dos clientes por $e$-mail, telefone, SMS, chat ou videoconferência. ${ }^{57}$

Este modelo descrito acima conviverá e dividirá espaço com as "agências do futuro". As agências, vistas pelos executivos do setor, serão "butiques financeiras”. Essa definição surgiu na ocasião do lançamento das "agências conceito" em agosto de 2012, quando os dois principais bancos concorrentes anunciavam o modelo de agência que deve vigorar nos próximos anos.

O novo modelo denominado "banco do futuro" ${ }^{58}$ não contará com atendimento presencial na função de caixa, apenas gerentes e consultores atenderão clientes que pretendem realizar alguma operação bancária mais sofisticada ou com maior valor transacional. Portanto, está claro que o padrão de atendimento futuro exclui definitivamente os mais pobres de entrarem naquilo que se configurará como "butique financeira", consolidando o Correspondente Bancário no atendimento presencial ao segmento de baixa renda.

Nessa perspectiva anunciada, as carreiras com maior valor agregado, normalmente vinculadas ao fechamento de negócios financeiros, tendem a ser preservadas e mais valorizadas, ao passo que outras funções, normalmente vinculadas às carreiras iniciais ou ainda de caráter eminentemente operacional, serão paulatinamente eliminadas.

A proposta do "banco do futuro" inclui caixas eletrônicos e considera a formatação de um ambiente com mais conforto e intimidade. $\mathrm{Na}$ modelagem disponibilizada ao público, que a autora teve a oportunidade de visitar, ${ }^{59}$ os recursos tecnológicos de última geração são disponibilizados para interagir com os clientes. Por meio do recurso da biometria os clientes podem solicitar planos de estudo para produtos e serviços bancários que lhe interessem, mas, além disso, ter acesso a consultorias especializadas via teleconferência que podem contar com a intermediação do gerente para apoiar sua decisão.

A relevância das experiências e possibilidades de atuação futura dos ambientes destacados acima aponta as mudanças em curso e se articula às nossas preocupações em torno do esforço de compreender o processo produtivo bancário.

\footnotetext{
${ }^{57}$ Fonte: Relatório Gerencial 2015 Banco $\Delta$

58 "O banco do futuro se torna realidade" (Jornal O Estado de S. Paulo, Caderno de Economia e Negócios, 24 de agosto de 2012).

${ }^{59}$ A descrição oferecida tem como base as informações relativas ao "banco do futuro" ou "agência do futuro" que foram coletadas em visita in loco feita pela pesquisadora na ocasião do lançamento da "agência conceito", por meio de observação direta e entrevista informal com os divulgadores.
} 


\section{Parte II - RACIONALIZAÇÃO DO PROCESSO DE TRABALHO NA GRANDE CORPORAÇÃO BANCÁRIA}

\section{Capítulo 3 - Modelos e referências de organização do trabalho}

Braverman (1987) e Mills (1969a), ao analisarem a nova composição da força de trabalho durante a segunda metade do século XX nos Estados Unidos, situaram o emprego em escritório cada vez mais semelhante às atividades executadas nas fábricas. A principal característica que os conduziram a essa afirmação se deu com base na racionalização presente nestes ambientes. O aprofundamento da divisão do trabalho e o controle guardavam semelhanças com o que acontecia na produção industrial de tipo taylorista-fordista, pois nos escritórios também eram realizados os mesmos estudos de tempo e movimento.

Com o desenvolvimento da empresa capitalista, o trabalho burocratizado passou a ser realizado por grandes quantidades de pessoas e consequentemente passou a seguir os mesmos princípios que governam a organização do trabalho na fábrica. Tratou-se, de acordo com Braverman (1987), da aplicação dos "métodos da gerência científica" ao escritório, por aquilo que se popularizou como taylorismo.

Como Katz (1995, p. 19) afirmou, "o taylorismo encarnou uma tendência geral do processo de trabalho no capitalismo que extrapolou o trabalho industrial e foi introduzido nos escritórios garantindo o fluxo contínuo das tarefas administrativas". Tal modelo de administração, também conhecido por "organização científica do trabalho", teve como base a racionalização do trabalho por meio da estruturação da linha de produção, controle do processo produtivo, introdução da divisão departamental, padronização e simplificação de funções obtidas pela codificação de movimentos corporais e mecanização do trabalho.

Autores como Braga (2006) e Cossalter e Venco (2012) colocaram sob evidência o debate acerca de as características do taylorismo serem compatíveis no trabalho realizado no setor de serviços, eles citam, em especial, as centrais de teleatendimento. Apesar de as análises dos autores serem específicas a este tipo de trabalho, o questionamento que fazem emergir se aplica a trabalhos em escritório, como os realizados por bancários, pois em contextos semelhantes, em que há grande volume de trabalho, padronização e controle constante, é possível perceber a permanência deste modelo - taylorista - em outros locais. 
O fordismo, ${ }^{60}$ como um estágio mais elaborado do taylorismo, se caracterizou dentre outros aspectos pela produção em massa. Tal modelo também está presente em atividades do setor de serviços, sobretudo em processos de trabalho realizados em larga escala por grupos numerosos de trabalhadores.

Braga (2009), partindo de uma análise sobre os múltiplos sentidos do fordismo, aponta que está em curso a desestruturação da empresa de modelo típico fordista, que cede lugar a um modelo de organização das relações de produção que terceiriza, reduz níveis hierárquicos, promove uma cooperação deficitária entre os trabalhadores e é ao mesmo tempo permeada pela fragmentação da relação salarial e pela administração de metas.

Em que pese as diferenças históricas e socioeconômicas que caracterizam o Brasil comparativamente com outros lugares onde a experiência fordista foi mais plena, entendemos que as grandes corporações bancárias sediaram em grande medida o modelo das relações sociais de produção com características fordistas, o que inclui o modo de inserir o trabalhador assalariado ao macro sistema político, econômico e social. ${ }^{61}$ Contudo, a exemplo do que ocorreu em todos os setores da economia, tais corporações receberam nas últimas décadas influências dos elementos característicos do que pode ser chamado "pós-fordismo" ou "acumulação flexível". 62

$\mathrm{Na}$ grande corporação bancária pesquisada por nós, Bancos, é perceptível a prática de um padrão híbrido de organização das relações de produção. Ao reunir características tayloristas-fordistas e pós-fordistas busca-se, na forma de administrar a força de trabalho e organizar o processo produtivo na contemporaneidade, obter aquilo que nunca esteve oculto: diminuir custos operacionais e melhorar os indicadores de produtividade de modo que resultem em maiores lucros.

As características do taylorismo-fordismo presentes nas situações de trabalho bancário que serão trazidas à tona nesta reflexão questionam a predominância de determinados aspectos do "novo paradigma produtivo", os quais aparecem mais como propaganda ou promessa do que de fato como algo realizável.

Jinkings (2002) e Rocha (2006) demonstraram quanto o discurso empresarial bancário apelou desde meados da década de 1990 à noção de "qualidade" nas práticas

\footnotetext{
60 O conceito fordismo pode admitir outros significados, como "uma época particular do capitalismo", "um modo de desenvolvimento", "um princípio da organização da produção", "um paradigma tecnológico" e "um método de gestão". Para uma leitura mais aprofundada ver Braga (2003).

${ }^{61}$ Adiantamos ao leitor que serão apresentados elementos que embasam esta noção no Capítulo 4 deste texto.

${ }^{62}$ Esclarecemos que termos como "novos métodos gerenciais"; "novo paradigma de produção"; "pós-fordismo"; "acumulação flexível" e "produção flexível" serão tratados pela autora ao longo desta tese como sinônimos nesta reflexão, pois todos visam demarcar as formas renovadas de racionalização dos processos de trabalho.
} 
de trabalho como se esta fosse uma característica intrínseca de um novo modelo de produção.

Concordando com Rosenfield (2009, p. 184), que destacou as "injunções paradoxais" das novas formas de organização do trabalho, as empresas pregaram qualidade e satisfação para os clientes enquanto exigiam um ritmo acelerado de trabalho em tempos cada vez mais reduzidos. Como sabemos, a "qualidade" revela a princípio uma intenção ou apenas uma estratégia de marketing que visa atender às exigências do mercado consumidor capitalista, que passou a contar com intensa concorrência.

A própria transferência de responsabilidade sobre a realização de etapas de trabalho às empresas terceirizadas, amplamente difundidas nos "novos métodos gerenciais", pode depor contra a suposta relação inequívoca com a qualidade dos serviços prestados. De acordo com um entrevistado, que acompanha os processos de contratação de empresas terceiras dentro do $\operatorname{Banco} \Delta$ :

\footnotetext{
Para economizar, o banco não quer reajustar o contrato das empresas terceirizadas, mas o trabalhador teve reajuste pelo sindicato, então como o banco acaba repassando o reajuste? Cobra coisas que a empresa não tem condição de dar. Esse é o grande problema das negociações, as empresas para conseguirem manter os contratos prometem mundos e fundos, mas quando você vê na prática a qualidade cai. (Bancário, Analista Júnior, 29 anos, 04 de banco)
}

Outros aspectos têm sido relacionados ao "novo paradigma de produção", como é o caso da supervalorização da autonomia dos trabalhadores no ambiente de trabalho. Tal característica contrasta com o alto nível de controle existente no interior das grandes corporações bancárias, sobretudo quando nesses locais deve-se trabalhar dentro das normas de transparência rigidamente estabelecidas por instâncias regulamentadoras nacionais e internacionais devido à expansão do escopo do negócio.

As formas de controle se mantêm alicerçadas, a princípio, na subordinação e respeito à hierarquia, característica na prática ainda predominante nestes ambientes, mas ganham outra abrangência e força pelos meios eletrônicos e digitais disponíveis que conseguem multiplicar e sofisticar substancialmente essas formas. Os limites estreitos de atuação dos trabalhadores ainda podem ser verificados em função dos controles externos impingidos pelas "boas" práticas de governança corporativa, ou, por exemplo, pelas ISOs que, em suma, fornecem parâmetros e modelagens de atuação a serem seguidos. 
Estes são alguns dos sinais que expressam o tensionamento entre uma possível visão estanque ou até dicotômica que desconsidera a convivência dos modelos de organização por nós já destacados e se apresenta mais preocupada em forjar novidades em cenários plasmados pelos interesses do capital, como é a visão difundida em larga medida por consultorias ou ainda por pesquisadores que reproduzem acriticamente as tendências contemporâneas que supostamente permeiam o novo modelo de processo produtivo.

A atividade bancária, como uma típica atividade do setor de serviços, é fortemente embasada na relação com o cliente. Vale considerar, em uma margem de tempo alargada, que até a década de 1960, no Brasil, tratava-se de uma atividade mais circunscrita, com menos atribuições socioeconômicas sob sua responsabilidade. Contudo, após o projeto de modernização bancária no governo militar, houve um redimensionamento do conteúdo original do trabalho bancário. Apesar de mantida a relação de serviço, na qual o cliente é peça-chave, a arte e o ofício de ser bancário passaram pela massificação de etapas de trabalho, que antes eram mais delimitadas geograficamente e em menor volume. Tal condição levou os administradores das instituições a dissecar tempos elementares, técnicas e métodos de trabalho associadas às determinadas funções aproximando, portanto, esse tipo de trabalho em escritório a um trabalho com características tayloristas.

Nos anos 1970 os bancos passaram a organizar "manuais administrativos" consolidando uma série de informações e procedimentos sobre o fazer bancário. Os Departamentos de Organização e Métodos passaram a atuar em conjunto com os CPDs - Centro de Processamento de Dados das instituições visando implantar sistemas descentralizados de informática (GRÜN, 1986).

A etapa fordista do processo produtivo de trabalho nos bancos brasileiros foi marcada pela automação periférica, ou seja, a criação dos bancos "eletrônicos". De acordo com o que analisou Grün (1986), esta nova configuração produziu o mesmo efeito que a esteira rolante produziu nas linhas de montagens industriais. Prossegue explicando o autor:

Na nova conformação informática, em que as informações são trocadas e consolidadas, para a maioria dos efeitos, por meio de terminais ligados aos computadores centrais das organizações, no momento mesmo em que são produzidas, a criação do autômato ganha realidade. Cessa assim a ociosidade da informação, matériaprima do banco, e nesse processo agrava-se qualitativamente a desqualificação do bancário. No sistema anterior, o essencial do 
trabalho nos setores usuários da computação era organizado segundo a sua lógica interna concreta, da qual o bancário de métier extraía a sua maestria; agora, a razão informática penetra a fundo a própria lógica do processo de trabalho interno aos setores usuários e vai encarnar-se no sistema de máquinas. A inteligibilidade do processo passa assim a deixar de ser atributo dos seus executores. Agora, os novos aparelhos, que possuem uma unidade lógica, programada para dar conta de um elenco de possibilidades extraído da análise das situações preexistentes e interconectadas entre si e com a unidade central de processamento, produzem a consolidação das informações e consequentemente do processo produtivo. (GRÜN, 1986, pp. 14 e 15)

Quando a padronização dos serviços se consolidou, as situações não previstas nas normas e nos manuais eram ocasiões em que os bancários podiam reafirmar o seu saber. Contudo, sobrava para a maioria dos trabalhadores a perspectiva de desvalorização da carreira profissional, haja vista o menor nível de exigência em termos de qualificação para executar determinadas tarefas administrativas. O saber contábil, antes muito valorizado, tornou-se facilmente parametrizável e com isso as atividades remanescentes ficaram mais simplificadas. Concomitantemente, a área comercial passou a ganhar prestígio desde então. Os conhecimentos financeiros, ligados ao atendimento de produtos e serviços aos clientes, ganharam espaço no fazer bancário e passaram a ser mais importantes nestes ambientes.

A informatização promoveu um processo de "desapropriação do saber do métier" (GRÜN, 1985, p. 111) e produziu uma nova divisão técnica do trabalho, fazendo surgir funções que são auxiliares às atividades informatizadas, com características operacionais, de menor valor agregado. Os programadores de sistema, por sua vez, se transformaram nos principais detentores da concepção do trabalho, situação que se explicitava quando um novo sistema, software, deveria ser implantado na organização e nesta ocasião surgia a oportunidade de realizar uma apuração rigorosa do passo a passo do fazer bancário. Como ainda explica Grün (1985, p. 148):

a inteligibilidade passa assim a deixar de ser atributo dos seus executores. Agora, os novos aparelhos, que possuem uma unidade lógica, programada para dar conta de um elenco de possibilidades extraído da análise das situações concretas preexistentes e interconectadas entre si e com a unidade central de processamento, produzem a consolidação de informações e consequentemente do processo produtivo.

Diversos processos passaram por um esvaziamento do conteúdo do trabalho durante as décadas posteriores aos estudos de Grün (1985, 1986). À medida que funções, antes mais complexas, mais dependentes da análise de indicadores e ainda de 
análise contextual, se tornaram informatizadas, elas passaram a limitar a ação do trabalhador que começou a operar majoritariamente, visando atender às quantidades, ou seja, cumprir metas de trabalho mensuráveis.

\subsection{Novas tecnologias e as diversas formas de controle}

O computador registra tudo, o sistema puxa a nossa produção.

(Bancária, Analista Sênior, 30 anos, 11 de banco)

Partindo do pressuposto de que o controle sobre o trabalho sempre esteve no cerce de toda produção assalariada, os meios técnicos disponíveis para realizar esse controle apenas são modernizados com o passar dos tempos.

O fluxo do processo de trabalho em um banco, pensado aqui como um grande escritório, consiste em síntese no fluxo de informações e documentos ${ }^{63}$ que desde o início até sua finalização é subdividido nas mãos de diversos trabalhadores que terão suas atividades controladas. Tal processo de trabalho preserva uma característica marcante que se funda na ausência de entendimento sobre o processo produtivo global por parte destes trabalhadores, apontando o caráter alienante do trabalho em si, quando visam fundamentalmente executar o planejado pela alta direção.

Como explica Antunes (2005, p. 70),

o resultado do processo de trabalho, o produto, aparece junto ao trabalhador como um ser alheio e estranho ao produtor [...]. Esse processo de alienação do trabalho (que Marx também denomina estranhamento) não se efetiva apenas no resultado - a perda do objeto -, mas abrange também o próprio ato de produção, que é o feito da atividade produtiva já alienada.

Quanto maior o volume de operações no processo produtivo de uma grande corporação, mais torna-se visível o parcelamento das atividades e mais se acentuará a alienação do trabalho, pois o trabalhador mantém sobre o processo de trabalho uma visão fragmentada e submetida ao regime discricionário de cumprimento de objetivos estabelecidos pela organização. Conforme já havia analisado Mills (1969a, p. 243) em estudo sobre os trabalhadores de escritório:

\footnotetext{
${ }^{63}$ A manipulação de dinheiro, seja na forma "física" moeda, nota ou moeda escritural (cheque), compõe uma parcela do processo de trabalho bancário que tem sido vigorosamente reduzida por conta das inovações tecnológicas no setor, sobretudo após a década de 1990. Isso explica que em nossa abordagem parte substancial do processo produtivo esteja associado ao fluxo de informações e documentos, afinal, é por meio deles que se efetiva uma intermediação financeira qualquer.
} 
A divisão detalhada do trabalho significa, naturalmente, que o indivíduo não realiza do começo ao fim o processo de produção até obter o produto final; mas significa também que, nas condições modernas, o processo é invisível para ele.

Os processos de informatização e automação promoveram, concomitantemente, melhor sincronismo dentro da cadeia produtiva corporativa e facilidades de conexão na relação banco-cliente. Mas, além disso, têm sido por meio deles que se estabeleceram novas formas de dividir e racionalizar o trabalho.

A conectividade dos diversos dispositivos eletrônicos móveis conferiu agilidade nos processos bancários. As informações e os procedimentos para fechamento de contratos eram, por exemplo, condicionados à espera do tempo de locomoção física da documentação. Aspectos que parecem singulares, como as possibilidades de digitalização de documentos bancários, as quais temos demonstrado, reorientaram o fluxo interno de trabalho nos bancos.

Nos anos 2000, tornou-se amplamente possível à distância lançar os dados que são necessários para efetivar determinada operação bancária, repassar cópias digitalizadas de documentos necessários e ainda conseguir facilmente a validação do cliente por meio da assinatura eletrônica ou digital, deste modo, foram viabilizados vários ganhos de tempo.

A informatização da gestão de contratos visou reduzir ou até eliminar o retrabalho que existia em muitas sessões administrativas dentro dos bancos. O volume de contratos em uma instituição financeira se articula com o nível de formalidade que suas operações financeiras ditam. Uma vez informatizado o processo de trabalho, é possível acessar com rapidez e facilidade os dados relativos ao contrato, que pode ser usado em muitas bases diferentes, ou seja, áreas diferentes, eliminando a guarda repetida do mesmo documento e propiciando a socialização de relatórios analíticos sobre o andamento administrativo deles (ABECS, 2009).

Por meio do monitoramento de contratos feito pelos softwares, uma vez integrados ao sistema corporativo, torna-se viável que os seguintes procedimentos sejam feitos a qualquer tempo e com o menor grau possível de intervenção humana: a) avaliação dos fornecedores e do cumprimento das obrigações contratuais, fiscais, legais, trabalhistas e previdenciárias; b) disponibilização de cópias digitalizadas, eliminando o extravio de contratos; c) notificação de renovação automática do contrato; d) aviso de contratos vencidos e com prazos próximos ao vencimento; e) aviso de reajuste do 
contrato e obrigações não cumpridas; e f) possibilidade de acompanhamento de outros departamentos internos como o Jurídico.

O uso de computadores pessoais e/ou notebooks foi generalizado nos processos de trabalho dos bancos nas duas últimas décadas, contudo, os trabalhadores do Banco $\Delta$ ainda mencionam que existem muitas etapas de trabalho que são selecionadas "manualmente", vistas como perda de tempo pelos próprios agentes envolvidos, pois as mudanças de telas no manuseio de softwares e ainda do próprio uso do teclado ou mouse são consideradas atividades manuais, quando se parte do pressuposto que será vantajoso aprofundar a automatização reduzindo etapas de trabalho. Assim, quando se quer, por exemplo, verificar em um grupo de contratos de crédito o número de clientes que pagou a parcela naquele mês e ainda assim incluir outras variáveis para compor um relatório analítico, refinando a triagem, é o técnico ou analista de TI que transfere esta opção para o "robô", que nesse caso pode ser um computador dedicado e programado para tal fim, realizando em alta velocidade, em qualquer horário, a varredura no sistema operacional do banco, que como se pode imaginar, dado o tamanho das corporações, é muito extenso.

Em determinadas áreas do Banco $\Delta$ é comum ver sobre os computadores bilhetes avisando: "robô trabalhando". A tarefa por ele realizada pode ser, por exemplo, a verificação dos clientes adimplentes na carteira de financiamento de veículos. Esse trabalho automatizado agiliza e simplifica as rotinas como relatam os próprios trabalhadores da área:

Eu recebo o follow up do robô e o monitoramento, então minha pendência é toda monitorada. Estou recebendo aquele problema, que é tudo o que vou ter que fazer naquele dia. Depois, quando estou resolvendo esse problema, conforme o que acontece, eu entro na planilha do robô e vou informando o que aconteceu e quando será o dia que eu tenho que atuar, que eu vou ter que ligar para aquele cliente novamente, que eu vou entrar no sistema para saber o que aconteceu. O robô vai controlando toda a minha atuação. Quando chega a data que eu registrei, aparece de manhã uma tabelinha que o robô manda com o número da proposta daquele dia que eu tenho que atuar e ele me manda o histórico também, que eu registrei e que várias pessoas podem acessar para ter a visão do que está acontecendo com aquele processo. O meu robô me dá a data que eu agendei um mês atrás. Ele vai ajudando a gente a trabalhar, porque se eu não fizer isso, eu perco seu processo. Por que como eu vou me lembrar do que estaria vencendo, do que o banco se comprometeu? Esse robô é maravilhoso pois me dá isso, então eu fico descansada. Antigamente, a gente tinha um follow up, uma pasta que tinha uns trinta dias acumulados e a gente colocava um monte de papel ali dentro, e quando chegava no dia " $x$ ", via o que 
tinha para fazer. Hoje o robô me dá prontinho, me envia uma planilha. E não usa papel. O que tem é por obrigação legal, o documento físico, mas o banco digitaliza, fica tudo na tela. (Bancária, Analista Júnior, 57 anos, 12 de banco)

O robô que a entrevistada se refere nada mais é do que um software especificamente desenvolvido para trabalhos em escritório que possibilitam automatizar rotinas, em geral mais trabalhosas e extensas. A ferramenta é mais um exemplo que demonstra que o controle antes exercido exclusivamente pelo gestor pode ser em grande medida repassado ao próprio software. Uma vez estabelecida a rotina, são os sistemas de TI que ditam o ritmo e possibilitam o controle do trabalho.

No Banco $\Delta$, o grupo de Gerentes de Contas das agências mantém acesso diário ao sistema de informações denominado Cockpit. Trata-se de um software que de forma análoga ao painel de controle de uma aeronave possibilita ao usuário ter uma visão panorâmica dos principais dados de sua carteira de clientes e também de indicadores de desempenho. A consulta pode ocorrer até determinados níveis conforme o cargo do funcionário. $\mathrm{O}$ gestor principal na hierarquia de determinada agência ou departamento tem amplo controle do processo produtivo, podendo selecionar, compartilhar e monitorar informações que dão suporte à gestão a partir de indicadores que se constituem em análises combinatórias, assim como incluir o filtro desejado e gerar gráficos e planilhas a partir desta ferramenta.

Neste contexto, o desafio dos profissionais de TI dentro dos bancos passa por satisfazer a demanda para agilização de processos de trabalho e redução de custos das diversas áreas que ainda são intensivas no uso de operações manuais. Analogamente ao que Braverman (1987, p. 279) observou:

o Analista de Sistemas é equivalente no escritório ao Engenheiro Industrial, e sua função é a de desenvolver uma visão completa do processamento de dados no escritório e haver-se com um sistema mecânico que satisfaça as necessidades de processamento.

A presença dos profissionais de TI permanentemente nos locais de trabalho aponta para a sua relevância no que tange a busca de maior eficiência das engrenagens das máquinas - hardwares e softwares - que são operadas no interior dos bancos, conforme é possível perceber nos depoimentos dos bancários entrevistados:

Todo dia tem uma mudança nos sistemas de TI... eles [os técnicos de TI] estão lá para automatizar o trabalho, eles integram os computadores, ajudam a alimentar os sistemas. Toda a informação do banco fica em uma rede, então a gente pede para que uma informação que está em um sistema possa alimentar o outro. Além do pessoal de TI que tem na área, tem o técnico que esta lá no ITM, 
na Raposo Tavares, e em outros lugares, e ele consegue capturar a minha máquina aqui, de qualquer polo do banco no Brasil. Olha que fantástico. Ele consegue te auxiliar, consegue instalar de novo um programa que foi apagado por engano. Primeiro ele captura sua máquina, manda um convite e você deixa ele entrar, depois você passa a não monitorar a sua máquina e você vê tudo o que ele está fazendo. É fantástico. A pessoa não precisa estar ao seu lado para mexer na sua máquina, ela pode estar em vários polos de TI.

Aqui tem os "robozeiros", eles criam e instalam o robô. Monitoram e fiscalizam o robô, porque às vezes ele [o robô] pula alguma coisa. Mas, você vê como é fantástico fazer um robô!? Ele pega muita coisa, filtra muitos dados e alimenta muitas bases de dados. É fantástico. Mas tem um outro pessoal que fica na salinha, aquele pessoal é o de campo, quando o pessoal de lá de longe não conseguiu capturar ou não podia capturar a máquina, tem coisa que precisa ser feita pessoalmente, tem que ter uma senha especial que não é todo mundo que tem, porque ele consegue mexer em tudo, abre a ocorrência. Dá muito problema, o sistema cai, trava, a máquina demora, fica rodando, isso tem bastante (Bancária, Analista Júnior, 57 anos, 12 de banco).

Como se nota, a entrevistada ressalta o quanto é corriqueira a atuação dos técnicos de TI no interior da organização. E ainda que ela mencione problemas com as inovações tecnológicas durante a rotina de trabalho: apontando falhas, lentidão e "queda" do sistema informático utilizado no interior da instituição, ressalta e deixa perceptível seu contentamento diante das vantagens e facilidades que encontra.

As inovações organizacionais e tecnológicas, como apontou Harvey (1992), interferem nas relações entre capital e trabalho, à medida que alteram a configuração dos próprios mercados de trabalho e suas formas de controle.

Houve uma sofisticação no gerenciamento dos processos produtivos. O amplo rol de etapas de trabalho pode ser observado e registrado segundo a segundo por meio do controle do próprio sistema de informações. Ao final de períodos escolhidos pelos gestores do banco podem ser disponibilizados relatórios completos e detalhados da atividade produtiva, seja por pessoa ou por locais de trabalho, incluindo aqueles em que os serviços estão terceirizados.

O controle e ritmo de trabalho são assim intensificados pelas inovações tecnológicas. No setor bancário, os administradores contam com os equipamentos (hardwares) e sistemas informatizados (softwares) para desempenhar este papel.

A abordagem feita por Boltanski e Chiapello (2009) em suas análises sobre processos de trabalho oferece uma visão que é por nós compartilhada ao passo que admite que um dos resultados mais evidentes da informatização foi: 
dotar a gestão empresarial de ferramentas de controle muito mais numerosas e sensíveis do que no passado, com condições de possibilitar o cálculo agregado não só no nível da empresa ou do estabelecimento, mas também no da equipe e até no indivíduo, o que é feito de certa maneira à distância, levando a diminuir, ao mesmo tempo, o número de supervisores (diminuição da extensão das linhas hierárquicas) que, não precisando estar mais na presença dos trabalhadores ou - como se diz - nos seus calcanhares, podiam tornar-se discretos e até quase invisíveis. (BOLTANSKI; CHIAPELLO, 2009, p. 276)

Para Sennett (2011), as novas tecnologias permitem que as empresas promovam o que Michel Foucault chamava de "vigilância panóptica"64 ao projetar na tela mapas de recursos e desempenho em tempo real.

No setor bancário, Grün $(1985,1986)$ ao analisar a tecnologia informática na década de 1980 já havia ponderado sobre o papel que ela teria no aperfeiçoamento das técnicas de previsão e controle. E, ainda, Venco (2003) em sua análise sobre a organização do trabalho em Centrais de Teleatendimento nos bancos nos anos 1990 afirmava que o software cumpria o papel do "pan-óptico eletrônico" exercendo o controle dos trabalhadores, monitorando a produtividade.

A percepção de Grün $(1985,1986)$ e Venco (2003) nos parece pertinente e serve de base para compreendermos o contexto atual do trabalho bancário. Conforme pôde ser apreendido nas respostas de $85 \%$ dos participantes do survey "Tecnologia e terceirização no setor bancário", as inovações tecnológicas têm levado a um maior controle sobre o tempo do trabalho nos bancos.

O controle de tempo, central no modelo taylorista-fordista, aplicado ao setor de serviços, tornou-se possível até mesmo em situações em que existe a interação do trabalhador com outro agente externo, o cliente.

As centrais de atendimento telefônico - teleatendimento - foram pioneiras nas formas de controle de tempo, as quais eram implementadas nos departamentos dos bancos. Segundo Venco (2003) havia apontado, os tempos foram impostos e delimitados via sistema. A autora explica que com base no mecanismo de cronometragem, foram determinados os tempos de atendimento ao cliente, ida ao banheiro, pausa para descanso, o intervalo entre ligações, dentre outras possibilidades.

No $\operatorname{Banco} \Delta$, de acordo com o que pudemos apurar em nossas entrevistas para esta pesquisa, a atividade de teleatendimento obedece em linhas gerais aos mesmos

\footnotetext{
${ }^{64}$ De acordo com Michel Foucault, em sua obra Vigiar e punir, a existência de um sistema chamado panóptico facilitava a vigilância de múltiplos indivíduos de uma só vez.
} 
controles, o que se faz mediante constrangimento dos trabalhadores, haja vista a variedade de cronometragens feitas pelos dispositivos informáticos que buscam evitar que qualquer minuto seja desperdiçado na produção. Caso os tempos fujam da margem estabelecida ou aceitável pelos coordenadores da unidade de produção, o trabalhador deverá se justificar e de toda forma seu resultado ficará registrado em seu histórico profissional, podendo servir para futuras advertências, dificultando seu processo de ascensão profissional ou inclusive balizando sua futura demissão.

O ritmo de trabalho e as formas de controle podem ser "configuradas" pelos softwares. De acordo com a descrição dos serviços ofertados pelas empresas prestadoras de serviço, ${ }^{65}$ as operações feitas nesses ambientes possuem mecanismos como:

a) distribuição automática de chamadas recebidas - as chamadas são automaticamente ordenadas em fila de espera, conforme parâmetros predefinidos. Nas configurações mais simples, podem ser distribuídas por ordem de entrada, direcionando-as para os atendentes que tenham permanecido disponíveis por mais tempo;

b) processo automático de discagem - este padrão é similar ao de distribuição de chamadas recebidas, no qual o próprio sistema divide as tarefas entre os trabalhadores. As ligações serão efetuadas aos clientes ou potenciais clientes pelo próprio software que lança o nome da pessoa com quem o operador começará a interagir por meio de roteiro preestabelecido;

c) gravação de ligações - são realizadas gravações de chamadas automaticamente, que podem ser interrompidas quando necessário. A análise das gravações permite controlar o atendimento feito pelos trabalhadores, bem como pode ajudar a perceber falhas de processos.

Como temos tentado demonstrar até o momento, por meio dos mecanismos descritos acima, a supervisão tecnológica conseguiu substituir em parte o papel da supervisão direta na redistribuição das tarefas e até mesmo no controle e cobrança diária. Os meios eletrônicos trouxeram a possibilidade de emitir relatórios de produtividade com alto grau de atualização, no momento em que se desejar, e com a facilidade de acompanhamento à distância. O nível de detalhamento dos relatórios

${ }^{65}$ Informações obtidas nos materiais de divulgação de empresa prestadora de serviço em TI para bancos e por meio das entrevistas com os trabalhadores. 
informatizados pode revelar, por exemplo, quantas vezes o trabalhador acessou a lista de clientes para ofertar produtos, quantas vezes recorreu ao tutorial de produtos do banco buscando alguma informação ou quantas vezes e por quanto tempo acessou os $e$ mails.

Poucas áreas ainda mantém a função do Supervisor(a) no Banco $\Delta$, notadamente aquelas em que se concentra o trabalho mais simplificado e repetitivo, sobretudo marcadas pelo ritmo de trabalho intenso. Caso emblemático é a própria Central de Teleatendimento, que mesmo mantendo dispositivos eletrônicos refinados para o controle da atividade de trabalho, mantém a figura da supervisão direta, ainda que redimensionada.

O Supervisor faz ainda o que os meios eletrônicos não fazem, conversam com os trabalhadores, tanto para enfatizar aspectos organizacionais como para "animar" as equipes a produzir mais ou a cumprir papel coercitivo, quando necessário. A Central de Teleatendimento concentra um dos maiores índices de absenteísmo dentro da corporação bancária. As explicações para tal situação remetem à idade da maior parte dos trabalhadores, considerados jovens e devido o trabalho ser extenuante. ${ }^{66}$

O circuito formado pelos dispositivos de controle informatizados é arrematado pelo papel atribuído ao Supervisor. Nas áreas em que ele é ausente, os coordenadores e gerentes garantem o respeito aos poderes constituídos internamente, adotando medidas de punição tradicionais, como: advertências, suspensões, isolamento, bloqueio ao encarreiramento e a própria decisão de encaminhar a demissão do trabalhador.

Resta claro, em nossa investigação, que os diversos softwares,${ }^{67}$ amplamente utilizados nas rotinas bancárias, têm potencial de controle sobre a produtividade do trabalho em todos ambientes do Banco $\Delta$, a exemplo do que continuaremos a detalhar a seguir. Os depoimentos dos trabalhadores, de locais de trabalhos distintos, ou seja, um está lotado na agência e outro em área administrativa, corroboram com esse pensamento:

Meu trabalho é controlado. Tem o modelo de execução: listas que trabalhamos e temos que atuar nelas, colori-las. Então como funciona... tenho que registrar: liguei pro cliente, consegui falar e o que disse. Não consegui, tenho que reagendar. Tenho que rodar a carteira em 90 dias, tenho que falar com todos. Os clientes tem que sentir que eles foram atendidos, então entro nas listas de clientes e tenho que atuar nelas. Quando preencho o campo que falei com o

\footnotetext{
${ }^{66}$ Informação fornecida informalmente pelo Supervisor da Central de Teleatendimento do Banco $\Delta$ à autora em setembro de 2014 .

${ }^{67}$ Informações obtidas nos materiais de divulgação de empresa prestadora de serviço em TI para bancos e por meio das entrevistas com os trabalhadores.
} 
cliente, aquele campo é colorido automaticamente. O sistema é que vai mostrando os clientes com quem eu tenho que falar naquele dia, caso eu não consiga naquele dia ele volta para a lista e fica na fila, o banco controla isso. Conforme vou falando com os clientes, o tempo de contato vai reduzindo e vai aparecer na minha carteira de novo para eu falar com ele em " $x$ " dias, aproximadamente 90 dias, então o banco vai saber exatamente como eu tenho falado com os clientes, ele controla direitinho isso sim. Se algum gestor quiser saber se eu estou atuando, ele consegue saber com base nas cores, que sinalizam se eu consegui falar ou não. Só batendo o olho, ele consegue saber se eu estou ou não atuando na lista. (Bancária, Gerente de Contas, 35 anos, 08 de banco)

Existem varias ferramentas de controle. Tem o "Simplesmente use", software que controla seu processo por cor... nele aparece uma bandeirinha vermelha dizendo que seu prazo está estourando. Diariamente a planilha é emitida para posicionar que um comprador dentro do banco, via sistema, solicitou algo e você tem período para registrar D+1, os Analistas tem D+3 para dar resposta. ${ }^{68}$ (Bancário, Analista Júnior, 29 anos, 04 de banco)

Nas agências do Banco $\Delta$ vigora um sistema de controle de tempo de fila pelo qual a qualquer momento do expediente surge na tela do computador de um dos trabalhadores a orientação para entregar ao último cliente da fila uma papeleta, que contém a hora exata registrada, sendo que quando este cliente for atendido, a papeleta deve ser entregue de volta ao trabalhador, proporcionando a aferição do tempo que levou para ser atendido. Caso passe do tempo médio estimado pelo banco, haverá pontuação negativa no programa de metas, atingindo o trabalhador individualmente e interferindo nas metas coletivas. ${ }^{69}$

O controle da produtividade é mensurado ainda pelo volume de trabalho, no caso, pode ser o número de produtos ou serviços efetivados pelos clientes ou o número de autenticações (validações de operações bancárias no sistema) realizadas ao longo de um dia.

Entrevistados registraram que não raramente o tempo de execução de uma tarefa é ajustado para um menor intervalo de tempo. Na área em que são autenticados e validados os malotes contendo documentos bancários de clientes, tanto do segmento Pessoa Física como Jurídica, a validação das assinaturas em cheques emitidos segue um padrão de velocidade que deve ser cumprido pelos trabalhadores. Segundo explicação de um trabalhador, "o tempo vem caindo cada vez mais, a gente trabalha como

\footnotetext{
${ }^{68} \mathrm{O}$ símbolo D+1 aponta o tempo que determinada transação bancária leva para se confirmar ou estar disponível. Pode significar a liberação do dinheiro de um depósito um dia após a solicitação do resgate. Em D+2, dois dias depois de solicitado. E assim por diante.

${ }^{69}$ Os programas de metas serão detalhados no Capítulo 5.
} 
máquina... para [validar] cheques Pessoa Física, são sete segundos, e para Pessoa Jurídica, quinze segundos" (Bancário, Analista Júnior).

A fração de minutos é objeto de tensão social entre gestores e trabalhadores, entre aqueles que querem tentar agilizar a produção e aqueles que sentem a pressão, é sabido que a rapidez exigida os leva a comparação inequívoca: trabalha-se "como máquina", conforme descreveu anteriormente um entrevistado.

Os controles difundidos em todas as funções de trabalho foram possíveis de ser acessados por meio desta pesquisa de campo e das entrevistas realizadas. Concordando com Boltanski e Chiapello (2009, p. 275), as inovações tecnológicas "podem organizar um controle muito mais cerrado das realizações dos trabalhadores, eliminado aos poucos os espaços "fora do controle".

Nos relatos dos trabalhadores entrevistados para esta pesquisa predominou um consenso acerca das facilidades derivadas das inovações tecnológicas. Os dispositivos eletrônicos de uso recorrente trouxeram por um lado facilidades às rotinas de trabalho, mas por outro lado induziram a agilização de processos e criação de novas demandas a serem cumpridas, como aquelas que chegam pelos $e$-mails e sistemas de comunicação instantânea, como apontam os entrevistados:

É tudo muito simples, muito fácil de entender. Com as novas tecnologias não é preciso nenhuma habilidade nova. Nós nos comunicamos muito por e-mail com os clientes e isso facilita, porque o cliente não tem que ir à agência, por exemplo, fazer uma reapresentação de cheque [...]. Há aproximadamente uns três anos, tem a máquina de digitalização, antes fazíamos cópia dos documentos. Hoje não é necessário anexar os documentos no formulário de abertura de contas, eles são escaneados e a gente já envia para abertura de conta, por sistema. Agora só documento digitalizado, o banco não guarda mais cópia destes documentos.

Isso agilizou, ficou muito mais fácil porque você só vai mandar o documento físico, a via do contrato que o cliente assinou, então menos documento, menos trabalho, até porque a cópia podia não ser aceita, porque não foi tirada da forma correta, a forma que você enxerga perfeitamente o documento, e às vezes você não tinha percebido. Então, isso facilitou. É mais seguro para o cliente porque tudo fica digitalizado, não ocupa mais espaço para guardar e correr o risco de extraviar [...]. A inovação tecnológica trouxe facilidade, mas não fez eu trabalhar menos. (Bancária, Gerente de Contas, 35 anos, 08 de banco)

O trabalho ficou mais fácil, hoje eu simplesmente gero o contrato do cliente, ele aceita, vai lá e dá o.k. pela internet. Eu não trabalho menos não. A gente é medido por produção, essas mudanças não trazem necessariamente a diminuição do nosso trabalho porque se eu faço uma venda pela internet logo estou livre para ligar para um 
outro cliente e oferecer um outro produto. Há a vantagem operacional, por exemplo, eu não tenho que mandar o motoboy, eu acho que diminui bastante o custo, mas isso não interfere tanto no meu trabalho não. (Bancário, Gerente de Contas, 32 anos, 07 de banco)

Hoje é mais fácil trabalhar, ficou mais rápido. Ficou mais fácil porque as informações que chegam para você são mais precisas. Mas, em compensação, eu tenho muita coisa rápida e fácil, eu tenho um acúmulo muito grande, você está entendendo? Assim... você me pediu uma informação, peraí... está aqui, mas não é só você que está pedindo, eu tenho cinquenta me pedindo hoje muito mais coisa. Agora vai caindo um monte de e-mail e você tem que responder toda hora. Hoje, por exemplo, eu saí [se referindo a sair mais cedo usando banco de horas] porque eu estava louca. Além disso, tem o MOC, é um tipo de SMS, ele abre uma caixinha de dentro da sua máquina. Aí aparece o nome e fica em baixo na máquina, igual mesmo,é mais rápido, quando abre a caixinha alguém já te pede algo, tem carinha triste, carinha chorando, quando está piscando em baixo eu já sei quem é que está querendo falar comigo. Às vezes você tem 3, 4 MOCs, você pode conversar com dez pessoas se você quiser ao mesmo tempo, consegue logar e cada uma dá um palpite. Tem que estar muito ligado... o gerente te cobra alguma coisa por ele mesmo. Tem câmera, microfone, só que lá na área a gente ainda não usa. (Bancária, Analista Júnior, 57 anos, 12 de banco)

Os trabalhadores entrevistados não apontaram espontaneamente a preocupação ou a percepção de que os avanços tecnológicos poderiam implicar a eliminação de seu próprio emprego, exceto no caso em que a própria trabalhadora relatou que sua tarefa principal se baseava na automatização de processos de trabalho. Contudo, foi predominante nas entrevistas o quanto o volume de trabalho é considerado elevado para poucos funcionários e a pressão para cumprimento de metas tem sido constante, o que contribui para explicar o alívio sentido pelos bancários quando a TI pode lhes proporcionar reduzir etapas de trabalho ou agilizar determinadas tarefas. Desta situação há de se notar que os procedimentos na organização do trabalho, considerando a sobrecarga prolongada, apontam para impulsionar, de forma não diretamente declarada, o próprio processo de automatização pelos trabalhadores.

O uso de e-mail faz parte da rotina das instituições financeiras tanto para se comunicar internamente como externamente com clientes e demais agentes. Contudo, outras formas de comunicação, mais ágeis, têm ganhado espaço no interior da grande corporação. A exemplo da vigorosa dinâmica comunicacional ofertada nas relações que se estabelecem via redes sociais nos meios eletrônicos e digitais (MSN, Skipe, 
Facebook, WhatsApp, dentre outras) no Banco $\Delta$, é utilizada uma "ferramenta",70 denominada MOC - Microsoft Office Comunicator, como mais uma alternativa que proporciona agilidade no processo produtivo. Trata-se em síntese de um sistema de comunicação instantâneo, utilizado em diversas áreas nos centros administrativos.

A interação visual realizada por meio de dispositivos digitais é outro tipo de recurso tecnológico que se amplia trazendo facilidades. Teleconferências ou videochats substituem tanto o atendimento presencial realizado aos clientes de alta renda como alteram o modelo de reuniões presenciais nos locais de trabalho dentro dos bancos, sobretudo quando envolvem participantes situados em localidades distantes. Por meio das teleconferências é possível obter a diminuição do tempo de reunião, pois considerando que o horário deve ser rigorosamente cumprido, a objetividade da pauta é respeitada. Desta medida resulta a agilização de decisões e encaminhamentos que compõem o fluxo de trabalho bancário paralelamente aliando ganhos oriundos da redução de custos com translado, passagens, hospedagem e refeições extraordinárias. ${ }^{71}$

Dada as facilidades com que os sistemas de informação posicionam os trabalhadores sobre sua situação no cumprimento das metas, pode-se afirmar que há, portanto, um autocontrole exercido pelos próprios profissionais na medida em que esses têm conhecimento sobre as consequências negativas em sua vida laboral caso as metas de trabalho não sejam cumpridas. A cultura e os valores disseminados no interior da empresa por meio dos canais de comunicação institucional são meios auxiliares que favorecem a posição de autocontrole, pois, permanentemente são evocados os compromissos que os participantes devem assumir.

Há também o controle exercido "espontaneamente" pelos participantes das equipes de trabalho, de forma que um não sobrecarregue ou como dizem "um não fique encostado nos resultados dos outros", pois as equipes também estão sujeitas ao cumprimento de metas. Esse tipo de situação faz com que os constrangimentos e a pressão para concluir determinado trabalho individual que interfere no resultado do grupo não fiquem centralizados na figura direta de um superior hierárquico apenas.

O grupo, indiretamente, chama a atenção do indivíduo para as responsabilidades coletivas, pois qualquer situação relacionada a atraso, falta ou até mesmo licença médica pode influenciar no resultado final dos trabalhos. A competição dentro da

\footnotetext{
${ }^{70}$ Expressão utilizada pelos trabalhadores ao se referirem aos diversos recursos que a informática disponibiliza em seu trabalho.

${ }^{71}$ Informações disponíveis na Revista Banco 4 , março 2013.
} 
empresa pode opor trabalhadores adoecidos em relação aos demais, pois os primeiros podem rebaixar os resultados esperados quando considerada a performance do grupo.

De acordo com Durand (2003), que analisou o "fluxo tensionado" nas relações de produção contemporâneas, além do controle exercido pelos dispositivos informáticos sobre o ritmo de trabalho dos empregados, há o controle entre os próprios trabalhadores, formando uma rede de conexões que atua simultanea e sincronicamente.

A rede de conexões presente no ambiente bancário da grande corporação analisada permite uma intensa relação entre as áreas. Desde a difusão dos programas de qualidade implementados nos anos 1990 e 2000, forjou-se o conceito de "cliente interno". Uma área dentro do banco pode ser cliente de outra. Esse cliente deve ser atendido a contento, pois, suas reclamações e queixas podem pontuar negativamente no sistema de avaliação.

O tipo de trabalho desenvolvido pelo Banco $\Delta$ implica na prestação de serviços e consequentemente na relação direta com o cliente externo. Como mostraram Durand (2003) e Venco (2009), os clientes, dadas as possibilidades de interagir durante a realização do trabalho em si, atuam mais como uma forma direta de controle e pressão.

No $\operatorname{Banco} \Delta$, na medida em que é preciso fazer "tudo pelo cliente", 72 parte do processo de avaliação também foi delegado a ele. A opinião dos clientes sobre o trabalho executado assume, discretamente, sem que seja percebido, uma parte do controle gerencial. Cada avaliação requer, ainda que rápida, a dispensa de tempo para fazê-la na ocasião da finalização do serviço prestado pelo trabalhador. Também há a possibilidade de acessar outros canais disponíveis pela instituição para registrar opiniões, que invariavelmente geram queixas e reclamações sobre os procedimentos tanto individuais como das unidades de trabalho. De acordo com os entrevistados, em número reduzido sabe-se que são registrados elogios e sugestões, pois o cliente prefere usar seu tempo para resolver um problema que encontrou no $\operatorname{Banco} \Delta$ a fazer boas avaliações de um trabalho que já é pago.

A corporação bancária analisada neste estudo convida e incentiva os clientes externos a registrarem sua opinião sobre o atendimento dos funcionários. Nas centrais de teleatendimento, ao final das transações, ele é convidado a dar uma nota para o atendimento recém realizado. Uma mensagem gravada anuncia que "o Banco $\Delta$ quer ouvir você, ao final da sua ligação, participe da nossa pesquisa de satisfação". Nas

72 Este é um dos itens constitutivos do "Decálogo", os "dez mandamentos", da instituição pesquisada. Será abordado em maior profundidade no Capítulo 4. 
agências, os mesmos clientes são permanentemente convidados a dar nota, atividade que pode ser feita no Caixa Eletrônico ou ainda pelos demais canais do banco como o SAC - Serviço de Atendimento ao Consumidor.

Há ainda a figura do "cliente secreto", que pode ser apenas um gestor da própria instituição escalado para acessar a qualquer tempo uma agência ou outro canal de atendimento do banco, simulando ser cliente para aferir a qualidade e a padronagem do serviço prestado.

Para Lahera-Sánchez (2005), o padrão ISO (International Organization for Standardization) estabeleceu um novo controle sobre os processos de trabalho. As empresas que têm a expectativa de conseguir a certificação devem seguir os requisitos que aperfeiçoam processos internos e produtos, monitorando o ambiente de trabalho e satisfação dos clientes. O ISO abrange centenas de países e pretende normatizar um conjunto de diretrizes para gerir processos produtivos, visando, de acordo com seus enunciados, nos mais diversos setores, assim como atingir e manter padrões de qualidade reconhecidos internacionalmente. ${ }^{73}$

O local de trabalho, submetido à norma, recebe a visita do auditor que verificará se todo o ambiente segue todas as orientações de padronização, o que inclui a organização física do ambiente, a disposição de objetos e o mobiliário. Nas centrais de teleatendimento do Banco $\Delta$, por exemplo, um objeto deixado sobre a mesa do operador já é motivo de inconsistência, pois a norma é explícita sobre o que pode ou não ficar no ambiente. A lista de proibições é grande e um calendário, uma bolacha, uma foto ou qualquer outro objeto sobre a mesa tornam-se motivo de inconformidade para a instituição, acarretando em advertência para os trabalhadores.

Apesar de terem vigorado com força durante a década de 1990, nos anos posteriores foram descontinuados vários programas internos no $\operatorname{Banco} \Delta$, que visavam ter o selo ISO, restando atualmente apenas casos isolados. A alteração da estratégia empresarial na adoção do padrão ISO para áreas restritas foi motivada pelos custos e obrigações que envolvem tais certificados, sobretudo considerando que o "modismo" gerencial da "qualidade total" perdeu força.

Concordando com Castilho (2009), em sua abordagem sobre a relação entre trabalho e informatização, as normas ISO desempenharam o papel de padronizar e adequar os processos produtivos, consolidando no setor de serviços o traço mais

\footnotetext{
${ }^{73}$ As normas mais adotadas pelos bancos brasileiros são aquelas pertencentes à família de normas ISO 9000 (gestão de qualidade); ISO 14001 (gestão ambiental) e a SA 8000 (responsabilidade social).
} 
tradicional do taylorismo-fordismo relacionado ao controle da produção e à divisão do trabalho.

Como percebe Braga (2009), as "promessas pós-fordistas" não conseguiram apagar as marcas do trabalho marcadamente taylorizado, mesmo em atividades atreladas àquilo que se define por "serviços informacionais" ou em outras palavras, serviços que são realizados com base nos recursos informáticos.

\subsubsection{Disciplina objetivada e subjetivada}

Como temos buscado apresentar, nas grandes corporações a ação disciplinar está disseminada em grande medida pelo controle sobre o tempo e pela vigilância constante sobre a realização das metas de trabalho ao longo do processo produtivo, mas ela ainda conta com outros recursos, tradicionalmente utilizados, como é o caso dos manuais e circulares normativas.

O processo de informatização fez o conteúdo dos manuais e das circulares normativas migrar para a via eletrônica, o que permitiu haver a homogeneização dos procedimentos das diversas etapas de trabalho de forma possivelmente mais eficiente, considerando que se tornou viável reunir recursos de ilustração, animação e ainda a possibilidade de atualização muito mais veloz. Vale considerar que os tempos de impressão e transporte de tais manuais e circulares foram eliminados, algo significativo, sobretudo quando se tratam de várias unidades dispersas e integradas na mesma organização, a qual reúne em torno de si milhares de pessoas espalhadas em todo o território nacional, como acontecem nos estabelecimentos bancários.

O papel das auditorias internas dentro dos bancos, desde a década de 1970, ganhou importância crescente, pois sobre esta área pesava a responsabilidade da fiscalização do cumprimento daquilo que estava previsto nos manuais e circulares, observando em sua ação as possíveis fraudes e irregularidades (GRÜN, 1985). O banco que destacamos para pesquisar neste estudo possui aproximadamente 300 auditores internos ${ }^{74}$ dentre seus objetivos centrais situam-se os controles do que se passa no âmbito administrativo e financeiro.

Vale destacar que no Banco $\Delta$ são expressivas outras formas de disseminar condutas internas, como: banners, materiais impressos, portal de notícias e inúmeros

\footnotetext{
${ }^{74}$ Revista Executivos Financeiros. Abr. 2013.
} 
murais eletrônicos, também reconhecidos como TVs corporativas. ${ }^{75}$ Por estes canais é divulgada a cultura organizacional da empresa. ${ }^{76}$ De forma atrativa, seguindo os protocolos do "marketing corporativo", as mensagens escolhidas são ditas e reditas nos locais de trabalho.

Os banners, grandes cartazes impressos que ficam expostos em locais fixos, cumprem o objetivo de manter determinada informação sob destaque por mais tempo possível em local amplamente visível. Pode ser a informação de determinada campanha que a instituição realiza, uma mensagem de incentivo à superação ou a foto dos trabalhadores que foram premiados por serem destaques em produtividade.

Os materiais de comunicação impressos sofreram drástica diminuição na segunda metade dos anos 2000, pois gradualmente cederam espaço para o formato eletrônico, como é o caso do portal, site alocado na intranet do banco que funciona como um centro aglomerador de conteúdos. Pelo portal são transmitidas as orientações ou notícias mais importantes de forma que ao ligar o computador o trabalhador já se atualiza sobre as demandas corporativas.

Os novos dispositivos tecnológicos permitem que a "assinatura eletrônica" do trabalhador confirme a leitura de determinada circular normativa ou comunicado. $\mathrm{O}$ documento institucional, para citar um exemplo recorrente a todas as áreas, conhecido como Código de Ética, tem recebido novas versões atualizadas desde o ano de 2000 desde quando surgiu, ${ }^{77}$ cada atualização requer uma nova leitura e um novo "de acordo" do empregado. A não confirmação da leitura atualizada de qualquer outra norma interna é monitorada e o funcionário será primeiramente advertido on-line, e, se persistir a "não conformidade", será registrada a falha em sua avaliação individual.

As TVs corporativas estão distribuídas em praticamente todos ambientes, que não exatamente o local de trabalho estrito. Ligadas dia e noite são encontradas nos elevadores, corredores, áreas de convivência, espaços para tomar café e água, recepções, restaurante interno e até mesmo no ambulatório há este tipo de veículo para a empresa se comunicar com os trabalhadores.

Analisamos que todos esses canais mencionados buscam gerar um clima de interação tornando inadequado apenas dar visibilidade aos executivos da instituição. É estratégico, do ponto de vista da comunicação empresarial, ou mais especificamente da cultura interna que se busca difundir, abrir espaço para que possam emergir as diversas

\footnotetext{
${ }^{75}$ Revista Banco 4 (diversos números).

${ }^{76} \mathrm{O}$ conceito de cultura organizacional será aprofundado no Capítulo 4.

${ }^{77}$ Revista Banco 4. Fev. 2009.
} 
pessoas que ali trabalham. Para fortalecer esta escolha, abrem-se espaços para que a opinião e as sugestões dos trabalhadores que estão em sintonia com o ambiente corporativo ganhe visibilidade, ainda que seja com menor exposição em relação aos executivos.

Há presença de câmeras de filmagem espalhadas por todas as agências e unidades administrativas, incluindo os locais de trabalho propriamente ditos, além das portarias, corredores, escadas e elevadores. Tais instrumentos aumentam o controle sobre o que acontece no local de trabalho. Os administradores do Banco $\Delta$ alegam que esta tecnologia não é empregada com o objetivo de controlar o trabalho, apenas visa controlar a circulação no ambiente detectando algo anormal ou podendo, em outras ocasiões, ter condições de verificação para procedimentos inadequados como pequenos furtos dentro da unidade.

A decoração temática dos locais de trabalho é frequente no ambiente dos centros administrativos do $\operatorname{Banco} \Delta$. As formas de motivação vindas do estímulo visual, que fogem da formalidade institucional, organizadas na maior parte das vezes pelos próprios trabalhadores, são promovidas para tornar mais suportável a pressão contínua. Recursos monetários são aportados pela própria instituição para comprar enfeites para decorar o ambiente e torná-lo diferente, acolhedor, um pouco mais alegre e colorido. Essas estratégias singulares contribuem, a exemplo do quem mencionou Mills (1969a), para atenuar as características alienantes e desagradáveis no trabalho, quando ele se torna "um sacrifício de tempo, necessário para construir uma vida exterior a ele". Pelo que observamos em nossa pesquisa, é mais comum o uso da decoração temática nas áreas em que se encontram os trabalhadores com as menores remunerações e que estão sujeitos a um ritmo intenso de trabalho.

As metas de trabalho, da mesma forma que as datas comemorativas escolhidas, como Carnaval, Páscoa, Festa Junina, dentre outras, tem data para começar e acabar. A decoração transmite sempre a sensação de algo novo, abrindo, discretamente, espaços da memória afetiva daqueles que em meio às celebrações atuam, supostamente, com mais leveza aplacando rotina e pressão existentes.

Assim, em determinados ambientes de trabalho é comum ver bexigas, placas comemorativas, cestas com balas e doces diversos à disposição sobre a bancada de trabalho. Para além do propósito da comemoração social, há nesta confluência de cores e sabores uma motivação destinada a lembrar os funcionários dos desafios impostos, pois as campanhas para atingir metas podem assumir uma marca visual conforme um 
tema escolhido, o qual é associado ao calendário comemorativo de domínio popular, disponível ao longo do ano.

Outro aspecto relevante para influenciar a disciplina no ambiente de trabalho analisado é o peso da "política do medo". Não foram poucos os pesquisadores que citaram o medo como elemento estruturante presente no cotidiano da gestão no trabalho contemporânea.

Dejours (2006) destacou em seu estudo que os trabalhadores partilham constantemente um sentimento de medo. Para o autor, esse medo gera condutas de obediência e submissão. Torna-se ainda uma forma de zelar pela inventividade que possa melhorar a produção e um meio de estímulo à competição, à medida que movimenta o indivíduo a buscar uma posição mais vantajosa que seu próprio colega, dada a possibilidade de haver seleção dos que podem permanecer empregados.

A pressão psíquica no ambiente de trabalho também foi tratada por Gaulejac (2007), sua narrativa reforça o pensamento de Dejours (2006) sobre o medo. Para o autor a ameaça constantemente imposta pelo sistema de competição é parte do modelo de gestão de pessoal que é predominante nas empresas.

Existe uma forma de "disciplina subjetivada" que é exercida pelo medo. Em uma conjuntura marcada pelo desemprego e pelas estratégias de rotatividade presentes tanto no setor pesquisado como no próprio país, e ainda localmente determinada por avaliações contínuas, subordinadas a complexos programas de medição de resultados e comportamento, o medo se torna um aspecto estruturante no ambiente de trabalho, pois contribui diretamente para manter o ordenamento no interior das grandes corporações bancárias. É em nome dele que muitos trabalhadores seguem as normas, aceitam sobrecarga de trabalho, trabalham adoecidos e até mesmo suportam o assédio moral ${ }^{78}$ para se manterem empregados.

Esse conjunto de circunstâncias descrito fundamenta a presença de indivíduos flexíveis, adaptáveis a qualquer situação ou imprevisto e que sejam, antes de mais nada, subjugáveis.

Diversos autores (SEGNINI, 1999; JINKINGS, 2002; VENCO, 2003; SOBOLL, 2008; GRISCI; SCALCO; KRUTER, 2011; BORGES; VITULLO; PONTE, 2012; SOARES, 2013; OLIVEIRA, 2014; NOGUEIRA, 2015; OSTRONOFF, 2015) que pesquisaram o universo de trabalho bancário ao longo das últimas décadas trouxeram à

${ }^{78} \mathrm{O}$ conceito que adotamos para assédio moral será exposto no Capítulo 5 juntamente com a análise das consequências do processo de trabalho sobre a saúde dos trabalhadores. 
tona a percepção de que o medo da exclusão, de perder o emprego, se torna fundamental para explicar a submissão dos trabalhadores às normativas organizacionais e às formas de despotismo gerencial no local de trabalho.

Grisci, Scalco e Kruter (2011) ao investigar a categoria profissional bancária a partir das consequências geradas no ambiente de trabalho, do ponto de vista psicológico e social, destacaram outras variações que envolvem um constante estado de alerta, como o medo de o trabalhador ser classificado de incompetente, de ficar estagnado profissionalmente e ser estigmatizado como perdedor.

O medo torna-se um elemento que condiciona o comportamento dos trabalhadores. Durand (2003) buscou compreender o que leva os indivíduos a adotarem comportamentos que atendam às expectativas das empresas. $\mathrm{O}$ autor parte do conceito de implicação constrangida para explicar uma relação paradoxal que se estabelece pelo desejo de os empregados pretenderem se manter em uma empresa que atende parte de seus interesses de sobrevivência, como o salário e demais vantagens sociais, ao mesmo tempo que convivem com situações degradantes. A base dessa decisão dá-se sobre um cenário de poucas ou nenhuma escolha, já que o desemprego é uma realidade presente em suas vidas, o que acaba por disciplinar o comportamento do funcionário conduzindo-o ao desejado pela empresa.

A visão dos autores citados é compartilhada por nós e esteve presente na fala dos entrevistados para esta pesquisa.

\subsubsection{Disposição do ambiente e controles}

A disposição no ambiente físico de trabalho dos bancos observa diferenças conforme o local. Nos Centros Administrativos as pessoas são reunidas por

proximidade da função executada, construindo assim uma "unidade de trabalho". O layout que predomina nestes escritórios leva em conta o relacionamento entre as diversas unidades, facilitando o fluxo de trabalho e consequentemente obtendo melhor produtividade.

Nos anos 1990 predominavam nas áreas administrativas a divisão de unidades de trabalho a partir de painéis com 1,60 $\mathrm{cm}$ de altura. Dentro da unidade, cada posto de trabalho possuía uma demarcação individual a partir do uso de painéis menores com $1,10 \mathrm{~cm}$ de altura, conforme ilustra a figura a seguir: 
Figura 4

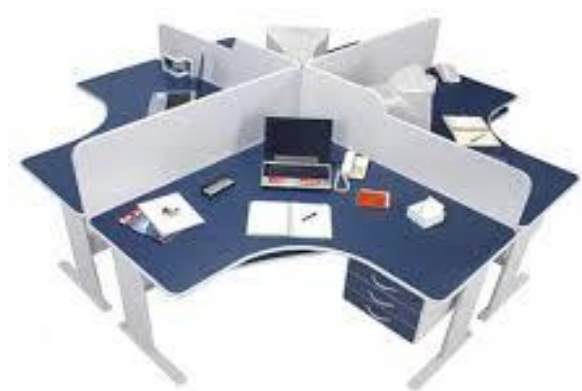

Modelo de mesa integrada com divisória individual de trabalho, denominada estação de trabalho, ainda existente no interior da instituição financeira pesquisada nas áreas que não passaram por readequação de layout. Neste exemplo, cada vez mais em desuso, há as divisórias de isolamento atingem a altura máxima de $1,10 \mathrm{~cm}$.

No final dos anos 2000, passaram a predominar as mesas em formato plataforma (ver Figura5). Tratam-se de mesas coletivas de trabalho, também nominadas pelos bancários de "espinha de peixe", "bancada" ou "régua". A disposição das diversas mesas distribuídas ao longo dos andares pode comportar mais de 400 pessoas em um plano aberto, facilitando o controle visual sobre os trabalhadores. De uma extremidade a outra, que pode compreender uma distância de 300 metros, é possível enxergar quem está de pé e perceber o que faz a pessoa, se toma café, se conversa descontraidamente ou se está solicitando algo ao parceiro de trabalho.

Figura 5

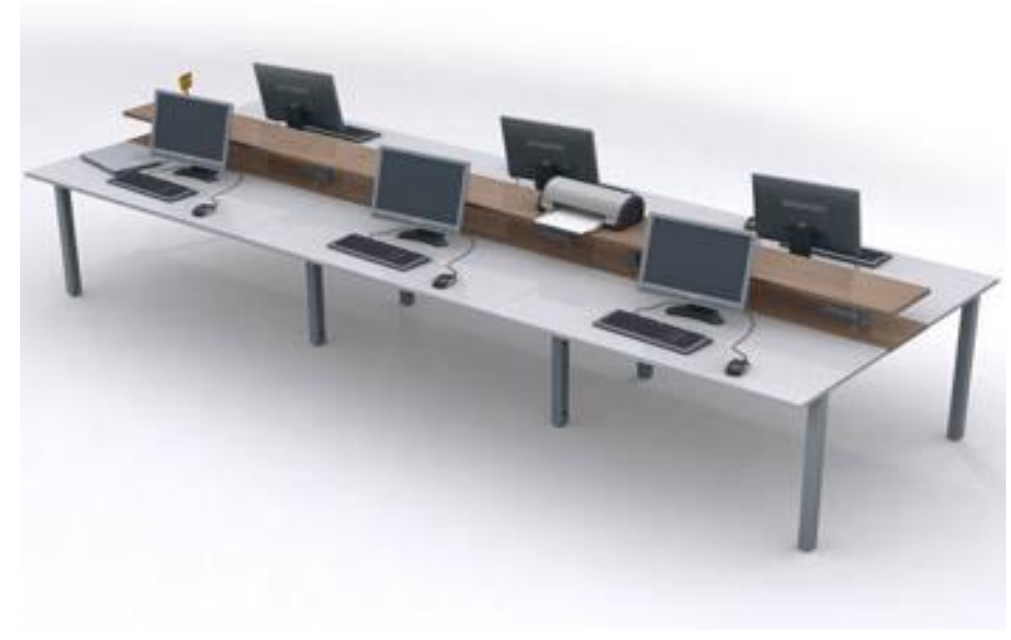

Modelo de mesa coletiva de trabalho estilo plataforma utilizada no interior do Banco $\Delta$. 
Alcadipani e Almeida (2000), ao analisarem o layout, arranjo físico, adotado pelas organizações contemporâneas, destacaram que os espaços abertos de trabalho guardavam relação com o estado de vigilância descrito por Foucault. No mesmo sentido, Venco (2003) apontou que a construção do poder disciplinar pode se dar pelo estabelecimento de um conjunto de mecanismos - cartões magnéticos, softwares, espaço físico e telemática $-{ }^{79}$ que formam uma "arquitetura do controle". Em que pese a autora ter realizado sua pesquisa nas centrais de teleatendimento dos bancos, reconhecemos que sua análise é pertinente para as demais áreas existentes no interior da instituição que pesquisamos.

Ao observarmos variáveis como: disposição de mobiliário, ponto eletrônico, câmeras de filmagem, fartos canais de comunicação com os trabalhadores distribuídos nos mais diversos locais no interior do Banco $\Delta$ e o papel que os softwares desempenham no processo de trabalho bancário, podemos admitir que há uma estrutura complexa e diversificada montada para estabelecer controle e disciplina dos trabalhadores.

A disposição do mobiliário revela algo que se articula com os novos tempos mais informatizados, pois não é preciso se preocupar com a proximidade de muitos trabalhadores, reunidos na mesma mesa de trabalho, um de frente para outro. O controle feito pelo Coordenador é menos intensivo porque o "sistema de informações" e os "programas de metas" disciplinam com eficiência a força de trabalho. Como comenta um trabalhador entrevistado, "hoje em dia você vai participar de qualquer reunião e as pessoas estão tão atarefadas que você fica no seu computador e eu tento falar e você não olha nem nos meus olhos" (Bancário, Analista Júnior, 29 anos, 04 de banco).

O ambiente físico da empresa se relaciona com os novos processos de trabalho amplamente informatizados, portanto, todos os seus postos utilizam-se dos computadores pessoais e incluem ainda o conjunto de periféricos: telefones com headseat ${ }^{80}$ tela, teclado, CPU - Unidade Central de Processamento e mouse. Ressaltamos que nos centros administrativos os headseats são amplamente utilizados, não se limitando às Centrais de Teleatendimento. $\mathrm{O}$ equipamento fica preso à cabeça do usuário que tem as mãos livres para usar o computador.

\footnotetext{
${ }^{79}$ Telemática: associação da informática às telecomunicações.

${ }^{80}$ Headset é um fone de ouvido com microfone acoplado que substitui o telefone.
} 
A separação de trabalhadores por meio de mobiliário, com divisórias mais elevadas denominadas "baias", 81 permanece na atividade de teleatendimento, dada a característica do trabalho que é mantido pela emissão de vozes múltiplas dos trabalhadores, ao mesmo tempo e no mesmo ambiente físico. Os bancos mantêm grandes estruturas que realizam o atendimento tanto ao cliente externo do banco como ao chamado cliente interno representado por outros trabalhadores da instituição que precisam de suporte ao trabalho que realizam.

É possível encontrar nos centros administrativos salas fechadas com porta, com isolamento necessário para realização de reuniões, teleconferências, videoconferências e cursos. São salas que se situam nas extremidades do espaço físico, normalmente feitas de paredes de vidro, o que também implica maior controle de seu uso.

Os gestores nesses ambientes, considerando os superintendentes, gerentes e coordenadores, obedecem em geral à seguinte distribuição física: os Superintendentes podem até possuir sala, que se situa em local mais reservado. Os Gerentes não possuem sala destacada, e também não possuem uma mesa destacada, sendo outro aspecto relevante o fato de que em muitas áreas o ocupante deste cargo não necessita estar no mesmo local que seus subordinados, situando-se até mesmo em andares diferentes. Entretanto, do ponto de vista da sua posição física no ambiente, também é usual encontrá-lo junto dos outros Gerentes em uma mesma mesa coletiva de trabalho. Já os Coordenadores ficam sentados na mesma bancada de trabalho da unidade que são vinculados, em situação praticamente imperceptível de diferenciação com relação aos demais.

A explicação para a distância dos Gerentes e Superintendentes com relação à presença física dos seus subordinados deve-se ao fato de os processos de trabalhos serem amplamente monitorados pelas vias eletrônicas, conforme já analisado em momento anterior desta reflexão.

Os terceirizados, quando presentes dentro do espaço físico dos bancos, normalmente ficam destacados ou separados por divisórias mais definidas, como paredes de vidro ou outros materiais. Nessas ocasiões, utilizam todo o equipamento e instalações do próprio banco, mantidas situações de diferenciação vinculadas ao transporte, refeitório, acesso ao prédio, cor de seus crachás nestes ambientes, entre outros.

\footnotetext{
${ }^{81}$ Mesa individual cercada por divisórias com aproximadamente $1,40 \mathrm{~cm}$ de altura.
} 
O trabalhador, desde o momento em que põe os pés na instituição, já pode ser monitorado. Para entrar, é preciso "passar" seu crachá na catraca de entrada a fim de ser feita a leitura óptica, depois, ao entrar na área específica em que trabalha, mais uma vez precisa atestar sua identidade e presença na empresa por meio do ponto eletrônico.

O registro de ponto eletrônico não eliminou por completo o monitoramento pessoal, pois interessa às instituições manter a veracidade das informações, uma vez que determinado funcionário em posse da senha de outro pode lançar o registro no ambiente virtual de trabalho do banco. Percebe-se que tem crescido as formas de cruzamento de informações que as instituições se utilizam para controlar tentativas de burlar o sistema.

Ampliam-se no interior dos bancos os espaços com circulação restrita permitida apenas aos funcionários que atuam em determinada área. Antes, tal prática era circunscrita a locais com maior risco como a antiga Tesouraria, onde havia guarda de dinheiro e outros papéis importantes. Tem se ampliado os controles de entrada e saída das áreas, pelos quais a liberação de entrada e saída só se concretiza após o reconhecimento feito tanto pela leitura óptica do crachá como pela digitação de senha ou leitura biométrica.

\subsubsection{Autonomia e criatividade diante das diversas formas de controle}

Na perspectiva da gestão pós-fordista ou flexível, a hierarquia extensa e rígida, que predominou no modelo taylorista, deve dar lugar a agentes mais autônomos, que passem a agilizar o esquema burocrático. Contudo, reunimos elementos que questionam essa perspectiva no setor bancário diante dos fartos limites impostos pelos controles.

Nogueira (2015), em seu estudo sobre o setor bancário, verificou, por meio dos trabalhadores entrevistados, que não há autonomia na realização do trabalho.

No $\operatorname{Banco} \Delta$, de acordo com o que pudemos apurar em nossa pesquisa, há uma autonomia muito restrita vinculada a determinados cargos, demonstrando ser mais adequado falarmos em medidas de "descentralização de alçada", ou seja, em estruturas de grandes proporções como são as corporações bancárias. Para agilizar procedimentos e reduzir custos derivados da morosidade, há um loteamento, uma definição de limites de poderes concedidos por área, por tipo de gestor.

Apesar de todo esforço em torno de ideias "renovadas", que atenderiam o padrão de produção flexível, como é o caso da autonomia, vimos no banco pesquisado que ainda prevalece a organização hierarquizada, mesmo considerando as mudanças que 
levaram ao enxugamento de cargos de primeiro nível de chefia e os movimentos que levaram à automatização ou terceirização de funções.

$\mathrm{O}$ excesso de formas de controle e a disciplina contrastam com valores que propagam a autonomia nas grandes corporações. Aquilo que se percebe como possibilidade de ação autônoma não consegue ultrapassar o campo das pequenas decisões que, ainda assim, em grande parte, requerem vigilância e aprovação de níveis superiores na instituição. As possibilidades de autonomia são confundidas por um tipo de trabalho pré-condicionado, no qual o trabalhador tem autonomia para realizá-lo da melhor forma, desde que siga as regras, muito rigorosas, de entregar no prazo, em outros termos, é como se coubesse a ele a autonomia para "ser mais ágil”, garantindo, na ponta, mais produtividade e retorno à instituição.

De acordo com os depoimentos dos entrevistados, é possível perceber alguns dos limites colocados:

Eu posso verificar onde posso ganhar, isso não dá alçada. Posso verificar onde posso ganhar índices... analisar bases de todas as propostas de crédito, onde eu estou perdendo, pois eu tenho acesso a estas informações, posso dar sugestão, posso dizer: "Olha, pode mudar esse processo!" A gente tem que mudar para ficar melhor. Vou sugerir, mas não tenho alçada para decidir, porque isso mexe direto com o lucro, né?! Só o Superintendente tem alçada, o Gerente, às vezes. (Bancária, Analista Sênior, 30 anos, 11 de banco)

$\mathrm{Na}$ verdade meu trabalho é como uma régua, uma esteira. Tenho liberdade para fazer meu trabalho, mas ele está bem desenhado. Liberdade que eu tenho é a tranquilidade de poder trabalhar, eu só tenho que apresentar o resultado, agora mudar o fluxo é difícil. (Bancário, Analista Júnior, 42 anos, 12 de banco)

No banco você tem que ter manuais de procedimentos e você tem que ter estrutura de alçada de decisões com processos bem definidos. Você tem que controlar a autonomia. (Bancário, Analista Júnior, 29 anos, 04 de banco)

A autonomia para tomar decisões se restringe em geral a cargos que compõe o alto escalão do $\operatorname{Banco} \Delta$. Tomemos por exemplo o caso sobre as decisões de alocação dos recursos disponíveis no orçamento de determinada área: o principal gestor na hierarquia da área, o Superintendente, tem poder para definir a distribuição dos recursos escolhendo, dentro de uma margem disponível, se contrata mais funcionários, de que forma contrata, paga horas extras, faz confraternizações ou realiza qual tipo de treinamento e formação dos trabalhadores. 
Das inovações tecnológicas resultam procedimentos simplificados e parametrizados que colocam limites bem estreitos e superficiais à noção de autonomia no trabalho. Grün (1985), em seu estudo sobre as organizações bancárias realizado na década de 1980, analisou a estimativa, à época manifesta, de que com a introdução em massa dos computadores $80 \%$ das decisões antes conferidas aos escalões intermediários das empresas passaram a ser tomadas automaticamente, ou seja, o próprio sistema já simplificava processos e imputava os limites de alçada de determinados cargos e sua respectiva liberdade de ação. Nas últimas décadas, com a informatização na área comercial, os Gerentes de Contas tiveram atuação reduzida diante das possibilidades enquadradas por meio de "pacotes" e "limites de crédito" preestabelecidos, por uma outra área da instituição que desenvolve produtos e serviços bancários, diminuindo seu poder de decisão e negociação.

As Circulares, dependendo do tema, contêm as definições sobre quais funcionários possuem ou não alçada e até que ponto ela pode chegar. A alçada de um Gerente de Contas, por exemplo, está condicionada ao limite pré-aprovado de crédito que a instituição determinou para o perfil do cliente ou a análise que o software gerou dentro dos parâmetros já estipulados pela instituição.

Pelo tipo de serviço realizado em um banco, que opera com recursos da sociedade, submetido a prazos, à físcalização e ao cumprimento de normas externas de atuação amplamente delimitadas, não é difícil imaginar que se trata de um trabalho rotineiro e pouco criativo, como já haviam apontado diversos autores (ROMANELLI, 1978; SEGNINI, 1988; BLASS, 1992; JINKINGS, 2002).

Oliveira (2014) destacou o fato de a separação da concepção e a execução sempre serem características do processo de trabalho nos bancos. O autor argumenta ainda que

um trabalho estritamente contábil deixa pouca margem para soluções criativas, uma vez que não há criatividade que dê conta de resolver um erro na atualização de um saldo ou no controle de um caixa, os números fecham ou não fecham. (Oliveira, 2014, p. 110)

Concordando com Oliveira (2014), as funções operacionais, comerciais, técnicas ou gerenciais presentes na rotina bancária apontam para um trabalho pouco criativo e altamente regrado pelo conjunto de normas de atuação. 
As atividades de planejamento ou que permitam doses maiores de criatividade são destinadas a grupos pequenos e esparsos. Contudo, apesar dessas limitações, não se pode considerar que toda a ação espontânea e criativa foi subtraída da maior parte dos trabalhadores. A experiência singular de cada trabalhador contém em si a possibilidade de microingerências sobre as normas estabelecidas, ainda que se faça isso silenciosamente, de forma “invisível” para os gestores ou até mesmo para clientes.

Assim, lidando com o que é posto a público sobre a rotina de trabalho na esfera corporativa, pode-se afirmar que o trabalhador é condicionado a manter o fluxo e a normatização, já definida a priori pela direção da instituição, podendo sim ultrapassar estes limites caso haja alguma contribuição, reconhecida pela hierarquia, que leve à ampliação da produtividade.

A possibilidade de participação, limitada ao fato de repassar conhecimentos e propor melhorias no processo produtivo, não pode ser romantizada. Qualquer possibilidade, mínima que seja, de atuação criativa e inovadora, está subordinada à aprovação de níveis superiores que obedecerão, antes de mais nada, à reserva orçamentária disponível e a outras conveniências da organização. Aquilo que é feito fora desses limites pode responder pelo descumprimento da normatização estabelecida, sendo inclusive punido com a maior das penas no regime de trabalho assalariado: a demissão por "justa causa".

Assim, considerando que o processo de trabalho é prescrito pelo gestor, os programas de metas gerenciam os trabalhadores e o controle dos resultados é realizado em tempos curtos de verificação graças às facilidades das TIs, concluímos que é um exagero afirmar que a autonomia é uma característica que pode ser atribuída genericamente aos trabalhadores do Banco $\Delta$ quando eles realizam suas rotinas.

No Banco $\Delta$ foram replicados elementos dos métodos de gestão vinculados ao toyotismo, que variam de acordo com os locais de trabalho analisados. Nas áreas administrativas desde os anos 2000 tem havido uma tentativa de tornar as relações entre gestores e trabalhadores mais horizontalizadas. Em reuniões periódicas os trabalhadores devem se manifestar sobre o processo de trabalho, sugerindo melhorias nos procedimentos e interagindo diretamente com os gestores. Tais reuniões denominadas Comitê Kaizen ${ }^{82}$ são uma referência direta ao modelo japonês de organização.

\footnotetext{
${ }^{82}$ Kaizen é nome dado ao método que visa o aperfeiçoamento constante dos processos produtivos (HIRATA; ZARIFIAN, 1991).
} 
Conforme relatado nas entrevistas, apuramos que em determinadas áreas os funcionários são obrigados a dar três sugestões por mês. Ao final do ano devem ter dez delas implementadas, sendo que o resultado compõe parte do programa geral de metas a ser cumprido e será considerado na avaliação individual.

A obrigação de dar ideias e ser avaliado em métricas por meio desse processo põe em xeque mais uma vez a noção de autonomia e criatividade das novas formas de organização do trabalho. Além disso, segundo chamam a atenção Dias e Zilbovicius (2009), os trabalhadores, quando submetidos à pressão de atingir os objetivos impostos pela gerência no curto prazo, tendem a repetir soluções já testadas.

As exigências direcionadas aos trabalhadores no que se refere à obrigatoriedade de dar ideias para aperfeiçoar o processo de trabalho, contingenciadas pelo seu respectivo monitoramento que podem levar a premiações e punições, nos coloca diante de uma nova "habilidade" exigida para atuar nesses ambientes.

Pode-se cometer um engano ao estabelecer cegamente determinadas marcas distinção relacionadas ao modelo de gerenciamento do trabalho contemporâneo. As possibilidades de os trabalhadores serem mais autônomos ou criativos em sua experiência laboral, em alguma medida, ou seja, por meio de suas microingerências, já estavam presentes no modelo de tipo taylorista-fordista. Na experiência analisada por nós, a diferença substancial foi transformar participação, ideias e proatividade em algo regular, obrigatório e mensurável.

As instituições bancárias, constituídas como grandes corporações, são dependentes de ganhos em escala, o que requer um rígido controle de seus processos, sobretudo quando submetidas aos interesses dos acionistas e suas expectativas de rentabilidade no curto prazo. Apesar de a valorização das ações envolverem uma "aposta" futura, os acionistas controlam o risco em tempo presente pelos instrumentos previstos nos manuais da "boa" governança corporativa, como são os relatórios gerenciais e as demonstrações financeiras, que são as formas finais de apuração da produtividade que envolveu o trabalho bancário altamente controlado.

\subsubsection{Significados da jornada flexível}

Outra forma de autonomia circunscrita, presente no cotidiano dos trabalhadores, é a possibilidade que a esses foi dada em ajustar horário de entrada e saída. Vejamos neste tópico, a partir da experiência do $\operatorname{Banco} \Delta$, um balanço dos seus significados. 
O horário flexível, conforme já havia observado Harvey (1992) em suas análises sobre os processos produtivos contemporâneos, faz parte da gestão marcada pela entrega de resultados. Trata-se de uma modelagem que subordina o tempo de trabalho dos empregados, no sentido de torná-lo mais disponível, favorecendo os objetivos de produtividade dos empregadores.

A medida, de forma análoga ao que analisou Krein (2007) sobre Banco de Horas, ajusta as eventuais sazonalidades da produção dos serviços. Essa flexibilização do tempo de trabalho, sobretudo em áreas em que não é feito atendimento ao público, está presente na rotina de milhares de trabalhadores do Banco $\Delta$. A estratégia administrativa abre a possibilidade de implementar ajustes na jornada, fazendo na prática, em determinado dia, ser mais relevante ampliar a jornada e em outro poder diminuí-la. O setor bancário conta com dias de "pico", dias em que o trabalho é intensificado pela pressão dos prazos que devem ser cumpridos.

O tempo é elemento central nas políticas de racionalização, otimização e controle no interior das grandes corporações. Da mesma forma que os administradores buscam fazer o gerenciamento das matérias-primas e do fator humano no processo de trabalho, o tempo, como insumo nesses ambientes, torna-se mais flexível. Arbitrariamente determinado e sujeito às variações constantes, o tempo flexível de trabalho pode trazer impactos negativos à sociabilidade dos trabalhadores, às práticas sociais que dão significado à sua vida fora do banco. Como analisou Gaulejac (2007, p. 78), as práticas de gestão no interior das grandes empresas que visam "a adaptabilidade e a flexibilidade são exigidas em mão única: cabe ao homem adaptar-se ao tempo da empresa e não o inverso".

O horário flexível no ambiente bancário é submetido a um acompanhamento rigoroso, viabilizado pela marcação do "ponto eletrônico", ou seja, a partir do momento que o trabalhador se conecta ou se desconecta ao sistema operacional informatizado da instituição. Por meio dessa ferramenta, as horas são computadas e calculadas automaticamente, gerando aquilo que se denomina usualmente de "Banco de Horas".

Nos anos 2000, o banco pesquisado passou a adotar em diversas áreas a política da jornada flexível, dando a possibilidade de o próprio trabalhador adaptar seu horário de entrada e saída desde que isso não comprometesse seus resultados e houvesse a autorização do gestor. 
A não aplicação do horário fixo fez com que a resolução de problemas ou quaisquer outros interesses particulares dos trabalhadores, que antes requeriam a utilização do horário "comercial", tornarem-se administrados, sem gerar ônus ao empregador. Os atrasos com transporte público, para citar um exemplo menor, saíam do rol de preocupações do Supervisor imediato, pois qualquer tempo de jornada não trabalhada seria adequada dentro do horário flexível.

Contudo, ainda que haja o horário flexível, é preciso esclarecer que persiste no ambiente bancário a necessidade de realização de horas extraordinárias para atender ao fluxo de trabalho em determinadas áreas ou ocasiões, sobretudo quando as cobranças por resultados convivem com a redução do quadro e a redistribuição das atividades entre os trabalhadores que ficam.

A jornada excedente para ser remunerada deverá passar por aprovação do principal gestor da área, o que acaba por inibir a demanda de pagamento uma vez que ela impactará negativamente na avaliação e nos resultados econômicos da área. Tal situação faz os trabalhadores trabalharem off-line, ou seja, acusarem o final da jornada de trabalho no sistema de ponto eletrônico, mas continuarem a executar tarefas necessárias, sem que isso gere registro.

O depoimento do entrevistado, a seguir, nos mostra detalhes sobre os impactos desta prática na vida do indivíduo:

Embora o banco te dê um índice de eficiência em uma jornada obrigatória de 08 horas, pois antigamente você podia fazer hora extra, hoje essas 08 horas são mascaradas. As pessoas batem o ponto e continuam trabalhando. Isso é $100 \%$. Porque você não consegue "entregar" e se você não consegue você perde o emprego e não consegue sustentar a sua família, simples assim. (Bancária, Gestora de Agência, 35 anos, 16 de banco)

Tem um Analista Pleno que eu conheço que chega às 10 da manhã porque a gente tem essa flexibilidade de horário, mas ele sai super tarde, ele ainda chega em casa leva o note, que teoricamente não pode, mas é uma prática comum entre as pessoas. Ele chega em casa com família, filho, esposa e só vai desligar o computador às 02 horas da manhã, porque tem que preparar o dia seguinte para poder continuar a trabalhar. Não entra no sistema quando você trabalha no notebook, fica off-line, mas você consegue acessar as planilhas e trabalhar, só não acessa o sistema, mas na manhã seguinte descarrega tudo no sistema. A questão é que você não consegue suportar isso por muito tempo, você olha para as pessoas, aquele semblante carregado, triste. Eu tenho muita empatia, eu consigo entender o sentimento da pessoa, eu chego, converso com o pessoal, às vezes simulando uma reunião para fazer uma pausa, para tomar um café. Ele é novo, mas parece mais velho, e isso interfere na vida 
pessoal dele, e ele tem um coração de ouro. (Bancário, Analista Júnior, 29 anos, 04 de banco).

O Banco de Horas ${ }^{83}$ contabiliza as horas em débito ou crédito que o indivíduo possui. A hora adicional trabalhada pode, por escolha arbitrária dos gestores, ser remunerada ou compensada.

O sistema de compensação de horas tem sido preferido pelas instituições. O Banco de Horas cumpriu o papel de reduzir os custos diretos com a força de trabalho, pois, na medida em que a hora extra trabalhada vale mais do que a hora comum, variando de acordo com a lei vigente entre $50 \%$ a $100 \%$, a compensação confere aos empregadores ganhos monetários. A hora compensada pelo trabalhador é feita no regime um para um, ou seja, uma hora extra trabalhada vale uma hora compensada, no dia e horário que, habitualmente, o gestor definir.

Nos cargos iniciais, marcadamente aqueles que ainda preservam a jornada de seis horas de trabalho, praticamente foram eliminadas as horas extras, conforme pudemos apurar nas entrevistas. Mas, sobretudo para outros cargos comissionados, o trabalho não pago, ou seja, a hora extra realizada e não remunerada, ainda persiste, mesmo que o sistema do Banco de Horas esteja em funcionamento, afinal é comum o trabalhador não conseguir folgar para compensar as horas.

Há um rearranjo administrativo que articula a estratégia de flexibilizar o horário de trabalho com a utilização do sistema de banco de horas, ambas medidas conferem ganhos monetários ao empregador, de um lado por promover um ajuste do fluxo de trabalho às demandas sazonais colocadas, conseguindo até mesmo driblar a legislação específica, e, de outro lado, por manter a prática do prolongamento da jornada a determinados cargos sem que recebam o pagamento adicional previsto em lei e raramente tendo para si disponibilizadas horas de compensação.

O trabalhador não tem livre-arbítrio sobre seu horário na jornada de trabalho que, apesar de mais flexível, não é de ampla e livre escolha. O horário flexível sempre está sujeito às normas internas e ao equilíbrio determinado pelo gestor local, que mantém a visão do processo de trabalho de maneira mais ampla. $\mathrm{O}$ trabalhador não poderá entrar e sair a qualquer hora. Limites sobre horários e quais cargos podem acessar o Banco de Horas são previamente definidos. Cargos de gestão (Supervisores, Coordenadores, Gerentes e Superintendentes) não têm acesso ao Banco de Horas por

\footnotetext{
${ }^{83}$ Os sindicatos dos bancários no Brasil em sua maioria não assinam acordos de Banco de Horas. As instituições formalizam diretamente e individualmente com os trabalhadores o "Acordo de Compensação de Jornada de Trabalho".
} 
serem considerados cargos de confiança e, portanto, qualquer extensão na jornada de trabalho é considerada "normal", haja vista as responsabilidades e o compromisso que tais trabalhadores devem honrar em suas posições. Tal fato contribui para explicar que funções de maior prestígio e status econômico e social dentro das corporações bancárias são intrinsicamente relacionadas à ideia de que não se pode cumprir o horário formal, sob risco de ter baixo compromisso com a instituição e não levar a sério a carreira.

Entre os trabalhadores entrevistados e nos materiais sindicais consultados, o dia ou horas de descanso motivados pela compensação do Banco de Horas são, em geral, determinados unilateralmente pelos gestores. É comum ir trabalhar e ter de voltar para casa no mesmo dia porque o gestor determinou que naquela ocasião o movimento estava baixo e portanto poderia quitar o saldo de compensação de horas.

Dessas circunstâncias são geradas insatisfações para os trabalhadores que, além do cansaço acumulado, negligenciam sua vida pessoal tornando difícil o planejamento de outras atividades que não seja o trabalho. A compensação de horas, quando realizada, não consegue muitas vezes recompor as perdas derivadas da desestruturação de outros compromissos fora do trabalho como: cursos, atividade física, encontro social ou convivência familiar.

Sob o ponto de vista da qualidade de vida e saúde dos trabalhadores que se submetem à realização de horas extras contínuas e excessivas, os sindicatos de representação têm advertido que as instituições com a finalidade de manter o quadro enxuto evitam novas contratações sobrecarregando os trabalhadores, favorecendo consequentemente o adoecimento.

Os entrevistados apresentam visões distintas sobre as alterações e aplicações do horário flexível e jornada de trabalho. Enquanto um destaca o que percebe de vantajoso, o outro frisa os problemas:

Tem quem reclama do horário flexível, porque não consegue cumprir [...]. Eu já acho ótimo, acho muito bom, posso entrar até 11 horas e posso sair a partir das $15 \mathrm{~h} 30,16 \mathrm{~h} 00$. Posso conversar com o gestor, e, se você tem horas, ele libera. Eu aprendi que tudo o que é combinado não é caro, isso ajuda; por exemplo, hoje eu sai às 05 horas da tarde, então eu aviso que vou ter que sair para resolver um problema particular. Preciso justificar, né? Porque e se alguém me procura? (Bancária, Analista Júnior, 57 anos, 12 de banco)

Não é interessante. Se trabalhou a mais deveria ganhar. Não ter em descanso. Não é vantajoso, às vezes acumula e você não consegue compensar no mês e perde. Tem gente que entra às 09 horas e sai às 02 da manhã. No registro está dizendo que eu cumpria o horário, 
mas se você olhar na catraca o horário que eu saia você vai ver diferenças de duas horas. Às vezes tinha tanta hora extra para compensar e nem conseguia porque era muito trabalho, mas se você tem tantas horas a mais você é taxado de ineficaz. Mas não é verdade porque você tem muito trabalho. Teu Diretor tem meta, eficiência é uma meta, e não querem contratar mais. (Bancário, Analista Júnior, 29 anos, 04 de banco)

De acordo com dados disponibilizados pelo Bancos, no ano de 2013 existiam 57.192 reclamações trabalhistas. No conteúdo dessas reclamações constam o cumprimento das diferenças salariais decorrentes de horas extras não devidamente registradas no sistema interno e reivindicações em relação ao método para estabelecer a compensação das horas extras trabalhadas (Relatório Gerencial, 2013). Tal constatação reforça o relato dos entrevistados.

Os trabalhos executados fora do "horário comercial" 84 apontam uma tendência de crescimento nos bancos que, ao buscarem acompanhar o movimento mais amplo do setor de serviços, passaram a atender clientes em horários estendidos, finais de semana e até feriados.

O horário estendido começou a ser implementado nas agências que se situavam no interior dos shoppings centers e posteriormente se ampliou para determinadas agências de rua, escolhidas para realizar atendimento focalizado em negócios ou refinanciamento de dívidas. Sob essa mudança os sindicatos dos trabalhadores bancários realizaram diversas manifestações de protestos contrários, advertindo sobre os prejuízos impostos ao planejamento privado dos trabalhadores e riscos físicos derivados da extensão do horário em locais mais vulneráveis a assaltos. ${ }^{85}$

As alterações não atingiram todas as áreas administrativas e rede de agências uniformemente. A jornada de trabalho bancário é regida pela CLT estabelecendo um padrão que considera 06 horas diárias em 05 dias trabalhados para cargos não comissionados.

O trabalho aos sábados havia sido abolido na década de 1960, representando uma grande conquista para a categoria profissional (FONTES; MACEDO; SANCHES, 2013). Contudo, diante da pressão do mercado representada pelo ciclo de realização do consumo em horários ilimitados, os bancos decidiram ampliar sua atuação para os finais de semana. Os executivos do setor abordam o tema sob o ponto de vista da necessidade

\footnotetext{
${ }^{84}$ Horário habitualmente divulgado entre 08 às 18 horas de segunda a sexta-feira, pelos estabelecimentos comerciais e de prestação de serviços para atendimento do público. No entanto, não há regra formalmente instituída, possibilitando ao administrador ajustar o horário conforme interesse. Com as mudanças nos hábitos de consumo, também alteraram os horários destes serviços, sobretudo após a propagação dos shoppings e sua comercialização em horários diferentes do tradicional "horário comercial".

${ }^{85}$ Folha Bancária (2012, 2013, 2014).
} 
de melhoria da prestação de serviços para o cliente, dando-lhe a possibilidade de ser atendido no final de semana.

A jornada de trabalho bancária, legalmente constituída por não prever trabalhos aos sábados e domingos, não é obrigatória, o que determina que todo trabalho realizado seja feito no regime de horas extras, Banco de Horas ou plantão.

As jornadas que acontecem nos finais de semana se concentram majoritariamente nas atividades de teleatendimento e em trabalhos que subsidiem a aprovação de crédito ao consumidor. Nesses casos vigora o sistema do "plantão" pelo qual a jornada semanal é distribuída pelos dias da semana, incluindo o sábado e o domingo, observando escalas de revezamento, de acordo com a demanda e o volume de trabalhadores. Por serem submetidos às oscilações destes processos de trabalho, os trabalhadores têm dificuldade de organizar compromissos pessoais.

Esta ausência de rigidez, de delimitação nos tempos de trabalho, de acordo com os entrevistados, leva a uma desestruturação no próprio tempo privado, interferindo nas suas escolhas de vida, como podemos notar:

Eu sou evangélica, gosto de ir à igreja, eu me sinto bem, a minha família está lá, é importante para mim, mas nem na igreja eu estou conseguindo mais me programar, porque a gente tem que seguir o plantão, mas eu já tinha pedido para me tirar naquele final de semana porque eu ia ser madrinha de casamento. Ela [referindo-se a Supervisora] fez pouco caso, disse que eu podia ir sim. Você sabe, a gente tem que ter tempo para se arrumar, foi difícil eu consegui ajeitar, só que aí me jogaram em um outro dia que não era meu plantão e eu já tinha marcado compromisso na igreja. Eles não têm a menor consideração... A supervisora falou assim: "Tudo bem se você não quer vir, tudo bem, mas eu vou ter que te dar um registro de advertência". Bem, foi isso... Eu estava mal, chorava, não queria levantar da cama para trabalhar, mas continuei vindo, aí aquele dia [referindo-se a um desmaio no meio do setor] eu não aguentei... (Operadora de Teleatendimento)

\subsubsection{Trabalhadores multifuncionais}

As novas modalidades de organização da produção que se estruturaram com base no modelo empresarial japonês, também reconhecido por "especialização flexível", a princípio, foram caracterizadas por: manter uma divisão do trabalho menos pronunciada, funções mais integradas e ausência de demarcação de tarefas prescritas a indivíduos. Tais condições, de acordo esta "proposta", fariam os trabalhadores 
participarem de um sistema de rotação de tarefas, em outros termos, serem polivalentes ou multifuncionais (HIRATA, 1994).

Durante nossa pesquisa encontramos subsídios, relativamente pouco expressivos, que apontam a presença de trabalhadores atuando como polivalentes ou multifuncionais no Banco $\Delta$. A experiência mais próxima do sistema de rotação de tarefas refere-se ao trabalhador que não se fixa apenas em atividades atribuídas a determinado cargo dentro da instituição, podendo, quando requerido, assumir a atividade de outro cargo.

Como já apontamos, há uma mistificação em torno de algumas das características ligadas às "novas formas de gestão", que não se confirmam no cotidiano de trabalho, em que pese haver um esforço grande por parte dos mentores intelectuais de tais promessas propagadas pelas consultorias de RH e até mesmo repetido por pesquisadores acadêmicos sem que haja uma demonstração efetiva.

É relevante assim questionar a noção atribuída à polivalência no sentido de identificá-la como um modo pelo qual o trabalhador teria suas atividades enriquecidas pela diversidade de conteúdos sob sua responsabilidade, escamoteando em realidade uma sobreposição de funções que não altera em si a rotina do trabalho repetitivo, prescrito, fragmentado e pouco criativo.

Como Mello e Silva (2004) nos explica, o sentido de polivalência não é unívoco. Um deles pode ser atribuído à necessidade de suprir ausência de outros trabalhadores e apenas agregar tarefas que não eram realizadas antes, sobretudo, em meio às transformações pelas quais a rotina do processo produtivo passa com as novas tecnologias.

De todos os ambientes observados no $\operatorname{Banco} \Delta$, foi na agência, o local onde a noção de multifuncional ou polivalente mais ganhou materialidade. Houve um rearranjo nas funções das agências, como buscamos demonstrar anteriormente. Desde 2008, o cargo de Caixa na agência agregou às suas atividades correntes a venda de produtos e serviços bancários. A função do Gerente Operacional foi completamente reorganizada para o "faz tudo" da agência. O trabalhador tanto pode estar na função de Gerente, propriamente dito, como de Supervisor, Tesoureiro, Caixa, e ainda se for o caso remediar alguma situação inesperada, como realizar o trabalho da Auxiliar de Limpeza da agência em situações nas quais o profissional responsável não está presente por atuar em duas agências no mesmo dia. 
O que está implícito nesta descrição é que as tarefas antes destinadas a cargos variados na instituição agora são distribuídas para um cargo escolhido que obrigatoriamente passa a acumular novas atribuições ao mesmo tempo em que ocorre a migração de parte das tarefas sob sua responsabilidade para os demais canais de atendimento do $\operatorname{Banco} \Delta$. Nesses ambiente, os cargos intermediários são extintos, como é o caso do Tesoureiro ou Chefe de Serviço. De toda forma, trata-se mais de um rearranjo das funções aos cargos nos contextos de mudanças no interior da organização.

\subsubsection{Autosserviço: o cliente como parte da racionalização do trabalho}

Partindo do pressuposto de que as estratégias do setor financeiro apontam para bancos que terão cada vez menos pontos de atendimento presencial, uma das principais funções dos dispositivos tecnológicos é promover cada vez mais a popularização do autosserviço no setor financeiro. Nesse contexto, o trabalhador bancário - ou o terceirizado que atende pelos Correspondentes Bancários - terá cada vez mais sua presença direcionada para atender apenas àquilo que as tecnologias da informação e as telecomunicações não puderem viabilizar para os clientes.

As tecnologias self-service permitem que os clientes efetuem serviços de uma forma autônoma e atemporal (FERREIRA, 2008). Dessa forma, parte do trabalho antes realizado pelo bancário passou a ser feito diretamente pelo cliente, o qual começou a digitar dados, manusear o cartão eletrônico; passar seu documento (boleto) na leitora de código de barras ${ }^{86}$ interagir com os serviços de resposta audível (voz eletrônica) das Centrais de Teleatendimento, seguir orientações de procedimentos dos caixas eletrônicos, ou acessar o sistema do banco via computador pessoal e celular para realizar uma série de transações bancárias possíveis.

Pesquisadores como Venco (2003), em seu estudo sobre o setor bancário, e Braga (2009), em sua análise sobre as Centrais de Teleatividades, observaram que as empresas têm transferido parte da carga de trabalho para os clientes.

Dessa forma, não é exagero dizer que os clientes contribuem com a racionalização dos serviços nos bancos. Estes, por sua vez, constituem parte do processo produtivo, tendo a sua ação também controlada a partir dos sistemas automatizados.

\footnotetext{
${ }^{86}$ O equipamento "leitora de código de barras" pode ser comprado de forma facilitada diretamente do banco e utilizado para funções de pagamento pelo cliente em sua residência ou empresa.
} 
Ao realizar uma transação bancária por meio dos dispositivos tecnológicos, os clientes deverão seguir todos os passos e normas institucionais para que possam atingir seu objetivo final. Eles deverão inserir senha, utilizar outras informações que apoiam a validação da senha, baixar o aplicativo, ler e aceitar as normas de uso e seguir cada etapa indicada da operação, digitando tudo corretamente. Os usos múltiplos que envolvem os meios eletrônicos e digitais devem ainda, por parte dos clientes, respeitar o tempo da tela em uso na programação estabelecida pelo sistema.

Os bancos fizeram os clientes trabalharem para si e, ainda que estes tivessem incorporado custos para estabelecer a conexão com internet ou ligação telefônica, as cobranças de tarifas foram mantidas. Nota-se que as tarifas obedecem a uma variação de custo $20 \%$ maior, se feitas por meio do canal presencial, ${ }^{87}$ ou seja, indo pessoalmente até a "boca de caixa" da agência tradicional e sendo atendido diretamente por um trabalhador.

Os clientes, em que pese não desprezarmos suas escolhas voluntárias motivadas pelo conforto e agilidade, são pelas questões financeiras e pelo estrangulamento do atendimento nas agências convencionais direcionados para migrarem sua relação com a instituição para os meios eletrônicos e digitais. $\mathrm{O}$ volume, propositalmente reduzido, de trabalhadores destinados a realizar o atendimento presencial na agência torna esse meio ainda desconfortável e lento.

Os próprios trabalhadores são incumbidos de contribuir com a migração para outros canais de atendimento, pois recebem metas de trabalho que visam retirar o cliente do atendimento presencial, seja direcionando o usuário que está na fila para o caixa eletrônico, seja cadastrando sua senha para usar a internet ou incluindo contas de pagamento como débito automático.

\subsection{Produtividade e ritmo de trabalho bancário}

O setor bancário apresenta dados expressivos para demonstrar os resultados financeiros favoráveis que vêm sendo obtidos nos últimos anos. Mesmo em situações adversas para a economia nacional e internacional, os bancos têm obtido rentabilidades e lucros elevados. Por meio de suas medidas de "eficiência", implementaram cortes em seus custos promovendo a redução de postos de trabalho, terceirizando e intensificando

\footnotetext{
${ }^{87}$ De acordo com a "Tabela geral de tarifas" publicada em 2014 no site do Banco $\Delta$ as tarifas relativas ao atendimento presencial ou que possuem intermediação do trabalhador são as mais elevadas.
} 
os processos de automação e informatização. Ao mesmo tempo, tais instituições financeiras obtiveram elevados ganhos derivados das cobranças com tarifas, e, principalmente, derivados das altas taxas de juros (DIEESE, 2014).

De acordo com o estudo divulgado por uma consultoria financeira internacional, ${ }^{88}$ a rentabilidade sobre patrimônio dos grandes bancos de capital aberto foi de $18,23 \%$ em 2014, representando mais que o dobro da rentabilidade dos bancos americanos que ficaram em 7,68\%. Como podemos observar a seguir os lucros auferidos no setor bancário brasileiro mantiveram tendência de crescimento ao longo dos anos.

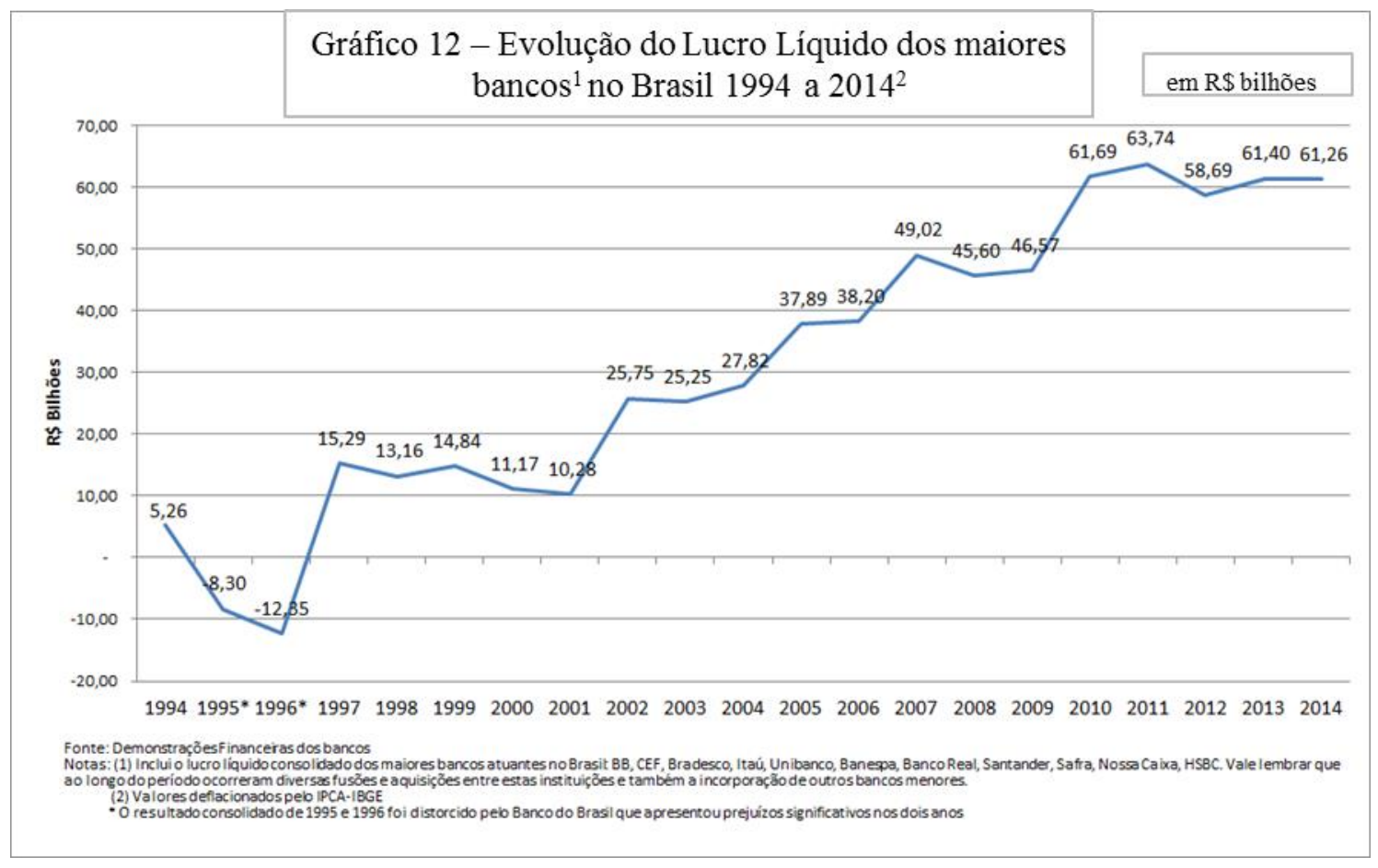

Elaboração: Rede Bancários - DIEESE

Em 2014, o Bancos obteve uma das taxas de rentabilidade mais elevadas do sistema, saindo de $24 \%$ para $25 \%$, enquanto seu lucro cresceu $30,2 \%$ atingindo o maior resultado da história dos bancos brasileiros de capital aberto (DIEESE, 2014).

88 De acordo com estudo realizado pela consultoria Economática em matéria disponível no site da UOL: http://economia.uol.com.br/noticias/bbc/2015/03/23/por-que-os-bancos-brasileiros-lucram-tanto.htm. Acesso em: abr. 2015. 


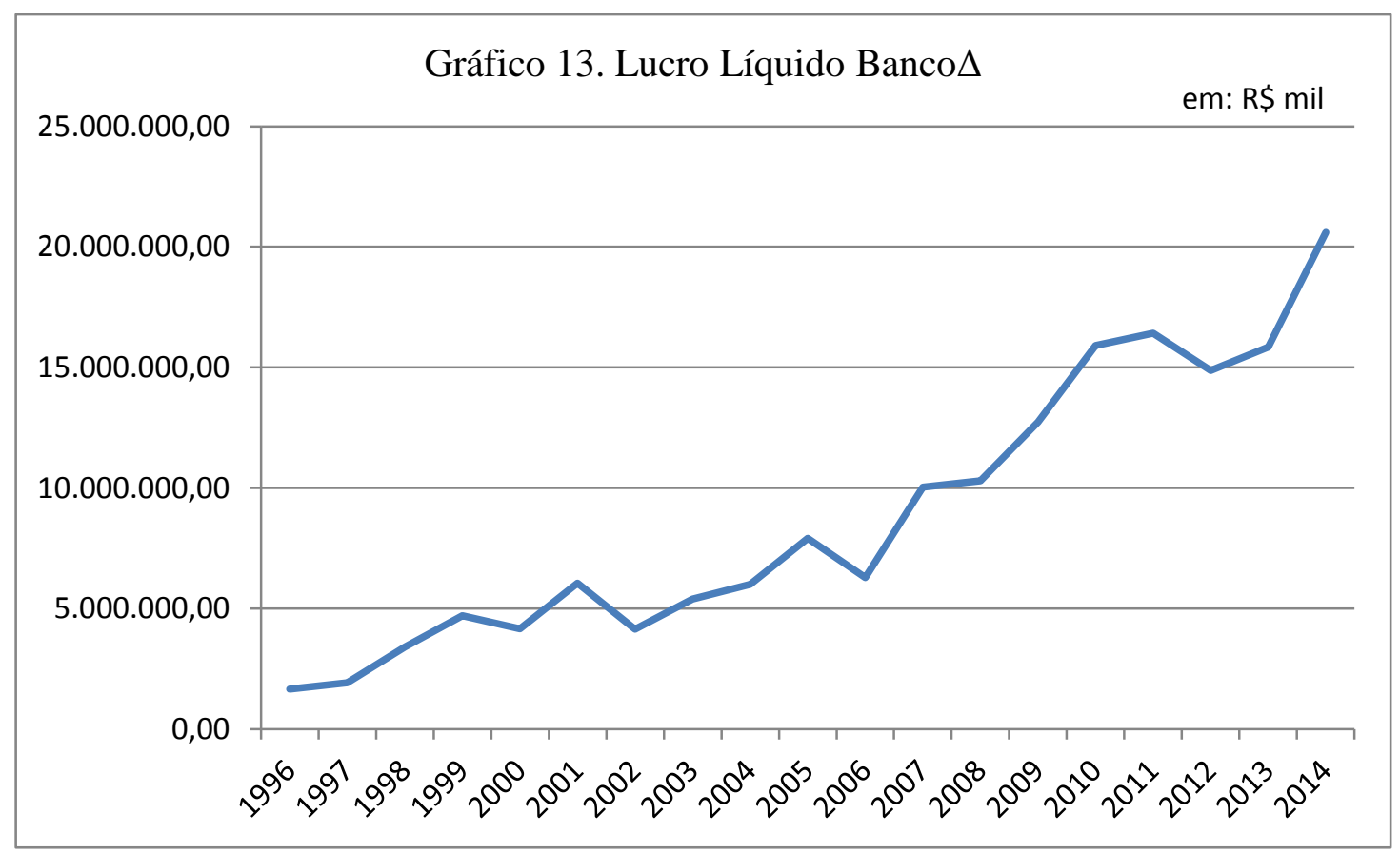

Fonte: Demonstrações Financeiras Banco $\Delta$. Elaboração da Autora.

* Em 2008 houve a incorporação de um grande banco privado nacional.

Além das razões já mencionadas para o crescimento do lucro dos bancos, quando observamos os dados do Banco $\Delta$ é perceptível que o processo de fusão com outro banco privado nacional de grande porte em 2008 ajuda a explicar o impulso dos resultados financeiros da instituição, o que fez, em 2011, elevar sua posição no ranking mundial ao oitavo lugar. ${ }^{89}$

Os dados mais recentes disponíveis, de acordo com o DIEESE (2014), apontam que o crescimento da receita com carteira de crédito e da receita com Títulos e Valores Mobiliários (TVM) tiveram participação expressiva na composição dos resultados do Banco $\Delta$. Analisando separadamente esses dois indicadores, podemos aferir objetivamente os efeitos do rentismo sobre o setor, pois quando comparamos a participação dos resultados da carteira de crédito concedidos para pessoas físicas e jurídicas, em relação à receita com TVM, que contabiliza as operações de compra e venda de títulos públicos e privados, observamos que o crescimento médio da receita com carteira de crédito foi de 7,46\%, enquanto a receita com TVM cresceu, em média, 41,1\%. Conforme explica o DIEESE (2014), isso significa uma proporção 5,5 vezes maior.

\footnotetext{
${ }^{89}$ Em 31 de dezembro de 2011, o Banco $\Delta$ figurava como $8^{\circ}$ maior banco do mundo pelo critério de valor de mercado, segundo ranking da Bloomberg. Fonte: Demonstrações Contábeis Completas Banco $\Delta 2011$.
} 
O crescimento desproporcional da receita com TVM tem por base a alta taxa de juro básico que orienta a economia nacional (Selic - Sistema Especial de Liquidação e de Custódia), o que torna mais atraente atuar nesse tipo de operação ao invés de ofertar crédito ao setor produtivo (DIEESE, 2014).

O fator trabalho é uma das variáveis relevantes quando se pretende analisar o aumento produtividade. No Banco $\Delta$, a queda na quantidade de empregados, quando paralelamente viu-se ampliar os resultados apurados na forma de lucro líquido, redimensiona a participação do fator trabalho apontando que foi possível alcançar melhores resultados econômicos, ainda que com menos trabalhadores.

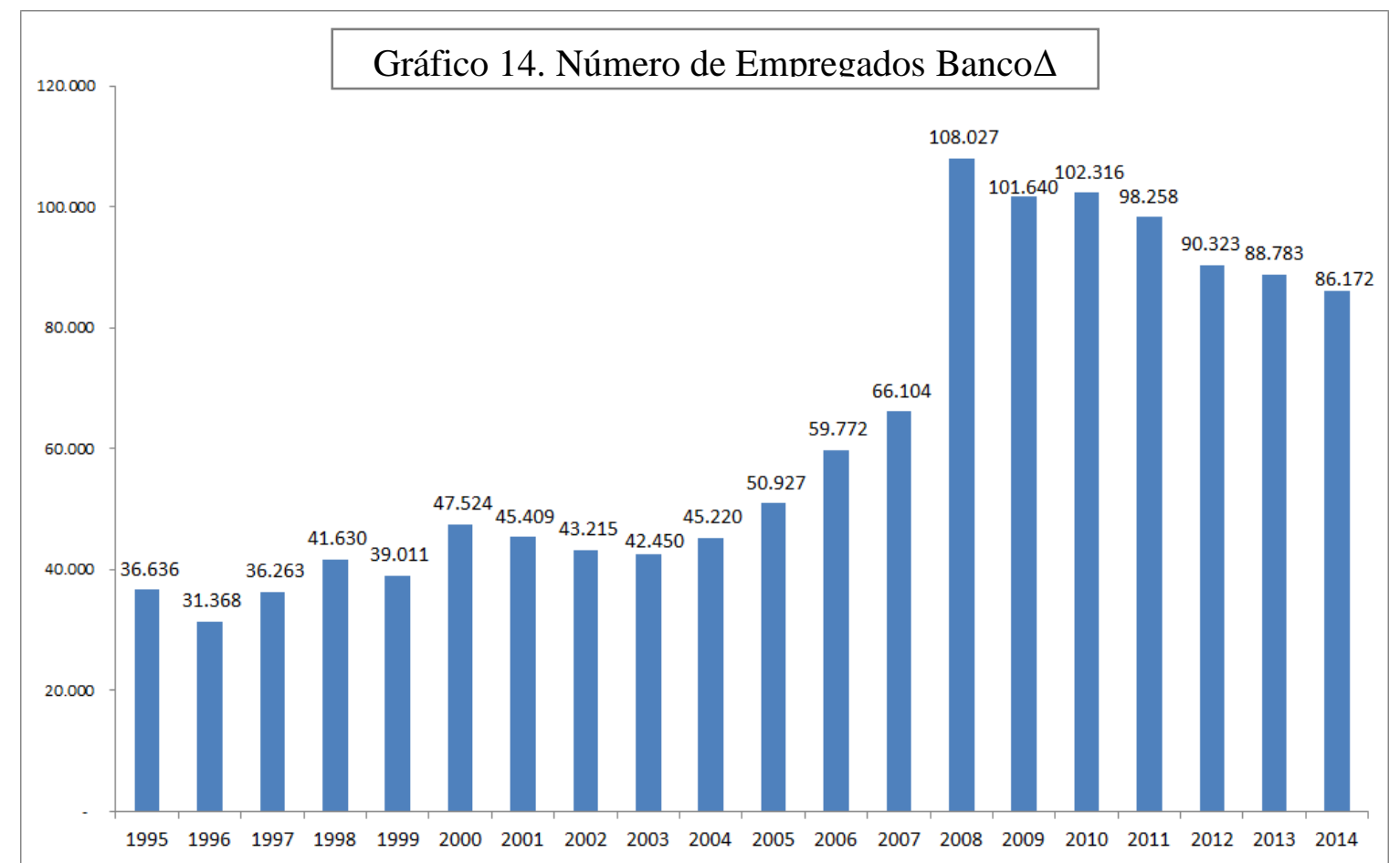

Fonte: Demonstrações Financeiras do Banco. Elaboração: DIEESE - Rede Bancários.

O volume de trabalho por bancário, se observado o indicador "carteira de crédito por empregado", conforme demonstramos, a seguir, no Gráfico 15, nos leva a inferir que houve intensificação do trabalho na categoria bancária, pois o aumento do volume de crédito por bancário cresceu sem cessar, enquanto o número de empregados, sobretudo a partir de 2009, começou cair. 


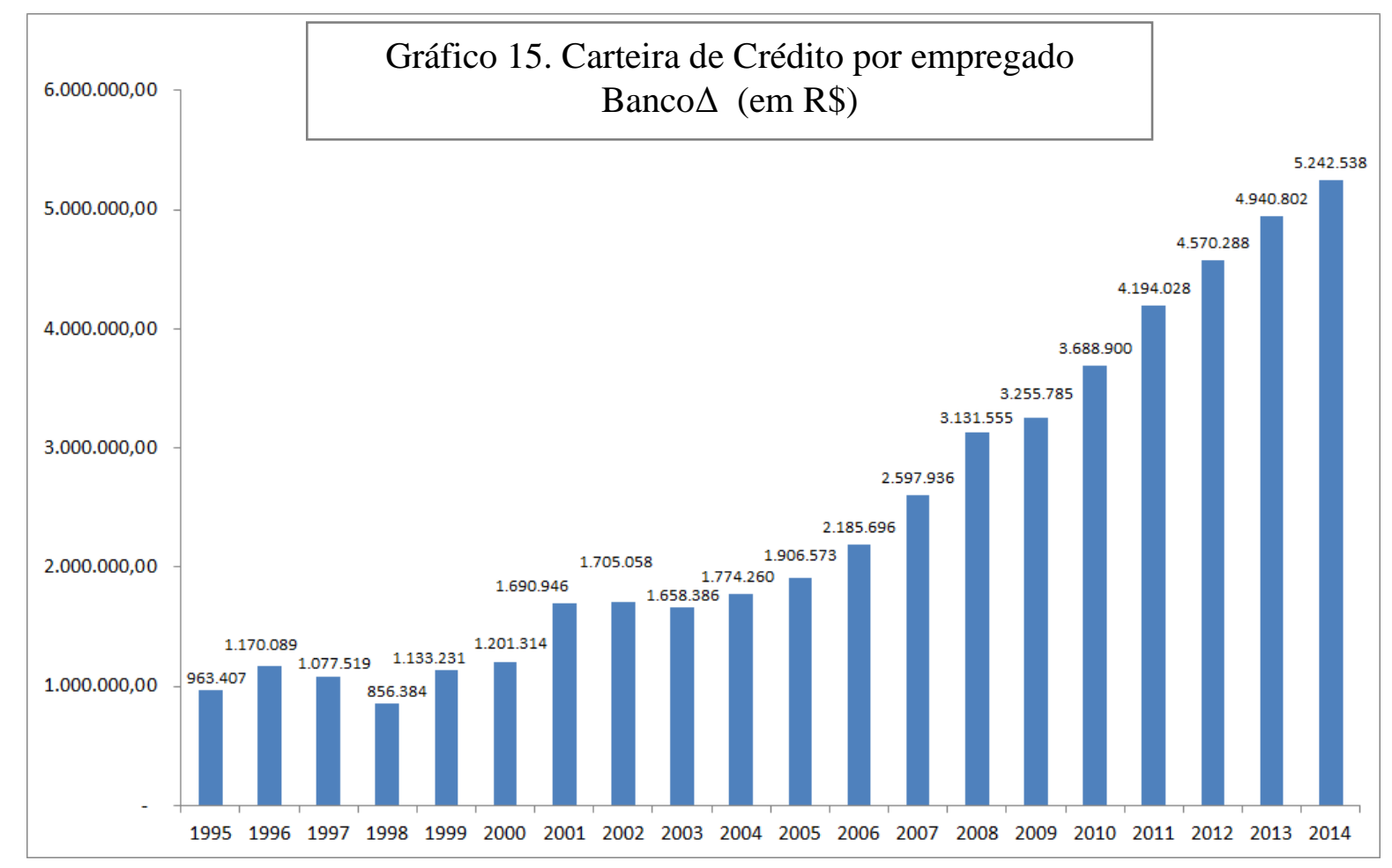

Fonte: Demonstrações Financeiras do Banco. Elaboração: DIEESE - Rede Bancários.

Nota: Em 2008 houve processo de fusão com outra grande instituição financeira.

Compreendemos que a relação número de carteiras de crédito por empregado é um dos critérios possíveis para mensurar a intensificação do trabalho bancário, servindo de referência em nossa análise. O uso da força de trabalho terceirizada, por exemplo, traz maiores dificuldades de mensurar a produtividade da empresa porque carrega consigo o trabalho coletivo de outros grupos de trabalhadores que fazem parte do processo produtivo global, que em termos finais gera os resultados financeiros dos bancos.

Os aspectos que compõem a nossa percepção sobre a intensificação do trabalho no Banco $\Delta$ residem na sobrecarga de trabalho, pois os resultados trazidos à tona apontaram que houve o aumento da atividade bancária com menor quantidade de trabalhadores envolvidos nos processos de trabalho.

Ao observamos as influências do uso de novas tecnologias aplicadas aos processos de trabalho bancário, a variação do número de empregos e as próprias declarações dos trabalhadores fornecidas nas entrevistas, podemos afirmar que a instituição, com o objetivo de obter mais "eficiência", buscou agilizar os processos produtivos ao mesmo tempo em que acumulou funções, antes atribuídas aos que foram desligados, àqueles que permaneceram empregados. 
Tal situação elevou a produtividade individual sobrecarregando os trabalhadores em diversas áreas, fazendo que, por meio de ameaças veladas àqueles que ficaram, deveriam suportar a carga adicional demonstrando competência e garra para lidar com as novas condições impostas, sendo que só os "melhores" são escolhidos para ficar na instituição.

Apenas no ano de 2012 o Banco $\Delta$ eliminou 7.455 empregos diretos. A esse respeito a instituição publicou:

A redução no número de colaboradores é explicada pela reestruturação resultante da integração dos sistemas e processos em uma única plataforma, que permitiram capturar sinergias entre as estruturas operacionais e revisar a estratégia de alguns negócios. (Relatório Gerencial Banco $\Delta$ 2012)

Por essa declaração, é razoável concluirmos que parte da explicação da redução do emprego bancário se dá em função do processo de fusão pelo qual a instituição passou e consequentemente pela racionalização do processo de trabalho viabilizada pelos recursos das tecnologias da informação.

As TIs foram e têm sido utilizadas nos mais diversos setores da economia para intensificar os processos de trabalho e aumentar a produtividade (PELAEZ; SZMRECSÁNYI, 2006). Com os recursos das tecnologias da informação foi possível acelerar os ritmos de trabalho no setor bancário, pois uma série de indicadores pôde ser monitorada com mais facilidade. O controle eletrônico de etapas de trabalho que pareciam intangíveis em outros momentos da história do trabalho bancário, como eram aquelas que dependiam da interação direta com os clientes, foi um importante meio para aumentar a produtividade.

Figura 6

Recebo e-mail, logo existo.

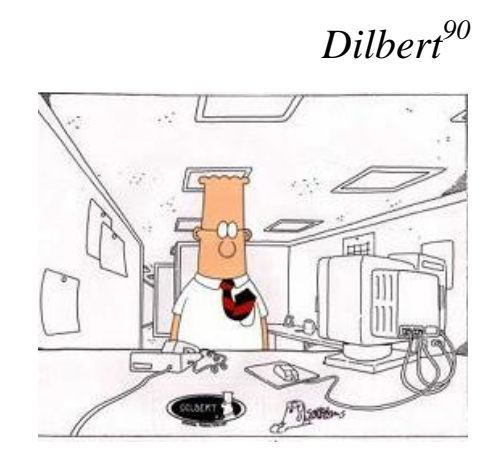

${ }^{90}$ Dilbert é um personagem de história em quadrinhos popularizado na década de 1990 criado por Scott Adams. A narrativa em torno do personagem satiriza o mundo corporativo, criticando aspectos como a rotina e a burocracia. Fonte: www.dilbert.com. 
Outros dispositivos, aparentemente simples, derivados das inovações tecnológicas promovidas nas últimas décadas, como e-mails, smartphones, celulares, notebooks, intranet e/ou similares foram considerados para $77 \%$ dos pesquisados no survey "Tecnologia e terceirização no setor bancário" como meios que levaram à intensificação do trabalho.

A facilidade e velocidade pelas quais circulam as informações são decisivas para o fluxo de trabalho no interior das corporações. A observação feita por Sennett (2011) é pertinente, apesar de sua abordagem não focar especificamente no universo das finanças, pois representa em certa medida as experiências que ocorrem no setor:

O e-mail e seus derivados diminuíram a mediação e a interpretação de ordens e normas transmitidas verbalmente para baixo da cadeia de comando. Graças às novas ferramentas de computação para o mapeamento de insumos e produção nas corporações, tornou-se possível transmitir para cima, de maneira instantânea e sem mediação, informações sobre o desempenho de projetos, vendas e do pessoal. Estima-se que na década de 1960 o decurso de tempo para que uma decisão da direção executiva chegasse à linha de montagem era de cinco meses, intervalo hoje em dia radicalmente reduzido a umas poucas semanas. $\mathrm{Na}$ organização de vendas, o desempenho dos representantes de vendas pode ser mapeado em tempo real em casa, na tela do computador. (SENNETT, 2011, p. 45)

Os administradores das instituições financeiras sempre buscaram eliminar qualquer forma de "ociosidade remunerada", assim foram implementados ao longo das últimas décadas inúmeros projetos alicerçados nos avanços e nas facilidades que as TIs proporcionaram, reduzindo o tempo chamado inoperante ou "tempo morto" no processo de trabalho.

Essas mudanças levaram à atribuição de novas e mais tarefas em contextos onde o processo de trabalho foi facilitado. Além disso, espaços antes inatingidos, como era o traslado do trabalhador de um ponto a outro, ainda que por necessidade derivada da função, tornaram-se permeáveis ao controle e às exigências de produtividade, pois pode-se estar à disposição do empregador bastando acessar qualquer dispositivo eletrônico móvel. Se antes o deslocamento podia significar um intervalo no ritmo de trabalho, na contemporaneidade, ele pode ser otimizado diante das inovações tecnológicas.

Sem unidade de tempo ou até mesmo de um lugar de trabalho exclusivamente delimitado, os trabalhadores podem usar os dispositivos que os conectam com a 
empresa. Ficam, desse modo, mais sujeitos a aumentar sua carga e preocupações decorrentes da relação com o trabalho, em grande parte dos casos, sem serem remunerados para isso.

De acordo com os resultados do survey "Tecnologia e terceirização no setor bancário" sobre o ritmo de trabalho, 78\% afirmaram que a aplicação de sistemas informatizados levou à sua intensificação, sendo realizadas mais e novas etapas de trabalho em menos tempo. O levantamento de opinião buscou apreender ainda elementos que pudessem qualificar e mensurar a elevação do ritmo de trabalho. Nesse sentido, foi perguntado se o trabalho havia ficado mais rápido, em virtude das novas tecnologias. A resposta afirmativa a essa questão atingiu $63 \%$.

A pesquisa coordenada por Rodrigues (2011), "Perfil do bancário e as condições de trabalho no setor financeiro na cidade de São Paulo", 91 conseguiu captar a opinião dos trabalhadores que representaram variados cargos constantes na hierarquia ocupacional dos bancos, incluindo desde aqueles que se situam no início da carreira até os que se encontram no topo. Destacamos alguns resultados que nos ajudam a dimensionar a percepção dos trabalhadores bancários sobre ritmo de trabalho, metas relacionadas à jornada de trabalho e quantidade de trabalhadores relacionados à demanda de trabalho: ${ }^{92}$

- Ritmo de trabalho:

$57 \%$ dos participantes da pesquisa concordaram totalmente com a frase o "ritmo de trabalho é muito intenso". Na sequência, a maior proporção dos respondentes, 28\%, concordaram parcialmente.

- Metas versus jornada de trabalho:

36\% discordaram totalmente da afirmação "as metas são compatíveis com a jornada de trabalho". Na sequência, à maior proporção dos respondentes, 25\%, discordaram parcialmente.

\footnotetext{
${ }^{91}$ A pesquisa intitulada "Perfil do Bancário e as Condições de Trabalho no setor Financeiro na cidade de São Paulo" fez parte do projeto "Transformações do trabalho e ação sindical no setor financeiro", ambos coordenados por Rodrigues (2011) e contou com a participação de 528 bancários. A amostra teve participação majoritária de bancários do setor privado, sendo composta por 53\% de homens e 46\% de mulheres. Foi coletada entre abril e maio de 2011, na ocasião da homologação da rescisão do contrato de trabalho no Sindicato dos Bancários de SP, Osasco e região.

92 Os participantes da pesquisa expressaram seu grau de concordância ou discordância, em uma escala de cinco pontos (1-discordo totalmente, 2-discordo parcialmente, 3-indiferente, 4-concordo parcialmente e 5-concordo totalmente).
} 
- Quantidade de funcionários versus demanda de trabalho:

29\% discordaram totalmente da afirmação "a quantidade de funcionários atende à demanda de trabalho". Na sequência, a maior proporção dos respondentes, $24 \%$, discordaram parcialmente.

Os dados e resultados das pesquisas que trouxemos à tona neste tópico nos ajudam montar um quadro do ambiente de trabalho nos bancos. As entrevistas que fizemos também foram significativas no sentido de reforçar a perspectiva de que o ritmo de trabalho se intensificou e houve aumento de produtividade. 


\section{Capítulo 4 - Dinâmica organizacional na grande corporação bancária}

\subsection{Quando a gestão empresarial incorpora o bem comum}

Nós, do Banco $\Delta$, acreditamos que, além dos negócios, podemos contribuir de forma efetiva por meio de diversas iniciativas que nos ajudam a promover uma sociedade mais crítica e consciente. (Revista Banco4, mai. 2015)

Estamos construindo uma cultura corporativa para inspirar nossos colaboradores a sentirem orgulho de fazer parte do Banco $\Delta$, reforçado por empenho em criar valor para os colaboradores, clientes, acionistas e a sociedade. (Vice-Presidente do Banco $\Delta$ Relatório Gerencial 2013)

Conseguimos mostrar para a sociedade que o Banco $\Delta$ está inserido nesse contexto de transformação e que por meio das nossas causas estamos contribuindo para um mundo melhor (Superintendente de Marketing do Banco $\Delta$ Revista Exame, fev. 2015).

Boltanski e Chiapello (2009, p. 39) debruçaram-se sob o estudo daquilo que definiram como um "novo conjunto ideológico mais mobilizador", o qual justificasse a adesão e o engajamento de executivos e assalariados na nova fase de acumulação capitalista. Os autores nesta trajetória estabeleceram um diálogo direto com a perspectiva de análise weberiana que explicou o desenvolvimento do capitalismo fundado em um ethos de conduta particular, o protestantismo. Tal análise considerou que, no século XVI, por meio da religião protestante, se instaurou uma nova relação moral entre os homens e seu trabalho, que serviu de apoio normativo aos empreendedores e aos operários, tornando possível controlar as atividades cotidianas marcadas por uma nova disciplina que garantisse a regularidade necessária para que fosse possível acumular riqueza.

No "primeiro espírito" do capitalismo era a "motivação psicológica", como Weber $^{93}$ assinalava, que possibilitava o engajamento e a adesão dos agentes sociais (BOLTANSKI; CHIAPELLO, 2009, p. 40). Ter vocação, nesse sentido, compreendia seguir os passos para atingir uma vida plena e eterna, guiando-se pela prosperidade do trabalho duro e buscando lucro como uma virtude estabelecida na vida cotidiana, no plano da realidade.

Considerando o longo tempo da vigência desse sistema de acumulação, Boltanski e Chiapello (2009, p. 54) defenderam que uma nova fase, um "segundo

\footnotetext{
${ }^{93}$ WEBER, M. L'éthique protestante et l'espirit du capitalisme. Paris: Pion, 1964.
} 
espírito" do capitalismo, havia se consolidado nos anos 1930, estendendo-se até os anos 1960. Na análise apresentada pelos autores, tratou-se de um período no qual as razões individuais e coletivas, que tornaram a ordem capitalista aceitável e até desejável, se pautaram pelo ethos do pacto social e mobilidade ascendente.

A década de 1970 marcou uma nova etapa para o sistema em questão, ensejando aquilo que os autores nomearam de "novo espírito do capitalismo" (BOLTANSKI; CHIAPELLO, 2009, p. 352). Uma nova configuração ideológica associada às novas formas de gestão da produção serviu de amálgama para promover um novo sentido ao trabalho e ao modo de se relacionar com o trabalho.

Assim, o espírito que sustenta o modo de ser capitalista contemporâneo carrega em sua base conceitual críticas ao modelo anteriormente predominante de gestão do trabalho, que mantinha alinhado a si um modo de vida e de organização societária. As novas ideias gerenciais ganharam amplitude e foram úteis no sentido de adaptar os interesses da nova fase de acumulação capitalista.

A interação entre ideias e o novo comportamento econômico é o que sintetiza o novo espírito do capitalismo que Boltanski e Chiapello (2009) buscam colocar em destaque. Para haver esta correspondência funcional é necessário dar sentido ao processo de acumulação conservando a adesão dos participantes do sistema.

Para os autores citados, o espírito do capitalismo congrega dois níveis lógicos diferentes, um que orienta a ação e outro que orienta um grau de reflexividade superior, com base em princípios universais. Trata-se de não apenas cobrar resultados objetivos econômicos que gerem lucro, mas em estabelecer outros estímulos que orientem a ação dos indivíduos para algo mais nobre, que aponte para o bem comum fazendo este sentimento perpassar por várias formas de agir no interior da instituição (BOLTANSKI;CHIAPELLO, 2009).

Tal perspectiva também já havia sido tratada por Mills (1969, p. 252) ao afirmar que: "para obter e aumentar a boa disposição para o trabalho é necessário criar uma nova ética que dê ao trabalhador outro incentivo além do econômico". Essa questão de fundo está na análise de ambos autores citados e nos ajudam a ampliar nossa perspectiva sobre os acontecimentos na grande corporação bancária.

As razões que se apresentam para explicar o "idealismo empresarial" que visa "mudar o mundo", como pudemos observar nas citações em epígrafe deste tópico, mantêm relação com as mudanças objetivas, operacionais, implementadas no setor e em especial no banco estudado. 
As campanhas publicitárias do Banco $\Delta$ evocam a "mudança no mundo". Apontam a importância de hábitos que preservem o meio ambiente, incentivam formas de relação pacífica entre os povos e o respeito às diferenças. Além disso, a instituição mantém projetos que interveem diretamente no espaço urbano de diversas cidades e até em outros países. Ao apoiar e investir em mobilidade urbana, projetos culturais, educacionais e esportivos, a instituição espalha sua marca e a torna reconhecida pela nobreza de seus atos que passam ao largo dos reais efeitos que suas práticas econômicas geram para a sociedade, sobretudo quando se leva em consideração a conivência das instituições financeiras com as políticas econômicas que privilegiam o rentismo.

Assim, mais do que imaginar que a cultura empresarial está apenas para a empresa, se trata de reconhecer nesta o papel que exerce como mediadora entre o indivíduo e o mundo, emitindo a todo tempo elementos cognitivos e normativos de comportamento (SHINYASHIKI, 2002).

O ambiente corporativo diante da fraqueza do pacto no trabalho atual é marcado por um simbolismo intensivo. Busca-se como disse Gaulejac (2007, p. 126) desenvolver “convicções e valores nos quais cada empregado deve comprometer-se a crer”. A gestão empresarial se empenha em "compensar a lógica do lucro por meio de construções morais, destinadas a legitimá-la".

A sustentabilidade ${ }^{94}$ pode ser pensada a partir do ponto de vista econômico, social e ambiental. Em todos esses pilares a gestão corporativa contemporânea evoca o longo prazo operando em uma lógica esquizofrênica quando, nas relações de produção, venda e circulação, atua contraditoriamente pautada pelo retorno ao acionista no curto prazo.

Desde o ano 2000 o banco pesquisado tem sido selecionado para compor a carteira do Dow Jones Sustainability World Index (DJSI) que, segundo seus idealizadores, trata-se de um dos mais respeitados índices de performance empresarial sustentável do mundo. Dos quesitos avaliados, a instituição obteve bons resultados sobre os itens: Desenvolvimento do Capital Humano, Engajamento com Públicos Estratégicos e Políticas/Ações Anticrime e Fraudes.

As empresas participantes do Dow Jones visam em última análise conseguir um atestado de confiança do mercado. O índice é composto por 340 instituições, dessas 09

\footnotetext{
94 De acordo com CORAL (2002) não existe consenso em relação ao conceito de sustentabilidade e principalmente na sua aplicabilidade ao contexto empresarial. Para a autora, uma empresa pode ser considerada sustentável se atender aos seguintes critérios: ser economicamente viável, ocupar uma posição competitiva no mercado, não agredir o meio ambiente durante a produção e contribuir para o desenvolvimento social de uma região.
} 
são brasileiras e apenas 30 países são representados. O Dow Jones reconhece as organizações com as melhores práticas de gestão e governança voltadas à geração de valor econômico, social e ambiental no mundo.

Para confeccionar relatórios que subsidiem as exigências das operações em Bolsas de Valores internacionais e possam conquistar a credibilidade pública, o Banco $\Delta$ mobiliza aproximadamente 60 pessoas que coletam um conjunto amplo de informações que demonstrarão o quão sustentável é o negócio para o mercado, para os acionistas ${ }^{95}$.

De acordo com Minella (2009), as instituições financeiras juntamente a outras empresas, brasileiras e multinacionais, atuam no financiamento de organizações envolvidas no programa mundial de Governança Corporativa. "Entre as 21 empresas 'associadas patrocinadoras' - que contribuem diretamente para a manutenção do Instituto Brasileiro de Governança Corporativa (IBGC), oito são vinculadas ao setor financeiro" (MINELLA, 2009, p. 31).

A "boa" governança corporativa é parte do "novo espírito do capitalismo". As instituições, para além das razões pragmáticas, buscam dar sentido à ação e esperam encontrar adesão dos participantes, tanto no que se refere aos indivíduos que trabalham para si como para os demais agentes envolvidos em seu ciclo produtivo.

O discurso da responsabilidade social e sustentabilidade, refletido nos relatórios que subsidiam decisões dos acionistas, tem como efeito direto a autopromoção. As atividades concretas no campo social se efetivam antes pelo cálculo de quanto podem alavancar sua imagem e trazer consequentemente retorno econômico do que pelo compromisso de transformação social das grandes corporações.

A força simbólica que envolve o Banco $\Delta$ pode ser medida pela sua popularidade, pelo quanto desperta admiração e respeito pelo outro. Não à toa que em diversas pesquisas realizadas por consultorias empresariais, em parceria com grandes veículos de comunicação, a instituição figura no topo das preferências das seguintes classificações: "Melhores empresas para trabalhar"; "A empresa dos sonhos dos jovens"; “A empresa mais sustentável” e "A marca mais valiosa no Brasil".

A relevância do valor da marca ajuda a compreender a dimensão desta questão da imagem no mundo corporativo. Isso, em outras palavras, resulta em maior credibilidade, maior fidelidade dos clientes e consequentemente melhores resultados financeiros. Segundo o ranking de 2014 da consultoria Interbrand, R\$ 21,68 bilhões é o

${ }^{95}$ Revista Banco 4 , mai., 2012 
valor atribuído à marca do $\operatorname{Banco} \Delta$, ocupando o primeiro lugar no Brasil (Relatório Gerencial Banco $\Delta$ 2014).

O investimento feito em marketing é parte estruturante do empreendimento capitalista. Os dados do Banco $\Delta$ apresentam gastos de mais de $\mathrm{R} \$ 950$ milhões no ano de $2014,{ }^{96}$ configurando a quarta maior despesa administrativa em valores absolutos que a instituição declara em seus resultados contábeis. As relações entre os usos do marketing e o imaginário social foram analisadas por Martins (1992, p. 4):

Os altos investimentos em marketing, possíveis exatamente pela escala em que operam as grandes corporações, são considerados pelos executivos como vantagens competitivas, fomentam no imaginário social admiração e em alguns casos identidade com o consumidor e ainda atingem aqueles que tem expectativa de trabalhar em uma empresa que possa manter esse conjunto de ações sociais e atitudes politicamente corretas.

O setor bancário, sobretudo por operar com recursos financeiros de terceiros, se ancora na credibilidade e reputação que dispõe. Nesse sentido é estratégico do ponto de vista do negócio adotar os parâmetros da "boa" governança corporativa e dentre eles dar destaque ao Código de Ética, o qual orienta a conduta dos seus trabalhadores e gestores. A seguir reproduzimos trecho de abertura do Código de Ética do Banco $\Delta$, em que é possível observar a relação que seus administradores estabelecem entre a perenidade do negócio, a moral e a disciplina dos seus protagonistas:

O mundo muda. Essa verdade inexorável nos faz constantemente repensar como nos relacionamos com a sociedade e o mercado. Por isso, sentimos a necessidade de atualizar nosso Código de Ética. Este documento contribui, junto à nossa Visão e nossa Cultura Corporativa, para o registro de nossos valores mais essenciais. Acreditamos que seguir os princípios nele contidos contribui para assegurarmos a perenidade e a credibilidade do banco. Nosso Código baseia-se em quatro princípios básicos: o da identidade (o que nos distingue das outras empresas), o da interdependência (motor da convivência social), o da boa-fé (confiança gera confiança) e o da excelência (busca contínua da qualidade superior). Tais princípios inspiram nossas normas. As mesmas foram reescritas visando torná-las ainda mais claras e compreensíveis, sem que percam a sua essência. O Código de Ética é, e deve ser, um documento de consulta constante tanto para administradores quanto para colaboradores da nossa organização. Ele tem, antes de tudo, um caráter educativo, além do disciplinar, permitindo orientar a postura mais adequada e coerente com nossas diretrizes. Aqui deixamos muito claro quais são as condutas julgadas certas e, portanto, necessárias, como também aquelas consideradas erradas e, portanto, inaceitáveis. Orientar-se por este Código é o mesmo que usar uma bússola moral, que nos permite

\footnotetext{
${ }^{96}$ Inclui gastos com propaganda, promoções e publicações. Fonte: Demonstração consolidada do valor adicionado Banco $\Delta 2014$.
} 
encontrar o melhor comportamento e a melhor decisão a ser tomada, sempre visando o bem comum (CÓDIGO DE ÉTICA $\mathrm{BANCO} \Delta$, grifo nosso).

A sustentabilidade na grande corporação, do ponto de vista do negócio, visa a princípio consolidar estruturas que possam dar garantias de retorno econômico pensadas no longo prazo. O investidor, o acionista ou o próprio dono do negócio busca minimizar o risco de ficar sem sua fonte de abastecimento monetário e consequentemente todo o seu poder econômico e político.

A ideia de sustentabilidade social ou ambiental não consegue se manter coerente diante de uma análise mais rigorosa das escolhas econômicas e administrativas, das quais as grandes corporações são mentoras, sobretudo quando se sabe que prevalece a ação pragmática com base nos resultados objetivos. Suas políticas comunitárias são experiências localizadas e transitórias que visam celebrar uma imagem de compromisso social. Ao atuarem nestas frentes e demonstrarem capacidade de organização, tangencialmente encontram uma forma para apontar o quão frágil é o Estado e o quanto supostamente essas experiências são importantes para as políticas sociais vigentes, pois o saber fazer do negócio, a competência em gestão, serve nessas circunstâncias de influência e autoridade para reafirmar seu próprio valor na sociedade.

A grande empresa bancária reúne melhores condições de alavancagem de capital e formas de operar, como são aquelas vistas por meio das redes, conglomerados e holdings nas quais conseguem pela escala e escopo de atuação vantagens para negociar, investir, obter ganhos tributários e ainda disseminar quais as normas e organização do trabalho são as melhores diante do cenário competitivo.

Os ganhos derivados da remuneração do capital dos acionistas se escondem atrás do pragmatismo das organizações, que apenas para citar alguns exemplos: contabilizam a redução do valor pago à força de trabalho terceirizada enquanto os usuários dos serviços perdem em qualidade ${ }^{97}$ ou implementam práticas cotidianas no trabalho, marcadas pela forte pressão e ritmo intenso, que conduzem milhares de trabalhadores ao adoecimento. $^{98}$

Os inúmeros programas sociais que giram em torno das "Fundações", entidades criadas para gerir projetos sociais das grandes corporações, representam esta

\footnotetext{
97 Tomamos como base para esta afirmação, além das informações disponibilizadas no Capítulo 2 sobre a comparação entre as relações de trabalho entre bancários e terceirizados, os dados do PROCON, apontando que o volume de reclamações de clientes aumentou. Fonte: Cadastro de reclamações fundamentadas 2013 PROCON - SP Dados, Rankings e Comentários Diretoria de Atendimento e Orientação ao Consumidor Procon SP, março de 2014.

98 No Capítulo 5 será apresentada uma análise sobre os efeitos do processo de trabalho e saúde dos trabalhadores na grande corporação bancária.
} 
necessidade de aplacar o pragmatismo dos operadores do setor e do próprio mercado, quando buscam a todo momento reforçar valores humanos e comunitários.

Um programa social de qualquer tipo mantido pela instituição financeira que analisamos pode a qualquer tempo ser descontinuado, o que inclusive põe sob questão a efemeridade dos tempos dos projetos, válidos para durar, em prazos curtos, aproximadamente um ano, quando nunca é demais dizer, que apesar disso as necessidades das pessoas participantes permanecem.

Este tipo de oscilação no compromisso com a comunidade certamente vem acompanhado da explicação do patrocinador do projeto de que é preciso ganhar autonomia. Observa-se que são raros os casos em que os projetos, mesmo sem o auxílio financeiro, conseguem se manter. De toda a forma, a empresa pode a todo o momento divulgar sua lista, prestando contas de quantas entidades e pessoas ajudou em seu balanço social. Cabe à sociedade questionar de que forma este investimento direto, resultado do processo de mutação dos recursos que foram abatidos no imposto de renda e nas outras formas de obter mais capitalização, ${ }^{99}$ é interessante à própria sociedade. Apesar de instigante, esse assunto não compõe nosso objeto de análise. Apenas nos pareceu adequado e oportuno levantar esta questão, uma vez que as grandes corporações bancárias mantêm um alto nível de exposição pública na sociedade, gozando de alta confiabilidade.

\subsection{A cultura organizacional}

A internacionalização das economias e em especial de grandes empresas fez com que práticas administrativas tivessem padrões semelhantes nos mais diversos lugares. Para atender a estratégia de homogeneizar as experiências de gestão, passou-se a falar em cultura organizacional.

O início dos debates em torno da cultura organizacional ganhou força no Brasil na década de 1990, após influência de autores norte-americanos que na década de 1980 estabeleceram formas de sistematizar as perspectivas de renovação no ambiente administrativo quando as reestruturações produtivas eram intensificadas nas empresas. Trata-se de um campo do conhecimento relacionado à administração, mas como os

\footnotetext{
${ }^{99} \mathrm{O}$ Banco $\Delta$ possui um fundo de investimento que aplica seus recursos em ações de empresas socialmente responsáveis, $50 \%$ da sua taxa de administração é doada para projetos educacionais desenvolvidos por ONGs. Entre 2004 e 2015 foram destinados mais de 27,5 milhões para 157 ONGs. Fonte: site do Banco $\Delta$ acessado em fev.2015.
} 
próprios autores da área reafirmam (FREITAS, 2007; FISCHER; FLEURY; URBAN, 2008), tem por base elementos da sociologia, antropologia e psicologia.

O conceito de cultura organizacional, que serve de referência para nosso entendimento sobre os acontecimentos no interior da grande empresa bancária, admite a noção defendida por Fleury e Fischer (1989, p. 22):

A cultura organizacional é concebida como um conjunto de valores e pressupostos básicos, expresso em elementos simbólicos que, em sua capacidade de ordenar, atribuir significados, construir a identidade organizacional, tanto agem como elemento de comunicação e consenso como ocultam e instrumentalizam as relações de dominação.

A discussão sobre cultura organizacional, do modo que a estamos situando, encontra pontos de contato com as reflexões de Boltanski e Chiapello (2009) acerca do "espírito do capitalismo", sobretudo porque ambas abordagens estão atentas às formas de compreensão da ordenação social, das práticas cotidianas, que se estabelecem com base no plano subjetivo e racional dos indivíduos.

O espírito do capitalismo é o conjunto de crenças associadas à ordem capitalista que contribuem para justificar e sustentar essa ordem, legitimando os modos de ação e as disposições coerentes com ela. Essas justificações sejam elas gerais ou práticas, locais ou globais, expressas em termos de virtude ou em temos de justiça, dão respaldo ao cumprimento de tarefas mais ou menos penosas e, de modo mais geral, à adesão a um estilo de vida, em sentido favorável à ordem capitalista. Nesse caso pode-se falar de ideologia dominante, contanto que se renuncie a ver nela apenas um subterfúgio dos dominadores para garantir o consentimento dos dominados e que se reconheça que a maioria dos participantes no processo, tantos os forte como os fracos, apoia-se nos mesmos esquemas para representar o funcionamento, as vantagens e as servidões da ordem na qual estão mergulhados. (BOLTANSKI; CHIAPELLO, 2009, p. 42)

Assim, complementam os autores:

A persistência do capitalismo, como modo de coordenação dos atos e como mundo vivenciado, não pode ser entendida sem a consideração das ideologias que, justificando-o e conferindo-lhe sentido, contribuem para suscitar a boa vontade daqueles sobre os quais ele repousa, para obter seu engajamento. (BOLTANSKI; CHIAPELLO, 2009, p. 43)

Boltanski e Chiapello (2009) buscam não reduzir a "ideologia dominante" como um sinônimo da não existência da vontade do dominado, à medida que esses também "participam", podendo inclusive assumir para si "vantagens" no funcionamento da ordem. A "boa vontade", o “engajamento", a “adesão" são formas variadas para 
mencionar a postura dos trabalhadores tanto na relação com a sociedade como na relação que estabelecem com as empresas.

Para participar de uma grande corporação é preciso que o empregado esteja em sintonia com os seus valores. Esta posição é repetidamente enfatizada pelos agentes que ditam normas no campo do recrutamento e da carreira através das consultorias de RH e revistas especializadas. As declarações contidas nas publicações institucionais do Banco $\Delta$ não deixam dúvida quanto ao pressuposto de "compartilhar valores e princípios" com os trabalhadores, da mesma forma que fica claro as consequências decorrentes desta máxima que dita como será a própria perspectiva de carreira na instituição, pois como anunciam "é pela aderência ao modelo que as pessoas vão se destacar" (Revista Banco $\triangle 2014)$.

A adesão do indivíduo e dos grupos à cultura da instituição cria condições melhores de produtividade, quando se considera que estes não sobreviveriam à relação estritamente objetivada. Como explica Freitas (2007, p. 50):

A vida organizacional, ainda que fundada em uma lógica e uma racionalidade instrumental, precisa do tempero que a irracionalidade e o simbolismo aportam, pois é ele que gera os envolvimentos, a dedicação, a lealdade e a paixão tão necessários a uma dinâmica organizacional marcada pela competição extremada em um ambiente turbulento.

Alves e Oliveira (2011) situam a importância da cultura organizacional como um mecanismo de controle, pois no modo que os trabalhadores se identificam com os objetivos e valores da organização cria-se uma relativa homogeneização que favorece um ambiente mais coeso.

$\mathrm{O} \operatorname{Banco} \Delta$ mobilizou, ao longo das últimas décadas, um conjunto objetivo de elementos que visaram garantir a produtividade como: programas de resultados/metas; processos de avaliação contínuos e novos dispositivos de controle. Paralelamente, deu ênfase à conduta comportamental de cada indivíduo na instituição.

As diversas formas de propagação de ideias no Bancos interagem com o novo momento tecnológico disponível. Como vimos anteriormente, no Capítulo 3, os veículos de comunicação institucional que promovem a difusão da ideologia empresarial são mais velozes, dinâmicos e até mesmo interativos.

Os conteúdos das mensagens disseminadas nesses veículos, destacadas em função da ideologia empresarial, visam difundir repetidamente as regras que envolvem tanto os procedimentos de trabalho, como as regras sobre a conduta e boa convivência 
na instituição. Mas, vão além, buscando em diversas ocasiões integrar o trabalhador com formas de diálogo humanizadas, alegres, descontraídas e que fogem dos temas relacionados diretamente à sua rotina de trabalho, como a divulgação de campanhas sociais que a própria instituição mantém e outras formas de incentivo à cidadania e solidariedade que vão desde plantar uma árvore, doar roupas para campanha do agasalho até a participação em gincanas internas com premiações e sorteios.

O Banco $\Delta$, na segunda metade dos anos 2000, criou uma diretoria específica para conduzir, em conjunto com uma consultoria internacional de serviços empresariais, a implementação de um amplo programa de gestão de resultados que paralelamente, e não secundariamente, atuasse no sentido de fortalecer a cultura organizacional. $O$ programa atuou em parceria com o RH e envolveu o treinamento de todo o corpo funcional. Nas palavras do executivo responsável do Banco $\Delta$ : “a ideia do programa é fazer com que todos os colaboradores pratiquem o modo de fazer da empresa e com isso alavanquem ainda mais os resultados do banco" (Revista Banco $\Delta$, dez. 2006).

Segundo Donadone (2009), as diversas consultorias nacionais e internacionais que atuam no interior das grandes corporações têm na sua composição antigos gestores egressos das mesmas empresas para as quais passaram a prestar serviço. $\mathrm{O}$ autor reflete sobre como se articula o ideário oriundo das consultorias no bojo das reestruturações produtivas. Os gerentes, ao buscarem o aumento de desempenho econômico de suas unidades, recorrem a uma legitimidade externa que situe as necessidades das mudanças organizacionais.

Também é oportuna a observação de Gaulejac (2007, p. 37) ao afirmar que nas multinacionais o "poder gerencialista" é cristalizado com a colaboração ativa dos gabinetes dos consultores que tentam justificar a "ideologia gerencialista" esforçando-se para lhe dar um ar de cientificidade. Assim, no curso da gestão do processo de trabalho, as atividades humanas são traduzidas em indicadores de desempenho e este desempenho é traduzido em custo benefício.

\subsection{Um amontoado de relativas inovações}

De acordo com Durand (2003, p. 146), “as novas técnicas socioprodutivas pósfordistas modificam mais o discurso sobre o trabalho do que os conteúdos do trabalho".

A construção de uma nova forma de gestão passou pela crítica ao modelo até então predominante no século XX que, considerado ultrapassado, se tornou ineficiente 
no contexto de concorrência exacerbada. A burocratização foi alvo central destas críticas e para ocupar seu lugar ganharam visibilidade premissas relacionadas à descentralização, meritocracia e administração por objetivos.

Segundo Boltanski e Chiapello (2009), os dispositivos propostos na literatura da gestão empresarial, caracterizada pela organização flexível, se constituíram como um amontoado de inovações que se articularam em torno de algumas palavras-chave, destacando-se: empresas enxutas; trabalho em rede; organização por equipes ou projetos; satisfação dos clientes; missão e visão do negócio. Tais elementos reportam-se em menor ou maior grau ao método de produção desenvolvido na empresa japonesa Toyota, portanto denominado toyotismo. ${ }^{100}$

Destacaremos ao longo deste tópico algumas das inovações que mais nos chamaram a atenção nos estudos que realizamos no Banco $\Delta$. Inicialmente, registramos que a gestão do processo de trabalho tem se baseado explicitamente em elementos do toyotismo para gerir seu negócio, se apoiando em algumas de suas diretrizes mais populares como as técnicas denominadas: Kaizen e $5 \mathrm{~S} .{ }^{101}$

O discurso empresarial busca relacionar todas as práticas do passado como inadequadas. Contudo, muito do que já se esperava do trabalhador se reproduz com novas roupagens e mudanças semânticas, que imputam novos patamares de ação no trabalho subordinados às decisões econômicas e políticas dos tempos voláteis em que operam os capitais.

No banco investigado, para atender o apelo à horizontalização ${ }^{102}$ na gestão e consequentemente reduzir símbolos de autoridade, foram observadas desde a primeira metade dos anos 2000 alterações nos usos e costumes dentro do ambiente corporativo. Uma das primeiras iniciativas consta da mudança de nomenclatura que se referia aos trabalhadores. A designação, outrora popularizada pelo termo "empregado" ou "funcionário", caia no desuso na comunicação institucional estabelecida, entrando em seu lugar o termo "colaborador", sendo paulatinamente adotado no linguajar habitual dos trabalhadores a ponto de se tornar predominante entre os recrutadores e consultores

\footnotetext{
${ }^{100} \mathrm{O}$ toyotismo compreende um conjunto de princípios organizacionais, dentre eles destacamos: just-in-time; qualidade total; Kaizen - processo de melhoramento contínuo; equipes autônomas de produção; circulo de controle de qualidade; Kanban; 5S; dentre outros (BOLTANSKI; CHIAPELLO, 2009).

${ }^{101}$ O 5S (cinco sensos) designa cinco condutas que devem permear o ciclo de trabalho, sendo elas: utilização, ordenação, disciplina, padronização e limpeza. Não por acaso, são "fiscalizadas" as diversas áreas no interior da instituição para verificar se tais condutas são cumpridas, que em caso negativo ensejará sua inscrição no sistema de avaliação como uma falha em relação à atitude esperada. De acordo com Durand (2003), ao se referir às metodologias em questão, trata-se de "um verdadeiro adestramento social" que ajusta o comportamento dos empregados.

${ }^{102}$ Horizontalização tem sido um conceito amplamente empregado quando se fala nos métodos de gestão toyotistas ou flexíveis, porém, conforme a abordagem ou autor pode significar redução de níveis hierárquicos, formas de aproximar trabalhadores e gestores no ambiente de trabalho ou ainda pode ser um modo de se referir às subcontratações e ou terceirizações.
} 
do mercado de trabalho. A declaração do jovem entrevistado ajuda ilustrar esta adaptação "linguística":

No começo, na época que eu entrei no banco, eu era bem novo, mas eu percebia que eles não chamavam Gerente, era Gestor. Essa pequena diferença eles passavam como se fosse uma super diferença. Você não é funcionário, você é colaborador. (Operador de Teleatendimento, 24 anos, 03 anos de banco)

A mudança de nomenclatura dos cargos neste cenário representa o esforço de criar uma novidade inexistente. O exemplo da troca da denominação "chefe" por "supervisor" ou "coordenador" não subtraiu o papel controlador que estes níveis da escala hierárquica possuem, como é o caso de ter poder suficiente para imputar penalizações por falta de comportamento adequado aplicando advertências, “suspensões” ou até a própria demissão.

$\mathrm{Na}$ tentativa de diluir o peso da hierarquia e promover uma maior integração entre os grupos ou equipes, a nova disposição física nos ambientes de trabalho desconsiderou posições de destaque antes garantidas aos superiores hierárquicos no Banco $\Delta$.

Essas medidas em nossa análise buscaram afirmar subliminarmente que existe simetria entre os participantes homologada pelo interesse comum de cumprir as metas estabelecidas. A ideia de que "todos estão no mesmo time" ganha sentido na medida em que as formas básicas de controle já são feitas com predominância pelos dispositivos eletrônicos já mencionados, restando ao gestor ter ingerência quando algo escapa, quando algum empregado deixou de se submeter ao regramento e à disciplina prevista. Portanto, em tese, todos estão unidos e querem os mesmos objetivos, favorecendo assim a produtividade operacional.

A autoridade, antes exclusividade dos superiores hierárquicos, é descolada da antiga figura hostil e ameaçadora calcada na figura do chefe ou do gerente. Torna-se relativamente mais abstrata. Ela passa a repousar no próprio programa de resultados/metas que a instituição estabelece. Sob seu cumprimento, ou não, são aplicadas todas as formas de controle e cobrança, premiações e punições, recebidas tanto em nome de um grupo, como em nome de um indivíduo.

Outros símbolos que demarcavam as hierarquias no banco pesquisado, como os crachás de identificação dos trabalhadores, também foram alvo de mudanças que visaram igualar os participantes no ambiente de trabalho. Antes, as diferenças de cor dos crachás correspondiam ao status dos cargos ocupados, divididos em três categorias - ouro, prata e bronze. Ressaltamos que o grupo de trabalhadores terceirizados que 
atuavam dentro da estrutura física do banco também possuíam crachás diferenciados e após estas mudanças apenas os cordões que seguraram os crachás visaram sutilmente demarcar a diferença, pois são confeccionados com o nome da empresa terceirizada.

Mello e Silva (2004) enfatiza que o novo modelo de organização do trabalho trouxe inovações quanto à relação possível entre os quadros gerenciais e demais trabalhadores no ambiente das empresas, tornando o envolvimento algo mais próspero à produtividade e afastando elementos como a forte hierarquia que antes, no regime fordista, ajudava a construir a identidade coletiva da força de trabalho que agora disputa entre si a melhor classificação, como times internos em um campeonato.

Jinkings (2006, p. 194), ao retratar as novas práticas gerenciais no setor bancário afirmou:

A disciplina e o controle do trabalho ficam obscurecidos por meio destas políticas de gestão, chamadas de "participativas", que se apresentam como instrumentos de democratização dos ambientes laborais. De fato, as novas práticas gerenciais buscam construir uma aparente identidade de interesses entre capital e trabalho e perseguem a adesão absoluta do trabalhador às estratégias mercadológicas das empresas. O discurso patronal, cotidianamente difundido nos órgãos de comunicação interna das empresas ou nos programas de treinamento, ressalta os desafios da concorrência e chama a colaboração e a mobilização de seus assalariados em face dos projetos empresariais.

Para nós faz sentido a análise dos autores acima citados. Este esforço de aproximação, esta busca pela "aparente identidade", está no cotidiano dos locais que pesquisamos e contribui para o distanciamento de uma perspectiva de identidade dos trabalhadores dada pela classe social e econômica em que se encontram.

Entre as medidas que visavam reduzir a formalidade e hierarquização, citamos ainda a alteração na forma de se reportar ao principal executivo do Banco $\Delta$. $\mathrm{O}$ modo historicamente instituído de demonstrar respeito, predominante por décadas, usado por força do hábito e não por regra escrita, era verbalizado pelo uso do prefixo "doutor" antes de incluir o nome do presidente ou de outro diretor da instituição. Em 2008, o próprio presidente da organização, orientado pela nova doutrina interna de gestão denominada "Cultura de Performance", reproduziu em e-mail corporativo uma mensagem na qual esclarece suas razões para abolir a deferência em questão. Em seus argumento deixou claro que visava um "ambiente de trabalho mais aberto, dinâmico e menos hierárquico", que facilitaria a trajetória de crescimento por meio de fortes resultados (Revista Banco 4 , mai. 2008). 
Somam-se a estas iniciativas outras pequenas mudanças que foram implementadas ao longo dos anos 2000 no $\operatorname{Banco} \Delta$, como destacaremos a seguir: a) determinados gestores, como são os gerentes de áreas, deixaram de ter secretárias; b) elevadores destinados a uso exclusivo de pessoas com maior nível hierárquico foram abolidos; c) salas suntuosas se tornaram mais rarefeitas; d) redução dos três níveis de segmentação de restaurantes existentes para dois níveis, um para diretoria e outro para os demais gestores e trabalhadores; e) redução do número de vagas de estacionamento exclusivo para gestores, abrindo espaço para pessoas com deficiência.

Vejamos a seguir, ainda com o objetivo de resgatar e analisar o discurso corporativo sobre as novas formas de gestão, a declaração do diretor da área de Recursos Humanos do Banco $\Delta$ :

A Cultura de Performance veio para reforçar que o perfil do executivo mudou. Sai de cena o estilo autoritário, acostumado a dar a palavra final e entra a figura do executivo da era do conhecimento, na qual as relações corporativas passam a exigir maior participação, envolvimento e comunicação aberta. (Diretor de Recursos Humanos, Revista Banco4, dez. 2006)

O chefe com viés de atuação autoritário e repressivo, neste novo modelo de gestão, cai em desuso passando a predominar o papel de "líder". Trata-se, de acordo com os cânones divulgados, de um gerenciador de responsabilidades, talentos, esforços individuais e coletivos e acima de tudo um motivador que sabe ouvir, compartilhar e comunicar as políticas da empresa (Revista Banco 4, várias edições, 2008 - 2009).

Contudo, é oportuno mencionar, em que pese o papel do chefe ter ganhado novos contornos, a postura autoritária do gestor ainda emerge. Em situações nas quais o modelo de horizontalização e toda a panaceia envolvida não conseguem no plano da realidade contornar situações, cada vez mais comuns, em que a existência de um quadro enxuto de trabalhadores e as exigências de produtividade em tempos mais curtos pressionam todos envolvidos, os gestores se tornam protagonistas de práticas despóticas, hoje nomeadas de assédio moral.

Como retratado por Boltanski e Chiapello (2009), a noção de gerenciamento participativo que foi desenvolvida na nova administração flexível é parte desses conjuntos de iniciativas descritas que visam demarcar diferenças com relação aos "antigos" métodos tayloristas-fordistas. Contudo,

o "caráter ideológico" da nova forma de gestão pode ser uma ilusão, um embuste, que reúne ao mesmo tempo o desejo de mudança, ou projetos, que contrastam com os fatos, a realidade do dia a dia. Assim, muitas das "promessas" da nova gestão 
empresarial se concretizam apenas marginalmente no funcionamento das empresas. (BOLTANSKI; CHIAPELLO, 2009, p. 88)

Lahera-Sánchez (2005), ao analisar a implantação de novas culturas organizativas empresariais, também chama a atenção para as propostas "supostamente rupturistas" quando contrastadas com as tradições tayloristas. O autor destacou que a aposta na gestão participativa visou centralmente aperfeiçoar os processos de produção expropriando os conhecimentos dos trabalhadores.

Outros autores (RODRIGUES, 1990; MELLO E SILVA, 2004; JINKINGS, 2006) em estudos que perpassaram por setores econômicos distintos corroboram com Lahera-Sánchez e também analisam que o "convite" à participação dos trabalhadores visou incorporar o saber prático contido no fazer cotidiano do trabalho. De modo geral, a participação é vista como algo positivo aos empregadores, mas algo limitado para os empregados.

Os trabalhadores do $\operatorname{Banco} \Delta$, entrevistados por nós, apontaram que a participação se tornou uma obrigação. O tipo de participação proporcionado pelas reuniões do Comitê Kaizen faz a empresa se apropriar das capacidades e saberes dos indivíduos dentro da organização, pois são eles que conhecem o processo de trabalho a fundo, por operar no dia a dia com aquilo que não é domínio absoluto do dono do negócio, nem mesmo dos gerentes ou superiores hierárquicos, sobretudo em um contexto de mudanças constantes e velozes no próprio produto ou serviço que se submete à efemeridade e competitividade do mercado.

Outra situação que evoca a participação dos trabalhadores é a pesquisa de "clima interno" realizada habitualmente uma vez ao ano no Banco $\Delta$. A abordagem visa captar a opinião dos trabalhadores de todas as áreas do banco quanto ao ambiente de trabalho, à relação com os superiores hierárquicos, à imagem da empresa, dentre outros aspectos. A participação na pesquisa é anunciada como livre, entretanto há pressão direta dos gestores para que haja engajamento. Nos canais eletrônicos, banners chamativos lembram, a todo o momento, os trabalhadores sobre a importância de sua participação.

As possíveis críticas à instituição ou aos seus representantes diretos, os gestores, é sufocada em geral pelo medo à represália. A pesquisa de clima institucional no Banco $\Delta$ é coordenada por uma consultoria externa. O anonimato é divulgado como um pilar estruturante da pesquisa que pretende "ouvir as pessoas", entretanto para o trabalhador acessar a pesquisa é obrigado a incluir seu CPF - Cadastro Pessoa Física e 
preencher o formulário de seu próprio computador que possui identificação numérica IP. ${ }^{103}$ Mas, se não bastassem estas questões, o trabalhador sabe que a avaliação, se ruim, pode fazer seu gestor lhe identificar e possivelmente o comprometer, pois como em qualquer grupo, invariavelmente se cristalizam preferências pessoais que aproximam ou rivalizam a relação entre o trabalhador e os superiores hierárquicos.

O depoimento do entrevistado aponta para os conflitos que emergem quando uma posição crítica é colocada em evidência:

Lá no banco tem a pesquisa de área, de clima organizacional. Existem pessoas que são selecionadas para responder e eu fui uma delas. Tudo devia ser sigiloso, mas o que frustra é que não fica sob sigilo... Eu tive acesso a um superintendente que me disse que o meu gestor iria me destruir porque falei as coisas que achava na avaliação de clima. (Bancário, Analista Júnior, 29 anos, 04 de banco)

O direito de se manifestar dentro dos muros corporativos também é observado criticamente por Alcadipani (Revista Você S.A., fev. 2015), que contesta a manifestação livre dos subordinados com relação aos seus chefes ou às decisões de negócios. No ambiente corporativo, são raras as possibilidades de ser autêntico com relação às críticas, que são invariavelmente mal recebidas. O mesmo autor ainda analisa que:

Há uma regra subentendida de falar apenas o "empresarialmente correto", ou seja, o que a empresa quer ouvir. As vozes contrárias rapidamente são estigmatizadas e caladas. O que deve imperar é um consenso mudo e asséptico, favorável a quem manda. As opiniões contrárias somente podem existir no comentário do cafezinho ou na "radio peão". (ALCADIPANI, Revista Você S.A., fev. 2015, p. 82)

A instituição em foco nesta análise emprega diversos modos para envolver os empregados abrindo canais de participação. Nas reuniões, "Portas Abertas", que acontecem pelo menos uma vez ao ano com os trabalhadores e os principais líderes das áreas - Gerentes, Superintendentes e até Diretores - é possível, a princípio, perguntar e dizer o que se quiser. Existem ainda vários espaços para opinar, sugerir e comentar, seja de forma presencial ou remota. Podem ser "cafés da manhã" ou "enquetes eletrônicas". Sobre essas formas de participação relatam os trabalhadores que dificilmente alguém se posiciona com uma crítica, ainda que leve, contra a conduta do gestor ou a organização e seu conjunto de normas.

No Banco $\Delta$ outro elemento a ser ponderado nesta construção ideológica de aparentes liberdades e simetrias percebidas por nós se estabelece na política de

\footnotetext{
${ }^{103}$ O IP, Internet Protocol, é um número que identifica o computador que pode estar conectado à rede interna ou externa.
} 
ampliação do espaço de influência da instituição sobre os trabalhadores quando paralelamente há o esvaziamento do papel atribuído habitualmente ao sindicato da categoria profissional.

Em meados da década de 2000 o Banco $\Delta$ criou um novo canal para realizar o atendimento da área de RH: uma central de atendimento telefônico exclusiva para atender os funcionários. A experiência, pioneira no setor bancário, visou centralizar todas as informações sobre a vida dos trabalhadores na empresa e esclarecer dúvidas sobre os direitos trabalhistas gerais e aqueles negociados especificamente com o sindicato da categoria profissional.

Esclarecer dúvidas sobre os mais diversos direitos trabalhistas foi e ainda é uma das funções atribuídas ao sindicato dos bancários que, por meio dos seus representantes, percorre os locais de trabalho levando informações e estabelecendo a partir daí uma rede de contatos que são a base para a política sindical. Saber quais as garantias e estabilidades são válidas; qual a regra e o valor de um auxílio creche; quando e quanto vem de aumento salarial, apenas para citar alguns exemplos, fazem parte da rotina que situa o dirigente sindical, como um fiscalizador e promotor dos direitos dos bancários. A introdução do novo canal de informações acima mencionado contribuiu para diminuir a importância do papel sindical nesse quesito.

Em 2007, não por acaso, outro canal de participação foi criado para atender os trabalhadores no $\operatorname{Banco} \Delta$. Funcionando como uma espécie de "ouvidoria interna", foi dedicado entre outras possibilidades para tratar de problemas de relacionamento dentro do ambiente de trabalho. De acordo com o discurso gerencial, o canal tem o objetivo de receber denúncias, críticas, sugestões e agir sobre elas imparcialmente, mantendo a confidencialidade e apurando os fatos para melhorar o ambiente de trabalho a partir das dificuldades colocadas pelos empregados. ${ }^{104}$

Nesse canal, os trabalhadores podem fazer denúncias sobre arbitrariedades cometidas pelo superior hierárquico, entretanto, segundo apuramos, prevalece mais uma vez o medo de sofrer represálias. À medida que a verificação sobre o caso avança, coloca-se o risco de a confidencialidade ser violada.

O sindicato dos trabalhadores mantém posição crítica sobre o uso desse canal argumentando que ele serve para expor a própria vítima à demissão, ${ }^{105}$ pois a assimetria dos cargos dentro da instituição deixa espaço para que haja represália ao subordinado

\footnotetext{
${ }^{104}$ Dados disponibilizados pela instituição afirmam que no ano de 2014 ocorreram 1.378 manifestações. Revista Bancod, mar. 2015.

${ }^{105}$ Folha Bancária, fev. 2015.
} 
que denuncia, ainda que em hipótese alguma isso seja admitido publicamente como possível pela instituição.

As ações de combate ao despotismo no local de trabalho sempre conferiram um importante papel político às instituições sindicais bancárias (BLASS, 1992). Considerando a disseminação dos programas de resultados/metas criados pelas organizações financeiras, multiplicaram-se casos em que os trabalhadores denunciavam os gestores por humilhações públicas, xingamentos, isolamento e outras formas que trouxessem algum tipo de sofrimento contínuo em decorrência do não cumprimento de metas de trabalho. ${ }^{106}$ Do ponto de vista da ação sindical, o combate a tais práticas contaram, ao longo das últimas décadas, com denúncias dos gestores e dos bancos envolvidos em materiais sindicais, tentativas de negociar o caso em que se solicitava mudança de postura ou realocação do denunciado, dentre outras medidas que visavam atingir as causas do problema, como a falta de funcionários no local de trabalho sobrecarregando os trabalhadores e gerando um clima interno de extrema pressão. ${ }^{107}$

Em nossa análise, o canal criado pela instituição visou esvaziar parte da função sindical. A denúncia quando recebida pelo $B a n c o \Delta$ é tratada como algo individualizado ao passo que o sindicato busca tratar casos aparentemente isolados com uma abordagem coletiva, pois tem o entendimento de que é o processo de trabalho tal qual está estruturado que favorece a exploração e o aparecimento de abusos sobre os bancários.

Em 2011, devido à relevância que o tema suscitou, o sindicato de representação da categoria assinou um "acordo" com o Banco $\Delta$ sobre o tratamento das denúncias recebidas a título de assédio moral ou de conflitos no ambiente de trabalho. ${ }^{108}$ Apesar de não por fim à "ouvidoria interna", o novo "acordo" possibilitava que houvesse mais uma opção para receber denúncias, permitindo ao sindicato o controle estatístico e o monitoramento sobre os casos, ou seja, nas questões mais problemáticas e reincidentes.

A busca de meios pelos administradores para "institucionalizar o conflito" não são iniciativas novas no mundo do trabalho. Como analisou Rodrigues (1990), o reconhecimento das comissões de fábrica, ao mesmo tempo em que significou uma conquista dos trabalhadores, foi uma forma da administração fabril assimilar o conflito e institucionalizar as demandas que causavam atrito entre as partes, o que levou a conter os movimentos com forte conotação espontânea. O caso, apesar de situado no setor

\footnotetext{
${ }^{106}$ Folha Bancária (várias edições) e jornais sindicais específicos para o Banco $\Delta$.

${ }^{107}$ Folha Bancária (várias edições) e jornais sindicais específicos para o Banco $\Delta$.

${ }^{108}$ Trata-se do "Protocolo para prevenção de conflitos no ambiente de trabalho".
} 
industrial, nos ajuda a refletir sobre o "acordo" que envolve o setor bancário quanto ao tratamento do tema do despotismo nos locais de trabalho.

Não é nosso propósito fazer uma avaliação profunda dos significados do "acordo" que envolve o tema do assédio moral no banco analisado, mas consideramos relevante destacá-lo por estar inserido em uma relação que envolve participação dos trabalhadores, bancos e sindicato em um tema que ganhou amplo destaque nos últimos anos no setor. Se por um lado o "acordo" abriu mais um espaço para os trabalhadores se pronunciarem e para que os sindicatos tenham maior controle sobre os desdobramentos das denúncias, por outro os bancos limitam a disputa política da atuação sindical, antes mais espontânea e sem "protocolos" a seguir, sendo que cada denúncia segue uma burocracia específica de apuração dos fatos e só se transformará em ato de protesto caso não haja um encaminhamento considerado adequado pelo sindicato.

\subsection{O papel do RH e da cultura organizacional}

A relevância que o fator subjetivo ganhou no processo produtivo nas últimas décadas reforçou o papel das áreas de Recursos Humanos e consequentemente o desenvolvimento da cultura organizacional.

Autores como Fischer (2002) e Freitas (2007) analisaram como as áreas de Recursos Humanos, preocupadas em aprimorar os processos produtivos, passaram a dar ênfase na atuação sobre o comportamento das pessoas, diretamente influenciando a adaptabilidade e flexibilidade dos funcionários ao novo cenário econômico, sobretudo em países desenvolvidos nos anos 1970 e 1980.

Nesse contexto, a comunicação com os empregados ganhou importância e o RH se tornou fundamental para a difusão da cultura organizacional. Os administradores, admitindo o peso da subjetividade nesses ambientes, buscaram envolvimento das pessoas e o fizeram não sem levar em consideração o binômio assistência-submissão, como teremos a oportunidade de tratar mais adiante neste texto.

Entretanto, como as mudanças são contínuas e aceleradas, Freitas (2007) aponta que nas últimas décadas a área de RH, considerada a "guardiã" da cultura empresarial, perdeu parte de sua capacidade política. Muitos processos de reengenharia foram implementados sem que ela fosse consultada, com decisões pautadas em planilhas de custos, cabendo-lhe apenas administrar os momentos mais difíceis, como eram as ocasiões das demissões. Segundo a autora, o esvaziamento da área de RH ocorreu 
também por forte influencia das novas tecnologias e das novas formas de estabelecer procedimentos e controles internos.

Este diagnóstico apresentado pela autora é também por nós percebido quando observamos os acontecimentos no Banco $\Delta$. Acrescentamos apenas que não se pode menosprezar o papel do departamento de comunicação e marketing, pois por meio dele se estruturou o discurso institucional que dá base e fundamenta a cultura corporativa.

No Banco $\Delta$ a área de Recursos Humanos passou por processo de ampla descentralização. A partir da segunda metade da década de 1990, o papel antes atribuído à área, dado o grande volume de informações e atribuições que envolviam todas as demais áreas da organização, perdeu relevância paralelamente à ampliação dos usos tecnológicos. Os softwares de gerenciamento de recursos humanos conectaram as empresas com os empregados, disponibilizando por meio da rede interna um conjunto de informações e serviços que antes eram realizados manualmente, e, inclusive, pessoalmente.

As atribuições de Recursos Humanos vinculadas às obrigações legais e cálculos que permeiam diversos itens da vida laboral dos empregados foram automatizadas ou terceirizadas. As funções relativas ao recrutamento, admissão e desligamento passaram a ser decisões descentralizadas em cada área onde a demanda se originava.

Por meio do sistema de informações, denominado Portal RH, planejado especificamente para operar as demandas de RH, os trabalhadores podem ser atendidos. O mecanismo possui um sistema de rotas que conduzem a um leque variado de temas, representando mais de 150 autosserviços, ${ }^{109}$ como:

a) folha de pagamento - demonstrativos de pagamento mês a mês, espelho de ponto, horas extras, solicitação de férias, agendamento, exames periódicos, solicitação de auxílios e licenças previstas em lei e na CCT;

b) carreira - inscrição em vagas internas e acompanhamento de requisitos para ascensão;

c) currículo profissional - sistema de informações completas sobre o perfil profissional do trabalhador. Os gestores podem inclusive saber se o funcionário é sócio ou não do sindicato;

d) sistema de gestão de performance - avaliações de performance, planejamento de atividades, indicadores de metas a cumprir e já cumpridas;

\footnotetext{
${ }^{109}$ De acordo com a Revista Banco 4, mar. 2015.
} 
e) treinamento - inscrições para cursos disponíveis on-line (e-learning) e presenciais, verificação de elegibilidade, solicitação de certificados;

f) qualidade de vida - eventos e campanhas relativas à qualidade de vida;

g) política organizacional - divulgação de materiais que dissipam a cultura organizacional, Código de Ética, normas, delegação de alçada, pesquisa de clima interno.

A busca de uma nova identidade para a área de RH tem perpassado pelas frequentes trocas de nomenclatura, que variaram entre "Gestão e Desenvolvimento", “Gestão de Pessoas", “Gente e Cultura”, dentre outras no Banco $\Delta$.

O modelo de RH, ou "gestão de pessoas", está diretamente associado ao modelo de gestão do capital. Fischer (2002) destaca o caso do RH de um grande banco brasileiro que, no início da década de 1990, incorporou em suas mensagens a seguinte declaração: "É nossa diretriz estratégica atender de forma equilibrada aos interesses de clientes, acionistas e funcionários”. A diretriz, já aparecia plenamente articulada com a nova fase econômica predominante na cena mundial do qual o capitalismo financeirizado é sua melhor expressão. A figura do acionista no cenário brasileiro passa a ganhar destaque e automaticamente é introduzida no discurso empresarial, pois afinal este passa a ser o seu fiel depositário do salário pago aos trabalhadores.

A área de gestão de pessoas atua coerentemente com a nova lógica administrativa que consequentemente se pauta por uma nova ordem econômica. De acordo com Freitas (2007, p. 52):

Todas essas modificações foram sustentadas por novas mensagens e valores, nos quais a noção de tempo claramente se alterou para o curto prazo, as margens de lucro foram redefinidas e o retorno sobre o investimento foi acelerado.

Nestas circunstâncias, é relevante considerar a intencionalidade de moldar padrões de comportamento que sejam adequados ao nível de competitividade e pressão colocados nacional e internacionalmente.

A ação comportamental vem sendo orientada desde os anos 2000 no Banco $\Delta$ por aquilo que os trabalhadores denominam "Decálogo". Em 10 itens foram reunidas as principais diretrizes da cultura organizacional que os trabalhadores devem seguir. Abaixo, reproduzimos cada uma delas com o significado atribuído pela própria instituição. 


\section{1) Atitude de dono}

$\checkmark$ Tem orgulho de pertencer à instituição e pensa nela em primeiro lugar.

$\checkmark \quad$ Luta pelas boas causas e mobiliza-se a qualquer instante para fazer o que é esperado de quem é dono do negócio.

$\checkmark$ Cuida das grandes iniciativas e dos detalhes com a mesma dedicação.

\section{2) Foco no cliente}

$\checkmark$ Sabe perceber as questões sob a perspectiva do cliente e tem como principal objetivo a sua satisfação. Acima de tudo, tem consciência de que servir o cliente é a razão de ser da instituição.

\section{3) Foco na performance}

$\checkmark \quad$ Gosta de receber e propor metas ambiciosas, perseguindo-as com obstinação.

$\checkmark \quad$ Vai além do esperado, com contribuições que fazem a diferença para a organização no curto e longo prazo.

$\checkmark$ Não perde jamais de vista o uso eficiente dos recursos da organização.

\section{4) Integridade}

$\checkmark$ Faz o que é certo, mesmo que não seja o mais fácil, rejeitando resultados obtidos a qualquer custo.

$\checkmark$ Assume a responsabilidade por seus atos, não oculta erros nem omite informações.

$\checkmark$ É ético, responsável, compromissado e zela pelos maiores ativos da instituição: sua imagem e reputação.

\section{5) Agilidade}

$\checkmark$ Prioriza o que é importante, não complica as coisas e vai direto ao ponto, combatendo a burocracia e agilizando processos.

$\checkmark$ Toma a iniciativa de desenvolver soluções simples, sem abrir mão da qualidade.

\section{6) Indignação construtiva}

$\checkmark \quad$ Indigna-se com o que pode prejudicar o negócio, posiciona-se claramente nas discussões e contribui positivamente na tomada de decisão.

$\checkmark$ Sabe olhar para os lados e vai além das fronteiras de sua área de atuação. Não promove nem sanciona a defesa de territórios.

\section{7) Lidar com pressão}

$\checkmark$ Mantém o equilíbrio emocional em situações de pressão e administra os problemas com lucidez, cuidando sempre do clima da área e da consistência das entregas.

\section{8) Parceria}

$\checkmark$ Constrói parcerias e sabe trabalhar em equipe.

$\checkmark$ É acessível, conquista apoio e confiança por saber gerar soluções em conjunto dentro e fora da estrutura à qual se encontra vinculado.

\section{9) Visão de risco}

$\checkmark$ Compreende que o risco é inerente à atividade de uma instituição financeira e que lidar com ele não é atribuição exclusiva de uma área central, mas de todos os colaboradores.

$\checkmark$ Responsabiliza-se por avaliar cuidadosamente a equação de risco e retorno em suas atividades, ajudando a disseminar essa postura na organização.

\section{0) Liderança}

$\checkmark$ É um líder inspirador, movido pelo desafio de melhorar continuamente a instituição, é referência da cultura corporativa do banco e sabe incorporar as pessoas no processo de ação, utiliza a meritocracia para formar equipes de alta performance, atraindo os melhores talentos, preparando sucessores de alto nível e desenvolvendo permanentemente as equipes. 
Este compêndio da cultura corporativa aplicada ao comportamento reúne todas as condições e qualidades almejadas para que em termos finais e "idealizados" consigase atingir os objetivos esperados pelos acionistas.

O "decálogo" circunscreve os limites da socialização corporativa. Pode ser traduzido como um conjunto de orientações que estruturam o pensamento da gestão administrativa que por sua vez dá suporte à gestão financeira, ou seja, cria um ambiente adequado à proliferação do lucro. Nesse propósito são reforçados aspectos subjetivos que envolvem o modo de se inserir e realizar o processo de trabalho em um esquema que ultrapassa a objetividade no trabalho, o controle direto exercido pela hierarquia ou a divisão de tarefas.

A existência de um elaborado arsenal de comunicação direta e interativa mediado pelas inovações tecnológicas possibilita a transmissão das "doutrinas administrativas" com maior agilidade e intensidade. A exemplo do que avaliou López Ruiz (2004), em seu estudo que abrangeu as grandes corporações, tais doutrinas influenciam o repertório de como as pessoas pensam, como pensam o mundo em que vivem e como ordenam suas relações.

O treinamento no interior do Bancos é determinante para propiciar o engajamento subjetivo dos trabalhadores, pois por meio dele a ordem arbitrada pela instituição é justificada e legitimada. Podemos dizer que este é o momento, por excelência, onde a produção simbólica assume uma função política direcionada a um sentido prático.

As formas de treinamento passaram a fazer parte daquilo que se convencionou chamar "educação corporativa". Essa nova nomenclatura ganhou força nos bancos brasileiros a partir da década de $2000 .^{110}$

A “educação corporativa" pode ser analisada sobre ângulos diferentes. Um calcado no interesse e necessidade da própria empresa, outro no interesse e vantagem para o próprio trabalhador. De acordo com Fischer, Dutra e Amorim (2009, p. 172) de um lado "as empresas lutam para minimizar a obsolescência do conhecimento e para alinhar o processo de aprendizagem à estratégia organizacional e, de outro, o trabalhador luta para se adaptar ao novo perfil, reaprender continuamente e manter sua empregabilidade".

\footnotetext{
${ }^{110}$ Segundo levantamento feito pela autora nos sites institucionais dos maiores bancos brasileiros, públicos e privados, em abril de 2015 para esta pesquisa.
} 
Mello e Silva (2004) também destacou o fato de a formação ser vista pelas empresas multinacionais como um ativo para o próprio trabalhador, pois lhe confere maior empregabilidade em ambientes competitivos, sendo ainda, considerada uma forma de remuneração indireta.

Eboli (2008) defende que a "educação corporativa" deveria, a princípio, superar os ensinamentos da racionalidade técnica e proporcionar uma ação mais reflexiva, com vistas a ter um trabalhador mais integrado e propositivo no ambiente de trabalho. Colado a este propósito idealizado que a autora traz a tona, emerge a noção de "desenvolvimento de pessoas", a qual se baseia essencialmente em desenvolver nas pessoas características como autonomia, iniciativa e dinamismo.

No bojo destas possibilidades formativas, a cultura organizacional se firma disseminando o sentido das condutas pessoais dentro e fora dos ambientes profissionais, ou seja, os conteúdos comportamentais ganharam espaço e importância maior. A massificação dos cursos e treinamentos à distância (e-learning) foi determinante para a profusão destes conteúdos que não exigem em geral aulas presenciais.

O treinamento comportamental é anterior aos anos 2000, como nos informa a pesquisa de Grün (1985 p. 125), que analisou este aspecto na década de 1970 no setor bancário. Buscava-se à época a modernização técnicas de chefia visando substituir o estilo autoritário por métodos de "manipulação doce" com a interiorização de valores. Como o autor ressalta, era emblemática, do ponto de vista dos modelos de gestão, a polarização entre democracia e autoritarismo. Não porque fosse algo que possuísse em si um sentido transcendente, mas apenas porque possibilitava melhores resultados.

A relevância dada à "educação corporativa" no Banco $\Delta$ se demonstra pela obrigatoriedade de cumprir horas de treinamento. Os trabalhadores são controlados pelo próprio Portal de RH, que avisa sobre a disponibilidade de cursos e o acesso aos conteúdos, possibilitando que o certificado seja emitido após aplicação da prova final, muitas vezes um teste de múltipla escolha.

Sob pena de serem punidos no processo de avaliação individual, caso não realizem toda a programação formativa, pode-se perceber o quanto a prática foi incorporada à rotina da organização. Os cursos podem ser acessados de casa, sendo que, ao entrar com a senha para acessar os conteúdos, logo surge uma mensagem que avisa que tal atividade não será contabilizada como hora extra.

A realização de cursos e treinamentos fora da jornada contratada pelos empregadores do sistema bancário é contestada pelo sindicato de representação da 
categoria profissional, pois ambos são a princípio uma exigência do empregador e atenderão às necessidades de melhoria no processo produtivo.

A inscrição para realização de alguns cursos específicos no centro de formação do banco estudado é condicionada à aprovação do superior hierárquico, excluindo os cursos considerados elegíveis e obrigatórios, portanto, acessíveis a qualquer momento, no formato on-line. Em média um funcionário pode ter 15 experiências formativas obrigatórias ao ano. Esses cursos são parte das metas individuais dos trabalhadores.

O Banco $\Delta$ investiu R $\$ 109$ milhões em treinamento dos trabalhadores apenas no ano de 2014. Os que são presenciais atingiram 96.882 de participações, sendo que o mesmo trabalhador pode ter realizado vários cursos. Os treinamentos a distância atingiram 1,54 milhões de acessos, segundo declarou a instituição. ${ }^{111}$ Há uma cartela bem variada de cursos e treinamentos que abrangem tanto os conteúdos técnicos, voltados para o negócio bancário e suporte administrativo, como os comportamentais.

\subsection{Direitos, benefícios e socialização corporativa}

A produção de determinado consenso entre trabalhadores e o Banco $\Delta$ encontra maior eficácia quando articula dimensões subjetivas às políticas ativas de RH, que se consolidam no acesso a direitos e benefícios, ou seja, em condições objetivamente dadas conforme analisaremos a seguir.

Como estamos demonstrando, parte das estratégias de RH visa capturar mais do que o tempo de trabalho do indivíduo pode render objetivamente. A unidade de horas trabalhadas no mesmo ambiente possibilita a influência direta na conduta do indivíduo, estabelecendo como ele deve trabalhar e pensar sobre o seu trabalho, mas além dessa situação propriamente dita, existem outras zonas de influência, outros campos por onde se estabelecem vivências comunitárias externas ao ambiente de trabalho em si.

Nesse sentido, procuraremos demonstrar neste tópico como se articulam outras políticas de RH focando nos direitos trabalhistas e nos benefícios associados às formas de integração sociocultural situadas tanto localmente, restrita à própria empresa, como também observando ações mais abrangentes, externas à empresa.

As políticas voltadas a incentivar a sociabilidade dos trabalhadores se mesclam ao conjunto de direitos e à política de benefícios ofertados pelo Banco $\Delta$. Tais medidas favorecem a adesão à cultura corporativa ao mesmo tempo que acabam por perfilar o

\footnotetext{
${ }^{111}$ Fonte: Relatório Gerencial Bancos 2014; Guia Melhores Empresas para se Trabalhar, 2014.
} 
compromisso do indivíduo no trabalho quando este se depara com as "vantagens" que a grande empresa lhe proporciona.

Aquilo que incorporamos neste texto a título de "benefícios" se diferencia dos direitos assegurados aos trabalhadores por força do que prevê a legislação trabalhista brasileira, a Convenção Coletiva de Trabalho ou o Acordo celebrado pelo banco.

A Convenção Coletiva de Trabalho é fruto de um processo de negociação anual entre representantes dos bancos e da categoria profissional bancária no Brasil. Os direitos contidos nesse instrumento jurídico devem ser cumpridos em todos os bancos e em nível nacional. Existem atualmente 67 cláusulas que tratam de diversos temas, garantindo avanços com relação ao que já é previsto na CLT e na legislação trabalhista em vigor no país (ver Figura 7).

O acordo celebrado por empresa no setor bancário tem menos força e abrangência que a CCT. Trata-se de processo que também negociado com o sindicato de representação e a depender do arranjo político construído será ou não estendido para todo o país. Sua existência não elimina a responsabilidade do banco no cumprimento dos direitos já previstos na CCT. Firmado bilateralmente em função da capacidade de pressão e das condições específicas de cada banco, é na prática um modo de tratar de aspectos não contidos na CCT e que podem ainda ser melhorados. $\mathrm{O}$ acordo específico assinado com o Banco $\Delta$ é bem mais limitado em variedade de temas, contudo, não é pouco relevante, pois toca em dois aspectos valorizados pelos trabalhadores bancários:

a) participação complementar de resultados (remuneração variável) - trata-se de valores adicionais ao pagamento de PLR, distribuídos de forma universal no interior da corporação. Em 2014 representou a quantia de R $2.080,00 .^{112}$

b) auxílio educação - 5.760 bolsas de estudos disponibilizadas por ano pela instituição. Consiste no Subsídio de 70\% do valor da mensalidade, limitado a R\$ 320,00 mensais para graduação ou pós-graduação, condicionado à necessidade de o candidato estar de acordo com as regras mínimas estabelecidas.

Apresentamos no esquema gráfico a seguir os conteúdos desses dois instrumentos jurídicos que consolidam os direitos negociados coletivamente e que estão em vigor no Banco $\Delta$ :

\footnotetext{
${ }^{112}$ As formas de remuneração variável serão tratadas no próximo capítulo por estarem associadas diretamente ao modelo de gestão por resultados.
} 


\section{Convenção Coletiva de Trabalho e Acordo celebrado por Banco}

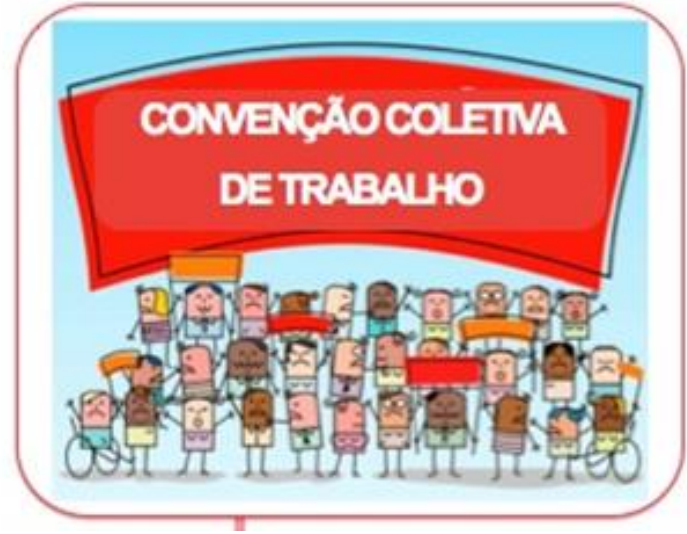

Cláusulas Econômicas

- Reajuste salarial

- Salário de ingresso

- Salário após 90 dias da admissão

- Adiantamento de $13^{\circ}$ salário

- Salário do substituto

- Adicional por Tempo de Serviço (ATS)

- Opção por indenização ATS

- Adicional de horas extras

- Adicional noturno

- Insalubridade / periculosidade

- Gratificação de função

- Gratificação de caixa

- Gratificação de compensador de cheques

- Auxílio refeição

- Auxílio cesta alimentação

- Décima terceira cesta alimentação

- Auxílio creche / auxílio babá

- Auxílio filhos excepcionais ou deficientes físicos

- Auxílio funeral

- Ajuda para deslocamento noturno

- Vale-transporte

- Custeio certificação profissional - CPA 10

- Vale Cultura

- PLR

\section{Cláusulas Sociai}

- Abono de falta do estudante

- Ausências legais

- Folga assiduidade

- Ampliação da licença-maternidade

- Estabilidades provisórias de emprego

- Opção pelo FGTS, com efeito retroativo

- Complementação de auxílio-doença previdenciário e auxílio-doença acidentário

- $\quad$ Seguro de vida em grupo

- Assistência médica e hospitalar - empregado despedido

- Igualdade de oportunidades

- Extensão de direitos na relação homoafetiva

\section{Cláusulas sobre Condições no Trabalho}

- Indenização por morte ou incapacidade decorrente de assalto

- Transporte de numerário

- Segurança bancária - procedimentos especiais

- Multa por irregularidade na compensação

- Uniforme

- Digitadores - intervalo para descanso

- Monitoramento de resultados (via exposição de rankings ou cobranças realizadas por meio de mensagens ou via celular)

- Protocolo para prevenção de conflitos no ambiente de trabalho (adesão voluntária)

\section{Cláusulas sobre Saúde e Trabalho}

- CIPA - Comissão Interna de Prevenção de Acidentes

- Exames médicos específicos

- Política sobre AIDS

- Programa de reabilitação profissional

- Acidentes de trabalho

- Dos afastamentos por doença superiores a 15 dias

- Declaração do último dia trabalhado (DUT)
Cláusulas Sindicais

- Frequência livre do dirigente sindical

- Quadro de avisos

- Sindicalização

Cláusulas abrangendo outras proteções e normas sobre o Contrato Coletivo e processos negociais

- Aviso prévio proporcional

- Prazo para homologação de rescisão contratual

- Férias proporcionais

- Carta de dispensa

- Multa por descumprimento da convenção coletiva

- Condições específicas - convenções aditivas

- Dias não trabalhados (greve)

- Complementação de pagamento pós-fechamento CCT

- Requalificação profissional

- Adiantamento emergencial de salário nos períodos transitórios especiais de afastamento por doença

- Grupo de trabalho bipartite - análise dos afastamentos no trabalho

- Comissão bipartite de segurança bancária

- Comissões paritárias

- Comissões temáticas

- Abrangência territorial

- Vigência

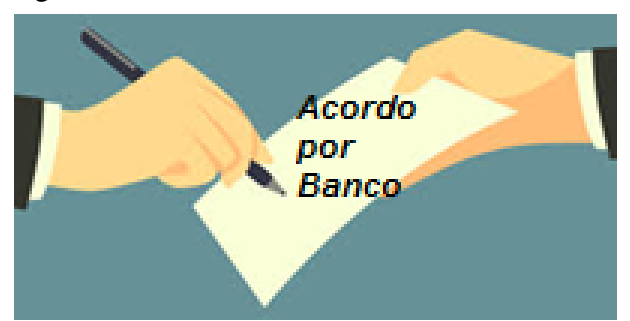

- Participação Complementar de Resultados (complementar a PLR/CCT)

- $\quad$ Auxílio Educação

Nota: A classificação das cláusulas da CCT em subgrupos foram atribuídas pela própria autora no sentido de reunir os principais aspectos do documento analisado Fonte: Convenção Coletiva de Trabalho, 2014 e Acordo sobre Participação nos Resultados e Auxílio Educação - Banco $\Delta, 2013$. 
Como se pode verificar, a abrangência de temas contidos na CCT nos dá conta de informar quão abrangente é o processo de negociação sobre as relações de trabalho no setor financeiro. As cláusulas econômicas são aquelas que possuem maior peso por determinarem as formas diretas e indiretas de remuneração, tratando-se de itens que chamam muita atenção dos trabalhadores pela questão central da autossustentação.

Para dimensionarmos o peso da remuneração fixa direta e indireta na vida de um trabalhador da base da pirâmide de cargos e salários, destacamos o exemplo de um dos cargos com maior presença nos bancos, o Caixa. ${ }^{113}$ A simulação, a seguir, considera apenas os direitos mais básicos que um bancário pode receber, ao mês, sendo que há uma variação de acordo com o perfil. Se, por exemplo, forem somados valores a título de auxílio creche ou auxílio educação, a participação da "remuneração fixa indireta" seria ainda mais relevante.

Tabela 3

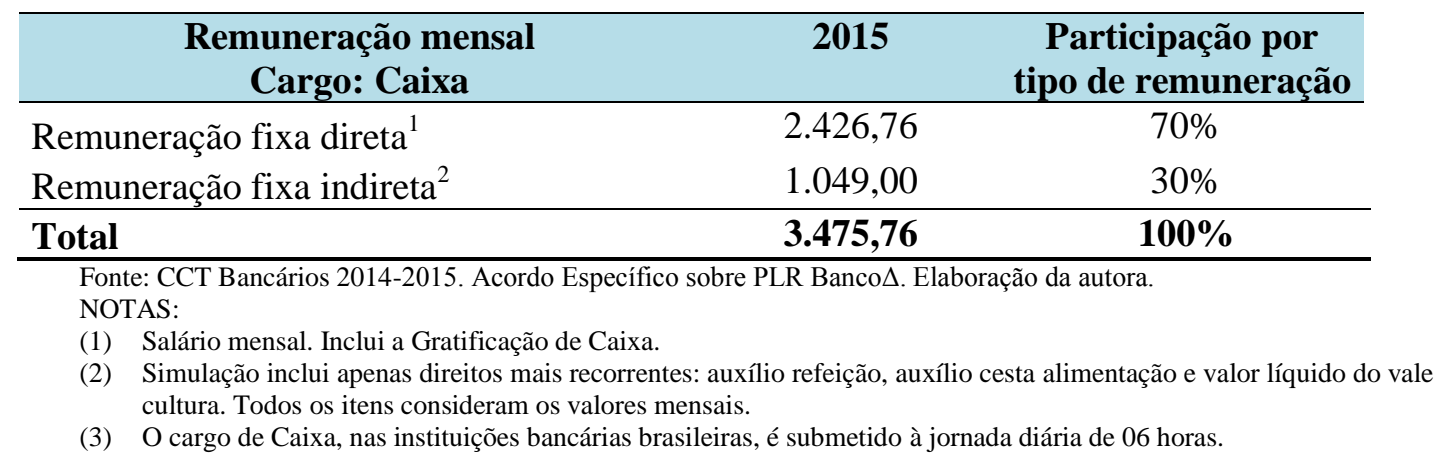

A remuneração total do trabalhador bancário, percebida ao longo de um ano, considera ainda a remuneração variável, PLR, que por força de lei apenas pode ser paga semestralmente. A seguir, destacamos as participações por tipo de remuneração, considerando o mesmo cargo citado na Tabela 3, o Caixa:

\footnotetext{
${ }^{113}$ Devido às reestruturações pelas quais as instituições têm passado, a nomenclatura pode variar significativamente. O cargo Caixa pode ser reconhecido por outras nomenclaturas que podem variar de acordo com a escolha da instituição financeira. No Banco $\Delta$ desde 2013 tem sido chamado por "Assistente de Negócios", o que indica a priori as mudanças sobre o seu papel na agência bancária. Contudo, para efeito de comunicação, neste texto escolhemos manter o nome do cargo pela forma em que é mais conhecida.
} 
Tabela 4

\begin{tabular}{|c|c|c|}
\hline $\begin{array}{l}\text { Remuneração anual } \\
\text { Cargo: Caixa }\end{array}$ & 2015 & $\begin{array}{c}\text { Participação por tipo } \\
\text { de remuneração }\end{array}$ \\
\hline Remuneração fixa direta $^{1}$ & $32.356,80$ & $57 \%$ \\
\hline Remuneração fixa indireta ${ }^{2}$ & $13.019,00$ & $23 \%$ \\
\hline Remuneração variável $^{3}$ & $11.093,18$ & $20 \%$ \\
\hline Total & $56.468,98$ & $100 \%$ \\
\hline \multicolumn{3}{|c|}{$\begin{array}{l}\text { Fonte: CCT Bancários 2014-2015 e Acordo Específico sobre PLR Banco } \Delta \text {. Elaboração da autora. } \\
\text { NOTAS: } \\
\text { (1) Salário anualizado, considerando } 13^{\circ} \text { salário + abono de férias. } \\
\text { (2) Simulação inclui apenas direitos mais recorrentes: valores anualizados do auxílio refeição, auxílio cesta } \\
\text { alimentação e valor líquido do vale cultura. O valor do auxílio cesta alimentação considerou ainda a décima } \\
\text { terceira cesta alimentação prevista na CCT. } \\
\text { (3) O valor considera a regra básica majorada e o teto da parcela adicional da PLR prevista na CCT. Inclui ainda } \\
\text { valores referentes ao acordo específico de remuneração variável, negociado com o Banco } \Delta \text { para o ano } 2014 \text {. }\end{array}$} \\
\hline
\end{tabular}

Nosso objetivo, nessa ocasião, não será de aprofundar uma análise sobre os direitos dos bancários, mas de deixá-los em evidência para dimensionar o estado da arte das relações do trabalho. A seguir, observaremos com mais detalhes o conjunto dos "benefícios" que particularizam a relação estabelecida no Banco $\Delta$. Mas antes, faz-se necessário frisar que é comum os representantes das instituições financeiras denominarem direitos estabelecidos nas negociações sindicais como "benefícios". Os trabalhadores reproduzem amplamente esta visão como foi possível verificar ao longo das entrevistas realizadas pela autora.

Cabe ressaltar que a classificação elaborada para essa reflexão escolheu propositalmente separar "direitos" e "benefícios". Os "direitos" são aqueles previstos em leis de abrangência nacional, CCT e Acordos por Banco, ou seja, aquilo que a instituição deve repassar aos trabalhadores e, portanto, dentro dessa lógica não são tratados por nós nesta análise como "benefícios". No caso particular da categoria bancária, há, como vimos, um conjunto de direitos individuais e coletivos estabelecidos por processo negocial que se tornam obrigações a serem cumpridas.

Conforme explica Nogueira (2015), em seu estudo sobre o setor bancário, o reconhecimento de políticas específicas de $\mathrm{RH}$ de cada instituição só pode ser identificado a partir das diferenças praticadas com relação àquilo que foi acordado em processo de negociação coletiva que tem em si caráter de cumprimento obrigatório:

As negociações coletivas são realizadas nacionalmente desde 1992 e produzem as Convenções Coletivas Nacionais, alinhando as condições dos bancários em termos de salários e condições de trabalho para todo o território nacional. As diferenças entre os bancos ficam definidas por meio de suas políticas de recursos humanos que devem considerar e cumprir em primeiro lugar a 
convenção nacional de toda a categoria. (NOGUEIRA, 2015, p. 162 , grifo nosso)

A reflexão do autor coloca no centro do debate as visões que os próprios trabalhadores mantêm sobre os seus direitos, ou seja, para esses suas condições de trabalho são resultados de uma "dádiva da política de recursos humanos dos bancos" e não "resultados de uma disputa entre capital e trabalho" (NOGUEIRA, 2015, p. 140). Isso significa dizer que está posta uma disputa de abordagens entre aquilo que se defende por parte dos sindicatos, como direitos coletivos resultantes das relações de trabalho estabelecidas entre os agentes e a abordagem patronal orientada pela noção de benefício que visa atender os indivíduos participantes da instituição.

O empregador pode conceder benefícios como uma forma de "liberalidade", pois não são itens obrigatórios na relação de trabalho regulada-formalizada; no entanto, vale frisar que por isso mesmo podem a qualquer tempo ser subtraídos, diferenciando-se neste aspecto fundamental daquilo que é garantido pela CLT, CCT ou Acordo Específico firmado com a entidade de representação sindical da categoria profissional em tela.

Ao adotar uma ampla política de benefícios, a empresa busca agregar vantagens ao contrato de trabalho delimitado, a princípio, pelas questões centrais que norteiam a cabeça de um indivíduo que aceita vender sua força de trabalho: Quanto será a remuneração? Quantas horas trabalharei? Quantos dias da semana? Os chamados benefícios, ainda que muitos deles se confundam com direitos, são muitas vezes o diferencial para reconhecer que determinada função ocupada em uma empresa seja mais ou menos atraente.

Certamente que a difusão de uma política abrangente de direitos e de uma política de benefícios, deliberados pelos administradores das corporações, não é uma ação altruísta. Primeiro porque os resultados dessa política retornam para a própria instituição em forma de melhor produtividade, considerando que os trabalhadores se sentem satisfeitos em ter acesso a esse diferencial. Como foi possível verificar nas entrevistas, a amplitude da abrangência do pacote de direitos e benefícios influencia a distinção positiva por parte dos trabalhadores em relação à empresa, dado que ambos assumem um peso significativo para si e suas famílias. Segundo porque o repasse de vários auxílios ${ }^{114}$ é feito mediante a possibilidade de dedução legal do custeio no

${ }^{114}$ Gastos com auxílio refeição e alimentação; auxílio creche e educação, extensão da licença maternidade até os seis meses, convênio médico e vale cultura são exemplos nesse sentido. 
Imposto de Renda da empresa. Para se ter uma noção, de acordo com os dados do relatório gerencial do Banco $\Delta$ em 2013, os incentivos fiscais apenas com gastos em alimentação perfizeram o montante de 5,5 milhões de reais ao ano.

Vejamos no infográfico a seguir como se estruturam os "direitos" e "benefícios" que estão contidos no arcabouço das relações do trabalho que permeiam a corporação bancária que serve de base para este estudo.

Figura 8

\section{DIREITOS}
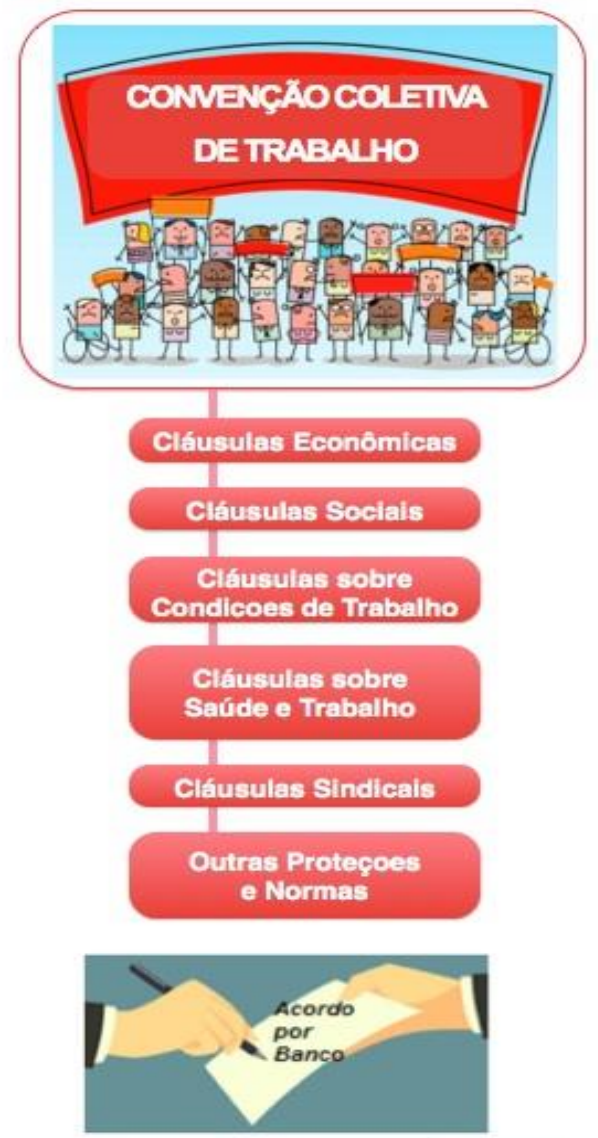

Auxilio Educação

\section{BENEFICIOS}

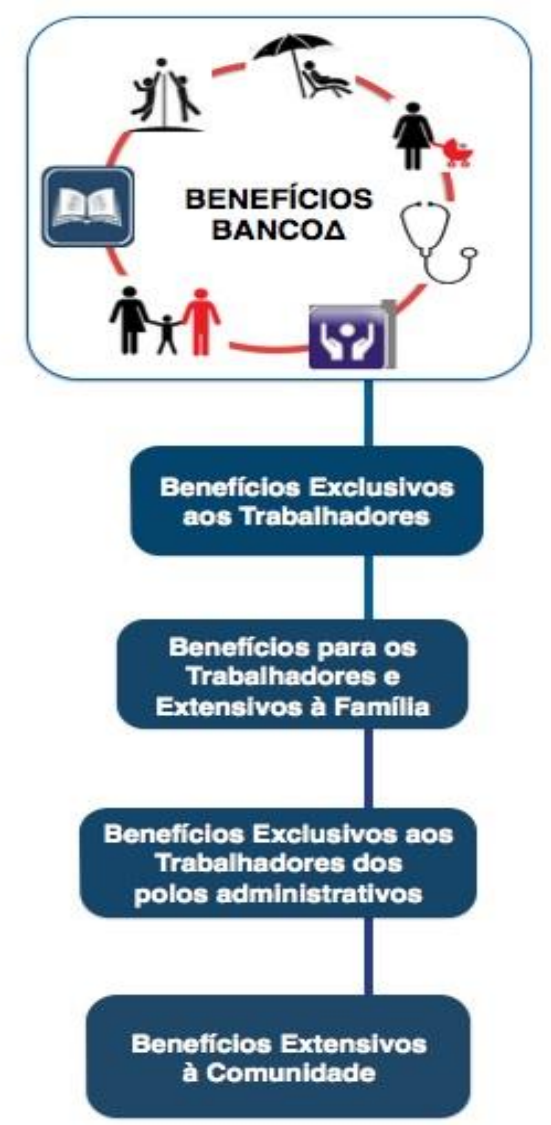

Fonte: Convenção Coletiva de Trabalho - 2014; Acordo sobre Participação nos Resultados e Auxílio Educação do Banco $\Delta$ - 2013; Revista Banco $\triangle$ (diversas edições). 
Os quadros que serão expostos a seguir foram classificados pela autora a partir de características que permitiram agrupar interesses dos diversos públicos abrangidos pela política de benefícios do Banco $\Delta$. Os trabalhadores terceirizados, ainda que atuem no mesmo espaço físico, não podem acessar nenhuma das possibilidades listadas em nenhum dos quadros subsequentes.

O Quadro 3 condensa os benefícios válidos para todas as unidades de trabalho agências e polos administrativos -, sendo exclusivos aos trabalhadores contratados diretamente pela instituição.

Quadro 3. Benefícios Exclusivos aos Trabalhadores

\begin{tabular}{|c|c|}
\hline Programa & Descrição \\
\hline \multicolumn{2}{|r|}{ Educação } \\
\hline Educação corporativa & $\begin{array}{l}\text { Cursos de qualificação e treinamento, técnico e comportamental; participação } \\
\text { em congressos e eventos temáticos de acordo com elegibilidade e aprovação } \\
\text { do gestor. Ao ano, } 18 \text { trabalhadores são escolhidos para participar de } \\
\text { programas de } M B A \text { e mestrado em universidades sediadas no exterior, como } \\
\text { Harvard, Stanford, Columbia, Duke ou Berkeley nos Estados Unidos. Outros } \\
17 \text { participaram do Summer Job, programa de atuação profissional em } \\
\text { unidades no exterior com duração de três meses a um ano. }\end{array}$ \\
\hline \multicolumn{2}{|r|}{ Saúde } \\
\hline $\begin{array}{l}\text { Programa Saúde da } \\
\text { Mulher }\end{array}$ & $\begin{array}{l}\text {-Ações de saúde preventiva, comportamental e reprodutiva da mulher por } \\
\text { meio de palestras presenciais, informativos, orientações eletrônicas e intranet } \\
\text { corporativa. • Bebê a Bordo: programa focado nas orientações fundamentais e } \\
\text { necessárias a serem adotadas durante os primeiros meses de gestação, como } \\
\text { nutrição da gestante, primeiros cuidados, questões psicológicas etc. Bebê em } \\
\text { Casa: visita de enfermeira especializada na primeira semana pós-parto na } \\
\text { residência para orientar sobre o aleitamento materno e primeiros cuidados com } \\
\text { o bebê • Vacinação HPV (Human Papiloma_Virus). }\end{array}$ \\
\hline Vacina da gripe & Oferta de vacinação gratuita para todos trabalhadores. \\
\hline Check-up & $\begin{array}{l}\text { Avaliação física completa ofertada para gerentes de alto nível hierárquico e } \\
\text { demais cargos acima. }\end{array}$ \\
\hline \multicolumn{2}{|r|}{ Outras proteções / vantagens } \\
\hline $\begin{array}{l}\text { Seguro de vida em } \\
\text { grupo }\end{array}$ & Inclusão de todos trabalhadores na apólice de seguro de vida em grupo. \\
\hline $\begin{array}{l}\text { Planos de previdência } \\
\text { complementar }\end{array}$ & $\begin{array}{l}\text { Acessos diferenciados a planos de previdência fechados e abertos, de acordo } \\
\text { com o banco de origem dos trabalhadores (considerando as várias fusões); } \\
\text { alterações no plano de benefícios específico; tempo e faixa salarial de cada } \\
\text { um. }\end{array}$ \\
\hline $\begin{array}{l}\text { Produtos e serviços } \\
\text { financeiros }\end{array}$ & $\begin{array}{l}\text { Descontos em créditos, consórcios, seguros; gratuidade em tarifas bancárias e } \\
\text { anuidade do cartão de crédito. }\end{array}$ \\
\hline \multicolumn{2}{|r|}{ Lazer / Integração } \\
\hline Eventos esportivos & 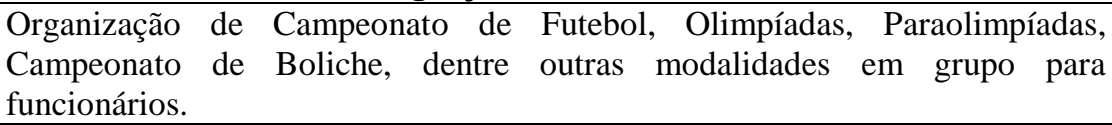 \\
\hline Corridas e maratonas & $\begin{array}{l}50 \% \text { de subsídio do valor da inscrição em maratona promovida por entidade } \\
\text { parceira. }\end{array}$ \\
\hline
\end{tabular}




\begin{tabular}{|l|l|}
\hline Coral & $\begin{array}{l}\text { Aberto a participação de qualquer interessado (o coral faz apresentações } \\
\text { internas e nos projetos sociais do banco). }\end{array}$ \\
\hline Concurso de fotografia & Organiza e premia concurso de fotografia. \\
\hline $\begin{array}{l}\text { Banco de Talentos } \\
\text { FEBRABAN }\end{array}$ & $\begin{array}{l}\text { Incentiva a participação em concursos e mostras artísticas promovidas pela } \\
\text { FEBRABAN. }\end{array}$ \\
\hline Biblioteca & $\begin{array}{l}\text { Empréstimos on-line entregues via malote interno de: literatura para adultos, } \\
\text { jovens e crianças; livros em formatos acessíveis como os audiolivros; DVDs - } \\
\text { filmes ou documentários. }\end{array}$ \\
\hline
\end{tabular}

Destacamos que alguns dos "benefícios" são direcionados para públicos específicos, como é o caso do "Programa Saúde da Mulher", do "Check-up", que atende apenas funções mais elevadas na hierarquia, e dos "Planos de Previdência", com abrangências bem diferenciadas baseadas no regimento particular de cada grupo, seja ele fechado ou aberto.

Esses programas descritos no Quadro 3 são parte de um conjunto mais amplo da política global de benefícios, como veremos adiante. Eles representam condições mais vantajosas aos trabalhadores, ainda que itens como "educação corporativa", "vacinação da gripe" e "check-up" estejam estreitamente ligados aos próprios interesses da gestão da força de trabalho. Bem treinados e preparados, os trabalhadores podem atingir melhores resultados, assim como estar bem de saúde e não se ausentar do trabalho torna-se uma garantia da manutenção do fluxo de trabalho.

A "educação corporativa" é central para a socialização dos trabalhadores. Como vimos, em tópico anterior neste texto, além de possibilitar o treinamento funcional, destinado a melhorar a execução do trabalho em si, tem papel essencial de difusão das normas e regras de convivência permitidas no interior da organização, dito de outro modo, reforça de forma planejada e sistemática como deve ser a ação comportamental do indivíduo.

No tocante à intermediação das práticas esportivas, de lazer e de integração descritas no Quadro 3, percebe-se que a instituição passa a ser a organizadora e a promotora de outros espaços de socialibilidade que se viabilizam em decorrência da relação de emprego que cada indivíduo mantém. Assim, reforçar os laços sociais e afetivos entre os trabalhadores em atividades que extrapolem o ambiente físico onde o trabalho se realiza é uma forma de reforçar a cooperação, a tolerância e trazer bem-estar que favorecerá mais uma vez a própria produtividade dentro da corporação.

No Quadro 4 veremos a extensão da política de benefícios derivados da relação de emprego do trabalhador à sua família. A estratégia, não menos relevante, consegue estabelecer formas discretas de cumplicidade entre os familiares e a corporação. Ao 
permitir o acesso a benefícios tangíveis e intangíveis, como são aqueles direcionados a melhorar a qualidade de vida na esfera privada, envolvendo outras pessoas do círculo de convivência do trabalhador, a instituição amplia sua zona de poder e influência.

Os cuidados com a saúde do trabalhador e seus familiares - cônjuge e filhos são subsidiados pela instituição, sendo esta uma das mais expressivas vantagens citadas quando o indivíduo analisa sua relação com a empresa. Também são oferecidos programas específicos para quem precisa cuidar de alguma doença ou vício em especial, como é o caso do alcoolismo. Há campanhas direcionadas exclusivamente à saúde dos bebês e campanhas de vacinação de HPV para as bancárias e suas dependentes a preço mais acessível em relação ao valor praticado pelo mercado.

As políticas de RH visam integrar os trabalhadores e suas famílias, o que torna a grande corporação responsável pela estruturação de um modo de vida que se aproxima nesse sentido do modelo fordista.

A família é envolvida em um propósito que vai além das meras concessões feitas em forma de vantagens, pois a corporação busca uma forma de compensar a necessidade de dedicação e lealdade do trabalhador, que muitas vezes se ausenta da própria vivencia em família em função do trabalho, ou ainda que não tenha dedicação extra, acaba por chegar em sua residência esgotado fisica e mentalmente, deteriorando laços de convívio e afetividade no interior da família.

A análise de Friedmann (1972, p. 139) nos ajuda a pensar esta situação colocada. Para o autor "são importantes as relações do trabalhador com a empresa para atenuar os efeitos nocivos exercidos sobre ele". Sua argumentação enfatiza que se trata de uma relação ambivalente. Se, por um lado, há a percepção de que por meio do trabalho o indivíduo tem uma ativa inserção familiar podendo constituir uma "espécie de indispensável cimento" que integra grupo e indivíduo conferindo certo equilíbrio social, por outro, paralelamente estão colocadas condições que deterioram a saúde física e mental dos próprios trabalhadores. Para o autor a coação institucional convive com certo engajamento que amiúde pode representar um fator de equilíbrio e de desenvolvimento para o indivíduo, assegurando inserção social. 
Quadro 4. Benefícios para os trabalhadores e extensivos à família

\begin{tabular}{|c|c|}
\hline Programa & Descrição \\
\hline \multicolumn{2}{|r|}{ Saúde } \\
\hline $\begin{array}{l}\text { Convênio Médico e } \\
\text { Odontológico }\end{array}$ & $\begin{array}{l}\text { Subsídio no pagamento dos valores que dão acesso à assistência média e } \\
\text { odontológica em todo o território nacional. }\end{array}$ \\
\hline Convênio Farmácia & Desconto em rede de farmácia credenciada. \\
\hline Vacinação HPV & Desconto no valor da vacina para trabalhadoras e suas filhas. \\
\hline Assistente Social & Acesso à consulta com assistente social via presencial ou telefone. \\
\hline \multicolumn{2}{|r|}{ Lazer / Integração } \\
\hline Colônia de Férias & $\begin{array}{l}\text { Em qualquer período do ano, hospedagem com desconto. Amigos também } \\
\text { podem participar, mas estão sujeitos a pagamentos mais elevados. }\end{array}$ \\
\hline $\begin{array}{l}\text { Acampamento para } \\
\text { crianças }\end{array}$ & $\begin{array}{l}\text { No período das férias escolares, mediante pagamento subsidiado, há } \\
\text { disponibilidade de inscrever filhos em semana de acampamento. }\end{array}$ \\
\hline $\begin{array}{l}\text { Concurso de desenho } \\
\text { infantil }\end{array}$ & $\begin{array}{l}\text { Desenvolvido para receber inscrições em nível nacional dos filhos de todos } \\
\text { trabalhadores que se interessarem. }\end{array}$ \\
\hline Festas temáticas & $\begin{array}{l}\text { Há desconto ou patrocínio para comemorar dias das mães, dos pais, das } \\
\text { crianças, festas juninas, natal, entre outros, com os familiares nos espaços de } \\
\text { lazer do banco. }\end{array}$ \\
\hline Excursões & $\begin{array}{l}\text { Banco por meio da Fundação promove excursões com a família (Holambra, } \\
\text { Paraty, cidades históricas etc.) }\end{array}$ \\
\hline Dia da Família & $\begin{array}{l}\text { Filho visita local de trabalho do pai/mãe, passa o dia inteiro e ganha um brinde } \\
\text { com a marca do banco. }\end{array}$ \\
\hline Convênios & $\begin{array}{l}\text { Os convênios possibilitam que na compra de um produto ou serviço o } \\
\text { trabalhador do banco possa obter desconto. }\end{array}$ \\
\hline
\end{tabular}

Elaboração da Autora. Fonte: Revista Banco4 (várias edições) e Relatórios Gerenciais (vários anos).

No Banco $\Delta$ existem 70 polos administrativos. Os dez maiores estão concentrados em São Paulo, cidade sede da instituição. Nesses locais, em concentrações que reúnem de 500 a mais de 8 mil bancários apenas em um único endereço, os trabalhadores tem acesso a outros benefícios que não são extensivos por completo àqueles que atuam nas agências bancárias como é descrito no Quadro 5 a seguir:

Quadro 5-Benefícios exclusivos aos trabalhadores dos polos administrativos

\begin{tabular}{|c|c|}
\hline Programa & Descrição \\
\hline $\begin{array}{l}\text { Programa Saúde da } \\
\text { Mulher }\end{array}$ & $\begin{array}{l}\text { Canto da Mamãe: espaço para retirada e armazenamento do leite materno } \\
\text { durante o expediente. }\end{array}$ \\
\hline Ambulatório & $\begin{array}{l}\text { Realiza atendimentos médicos de emergência e consultas. (Exames: } \\
\text { admissional e demissional podem ser acessados também pelos trabalhadores } \\
\text { de agências). }\end{array}$ \\
\hline $\begin{array}{l}\text { Restaurante } \\
\text { Lanchonete }\end{array}$ & $\begin{array}{l}\text { Ambos localizados dentro dos polos. O restaurante contém oferta de refeições } \\
\text { com valores mais acessíveis que o mercado. }\end{array}$ \\
\hline Academias & $\begin{array}{l}\text { Localizadas dentro dos polos administrativos do banco com pagamentos } \\
\text { subsidiados em } 30 \% \text {, limitado a } \mathrm{R} \$ 60,00 \text { mensais (valores válidos em } 2014 \text { ). }\end{array}$ \\
\hline $\begin{array}{lrl}\text { Acesso facilitado a } \\
\text { serviços }\end{array}$ & $\begin{array}{l}\text { Manicure, espaço para massagem, sapataria, lavanderia, revistaria (não há } \\
\text { subsídios para estes serviços). }\end{array}$ \\
\hline Transporte & $\begin{array}{l}\text { Translado gratuito de micro-ônibus saindo de estações do metrô próximas aos } \\
\text { polos administrativos mais distantes. }\end{array}$ \\
\hline
\end{tabular}


Os serviços de atendimento à saúde e a academia dialogam com as necessidades de atenuar ou compensar as consequências da vida estressante que permeia a atividade corporativa. Os demais espaços de sociabilidade, como se observou em nossa pesquisa de campo, são bem decorados e conferem um clima mais descontraído no ambiente, contudo, em boa medida, os decks, ${ }^{115}$ cafés e restaurantes são espaços que funcionam como extensão do trabalho, ainda que não construídos, explicitamente, para esta função.

Ao instalar no ambiente corporativo o serviço de manicure, o Banco $\Delta$ demonstra que busca visivelmente atender as mulheres, grupo que se tornou maioria dentro da instituição. Certamente, uma facilidade para elas que, uma vez somadas todas as suas possíveis atribuições, têm maior dificuldade de reservar tempo privado para cuidar do visual, aspecto que também não é declarado formalmente como uma exigência profissional, mas que faz parte do alinhamento com a "etiqueta" corporativa que inclui ainda orientações sobre vestimenta e vocabulário. ${ }^{116}$

Em alguns polos administrativos, como aqueles que possuem maior circulação de diretores e superintendentes, em que pese não haver uma determinação sobre o uso de uniforme para os trabalhadores, percebe-se um código de vestimenta razoavelmente padronizado, onde predominam: homens com camisa, terno e gravata; mulheres com calças e camisas sociais, ambos com o uso recorrente de tons escuros, considerados mais sóbrios. De acordo com nossa pesquisa nos materiais institucionais, foram registradas diversas palestras com uma estilista brasileira renomada a fim de orientar o uso de roupas que sejam adequadas à atuação em uma grande corporação.

A possibilidade de ter acesso aos benefícios descritos nos Quadros 3, 4 e 5 é algo que contribui para que haja maior disposição ou dedicação do trabalhador à instituição. Tais políticas internas, isoladas, não são determinantes, devem ser vistas levando ainda em consideração demais aspectos contidos na cultura organizacional que reforçam a vontade de "pertencer" a uma instituição que aparece na cena social, difundindo valores solidários de abrangência universal.

\footnotetext{
${ }^{115}$ Estruturas destacadas na arquitetônica dos polos administrativos, confeccionadas com chão de madeira, paisagismo próprio, mesas, cadeiras, sombreiros ao ar livre.

${ }^{116} \mathrm{O}$ Banco $\Delta$ disponibiliza na grade de cursos à distância um tutorial sobre vestimenta no trabalho.
} 


\subsubsection{Outras políticas de integração social}

Mencionamos no tópico anterior que a cultura organizacional do $\operatorname{Banco} \Delta$ se assenta em um discurso universal que visa atingir tanto os trabalhadores que atuam para si como toda a sociedade. Grandes linhas de marketing se estruturam no sentido de dar visibilidade às políticas de responsabilidade social ou sustentabilidade das grandes corporações. A seguir destacaremos partes destas políticas que buscam envolver diretamente os trabalhadores, como é o caso do tema diversidade e do voluntariado. Na sequencia listamos outros programas que reforçam a capacidade de promoção de integração social do $\operatorname{Banco} \Delta$.

- Diversidade

As políticas de diversidade se estruturam com base no recrutamento de pessoas com deficiência física, auditiva, visual e intelectual. Também se somam a essas pessoas os jovens de 14 a 24 anos originários da escola pública, vindos por meio de programas governamentais. Ainda que o banco divulgue a preocupação com a diversidade como um aspecto relevante da sua cultura corporativa, sabe-se que as empresas que mantêm número superior a 2 mil funcionários precisam manter, por força de lei, 5\% da reserva do número de trabalhadores para cada programa - pessoas com deficiência e jovens vindos de escola pública. ${ }^{117}$

- Voluntariado

Os programas de incentivo ao voluntariado são realizados em parceria com os programas sociais já desenvolvidos pela Fundação Social do qual o banco é mantenedor. Os trabalhadores participantes são constantemente destacados nos canais de comunicação interna como exemplos positivos dentro da organização, por sua dedicação, desprendimento e altruísmo.

$\mathrm{O} \operatorname{Banco} \Delta$, ao extrapolar as paredes de seus escritórios com projetos que se tornam benefícios para toda comunidade (ver Quadro 6), alia intensas ações de marketing visando atingir trabalhadores e clientes, mas não apenas esses, pois busca a aprovação de toda a sociedade para consequentemente atingir o objetivo de valorizar sua marca ao manter uma boa imagem.

\footnotetext{
${ }^{117}$ O programa social governamental, nomeado de "Jovem Aprendiz", permite que a remuneração do trabalho seja menor que o salário mínimo nacional.
} 
Quadro 6 - Benefícios extensivos à comunidade

\begin{tabular}{|l|l|}
\hline \multicolumn{1}{|c|}{ Programa } & \multicolumn{1}{c|}{ Descrição } \\
\hline \multicolumn{2}{|c|}{ Saúde / Educação / Lazer } \\
\hline $\begin{array}{l}\text { Programação Terceira } \\
\text { Idade }\end{array}$ & $\begin{array}{l}\text { Atividades de ginástica e lazer para idosos, realizadas em parcerias com } \\
\text { entidades e shoppings. }\end{array}$ \\
\hline Ações Culturais & $\begin{array}{l}\text { Patrocínio e parcerias com: cinemas, teatros, museus, concertos de música } \\
\text { clássica. }\end{array}$ \\
\hline Ações Universitárias & Patrocínio de auditórios universitários e demais parcerias. \\
\hline $\begin{array}{l}\text { Ações pela Mobilidade } \\
\text { Urbana }\end{array}$ & $\begin{array}{l}\text { Parcerias com as prefeituras de várias cidades para manter estações de } \\
\text { bicicletas compartilhadas. }\end{array}$ \\
\hline Projetos Sociais & $\begin{array}{l}\text { Projetos sociais com ênfase na educação são apoiados via Fundação Social em } \\
\text { várias cidades }\end{array}$ \\
\hline
\end{tabular}

A grande corporação bancária ao se inserir em outros locais da vida comunitária assume o papel de mediadora em projetos de cunho sociocultural, que extrapolam a atividade circunscrita em função de sua razão econômica, qual seja, em atuar como operadora do sistema financeiro.

No discurso institucional do Banco $\Delta$, em seu site é declarada sua intenção de assumir um compromisso com a sociedade que não seja marcado apenas pelo resultado positivo dos números e valores contidos nos relatórios gerenciais. Nesse sentido, buscase tornar a participação do trabalhador nesse ambiente em algo muito mais grandioso, que extrapole aos interesses imediatos e particulares da grande corporação, como podemos observar na declaração a seguir:

Vinculamos nosso crescimento à evolução das pessoas, da sociedade e do país. Por isso é que investimos em ações próprias e em patrocínios voltados à educação, à cultura e ao esporte. Apoiamos o poder transformador dessas práticas, para a formação da atual e das futuras gerações. Fazemos isso ampliando o acesso ao conhecimento, estimulando o pensamento crítico e fortalecendo a cidadania. Foi a sua contribuição que nos trouxe até aqui. Tornounos capazes de gerar um valor compartilhado por meio de uma relação em que todos saem ganhando. Sentindo orgulho de pertencer é que você tem nas mãos a chance de atuar, para que a nossa organização continue a se transformar, a inovar e a crescer. $\mathrm{O}$ mundo muda, nosso banco muda com ele - e você é protagonista dessa mudança (Revista Banco 4, mai. 2012).

Abordar assuntos como gestão eco eficiente na grande corporação estudada é mais uma parte desse "compromisso" com a sociedade e tem como fundamento a redução do impacto ambiental que suas ações promovem por meio de controles, reciclagem e reuso de água nos polos administrativos da própria instituição. 
Como vimos, o ambiente de trabalho no Banco $\Delta$ é marcado por um arcabouço de direitos com caráter universal, aplicado para a totalidade dos trabalhadores em bancos, que se soma aos direitos específicos, ambos negociados coletivamente com o sindicato de representação dos trabalhadores. Além destas formas de regulação das relações do trabalho há a influência direta de políticas ativas de $\mathrm{RH}$, denominadas especificamente para este estudo de "benefícios estendidos", os quais permeiam a vida dos trabalhadores e de suas famílias.

Esta conformação da vida social no espaço da corporação, sobretudo, quando aliada aos benefícios extensivos à comunidade, aponta para a existência de um micro território de coesão e ação social pelo qual formas de solidariedade são reforçadas. A narrativa que envolve a cultura corporativa atinge temas relevantes como o respeito à diversidade étnica, social e física; valorização da caridade e da atitude colaborativa; e integra ainda outros valores politica e ecologicamente corretos.

Contudo, a despeito de tudo o que trouxemos à tona, inferimos pelos depoimentos que essas experiências se tornam efêmeras, não sendo apenas elas suficientes para conferir motivação e bem-estar ao trabalhador por tempos prolongados na instituição quando o cotidiano de trabalho é altamente pragmático e acachapante. Os sinais de desencanto são evidenciados pelos trabalhadores em seus depoimentos, ainda que estes não desprezem por completo as relativas vantagens de se trabalhar em uma grande corporação. É, por assim dizer, uma relação marcada por muitas ambiguidades.

Concordando com Rodrigues (1990), ainda que o autor tenha se referido a outro contexto e a outros grupos de trabalhadores:

A experiência concreta dos trabalhadores é bem mais diversificada e, por isso mesmo, mais rica. Essa é a razão da impossibilidade de apreendê-la a partir de pressupostos que nada mais são que avatares da velha dicotomia bem/mal (RODRIGUES, 1990, p. 116, grifo do original).

Em nossa reflexão sobre o processo produtivo bancário, nos orientamos no sentido de compreender a inserção dos trabalhadores no Banco $\Delta$, analisando suas condições objetivas e subjetivas. Tentamos superar o reducionismo da via denuncista, que enfatiza apenas a exploração do trabalho, e buscamos trazer à tona outros elementos que possam esclarecer sobre a interação entre trabalhadores e as organizações.

Nesse sentido, existem ainda outros aspectos que compõem a sociabilidade dos trabalhadores e que nos interessa levar em consideração. O sentimento de reciprocidade, contido no ato de realizar seu trabalho e o status atrelado à participação em uma grande 
corporação - itens que serão abordados no próximo tópico - podem ajudar a complementar a explicação do "cálculo" feito pelos bancários quando contabilizam os prós e contras de sua relação de emprego.

Como Rodrigues (1990) analisou, os trabalhadores estabelecem um "cálculo de custos e benefícios" sobre o trabalho e o tipo de empregador que se relacionam a partir de suas trajetórias de vida, marcadas pelas suas especificidades e dificuldades. Essa abordagem nos parece profícua para buscar explicar como os trabalhadores do Banco $\Delta$ mantêm uma forte ligação com a instituição ao mesmo tempo que destacam elementos de cunho negativo em sua vivência profissional.

\subsection{Indivíduo, grupo e sociabilidade}

\subsubsection{A tensão indivíduo versus grupo na gestão contemporânea}

A tendência ao trabalho em grupos, equipes, times ou células de produção foram disseminados como resposta ao clima de competitividade acirrada, nos anos 1990, no Brasil, quando se buscava atender a padrões de qualidade (MELLO E SILVA, 2004). Na pesquisa de campo que realizamos, nas entrevistas, nos materiais institucionais e no discurso das consultorias, tais expressões ainda são comuns. No ambiente corporativo bancário elas se confundem com as tradicionais formas de se reportar a uma unidade de trabalho ou setor, quando se busca paralelamente remeter ao trabalho coletivo com base na cooperação mútua. As grafias diferentes pouco apontam para formas inovadoras no dia a dia do trabalho.

A estratégia de gestão atrelada à popularização dos grupos de trabalho na década de 1990 se concentrou no refinamento das formas de apreensão do conhecimento tácito adquirido pelos trabalhadores, de modo que nessa ocasião pudessem ser feitos os respectivos ajustes do processo produtivo.

Os grupos que atuaram no interior das organizações estudadas por Mello e Silva (2004) foram submetidos ao que o autor definiu como "gestão pela insegurança". Isso significa dizer que as relações sociais no interior das empresas estavam submetidas em última instância à insegurança do mercado de trabalho. As relações que se estruturam nesse contexto forjaram um comportamento competitivo, que por sua vez conduziu uma tendência à fragmentação oposta à noção de solidariedade. 
O relato a seguir ajuda a ilustrar a tensão indivíduo versus grupo que permeia o mundo empresarial. O conteúdo foi extraído de um programa de rádio, de abrangência nacional, apresentado por um consultor de RH:

Escreve um ouvinte: "nos comunicados internos e no site de nossa empresa é apontado o trabalho em equipe. É destacado como um dos pontos fortes da organização, só que eu não vejo isso no dia a dia, pelo contrário, parece que cada um está apostando a sua própria corrida, sem muita preocupação com os demais".

Comentário do consultor: "quem participa de uma entrevista de emprego sempre ouve a indefectível pergunta: Como você se sente trabalhando em equipe? E a resposta deve ser: É o que eu mais gosto de fazer. Como qualquer pessoa normal sabe isso não é bem verdade, na maior parte do tempo nós preferimos controlar o nosso ritmo de trabalho e não desperdiçar o nosso tempo ouvindo colegas que pouco ou nada tem a dizer. Depois da contratação a história muda, os que trabalham em equipe vão ser elogiados mais vezes, porém, os individualistas é que são promovidos (Max Gehringer, Rádio CBN, 04 fev. 2014).

Gaulejac (2007), por sua vez, frisou que há uma diferenciação entre o período fordista, reconhecido pelo autor como um "modelo hierárquico e disciplinar" e o período marcado pelo "modelo da gestão gerencialista". No primeiro, as adversidades do ambiente de trabalho forjavam solidariedades entre os empregados, no segundo, o forjavam individualismo. Nas palavras do autor:

No modelo hierárquico e disciplinar, as condições de trabalho eram sem dúvida penosas, mas a solidariedade entre os empregados atenuava seus efeitos psicológicos. A comunidade dos trabalhadores fornecia um apoio para suportar as obrigações. Essa solidariedade orgânica se enfraqueceu. A tentação do "cada um por si" é mais forte por ter sido encorajada pela corrida ao mérito, a ameaça dos planos sociais, a diversidade dos estatutos, a mobilidade vertical e horizontal e a individualização das remunerações. (GAULEJAC, 2007, p. 211)

Soboll (2008) observou as dificuldades do trabalho em equipe no setor bancário. Em sua pesquisa sobre a organização do trabalho e a prática do assédio moral a autora detalha:

No trabalho bancário, o discurso de trabalho em equipe nem mesmo propicia a prática superficial dessas relações, pois o trabalhador é individualizado de tal forma que seus pares tornam-se concorrentes, inimigos e fonte de ameaças, delineando relações (des)humanas no trabalho, dominada por hostilidade, concorrência, falta de solidariedade e isolamento. (SOBOLL, 2008, p. 111) 
A sociabilidade no ambiente de trabalho no Banco $\Delta$ é marcada pela vulnerabilidade de atuar em uma empresa altamente competitiva, posicionada entre as vinte maiores de seu segmento no mundo. No contexto em que aumentam as exigências internas derivadas dos novos métodos de controle e administração por resultados, ocorrem movimentos cíclicos, tanto de renovação como de redução do quadro funcional, que interferem na disposição dos trabalhadores em manter uma ação mais solidária entre si.

Diante da pressão para cumprimento de resultados/metas instala-se nos diversos locais de trabalho bancário uma relação ambivalente de parceria e rivalidade entre os agentes, em que prevalece, segundo alguns autores (SOBOLL, 2008; GRISCI; SCALCO; KRUTER, 2011), a corrida individualizada para o mérito e uma cooperação de tipo superficial.

Os depoimentos dos entrevistados do $\operatorname{Banco} \Delta$ para esta pesquisa retrataram a ambiguidade com que vivenciam a experiência em equipe quando o individualismo é parte estruturante do sistema meritocrático:

No banco tem muito kaizen e saem trabalhos em equipe que são legais, dá para realizar, dentro do banco funciona bem. Um dependendo do outro, tem que sair bom. Porque se não sair, vai estourar para todo mundo. Pela questão meritocrática... O cara está trabalhando em equipe, mas ele precisa se projetar individualmente, existe uma pressão. A gente fala em grupo, mas o grupo não recebe uma promoção como grupo, quem recebe é o indivíduo, então ele precisa mostrar o individual dele, aí é um conflito. Não é solidário, a competição sempre vai existir... (Bancária, Analista Sênior, 30 anos, 11 de banco)

Eles querem que você trabalhe em equipe, mas, ao mesmo tempo, eles querem que você tenha um resultado diferenciado, então você não pode passar tudo para a equipe, você tem que guardar algumas coisas com você. Isso de fato existe. (Bancário, Analista Júnior, 29 anos, 04 de banco)

Todos os funcionários de uma agência estão interligados. O Gerente Geral é quem coordena toda essa equipe em busca do cumprimento das metas estipuladas. Tem que ter uma colaboração de todos para que os clientes se sintam bem atendidos. A parceria existe, até mais que a rivalidade. (Bancário, Gerente de Contas, 32 anos, 07 de banco)

Você tem sua carteira de clientes. Você tem uma meta de abertura de contas, mas como eu falei, vem na sua lista... Cada um tem a sua, então é uma concorrência, você está concorrendo com outro funcionário, ele é o seu adversário. (Bancário, Gerente de Contas, 25 anos, 04 de banco) 
O trabalho em equipe funciona adequadamente em parte, né!?! Porque existem pessoas que realmente não estão ali para te ajudar, que não querem ajudar realmente [...] quando tem um trabalho ou uma análise que está sendo feita que envolve varias áreas, aí você fala: Poxa, você consegue me ajudar com essa informação? Aí a pessoa fala assim: Pô, isso aqui não é problema meu, não é minha atividade. Eu não vou ser analisado por isso, então eu não vou te ajudar. (Estagiário, 23 anos, 05 meses de banco)

O banco pede sinergia para atuar como time, mas a gente trabalha em uma esteira, aí uma pessoa pega o erro de outra, mas ao invés de chegar e trazer e dizer você errou aqui, manda um e-mail... Uma vez, duas, pode acontecer, porque você trabalha dez anos no banco e não errar é impossível. Você vai errar porque tem dia que você não está bem e ponto. E aí você fala em grupo, em sinergia... E a pessoa mandou um e-mail para você com cópia para o Superintendente, Gerente, Coordenador, vizinho, papagaio, e aqui tem gente que faz isso... Parece, infelizmente, que a gente virou robôs, você tem que produzir e acabou. Antes a gente trabalhava junto para todo mundo sair junto. Hoje em dia para ter reconhecimento, você é atropelado. (Bancário, Analista Júnior, 42 anos, 12 de banco)

Competitividade é a pior coisa, porque você nunca pode confiar no seu colega de trabalho. (Bancária, Analista Júnior, 57 anos, 12 de banco)

Em que pese o discurso corporativo enfatizar a importância do trabalho em equipe observado desde os processos de recrutamento, seleção, e, nos conteúdos das mensagens institucionais disseminadas, os depoimentos dos entrevistados acima nos levam a corroborar com Pagés et al. (1990, p. 112), pois, as relações no ambiente de trabalho se configuram tendo como base que:

cada trabalhador depende exclusivamente do seu trabalho para ter sucesso. Participar na tarefa do outro é perder de vista e desviar dos seus objetivos individuais. A necessidade de superação dos próprios limites fixa o indivíduo no aperfeiçoamento de estratégias visando melhorar os resultados e ampliar as possibilidades de sucesso.

Parece-nos plausível à luz dos depoimentos dos trabalhadores também a reflexão de Lahera-Sánchez (2005), que por sua vez destacou a instalação de uma relação mercantil entre os próprios trabalhadores da mesma empresa, pois, na medida em que um é "cliente interno" do outro, atuam eles próprios como controladores e disciplinadores do processo de trabalho, experiência que promove a ruptura da solidariedade de interesses e ao mesmo tempo mina as possibilidades de mobilização coletiva frente à direção. 
O modelo de concorrência entre as pessoas, como observou Gaulejac (2007), enviesa a crítica que fica circunscrita ao próprio colega de trabalho enquanto esta deveria ser direcionada para o modo como se organiza o processo produtivo.

O relacionamento da gerência, da supervisão e dos trabalhadores foi afetado pelas influências do "novo modelo produtivo", como defende Mello e Silva (2004), pois reforça-se um tipo de "corporativismo de empresa" com "microcontratos" firmados no âmbito local. Apesar de o novo modelo continuar a extrair sua força do trabalho coletivo, a exemplo do que sempre ocorrera na história do trabalho assalariado, o autor destaca que a solidariedade de classe perde força e nem sempre a cooperação entre os trabalhadores é plena, pois o caráter privatizante predomina nessas relações, favorecendo a individualização, sobretudo evidenciada pelo sistema de premiação e punição conferida a cada participante a partir de sua performance, esvaziando outro tipo de regulação, a de caráter público entre capital e trabalho.

Mello e Silva (2004) percebe, portanto, uma valorização do operador direto com seu trabalho no momento em que se busca quebrar a solidariedade civil constituída com base em uma classe e se constrói uma solidariedade de outro tipo baseada na empresa. A negociação de "microcontratos" entre o indivíduo e a empresa requer envolvimento, esvaziando a possibilidade pública de negociação em que as partes, declaradamente distintas em seus interesses, estão associadas ao capital e ao trabalho.

A experiência relacionada aos "microcontratos", 118 da qual tomamos conhecimento no $\operatorname{Banco} \Delta$, atinge diversos aspectos do processo de trabalho como: banco de horas; metas individuais; código de ética; dentre outros compromissos que o empregador pretender selar. Pode-se, a exemplo do tema que envolve as horas extraordinárias, implicar em desvantagens ao trabalhador dada a relação assimétrica colocada entre as partes. O acerto realizado sem a intermediação do sindicato de representação dos trabalhadores em torno das horas em haver se submete invariavelmente à lógica da imposição em que valem primeiro os interesses da empresa e só depois os interesses dos indivíduos.

De acordo com o jargão corporativo presente nos materiais institucionais do Banco $\Delta$, os trabalhadores devem se submeter e atuar com base no "contrato de metas". Tal instrumento, ajustado entre um indivíduo e o gestor da área, é assinado eletronicamente uma vez ao ano. Seu conteúdo aborda os seguintes itens: resultados

\footnotetext{
118 Os "microcontratos" podem ser fixados para diversas ações no interior da grande corporação bancária estudada, e são assinados on-line, atingindo $100 \%$ dos trabalhadores.
} 
esperados; prazo de entrega; papel do funcionário para o alcance dos resultados e indicadores que possam mensurar a entrega. É realizada a avaliação do gestor ao final do prazo estipulado para o vencimento do contrato.

Embora o trabalho em grupo evoque o coletivo, nas novas formas de gestão há, contraditoriamente, o fortalecimento do indivíduo. A produtividade individual, quando apurada, serve de referência tanto para premiações, cito como exemplo os pagamentos relativos à remuneração variável, quanto para expor o trabalhador menos produtivo à demissão. A produtividade da equipe também deve estar de acordo com os parâmetros esperados, para atingi-la se estabelece o controle de um indivíduo sobre o outro, à medida que o resultado ruim de um pode afetar a todos. Dessa condição resulta que, ao contrário de obter o fortalecimento de vínculos sociais, convergem relações fragilizadas entre os próprios indivíduos, que afetam a sociabilidade dentro e fora da corporação.

No $\operatorname{Banco} \Delta$, a preocupação em torno da valorização do trabalho em equipe, ainda que contraditoriamente situada, consta na arquitetura das políticas de gestão por resultados. As equipes, ainda que com peso menor, também são premiadas e destacadas. Mas, cabe enfatizar que aquilo que define de fato a vida profissional de um indivíduo na instituição são os seus próprios resultados.

A narrativa a seguir aponta aspectos da sociabilidade de um trabalhador, em especial dá destaque à relação com o grupo no ambiente de trabalho do $\operatorname{Banco} \Delta$ :

Você se sente bem indo trabalhar, porque é uma empresa que te dá segurança, é bonita de trabalhar, você faz alguma coisa que gosta, você se sente realizado no que faz, só que ao mesmo tempo você pode não se sentir bem com a sua equipe, você não consegue confiar nela e nas pessoas da área. As pessoas são... existem muitas máscaras lá dentro, elas falam muito mal pelas costas uma das outras, isso é uma realidade. É uma guerra. É um vampirismo, de sugar as suas forças, você volta para casa destruído, se você perguntar para outras pessoas, elas vão dizer a mesma coisa. É muito triste isso, porque aos poucos você vai tendo a sua essência perdida, como humano. A minha mãe falava para mim: Você perdeu a sua essência no banco, assim você vai ter uma relação ruim com sua esposa, com seus filhos. Quando você chega aqui em casa qualquer coisa te irrita e você acaba tendo uma agressividade que não justifica. Isso tudo mexeu comigo, porque entre iguais você não percebe, no $\operatorname{Banco} \Delta$ a gente não percebe, e ter frieza é fundamental em negociações de alto nível como as do $\operatorname{Banco} \Delta$. E se você tem um relacionamento, uma preocupação humana, o pessoal tenta te anular. A realidade do banco é o individualismo. Não existem amigos dentro da instituição, existem colegas, amigos são muito poucos, as pessoas lá dentro se demonstram ao longo do tempo, as pessoas se perdem no banco, perdem a sua essência, isso é uma realidade, o banco te consome. (Bancário, Analista Júnior, 29 anos, 04 de banco, grifo nosso) 
Como abordou Gaulejac (2007), passar por uma empresa é estar envolto em um regime tutelar simbólico no qual o trabalhador, a depender do peso da logomarca, toma para si o status dela. É o que também observou Romanelli (1978) acerca dos trabalhadores bancários em sua pesquisa ao inferir que estes se imaginam investidos simbolicamente de parte do prestígio que envolve o nome do banco. O depoimento do trabalhador citado acima deixou transparecer esse deslumbramento que se dá no campo da aparência. Contudo, a partir do momento em que começa a descrever as dificuldades encontradas no trabalho em equipe, o entrevistado espontaneamente faz uso da metáfora da "guerra" ao se referir às relações sociais no ambiente de trabalho do banco estudado.

A exemplo do que foi retratado por Dejours (2006) e Gaulejac (2007), a intensificação do trabalho gerou uma espécie de "guerra social" no interior das instituições onde a violência é cotidianamente sentida e há o rompimento dos laços sociais. A declaração a seguir reforça esse pensamento:

As pessoas que trabalham em banco são sociáveis. Mas essa sociabilidade acaba sendo comprometida pelo cumprimento da meta. O não cumprimento de metas acaba interferindo no ambiente, então você vê relações saudáveis penalizadas pela cobrança exagerada, o não cumprimento de uma meta já cria uma indisposição social entre as pessoas, interferindo no clima nessas ocasiões. Dado o nível de pressão, existe certa rivalidade, tanto nos pares (mesmo nível hierárquico) quanto com os pares e seus superiores. O subordinado tem uma rivalidade com o gestor, porque o subordinado é o gestor de amanhã, então se o gestor não está indo bem, o subordinado vai tomar o lugar dele. (Bancário, Gerente de Contas, 32 anos, 07 de banco)

Contrastando com o depoimento dos trabalhadores, segue trecho do discurso institucional, divulgado em veículo de comunicação interna do $\operatorname{Banco} \Delta$, pelo qual se evocam modos de sociabilidade no trabalho que reforçam o colaboracionismo e a participação:

Nossa cultura é aplicada para desenvolvimento e ampliação da melhoria da performance das competências de cada um, por meio de espírito de colaboração, trabalho em equipe e participação, focados na relação entre as pessoas, com uma maior participação e responsabilidade de todos os funcionários, para que os valores humanos sejam evidenciados, buscando melhorias contínuas. (Revista Banco4, mai. 2013)

Na análise de Castillo (2009), a formação de grupos ou equipes de trabalho se constituiu como a panaceia dos novos métodos de organização do trabalho. Contudo, 
como estamos apontando, a relação indivíduo versus grupo contém muitas contradições. Diante da fragmentação dos trabalhadores, os administradores buscam formas de manter a coesão do grupo preservando o que há de mais rico neste encontro social promovido pelo pretexto do ato de trabalhar: as combinações e as trocas estabelecidas entre os agentes do trabalho, pois elas são em potencial aquilo que garante o valor da força de trabalho.

Pretende-se assim jogar luz nesse conflito interno orquestrado pelas próprias políticas de $\mathrm{RH}$, que tensionam nas duas pontas tanto pelas expectativas de resultados individualizadas como pelas expectativas com relação ao grupo. Há uma disjuntiva colocada, sob a qual é possível perceber que a ênfase dada ao trabalho individual pode conduzir ao sabotamento da atuação em grupo e aquilo que ele contém de melhor, o espírito colaborativo pelo qual as trocas fluem e favorecem o alcance dos resultados.

\subsubsection{Socialização e sociabilidade}

De acordo com Mills (1969a), a grande empresa na sociedade moderna impôs a dependência econômica dos indivíduos, mas, além disso, se tornou um espaço de convívio e um lugar de pertencimento social.

O local de trabalho é um dos espaços fundamentais pelo qual se realiza o processo de socialização do indivíduo na sociedade. Trata-se de um microssistema que se organiza no plano objetivo e, não menos relevante, no plano subjetivo. Por meio da adaptação e integração, o indivíduo atinge um comportamento que é aprovado pelo grupo e tal condição lhe confere sentimento de pertencimento.

Dubar (2012, p. 358) analisa a socialização profissional destacando que se trata de:

um processo muito geral que conecta permanentemente situações e percursos, tarefas a realizar e perspectivas a seguir, relações com outros e consigo ( elf), concebido como um processo em construção permanente.

E de acordo com Gaulejac (2007, p. 157):

cada indivíduo - sejam quais forem as condições de trabalho, seja qual for o grau de instrumentalização de que é objeto - tem necessidade de dar valor àquilo que produz, de colocar coerência diante do caos, regulação diante da desordem, racionalidade diante das contradições, criatividade diante da uniformidade. Isso the permite realizar-se ao realizar sua tarefa. 
Nas entrevistas realizadas para esta pesquisa foi possível apreender alguns dos principais nexos que dão sentido à ação social dos trabalhadores bancários. Na visão desses, por meio do trabalho que realizam, eles podem sentir satisfação pessoal, obter reconhecimento, sentirem-se úteis, manter sua subsistência e ainda manter um relativo status social.

O reconhecimento raramente se expressa por parte do gestor e dos demais trabalhadores que atuam na mesma unidade, mas é essencialmente fundado no retorno dado pelos clientes quando a atuação no trabalho é validada pela sua efetividade, seja pelo cumprimento de um objetivo prescrito ou não.

$\mathrm{Eu}$ amo o que eu faço. Trabalhar no banco para mim significa remuneração, satisfação pessoal, satisfação profissional, é um lugar que eu me sinto! Até um determinado ponto... Porque o negócio degringolou, ficou abusivo, tá? Eu me sinto alguém que pode ajudar, alguém que ajuda o próximo. (Bancária, Gestora Regional Agências, 43 anos, 16 de banco)

Eu me sinto realizada porque eu sei que faço aquilo para o ser humano, eu não penso como o banco, embora às vezes eu tenha que pensar comercialmente. A minha realização vem por parte do cliente, e eu acho que isso para mim é muito bom. Agora, reconhecimento do banco eu não espero mais como esperava no começo. Antes, quando eu tinha um pouco mais de falta de maturidade, eu pensava em ter mais reconhecimento do banco. (Bancária, Gerente de Contas, 35 anos, 08 de banco)

O meu maior sonho é fazer o que faço hoje no banco, é escutar o cliente e resolver o problema dele, então isso é uma realização pessoal e profissional muito grande. (Bancária, Analista Júnior, 57 anos, 12 de banco)

A melhor parte de ser bancário é você ver desenrolar uma operação do cliente, você vai lá, faz acontecer, puxa a informação, resolve o caso... É servir pessoas... É muito gratificante receber o sinal de satisfação do cliente. (Bancário, Analista Júnior, 42 anos, 12 de banco)

A reciprocidade, esta forma de correspondência mútua entre as partes envolvidas - trabalhadores e clientes - nesse micro território social investigado, abre espaço para que os trabalhadores sintam-se reconhecidos em seu trabalho, atribuindo sentido, que a exemplo do que analisa Sabourin (2011), nunca é acabado e unívoco, mas que pode proporcionar algum tipo de coesão social, reforçando valores sociais e simbólicos essenciais à sociabilidade.

A percepção dos entrevistados sobre a troca estabelecida na relação social com os clientes evidencia alguns dos elos de afetividade, solidariedade e respeito que 
acabam amparando a atividade profissional que analisamos marcada pelo pragmatismo dos resultados financeiros.

Conforme analisou Alcântara Júnior (2005, p. 33):

A sociabilidade é resultante das condições inerentes e gestadas pelas múltiplas combinações interacionais acionadas a partir dos indivíduos, por grupos e por classes sociais, sintetizadas e cristalizadas na própria sociedade.

Essa abordagem enfatiza para nós a perspectiva de tratar este evento fundado na reciprocidade como algo que escapa a zonas institucionais mais duras ou cristalizadas, pois nela os investimentos subjetivos "pessoalizados" de cada agente singular em sua ação no trabalho podem ser múltiplos, e não são normatizados ou arquitetados de antemão (OLIVEIRA; VIEIRA, 2014).

Assim, imbuídos de trazer à tona as ambiguidades que tornam os processos de trabalho interações complexas, buscamos tanto no trabalho de campo como nas entrevistas captar aspectos da sociabilidade que podem nos contar algo mais sobre o que se passa no interior das grandes corporações. Contudo, não se pode desconsiderar a intensidade da pressão pela alta produtividade exercida nestes ambientes, a qual gera paralelamente uma demanda insatisfeita de reconhecimento por parte daqueles que se esforçaram ao máximo para atingir as metas de trabalho, mas que ainda assim não se colocaram como primeiros no mapa de produtividade controlado pela instituição.

O encontro de "perdedores" e "ganhadores" de prêmios por melhor desempenho no grupo de trabalho, unidade, ou qualquer outra definição que possamos dar, cria marcas indesejáveis, estigmatizando aqueles que se mantêm nas últimas colocações. A gestão pela meritocracia proporciona essencialmente o reconhecimento por metas cumpridas e avaliza o pertencimento dos poucos que estão diametralmente em posição diferenciada daqueles que se encontram nas posições sofríveis.

Além disso, como Dejours (2006) ponderou, os trabalhadores submetidos à dominação gerencial, à ameaça de perder seu posto de trabalho, se veem premidos pelo medo que conduz à falta de empatia entre si, desligando um sujeito do sofrimento do outro, que também padece, no entanto da mesma situação.

A subsistência, razão que funda o vínculo do indivíduo neste ambiente, amparase na manutenção de um determinado padrão de vida, o qual se mantém por meio do salário e demais direitos, invariavelmente acima da média de mercado. Os entrevistados estabelecem uma análise comparativa de sua realidade econômica com aquilo que 
observam no mercado de trabalho e destacam aspectos que valorizam na relação de emprego que mantêm com o Bancos.

O banco é uma boa empresa para se trabalhar... O melhor de ser bancário para mim é o salário e os benefícios que temos. A PLR, os vales refeição, alimentação, etc. (Bancário, Gerente de Contas, 32 anos, 07 de banco)

Eu não posso falar que o meu salário é baixo... A PLR é boa, porque comparando com outras profissões, a gente sabe, e eu converso com várias pessoas e então eu sei, que a PLR do banco é boa, então a gente tem que comparar, tem que ter uma referência. Os benefícios do banco também são bons, então para a minha realidade é bom. (Bancária, Gerente de Contas, 35 anos, 08 de banco)

Se eu for olhar para o trabalhador nacional, acho que os bancários têm muitos benefícios, comparados com a média do trabalhador nacional... Nossa... É bastante... PLR, salário, tickets: vales alimentação e refeição. (Bancária, Analista Sênior, 30 anos, 11 de banco)

Analisando o cenário, o mercado, eu não acho meu salário ruim. Eu acho os benefícios muito bons. Convênio médico é muito bom... É interessante sim, até porque sabe como que é a saúde pública. Não sou só eu, eu ouço isso de muita gente. Vale refeição, vale alimentação, mesmo que o valor não seja lá um absurdo porque a gente sabe que está muito caro comer fora, ajuda muito. E é muito legal, porque ajuda nas compras no final do mês [se referindo ao auxílio alimentação]. Então todo mundo acaba achando isso muito legal. Eu tinha auxílio graduação e pós-graduação. Eu podia fazer quantas eu quisesse que o banco contribuía com $60 \%, 70 \%$ do valor e às vezes $100 \%$. As duas pós que eu fiz, o banco pagou $100 \%$, em escolas de renome. Então o banco faz por você, mas não são para todos os cargos, conforme você vai aumentando na hierarquia, o banco investe em você, mas também te cobra muito mais retorno. (Bancária, Gestora Regional Agências, 43 anos, 16 de banco)

Os entrevistados destacados acima, ainda que relativizem suas posições, reconhecem, em grande medida, a reciprocidade econômica por parte da instituição. Destacam que não apenas o salário e a PLR, mas também outros subsídios como auxílio refeição, alimentação, acesso a convênio médico particular e formação acadêmica são formas concretas que justificam e reforçam a permanência na instituição.

Embora essas visões não ofusquem, em nenhuma circunstância, todas as críticas e problemas destacados pelos mesmos entrevistados sobre o ambiente de trabalho, visamos evidenciar que a reciprocidade econômica é, portanto, sem muito mistério, um dos elementos que conferem sentido aos participantes dessas instituições. 
Contudo, é relevante destacar que esta percepção, apesar de ter sido majoritária nesta pesquisa, não é uma unanimidade. $\mathrm{O}$ depoimento do entrevistado a seguir se coloca no sentido de demonstrar a falta de reconhecimento econômico por parte da instituição. Ele explica que sua posição parte de uma análise que considera com exclusividade o espaço em que está inserido objetivamente. Entende que é possível atribuir o valor de seu trabalho quando confronta sua experiência, a especificidade da sua atuação e seu empenho, com os resultados econômicos mais gerais que a própria instituição apura.

Eu ouço muitas pessoas dizerem dentro do banco que em vista de mercado tá bom. Mas eu não posso me contentar com isso porque eu sei o valor do meu trabalho, entendeu? Eu sei o valor do meu trabalho, eu sei o que eu faço para chegar naquilo. E, pior ainda, eu sei o quanto que o banco ganha em cima de mim. Então, eu não posso me contentar. Eu sei que é o salário que paga minhas contas, né?! Com ele eu consigo fazer minhas viagens, consigo dar uma condição para minha família. Mas eu sei que pelo que eu faço, pelo meu desempenho, é.... eu sinceramente eu acho pouco. Eu não posso me comparar com uma outra área no mercado porque eu sou bancário, eu não posso me comparar a um metroviário, a uma terceirizada, eu tenho que ficar na minha realidade, entendeu? Então, eu não posso me contentar com isso, e eu acho que é um pouco injusto essa parcela, esse retorno versus trabalho, eu acho injusto. Mesmo me falando que eu trabalho só seis horas, entendeu? Essas seis horas valem como doze horas em uma fábrica. É muito intenso, porque você trabalha com pessoas, então nenhuma pessoa é igual à outra. Então você tem que estar sorrindo para todas, entendeu? Mesmo que você esteja em um dia ruim, seu filho está doente, mesmo que você não tá legal, você tá com um problema de saúde, um problema de família, entendeu? Então ele [o banco] não vê isso e eu acho que a remuneração poderia ser muito melhor em vista do que a gente faz. Em vista do retorno que a gente traz. (Bancário, Agente Comercial, 29 anos, 07 de banco)

Rodrigues (2011) apurou em sua pesquisa, com trabalhadores que se desligavam das instituições financeiras majoritariamente pertencentes aos bancos privados, que $52 \%$ dos participantes voltariam a trabalhar no setor. Esse resultado nos parece relevante, pois reforça, ainda que tangencialmente, as ambiguidades das relações presentes nesses ambientes.

O componente status, como mais um nexo que dá sentido a ação dos indivíduos neste ambiente pesquisado, carrega também em si um caráter ambivalente. Apesar das visões críticas expressas por parte dos trabalhadores do Banco $\Delta$, que diante da realidade vivida sentiam-se desvalorizados, explorados e demonstravam desencantamento com o ato de trabalhar em uma grande corporação, foi possível captar a percepção de que, 
derivada da ocupação profissional que mantêm, há uma atribuição de prestígio social, conforme veremos a seguir.

\subsubsection{Status e sociabilidade a partir do emprego bancário}

Fazendo uma rápida digressão, recuperamos na análise de Canêdo (1978) que a profissão bancária, em meados da década de 1940, foi altamente valorizada. Contudo, registra a mesma autora que a partir dos anos 1960 seu prestígio foi circunscrito à atuação nos bancos públicos.

Com a reforma bancária, pós-1964, a categoria atomizou-se em numerosas agências espalhadas pelo país e os trabalhadores do setor, influenciados pela conjuntura, alteraram suas expectativas com relação à carreira, estabilidade e prestígio vinculado ao trabalho bancário, tornando-o provisório. Como descreve Canêdo (1986, p. 4):

A aspiração de trabalho no banco, desejo de muitos em uma época de poucas possibilidades, foi substituída pela aspiração à carreira liberal, no momento em que as oportunidades de educação formal se alargaram e ampliou-se o assalariamento dos antigos profissionais liberais. Ser bancário para muitos passou a ser trampolim para os estudantes. Assim, a força do sindicalismo bancário que era a reivindicação profissional se enfraqueceu no período do "milagre".

Romanelli (1978) reafirma a percepção de que a profissão bancária foi portadora de status, tinha "prestígio social" e permitia a obtenção de um "salário bastante razoável", contudo, explica o autor que após as diversas mudanças ocorridas no setor, as tarefas não especializadas aumentaram e os bancários foram submetidos a uma rotina de trabalho parcelar e fragmentária que os conduziram a um movimento de "proletarização", submetendo-os à mesma cadência de uma linha de montagem. Aspectos estruturantes, como a queda da remuneração e aproximação de seu trabalho às tarefas manuais, levaram a profissão a perder prestígio.

Durante as décadas de 1970 e 1980, enquanto via-se progressivamente multiplicar o número de agências, alteravam-se também as atribuições bancárias. A introdução, por exemplo, do cargo de Caixa Executivo em boa medida redimensionou o papel do Contador e até mesmo do Gerente por realizar de forma direta diversas operações que se tornaram possíveis diante da mecanização e do processamento eletrônico. Desta forma, a rotinização e automatização dos serviços que foram 
implementadas levaram ao rebaixamento dos pré-requisitos de admissão (ROMANELLI, 1978).

Vale registrar que no final dos anos 1970 os trabalhadores de modo geral vivenciaram políticas de arrocho salarial e aumento de rotatividade. Com a crise econômica instalada no país nos anos 1980 aprofunda-se a desvalorização profissional da categoria bancária e, consequentemente, seu rebaixamento salarial (DIEESE, 1980; CANÊDO, 1986).

Deste contexto resultou uma relação ambígua que passou a permear a representação que os bancários têm sobre o seu trabalho. Enquanto para alguns era visto apenas como um "trampolim", algo provisório até que se conseguisse outra posição melhor no mercado de trabalho, para a maior parte dos trabalhadores havia a expectativa de fazer carreira dentro das instituições, pois apesar das adversidades, ainda comparativamente no mercado geral de trabalho brasileiro, a profissão concentrava mais vantagens do que desvantagens, o que os colocavam em um quadro de submissão às regras de funcionamento interno, à pressão e até ao adoecimento vinculado ao trabalho (ROMANELLI, 1978).

Segnini (1988) apontou que a ameaça de perda do emprego, sobretudo nos bancos privados, impelia os trabalhadores do setor a adotar relativa conduta de aceitação dos padrões de controle e produtividade impostos, nos quais já se colocavam competição interna e vigilância mútua. Assim, se estabeleceu em um contexto propício a proliferação de diversas formas de autoritarismo e despotismo no local de trabalho. Contudo, ainda que imerso nessa realidade, a autora aferiu que "o trabalho bancário é entendido como uma forma de ascensão social mesmo que a tarefa a ser realizada seja tão parcelada, repetitiva e desqualificada quanto o trabalho operário e que o salário seja, muitas vezes, mais baixo" (SEGNINI,1988, p. 64, grifo nosso).

Blass (1992), em sua investigação sobre a condição bancária, a partir do maior movimento grevista organizado após a ditadura militar ocorrido em 1985, ressaltou as marcas de distinção associadas a esta categoria profissional, explicando que o serviço "limpo", baseado na relação com o público, intelectualizado e caracterizado pela manipulação de grandes somas de dinheiro remetia a um trabalho de maior prestígio social, ideia que fora construída em oposição ao trabalho fabril, considerado pelos entrevistados à época como um "trabalho sujo". 
Contudo, Grisci, Scalco e Kruter (2011) apontaram que aos olhos dos bancários o trabalho tem se resumido a um meio de sustento cada vez mais desvinculado àquela posição de status anteriormente experimentada.

Silva e Navarro (2012), a partir de uma análise similar, retomam a questão do prestígio relacionado à profissão. Os trabalhadores entrevistados para a pesquisa empreendida pelas autoras, que enfrentaram problemas relacionados à saúde ocupacional, afirmaram que o trabalho bancário perdeu o status que tinha, sobretudo diante das inovações tecnológicas, que absorveram o saber fazer dos trabalhadores, e também pela constatação de que a realização profissional, outrora vivenciada, foi substituída pela obrigatoriedade das vendas e cobrança por resultados, que colocou em segundo plano o interesse em ajudar os clientes.

Borges, Vitullo e Ponte (2012) buscaram compreender os significados de "ser bancário" no cenário das reestruturações produtivas pós anos 1990. Os autores polarizaram a noção do trabalho bancário atribuído como "esplendor social" com a noção do "trabalho precário". Apesar de reconhecerem que há no imaginário popular, ainda que rarefeita, uma visão glamourizada sobre a profissão, jogaram luz à noção de que o status, estabilidade e possibilidade de construir carreira, antes atribuídos à profissão, mesmo nos bancos públicos, é algo questionável, quando paralelamente observou-se, via processos de privatização e por meio das mudanças organizacionais, intensificação do trabalho e maior cobrança para atingir resultados e realizar requalificações constantes.

A partir do balanço das posições trazidas à tona pelos diversos autores citados, pode-se concluir que a profissão bancária foi perdendo prestígio ao longo das últimas décadas, sobretudo quando são analisados os problemas vividos no ambiente corporativo após a aplicação dos novos métodos de gestão que conduziram a deterioração da qualidade de vida no trabalho.

Entretanto, nesta tese pretendemos matizar essa tendência analítica a partir da percepção trazida à tona pelos entrevistados, sobretudo ao considerar aquilo que Mills (1969a, p. 257) apontou em seu estudo sobre os trabalhadores de escritório: "o prestígio envolve pelo menos duas pessoas: uma para prevê-lo e outra para atribuí-lo".

O status, como um sentido social, atribuído ao trabalho bancário, é compartilhado por familiares, amigos e demais pessoas que compõe o quadro de interação social do qual o trabalhador faz parte, levando a posição ocupada na grande corporação a ser admirada, e vista como sinônimo de sucesso, capacidade e boa situação 
econômica. Mesmo que as idealizações não correspondam à realidade objetiva, como contrapõem os próprios trabalhadores, esse sentido social atribuído pelos grupos de convivência se assenta em um julgamento de valor, que alimenta a percepção de status social relacionado ao trabalho realizado em bancos que tende a projetar a imagem e a marca do próprio empregador.

A sociabilidade dentro do ambiente bancário é mediada pela visão que os outros possuem sobre si. O status confere um sentido de aceitação e pertencimento social na medida em que essas percepções são compartilhadas pelas pessoas que acompanham a vida cotidiana dos trabalhadores do $\operatorname{Banco} \Delta$, conforme nos situam as declarações dos entrevistados a seguir:

A minha família pensa muito bem do meu trabalho... Tem orgulho... a minha família acha meu serviço muito bom porque também eu me sustento com isso... Os meus amigos têm uma boa visão por eu ser bancária. Acho que ainda é uma profissão que dá status, deu muito mais antigamente, passado bem antigo, mas, ainda dá status sim. Ser gerente! Ainda mais, porque você lida com quem tem mais de cinco mil de renda e que tem investimento (Bancária, Gerente de Contas, 35 anos, 08 de banco)

Minha família pensa que o bancário ganha super bem, que é um privilegiado, dentro do mundo do trabalho esta em um nível melhor do que outros. E se você pensar nesta perspectiva é verdade que o trabalhador bancário está melhor do que em outros setores, mas, ganhar super bem, não é assim não. (Bancária, Analista Sênior, 30 anos, 11 de banco)

Meus pais têm orgulho de eu trabalhar no banco, mas acham que eu sou mal pago. Chama a atenção trabalhar no banco, vou receber PLR, vou ter certa estabilidade. (Bancário, Analista Júnior, 29 anos, 04 de banco)

As pessoas têm uma ilusão... Quando você fala que é bancário elas te olham de uma forma. Ohh!... Hoje não existe mais esse orgulho de dizer que é bancário. As pessoas acham que você trabalha das dez às dezesseis e ganha horrores. É absurdo. Tem um amigo meu que disse: "você deve ganhar de cinco pau para cima". No dia seguinte levei meu holerite para ele e mostrei. Eu disse: "é meu amigo, é status". A renda para um analista é baixa, o ticket alimentação, a PLR, o ticket refeição e o convênio médico é o que prende os bancários. Trabalhar em uma instituição de nome como o banco e se manter, que é o mais complicado de tudo, foi uma meta alcançada. Tem status, por exemplo, para a minha família, para a minha filha, mas não é igual há dez anos atrás (Bancário, Analista Júnior, 42 anos, 12 de banco)

Minha família, meus amigos acham que eu tô... Nossa! "Você é gerente de banco"... E não é bem assim, né? Acham que você manda, você é gerente então você trabalha a hora que quer, faz o 
que quer, e não é assim, né? O pessoal acha um excelente trabalho. Alguns amigos que eu tenho o salário deles é menor, em alguns casos, assim, depende também da empresa. É que hoje pelo menos os amigos que eu tenho trabalham em empresas de médio porte, que pagam um salário menor. Tem um que a esposa é formada em publicidade, ela trabalha em uma empresa de publicidade que ela ganha muito mais, tipo não tem pós, não tem nada, só trabalha na empresa de publicidade. Eu sei que ela ganha muito bem, mais que o dobro... Acho que dos amigos próximos, eu tenho o maior salário. Tem exceções, em uma galera de amigos grande é um ou outro que ganha mais que você. (Bancário, Gerente de Contas, 25 anos, 04 de banco)

A minha família acha que eu sou a mina! É verdade, eles me veem e falam: "Nossa, ela conseguiu!" Eles acham maravilhoso, tanto que muita gente quer vir para o banco. Eu tenho parente dentro do banco. Por conta de ver o meu encarreiramento, de ver como que as coisas aconteceram para mim, acham que aqui é um paraíso e querem vir também. Meus amigos a mesma coisa. (Bancária, Gestora Regional Agências, 43 anos, 16 de banco)

Hoje você ser bancário assim na realidade, no mercado, é visto assim como um bom emprego. Você trabalha em uma empresa grande, em uma empresa de nome, né?! Esses bancos anualmente aparecem no top 100 das grandes empresas desejadas para trabalhar, revista Veja, também não sei se é verdade, mas aparece. Enfim, todo mundo acha que é um sonho de consumo entrar em um banco, perguntam como faz para entrar no banco, mas não sabem da realidade. Eu sei que todo trabalho tem sua parte estressante, mas a maioria das pessoas não sabe como que é a vida de um bancário. Elas têm uma visão idealizada do que é. Acham que é bacana... Vêm as propagandas do banco e acham que é aquele mundo colorido, mas não é. (Bancário, Agente Comercial, 29 anos, 07 de banco)

Corroborando com a análise de Lima (1996) em sua abordagem sobre o setor industrial, reafirmamos que a noção de emprego é mediada por relações sociais fora do ambiente de trabalho, compondo uma forma de sociabilidade que responde a estratégias individuais e familiares de sobrevivência e reprodução, e ainda vai além disso. Como explica o autor:

Essas estratégias frente ao mundo do trabalho, elaboradas no âmbito do grupo familiar e das relações pessoais, extrapolam a mera sobrevivência material, incluindo elementos subjetivos de realização pessoal e afetividade, necessários para a viabilização de projetos de vida. (LIMA, 1996, p. 124) 
A relevância deste universo simbólico que envolve a posição do indivíduo no trabalho e consequentemente o modo como se insere em outros grupos externos ao banco é algo que nos chama a atenção.

O emprego bancário, quando visto de longe, é admirado e até mesmo cobiçado. Fruto da percepção socialmente construída embasada em dados que compõem sua materialidade, como remuneração e demais direitos que estão presentes nas relações vinculadas ao contrato de trabalho, assim como na tradição de que o trabalhador de uma grande corporação financeira, a começar pela forma de se vestir, é por decorrência bemsucedido e valorizado.

O glamour que ainda ronda a profissão é também relacionado diretamente à figura do empregador. Nada mais do que a imponência de um "banco", reconhecido como instituição que arrecada e movimenta altos recursos financeiros, para carregar de significados o imaginário daqueles que não vivendo a realidade concreta de ser um profissional bancário podem rapidamente vincular o fato de se trabalhar em um banco a bons pagamentos, ambientes agradáveis, bonitos e suntuosos.

Como observamos anteriormente, a instituição empenhada em alavancar sua imagem de empresa sustentável, socialmente responsável, divulga sistematicamente suas ações comunitárias apontando uma preocupação que extrapola seus interesses corporativos, atingindo a sociedade de forma mais ampla. Em decorrência das aparências, plasticamente impecáveis expostas nas peças de marketing e nas propagandas, o Banco $\Delta$ se apresenta como instituição moderna, sólida, sensível às questões humanas mais relevantes, capaz de atender os interesses dos clientes articulados aos interesses do país. Sendo assim, leva a crer que em seu interior exista uma convivência harmônica, com pessoas que partilham de seus valores, e, portanto, trabalham satisfeitas e felizes.

\subsubsection{Ambiguidades no ambiente de trabalho e perspectivas dos}

\section{trabalhadores}

A partir das entrevistas com os trabalhadores foi possível apreender que existem várias ambiguidades colocadas no ambiente corporativo. Uma delas se marca pela necessidade de realizar o processo de trabalho calcado na equipe quando paralelamente o individualismo é fortalecido pelo regime meritocrático. Outra ambiguidade é marcada pela confrontação entre o reconhecimento, a satisfação que os trabalhadores encontram 
no exercício de seu trabalho, sobretudo por meio da possibilidade de ajudar os clientes, e, as expectativas frustradas que mantêm em relação ao mesmo.

As dificuldades de obter valorização profissional em um ambiente marcado pela pressão convivem com a percepção de que o banco é ainda um local que melhor atende ao conjunto de suas necessidades, considerando não apenas a remuneração recebida, mas também os demais aspectos do contrato de trabalho que ampara não apenas o indivíduo, mas acolhe também outros aspectos de sua vida social, conforme detalhado em tópico anterior deste texto quando abordamos "Direitos, benefícios e sociabilidade corporativa".

Certos "direitos" ou "benefícios", como o uso do subsídio com gastos em restaurantes, nas diversas ocasiões de lazer com os amigos, fazem o trabalhador bancário lembrar-se de que a instituição faz parte de sua vida, assim como as demais conveniências que envolvem a sua própria família, como podemos citar o convênio médico e uso do subsídio às compras no comércio de alimentos.

Nesse diapasão a experiência dos trabalhadores bancários é complexa e envolve variáveis que desafiam o pesquisador a compreender elementos que perpassam por um leque de problemas vividos no ambiente de trabalho, mas ainda assim não eliminam formas de sociabilidade e de interação social que sejam pelos próprios trabalhadores apreciadas.

O reconhecimento de status social, por parte daqueles que fazem parte da vida privada dos trabalhadores, é mais um componente que aponta para como a relação que envolve o trabalho bancário é cheia de ambiguidades, haja vista os próprios trabalhadores questionarem esta posição. No entanto vale a indagação: Mas o que é status se não aquilo que o outro atribui na relação estabelecida socialmente. O que adiantaria ter a melhor posição social possível se não houvesse a opinião, a percepção do outro? Assim, admitindo que a noção de status está embasada em uma atribuição relacional, deve-se considerar o que os "outros" agentes, que fazem parte do universo dos trabalhadores, percebem e reforçam essa ideia, ainda que seja algo idealizado.

Há um conflito interno vivenciado pelos trabalhadores que se desencadeia pela polarização de percepções distintas acerca da mesma experiência. Por um lado, pesa a necessidade de sobrevivência e as vantagens relativas de ser empregado de uma grande corporação, somadas às formas de reconhecimento e reciprocidade que destacamos anteriormente. Por outro, pesa o fardo da pressão contínua no ambiente de trabalho, a 
não realização pessoal diante da valorização considerada insuficiente e a ameaça de desligamento a qualquer tempo.

Em nossa tentativa de explorar no tempo presente a visão outrora analisada por Canêdo (1978) e Romanelli (1978) sobre o caráter, se provisório ou definitivo, do emprego bancário, discorreremos sobre as entrevistas a seguir relacionando-as ao contexto que os participantes se inserem.

Os trabalhadores entrevistados, ao retratarem o pragmatismo que envolve a gestão do processo de trabalho no Banco $\Delta$, manifestam seu desejo de partir para outra condição, buscar uma alternativa que seja mais suportável, entretanto, os mesmos trabalhadores invariavelmente ainda consideram que esse espaço social de trabalho atende a suas necessidades ou lhe dá estrutura para alcançar seus sonhos estabelecidos no plano material, como adquirir uma casa própria.

Eu quero ficar dentro do banco pelo menos uns cinco anos, não me vejo mais do que isso. Porque é muita pressão, chega uma hora que... Cinco anos, pode ser mais, menos, pode ser que eu nem saia. Só que é tanta pressão, que eu falo, né? Então, assim, eu tô meio zuado esses dias, aí o meu amigo perguntou: Por que você tá assim? Pressão de meta? É. Aí meu, juntou tudo. Você ainda tem os problemas pessoais, é última semana do mês, é isso. Então, você fica... É meio assim, eu vejo por mim, eu meço muito pela minha qualidade de vida, eu não quero chegar nos meus trinta e tá doente, tá mal. Então, quero aproveitar agora, o momento enquanto eu tô novo. Trabalhar, ver se eu consigo alguma coisa, uns projetos pessoais. Conseguindo, eu quero sair do banco mesmo. Pode ser que não... Pode ser que... Assim... Se você me perguntar se eu quero crescer dentro do banco, quero, pode ser que daqui uns três anos eu esteja como Superintendente... Aí eu não vou querer sair, o trabalho é outro, a dinâmica é outra. Agora e se eu casar? Eu amo criança, hoje eu não teria coragem de ter um filho por conta disso. Eu quero dar muita atenção para o meu filho, lógico que você vai trabalhar, só que assim... Hoje dentro do banco, nas condições que tá, não tem como... Se bem que você tem os finais de semana, mas não dá... Eu saio de casa cedo, chego à noite. Chego morto. Minha jornada é de oito horas, com almoço, nove... Então hoje não, dentro do banco não tem essa possibilidade. Dois meses atrás eu tava como assessor e tava querendo sair, e tava bem... Eu fui campeão do programa de metas no primeiro semestre como assessor. Mas, assim... Fui campeão, mas foi muita pressão, e eu falei: Meu, se hoje surgir alguma oportunidade, eu saio do banco. Aí eu fui promovido. Nessa semana, uma amiga minha falou: Tenho uma proposta para te fazer, vai estudar inglês, fica uns três meses que eu te arrumo um trabalho... Se tivesse aparecido isso há uns dois meses atrás, meu... Eu tava lá. Hoje eu já não sei se tomaria essa decisão. Acabei de ser promovido, então eu tô naquelas, ainda acho que eu consigo dar um gás aqui no banco pra ver o que eu faço. (Bancário, Gerente de Contas, 25 anos, 04 de banco) 
Têm os direitos e muitos benefícios, acho que é por isso que às vezes quando surgem outras oportunidades você fica meio que com medo de sair porque você fala...É bom o trabalho... Não é em toda a empresa que você vai conseguir tudo o que você tem dentro do banco. É difícil, muito difícil mesmo. (Bancário, Gerente de Contas, 25 anos, 04 de banco)

Meus amigos e familiares acompanham a forte pressão que é trabalhar no banco. De um lado, você tem a boa remuneração e o status de trabalhar no banco, tem boa colocação socioeconômica na sociedade, mas, de outro lado, eu desenvolvo um trabalho extremamente estressante, extremamente pesado, com uma pressão muito forte. Não pretendo continuar no banco minha vida toda, não no banco privado pelo menos, este é um objetivo de curto prazo, talvez médio. Estou fazendo História, então talvez lecionaria. Quero acumular capital para poder lá na frente adquirir uma casa.

Não me sinto realizado devido à forte pressão e à constante ameaça de desligamento pelo não cumprimento das metas. Não é saudável trabalhar em banco. É um bom trabalho, mas você sabe que trabalha em um lugar oneroso. É a mesma coisa que um profissional que trabalha em uma área de risco e se aposenta cedo, ele gosta de trabalhar ali, ele tem uma recompensa por trabalhar ali, mas ele tem também outro lado. Já pensei em sair do banco. Hoje estou estudando pra concurso público em banco, para ter estabilidade maior, essa ameaça constante do banco privado eu não vou ter. (Bancário, Gerente de Contas, 32 anos, 07 de banco)

Os entrevistados, quando elaboram perspectivas de superação para o estado de coisas relatado, apontam saídas individuais como a de se preparar para um concurso público, ocasião em que são reforçados os valores de estabilidade no emprego.

Eu acho que a gente tem bastantes benefícios e eu gosto de ser bancária. Só que assim, hoje se você for ver, eu tô um tanto quanto infeliz porque eu sou Gerente Operacional em um cargo, mas eu não sou operacional, se eu fosse eu não teria meta de vendas. Inclusive, uma coisa que me incomoda muito é a meta a cumprir, que é da minha equipe, mas se eles não baterem a meta quem é demitida antes deles sou eu, porque eu sou responsável pra entregar... Hoje o que eu penso é que eu tenho que prestar um concurso público pra sair antes de ser demitida. Tudo hoje gira em torno de vendas e eu não tenho esse perfil de vendas. Eu até tento, sabe?! Faço o possível, acho que a gente tem que se adaptar, mas não é aquilo que eu gosto de fazer, que se eu gostasse de vender eu ia trabalhar de vendedora, porque se você ainda é vendedora de uma loja, o cliente entra lá pra comprar, por exemplo, um carro, aí você vai oferecer seu produto. É diferente do cara entrar no banco pra pagar uma conta de água e ter que sair com uma previdência. (Bancária, Gestora Agência, 35 anos, 16 de banco)

As consultorias de $\mathrm{RH}$ chegam a estimar tempo médio para viver uma experiência em uma grande empresa. Elas consideram que nesses ambientes a passagem do trabalhador deve respeitar o tempo de adaptação, realização e consequentemente 
estabilização de resultados, ao fim deste ciclo fica subentendido que seu tempo foi completado. A "estabilidade" não interessa às empresas, por isso a todo o momento são evocadas ações que sinalizem inovação e criatividade por parte dos trabalhadores, demonstradas no sentido de construir novas formas de trazer resultados e rentabilidade. Se mais "velho", mais tentativas já foram feitas, mais derrotas já foram sentidas, menos "ilusão" tem o trabalhador, como um dos jovens entrevistados afirmou ao se referir criticamente a experiência vivida no $\operatorname{Banco} \Delta$.

Não será demais frisar que a noção "provisório-definitivo" atribuído ao emprego bancário por Romanelli (1978) deve ser situada dentro do território no qual o autor pesquisava, qual seja, um banco público. Isso significa que, atualmente, em especial no caso destacado para este estudo, precisamos levar em consideração o contexto específico do qual tratamos, qual seja, a empresa privada, pois seguindo a legislação nacional tem permissão para promover a dispensa imotivada, o que nos faz insistir que pesa sob este segmento o fator rotatividade, sendo o desligamento por parte do empregador algo corriqueiro. Assim, podemos concluir que o emprego de tipo "definitivo" não se encontra no campo das opções dos trabalhadores cada vez mais ameaçados e pressionados, tornando-se algo viável para grupos cada vez mais reduzidos.

Os trabalhadores entrevistados, quando acenam com a perspectiva de querer se manter na instituição pesquisada, apesar de terem clareza das adversidades a que estão submetidos, racionalizam sobre sua condição de "empregado dependente", nos termos atribuídos por Mills (1969a), que lhes proporciona a inserção no mercado de consumo e, ainda mais do que isso, a possibilidade de autovalorização e prestígio, ainda que esta percepção seja mais fortemente externalizada, vinda daqueles que pertencem ao seu ciclo social.

Analisando as entrevistas realizadas para esta pesquisa, foi possível identificar algumas tendências predominantes no pensamento dos trabalhadores. Para uma parte dos entrevistados o emprego bancário surge como algo passageiro, como um trampolim que lhe serve como esteio para conseguir ou manter sua estabilidade financeira, portanto, algo em tese "provisório". Para outra parte há uma perspectiva, ainda que remota, que possam se desenvolver e construir carreira na instituição, o que colocaria em tese uma perspectiva "definitiva", uma relativa estabilidade.

De toda a forma a percepção do emprego bancário ou de uma carreira bancária passa por uma perspectiva socialmente construída, à luz do seu tempo e das condições 
objetivas e subjetivas vividas tanto no interior da grande corporação como em suas relações exteriores com o mundo, onde os indivíduos interagem e ressignificam suas ações.

A experiência de trabalho em instituições financeiras é marcada por percepções ambíguas que refletem o quanto as relações sociais são complexas e obedecem a inúmeras variáveis, tornando nossa análise algo desafiador quando buscamos superar a velha visão dicotômica entre bem ou mal.

\subsection{Carreira}

Nas últimas décadas foi forjado um novo ambiente de trabalho nas instituições financeiras que acompanhou o movimento econômico-cultural do capitalismo baseado em um padrão flexível. Nesse âmbito houve o enfraquecimento da ideia de empresa verticalizada com tradição fordista-keynesiana. Como explicou Sennett (2002), essa tradição, marcada por um lócus de trabalho regular, conferia a possibilidade de construção de uma carreira profissional em uma perspectiva de longo prazo.

A noção de curto prazo permeia e absorve cada vez mais a definição da carreira atual, deixando trabalhadores à deriva tanto econômica como ética na análise de Sennett (2002). Da falta de perspectivas futuras gera-se a experiência dos indivíduos com a "deriva do tempo". A incerteza torna-se parte do cotidiano vivido no mundo do trabalho.

A ideia de ficar muito tempo em uma mesma empresa pode levar a crer que o indivíduo se acomodou e não tem potencial para alçar novos voos. Assim, no novo espírito do capitalismo, quanto mais o trabalhador correr risco mais ele inscreve seu nome no livro das virtudes.

No Banco $\Delta$ entre 2012 e 2014 foram eliminados 11.586 postos de trabalho (Relatório Gerencial Bancos 2012, 2014). Diante desse cenário a ideia de superação constante, no que concerne o cumprimento de metas de trabalho, é difundida pelos gestores como uma forma de escapar da "deriva econômica" ou em outros termos do desemprego.

O homem forjado para desempenhar sua função na produção flexível é aquele que compreende o valor de viver sob instabilidade, sem vínculos fortes, mudando de função e principalmente de empresa, fazendo dessa prática uma virtude em si mesma a despeito da conjuntura e das condições objetivas que se encontram os grupos de 
trabalhadores dentro da mesma unidade de trabalho ou categoria profissional. Nessa defesa empenhada pelos diversos agentes representantes do capital contra a estabilidade e períodos longos na mesma empresa, busca-se refutar a acomodação ou manutenção do indivíduo em sua "zona de conforto".

Castells (2005) traz ponderações relevantes sobre as nuances que envolvem as relações entre capital e trabalho contemporâneas:

A noção de uma carreira profissional estável, previsível entrou em erosão, na medida em que as relações entre capital e trabalho foram individualizadas e as relações contratuais do segundo escapam à negociação coletiva [...] Contudo, este processo de individualização e fragmentação da força de trabalho não significa que os contratos a longo prazo e os empregos estáveis tenham desaparecido. É uma estabilidade construída dentro da flexibilidade. E existem diferenças consideráveis para as várias categorias de trabalhadores e níveis de qualificações (CASTELLS, 2005, p. 21).

No Banco $\Delta$ ainda é possível encontrar trabalhadores atuando em longos períodos. Contudo, são cada vez mais rarefeitas as experiências que remetem à construção de uma carreira profissional bancária alicerçada por décadas na mesma instituição, quando paralelamente se constrói uma história de vida para o trabalhador e sua família, culminando com o momento da aposentadoria. $\mathrm{Na}$ instituição citada, considerando as informações disponibilizadas pelo Relatório Gerencial, cerca de 0,08\% do total de trabalhadores conseguiu entre 2012 a 2014 completar trinta anos na instituição. $^{119}$

A retórica difundida pelas consultorias de $\mathrm{RH}$, revistas especializadas e ainda contida nas diversas formas de comunicação da instituição por nós consultada busca sedimentar uma determinada noção de carreira no mercado de trabalho, baseada na transitoriedade, com foco no curto prazo, pois se ampara ascensão hierárquica derivada dos resultados objetivos alcançados. Assim, perde força a visão de carreira tradicional em que havia uma sequência linear e ascendente de cargos na mesma empresa, dada em função do histórico profissional e tempo de casa, e se cristaliza a gestão da carreira por si próprio, que aponta que o indivíduo diligente, disciplinado e com mérito será recompensado (ARONI, 2011).

Em torno do tema carreira existe um discurso de caráter universal que visa atingir todos aqueles que estão ou pretendem entrar no mercado de trabalho. Trata-se de uma narrativa em que a princípio todos podem alcançar boas posições, bastando para

\footnotetext{
${ }^{119}$ De acordo com matéria no jornal sindical Folha Bancária (dez. 2014), a festa bianual promovida pelo Banco $\Delta$ para homenagear cerca de 700 trabalhadores que completaram 30 anos na instituição conta com o discurso presencial de agradecimento do presidente do banco, em que um relógio folhado a ouro é distribuído para cada participante.
} 
isso seguir as orientações dos formadores de opinião que circulam repetidamente nos mais diversos canais. Os caminhos para ser bem-sucedido passam pelo comportamento, pelas atitudes que o indivíduo deve ter, e, como não poderia deixar de ser, pelas suas realizações.

Em uma revista especializada em carreira, que tivemos a oportunidade de analisar, ${ }^{120}$ percebemos que apesar do discurso universal, a maior parte das orientações dos consultores se aplica àqueles que têm expectativa de atingir cargos de gestão ou executivos como se isso fosse possível para a grande massa de trabalhadores, a qual realiza múltiplas tarefas operacionais ou intermediárias constantes na hierarquia funcional das empresas. Ao desconsiderarem as heterogeneidades, as segmentações do mercado de trabalho e, sobretudo, o quanto o topo das pirâmides é estreito, pode-se concluir que cumprem o papel de forjar um consenso sobre a perspectiva de carreira que, trocando em miúdos, serve para orientar a conduta ideal para o trabalho influenciando diretamente as novas gerações.

A pirâmide hierárquica nas instituições tem sido comprimida e na prática existem chances mais reduzidas impostas por um sistema que opera como um funil no qual a proporção de demandantes não é a mesma daqueles que conseguem alcançar posições de nível elevado. No Banco $\Delta$, no universo de 86.192 trabalhadores em 2014, foram registradas 13.830 vagas ocupadas por diretores e gerentes, ${ }^{121}$ perfazendo um percentual em relação ao número total de participantes de $15 \%$.

De acordo com o consultor de RH entrevistado para esta pesquisa,

o banco tem uma base operacional muito ampla, então a possibilidade de alguém que entra na base fazer carreira é muito pouco provável, porque é uma realidade de alto turnover... E se a pessoa ficou muito tempo em uma função da base isso não interessa para o banco, por conta do salário, de motivação, espaço que está ocupando e bloqueando o caminho de outro. Existem as posições gerenciais, mas elas vão se afunilando, então eu não tenho espaço para todo mundo que está se desenvolvendo. (Consultor RH entrevistado)

Poucos passarão pela triagem corporativa atingindo postos mais elevados, contudo o passo a passo para obter êxito, o discurso que paira no mundo corporativo para atingir o sucesso, se transforma em um conjunto de obrigações permanentes sobre

\footnotetext{
${ }^{120}$ Revista Você S.A. (várias edições 2013, 2014 e 2015).

${ }^{121}$ De acordo com o Relatório Gerencial Banco $\Delta$ 2014. Ponderamos que nem todo cargo de "Gerente" é equivalente a de "Gestor", ou seja, aquele que faz o gerenciamento de unidades, áreas, departamentos ou equipes, com subordinados diretos. Muitos dos gerentes nas instituições bancárias são "Gerentes de Contas", função relacionada ao gerenciamento da carteira de clientes.
} 
o modo de ser e estar, enquanto paralelamente aqueles que não se encaixam são expurgados.

A noção de sucesso profissional, de acordo com o que pudemos apreender nas entrevistas com trabalhadores, no discurso difundido pela corporação analisada e nas diversas consultorias pesquisadas, baseia-se nos seguintes eixos:

a) valorização econômica;

b) posição hierárquica que confere status ao indivíduo;

c) reconhecimento dos pares ou subordinados;

d) satisfação ao ver seu trabalho como algo relevante para alguém que não seja a si próprio.

A perspectiva de ter sucesso profissional e construir carreira norteia as expectativas e as frustrações dos empregados constituindo-se em um paradoxo, pois, se por um lado, atua como base motivacional, por outro, deixa claro que as condições são adversas e as chances limitadas nesses ambientes causam desalento.

Eu acho que a princípio tem perspectiva de carreira. Mas dependendo da área que você tá, as pessoas acabam desistindo disso. Lá na central tem pessoas que têm vinte anos de banco e vinte anos na central, entendeu? Então eu acho que não é porque tá cômodo pra eles, é porque realmente eles veem que as vagas não são acessíveis pra todos. Você tem que estar em um grupo, se você estiver na agência você só desempenhar o seu trabalho, não é suficiente pra você crescer. Você tem que superar tudo. Se você é um Caixa, eu conheço Caixas que batem todas as metas, mas que estão há cinco anos como Caixa, não tem uma oportunidade pra virar um Assistente Operacional. Mas eu também entendo que vai do interesse de cada um. Se você tá em uma área que você não vê oportunidade, tenta mudar mesmo que seja lateralmente. Foi o que eu busquei, na central de atendimento eu não via essa oportunidade de crescer, lá não existe. Eu entendi que eu vou tentar ir pra área de agências, vamos ver o que vai acontecer. Mas existem sim promoções... Existem, mas enfim, não é pra todo mundo. (Bancário, Agente Comercial, 29 anos, 07 de banco)

Nem eu nem os colegas têm perspectiva de carreira... Aqui tem uma pessoa que está há 04 anos e já não tem perspectiva de ter promoção, ele não é ruim, porque é mau profissional, senão ele não estava lá, e é promovido quem? No banco em determinado período 02 pessoas terão um aumento de mérito e uma promovida, no meu setor tem 10 que têm condições pra ser promovidos, como faz? (Bancário, Analista Júnior, 42 anos, 12 de banco)

Para sair de Analista Júnior para Pleno você tem que atingir avaliações anuais no eixo $x$ e $y$. Você é avaliada pelo relacionamento, pelas suas entregas, por cumprir suas metas, e não basta só isso. O que o banco diz para você: Que além das suas 
metas, você é bom quando você dá ideias, quando você faz além do que acordou com o gestor. É muito difícil. (Bancária, Analista Júnior, 57 anos, 12 de banco)

De acordo com a declaração de uma gestora do Bancos reproduzida a seguir, a mobilidade na carreira é possível. Contudo, a mesma ressalta que essa condição implica variáveis que impossibilitam pensar em carreiras de longo prazo, dado o nível de exigências e pressão para atingimento de resultados atualmente predominante:

Antigamente o processo de carreira era muito mais estruturado, demorava, mas acontecia. Mas, por outro lado tem gente com um ano de banco que vai pra gerente e não dá certo porque você não sabe lidar com muitas situações. É suicídio e aí você é desligado muito rápido, porque cai em um golpe, cai em um assalto que você não sabe como proceder, erra em um processo. Porque as pessoas na área administrativa são desvalorizadas, não são preparadas e treinadas, não conseguem lidar com dinheiro, com reclamação de clientes, falta funcionário. Há muito curso para área de vendas, tudo quanto é venda, mas para lidar com as rotinas do dia a dia, não. E exige muito das pessoas. $\mathrm{O}$ banco tem uma cobrança muito ferrenha em cima de processos, a gerência de compliance, a ISO 9000, e se a vistoria chegar lá e não estiver do jeito que foi estabelecido na regra, você vai pra rua, então por isso que eu estou dizendo que é suicídio. São poucos os que conseguem fazer carreira, por que a maioria não consegue produzir como o banco quer. Porque você vai dinamitando os caras. Não é fácil sobreviver muito tempo. Hoje na minha leitura, a vida útil de um bancário, eu duvido que dure mais que dez anos, antigamente você ouvia dizer que as pessoas queriam se aposentar dentro do banco, e tinha situações de pessoas que se aposentavam com 30 ou 35 anos. Hoje as pessoas estão sobrecarregadas, estão com olheira, estão inconformadas e as pessoas ficam até quando der. Antes, mesmo que a pessoa não tivesse perfil para vender, o banco arrumava um lugarzinho para essa pessoa, então elas iam ficando, hoje em dia é assim, se você tem perfil você fica, se não tem você sai e outros vêm, por isso que a rotatividade dentro do banco é tão grande. (Bancária, Gestora Regional Agências, 43 anos, 16 de banco)

Em nossa análise o modelo de gestão por resultados, que vigora no Banco $\Delta$, prevê em seu desenho passagens mais rápidas na organização, sobretudo para áreas em que há comercialização de produtos e serviços bancários, pois o ritmo intenso de trabalho aliado aos controles mais sofisticados tornam essa experiência um tanto quanto exaustiva física e mentalmente para os participantes que tendem à queda de produtividade com o passar do tempo, pois é muito difícil se manter sempre no topo das classificações e avaliações. 


\subsubsection{As novas gerações e as percepções sobre carreira}

Os termos "Geração X" e "Geração Y" fazem parte de um conjunto de neologismos adotados por consultores de RH que visam identificar grupos de trabalhadores conforme o período político, econômico e social em que nasceram e se desenvolveram, para a partir deles estabelecer perfis. De acordo com Santos (2011), diversos autores buscaram reunir características predominantes separando-os por períodos, entretanto não há um consenso sobre qual a datação exata de cada período, sendo que ele pode variar considerando os acontecimentos locais de cada país.

Lancaster e Stillman (2011) classificaram a entrada das gerações que atuam no mercado de trabalho a partir dos seguintes grupos: GeraçãoY - nascidos entre 1982 e 2000; Geração X - nascidos entre 1965 e 1981; Baby Boomers - nascidos entre 1946 e 1964; e Tradicionalistas - nascidos antes de 1946.

Essas classificações não são consideradas tão relevantes para esta pesquisa, entretanto, por serem evocadas pelos próprios entrevistados, por estarem contidas nos discursos das consultorias e das corporações, sentimos a necessidade de fazer uma rápida contextualização sobre os termos.

No Banco $\Delta$ há uma elevada participação de jovens com até 30 anos. O perfil das gerações de trabalhadores participantes na instituição se divide da seguinte forma:

\begin{tabular}{cc}
\hline Tabela 5 - Gerações de trabalhadores Banco $\Delta$ \\
\hline (por faixa etária) & Participação \\
\hline Abaixo dos 33 anos & $\mathbf{3 8 \%}$ \\
$33-46$ & $\mathbf{2 8 \%}$ \\
$47-65$ & $\mathbf{1 5 \%}$ \\
Acima de 65 & $\mathbf{0 , 0 5 \%}$ \\
\hline Fonte: Revista Banco4, mai. 2012. Elaboração da autora.
\end{tabular}

Interessados em conhecer a percepção dos jovens sobre o emprego na grande corporação bancária estudada, traremos à tona algumas das suas posições. Partimos do pressuposto que determinadas afirmações generalizadas vindas das consultorias e similares pedem maior ponderação, sobretudo quando aparentes diferenciações em relação às gerações passadas são enfatizadas.

Vejamos o que diz a seguir o consultor de RH sobre a postura das novas gerações com relação à carreira:

Comprometimento com a carreira era colocar em segundo plano saúde, família, submetendo-as à vida profissional, por conta das dificuldades do mercado desfavorável. A Geração Y, que teve sua formação a partir do final dos anos 1980, não se compromete, tem 
apreço pela vida e família, então tende a colocar o trabalho subordinado a isso. A cultura da empresa diz que se você saiu às $18 \mathrm{~h}$ está descomprometido. E esse jovem entra no mercado de trabalho em um momento em que há muita demanda e pouca oferta. (Consultor de RH entrevistado, grifo nosso)

A polarização existente entre a visão de comprometimento com a carreira, supostamente atribuída às gerações nascidas antes da década de 1980, e o "descompromisso" das gerações que passaram a entrar no mercado de trabalho posteriormente, em nossa análise só poderia admitir algum fundamento se respaldada no contexto socioeconômico pelo qual foram forjados. Ou seja, como aponta o próprio consultor, são os movimentos de demanda e oferta de emprego que tornam os trabalhadores mais submissos e os fazem colocar em segundo plano a família.

Assim, não compreendemos que as novas gerações mantenham sobre sua experiência no trabalho uma visão diferenciada com relação às gerações anteriores.

Se tomarmos por base as razões que levaram um jovem entrevistado, pertencente à Geração Y, a se retirar do Banco $\Delta$, teremos de considerar que foi a sua expectativa frustrada de ascensão na carreira o fator desencadeador. Em sua narrativa, apesar de deixar claro que dispunha de menos tempo para a família e amigos, que o ritmo de trabalho era intenso, foi a frustração de se sentir tão capaz, tão disponível e ainda assim ter pouca perspectiva:

No Banco $\Delta$, pra ser promovido é muito difícil [...] mas quando você entra em uma instituição como o banco que te promete mundos e fundos, e por aí vai, você pensa: vou fazer carreira. E você se depara com a realidade, isso varia muito da percepção de cada um com o tempo, mas todos vão chegar à mesma conclusão, não vale a pena. O banco pode até mascarar, promete-se coisas maravilhosas, mas quando você vê na verdade não é nada disso, o seu trabalho em si no banco, você sempre trabalha por mais de uma pessoa, as vezes dois ou mais, em seis meses você aguenta mas depois você sofre as consequências, sua consciência muda, a Geração Y tem muito menos tolerância a aguentar isso. Se eu ganhasse uma remuneração maior justificaria eu ficar até mais tarde, por exemplo. A questão é que tem Geração Y casada, com filhos, e tem solteira, namorando, em outra condição, que tem independência financeira, isso varia muito com o grau financeiro da sua família ou seu próprio te possibilitam tomar atitudes mais drásticas como a que eu tomei (pedir demissão). Mas 90\% das pessoas não conseguem sair porque eu conheço muitas pessoas ali que embora sejam Geração Y precisam do dinheiro, embora o banco pague mal, para aquilo que você faz. (Bancário, Analista Júnior, 29 anos, 04 de banco, grifo nosso)

Na opinião do jovem entrevistado, o esforço sem retribuição não vale a pena. Entretanto, ele próprio ressalta que dadas as condições socioeconômicas de cada 
indivíduo, o que prepondera é a escolha racional pela manutenção de sua relação de trabalho, em um movimento de adaptação à cultura corporativa.

Nogueira (2015) e Ostronoff (2015) em suas pesquisas apontaram que os jovens bancários têm como objetivo a ascensão profissional no interior das instituições o que os levam a suportar diversas adversidades no ambiente de trabalho. Colombi (2014) ao observar a composição da força de trabalho nos bancos privados, entre 2000-2010, apontou convergência com os autores citados. Sua pesquisa demonstrou que há predominância de trabalhadores mais escolarizados e jovens. A autora frisa que esse segmento é influenciado pelos valores da sociedade em que estão inseridos, como o individualismo e a competitividade, análise sobre a qual mantemos concordância.

O grau de "descomprometimento" dos jovens com a empresa se coloca mais pela falta de reciprocidade às expectativas criadas, do que por contestar o modelo de trabalho. De acordo com dados disponibilizados pelo Banco $\Delta$, há um índice de $84 \%$ de retenção do público de trainees entre os anos de 2012 a $2014 .{ }^{122}$ Os trainees fazem parte de uma "elite" de jovens selecionados para atuar nas grandes corporações em cargos-chave, com maior poder de influência e mais valorizados economicamente.

Os estagiários de nível superior e trainees são parte da força de trabalho jovem das grandes corporações. Freitas (2007), em sua análise sobre a organização das carreiras nas grandes empresas, comentou sobre esses dois grupos retomando mais uma vez a questão do "comprometimento", nesse caso a autora estabelece uma relação direta com a recompensa material, o que a distancia das visões mais romantizadas que relacionam os jovens de determinada geração, por exemplo, a "Y", como agentes da mudança de um modo de pensar e viver a experiência no trabalho.

A nova geração de estagiários e de trainees foi saudada com um capital próprio, e a questão da falta de compromisso com a organização não demorou a aparecer; muitos deles foram acusados de ser desleais e estrategistas interessados apenas em recompensas materiais. (FREITAS, 2007, p. 54)

Dialogando com as ideias trazidas à tona pela autora, a crítica direcionada aos empregados "desleais" visa mais uma vez culpabilizar o próprio trabalhador, pois apesar de ter obtido uma "grande oportunidade", não foi o suficientemente grato e subserviente quanto se esperava.

A declaração de um estagiário entrevistado aponta para a perspectiva de construir carreira na instituição bancária, estando claramente motivado a ocupar

\footnotetext{
${ }^{122}$ Relatório Gerencial Banco $\Delta 2014$.
} 
posições elevadas. Apesar do pouco período de experiência, ressaltamos, na função de estagiário, ele já pensa em ocupar uma vaga na diretoria.

Quando eu entrei no Banco $\Delta$ eu tinha a intenção de fazer realmente carreira, é uma coisa que me agrada, um lugar onde eu sempre quis trabalhar, uma empresa grande, um banco... Me agrada e eu sempre quis fazer carreira. E eu também, particularmente, nunca pensei muito pequeno assim, não queria ficar como Analista para o resto da vida. Eu sempre pensei em fazer carreira e ir tentando uma gerência, uma superintendência, quiçá uma diretoria, né?! Então minha meta sempre foi essa. (Estagiário, 23 anos, 05 meses de banco)

Consideramos relevante observar que o próprio processo de seleção coloca um nível de competição muito elevado para ocupar vagas nas grandes corporações, situando tais segmentos, como estagiários de nível superior e trainees, em um patamar de idealização insustentável, pois o pragmatismo dos resultados a serem alcançados devora em muitas circunstâncias o sonho plantado na cabeça deste público composto por jovens. Quando as “promessas” do mundo corporativo não se confirmam na prática, há desmotivação que pode encontrar razões na morosidade da ascensão na carreira, na retribuição monetária considerada insuficiente ou pelas características do processo de trabalho em si, muitas vezes incoerente com os princípios gerais que a instituição havia divulgado, sendo burocratizado, pouco criativo, sem autonomia, restrito e, porque não dizer, repetitivo.

Os programas de estagiários com nível superior e trainees ${ }^{123}$ são amplamente divulgados nas principais universidades. Contam com marketing direcionado para o público jovem e evocam nas chamadas aqueles que se identificam com os valores de transformação social, que buscam a construção de um mundo melhor, que sejam inquietos, com potencial criativo e queiram superar limites.

Os jovens que entraram no mercado de trabalho na década em curso, pertencentes à Geração Y, têm sido caracterizados pela familiaridade em manusear as novas tecnologias disponíveis, mas para além disso têm sido insistentemente classificados pelas consultorias e outros veículos de opinião como “jovens que não

\footnotetext{
${ }^{123}$ Os processos de seleção para trainees no Banco $\Delta$, assim como os demais programas das grandes corporações, são altamente disputados pelos jovens em nível nacional. Em 2009, houve 34.287 inscritos, com 487 finalistas, entre os quais foram selecionados 87 candidatos (Relatório Gerencial Banco $\Delta$ 2010). Os jovens devem reunir os seguintes pré-requisitos: cursando o último ano da graduação ou até dois anos de formado; pertencente ao curso de exatas e humanas; com inglês avançado e disponibilidade para morar em São Paulo. O programa contém três macroetapas: a) integração - prevê integração com duração de um mês, realizando neste período treinamento interno; b) generalista - o jovem passará pelas principais áreas para conhecer processos-chave; e c) especialista - atuará na área de alocação final com responsabilidades e metas preestabelecidas. O programa ainda conta com mentoring, um executivo do banco que acompanha o processo de aprendizagem; possibilidade de experiência internacional para complementar a aprendizagem; encontros com lideranças do banco; e participação em projetos sociais. Fonte: material de divulgação do Banco $\Delta$ distribuído na Faculdade de Direito/USP, maio, 2015.
} 
hesitam em colocar a realização pessoal e profissional acima da segurança de um emprego fixo ou respeito a uma hierarquia rígida". ${ }^{124}$

A questão central que se coloca em meio a estas posições está no crédito que damos à suposição de que há um novo "modelo mental" do qual esses jovens são portadores.

O conteúdo preponderante da fala dos entrevistados indica que a perspectiva da Geração Y não tem uma envergadura moral diferenciada, uma postura que traga novos valores no trabalho, talvez ao contrário, apenas reafirme uma visão de sucesso condicionada à ascensão na carreira e remuneração mais elevada, o que aparentemente tem condicionado sua saída voluntária da instituição, combinada a uma situação favorável relacionada à idade e aos compromissos pessoais que estão sob sua responsabilidade, o que lhes possibilita correr certo risco e apostar em novas oportunidades de construir carreira em outro lugar, sobretudo quando, ao mesmo tempo, se observou um mercado de trabalho mais amigável, com menores taxas de desemprego, como foram aquelas sentidas na última década. ${ }^{125}$

Isso nos leva a questionar a ideia de que há uma nova geração que prioriza a família, os amigos, o lazer, a saúde em detrimento do trabalho, pois se por um lado há aqueles que reúnem condições para superar a insatisfação presente, por outro lado há pessoas que se mantêm no emprego, ainda que lhes faltem perspectivas melhores no Banco $\Delta$, por avaliarem que pesam mais os prós do que os contras.

Certamente, as trajetórias de vida dos trabalhadores, se mais preparados, se mais jovens e com menos compromissos que envolvam outras pessoas ou que ainda se encontrem em situação econômica não vulnerável, são fatores relevantes para explicar suas escolhas, assim como sempre ocorreu com gerações passadas. De acordo com Super (1957, apud DUTRA, 2002), a pessoa submetida a um conjunto de pressões socioeconômicas, sobretudo na idade adulta quando assume compromissos que extrapolam a si mesmo, tende à estabilização.

\subsubsection{Retóricas acerca da carreira e emprego}

A retórica dominante sobre a carreira evoca conceitos como empregabilidade e empreendedorismo de si mesmo em um contexto social que aprofunda a divisão do

\footnotetext{
${ }^{124}$ Jornal Claro! ECA - USP. Julho, 2011.

${ }^{125}$ De acordo com dados disponíveis em matéria no site da UOL: "A taxa de desemprego no Brasil caiu de 12,4\% em 2003 para 5,4\% em 2013. Em dez anos a taxa caiu 07 pontos percentuais". Disponível em: http://economia.uol.com.br/empregos-ecarreiras/noticias/redacao/2014/01/30/em-10-anos-numero-de-desempregados-cai-pela-metade-mostra-ibge.htm.
} 
trabalho. Ambos conceitos foram forjados em um mercado de trabalho desfavorável submetido às diversas reestruturações produtivas pelas quais as empresas passaram no Brasil pós abertura econômica na década de 1990. Neste período convergiram o aumento dos processos de terceirização, participação de consultorias atuando internamente e trabalhadores atuando no modelo PJ. Essas particularidades nortearam o aprofundamento da divisão entre núcleo de trabalhadores contratados diretamente e aqueles que são subcontratados.

A empregabilidade é a condição que o empregado tem para se manter atrativo no mercado de trabalho e ser capaz de acessar uma vaga ou manter-se naquela em que está. Dentro do conceito podem estar embutidas capacidades técnicas, escolaridade, conhecimentos de outros idiomas, certificações profissionais, e, como não poderia faltar, "postura", ou seja, aquilo que conecta o trabalhador com as necessidades subjetivas que a empresa espera. O comportamento é assim também um capital que o trabalhador tem para oferecer, suas habilidades emocionais e suas atitudes são fundamentais para lhe conferir boas condições no disputado mercado.

As consultorias, pautadas pela necessidade constante de apresentar algo novo, criam e recriam conceitos aleatoriamente como "trabalhabilidade". Em sintonia com as expectativas das grandes corporações, essas consultorias visam orientar o mercado de trabalho, como pode ser observado no trecho de um artigo publicado na revista corporativa destinada aos trabalhadores do $\operatorname{Banco} \Delta$ :

Durante muitos anos, vivemos em um país fechado, com ciclos de emprego longos e pessoas preparadas para trabalhar em uma empresa e se aposentar nela. A abertura da economia fez com que os profissionais tivessem de pensar na sua competitividade no mercado. Surgiu o termo "empregabilidade", que significava o valor de uma pessoa no mercado. Nos anos 2000, contudo, esse conceito começou a se mostrar falho: os novos tempos exigiriam pensar além do emprego tradicional, transformando o conhecimento em trabalho, seja como empregado, consultor, empreendedor, investidor ou qualquer outra forma de gerar renda. A trabalhabilidade é a estratégia de sustentação da carreira no longo prazo (Revista Banco A, mar. 2015, grifo nosso)

A mensagem acima relatada é explícita na orientação de que o trabalhador não deve apostar em empregos de longo prazo, o que afasta automaticamente a perspectiva de construir carreira na mesma empresa. Em uma clara alusão à noção de sustentabilidade, termo amplamente utilizado no meio empresarial, o trabalhador deve, portanto, "sustentar" sua carreira no longo prazo, como uma sucessão de reinícios, 
sendo que para isso deve vislumbrar novas formas possíveis de continuar a trabalhar independente do emprego tradicional.

Para o consultor de RH Max Gehringer, popularizado por sua participação em programa na TV aberta e também no rádio, a "era do empregado" se encerrou no século passado e agora estamos sob a vigência da "era do empreendedor". Segundo ele,

as vagas de emprego diminuíram, e, por outro lado, aumentou bastante o número de consultores, profissionais autônomos, que decidiram que trabalhar por conta é melhor do que trabalhar pela empresa. (Entrevista disponível no YouTube https://www.youtube.com/watch?v=BQQnUddzyiU).

Observamos que há uma generalização na fala do consultor, que apenas quer reforçar conceitos e paradigmas. A figura do empreendedor a que o consultor se refere de modo positivo em muitas situações está associada às grandes corporações, mantendo uma relação de subordinação direta. Nem toda nova forma de relacionamento, por exemplo o modelo de contrato de curto prazo reconhecido como PJ - Pessoa Jurídica, pode ser algo mais vantajoso do que ser empregado contratado diretamente.

A grande corporação destacada para este estudo constou seguidas vezes no Guia As Melhores Empresas para você trabalhar e ainda foi eleita a primeira no Guia As Melhores Empresas para Começar a Carreira, ambos publicados pela revista Você S/A. As revistas especializadas, direcionadas ao tema da carreira e emprego, ao reproduzirem matérias e resultados de pesquisas deste tipo, estão continuamente difundindo a ideia de que boas empresas são, dentre outros aspectos, aquelas em que se pode fazer carreira, em que há possibilidade de ascensão. Entretanto, contraditoriamente, apesar de tais prêmios remeterem a um local ideal de trabalho, são os próprios consultores que fazem questão de explicar que não se deve ficar no mesmo lugar por muito tempo.

Os participantes inseridos neste contexto vivenciam um impasse diante da falta de coerência entre as promessas de realização pessoal e as experiências concretas dos indivíduos, materializadas pelo interminável esforço ou quando não o próprio fracasso.

Aqueles que almejam uma carreira de sucesso deverão despender grandes esforços em curtos períodos, pois no receituário organizacional flexível não é permitido apostar em trajetórias longas. Para justificar essa perspectiva, sustenta-se que a diversidade de vivências corporativas são positivas tanto para os trabalhadores como para as organizações.

Contudo, como ressalta Sennett (2002), essa dinâmica cultural predominante não se faz sem um custo pessoal elevado, pois a flexibilidade causa ansiedade, as pessoas 
não sabem que riscos serão compensados e ficam desorientadas. Lealdade, compromisso mútuo e confiança precisam de tempo para se estabelecer nas relações sociais. As carreiras, como caminhos trilhados em períodos longos, contribuíam para fortalecer valores e consequentemente laços de convivência. Assumir o controle da carreira era ao mesmo tempo assumir o controle de sua vida, segundo analisou Sennett (2002).

Os ciclos que marcam a carreira, sob a lógica da gestão pós-fordista, devem se refazer pelo recomeço da trajetória em várias empresas ou por meio de novas relações de trabalho mais flexíveis. A experiência de longo prazo tornou-se disfuncional.

Mas, como alerta Sennett (2011), há uma questão de classe posta. Aqueles que têm uma situação mais privilegiada ou são parte da elite econômica não estão premidos pelo tempo, não precisam planejar sua vida pensando no longo prazo, pois já possuem condições materiais suficientes para sobrevivência. Assim, elementos de incerteza relacionados ao emprego e à carreira tendem indiretamente a favorecer a desigualdade e a concentração de renda.

Considerando a diversidade de cargos e ocupações existentes em um banco, sabe-se que é um tanto quanto mais fácil mudar de empresa com perspectiva de valorização da carreira quando se trata de um cargo de alta posição na hierarquia funcional.

É oportuno mencionar que a experiência acumulada por um executivo tende a ser mais valorizada no mercado de trabalho do que a experiência de alguém que exerce funções operacionais. No setor bancário, quando existem condições mais favoráveis do que a média praticada pelo mercado de trabalho, relativas à renda, direitos e benefícios, o trabalhador de nível hierárquico inferior inclina-se para a estabilidade, pois, como demonstra a trabalhadora entrevistada a seguir, ter um salário acima da média e experiência em um conteúdo de trabalho pouco valorizado passam a ser empecilhos à inauguração de um novo ciclo na carreira, colocando em questão a visão simplificada das consultorias que tratam todas as frações de trabalhadores de modo igual:

Quando você sai do banco, ninguém te admite com salário maior de que você tem, o bancário é desrespeitado aí fora. É difícil mesmo porque o bancário é tido como uma pessoa alienada, ele está acostumado a copiar e colar, se você vê na área operacional ele faz pagamento, debita e credita, alimenta uma planilha, ele só faz aquilo. É uma atividade muito fechada, ela não tem nenhuma visão, um Caixa fica ali, só naquilo... A função do bancário não tem compatibilidade. No banco cada um faz uma coisa muito separada da outra. (Bancária, Analista Júnior, 57 anos, 12 de banco) 
Apesar de todo empenho para forjar nos trabalhadores a perspectiva da flexibilidade em contraposição à noção de estabilidade profissional, é significativo o resultado de uma pesquisa interna realizada pelo Banco $\Delta$ que aponta que $90 \%$ dos trabalhadores participantes da instituição manifestaram que desejariam ficar nos próximos cinco anos. ${ }^{126}$ A pergunta que já apontava um prazo limitado nos faz inferir que prazos ilimitados ou o cogitar em trabalhar até a aposentadoria na mesma empresa não devem ser colocados como hipóteses a fim de não criar expectativas distorcidas.

A distância entre a perspectiva dos trabalhadores e o que ditam, ou, buscam naturalizar, determinadas consultorias de RH, pode se espelhar no resultado de outra pesquisa $^{127}$ realizada por uma consultoria internacional de RH, de 2011 até 2015, em que os jovens apresentam como perspectiva futura a estabilidade. Pelas respostas de 67 mil estudantes brasileiros, foram constados no topo das suas prioridades os seguintes itens: primeiramente "equilíbrio entre vida e trabalho", e, na sequência, "segurança ou estabilidade".

A declaração do consultor a seguir, já em sentido contrário, reforça a visão sobre ciclos mais curtos para a carreira:

A carreira não pode ser confundida com uma profissão ou uma função, como se entendia anteriormente, nós entendemos a carreira como uma sucessão de experiências que a pessoa vive ao longo de sua vida, em um conjunto de atribuições e responsabilidades da mesma natureza... O que nós temos observado é que as carreiras têm cada vez um ciclo mais rápido. (Consultor de RH entrevistado)

Freitas (2007, p. 52) menciona que as carreiras longas foram consideradas “obsoletas e quase imorais", sendo que a lealdade e os vínculos de longo prazo se tornaram empecilhos a uma vida organizacional revigorada e mais dinâmica.

Ainda, outro exemplo claro das tendências retóricas contemporâneas se situa na orientação de fazer a gestão de pessoas por competências e não mais por cargos, como era tradicionalmente praticado no modelo taylorista (EBOLI, 2008), o que implica no descarte da importância do tempo de experiência como a medida da valorização profissional.

Pelo paradigma que tem predominado nas últimas décadas, segundo relatam os autores da área de administração (ALBUQUERQUE; OLIVEIRA, 2001; EBOLI, 2008), busca-se valorizar o perfil individual do trabalhador - formação escolar,

\footnotetext{
${ }^{126}$ Revista Banco 4, dez. 2006.

${ }^{127}$ Jornal Folha de S.Paulo. Especial Carreiras, jun. 2015.
} 
habilidades técnicas e comportamento - relacionando-o com os resultados atingidos. Tal dinâmica daria conta de identificar e reconhecer o trabalhador mais produtivo podendo admitir premiações intermediárias que não sejam exatamente a promoção na carreira. $\mathrm{O}$ contrário disso, ou seja, o trabalhador que não atinge os padrões desejados pode rapidamente ser substituído por outro mais adequado e atualizado.

O sistema de carreira no setor privado bancário desconsidera a promoção por antiguidade e valoriza a eficiência. A mobilidade interna obedece ao critério da meritocracia, outro conceito fortemente presente na retórica institucional das corporações.

A carreira, nos termos da "antiga" gestão bancária, organizava um ciclo de vida. O trabalhador quando jovem auferia uma renda mais modesta, mas mantinha a expectativa de crescimento profissional que o conduzisse a uma condição mais vantajosa a ponto de haver equilíbrio entre a retribuição monetária de seu trabalho e aquilo que o mercado de trabalho pudesse oferecer, tornando a passagem pela instituição um feito de longo prazo.

Esta trajetória, ainda que no rascunho para muitos, favorecia empreender projetos pessoais de maior fôlego, como fazer uma dívida para adquirir a casa própria envolvendo prazos largos que ultrapassam décadas. Na dinâmica prevalente, o mais jovem, se mais produtivo, conseguirá arrecadar mais recursos em menos tempo do que aqueles com mais tempo de casa, pois sua ascensão profissional se dará em função dos resultados que obtiver, os diferenciando dos demais.

A atividade profissional torna-se, com o efeito das recomendações das consultorias, uma conexão temporária para grande parte dos trabalhadores, que se explica na prática pelas dificuldades de se manter em patamares continuamente elevados de produtividade.

A opinião do consultor, reproduzida abaixo, reforça a percepção de ciclos mais curtos na carreira influenciados pela produtividade. O histórico de médio ou longo prazo de um trabalhador, ainda que reúna dados objetivos de suas realizações passadas, não são suficientes para manter ou projetar sua carreira, pois interessa o resultado recente daquilo que se é capaz de fazer.

As profissões estão cada vez mais parecidas. A carreira de um empregado normal se parece com a carreira de jogador de futebol, depende do resultado do jogo de ontem... Se você tem 10 anos de carreira é centro avante e não faz gols vai ser substituído, seu passado não te ajuda mais. (Max Gehringer, Rádio CBN. Entrevista programa: "Fim de Expediente", 28 jul. 2006) 
Percebe-se que entre a maior parte dos entrevistados para esta pesquisa há uma expectativa esterilizada de fazer carreira na instituição até se aposentar. Contudo, apesar de tão mal recomendada pelas consultorias, aspirar a uma vida mais protegida nunca deixou de estar presente no pensamento dos trabalhadores, sobretudo entre os jovens que, não tendo retaguarda financeira, mantêm perspectivas avessas ao risco.

No campo dos modismos trazidos pelas consultorias defende-se a ideia de que não se muda de emprego, mas sim, de projeto. Trata-se de uma generalização que apenas reforça a marcação dos tempos de trabalho mais curtos e voláteis.

Para Dias e Zilbovícius (2009), a noção de emprego quando substituída por "projeto" visa, antes de mais nada, facilitar a redução de funcionários e custos atrelados a esses em uma estratégia que transfere riscos do capitalista para o trabalhador.

Trabalhar por projeto pode significar a acentuação da vulnerabilidade dos trabalhadores assalariados, sobretudo quando se tratam de cargos que correspondem a salários modestos em que a reserva monetária disponível ou a "poupança" individual não é capaz de suportar os custos de sobrevivência enquanto aguardam entre a finalização e o início de um novo ciclo como fazem os executivos, gestores com graduação elevada e consultores. Há, portanto, um romanceamento dessa perspectiva, que também é propagada pelas instituições financeiras. No Banco $\Delta$, diversos "projetos" ou "operações" são, na prática, a execução de estratégias gerencias definidas pelos superiores hierárquicos ou, simplesmente, etapas do processo produtivo em curso.

Para manter a empregabilidade, são mantidas exigências contínuas de qualificação e aprimoramento da escolaridade que possam agregar valor ao trabalho diário. Conforme apontam os dados a seguir, os trabalhadores têm dedicado mais anos de suas vidas ao estudo formal: 
Gráfico 16

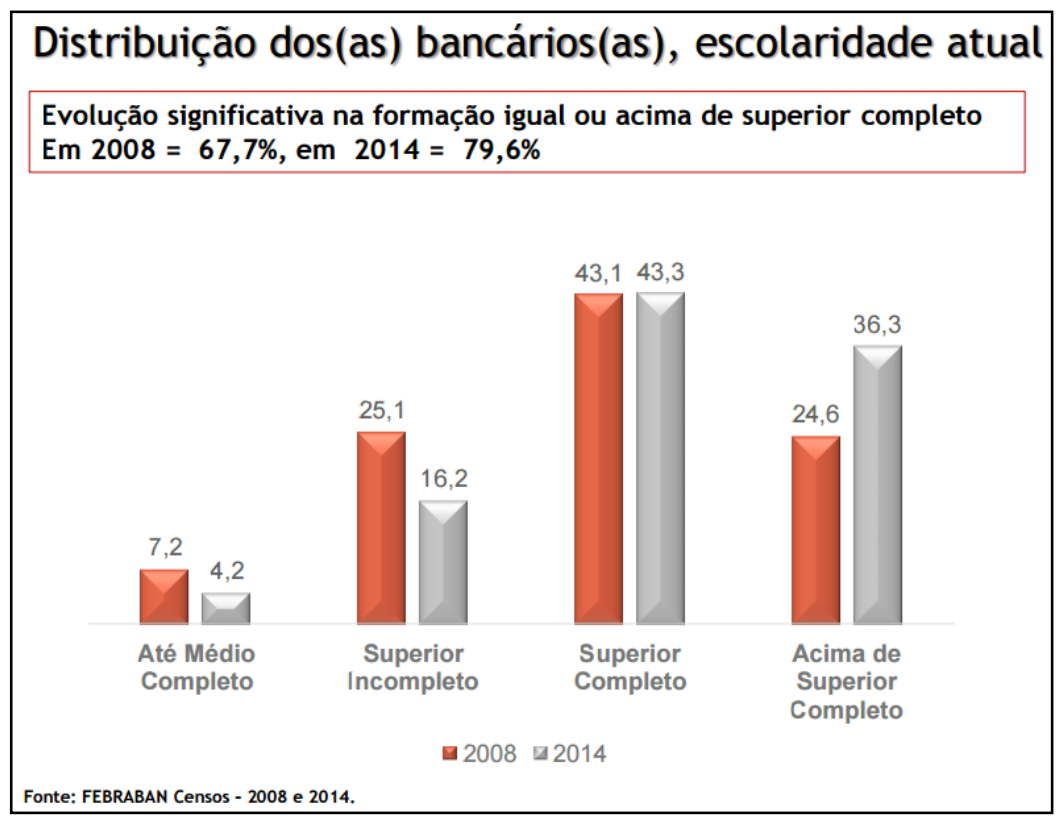

Em pesquisa encomendada pelo Sindicato dos Bancários de SP, ${ }^{128} 52 \%$ dos trabalhadores do Banco $\Delta$ concordaram muito com a afirmação: "Fiz faculdade, MBA ou pós-graduação exclusivamente para ter mais oportunidade no banco". As entrevistas que realizamos para esta pesquisa confirmam esta demanda por profissionais com alta escolaridade e treinamento, o que reforçou nos últimos tempos o peso da pós-graduação e das certificações específicas para atuar no ramo financeiro, como Certificação Profissional ANBIMA ${ }^{129}$ Série 10 - CPA10, Certificação Profissional ANBIMA Série 20 - CPA 20, Certificação Especialista em Investimento ANBIMA - CEA, entre outras.

Contudo, a despeito das exigências em torno da escolaridade se manterem elevadas, é preciso considerar que há grande oferta de trabalhadores qualificados disputando estes espaços no mercado de trabalho, assim, o grande diferencial para permanecer empregado passa pelos resultados individuais de produtividade.

Mesmo em empregos "regulares" ou "fixos", como são os dos bancários, submetidos à alta competitividade interna e à rotatividade, está colocada a sensação de insegurança constante que conduzem os trabalhadores a garantir diariamente sua

\footnotetext{
${ }^{128}$ A pesquisa "O impacto da organização e do ambiente de trabalho bancário na saúde física e mental da categoria" foi realizada em 2011, envolveu 818 participantes e abrangeu uma ampla gama de cargos e locais de trabalho, representantes tanto das agências como das áreas administrativas.

${ }^{129}$ A ANBIMA - Associação Brasileira das Entidades dos Mercados Financeiro e de Capitais é a principal entidade certificadora dos profissionais dos mercados financeiro e de capitais brasileiros.
} 
manutenção na empresa, sobretudo, quando há um sistema de controle e cobrança por cumprimento de metas tão rigoroso.

Sabe-se que, do ponto de vista das relações profissionais nas grandes corporações,torna-se procedimental participar dos networkings, ou seja, reuniões informais, happy hours, celebrar datas comemorativas com os demais empregados e superiores hierárquicos. Tanto são relevantes esses espaços quanto por meio deles é possível ser mais conhecido ou popular. Fazer desses momentos fonte de divulgação de si próprio e conhecer ainda mais, em detalhes, os meandros que alinhavam as decisões e o poder político constituído acabam por situar estrategicamente o indivíduo na arena pela qual a luta pela sobrevivência nesses ambientes se passa.

O entrevistado, a seguir, relata sua visão sobre os relacionamentos pessoais e a carreira no ambiente corporativo:

Hoje, para ser promovido, você tem que puxar muito o saco, puxar mesmo, sabe? Tem que ter relacionamentos estratégicos, não pode se expor muito, porque tem pessoas que tiram sarro de tudo, são bem manipuladoras, inteligentes. Tem de sair da categoria operacional e ir para uma categoria estratégica assim você tem mais visibilidade. (Bancário, Analista Júnior, 29 anos, 04 de banco)

Na equipe sempre tem dois, três grupos... Eu, por exemplo, não sou quem almoça com o chefe. Então é fato: quem é mais próximo do chefe é mais beneficiado. (Bancário, Analista Júnior, 42 anos, 12 de banco)

O conteúdo da fala do entrevistado, acima destacado, nos dá pistas para perceber que além do critério que considera a meritocracia para justificar a promoção na carreira, existem outros elementos que compõe este "jogo social". Ainda que não transparentes e formalizados, os critérios de sociabilidade calcados na amizade e compartilhamento de formas de lazer entre os membros da empresa poderão favorecer a avaliação subjetiva de determinados trabalhadores.

Conforme analisou Boltanski e Chiapello (2009), a nova forma de gestão que se consolidou a partir dos anos 1990 e serve de paradigma para as grandes corporações baseia-se na administração por objetivos. Nesse escopo o nível do desempenho do indivíduo no ambiente de trabalho torna-se um dos indicadores fundamentais para delimitar a evolução na carreira, o que em termos ideais evitaria apadrinhamentos e o uso de critérios subjetivos, rechaçando "julgamentos pessoais" e valorizando o profissional pelos resultados obtidos. 
Apesar de toda a ideologia que gira em torno do sistema meritocrático e de sua objetividade, vale registrar que a principal porta de entrada nos bancos privados é a "indicação". 130

As relações de "apadrinhamento", pouco objetivas do ponto de vista meritocrático, encontram sobrevida nos chamados "networkings" e "happy hours", considerados pelos trabalhadores relevantes para se estabelecer ou crescer na carreira.

A eloquência daqueles que defendem os aspectos positivos do sistema meritocrático ainda pode ser questionada quando ocorre o rompimento da relação de emprego pelo "encarecimento" do trabalhador, mesmo que ele tenha comprovada experiência e esteja na média estabelecida de produtividade. A decisão de cortar trabalhadores com muito tempo de casa, e que, portanto, se tornaram mais custosos, está em sintonia com os demais ajustes financeiros internos das instituições, que invariavelmente passam pelo principal elemento do processo produtivo: a força de trabalho.

Em que pese os resultados objetivos dos trabalhadores serem centrais para estabelecer parâmetros de ascensão na carreira, percebemos que o peso das subjetividades também é relevante nesses processos, vide toda importância atribuída ao comportamento.

A trajetória profissional na grande corporação estudada não tem se definido por assalariados inseridos em um conjunto hierárquico cujos degraus são fáceis de subir. Para conter a desilusão dos indivíduos, existem as "promoções horizontais", que representam formas singulares de conceder um valor adicional no salário e mudar discretamente o status econômico da carreira que é alheio à negociação coletiva realizada com o sindicato dos trabalhadores.

As "promoções horizontais" ocorrem por "mérito", analisado pós-avaliações de resultados e comportamentos. A estrutura da pirâmide ocupacional no banco estudado mantém uma ampla variação atribuída a um mesmo cargo em linha horizontal, ou seja, um cargo possui as variações júnior, pleno e sênior e em cada uma delas pode alcançar níveis I, II,e III.

Sobre as promoções horizontais incorre um acréscimo salarial que se inicia no patamar de R\$100,00. Em 2011, o Bancos possuía 104.542 trabalhadores em todo o Brasil e no exterior. De acordo com informações divulgadas pela instituição, ocorreram

\footnotetext{
${ }^{130}$ Informações acerca desta afirmação serão tratadas com mais detalhes no Capítulo 5.
} 
aproximadamente 13.200 promoções e aumentos por méritos, o que representa $12 \%$ do quadro total (Relatório Gerencial Banco $\Delta$ 2011).

As "promoções verticais", que envolvem a mudança para um cargo superior àquele em que o trabalhador se encontra, também se submetem à triagem realizada pelos processos de avaliação.

Outro componente para merecer subir na carreira se relaciona diretamente à capacidade de suportar pressão em ambientes de trabalho competitivos. Não à toa, como vimos no capítulo anterior, o próprio $\operatorname{Banco} \Delta$ mantém um mecanismo interno de apuração sobre os conflitos e abusos de autoridade no ambiente corporativo.

Apesar de toda a retórica do novo paradigma de gestão sobre a eliminação dos métodos autoritários de se relacionar no trabalho, sabe-se que o problema da "violência organizacional" persiste ou se agrava, afinal é incongruente pensar em maior participação, maior integração e horizontalidade, quando o gestor reproduz em efeito cascata a pressão que recebe dos altos executivos da instituição. Assim, para ascender na carreira, deve-se ter a qualidade básica de suportar a pressão em ambientes altamente competitivos, como são as corporações bancárias.

De toda a forma, considerando as declarações dos entrevistados, podemos afirmar que há possibilidade de ascensão profissional, sobretudo se o trabalhador for tão produtivo quanto o esperado, ou seja, consiga trazer os resultados acima do esperado e esteja "alinhado" à cultura corporativa. Vale relembrar o que havia dito Romanelli (1978:161) há quase quatro décadas atrás e permanece atual: "produtividade e sujeição convertem-se em passaporte para o sucesso". Se, por um lado, a fórmula é conhecida e posta em ação por muitos trabalhadores, por outro, ela também expressa o pouco entusiasmo de outros:

A pessoa consegue fazer carreira. Eu acredito que... é que assim, cada caso é um caso. Existem casos em que a pessoa é muito boa. Mas eu diria que é 50\% de chances, não é muito alto.[...] pra você crescer você precisa ter uma ambição muito grande ali no banco. Porque cada salto que você dá, você vai tá subindo pra coisas piores. Eu tenho uma visão de crescimento no banco que é assustadora. Porque quanto mais você vai crescendo, mais você vai vendo coisa errada. (Operador de Teleatendimento, 24 anos, 03 anos de banco) 


\section{Capítulo 5 - A política da meritocracia e a face pragmática da grande corporação}

\subsection{A gestão por resultados}

$\mathrm{O}$ acionista pensa em dólares. Se não tiver a remuneração que ele quer, bota o dinheiro em outro lugar. (Mathias Mangels, diretor empresa especializada em Balanced Scorecard ${ }^{131}$ )

No mercado financeiro, a concorrência está cada vez maior e o que nos diferencia não são mais os nossos produtos e serviços, mas sim trabalhar em um ambiente de alta performance, com foco no cliente, equipes comprometidas e gerando riqueza para o acionista. Com isso, conseguimos lucrar e, consequentemente, pagar impostos, empregar e pagar em dia os funcionários. (Informativo bimestral Banco $\Delta$ mai./jun. 2008 - entrevista diretor executivo área de Desenvolvimento e Performance de Pessoas)

A meritocracia - reconhecer e diferenciar as pessoas de acordo com seu desempenho relativo - é uma de nossas principais crenças e um direito e um dever de todos os que compõem a organização. (Relatório Gerencial Banco $\Delta$ 2009)

As empresas de capital aberto, que negociam ações na Bolsa de Valores, são obrigadas a publicar suas informações financeiras em períodos anuais, semestrais e até trimestrais. É por meio desse tipo de informativo e outros relatórios gerenciais detalhados que os acionistas monitoram o desempenho e a rentabilidade das instituições. Os resultados apurados e divulgados em curtos períodos de tempo interferem nos preços das ações e podem servir de base para reorientar novas estratégias administrativas e financeiras que atingem diretamente os processos de trabalho e os trabalhadores.

O Banco $\Delta$ negocia suas ações desde 2002 na Bolsa de Valores de Nova York (NYSE). O período que segue a esse evento foi marcado por maior pressão interna no processo de trabalho, observada no alastramento dos programas de gestão por resultados, reformulação dos processos de avaliação e lançamento de um amplo programa para reorientar a cultura organizacional.

A agilidade dos tempos e o refinamento dos controles, possibilitados pelas inovações tecnológicas, são emblemáticos para compreender a lógica produtiva

\footnotetext{
${ }^{131}$ Balanced Scorecard (BSC) é uma metodologia de gerenciamento de indicadores de desempenho baseada em uma plataforma eletrônica amplamente utilizada pelos bancos. Por meio dela pode-se, por exemplo, integrar e monitorar diversos indicadores que consolidam os programas de metas, inclusive considerando os fatores intangíveis. Fonte: Revista Exame, set. 2002.
} 
predominante pautada por ritmos e ciclos mais curtos. A publicação das informações financeiras aos acionistas, sobretudo quando há atuação internacional, impõe mais cobrança sobre os resultados dos trabalhadores. Devido à expectativa elevada dos "donos voláteis do negócio", o retorno auferido com o investimento nas ações é analisado comparativamente com os instrumentos de rentabilidade e liquidez disponíveis no mercado financeiro.

O fator trabalho foi diretamente influenciado pelo contexto altamente competitivo em que o Banco $\Delta$ se inseriu. A pressão para que os trabalhadores pudessem superar metas e aumentar sua produtividade foi percebida em nossa pesquisa e gerou desdobramentos indesejáveis questionando inclusive "as boas práticas" administrativas no que tange ao relacionamento com os clientes. É o que buscaremos demonstrar neste capítulo.

Os programas de gestão por resultados, também conhecidos por programas de metas ou ainda por programas de remuneração variável, são a expressão mais acabada da lógica do curto prazo no ambiente corporativo bancário.

Sob o argumento de atender às demandas de alta rentabilidade e lucratividade vindas dos acionistas, os altos executivos das grandes corporações bancárias estabelecem metas de produtividade que atingem todos os processos de trabalho e, consequentemente, todos os trabalhadores. Nesse contexto, o conceito de carreira de longo prazo na mesma empresa, que envolve permanências prolongadas e promoções por antiguidade, se esvazia enquanto a meritocracia ganha centralidade e passa a influenciar com maior peso a possibilidade de ascensão profissional e de encerramento do contrato de trabalho em ciclos mais curtos.

Segundo Barbosa (2006, p. 22), em uma sociedade que dá muita ênfase à competição, o conceito de meritocracia se define, no nível ideológico, como "um conjunto de valores que postula que as posições dos indivíduos na sociedade devem ser consequência do mérito de cada um". Trata-se de se admitir que as realizações individuais são medidas pela realização de outras pessoas ao contrário do que acontecia no século XIX, quando a autodisciplina e comedimento eram suficientes.

O foco no indivíduo arremata sob si a responsabilidade dos resultados de sua própria vida, ignorando quaisquer outras variáveis. "Por essa lógica, o progresso e o fracasso das pessoas são vistos como diretamente proporcionais aos talentos, às habilidades e ao esforço de cada um independente do contexto" (BARBOSA, 2006, p. 26). Na lógica do mercado, cada um dispõe dos recursos disponíveis de acordo com sua 
capacidade e não exatamente de acordo com as suas necessidades. Desse modo, o "lado afirmativo" da meritocracia se ancorou na oposição de privilégios hereditários e corporativos.

De acordo com a mesma autora, em determinado tempo histórico agentes políticos e econômicos enfatizaram o "lado afirmativo" da meritocracia, como aconteceu com os expoentes do discurso neoliberal, Thatcher e Reagan, ao desencadearem um debate moral que buscou em essência reordenar a sociedade a partir de um novo tipo de homem que, uma vez "encarnado" no espírito meritocrático, assumisse as seguintes características: autônomo, competitivo, empreendedor, criativo e esforçado. Isso significava deixar para trás o homem reativo, acomodado, que espera a ação do Estado.

Assim, foram colocados em evidência os pilares que estruturaram a "empregabilidade" ao mesmo tempo em que se buscou destruir sistemas de trabalho pelo qual a antiguidade era recompensada.

As trajetórias profissionais no Brasil foram reestruturadas de modo que sua evolução estivesse condicionada a ciclos demarcados pelo nível de atingimento de resultados. No início dos anos 2000, segundo reportagem da revista especializada em negócios e administração, ${ }^{132}$ a pressão por desempenho havia crescido muito. Isso levou à redução do tempo de permanência de um executivo na empresa, antes estimada em sete anos, para ser demitido caso não estivesse apresentando números satisfatórios, para quatro anos e meio em média. A declaração a seguir nos oferece pistas para esclarecer como a engrenagem administrativa está planejada para alcançar resultados no curto prazo e como a pressão se inicia no topo da administração:

Até uns cinco anos atrás, todo diretor queria crescer na empresa. Hoje, já entra planejando a saída. E, se você entra com a cabeça no curto prazo, privilegia a maximização dos resultados imediatos. (Revista Exame, set. 2002).

A preocupação que emerge por parte dos representantes dos órgãos regulamentadores do universo das finanças, com os riscos embutidos neste modelo de resultados premidos pelo tempo, tem motivado orientações quanto às formas de pagamentos dos bônus - remuneração variável - dos administradores e altos executivos que atingem cifras altíssimas. ${ }^{133}$ Com o objetivo de diminuir a exposição ao risco, o resgate da remuneração desses agentes passou a obedecer a prazos mais longos, ou seja,

\footnotetext{
${ }^{132}$ Revista Exame, set., 2002.

${ }^{133}$ De acordo com pesquisa realizada por consultoria de $\mathrm{RH}$, os executivos brasileiros recebem os maiores salários e a maior remuneração variável de curto prazo no mundo. A pesquisa comparou a realidade brasileira com o que é praticado na China e Estados Unidos, países que apontaram valores 38\% menores e Alemanha 39\%. (Revista Exame - Especial Remuneração, out. 2012).
} 
deve ser diferido no tempo. ${ }^{134}$ Ao considerar os pagamentos em prazos mais longos, que extrapolem o ano de publicação dos resultados, busca-se manter a sustentabilidade da própria empresa evitando medidas imprudentes dos administradores.

\subsubsection{Os programas de resultados relacionados à remuneração variável}

Nos setores mais dinâmicos da economia, o padrão de remuneração dos trabalhadores foi alterado com base na orientação de reduzir os custos fixos, assim a remuneração variável possibilitou aos empregadores "adaptar os salários" às flutuações econômicas, ao desempenho da própria empresa, evitando em momentos de maior dificuldade comprometer o lucro líquido apurado, gerando maior apropriação da renda em favor do capital (KREIN, 2007).

No setor bancário os programas de gestão de resultados/metas tornaram-se mais abrangentes após a regulamentação da PLR por Medida Provisória em $1994^{135}$ (SEEBSP/DIEESE, 2011). A possibilidade de realizar pagamentos aos trabalhadores sem o recolhimento de encargos levou as empresas a fortalecerem o conceito de meritocracia balizado na retribuição monetária extraordinária atrelada ao atingimento de resultados.

Há, portanto, datada historicamente na cena do processo de trabalho bancário, uma estreita ligação entre os pagamentos feitos a título de remuneração variável e os programas de gestão de resultados/metas, sobretudo nos primeiros anos de implantação. No entanto, a remuneração variável foi e ainda é coadjuvante de um propósito maior, qual seja, o de ajudar a estabelecer um padrão de trabalho mais controlado, menos poroso ao tempo morto e por isso mesmo mais intenso baseado nos resultados.

Os pagamentos de remuneração variável, planejados por ciclos e caracterizados pela sua efemeridade, estão condicionados ao lucro ou a resultados obtidos em um período previamente estimado. Nesse sentido, o que estrutura esta estratégia de flexibilização da remuneração é em essência a gestão orientada por resultados no curto prazo. Havendo resultado, há pagamento. O contrário não se aplica.

\footnotetext{
${ }^{134}$ A Resolução n 3921, de novembro de 2010, do Banco Central no Brasil, determina diretrizes para as políticas de remuneração dos administradores das instituições financeiras que deverão dar informações sobre a composição da remuneração fixa, variável e benefícios repassados. A resolução disciplina ainda os pagamentos da remuneração variável, estabelecendo que $50 \%$ devem ser pagos em ações e $40 \%$ deve ser diferidos no prazo mínimo de 03 anos.

${ }_{135}$ A primeira Medida Provisória, MP $\mathrm{n}^{\mathbf{0}} 794$, foi reeditada em várias ocasiões e no ano de 2000 foi votada a Lei $\mathrm{n}^{\mathrm{o}} 10.101$ específica sobre o tema (SEEB-SP/DIEESE, 2011). A PLR é uma das formas mais expressivas de flexibilização das relações do trabalho implementadas nos anos 1990 no Brasil. Para mais esclarecimentos sobre as circunstâncias históricas em que a regulamentação da PLR surge, consultar KREIN (2007).
} 
De acordo com as análises de Jinkings (2002), Krein (2007) e Santos (2012), é por meio da remuneração variável, em especial dos pagamentos feitos a título de PLR, que os administradores conseguem flexibilizar os salários, obter maior adesão dos trabalhadores, dentre outros efeitos não menos relevantes, como a intensificação no ritmo de produção, acirramento da individualização na relação capital-trabalho e a consequente quebra de solidariedade.

As posições anunciadas pelos administradores ou consultorias especializadas relacionam os programas de remuneração variável ou as PLRs a formas de valorizar o trabalhador e incentivar sua produtividade. No entanto, como destacou Santos (2012), há críticas entre os especialistas sobre sua efetividade quando as metas coletivas são as predominantes, pois um trabalhador com menos desempenho pode se beneficiar do resultado obtido pelo grupo. Diante dessa preocupação, as instituições tendem a reforçar as metas individuais aprofundando os valores em torno da meritocracia.

A remuneração variável paga aos trabalhadores, em especial a PLR, viabiliza-se mediante dois grandes indicadores: lucro ou resultados operacionais. Assim, as consultorias especializadas no tema orientam que esses pagamentos sejam feitos mais com base nos resultados operacionais, de preferência individualizados, do que no lucro apurado, que representa o resultado do esforço global.

Os trabalhadores bancários, por força da CCT, recebem dois pagamentos semestralizados, ${ }^{136}$ lançados a título de PLR. Esses pagamentos compõem o patamar mínimo estabelecido por meio do processo de negociação coletiva, mas que pode ser ampliado caso haja acordo específico com um determinado banco.

No modelo negociado com os sindicatos que representam os trabalhadores, via CCT, válido para todos os bancários em nível nacional, há um único indicador para o pagamento da PLR: o lucro. Nesse caso, podemos afirmar que a meta estabelecida tem caráter coletivo e os pagamentos são universalizados, seguindo variações pequenas de proporção salarial e favorecendo os cargos mais baixos nas instituições, observando que a regra ainda estabelece um teto na distribuição dos valores.

Como é perceptível, o modelo da CCT contraria as recomendações dos consultores, contudo, os bancos adotam outros "programas próprios de remuneração variável", que permitem o pagamento de valores mais elevados, restrito a um grupo menor de trabalhadores, que superam os valores recebidos fruto do já acordado na CCT.

\footnotetext{
${ }^{136}$ A semestralização está prevista na Lei no 10.101 específica. A regra tem por objetivo evitar a substituição do salário fixo, para isso proíbe pagamento em intervalos menores.
} 
A questão elementar se concentra no fato de que todos os programas de remuneração variável estão amarrados aos programas de resultados, também nomeados por programas de metas. Mas, mais fundamental ainda é que o fato de ter o programa de resultados não significa que necessariamente o trabalhador venha receber a remuneração variável.

Nesse sentido, pretendemos reafirmar que os programas de gestão por resultados/metas se utilizaram da remuneração variável como um meio para estruturar a nova forma de administrar o processo de trabalho pelo regime de metas de curto prazo no setor bancário.

A rotina diária de trabalho no Banco $\Delta$ gira em torno dos programas de metas. Os trabalhadores mais do que almejarem receber remunerações adicionais buscam cumprir o conjunto de indicadores dos programas, que incluem até mesmo aspectos comportamentais, para que possam se manter empregados. O que nos leva a inferir que o "incentivo" maior não é a remuneração adicional, mas sim a própria sobrevivência no emprego, sobretudo quando as metas são difíceis de serem atingidas no ambiente interno e externo altamente competitivo.

Os programas de gestão por resultados/metas buscam aumentar as performances de trabalho e não aumentar os rendimentos dos trabalhadores, ainda que estes sejam variáveis e não representem aumento no custo fixo das empresas.

Com duração de um ano, os programas visam objetivamente estabelecer metas de desempenho tanto em âmbito individual como para as áreas. Por meio dos instrumentos que orbitam em torno de tais programas é realizado o monitoramento contínuo de desempenho dos envolvidos. Como abordamos no Capítulo 3, o processo de trabalho pode ser medido em fração de segundos, dadas as facilidades tecnológicas.

A gestora do Banco $\Delta$ entrevistada deixa transparecer o quanto são eficientes os programas do ponto de vista do controle do processo produtivo e como isso pode influenciar na intensificação do trabalho:

Eu vou dizer o que eu falo aos quatro cantos ... eu acho fantástico o modelo de gerenciamento de resultados do banco. Eu acho que é uma ferramenta muito, muito legal, ela é justa e é uma ferramenta que se você não tivesse que atribuir meta, ela seria o ideal. Você tem lá os indicadores. É legal pra você saber. Como é que tá a sua qualidade de atendimento, você tá atendendo seus clientes até quinze minutos, até trinta minutos, como é que você tá. Você tem lá um indicador que vai falar sobre a qualidade do seu atendimento. Quem tá reclamando muito, quem não tá reclamando muito. Como é que tá a sua produtividade? Pra realizar o trabalho você tá fazendo muita hora extra? Ele é um bom indicador até pra você fazer as suas 
escolhas corretas dentro daquilo que você acha que não tá legal. Então, o que precisa... pô, eu tô fazendo muita hora extra. Porque que eu tô fazendo muita hora extra? Os Caixas não tão indo no mesmo nível? Tem algum Caixa que não tá produzindo igual aos outros... Qual é o problema? Vamos identificar, se todos os caixas produzem de maneira igual, o problema aqui é que a gente precisa aumentar o quadro... Então ele é um bom balizador até para você analisar situações. O problema é que quando você pega esse balizador e imputa meta. E aí não é só colocar meta, é colocar meta abusiva. Na área comercial é legal você saber quantas contas você abriu em um mês. O problema é que você coloca... Olha você abriu tantas contas nesse mês e no mês que vem você vai ter que abrir $150 \%$ disso. E acima de $150 \%$ depois de um tempo... Que cenário você tem que as coisas crescem desse jeito? (Bancária, Gestora Regional Agências, 43 anos, 16 de banco)

O funcionamento dos programas de gestão por resultados/metas e dos programas de remuneração variável adotados pelo $\operatorname{Banco} \Delta$ tiveram origem em meados dos anos 1990 de acordo com o que foi possível captar nos materiais institucionais e na bibliografia pesquisada, ${ }^{137}$ sendo, portanto, uma das instituições pioneiras nesse tipo de modelo de organização do trabalho no setor.

Dada a dinâmica do mercado financeiro e, sobretudo em ocasiões pós-processo de fusão ou aquisição, tais programas passaram por ajustes com vista a atender a expectativa de melhorar a eficiência do processo produtivo.

A seguir, detalhamos os pagamentos de remuneração variável para dimensionar qual a influência que possuem sobre o modelo de gestão da força de trabalho do $\operatorname{Banco} \Delta$. Todas as modalidades estão ancoradas na regulamentação da PLR no Brasil, o que livra os valores pagos aos trabalhadores de terem sobre si o recolhimento de encargos legais. Vejamos as possibilidades de remuneração variável:

1) Pagamento de um patamar mínimo e universal estabelecido via negociação coletiva, CCT, com base no resultado do lucro da holding;

2) Pagamento de uma Parcela Complementar de Resultados (PCR), estabelecida via negociação coletiva, por meio de Acordo Específico. É um valor fixo, adicional ao que estabelece a CCT, também de caráter universal, apurado após cálculo sobre a variação do lucro da instituição e retorno sobre o patrimônio líquido;

3) Pagamento por desempenho individual : “modelos próprios de remuneração variável” . Os valores são variáveis, pagos de forma discricionária, conforme área de atuação e cargos ocupados na instituição. Nesta modalidade, os

\footnotetext{
${ }^{137}$ Revista Banco 1995 , jornais sindicais e Jinkings (2002).
} 
trabalhadores que se destacam com a melhor pontuação no programa de gestão de resultados/metas recebem valores adicionais ao que está previsto nos itens 01 e 02 .

É relevante frisar que os pagamentos previstos nos itens 01 e 02 se submetem a resultados macroestruturais da instituição, fruto do desempenho coletivo. $\mathrm{O}$ item 03 condiciona o pagamento, sobretudo, ao desempenho individual, alicerçado no programa de gestão de resultados existente na corporação estudada.

Os "modelos próprios" representam o modo pelo qual haverá retribuição monetária extraordinária individualizada. Trata-se de uma retribuição que extrapola os pagamentos já negociados pelos representantes sindicais através da CCT - itens 02 e 03 - e que obedecem à dinâmica "particular" da gestão do banco. Em nossa pesquisa apuramos no Bancos em 2012 a existência de 25 modelos submetidos a metas específicas, distribuídos em diversas áreas. Nenhum deles contava com pagamentos lineares ou iguais para participantes da mesma área ou agência.

Em nossa análise sobre estes modelos pudemos apreender que os trabalhadores apenas poderão ser remunerados se ficarem entre os melhores colocados nos rankings internos, separados por segmentos e áreas. Verificamos que em determinados programas apenas $20 \%$ do quadro serão beneficiados pela remuneração extraordinária.

Vale sobre este ponto reforçar as circunstâncias, ou seja, todos foram submetidos ao regime de metas e ainda que tenham alcançado as pontuações previamente esperadas, dentro da margem de $100 \%$, isso não determina a reversão em prêmios monetários. Apenas os desempenhos considerados excepcionais ou diferenciados é que atingirão tais benefícios, proporcionando neste caso a exclusão da maior parte dos trabalhadores deste "incentivo".

O entrevistado, a seguir, deixa claro as dificuldades para atingir as metas estabelecidas em um unidade em que, apesar de mantida a gestão por resultados/metas, os pagamentos de remuneração variável foram inclusive abolidos.

Lá na central não tem mais remuneração variável, mas eu achava muito injusto porque pra bater a meta e receber a remuneração você tinha que ser é... como eu vou te dizer? Assim... Você tinha que ser cem por cento de aderência, cem por cento de monitoria, superar a meta, entendeu? Era quase impossível. Tanto é que não eram todos que chegavam à faixa máxima. Então às vezes você superava tudo, tudo e por causa de uma monitoria que você tirou 85 , você perdia sua variável. Você entendeu? Então eu achava um absurdo. Eles cobram venda, eles cobram tudo em uma forma que é praticamente impossível você bater a meta, você tinha que ser quase um semideus pra chegar naquilo que eles pediam. E eu achava que 
aquilo era muito massacrante. Tanto é que as pessoas batiam um, dois, três meses depois não aguentavam mais. Não bate mais. Não consegue ficar nessa rotina. (Bancário, Agente Comercial, 29 anos, 07 de banco)

As metas, classificadas como "impossíveis" de serem atingidas, foram mencionadas nas entrevistas realizadas. A insuficiência do resultado, do ponto de vista da gestão interna, além de ser um elemento de ameaça ao próprio emprego, pode limitar a ascensão profissional dos trabalhadores.

Você tem que bater a meta em $100 \%$. Um exemplo, na grade do gerente de contas, são mil pontos que você tem que fazer pra você fechar ali o mês. Abaixo, nunca. Mas, se você fizer os mil você ainda sente ameaça, você tem que fazer mais. Eles dizem o seguinte: mil pontos é pra pessoa acomodada e o banco não quer ninguém acomodado. Então o objetivo é 1.200, 1.300, 1.400. E isso é impossível, significa 120,130, 140 por cento da meta. (Bancária, Gerente de Contas, 46 anos, 28 de banco)

O banco não quer saber, todo mês tem uma meta. A cada mês eles diminuem o TMA - Tempo Médio de Atendimento. Mas, eles não querem saber da qualidade do atendimento. A média... A meta era 1,87 segundo quando eu sai de lá. Enfim, você tem esse objetivo, tem que atender a demanda do cliente, e você tem que ofertar produto. Na agência é quase isso. Se o problema não é nosso, passa pra outra agência próxima. Entendeu? Atende rápido aquele e aí vem outro pra aproveitar negócio. Se você vir que não vai dar negócio, dispensa. Na central é isso. Atenda rápido, atenda o cliente, explique e oferte. E você tem que fazer isso em 1,87. Agora deve ser 1,75 . A pressão é grande e se você não oferta, você é penalizado. Se a monitoria pegar uma ligação em que você não ofertou, você é penalizado. Mesmo se o cliente não quer saber de oferta nenhuma, você é penalizado. Uma penalização na monitoria, por exemplo, se você tem uma nota de monitoria baixa por causa disso, o seu ENE fica baixo. O ENE é a pontuação pra você poder concorrer a outras vagas, pra poder crescer no banco. Não sei dizer o significado da sigla, mas tem o ENE1, que é... Enfim, é de um a dez. Então pra você participar, começar a concorrer a alguma vaga, você ter chances de crescer ou disputar uma outra vaga, seu ENE tem que ser no mínimo três, só que todas as vagas pedem no mínimo ENE 4. Eles falam que você é elegível no ENE3, só que todo o gestor pede ENE 4, ENE5. ENE 5 é aquele que tira 100\% de monitoria, $100 \%$ de meta, $100 \%$ de aderência... Ou seja, é o perfeito, que só tem $1 \%$ na central. [...] então você recebe cem ligações, você é obrigado a ofertar nas cem. É um absurdo. A pessoa sai desgastada de lá, não aguenta, entendeu? (Bancário, Agente Comercial, 29 anos, 07 de banco)

De acordo com a explicação do consultor de RH:

A empresa está em um ambiente competitivo e a todo momento busca se desenvolver. Através das metas ela quer trazer a organização para outro patamar de performance. Esse processo é 
continuo e se a pessoa não está contribuindo para esse processo de superação, ela não está interessada. (Consultor de RH entrevistado).

Como vimos, os "modelos próprios de remuneração variável” não contemplam todo o universo de trabalhadores com premiações monetárias extras, o que poderia justificar a corrida "voluntária" pela produtividade, assim reafirmamos aqui a perspectiva de que, mais do que trabalhar por conta da remuneração variável, trabalhase sob ritmo intenso e condições adversas visando cumprir ou superar as metas estabelecidas de produção em virtude do medo de perder o emprego ou esterilizar a expectativa de ascensão profissional.

A gestão por resultados/metas está articulada a todas as formas de controle objetivo e subjetivo, de participação e adesão, de estruturação de carreiras e perfis, de incentivo e punição dentro da grande corporação bancária. $\mathrm{O}$ fio condutor que perpassa e integra todos os meandros do processo de trabalho que analisamos se expressa na entrega de resultados em curto prazo.

\subsubsection{As metas}

Os trabalhadores, segundo analisaram Dias e Zilbovicius (2009, p. 122), estão inseridos em um "contexto de criação de valor ao acionista que se posiciona de acordo com o custo de oportunidade e de flexibilidade de seu investimento". Para atender a essas expectativas dos acionistas, o processo de trabalho é gerenciado por metas, por um sistema de indicadores que admitem mudanças contínuas e que tornam a incerteza algo legitimado.

No Banco $\Delta$, os programas de gestão por resultados/metas começaram pela área comercial, tendo como base de referência os indicadores de performances sobre a venda de produtos e serviços. Com o passar dos anos tais programas foram difundidos para todas as áreas e atividades, inclusive aquelas em que supostamente não era possível mensurar indicadores, por causa da dificuldade em obter quantificação e, sobretudo, por envolverem uma interação direta com os clientes.

As metas podem ser compreendidas por um conjunto de indicadores definidos arbitrariamente pelo gestor. Para as agências, na área comercial, valem quatro macro indicadores subdivididos da seguinte forma:

a) Venda de Produtos;

b) Venda de Serviços; 
c) Validação de investimento e crédito;

d) Atendimento e qualidade dos processos.

Pudemos apreender que os trabalhadores do $\operatorname{Banco} \Delta$ têm dificuldade em entender a complexidade dos programas de metas, quando eles incluem uma lista extensa de indicadores e subindicadores, alguns dos quais fogem à sua governabilidade, pois tem a ver com a demanda ou com condições de infraestrutura deficitárias. Além disso, em determinados locais, como são as agências, os indicadores de cumprimento de meta dependem da variação com relação aos demais colegas, pois a "classificação" individual de um trabalhador no ranking depende do efeito comparado entre os participantes.

Nas agências está disseminado um programa de metas que considera uma determinada pontuação a ser atingida. O trabalhador que atinge $100 \%$ da pontuação é aquele que no jargão corporativo conseguiu "bater as metas" ou "entregar os resultados". Entretanto, pelo fato das métricas serem comparativas ao longo do tempo de execução das tarefas, elas podem ser reajustadas para cima conforme a oscilação dos demais trabalhadores que obtenham melhor pontuação.

Os mecanismos de controle informatizados ao estabelecerem o cruzamento de informações de produtividade individual apontam possibilidades de crescimento das metas em situações que podem se conformar quando alguns trabalhadores atingem mais do que os $100 \%$, gerando um efeito comparativo que irradia para toda a rede como meta possível. Dito de outro modo, atingir os $100 \%$ torna-se na prática o mínimo e não mais o máximo das metas estabelecidas, pois a métrica poderá considerar $120 \%$ ou $140 \%$.

Os entrevistados relatam que há um limite para o corte de trabalhadores com base no cumprimento das metas:

$100 \%$ é o limite de corte da demissão. (Bancário, Gerente de Contas, 32 anos, 07 de banco)

O banco deixa claro, se você não bateu três vezes a meta, é rua. Isso já é claro. Um gerente que não bateu a meta durante três meses... mas a meta que ele fala é tipo assim, você ficou três vezes dentro do mil, você tá ali no mediano e ele não vai te mandar embora... Ele tá te cobrando, enchendo, azucrinando. Três vezes você fez abaixo de mil, é rua. No final de mês, que o pessoal tá louco pra bater a meta, você vê assim: Nossa, tal gerente bateu tanto... Quem bateu mais? Então você vê que tem essa coisa e você tá lá tentando, tentando, e fica meio constrangido né! É... o pessoal fez tanto e você ali não conseguindo. Você fica meio chateado com isso. Ai seu Gestor pega e remete um e-mail pra você de novo dizendo: Vai pra cima! (Bancário, Gerente de Contas, 25 anos, 04 de banco) 
Ao superar a margem de cumprimento da meta em $100 \%$, ou seja, obter níveis mais elevados, o trabalhador passa a ser elegível à remuneração variável, que obedece a valores escalonados de acordo com a posição ocupada no ranking de determinada região.

Um aspecto importante a considerar é que dadas essas circunstâncias nem todos os trabalhadores elegíveis recebem a remuneração variável extraordinária, pois ela se submete ao efeito comparativo com os demais trabalhadores na competição interna estabelecida.

A tabela a seguir reproduz a pontuação dos trabalhadores, ocupando o cargo de Gerentes de Contas de uma determinada região de São Paulo. Os Eixos X e Y representam respectivamente as metas objetivas e as metas subjetivas que foram alcançadas até o momento da verificação. O "GAP” é a lacuna que se estabelece por comparação entre os trabalhadores com mais pontuação para cada tipo de meta (Eixos X e Y). O "Total” representa a soma dos dois eixos de avaliação. O item "Quadrante" indica a ação do trabalhador correspondente à sua posição naquele momento.

Tabela 6 - Pontuação dos trabalhadores

\begin{tabular}{|c|c|c|c|c|c|c|c|}
\hline Agência & Nome Gerente & Eixo $X$ & GAP $X$ & Eixo $Y$ & GAP Y & TOTAL & $\begin{array}{c}\text { Quadrante } \\
\text { MPG }\end{array}$ \\
\hline 1633 & & 300,2 & 133,6 & 169,2 & 21,6 & 469,4 & Superar \\
\hline 2969 & 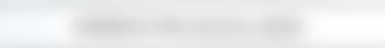 & 355,8 & 189,2 & 112,5 & $-35,1$ & 468,3 & Contatar \\
\hline 1574 & 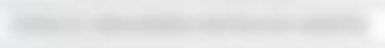 & 286,5 & 119,8 & 131,5 & $-16,1$ & 418,0 & Contatar \\
\hline 8058 & 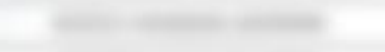 & 263,3 & 96,6 & 104,6 & $-43,1$ & 367,8 & Contatar \\
\hline 1016 & 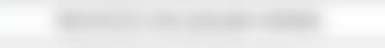 & 214,2 & 47,5 & 140,0 & $-7,6$ & 354,2 & Contatar \\
\hline 0622 & 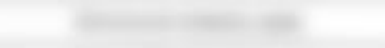 & 215,2 & 48,5 & 127,8 & $-19,8$ & 343,0 & Contatar \\
\hline 1016 & 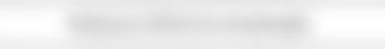 & 191,2 & 24,6 & 138,9 & $-8,7$ & 330,2 & Contatar \\
\hline 0354 & 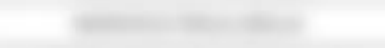 & 172,5 & 5,8 & 155,0 & 7,4 & 327,5 & Superar \\
\hline 0762 & 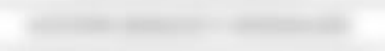 & 194,9 & 28,2 & 100,0 & $-47,6$ & 294,9 & Contatar \\
\hline 6502 & 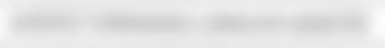 & 149,3 & $-17,3$ & 141,7 & $-5,9$ & 291,0 & Reagir \\
\hline 6645 & 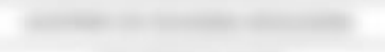 & 163,8 & $-2,9$ & 121,3 & $-26,4$ & 285,1 & Reagir \\
\hline 0466 & 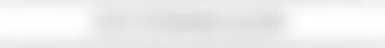 & 131,2 & $-35,4$ & 135,3 & $-12,3$ & 266,6 & Reagir \\
\hline 8137 & 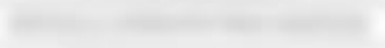 & 134,4 & $-32,3$ & 125,0 & $-22,6$ & 259,4 & Reagir \\
\hline 1024 & 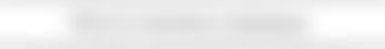 & 108,9 & $-57,7$ & 141,3 & $-6,3$ & 250,3 & Reagir \\
\hline 6646 & 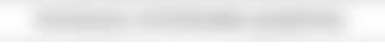 & 135,8 & $-30,9$ & 100,0 & $-47,6$ & 235,8 & Reagir \\
\hline
\end{tabular}

Reprodução material institucional do Banco $\Delta$ em matéria disponível no site do Sindicato dos Bancários de SP, Osasco e região. A subtração de nomes já havia sido feita na versão publicada pelo Sindicato no sentido de preservar os trabalhadores. Disponível em: | http://www.spbancarios.com.br/Noticias.aspx?id=10085. Acesso em: jul.2015.

A declaração do entrevistado que atua em área administrativa da instituição pesquisada dimensiona o peso das metas nas agências bancárias, situando este local 
como um dos piores quanto à pressão temporal e à cobrança de resultados, dada a condição de que a meta é renovada mensalmente.

O banco, independente do nível, quer ver resultado. Um processo com maior qualidade, com custo, ele deixa de lado e isso envolve o bem-estar do trabalhador [...] Na agência, de fato, são massacrados, não são metas anuais e semestrais como no departamento, mas tem agenda de entregas que também não é fácil de alcançar, mas a realidade do pessoal de agência é de metas mensais, então eles têm que quebrar todo mês aquilo, eles tão apanhando pra caramba, são os que mais sofrem, lá também bate ponto e continuam a trabalhar, mas em departamento também. (Bancário, Analista Júnior, 29 anos, 04 de banco)

Os trabalhadores do Banco $\Delta$ têm suas metas registradas em um "microcontrato"138 que ficará disponibilizado eletronicamente no sistema de informações da instituição, sob o qual o trabalhador é obrigado a registrar sua assinatura eletrônica, dando conhecimento público sobre as suas obrigações que se tornam monitoradas por um programa interno estruturado exclusivamente para acompanhar sua performance.

O aprofundamento da individualização das relações capital-trabalho é asseverado pela adesão direta do trabalhador ao "contrato de metas". Tal prática conduz ao isolamento do trabalhador responsabilizando-o diretamente pelo seu fracasso, quando no processo avaliativo as causas da sua não promoção, do não recebimento de remuneração variável e até mesmo de seu desligamento estarão condensadas em um "problema individual", habitualmente ligado à explicação-padrão de "baixa produtividade".

Soares (2013), em sua pesquisa sobre o setor, havia detectado que os próprios trabalhadores adquirem produtos bancários para cumprir as metas de produtividade. É o que também verificamos nas declarações dos entrevistados, para esta pesquisa, que tomaram tal atitude com o objetivo de contornar o risco relacionado à perda de emprego.

Os processos de avaliação, que serão analisados em tópico deste capítulo mais adiante, são centrais para dar suporte aos programas de gestão por resultados. No fechamento do ciclo avaliativo ocorrem as premiações ou são implementadas outras medidas intermediárias de ajuste que podem inclusive culminar com a demissão dos menos capazes em trazer retorno.

\footnotetext{
${ }^{138}$ De acordo com informações divulgadas pelo $\mathrm{Banco} \Delta, 100 \%$ dos trabalhadores têm metas contratadas (Relatório Gerencial do $\operatorname{Banco} \Delta 2010)$
} 
A declaração do administrador do $\operatorname{Banco} \Delta$ reforça a relação entre meritocracia e avaliação no universo corporativo:

A meritocracia tem de ser o elemento-chave de nossa cultura, para colocar as melhores pessoas em cada posição e desenvolver a qualidade das equipes. Todos somos avaliados na organização e temos de encarar esse processo com mais naturalidade e superar a dificuldade de dar e receber feedbacks. (Presidente Conselho Administração Banco $\Delta$. Revista Banco 4 , Edição 2, 2014)

Pela nossa observação é possível afirmar que os programas de gestão por resultados disciplinam os trabalhadores, subtraindo um papel antes destinado exclusivamente ao supervisor imediato, pois não há maior ameaça que o não cumprimento das metas de trabalho para tornar o indivíduo focado no trabalho.

\subsubsection{Pressões no trabalho}

No ambiente corporativo criam-se exigências cada vez mais elevadas. Como analisou Gaulejac (2007, p. 41), em seu estudo sobre a gestão nas empresas, o “desempenho e a rentabilidade são medidos em curto prazo, em tempo real, pondo o conjunto do sistema de produção em tensão permanente".

Aquilo que se define por exigências dos acionistas pode ser traduzido por microobjetivos locais, em práticas cotidianas que respondem ao nível de competitividade instalado e conformam assim as várias formas de pressão.

A pressão que ocorre no ambiente de trabalho percorre toda a cadeia produtiva da organização. Começa definida pelos parâmetros do mercado financeiro, gerando expectativas de retorno elevadas. Depois se localiza entre os altos executivos e administradores. Estes, apoiados nas sofisticadas formas de racionalização do trabalho, reproduzem em todos os espaços corporativos, para todos trabalhadores, inclusive trainees, estagiários ${ }^{139}$ e até mesmo os terceirizados, a tensão competitiva instalada em nível macro. Todos devem assumir seus compromissos e serão amplamente cobrados por isso.

Conforme abordou Jinkings (2002) entre os bancários, como em outros segmentos da classe trabalhadora, a pressão por produtividade "apresenta-se diluída e obscurecida pelas "leis" do mercado e exigências atribuídas aos clientes" (JINKINGS, 2002, p. 196).

\footnotetext{
${ }^{139}$ Estagiários, desde 2014, passaram a ser submetidos ao regime de metas, entretanto não recebem remuneração variável em nenhuma circunstância investigada, nem aquela regrada pela CCT nem derivada de "programas próprios".
} 
É razoável, portanto, admitirmos que os programas de qualidade total e de remuneração variável constituíram-se em instrumentos auxiliares à gestão do trabalho, ainda que não fossem assim declarados pelos seus mentores.

Os programas de Qualidade Total consubstanciaram uma nova "moda" da gestão administrativa que vigorou nos anos 1990. Ancorados nas reestruturações produtivas que ocorriam em diversos setores da economia, tais programas buscaram, do ponto de vista do marketing empresarial, implementar um discurso que fosse imbuído de algo mais nobre do que apenas alcançar lucros maiores, mas que trouxessem ganhos para a sociedade.

Os pagamentos de remuneração variável condicionados ao cumprimento de metas até certo ponto também visaram tornar a produtividade no ambiente de trabalho algo que fosse uma vantagem não só para os bancos, mas também para os trabalhadores.

À medida que os programas de gestão por resultado foram se ampliando e a negociação sindical passou a regular cada vez maiores fatias da remuneração variável a partir do indicador "lucro", a idealização de parcela dos trabalhadores foi obscurecendo, enquanto a espinha dorsal dos programas, que é o resultado no curto prazo, foi evidenciada.

Nesse propósito, os bancários são "desafiados” a dar mais de si, a superar a meta já estabelecida em troca de outra maior. O crescimento da produtividade e, consequentemente, da intensidade do trabalho, mediante todas as formas de controle e pressão, fica exposto, a seguir, nas falas dos trabalhadores:

Aumentou o trabalho, a pressão, as formas de cobrança em relação às metas. No passado, quando eu iniciei no cargo de gerente, nós tínhamos uma campanha de um determinado produto e depois foram incorporadas uma grade, né? Nessa grade existem diversos produtos e nós temos que atingir as metas de cada produto. Então foram incorporadas cobranças maiores em cima do cumprimento das metas. Então isso quadriplicou a nossa função, nosso trabalho no dia a dia, sobrecarregando o funcionário, o que significou um ritmo de trabalho mais intenso. (Bancária, Gerente de Contas, 46 anos, 28 de banco)

Nós vivemos por produção [...] existe controle diário por produção. Tem época que eu fazia 20 operações, mas como tem que ser uma coisa criteriosa que precisa conferir valores, percentual, taxas, se o cliente é $100 \%$ nacional, então quando você faz, não tem jeito, é a sua assinatura eletrônica, então tem que fazer dentro do critério. Mas aí o coordenador chega e diz - Você está fazendo quantas por dia? Digo 20. Então ele pergunta se não dá pra melhorar. Eu digo: Posso me esforçar. Já cheguei a fazer 25 e aí na mesma semana ele chegou pra mim e disse: E aí, tá fazendo 25! Me deu os parabéns e 
perguntou: Não dá pra fazer umas 30 ? Eu abertamente disse pra ele que não dava! Sabe por quê? Se eu liberar um valor que não devo, de um cliente que não está apto, é a minha assinatura, sou eu que vou ser penalizado. Vou fazer 25, é apertado, mas vou fazer o que é pedido. Não vou fazer vista grossa. E foi assim, mas, coincidentemente logo após 08 meses eu tive um problema de estresse e fiquei afastado. (Bancário, Analista Júnior, 42 anos, 12 de banco)

Você sempre deve buscar a superação. Se hoje tenho que vender duas previdências no mês, se eu atingir essa meta hoje, no mês que vem serão 03, depois 04, 05, 06. Ela sempre vai aumentando, tem um caráter de inatingível. É uma meta que considera aquilo que você atinge, mas no mês que vem ela aumenta e isso significa que sempre temos que demandar um esforço muito grande, por exemplo, você fez um trabalho, você conseguiu, parabéns, mas amanhã você vai ter que fazer o dobro para atingir de novo. Hoje o $100 \%$ de cumprimento da meta é um referencial. Algumas metas ultrapassam o $100 \%$, esse é apenas um referencial, o que a nossa gestão pede é para atingimos $150 \%$ da meta. Existem campanhas que vão até $200 \%$, esses produtos que o banco escolhe, mensais, tem que ter um desempenho maior. O $100 \%$ é fictício. A meta não é $100 \%$, é $150 \%$ até 200\%. (Bancário, Gerente de Contas, 32 anos, 07 de banco)

Todo mês tem aquela meta de todos os produtos e não necessariamente você encontra os clientes que vão querer todos aqueles produtos todos os meses... Chegou dia 31, eu consegui bater a meta e aí vem o próximo mês e tá tudo zerado. A meta está toda zerada de novo e eu tenho que oferecer tudo de novo e é esse o objetivo do banco, que é uma instituição financeira [...] A meta de um mês para outro muda 10 mil reais, mas ela não precisa aumentar porque ela já é alta. Mas o banco sempre vai colocar metas ousadas. (Bancária, Gerente de Contas, 35 anos, 08 de banco)

Diversos autores (JINKINGS, 2002; GRISCI; SCALCO; KRUTER，2011; BORGES; VITULLO; PONTE, 2012; SANTOS, 2012; GEHM, 2013; SOARES, 2013; OLIVEIRA, 2014; NOGUEIRA, 2015; OSTRONOFF, 2015) apontaram que a pressão para o cumprimento de metas se tornou um dos principais problemas registrados pelos trabalhadores bancários.

A pesquisa "Perfil do bancário e as condições de trabalho no setor financeiro na cidade de São Paulo" coordenada por Rodrigues (2011) demonstrou que 30\% dos respondentes destacaram as "metas" como o item que mais deveria ser regulado pela CCT. A relevância do percentual demonstra a sua importância na cena do trabalho bancário quando comparada às respostas sobre outros itens: $15 \%$ cita o ritmo de trabalho, $12 \%$ jornada de trabalho, $11 \%$ igualdade de tratamento e $11 \%$ menciona a relação com gerentes. Foi questionado ainda na mesma pesquisa se as metas eram 
compatíveis com a jornada de trabalho, item sobre o qual 36\% discordaram totalmente. Por fim, vale destacar que quando perguntados sobre a pressão no trabalho, $61 \%$ dos respondentes concordaram totalmente que a pressão no trabalho é muito intensa.

Ainda no sentido de tornar evidente o peso que as metas assumiram na vida do trabalhador bancário, situamos os resultados de outra pesquisa, ${ }^{140}$ encomendada pelo Sindicato dos Bancários de SP em 2011, que corroboram com as análises trazidas à tona.

Quadro 7. Pesquisa "O impacto da organização e do ambiente de trabalho bancário na saúde física e mental da categoria" - Grupo Respondente: Bancos Privados

\begin{tabular}{lc}
\hline Frase apresentada ao bancário (a): & $\begin{array}{c}\% \text { de } \\
\text { concordância }\end{array}$ \\
\hline A meta em si não é o problema, mas sim a pressão abusiva para superá-la. & $60 \%$ \\
\hline As metas nos obrigam a vender produtos que os clientes não precisam. & $40 \%$ \\
Faço tudo para bater minhas metas, até pedir para clientes "por favor" para & $32 \%$ \\
comprar.
\end{tabular}

Me sinto um número, se bato a meta, tudo bem. $44 \%$

Fonte: Sindicato Bancários de SP, Osasco e região, 2011.

Os percentuais elevados de concordância dos respondentes com as afirmações acima destacadas confirmam nossa atenção para a problemática que envolve o tema das metas. A percepção dos trabalhadores na pesquisa citada reafirma o trabalho submetido à forte pressão e aponta para a "necessidade" de superação das metas estabelecidas, o que ajuda a explicar uma outra questão não menos relevante sobre a venda de produtos que estão desvinculados das necessidades reais das pessoas.

\subsubsection{A superação no ambiente corporativo e a metáfora do atleta}

É, principalmente, sob o argumento de "baixa produtividade" que diversos trabalhadores são demitidos das instituições financeiras. A explicação padrão, apresentada à maioria dos trabalhadores na hora da demissão, pode ou não ser a razão exata do desligamento, mas, independente disso, assume a função de reafirmar a mensagem fundamental aos que ficam: é preciso justificar a vaga ocupada mantendo a alta produtividade, afinal, os resultados de ontem não valem para hoje.

Como analisou Gaulejac (2007, p. 84):

\footnotetext{
${ }^{140}$ A pesquisa "O impacto da organização e do ambiente de trabalho bancário na saúde física e mental da categoria" foi realizada em 2011, envolveu 818 participantes e abrangeu uma ampla gama de cargos e locais de trabalho, representantes tanto das agências como das áreas administrativas.
} 
O postulado inicial é que a situação presente não pode ser satisfatória porque é sempre possível fazer melhor. Deixamos na sombra as consequências da exigência do sempre mais. Para um ganhador, quantos foram os perdedores? A busca de um ideal de perfeição leva a uma competição sem fim. O sucesso torna-se uma obrigação: é preciso ganhar caso contrário o indivíduo é eliminado.

Estabelecendo um paralelo da trajetória profissional de um bancário com um atleta profissional, ${ }^{141}$ observamos, em ambos os casos, que a capacidade para se manterem atuantes é medida constantemente por suas performances.

No caso do atleta de alto rendimento, as influências das novas tecnologias calcadas nos estudos da aerodinâmica, biomecânica e biofísica forneceram parâmetros refinados sobre seu modo de ser e atuar nesses ambientes. Os treinadores podem acompanhar as estatísticas dos atletas em tempo real verificando velocidade, deslocamento, aceleração, fadiga, tudo captado por chips e sensores de movimento que podem até ser projetados em telas holográficas. ${ }^{142}$

O atleta deve, assim, com estas condições, buscar atingir seus limites. Contudo, a maximização do seu desempenho pode aumentar a propensão à lesão física. Uma vez lesionado, ainda que afastado para tratamento, com possibilidades remotas de voltar a atingir níveis altos de produtividade, seu valor tende a cair, da mesma forma que podem ser perdidas novas oportunidades de contratos com patrocinadores.

Um trabalhador de uma grande instituição bancária dificilmente conseguirá manter desempenhos elevados por longos períodos. Cada indivíduo possui uma "resistência própria", uma constituição social, física e mental que pode ou não encurtar sua trajetória de alto desempenho profissional.

Se, no âmbito das competições esportivas, ganha e se mantêm competindo aqueles que possuem boa ou excelente performance, pode-se afirmar que no âmbito corporativo algo muito similar acontece. As métricas de acompanhamento e controle em tempo real, possibilitadas pelos meios informatizados, evidenciam as performances individuais baixas ou médias que se constituem desse modo em uma ameaça constante à permanência no emprego.

A velocidade proporcionada pelas tecnologias da informação alterou a vivência dos tempos de trabalho, pois implicou em comparações ainda mais claras entre os diferentes níveis de produtividade de cada trabalhador. Assim, como ocorre com um

\footnotetext{
${ }^{141}$ É corrente no ambiente corporativo o uso de palavras que reforçam o universo das competições, como: time, técnico, líder, performance, ranking, superação, dentre outras.

${ }^{142}$ Disponível em: www.cienciahoje.uol.com.br. Acesso em: fev. 2015.
} 
atleta profissional, monitorado pelo seu patrocinador, a queda de performance se torna fator de exclusão gerada pela falta de reciprocidade com o investimento esperado em circuitos altamente competitivos.

A "pontuação" dos bancários é calculada e validada no curto prazo, de forma que os resultados de hoje não valem para amanhã. A cada fechamento de balanço divulgado aos acionistas é preciso dar sinais de vitalidade. Portanto, a exemplo do que ocorre com o atleta de ponta, é difícil suportar no longo prazo e, repetidamente, a dinâmica competitiva, que coloca sob efeito reverso a própria condição física e psíquica dos trabalhadores submetidos a essa condição.

A metáfora do atleta ainda pode nos fornecer mais uma chave de leitura. Considerando que ambos, o atleta e o bancário, buscam a todo o momento superar seus limites, não é desprezível observar o uso de métodos pouco ortodoxos para atingir o que às vezes está inatingível. Nessas ocasiões são registrados casos em que foram cruzadas as fronteiras da ética dos negócios e do próprio respeito à sua integridade física.

No campo das competições esportivas os controles antidoping se tornaram parte da rotina dos eventos. Nas corporações para combater desvios, fraudes e práticas "politicamente incorretas" que atinjam acionistas e clientes, são disseminadas formas de vigilância que passam pelas normas internas, processos contínuos de auditoria e, ainda, as populares "boas" práticas de governança corporativa.

\subsubsection{Metas são um convite ao vale-tudo}

"Sem ética, metas são um convite ao vale-tudo."

(Revista Exame, set. 2002)

"No mundo das empresas, dos negócios e das carreiras, onde há metas a serem atingidas, parece que vale-tudo para sua conclusão."

(Revista Você S.A., fev. 2015)

"O recorrente apelo à ética é a expressão do desejo de reconstituir a coerência e o simbólico em um universo incoerente e caótico."

(Gaulejac, 2007, p. 124) 


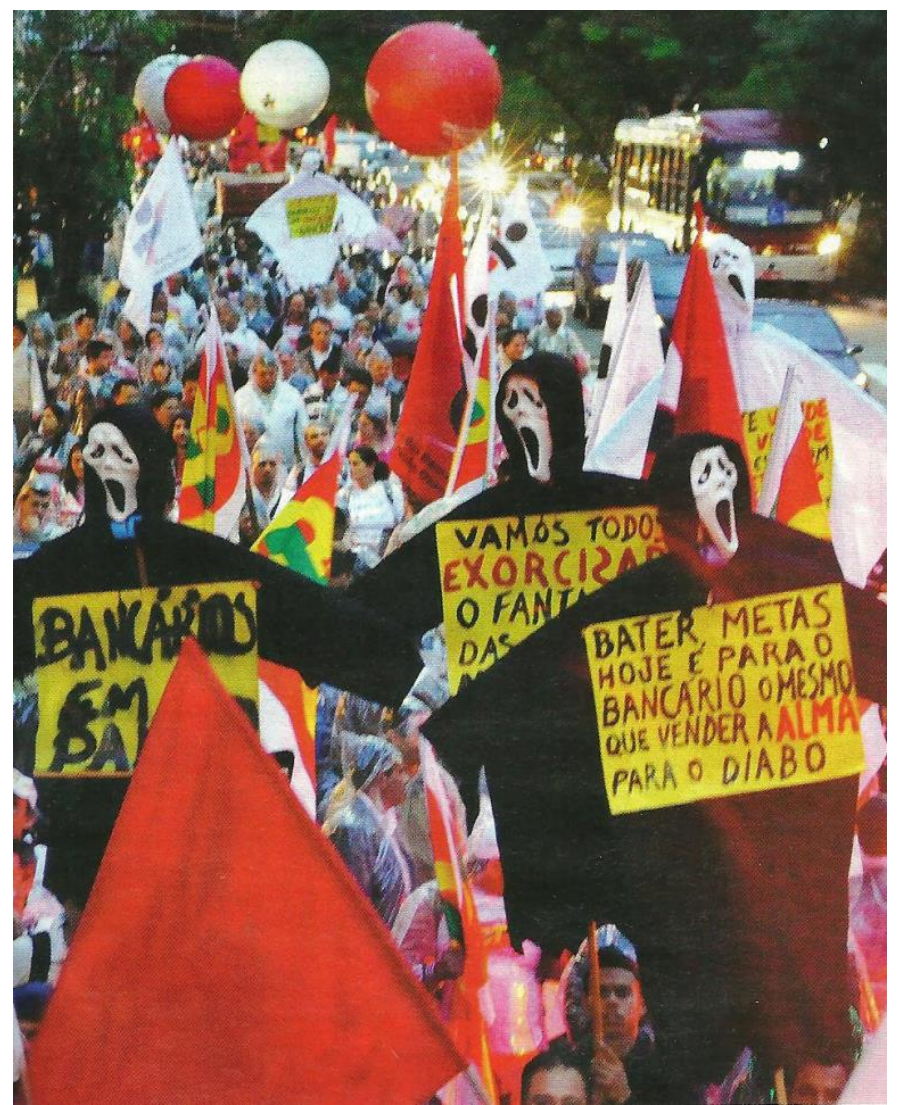

Imagem 4: Passeata dos bancários na Av. Paulista durante Campanha Salarial em setembro de 2013.

Foto: Maurício Morais/SEEB-SP

Para iniciar a reflexão sobre os limites que envolvem as pressões para cumprimento de metas no trabalho, recuperamos o conteúdo de uma revista especializada em economia e administração, ${ }^{143}$ publicada no início da década de 2000 , que em matéria de capa afirmava que muitas metas nas empresas eram fixadas com base em expectativas irreais e com a ajuda de uma contabilidade duvidosa. Apesar da matéria ter sido escrita há 13 anos, o argumento central, à época utilizado, para explicar tal razão ainda se mantém ativo, pois, como já apontava, era, e, ainda é forte a pressão para que as empresas tenham rentabilidades elevadas a despeito de cenários adversos do ponto de vista econômico, político e social em que estão inseridas.

Enquanto as economias nacionais crescem em margens modestas, na margem de um dígito, as empresas ditas competitivas são incitadas a crescerem dois dígitos como apurou um estudo da UNCTAD. ${ }^{144}$

\footnotetext{
${ }^{143}$ Revista Exame, set. 2002.

${ }^{144}$ UNCTAD. "The global economic crisis: systemic failures and multilateral remedies". Genebra: Organização das Nações Unidas, Conferência das Nações Unidas sobre Comércio e Desenvolvimento, 2009, p. XII., apud Bresser-Pereira (2010).
} 
"Deslizes" e "falcatruas" na gestão administrativa e financeira das empresas são apontados na matéria mencionada como formas de burlar os resultados. Como desdobramento dessa percepção, ao longo das últimas décadas foram reforçadas as orientações de conduta para aqueles que pretendiam se situar na arena competitiva. Além da atualização das normas para publicação de balanços em convergência com os novos padrões internacionais, ${ }^{145}$ foi dada nova e funcional relevância à discussão sobre ética no ambiente de negócios. As grandes corporações atentas ao novo protocolo de convivência concorrencial passaram cada vez mais a dar transparência de seus atos.

Os relatórios gerenciais das grandes corporações, com base nos princípios da "boa" governança, foram elaborados para informar os investidores sobre as estratégias empenhadas em obter resultados, riscos aos quais estão submetidos e medidas que são tomadas no sentido de tornar o rendimento sustentável. Nesse âmbito, as instituições que negociam ações em Bolsa de Valores, como já mencionado por nós, passaram a divulgar massivamente os pressupostos da sua administração, o que incluía o conjunto de normas internas denominado Código de Ética.

Contudo, a dinâmica dos negócios e dos processos de trabalho em si está baseada em conduzir os indivíduos - sejam eles altos executivos, gestores e demais trabalhadores - a um estado de superação constante. Diante desta realidade, ainda que se busque de alguma forma equilibrar esta difícil relação entre a pressão exercida sobre os indivíduos e os "desvios indesejáveis", está claro que não cumprir as metas de produtividade implica, sobretudo no setor privado, colocar em risco a própria subsistência.

Também não se pode desprezar o fato de que os trabalhadores inseridos em uma relação marcada pela assimetria de poder em muitas circunstâncias são constrangidos a adotar certas práticas que o próprio superior hierárquico pode assumir como corriqueira, admitindo, ainda que veladamente, um modo legítimo de atuar na corporação, haja vista trazer os resultados esperados.

Adentrando no universo bancário, a pesquisa de Soboll (2008) apontou como as pressões sobre os trabalhadores podem gerar distorções no processo de trabalho e

\footnotetext{
${ }^{145}$ As empresas brasileiras concluíram em 2010 a adequação de seus balanços às Normas Internacionais de Contabilidade - IFRS (Internacional Financial Reporting Standards). Nos Estados Unidos e na União Europeia desde meados dos anos 2000 tais normas passaram a ser adotadas obtendo a adesão progressiva de diversas nações. A nova política de governança surgiu após os escândalos e falências que contribuíram para perdas recordes no mercado de ações, sobretudo aquelas associadas às fraudes contábeis em empresas multinacionais como a Enron e Worldcom. Fonte: Revista Exame, ago. 2010; Artigo disponível em: https://www.knowledgeatwharton.com.br/article/normas-contabeis-e-de-auditoria-iasb-fasb-etc/. Acesso em: jul. 2015.
} 
inclusive por em xeque os compromissos morais assumidos publicamente pelas instituições:

O profissional sente-se forçado a executar mal o seu trabalho, contra seus princípios éticos, diante das pressões sociais do trabalho e das ameaças e situações reais de exclusão. Diante das pressões e da necessidade de gerar números, a produção real abre espaço para a "fabricação de números" e desafia os valores pessoais. (SOBOLL, 2008, p. 114)

Os entrevistados do Banco $\Delta$ relatam como se dá a cobrança das metas e por quais caminhos elas se tornam um convite ao "vale-tudo". A ética profissional, quando sucumbe no ambiente corporativo, se faz diante da pressão exercida sob os trabalhadores e do pragmatismo dos gestores da instituição, que fazem "vista grossa" quando os resultados no curto prazo são alcançados.

O gerente fala: $\mathrm{Na}$ hora que você estiver em casa desempregada, sem convênio e com conta pra pagar você vai lembrar se você tem ou não tem que vender pra ele [cliente]. (Bancária, Analista Júnior, 57 anos, 12 de banco)

Eu trabalho de uma forma ética, mas eu vejo que o banco cobra... Sempre falou muito de ética, em propaganda e tudo mais. Se você trabalha ofertando e bate a meta, você fez tudo certo. Só que tem mês que mesmo ofertando você não consegue, você não encontra todos os clientes falando sim para você. E aí o que acontece com algumas pessoas, você tem que pedir... Como se fosse um favor. Tem que pedir: Me ajuda! Ou de repente trabalhar com uma coisa goela abaixo, por exemplo, para liberar o crédito você compra um produto, porque a gente precisa melhorar o seu relacionamento com o banco, então você faz a venda casada. Eu não costumo fazer isso, mas vamos dizer que isso ajuda e que às vezes preciso recorrer a isso. E faço dando opção para o cliente, olha, depois a gente cancela, para de toda forma não ficar com a consciência tão pesada. [...] A ameaça vem depois, se você não bate a meta você começa a ser... Olha você não está atingindo o perfil que o banco tá querendo. Você não está performando, ou seja, você não está atingindo a meta, os mínimos mil pontos. O banco te dá estes pontos para você atingir só que se você passa muito disso e começa a ter remuneração maior no salário, aí o banco coloca meta alta para você não ter facilidade de atingir, para você não ganhar pra não pagar. A gente percebe isso. Você tem que agir eticamente, mas às vezes é incoerente com o que ele pede de meta para atingir. Então às vezes parece assim: Poxa vida, mas como eu vou agir eticamente sendo que vocês estão pedindo esta meta tão absurda e se eu não bater essa meta pelo menos uns 03 meses você vai vir aqui e me ameaçar.

O meu gestor é uma pessoa muito legal, só que em dezembro ele foi muito pressionado, ele não estava batendo muito bem as metas, ficou um pouco abaixo dos mil então ele não teve um bom feedback do gestor dele. Então em dezembro ele me pressionou muito. Gerente de relacionamento precisa de tempo para se relacionar. Ele 
fazia reunião e ficava repetindo: Esse mês a gente pode tudo, mas não pode deixar de bater meta, e esse pode tudo, só não pode deixar de bater meta é que soava falta de ética. (Bancária, Gerente de Contas, 35 anos, 08 de banco)

Olha, muitos colegas que eu vi conseguiam mesmo superar a meta. Infelizmente eles caíram em uma armadilha, acabaram trabalhando de uma forma incorreta, faziam coisas erradas e muitos dos que conseguiram, quando você vê né a pessoa muito lá em cima, fechando tudo, logo dava alguma coisa errada e o funcionário era demitido por justa causa. Você entendeu? Porque era forçado a trabalhar errado. Acaba fazendo coisa errada por quê? Por causa dessa cobrança. Porque ele quer atingir, porque ele se sente ameaçado, porque se ele fizer só mil, não é o suficiente. Então acaba fazendo alguma coisa incorreta. (Bancária, Gerente de Contas, 46 anos, 28 de banco)

O banco obriga você a vender tantos produtos e o cliente não quer produto, ele não precisa disso. Só que o banco ganha em cima disso. Então o funcionário, nesse exemplo, ele acaba sendo obrigado, de uma certa forma, a induzir o cliente a comprar um produto mesmo que ele não precise [...] Então às vezes você é forçado a fazer certas coisas que na maioria das vezes o cliente não quer, mas é que você precisa bater a meta. A pessoa com medo de perder o emprego acaba fazendo isso. Você entendeu? Você tem seu salário, você tem seu emprego, mas você vendo outras pessoas conseguindo, porque você tem relatórios de outros gerentes batendo a meta, mas você sabe como que eles estão batendo a meta, você vai acaba fazendo isso, porque tem um superior que fica te cobrando, tem o superior que fala: Olha, sua meta é mil, mas aquela pessoa fez mil e duzentos. Exatamente, se bate nesse estilo de mexidinha, jeitinho. Porque nenhum cliente em sã consciência vai sentar na sua mesa e vai falar: Eu quero contratar dois seguros de vida. Não tem isso. Tem cliente que tem até mais de dois seguros de vida e acidentes pessoais. Mas, é... entendeu? E às vezes você acaba entrando nesse quesito. Será que eu faço ou não faço? Vou precisar porque o meu gestor superior está me pressionando e você acaba tendo alguns deslizes por causa disso, por causa da pressão. (Bancário, Agente Comercial, 29 anos, 07 de banco)

A abrangência do enfoque dado por nós extrapola o setor bancário. Na pesquisa sobre o trabalho no setor de call centers, Rosenfield (2009) registra como a busca por resultados se torna um problema que afeta a estrutura do processo de trabalho, na medida em que as pressões sobre os trabalhadores são reflexo das pressões sofridas pelos superiores. De acordo com a autora:

A hierarquia faz "vista grossa" - finge que não vê - para usurpações das normas, mas que revertem em vendas, ou mesmo quando estimulam espertezas desonestas com o cliente. (ROSENFIELD, 2009, p. 177) 
Embora constantemente sejam criados novos mecanismos para tentar controlar as fraudes de trabalhadores nesses ambientes de trabalho competitivos, em que há pressão para cumprimento de metas elevadas, sempre há uma forma de burlar o sistema e, ainda que envergonhadamente ou veladamente, há conivência de outros trabalhadores, pois existem metas para as equipes e para o próprio superior hierárquico, que também responde diretamente a quem está acima de seu cargo e almeja resultados (ROSENFIELD, 2009).

A interação no ambiente corporativo se dá como se fosse uma partida com tempo para acabar e tudo poder recomeçar. Busca-se jogar dentro das regras, mas quando isso se torna irrealizável, algumas "faltas" são cometidas por alguns participantes, sobretudo quando se trata do cumprimento de metas elevadas que ditarão, em caso de fracasso, sua exclusão deste espaço social.

Com vistas a compreender o modo de agir destes trabalhadores no ambiente corporativo a partir das condições concretas em que se inserem, observando a regularidade dos eventos, tentamos encontrar nexos causais para o fenômeno dos “desvios indesejáveis", tentando, assim, transcender à ação singular do agente.

Diante desta perspectiva visamos estabelecer conexões entre a ação e o contexto em que os agentes estão inseridos. Em nosso estudo de caso, a grande corporação bancária é, por excelência, o espaço de interação entre os diversos agentes. Por meio do encontro que ela propicia os trabalhadores, gestores e clientes são influenciados diretamente pelas expectativas de retorno dos acionistas no curto prazo.

Admitindo que os trabalhadores agem sob domínio cultural de seu tempo e são influenciados pelos pensamentos individualistas socialmente estabelecidos, consequentemente passam a racionalizar sobre suas escolhas a partir das condições dadas buscando se autopreservar em meio ao medo, à insegurança e à pressão.

Suas ações devem ainda ser matizadas pelo reconhecimento de que fazem parte de um sistema corporativo. Submetidos à dominação gerencial, recebem diretrizes explícitas ou implícitas de como devem conduzir seus atos.

Considerando que os trabalhadores descreveram nas entrevistas situações em que as normas internas são burladas e procedimentos pouco ortodoxos são adotados com a finalidade de atingirem ou superarem as metas de trabalho, nosso desafio é interpretar como esses acontecimentos se tornaram implicitamente aceitáveis e usuais.

Poderíamos dizer que os agentes incorporaram e naturalizaram suas condutas pela tradição do meio, pela repetição do gesto quase mecanicamente, o que explica certa 
normalidade e disseminação das práticas "indesejáveis" dos gestores ou trabalhadores. Mas, em outra perspectiva analítica, inferimos que tais agentes, uma vez que se encontram subordinados e acuados ao descumprirem normas ou cometer pequenos ilícitos, desenvolvem estratégias singulares de subversão aos fundamentos da ordem meritocrática e competitiva. Afinal, para os que "fracassam", a ordem impõe o desalento marcado pela perda do emprego e das demais vantagens comparativas, que conferem pertencimento social aos agentes, como aquelas que descrevemos no Capítulo 4.

As situações que podem por em xeque as orientações do Código de Ética do $\operatorname{Banco} \Delta$ foram sistematicamente narradas pelos trabalhadores. $\mathrm{O}$ conjunto de ações evidenciadas sempre esteve interligado a um cotidiano de trabalho marcado pela pressão, na qual a forma mais evidente de sobreviver passa pela aceitação das práticas “indesejáveis" ou crítica velada.

Foi perceptível pela mostra de nossos entrevistados que sobre aqueles que adotam tais práticas fica o peso da inadequação dos fatos. A declaração aberta sobre a omissão intencional de informações, mentiras ou de outros modos de agir no trabalho que configuram o ilícito ficaram, portanto, "proibidas" de serem divulgadas em detalhes na medida em que se pode criar prova contra si próprio.

Para Dejours (2006) o "sofrimento ético", derivado dos atos que o trabalhador moralmente condena, mas que foram experimentados em função do seu trabalho, pode ser ressignificado à medida que o trabalhador constrói defesas contra esse sofrimento e diante delas preserva seu equilíbrio psíquico.

No mesma direção, Gaulejac (2007) analisou que os trabalhadores imersos em um cenário repleto de "injunções paradoxais", como se vivencia no ambiente corporativo, faz estes, para não enlouquecerem, se "defenderem" de diferentes modos.

A resistência mais frequente é a clivagem entre um "Eu organizacional", o que parece responder às exigências da empresa, e um outro "Eu", o Eu "verdadeiro", aquele que se revela fora, nos lugares de expressão íntimos ou privados. O "Eu oficial" manifesta seu entusiasmo e sua adesão. O "eu privado" murmura suas reticências e suas críticas”. (GAULEJAC, 2007, p. 108)

Tais ponderações apontam a existência de um sistema que, em que pese aparentemente funcionar a contento dado os resultados financeiros obtidos no curto prazo, traz consequências indesejáveis no médio e longo prazo que extrapolam a relação capital-trabalho e atingem inclusive os consumidores dos serviços e produtos bancários. 


\subsection{Processo de Avaliação}

A avaliação periódica de performance é um dos mais importantes instrumentos no sistema meritocrático. Por meio dela são considerados, em uma análise individualizada, quais e como foram alcançados os resultados esperados. Ainda, por meio desse instrumento de gestão podem ser verificados em que patamar se encontra o alinhamento do trabalhador com a cultura corporativa.

Nas organizações, as avaliações são feitas para medir o desempenho dos trabalhadores repercutindo diretamente em suas carreiras e nas remunerações (HIPÓLITO; REIS, 2002). Trata-se de uma forma de buscar periodicamente identificar o grau de retorno dos trabalhadores diante das tarefas a eles atribuídas e resultados esperados, buscando em termos finais manter a produtividade.

Jinkings (2010) analisou que a avaliação era um importante mecanismo de poder organizacional. Nas palavras da autora:

[...] as avaliações de desempenho sintetizam os atuais conceitos dos bancos relativos à qualificação da força de trabalho, expressos nos critérios qualitativos e quantitativos de avaliação do trabalhador. Atributos, habilidades e modos de comportamento considerados fundamentais à eficiência do trabalho e à competitividade da empresa são analisados no processo de avaliação, juntamente ao desempenho em relação a metas de produtividade [...]. (JINKINGS (2010, p. 191)

No Banco $\Delta$, segundo consta no relatório gerencial da instituição: "Todos os colaboradores estão inseridos em algum modelo de avaliação de desempenho e têm metas contratadas de acordo com as características de cada negócio" (Relatório Gerencial Bancos 2013).

Como vimos ao longo desta reflexão, a instituição mencionada já dispõe de instrumentos que possibilitam o exercício de um controle detalhado sobre o processo de trabalho e os trabalhadores, mas é por meio da avaliação que se define um espaço formal, exclusivo, para estabelecer claramente as críticas, as punições ou as formas de elogio e recompensa.

O programa de gestão por resultados que o Banco $\Delta$ mantém está fortemente estruturado na "contratação" individualizada de metas de trabalho e no respectivo acompanhamento de sua execução sob o qual o sistema de avaliação ganha destaque.

Um complexo processo de avaliação é estruturado com base em indicadores que possam mensurar os resultados e a partir disso justificar: a) promoções na carreira a 
serem efetivadas ou não; b) os pagamentos em forma de remuneração variável; c) apontar as falhas, advertindo os trabalhadores que não estejam alinhados à cultura organizacional ou tampouco ao desempenho esperado; d) servir explicitamente para delimitar quais são os trabalhadores potencialmente substituíveis.

Gaulejac (2007) analisa em seu estudo sobre a gestão em grandes corporações que a estratégia do desligamento daqueles que não alcançaram os resultados esperados se ancora na desqualificação das pessoas, pois desse modo almeja desencorajar o recurso à justiça. Esse viés analítico, ainda que se reporte à experiência francesa, serve de espelho àquilo que se passa no ambiente por nós estudado, pois é habitual observar a culpabilização dos assalariados por meio de uma crítica sistemática, dando-lhes objetivos inalcançáveis e registrando nas avaliações individuais um desempenho negativo que conduz "naturalmente" à demissão.

O mecanismo de avaliação encontra questionamento por parte dos trabalhadores entrevistados do Banco $\Delta$, uma vez que o processo não considera as falhas constantes na própria infraestrutura do trabalho em si. São mencionados pelos entrevistados o uso de ferramentas ou condições deficientes como softwares inadequados e sem atualizações necessárias; sistema operacional lento, com limitações de informações ou que trave durante o andamento das tarefas; venda de produtos inadequados para o perfil de determinada região que atuam; mercado saturado; dentre outros motivos.

A redução de quadro de funcionários também é outro motivo que dificulta o cumprimento de metas e influencia diretamente o desempenho do trabalho. As metas, por exemplo, nas agências bancárias são programadas mês a mês, considerando os 12 meses que compõem o ano. Entretanto, pela legislação brasileira os trabalhadores podem folgar um mês de férias. Assim, é evidente que ao não redimensionar as metas considerando o descanso legal do trabalhador há uma sobrecarga para aqueles que ficam, sendo que o mesmo ocorre para as licenças de saúde.

Esta situação aponta para o quanto a culpabilização pode ser de fato algo construído pelos gestores, na medida em que as condições para alcançar resultados satisfatórios são deficientes e adversas. Contudo, desprezando os fortes indícios de despotismo na cobrança de resultados, o discurso oficial da instituição pesquisada em veículo de comunicação interno afirma que "a avaliação ficou mais justa e as pessoas são julgadas por critérios objetivos" (Revista Banco 4 , fev. 2014).

A objetividade dos resultados, balizados por metas quantificáveis, como o volume de produtos vendidos ou as ligações atendidas, faz parte da rotina dos bancários 
desde a década de 1990, sobretudo nos ambientes das agências e nas áreas comerciais. Mas, na década seguinte, com a massificação dos "contratos de metas" em todas as áreas do banco, incluindo as áreas administrativas, se tornou perceptível o esforço adicional para racionalizar e refinar os controles internos, quando até mesmo o comportamento, um indicador subjetivo, se tornou quantificável numericamente. Pelo sistema de avaliação é possível pontuar o nível de aderência do trabalhador individualmente quanto aos princípios da instituição.

Para apurar o desempenho dos empregados no $\operatorname{Banco} \Delta$ são implementadas metodologias com diversas variáveis que se consolidam em dois eixos básicos de um mesmo gráfico: um focado no cumprimento de metas de trabalho, denominado Eixo X e outro focado no desempenho comportamental, denominado Eixo Y. As métricas desta metodologia de avaliação são cruzadas em um gráfico como o que reproduzimos no esboço a seguir:

Figura 9

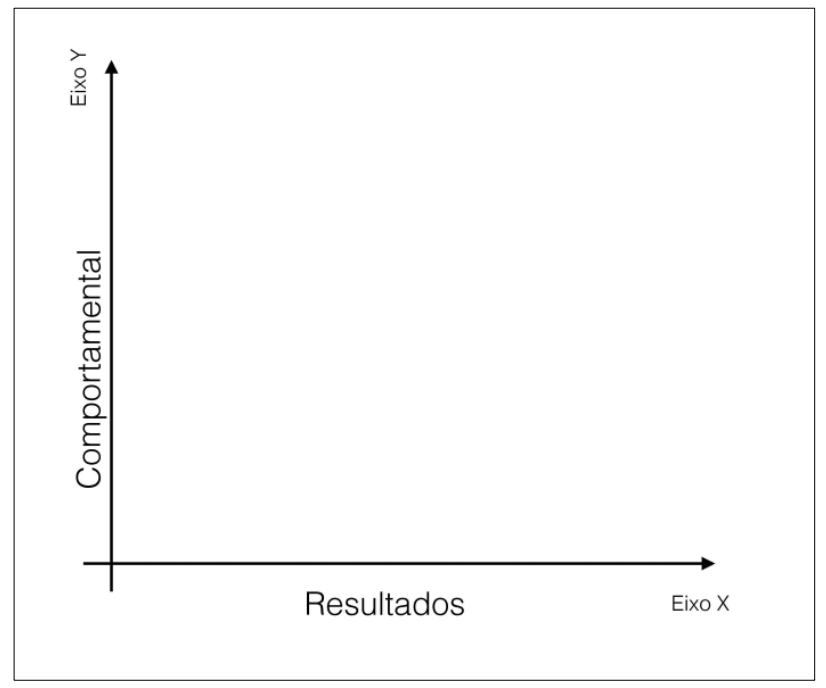

Fonte: Revista Banco 4 , abr. 2013.

Para compor o Eixo X são construídos indicadores de performance a partir da medição quantitativa dos trabalhos realizados em praticamente todas as etapas da produção dos serviços, mesmo os administrativos. Trata-se, em outras palavras, da avaliação da entrega dos resultados individuais, do cumprimento de metas objetivas de trabalho.

Para compor o Eixo Y os indicadores são calcados no nível de aderência que cada trabalhador tem em relação a dez comportamentos esperados pela instituição (conforme relatamos no Capítulo 4). Trata-se da avaliação comportamental, do 
cumprimento de metas subjetivas. O trabalhador deve estar alinhado a este conjunto que reúne as orientações sobre os modos de ser e estar. Sob cada item seu comportamento será avaliado em uma escala que varia de 0 a 5.

No Eixo Y, o processo de avaliação considera dois níveis conforme o lugar ocupado na organização. A avaliação "180 graus” e "360 graus". De acordo com o que apuramos, apenas os gestores passam pela avaliação "360 graus", modelo pelo qual os subordinados também podem avaliar o superior hierárquico. Os demais trabalhadores são submetidos à avaliação "180 graus”, pois não estão sujeitos a esta condição.

A avaliação "180 graus" prevê que pessoas com níveis diferenciados de interação com o trabalho do avaliado possam opinar, superando o modelo de avaliação tradicional realizado apenas pela chefia direta. Neste formato é previsto: a) autoavaliação; b) avaliação dos parceiros, ou seja, de outros trabalhadores que atuam em outras áreas dentro da instituição e mantêm alguma relação com o trabalho da pessoa avaliada; c) avaliação dos pares, ou seja, dos trabalhadores que têm função semelhante no mesmo ambiente; d) avaliação do gestor da área.

Para ambos os grupos de gestores e trabalhadores a autoavaliação não tem peso algum nos indicadores que vão compor o resultado final do processo avaliativo. Tem apenas a função de "situar" o ponto de vista do avaliado.

A avaliação de parceiros, dos pares e do gestor direto possui pesos diferenciados. O peso maior fica concentrado na mão do gestor, podendo oscilar entre $40 \%$ a $60 \%$ da média ponderada. O trabalhador indica as pessoas que deseja que realizem a avaliação de si, parceiros e pares, mas ainda assim estas indicações passam por aprovação do gestor. O trabalhador poderá escolher de 02 a 08 indicados. Entretanto, nas entrevistas foi relatado que cada indicado tem um número de pontos limitados para distribuir, ou seja, quanto mais pessoas o indicado avaliar, mais terá de distribuir a mesma quantidade de pontos. Na regra estabelecida pela instituição, há uma conta que nunca permite que todos sejam avaliados pela nota máxima. Em síntese, "os pares" acabam apontando qual colega é mais ou menos adequado à função que exerce.

O depoimento da trabalhadora coloca em questão o processo de avaliação, evidenciando seus limites e apontando o desconforto entre os colegas que avaliam:

Você tem que pedir avaliação pra os colegas, até que ponto isso é válido? As pessoas levam pra o lado pessoal, pode ser seu amigo e favorecer e colocar uma avaliação melhor. Mas o banco faz com que você não possa avaliar bem todos, você pode até achar bom o trabalho de todos, mas você tem um número " $x$ ", um limite de pontos para distribuir. Não é que eu quero favorecer todo mundo, 
mas eu acho que todo mundo fez o seu papel bem-feito, mas não posso dar uma nota boa pra todo mundo $\mathrm{O}$ critério do banco já coloca que todo mundo não é bom! Não vai caber todo mundo no funil da meritocracia, você vai ter que escolher. (Bancária, Analista Júnior, 57 anos, 12 de banco)

Na composição da avaliação pode também ser agregado como um indicador, no Eixo Y, as notas que os clientes atribuem para os trabalhadores ou para determinadas atividades de trabalho, sendo suas críticas ou elogios considerados neste processo.

De acordo com a visão do sindicato que representa a categoria profissional bancária, os programas de avaliação são injustos e pressionam mais ainda os trabalhadores, sendo que alguns dos principais problemas na metodologia estão localizados na limitação da quantidade de pontos a distribuir e no enquadramento de trabalhadores com resultados previamente insatisfatórios, conforme podemos verificar a seguir:

A quantidade de pontos a distribuir entre a equipe é limitada. Muitas vezes, por exemplo, o gerente tem 11 pontos para distribuir, mas ele tem três bancários para avaliar. Nesse caso, se todos os três merecessem a nota máxima, 05 não seria possível porque teria que dar uma nota menor para alguém. Ou seja, não é justo e é um modo de rebaixar a nota do pessoal. (Diretora do Sindicato dos Bancários de São Paulo) ${ }^{146}$

O processo de avaliação ao final do ciclo gera um gráfico de desempenho pelo qual é possível visualizar "o quadrante" que cada trabalhador foi situado após o cruzamento do Eixo X e do Eixo Y (ver gráfico 17). O “quadrante” é sua posição com relação ao grupo e demonstra visualmente se sua situação é de maior ou menor risco.

É relevante explicar que a posição final que cada trabalhador assumirá no gráfico obedecerá às regras de ajuste gerencial, ou seja, após toda a trajetória descrita sobre o processo de avaliação haverá uma última etapa pela qual a nota da avaliação individual do trabalhador será submetida a um comitê composto por gestores das áreas e à consultoria de Recursos Humanos. Nesta ocasião são realizados ajustes para adequar o conjunto de avaliações à forma final do programa que obriga a representação do total dos avaliados nas seguintes proporções:

\footnotetext{
${ }^{146}$ De acordo com matéria disponível no site do Sindicato dos Bancários de SP, Osasco e região em 23 set. 2014.
} 


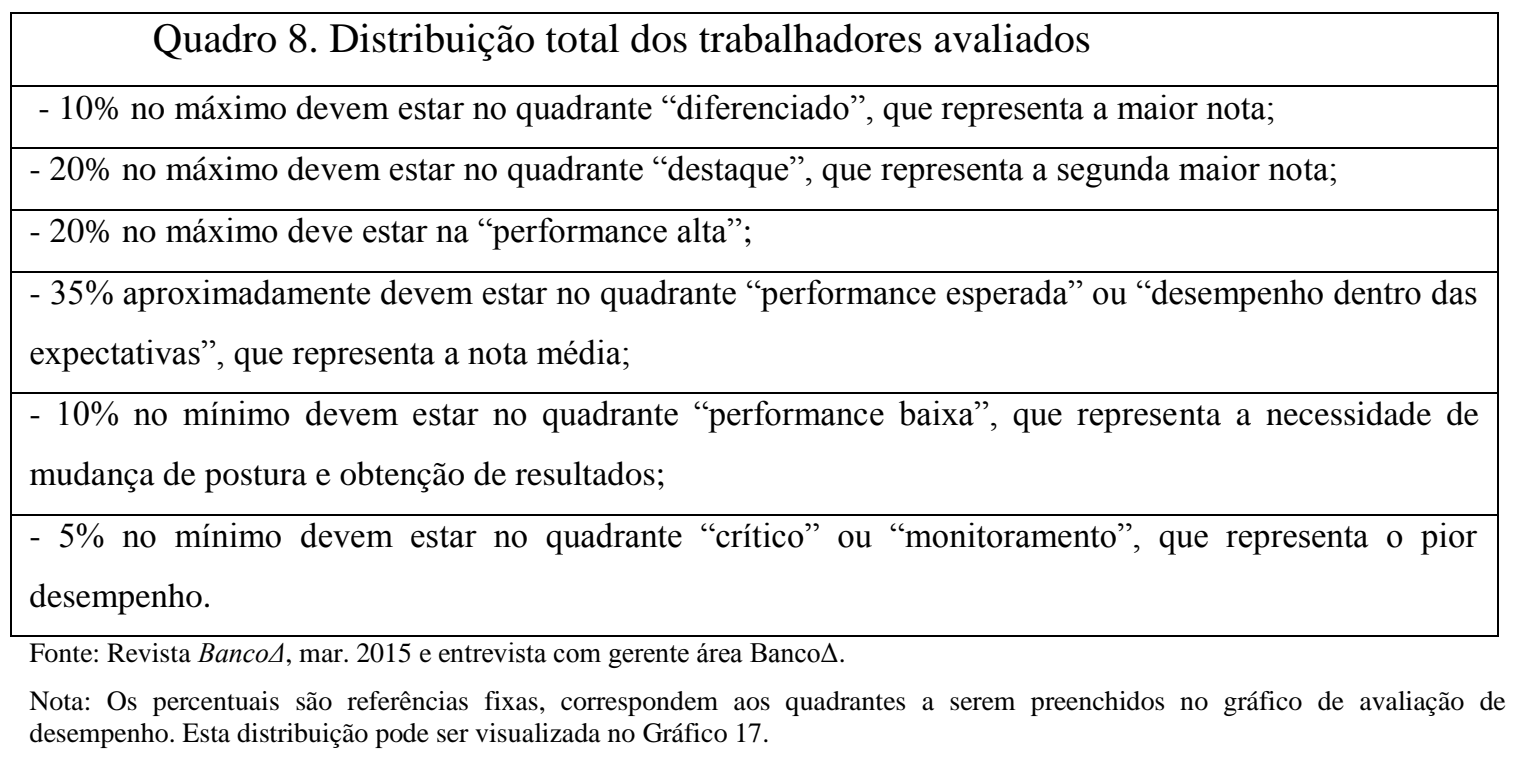

Os resultados da avaliação individual embasados tanto no Eixo Y como no Eixo $\mathrm{X}$, de acordo com a instituição pesquisada, se submetem àquilo que definem de "curva forçada", ou seja, o ajuste que é realizado no comitê pode "reenquadrar" os trabalhadores para que se chegue aos percentuais de classificação pré-determinados pela organização detalhados no quadro 8. Essa condição deixa clara a imposição velada para superar as metas, pois $50 \%$ da composição total dos trabalhadores avaliados devem estar acima da "performance esperada", espelhando aquilo que foi narrado pelos trabalhadores no tópico anterior sobre as metas.

Dentro do sistema de meritocracia estabelecido, do total de trabalhadores participantes, aqueles que estão no quadrante "diferenciado" são elegíveis às premiações e à mobilidade na carreira.

De acordo com o depoimento de um gestor sobre a parametrização final da avaliação do conjunto de trabalhadores: "se o número passar do que é aceito na plotagem do sistema, tanto para cima como para baixo, aí é preciso fazer a curva forçada" (Bancário, Gerente de Área).

Cumprir o mínimo que foi atribuído, estar na "performance esperada" no gráfico de avaliação, concentra $35 \%$ dos trabalhadores, que mantêm-se, até certo ponto, com chances de permanecer empregados. $\mathrm{O}$ fato da avaliação delimitar, de modo obrigatório, quem está na pior condição em relação ao seu desempenho, possibilita a realização da triagem que coloca em evidência aqueles que serão substituídos.

A imagem a seguir representa o gráfico que é gerado a partir dos eixos de avaliação. Os quadrantes: "performance baixa" e "crítica" representam as piores 
avaliações, o que automaticamente impõe sobre os trabalhadores maior risco de perda de emprego.

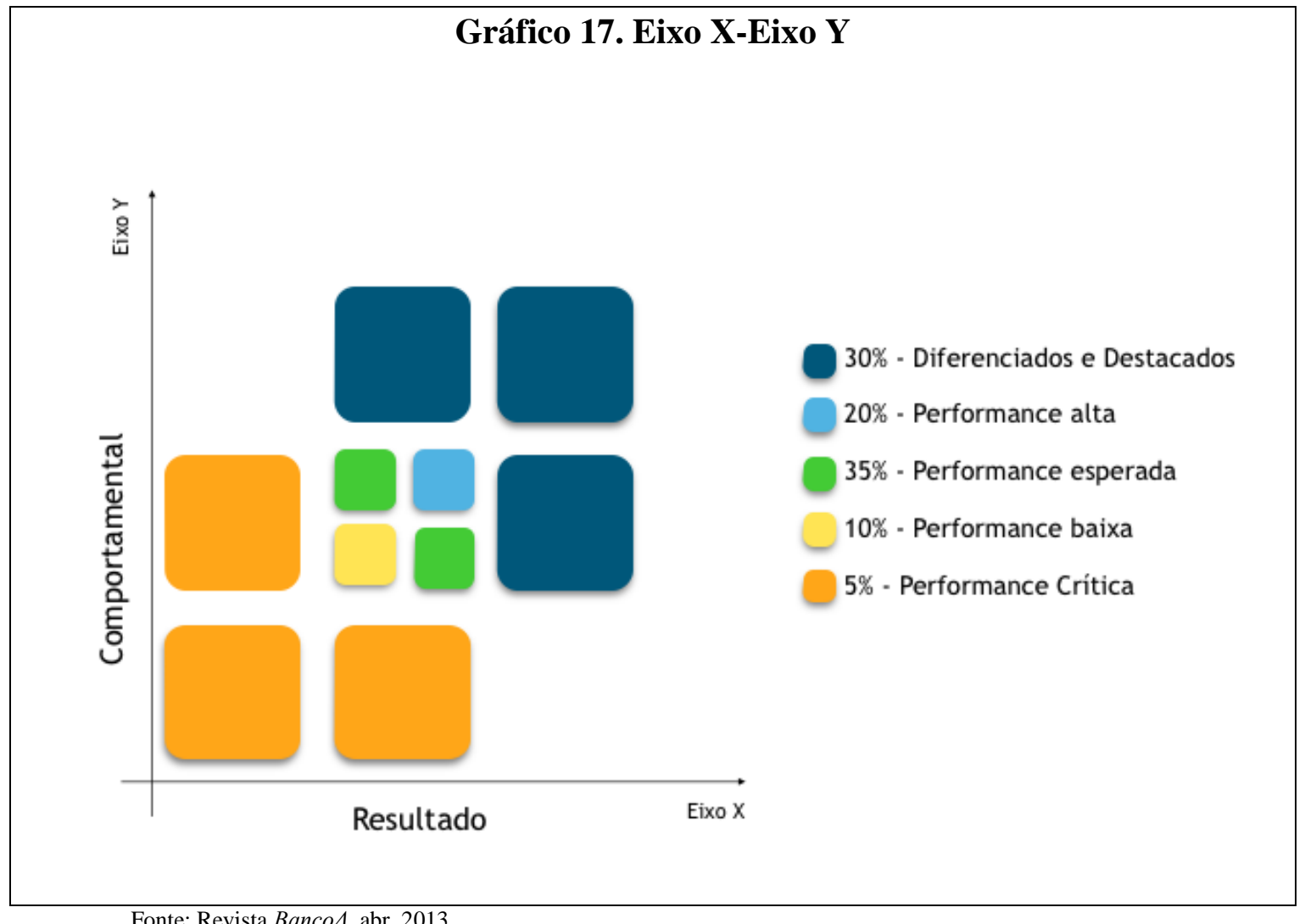

De acordo com o que a instituição divulga, os programas de avaliação

servem de base para o planejamento estratégico de pessoas, no qual as performances são analisadas e comparadas relativamente em Comitês, favorecendo a gestão das consequências e resultando em ações de reconhecimento, desenvolvimento e planejamento de carreira dentro da instituição. (Revista Banco 4 . fev. 2015, grifo nosso)

A expressão "gestão das consequências" contida no documento institucional é sutil, pois aponta apenas as vantagens que o trabalhador poderá obter, sem mencionar em nenhum momento punições ou qualquer palavra que remeta ao desligamento do quadro. No entanto, é consensual entre os entrevistados que o não cumprimento de metas e a não conformidade com o comportamento esperado conduz a um caminho sem volta, o caminho para a demissão.

A declaração do entrevistado, a seguir, reafirma as consequências negativas do processo de avaliação e aponta para o ajuste artificial de resultados por parte do empregador: 
Os que performam abaixo são aqueles que são demitidos pelo banco. Mas, se você olhar, muitos tiveram notas próximas à média, o ajuste pra baixo é o que manipula, o que direciona para aqueles que vão cair fora, para os ajustes que o banco quer fazer. (Bancário, Coordenador, 52 anos, 23 de banco)

\subsection{Perfil dos trabalhadores}

Considerando que a reorganização da força de trabalho tem um peso fundamental neste conjunto de mudanças ocorridas no setor, um novo perfil de trabalhador também foi traçado para se alinhar às novas formas de operar nas instituições.

Observamos nas últimas décadas mudanças de nomenclatura dos cargos, redução de níveis hierárquicos e extinção de funções em áreas administrativas - back office - e também nas áreas comerciais, habitualmente denominadas front office.

Nas agências bancárias as inovações tecnológicas e a terceirização reduziram diversas atividades antes realizadas pelos trabalhadores do back office. Nesse contexto prevaleceu a orientação de massificar a política de vendas de produtos e serviços financeiros aos clientes, que acabou forjando um novo perfil alinhado a funções que se mantiveram ou cresceram em importância nesses ambientes, como retratam os entrevistados para esta pesquisa:

$\mathrm{O}$ banco hoje quer um vendedor. $\mathrm{O}$ trabalho do bancário na área comercial é semelhante ao do vendedor. Até mesmo na área operacional da agência, no Caixa, eles querem vendedor. Os destaques do banco são aqueles que vendem mais. (Bancário, Gerente de Contas, 32 anos, 07 de banco)

A carreira operacional e administrativa que era longa foi ficando curta nos bancos, o Caixa crescia no back office dos bancos, hoje não tem back office, por isso o perfil do Caixa teve que mudar, você tem que trazer um cara que possa ser um gerente, isso leva a própria reorganização do trabalho do Caixa. (consultor de RH entrevistado)

Na segunda metade da década de 1990, como já mencionado no Capítulo2, foi possível observar a proliferação de Gerentes de Contas que passaram a atuar divididos por segmentos Pessoa Física e Jurídica classificados pela renda média dos clientes. Para dar suporte à área comercial e aos gerentes, surgiram cargos auxiliares, como o de Assistente de Gerente e o de Agente Comercial. 
Em paralelo, funções relacionadas às áreas administrativas, como Escriturários, Tesoureiros, Supervisores e Caixas, ou foram extintas ou reduziram significativamente. O papel atribuído ao Caixa foi remodelado para atender às orientações estratégicas das instituições bancárias, assim, ao longo dos anos cada vez mais os trabalhadores que atuavam neste cargo assumiram a atividade de vendedores.

A literatura consultada, especializada nos estudos do setor, menciona frequentemente as mudanças ocorridas nas agências, provavelmente pela maior facilidade de ter acesso às informações e também porque boa parte das alterações é visível, pois se trata de um espaço público. Contudo, a generalização de que todo bancário é um vendedor torna esta afirmação um reducionismo quando sabemos quão heterogênea é a composição da força de trabalho em uma grande corporação.

As áreas administrativas, ou seja, back offices dos múltiplos produtos e serviços financeiros ofertados pelos bancos, se encontram fora das agências bancárias e absorvem aproximadamente $40 \%$ do total da força de trabalho do setor. Nessas áreas também ocorreram mudanças que influenciaram o perfil de atuação esperado dos trabalhadores. Como pudemos verificar em nossa pesquisa, o cargo que mais se expandiu foi o de Analista de Processos, considerando que a burocracia na atividade financeira ainda é intensa devido à formalização e controles que seus negócios demandam. O novo perfil dos trabalhadores nas instituições financeiras é permeado pelas características desejadas para atuar no negócio e considera ainda outras variáveis.

Com o intuito de traçar as principais etapas e orientações que conformarão a escolha do trabalhador da grande corporação bancária, destacaremos a seguir alguns aspectos que nos parecem ajudar neste propósito.

\subsubsection{Como as vagas são disponibilizadas}

A principal porta de entrada no Banco $\Delta$ depende do tipo de vaga procurada. Para as vagas de ampla concorrência, como são para trainees e estágios de nível superior, os candidatos passam por processos seletivos mais complexos e aprofundados intermediados por consultorias especializadas em recrutamento para este segmento. $\mathrm{O}$ mesmo pode acontecer com cargos de gestão, sobretudo para executivos.

Já as vagas para carreiras iniciais, como Caixa e Operador de Teleatendimento, podem ser anunciadas via site institucional do banco ou por meio de sites de agências de 
emprego. Os Gerentes de Contas e Analistas de Processos também podem ser recrutados por esses meios ou ainda por outros que sejam mais convenientes.

O processo de seleção externa no $\operatorname{Banco} \Delta$, apesar de aberto, considera fortemente o viés da "indicação", forma pela qual o candidato com referências apresentadas por outros funcionários, parentes e amigos pode ser favorecido.

O gráfico a seguir espelha essa influência em nível macro setorial. Em uma das repostas contidas na pesquisa "Censo da Diversidade", ${ }^{147}$ realizada pela FEBRABAN em 2008, chamou nossa atenção que $74 \%$ dos bancários que trabalhavam à época nas instituições participantes da pesquisa tiveram conhecimento das vagas por meio de sua rede de contatos.

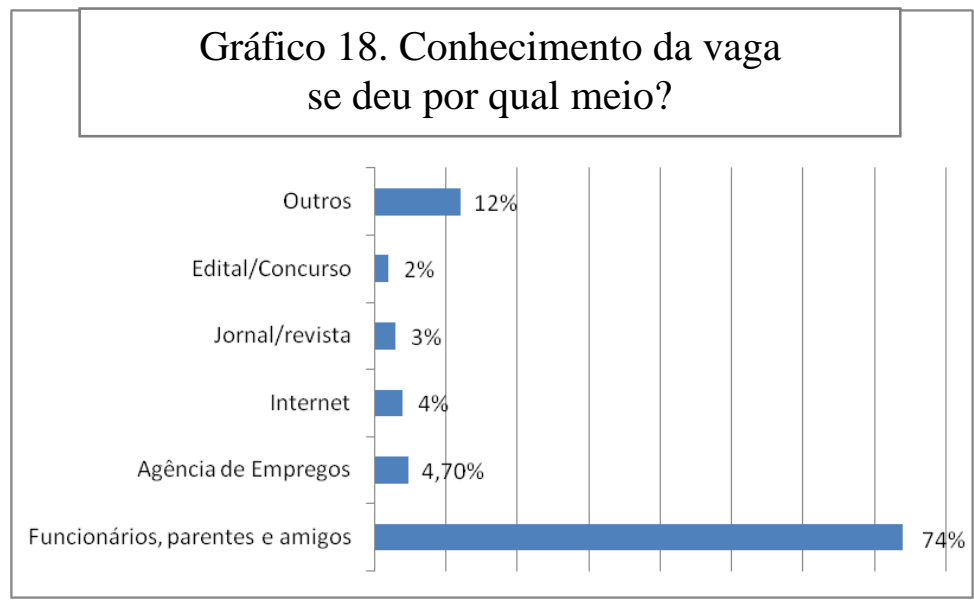

Fonte: CENSO 2008 FEBRABAN. Elaboração da autora

Nota: os dados apresentados referem-se ao setor privado.

A "indicação" é associada a uma forma de comprometer, ainda mais, o trabalhador com o emprego. Segundo aponta uma pesquisa ${ }^{148}$ realizada em uma grande corporação norte americana, "a indicação de outro funcionário funciona como uma préavaliação", pois ao sugerir a vaga para alguém que considerou adequado, está estabelecendo chances de melhor desempenho.

Estar "comprometido" com o emprego é um dos requisitos fundamentais do perfil esperado do trabalhador de uma grande corporação. Não porque isso represente algo novo no mundo assalariado, afinal, sabemos o quanto é antiga a ideia de "vestir a camisa da empresa”. Apenas é o que nunca deixou de ser, um requisito que não

\footnotetext{
${ }^{147}$ No total 18 bancos estiveram representados por meio de 204.133 trabalhadores que responderam o questionário via internet. A pesquisa foi realizada sob a coordenação do CEERT e com a participação de profissionais do IBGE, do IPEA e do Departamento Intersindical de Estatísticas e Estudos Socioeconômicos (DIEESE). Disponível em: https://www.febraban.org.br/Febraban.asp?id_pagina=339\&id_paginaDe=95.Acesso: fev.2015.

${ }^{148}$ A pesquisa realizada por James A. Breaugh, da Universidade de Missouri, teve seus resultados publicados no International Journal of Selection and Assessment. http://www2.uol.com.br/vivermente/noticias/pistas_no_curriculo_indicam_se_o_candidato_pretende_permanecer_na_empresa.html.
} 
necessariamente é ligado à qualificação técnica ou acadêmica, que se marca no campo da subjetividade das relações interpessoais e dos espaços de micro poder, sobretudo exercido pelos gestores que são nestas instituições os principais "indicadores" no preenchimento das vagas.

A atenção dada ao processo de seleção dos candidatos às vagas de ampla concorrência - trainees e estagiários de nível superior - se explica pelo motivo de que neste grupo se deposita a formação de futuros líderes, gestores ou até mesmo técnicos de ponta que comporão parte do quadro de trabalhadores das grandes corporações.

No site institucional do banco ou nos sites de agências de emprego, o candidato deverá preencher um cadastro informativo e na sequência responder a dois testes, um de raciocínio lógico e outro de interpretação de texto e de português. Os dados do cadastro já apontam as suas características sobre formação escolar, incluindo o nome da instituição de ensino, capacitação em outros idiomas e conhecimentos de informática.

No processo de seleção pesa a importância atribuída ao comportamento e valores do candidato. Assim, para verificar a adequação ao perfil desejado, é realizado um inventário comportamental.

As consultorias de RH, muitas com atuação internacional, aplicam métodos de recrutamento já praticados em outros países. ${ }^{149}$ É o que ocorre com o questionário de nome "Facet5" (5 facetas), o qual avalia o perfil comportamental de cada profissional com base em cinco fatores: energia, determinação, controle, afetividade e a emocionalidade. A principal expectativa na utilização deste método é apurar como cada um reage diante de uma situação de estresse ou conflito.

Nesses processos amplamente concorridos, apenas um grupo seleto terá a “oportunidade" de participar da experiência profissional em uma grande corporação. Para mensurarmos o tamanho da disputa em torno destas vagas, segundo a declaração dada por uma consultora de $\mathrm{RH},{ }^{150}$ há 15 anos um programa de trainee poderia receber até 3 mil inscrições, porém, hoje com os avanços tecnológicos, ele pode receber até 40 mil.

\footnotetext{
${ }^{149}$ Fontes: site de consultoria de RH que presta serviço para grandes corporações. Disponível em: http://www.dmrh.com.br/nossassolucoes/desenvolvimento/facet-5/. Acesso em: jan. 2015; Revista Você S.A., "Há teste para tudo nas entrevistas de emprego", set. 2011.

${ }^{150}$ Consultora Sandra Cabral representante do Grupo DM Cia de talentos, em entrevista à rádio CBN, no Programa Mundo Corporativo, fev. 2014. Disponível em: http://cbn.globoradio.globo.com/colunas/mundo-corporativo/MUNDOCORPORATIVO.htm. Acesso em: jul. 2015.
} 


\subsubsection{Elementos definidores dos perfis dos trabalhadores}

Encontramos algumas dificuldades em nossa tentativa de apreender qual o perfil requerido pela grande corporação bancária. A primeira delas se explica pelo tamanho e extensão do universo investigado, por reunir em torno de si um conjunto heterogêneo de profissionais. Ainda que esses estejam majoritariamente unidos em torno de uma classificação política e econômica, ou seja, uma categoria profissional, partimos do pressuposto que a ampla gama de cargos e áreas existentes no interior do Banco $\Delta$ podem demandar não "um” perfil, mas diversos perfis específicos.

Mesmo com esses limites foi possível reunir elementos que têm sido generalizados pelos recrutadores os quais serviram de base para nossa ponderação quando buscamos ouvir a percepção dos trabalhadores acerca do perfil requerido para atuar na grande corporação bancária.

É razoável que haja muita confusão acerca do perfil "adequado", afinal, os grandes veiculadores desses padrões, as consultorias e áreas de RH, costumam atribuir um caráter genérico ao perfil desejado, sobretudo quando estão preocupados em alimentar a subjetividade, ou seja, o imaginário social dos candidatos mais "interessantes" e quando, ao mesmo tempo, buscam sinalizar para a sociedade a imagem de uma empresa moderna, eficiente e sustentável.

Os limites do discurso dominante sobre o perfil esperado dos trabalhadores contemporâneos, especialmente na grande corporação bancária analisada, são colocados à prova quando o pragmatismo da gestão por resultados subtrai características valorizadas na hora da admissão.

Uma questão a ser enfrentada neste debate acerca do perfil esperado dos trabalhadores nas grandes corporações é discernir como o ideário generalista perpassa o discurso institucional corporativo e quanto suas promessas são viáveis no cotidiano de trabalho.

Ao selecionar um candidato para uma vaga, o $\operatorname{Banco} \Delta$ mobiliza dimensões subjetivas dos atores participantes, evocando seu lado sonhador e ufanista.

A estratégia de comunicação utilizada pelas grandes corporações e consultorias para recrutar os "melhores quadros" não é um ponto irrelevante, pois interfere diretamente na ordem simbólica. A esse respeito, vale destacar a contribuição de Gaulejac (2007, p. 274): 
Os homens não podem trabalhar e viver sem dar sentido à sua ação. $\mathrm{O}$ homem racional que procura otimizar seus recursos e defender seus interesses por meio de comportamentos estratégicos é um homem amputado de suas paixões, de suas capacidades imaginativas e principalmente da sua necessidade de dar sentido à sua existência. A ordem simbólica é a expressão dessa necessidade. Em primeiro lugar por meio da linguagem, que permite comunicar, elaborar, colocar em palavras. Em segundo lugar, na construção permanente de símbolos que fixam os "achados" e as referências necessárias para a vida social. Quando a ética do resultado substitui outras considerações, ela produz uma forma de simbolização abstrata e desencarnada, que não pode satisfazer a necessidade de crer.

A interação que se estabelece a partir do ambiente corporativo, entre trabalhadores e gestores, gestores e executivos, e executivos e acionistas com base no pragmatismo, na meritocracia e na frieza da gestão dos resultados, requer um alento que se forja no campo simbólico. Para aplacar a dura realidade do mundo corporativo, em diversas formas e meios de comunicação são permanentemente ressaltadas as razões "não econômicas", "não objetivas", que visam cimentar o "espírito corporativo" fazendo os indivíduos se sentirem parte de um projeto diferenciado e mais interessante.

Mais do que apenas contratar alguém para ocupar uma vaga na instituição, a ocasião do recrutamento é um momento em que a instituição reforça sua marca, buscando legitimar seus atos e relevância na sociedade contemporânea.

Os anúncios estabelecem um diálogo direto com o público jovem, a considerar a composição das imagens utilizadas em que são privilegiadas situações onde predominam a diversidade, descontração, irreverência, cenas de lazer e esportes radicais. As peças publicitárias se espalham por revistas de grande circulação e principalmente nos sites e redes sociais.

O texto, a seguir, consta em anúncios para ocupar vagas no Banco $\Delta^{151}$. Antes que se apresentem requisitos acadêmicos ou técnicos, o candidato entra em contato com o "espírito corporativo":

Queremos o caminho que ninguém usou, porque ele geralmente leva aonde ninguém foi.

Queremos perguntas melhores, porque é delas que nascem as melhores respostas.

Queremos tentar, tentar e tentar.

E quando já estiver bom, queremos tentar um pouco mais.

Queremos pessoas que pensem como donos, para que se sintam donas dos resultados.

Queremos os inconformados, os inquietos, os indignados.

Queremos os impacientes e os inventivos.

\footnotetext{
${ }^{151}$ Disponível em: http://www.vagas.com.br. Acesso em: fev. 2015
} 
Queremos aqueles com vontade de mudar o mundo.

Não queremos você apenas por achar que você tem a nossa cara.

Queremos ter um pouco da sua também.

Queremos você.

A "chamada" evoca um cenário nada objetivo do ponto de vista da atuação profissional. Usa em abundância adjetivos que em nada remetem ao ambiente institucional e altamente burocratizado como é um banco.

Ainda que não se constitua como algo específico do setor ou uma novidade em si, foi evidenciada a preferência pelos jovens, declarada com frequência pelos entrevistados como parte do perfil desejado para trabalhar no Banco $\Delta$, o que corrobora com os resultados da pesquisa de Colombi (2014), que observou a participação dos jovens no setor privado entre 2000-2010, ${ }^{152}$ constatando que mais da metade dos trabalhadores nesses bancos possuíam entre 18 e 39 anos na mostra coletada. Há um corte etário, não declarado publicamente pela instituição pesquisada, mas percebido pelos trabalhadores entrevistados, conforme retratado a seguir:

O banco tem preferência pelos novinhos, faixa de 20, 25 anos. É raro contratar pessoas acima de 30 anos. (Bancário, Analista Júnior, 42 anos, 12 de banco)

Para entrar no banco eu sei de uma coisa: não pode ter mais que 30. O limite é 30 anos. (Bancária, Analista Júnior, 57 anos, 12 de banco)

O banco hoje prefere um pessoal mais novo, tanto que o banco mandou embora alguns gerentes que já estavam lá fazia tempo e contratou um pessoal mais novo, com um salário três vezes menor. Acho que hoje o banco prefere um pessoal não tão sênior por conta de salário mesmo. (Bancário, Gerente de Contas, 25 anos, 04 de banco)

Na percepção do último entrevistado também foi mencionada a questão salarial, como um elemento que explica a preferência pela entrada de trabalhadores novos, substituindo aqueles com maior tempo de casa, o que nos parece um aspecto que deve ser considerado, sobretudo, quando analisamos a rotatividade na categoria profissional bancária e a curva da média salarial caindo em decorrência da entrada de novos trabalhadores, substituindo outros com mais tempo de casa e consequentemente maiores salários (DIEESE; CONTRAF, 2013).

\footnotetext{
${ }^{152}$ De acordo com a autora com base nos dados da RAIS - Ministério do Trabalho e Emprego.
} 
A seleção de novos trabalhadores na instituição pesquisada baseia-se na formação acadêmica, qualificação técnica e no comportamento do candidato, sendo este último o grande diferencial na contratação.

A formação acadêmica acima da média da população brasileira é uma característica dos admitidos no setor bancário há muitos anos, percebidas por diversos autores (ROMANELLI, 1978; DIEESE, 1980; JINKINGS, 2002; VENCO, 2003).

Venco (2003) ponderou que a alta escolaridade exigida pelas instituições bancárias, sobretudo nos anos 1980 e 1990, não se justificava em função da difusão tecnológica, pois esta não implicava necessariamente em maior qualificação dos novos contratados para executarem um trabalho padronizado e simplificado. Ainda, segundo a autora, a importância do diploma em termos de conteúdo é relativizada "adquirindo muito mais um caráter legitimador do posto de trabalho ocupado do que mobilizador de conhecimentos" (VENCO, 2003, p. 16).

A atualidade da análise de Venco (2003) sobre a relação entre alta escolaridade, tecnologia e ocupação no trabalho bancário é por nós reafirmada por meio das entrevistas que realizamos com os trabalhadores e do estudo de campo. Vale mencionar que a própria manipulação de softwares ou hardwares está relacionada à familiaridade dos trabalhadores com a informática ou ao domínio dos aplicativos para escritório, que independe de cursar o nível escolar superior.

A ênfase nos processos de treinamento contínuos realizados no interior do $\operatorname{Banco} \Delta$, como já mencionado no capítulo anterior, demonstra na prática a relativa necessidade de elevado nível da educação formal para o exercício da profissão, pois do ponto de vista das grandes corporações os conteúdos padronizados das faculdades pouco contribuem com as tarefas bancárias no dia a dia.

Ainda assim, analisando as reportagens contidas em uma revista especializada em carreira, observa-se que a graduação e pós-graduação, por serem uma experiência intelectual relevante, sobretudo quando vinculadas a instituições de ensino com melhor grau de avaliação relacionado à qualidade, têm sido usadas como critério para selecionar os candidatos a ocupar determinadas vagas nas instituições financeiras, como também servem de critério para manter a perspectiva de ascensão na carreira. ${ }^{153}$

De acordo com um bancário entrevistado: "o banco quer que você melhore por conta do resultado dele. Então, por exemplo, você vai ter mais resultado se você estudar mais" (Operador de Teleatendimento, 24 anos, 03 anos de banco). Como temos tentado

\footnotetext{
${ }^{153}$ Revista Você S.A. (várias edições, 2014).
} 
demonstrar, a valorização da educação formal não ofusca as políticas internas de treinamento ou "educação corporativa", mas apontam para o cálculo gerencial que vê como positiva a relação entre produtividade e maior escolaridade.

Observamos, por meio dos anúncios de vagas para o $\operatorname{Banco} \Delta$, que são disponibilizados nos sites, bem como por meio das entrevistas, que os requisitos de formação acadêmica têm sido ampliados, tornando a pós-graduação um diferencial para os candidatos.

Os pesquisadores Lemos e Pinto (2008) destacaram em seu estudo a preferência de candidatos que tenham passado por "faculdades de primeira linha" para ocupar determinados cargos mais altos na hierarquia organizacional das grandes instituições. $\mathrm{O}$ mesmo aspecto foi mencionado pelos consultores ${ }^{154}$ e também constou na declaração de entrevistados para esta investigação.

O nível de escolaridade exigido é superior, até mesmo por conta da remuneração o piso de um Caixa no banco é muito competitivo, o que atrai pessoas de nível superior. Não há exigência de faculdades de primeira linha para a base operacional. Os programas de trainee $e$ estágio de nível superior, programas que buscam formar gestores, aí sim há a preferência. (Consultor de RH entrevistado)

Em um primeiro momento você vê no jurídico que os cargos mais altos são ocupados por pessoas da São Francisco [USP] e os demais acabam ficando com as outras faculdades. Coincidência? Também não sei... [risos]. Quando eu entrei, só tinha uma estagiária da São Francisco, a maioria era do Mackenzie e da PUC. (Estagiária, 19 anos, 01 ano de banco)

Tal requisito não é extensivo à maior parte dos trabalhadores admitidos, pelo que pudemos apreender no $\operatorname{Banco} \Delta$. Contudo, verificamos que ele se torna interessante nos processos de triagem para determinadas ocupações, pois ter passado por uma "faculdade de primeira linha" 155 já imputa ao candidato a credencial de quem já foi anteriormente selecionado no vestibular e obteve acesso a uma boa formação. A escolha deste item para compor o perfil do trabalhador na grande corporação, pelo que pudemos perceber nos últimos anos, raramente é declarada nos comunicados sobre as vagas, que consultamos para esta pesquisa, por ser considerado algo "politicamente incorreto".

A questão do "aumento da exigência de profissionalização" foi abordada na pesquisa de Varella e Borges (2012) sobre o setor bancário. Os participantes afirmaram

\footnotetext{
${ }^{154}$ De acordo com a consultora Sandra Cabral, representante do Grupo DM Cia de Talentos, um dos cortes para triagem se dá pela separação das pessoas que cursaram faculdades de primeira linha. Em entrevista à CBN, no Programa Mundo Corporativo, fev . 2014

${ }^{155}$ De acordo com os entrevistados, as faculdades de primeira linha mais populares são: USP - Universidade de São Paulo; FGV Fundação Getúlio Vargas; PUC - Pontifícia Universidade Católica e Mackenzie.
} 
que para o perfil do trabalhador da agência é desejável, além de ter nível superior, "ter um conhecimento mais técnico acerca de economia e finanças, ser mais atualizado e especializado".

Um aspecto relevante a ser considerado sobre o perfil técnico envolve as estratégias futuras dos administradores dos bancos, que apontam um novo modelo de agência bancária representado pela extinção de alguns cargos e funções considerados de baixa complexidade e repetitivas. O prognóstico dos administradores do setor anuncia que a "agência do futuro" será um espaço para aqueles clientes que tem interesse em fechar negócios financeiros de maior relevância. Nesse desenho, portanto, fica claro que o restante do conjunto de operações e transações bancárias pertinentes ao sistema será em sua totalidade realizado nos diversos canais digitais ou Correspondentes Bancários das instituições. Essa tendência, se confirmada, redimensionará o papel dos trabalhadores destes ambientes, fortalecendo a especialização técnica à medida que assumirão o papel essencial de consultores financeiros. ${ }^{156}$

As exigências de certificações para atuar na profissão são cada vez maiores. No setor bancário existe um conjunto de qualificações técnicas que podem ser exigidas de acordo com a função exercida. Citamos as principais: CPA 10 - Certificado Profissional ANBIMA; CPA 20 - Certificado Profissional ANBIMA; e CEA - Certificação de Especialistas em Investimentos ANBIMA.

No início da década de 2000, as certificações passaram a ser exigidas para operar no mercado financeiro. As funções que comercializavam produtos financeiros ou atuavam diretamente com investimentos, mesmo que estivessem fora das agências físicas atendendo remotamente, estavam entre aquelas em que era preciso obter o certificado.

No Banco $\Delta$ há um amplo programa de "educação corporativa”, como tratamos no Capítulo 4, que propicia treinamento e cursos voltados para a capacitação dos trabalhadores. Assim, pode-se dizer que parte da qualificação técnica para atuar no banco é produzida internamente. Mas não se pode desconsiderar, como os próprios trabalhadores manifestaram, que muito do que realizam foi aprendido no fazer diário, pela transmissão de conhecimento de quem já era mais experiente.

Em nossa pesquisa sobre os requisitos presentes nos anúncios de vagas para trabalhar no $\operatorname{Banco} \Delta$, além dos aspectos relativos à escolaridade e capacitação técnica

\footnotetext{
${ }^{156}$ A autora teve a oportunidade de participar do último CIAB - Congresso Internacional de Automação Bancária, que ocorreu em junho de 2015 em São Paulo. Os representantes da FEBRABAN e representantes de diversos bancos reafirmaram esta perspectiva de "agência do futuro" e qual o perfil profissional necessário para atuar nesta configuração.
} 
referentes à atuação envolvendo os produtos e serviços financeiros, percebemos com frequência a solicitação de "bons conhecimentos no pacote Office". ${ }^{157}$ Outros itens como domínio de língua inglesa, conhecimento de linguagem de programação de computadores, experiência pregressa em determinada atividade bancária, capacidade de comunicação, análise crítica e raciocínio lógico também constaram nos anúncios pesquisados. Esses itens não aparecem condensados em um único anúncio e repetidas vezes. Explicamos que surgem de modo pulverizado, o que nos leva a inferir que são mais pontuais e correspondem às necessidades do cargo ofertado no momento.

O quadro a seguir reúne uma síntese dos requisitos presentes na coleta de informações disponíveis nos anúncios de vagas de emprego no $\operatorname{Banco} \Delta$.

Quadro 9. Síntese dos principais requisitos
para admissão Banco $\Delta$
Formação acadêmica
Faculdade (cursando ou concluída)
Pós-Graduação
Requisitos técnicos mais mencionados
Bons conhecimentos "Pacote Office"
Certificado CPA 10
Certificado CPA 20
CEA
Inglês (prioritariamente exigido para trainees e
estagiários nível superior)
Habilidades comportamentais
e cognitivas
Capacidade para trabalhar sob pressão
ou resiliência
Capacidade de trabalhar em equipe
ou bom relacionamento interpessoal
Proatividade
Criatividade
Capacidade de comunicação
Capacidade de análise crítica
Raciocínio lógico

157 O "Pacote Office" é um conjunto de softwares utilizados nas grandes corporações, contém: Word (processador de texto), Excel (planilha de cálculo), Access (banco de dados), PowerPoint (apresentador gráfico) e Outlook (e-mails e contatos). 


\subsubsection{Comportamento, o principal diferencial}

A pesquisa de Lemos e Pinto (2008), que analisou o perfil profissional demandado pelas empresas para ocupar cargos de nível gerencial, concluiu que a formação cognitiva específica recebida pelos recém-formados nas faculdades não é fator decisivo na contratação. No contexto de mudanças organizacionais o que mais tem pesado são as variáveis comportamentais e vivenciais do aspirante ao cargo e a excelência da instituição de ensino cursada.

De acordo com os autores mencionados, há uma ruptura com a noção tradicional de qualificação profissional enquanto o "modelo de competência" ganha destaque definindo-se por uma "nova atitude do trabalhador com relação ao trabalho". Citando Zarifian (1996), ${ }^{158}$ eles enfatizam que nesse propósito são mobilizados com mais intensidade aspectos subjetivos. Os processos de seleção buscam mais atitude social do que o conhecimento profissional acumulado do trabalhador, pois é o que favorecerá o processo produtivo.

$\mathrm{Na}$ análise de Mello e Silva (2004, p. 60), a abordagem das "competências" coloca em evidência que componentes abstratos, atributos desejáveis classificados pelas empresas, sejam combinados com componentes dos "saberes" ou dos "conhecimentos" profissionais requeridos, produzindo uma espécie de "matriz" de qualificação que se torna funcional.

Tal modelagem pode reunir uma grande variedade de adjetivos para designar os traços da pessoa que melhor compõe o perfil do trabalhador desejado pela grande corporação.

As características valorizadas pelas empresas, segundo a pesquisa de Lemos e Pinto (2008), são as seguintes: perfil generalista em detrimento do especialista, capacidade de adaptação a situações novas, aceitação ao risco, aptidão para atuar sobre pressão, habilidade de liderança e atuação em equipe, solidariedade e ética no alcance dos objetivos.

A percepção resultante desta pesquisa expressa em grande parte o discurso oficial das consultorias de RH veiculadas nas publicações especializadas e nos diversos sites disponíveis que tivemos acesso.

\footnotetext{
${ }^{158}$ ZARIFIAN, P. “A gestão da e pela competência.” In: Seminário internacional educação profissional, trabalho e competências. Rio de Janeiro, 1996. Anais... DN, 1998. pp. 15-24.
} 
Características muitas vezes atribuídas a funções específicas, ou ainda, a cargos com maior poder na instituição, como são os executivos, são mecanicamente repetidas para todos os cargos e funções dentro da mesma empresa, conformando em muitos casos uma situação contraditória, onde não há espaço para agir conforme aquilo que foi anunciado e requerido previamente.

Ainda que no novo paradigma de gestão os consultores e as corporações busquem "acomodar" interesses de classe ao afirmar que ao invés de trabalhadores existem "colaboradores" e que todos são "donos do negócio", é insustentável afirmar que certas características evocadas no perfil dos candidatos a ocupar uma vaga na instituição, contidas nas peças publicitárias, façam necessariamente parte da rotina de trabalho no interior das grandes corporações.

Nas chamadas para seleção de candidatos, o Banco $\Delta$ convoca os interessados, incansáveis, improváveis, inovadores, inventivos, inspiradores, inquietos, inconformados, indignados e impacientes, o que pode gerar no leitor a impressão de que a instituição só opera com este perfil profissional. Nossa pesquisa e os depoimentos dos trabalhadores indicam que esse conjunto de adjetivos se aplica a pouquíssimos cargos dentro da organização, pois no geral os limites são muito claros.

As consultorias de $\mathrm{RH}$ e as corporações, desde o recrutamento e durante o processo seletivo, interagem com o imaginário dos candidatos no sentido de criar expectativas quanto ao seu papel na instituição. A divulgação generalizada de um determinado perfil, que mais se adequa a cargos restritos na instituição, serve a perspectiva de idealização de trabalhar em uma grande corporação.

Com expectativas altas de encarreiramento no curto prazo, dezenas e milhares, respectivamente, de trainees e estagiários de nível superior passam a fazer parte do universo corporativo. Com o passar do tempo, se integrados ao processo de trabalho, passam a lidar com as contradições internas, como podemos citar: a perspectiva de trabalhar em equipe versus a necessidade de apresentar resultados individuais, a possibilidade de ser criativo versus a prescrição no trabalho.

Feitas essas considerações sobre a questão comportamental, vamos buscar nos aprofundar sobre os seus significados para os agentes envolvidos. Citamos abaixo trecho da fala de um consultor de RH sobre o perfil comportamental:

As empresas cada vez mais contratam o seu perfil comportamental, não há dúvida de que o lado técnico é importante e necessário e sem ele é difícil atingir muitas posições, mas uma vez que isso muitos tem, hoje muita gente cursou a faculdade de engenharia ou cursou 
essa ou aquela faculdade ou fez aquele curso, aquele MBA, aquele curso de pós-graduação. $\mathrm{O}$ que faz decidir entre um profissional e o outro? É o seu perfil comportamental. A empresa quer saber como você se comporta. Você é um profissional proativo? Trabalha em grupo? Tem humildade? Sabe se comunicar? Entende que o todo é maior do que o indivíduo? É comprometido? De vez em quando vai ter que trabalhar até mais tarde, vai dar sangue pela empresa? Vai entregar o que se pede no tempo menor do que se espera? Vai suportar pressão? Tudo isso é difícil. É, mas é isso que a empresa busca, o seu perfil comportamental. (Fernando Mantovani, Diretor Administrativo, Consultoria $\mathrm{RH}^{159}$ )

Empresas de consultoria de $\mathrm{RH}$, com abrangência internacional, prestam serviços para os bancos brasileiros. Tal como as grandes corporações, atuam de forma padronizada disseminando orientações sobre as tendências do mercado de trabalho articuladas às necessidades contemporâneas de flexibilidade e obtenção de resultados no curto prazo.

A consultoria DMRH/Cia de Talentos divulga em seu site institucional que em 1997 obteve a certificação IS0 9002, o que reforça sua atuação padronizada na cena corporativa, contribuindo para estender sua influência sobre diversos ramos, incluindo o setor bancário. Seu foco está na seleção e formação de executivos, alta gerência, trainees e estagiários de nível superior, sobretudo para grandes empresas.

O papel das consultorias de RH espelhadas nas publicações especializadas direcionadas aos aspirantes e participantes do mercado de trabalho, como podemos citar: revista Você S.A. e Caderno Emprego do Jornal Folha de S.Paulo e do Jornal $O$ Estado de S. Paulo contribuem para explicar como certas características e qualificações são sistematicamente "tabuladas" para se traçar o perfil desejado pelas grandes corporações em qualquer local independente do ramo da economia. Como abordou Galeujac (2007, p. 189):

Testes de conhecimentos técnicos, testes de inteligência, testes de psicomotricidade, testes de personalidade e de comportamento, as psicologias comportamentais e cognitivas são mobilizadas para construir tipologias, indicadores, grades que permitem identificar os traços de personalidade, os talentos e as aspirações a fim de traduzilos em apostas profissionais, de racionalizar os processos de ajustamento ao emprego.

A adequação é, portanto, algo central nesta interação social que promove o encontro de muitos agentes: o candidato, a consultoria e a empresa. Nessa relação, a

\footnotetext{
${ }^{159}$ Vídeo "Qual o tipo de profissional que as empresas mais buscam?" Disponível em: http://exame.abril.com.br. Acesso em: fev.
} 2015. 
consultoria de RH terá como atribuição relevante verificar quais candidatos têm aderência ao perfil desejado, utilizando como instrumento o "inventário comportamental" ou similar, reforçando mais uma vez a importância deste quesito em tempos que há ampla oferta de candidatos com elevada formação acadêmica disponíveis para atuar em instituições financeiras. Vejamos a seguir a abordagem extraída de um veículo de comunicação do $\operatorname{Banco} \Delta$. Como podemos notar, a "atitude" é o diferencial:

Você fala bem inglês. Cursou uma boa faculdade. Tem um histórico profissional exemplar. Mas... já parou para pensar que os demais concorrentes selecionados para concorrer à vaga provavelmente têm um currículo bem parecido com o seu? O que faz de você um profissional único é a combinação das suas características pessoais: seu perfil, seus valores, seu conhecimento, sua experiência... Por isso, as características atitudinais são cada vez mais valorizadas pelas empresas. "Atualmente é o atitudinal que diferencia os candidatos e os colaboradores. Quando a empresa desenha seus valores, ela identifica o que espera de seus profissionais." (Gerente de Atração e Seleção do Banco $\Delta$, Revista Banco 4 , ago. 2013)

Os anúncios de vagas para trabalhar no Banco $\Delta$ que tivemos acesso solicitam habilidades ligadas ao comportamento ou associadas à capacidade cognitiva do indivíduo. Como podemos citar: capacidade para trabalhar sob pressão e em equipe; proatividade; criatividade; capacidade de comunicação; capacidade de análise crítica e raciocínio lógico.

Os trabalhadores a seguir manifestam sua percepção acerca das características comportamentais presentes neste universo a partir da sua experiência:

$\mathrm{Eu}$ acredito que eles estejam buscando pessoas que tenham um senso crítico, né? Que consigam acrescentar alguma coisa. O banco tem várias vertentes. Ele tem a parte que é de produtos, de desenvolvimento, né? $\mathrm{E}$ tem a parte operacional. A parte operacional realmente são pessoas ali que vão ficar executando. Não precisa necessariamente ser um engenheiro, ser alguém... Um economista. Pode ser qualquer formação. As pessoas vão executar atividades braçais. E tem também o outro lado que são as pessoas que são mais analistas mesmo, essas pessoas precisam ter um senso crítico, precisam ter uma disponibilidade de... de... uma vontade realmente de tá ali fazendo aquela atividade, porque se ela não tiver isso, ela vai acabar entrando na mesmice. (Estagiário, 24 anos, 04 meses de banco)

Eu acho que o banco quer alguém que tome iniciativa, mas nem tanto. Eles esperam que você entregue alguma novidade, mas não o suficiente pra abalar toda a estrutura que já está presente. Você tem que apresentar algo novo, mas sempre limitado. Assim, dentro da caixinha, tudo bem [...] tem que ter também comunicação [...] eu percebi que eles valorizam muito as pessoas tentarem aprender com 
o que está em volta, tenta explorar algumas coisas além das atividades rotineiras. (Estagiária, 19 anos, 01 ano de banco)

$\mathrm{O}$ banco prefere alguém bem quieto. Apático. $\mathrm{O}$ banco não gosta de questionamentos. (Operador de Teleatendimento, 24 anos, 03 anos de banco)

Eles querem alguém que siga os modelos pré-estabelecidos pelo banco, que não seja muito crítico, pode questionar se levar a um jeito que vai dar mais lucro, não pode questionar a forma de trabalho. Você tem que ser flexível, proativo em relação a fazer as críticas do que pode ser melhor para o banco, pode ser proativo em determinadas circunstâncias, não é para tudo que pode ser proativo, pra melhorar o lucro pode, mas não pode ser muito questionador, tem que se cumprir a cartilha meritocrática. (Bancária, Analista Sênior, 30 anos, 11 de banco)

Como se pode observar, os trabalhadores entrevistados apresentam visões divergentes sobre o modo de se comportar na instituição. Apesar de algumas posições trazerem à tona aspectos mencionados na fase de recrutamento, ou ainda repetir o que as consultorias dizem, como a capacidade de criar coisas novas ou ter senso crítico, também foi mencionado que se espera um trabalhador apático e que atue dentro dos limites.

Para uma análise apurada, salientamos que a função exercida, o cargo e inclusive a área são variáveis que devem ser ponderadas quando tratamos de qual perfil é requerido para exercer as atividades estabelecidas pelo banco.

Desse modo a declaração do pesquisador e também consultor Dutra (2002), a seguir, reitera em nós a necessidade de ponderações, no sentido de fugir de generalizações que pouco esclarecem sobre as complexas organizações que atuam em rede e podem admitir contingentes altíssimos de volume de trabalhadores:

A busca de posicionamento mais competitivo em seus mercados tem conduzido as empresas à redefinição do perfil exigido de seus recursos humanos. Tal perfil desloca-se da postura $e$ do comportamento obedientes e disciplinados para a inovação e a capacidade de empreender". (DUTRA, 2002, p. 102, grifo nosso)

Analisando a citação acima mencionada é difícil imaginar que as empresas desconsiderem comportamentos que estruturam a organização do trabalho, como é o caso da obediência e da disciplina. Assim, a capacidade de inovar e empreender, a depender do cargo e do local em que o trabalhador se insere, tem alguma ou até nenhuma chance de se viabilizar. 
Percebe-se que, em determinados momentos, consultores, pesquisadores e empresas estão se pronunciando acerca do perfil dos executivos ou gestores das empresas, mas ao usarem um discurso genérico acabam alimentando a existência de características desconectadas da realidade quando se observa o processo de trabalho objetivamente.

A literatura da nova gestão empresarial, como apontou Boltanski e Chiapello (2009), divulga qualidades que no novo espírito do capitalismo são penhores de sucesso. No Banco $\Delta$ há um conjunto de virtudes e condutas que orientam o perfil dos trabalhadores expressos na forma de "dez mandamentos", sendo eles: 1) atitude de dono; 2) foco no cliente; 3) foco na performance; 4) integridade; 5) agilidade; 6) indignação construtiva; 7) lidar com pressão; 8) espírito de parceria; 9) visão de risco; e 10) capacidade de liderança.

Os anúncios por nós pesquisados reproduzem alguns dos itens deste compêndio comportamental ou retomam os adjetivos de caráter mais idealizado que compõem as chamadas para as vagas disponíveis no $\operatorname{Banco} \Delta$.

Chamou nossa atenção o fato de os anúncios serem explícitos ao requerer a habilidade: "capacidade de trabalhar sob pressão" ou "resiliência". No texto em destaque a seguir, reproduzimos a posição do consultor de RH entrevistado, que reafirma o quanto a pressão faz parte destes ambientes por nós analisados e, portanto, justifica-se o fato de saber lidar com esse elemento no cotidiano:

Os bancos tendem a ter atuação global neste ambiente altamente competitivo, e isso pressionou bastante as lideranças, então é claro que este é um profissional que tem que conseguir lidar bem com esse ambiente de pressão. Precisa lidar com essa pressão que é contínua. É um perfil particular de uma pessoa que suporta esse ambiente continuamente mais tenso. (Consultor RH entrevistado)

Na sequência, trazemos à tona a percepção dos bancários entrevistados, sobre o perfil requerido para atuar no $\operatorname{Banco} \Delta$. De acordo com o que descrevem, é possível reconhecer características já mencionadas nas chamadas para preenchimento de vagas, como ser criativo, proativo, flexível e participativo. Destaca-se, ainda, como uma das mais relevantes habilidades para atuar no ambiente corporativo a capacidade de suportar a pressão, conforme reproduzimos a seguir:

$\mathrm{Na}$ agência, ele [o banco] quer uma pessoa com gás que tenha criatividade, que seja, como é que chama aquele termo que está...é que, como se fala mesmo aquele termo que a pessoa pode aguentar pressão... é... resiliente. Esse é o termo do momento. Eles querem 
pessoas novas de idade, para estar aberto às mudanças, porque sempre há mudanças de um mês para outro de um ano para outro e as coisas acontecem muito rapidamente, o banco está mudando rapidamente e ele não quer gente engessada, ele não quer gente que esteja com dificuldade [...] Ele quer pessoas novas, que tenham atitude, que sejam proativas, que deem ideias novas e que estejam preparadas para aguentar as marteladas [risos], para aguentar a cobrança de metas e dizer: Não, tudo bem, vamos lá, eu vou conseguir... Tudo bem, eu vou passar o outro que tá conseguindo. Quer pessoa com gás, competitiva, e quem é mais velho tem mais dificuldade de encarar isso, por isso que ele quer todas essas gerações novas aí, X, Y e Z! (Bancária, Gerente de Contas, 35 anos, 08 de banco)

É muito difícil ex-bancário entrar. O banco quer... por exemplo, estagiário, porque ele molda... O comportamento pesa. $\mathrm{O}$ banco fala, no discurso do gestor, que tem que ser proativo, ter bom relacionamento, inovar, dar ideias que tragam lucro para o banco, ser flexível, que não crie polêmica. Tem que suportar pressão, no fechamento do mês um pede uma coisa, vem outro pede outra coisa, então ele diz que você tem que ser flexível, ele não fala diretamente suportar pressão, porque é ruim, é ruim pressão, é ruim ser pressionado, então ele não bota essa palavra no discurso, para não causar polêmica, ele não viu, não sabe, não sente. (Bancária, Analista Júnior, 57 anos, 12 de banco)

O banco gosta de construir seu profissional. Já vi o banco buscar empregados de fora, como uma moça que trabalhava como vendedora no setor aéreo. Mas isso é mais raro, o banco gosta de criar seus funcionários. Tem que ser proativo, inovador, participativo, flexível e que suporte pressão. A pessoa tem que ter estômago. (Bancário, Gerente de Contas, 32 anos, 07 de banco)

Das características pessoais, o principal é suportar pressão. Se você não suportar pressão no banco, você espana. Eu tenho uma amiga que trabalha dentro do banco e ela é muito assim, ela é mais na dela, tranquila e ela não aguenta pressão, ela espana. Nesse último um ano, ela ficou três vezes afastada... com síndrome de pânico. (Bancário, Gerente de Contas, 25 anos, 04 de banco)

O ambiente aparentemente amigável, asséptico e moderno não disfarça a pressão por resultados que ocorre em efeito cascata. A resiliência se tornou nos últimos anos um dos novos jargões corporativos. Não fosse a novidade de um termo emprestado do vocabulário da física, ao se referir sobre a capacidade de um material voltar ao seu estado normal depois de ter sofrido tensão, apenas estaríamos falando de "flexibilidade" no ambiente corporativo, uma capacidade de se adaptar ao ambiente seja ele favorável ou desfavorável. 
A pesquisa de Benossi (2010), que observou o contexto das grandes corporações, também destacou que a resiliência é uma característica desejada no ambiente corporativo já incorporada no vocabulário corrente nestas organizações.

A matéria "Mais do que só competência, resiliência" foi carro chefe da edição do caderno de empregos em um jornal de grande circulação. ${ }^{160}$ De acordo com o levantamento jornalístico, "o conceito de resiliência discutido no ramo da psicologia positiva tem ganhado importância na área de gestão de pessoas, tanto na seleção de candidatos quanto no gerenciamento de carreiras". Como aponta o consultor entrevistado para a mesma reportagem, isso ocorre porque os executivos vivem constantemente sobre pressão para obter resultados e produtividade. Ser resiliente é vivenciar essas experiências não sucumbindo ao desespero e mantendo o otimismo.

$\mathrm{Na}$ explicação de outra consultora, ${ }^{161}$ "resiliência é administrar tudo isso sem perder o foco". De acordo com sua abordagem, a busca por profissionais com essa característica só aumenta no mercado de trabalho como um todo e a tendência não deve desaparecer tão cedo, pois todas as empresas pedem que o candidato tenha a capacidade de ser resiliente, seja no varejo, na indústria ou em serviços.

Como observamos ao longo deste texto, a pressão no ambiente de trabalho bancário se configura por diversas formas e está impregnada no cotidiano dos trabalhadores. A gestão por resultados é o núcleo ativo da cultura organizacional que admite a pressão como um elemento banal no processo de trabalho.

\subsubsection{O "bom bancário"}

A visão "politicamente correta" do mundo corporativo contemporâneo se ergueu a partir do discurso da democratização no ambiente de trabalho, e, em que pese a superficialidade dos atos efetivos de gestão, tornou-se fundamental alavancar novas subjetividades, novas virtudes que pudessem ser atribuídas aos participantes em prol de um clima que favorecesse a produtividade vinda do trabalho.

Recorrendo à literatura específica do setor bancário, fica claro que as exigências sobre o perfil comportamental dos trabalhadores sempre estiveram presentes. Essas exigências estiveram fortemente associadas à disciplina no ambiente de trabalho. Elas visavam submissão e dedicação, aquilo que o capitalista sempre esperou da força de

\footnotetext{
${ }^{160}$ Jornal O Estado de S. Paulo, 16 mar. 2014.

${ }^{161}$ De acordo com a consultora Sandra Cabral, representante do Grupo DM Cia de Talentos, em entrevista à CBN, no Programa "Mundo Corporativo", fev. 2014.
} 
trabalho em qualquer tempo e lugar. Apesar de tais elementos não entrarem na lista de características desejáveis e divulgadas para atuar nas organizações bancárias, sabemos que são estruturantes na relação capital-trabalho.

Encontramos na pesquisa feita por Canêdo (1978, p. 43), que abrangeu desde os anos 1923 até 1944, descrições acerca do perfil comportamental requerido dos trabalhadores do setor, pelo qual lemos: "o bancário deve ser diligente, ativo, discreto, prudente e capaz, deve saber lidar com o público". Romanelli (1978, p. 161), em seu estudo de caso em um banco público, durante os anos 1970, apurou que no processo de seleção eram considerados apenas os critérios de escolaridade e técnicos, contudo, para manter-se empregado e ser considerado um "bom bancário", o trabalhador deveria ser “dócil, submisso e diligente no trabalho". Segnini (1988), que realizou um estudo de caso no maior banco privado brasileiro durante a década de 1980, verificou que os processos de seleção consideravam, além dos requisitos de escolaridade e experiência sobre a tarefa, as variáveis comportamentais diante de um processo de trabalho marcado por um controle disciplinar intenso. Jinkings (2002, p. 191), em seu estudo sobre as transformações do setor nos anos 1990, registrou as contradições derivadas da idealização do perfil do bancário-vendedor, com base nas expectativas do sujeito “empreendedor, autônomo e responsável" voltado para o atendimento qualitativo dos clientes. A autora já menciona à época a visão de que havia um conjunto de conhecimentos e atitudes que em tese buscavam se diferenciar do taylorismo e fordismo. Isso significa dizer que os aspectos subjetivos, que ressaltam o comportamento de um trabalhador como: "espírito inovador, criatividade, facilidade de comunicação, tolerância à pressão, motivação, dentre outros" (JINKINGS, 2002, p. 194) seriam mais valorizados na admissão e treinamento.

Como foi possível notar, a partir de nossa investigação, nas décadas subsequentes, pode-se dizer que houve maior dedicação ao tema do comportamento no ambiente corporativo que até passou a ser mensurado e avaliado.

A partir da sistematização e análise trazida à tona, que considerou o discurso das consultorias de $\mathrm{RH}$, o discurso institucional do Banco $\Delta$, a percepção dos trabalhadores e a revisão da literatura das últimas décadas (ROMANELLI,1978; SEGNINI, 1988, 1998; JINKINGS, 2002; SOARES, 2013; OLIVERIA, 2014; COLOMBI, 2014; DULCI, 2015; NOGUEIRA, 2015), verificamos que as características comportamentais sempre estiveram na mira dos recrutadores, mas não com o mesmo peso que aparecem nas décadas recentes. 
No contexto pesquisado, tais características subjetivas das quais o trabalhador deve ser portador, além de serem exigidas na admissão, devem manter-se ativas durante a permanência na instituição, pois assim existem melhores possibilidades de manter-se no emprego. Ilustra esta condição o caso do $\operatorname{Banco} \Delta$, haja vista ser atribuído periodicamente nota para as características relacionadas ao comportamento no processo de avaliação individual, como tivemos a oportunidade de analisar em tópico anterior deste texto.

As marcas de distinção que configuram o "bom bancário" foram reunidas nos aspectos já mencionados neste texto e podem ser complementadas pelas descrições postas pelos próprios trabalhadores entrevistados:

O que é preciso pra ser um bom bancário dentro do banco? Você precisa chegar de manhã bem-humorado, sem problemas, se relacionar muito bem com todo mundo. Abrir a agência, entregar 70 pontos por dia, você tem que entregar 70 pontos ou mais, tem que lidar com essa situação com a maior normalidade possível e ir embora e falar que o banco é o melhor lugar do mundo pra você trabalhar. É esse cara que o banco quer. O bom bancário é o bom vendedor. Porque o cara que vende, gera negócio. Se ele vende bem, ele vai sair feliz. Então é isso que a gente precisa. (Bancária, Gerente Regional, 43 anos, 16 de banco)

O cara que chega de manhã, faz seu trabalho, não reclama, que não tem direito a estar insatisfeito, não pode ter TPM, tem que aceitar mudar de local de trabalho, tem que aceitar caladinho, ficar além do horário, tem que ficar, fazer hora extra no final de semana... Outro dia eu cheguei às 05 h40 da manhã e não saí antes das 05 da tarde. Esses são bem-vistos. (Bancário, Analista Júnior, 42 anos, 12 de banco)

Vestir-se bem, ser doutrinado na moda, ter esse perfil que a gente estava falando do cara proativo... Você não pode questionar metafisicamente as coisas, filosoficamente, você só pode questionar se for para o banco lucrar mais. Tem que dar as melhores ideias e trazer resultados. (Bancária, Analista Sênior, 30 anos, 11 de banco)

Estar comprometido com o banco, seu trabalho, horário, ser responsável, cumprir as demandas, ter proatividade, saber trabalhar em equipe e saber suportar pressão. Esses são os fatores que criam um bom profissional. (Bancário, Gerente de Contas, 32 anos, 07 de banco)

Eu acho que você tem que se desligar muito do que tá fora, das coisas do seu dia a dia e simplesmente focar no seu trabalho durante aquele tempo que você tá lá só pra trabalhar. Acho que todos os bons bancários que eu conheci são muito focados em fazer aquilo naquele momento. É tudo muito concentrado. (Estagiária, 19 anos, 01 ano de banco) 
Para ser um bom bancário você tem que bater as metas todos os meses, você tem que estar sempre de acordo com o perfil que o banco pede. (Bancária, Gerente de Contas, 35 anos, 08 de banco)

Para ser um bancário é preciso bater as metas, isso é o principal (Bancário, Gerente de Contas, 25 anos, 04 de banco).

Para ser um bom funcionário, eles esperavam que eu tivesse feito mil e trinta pontos. Você tem que ultrapassar a expectativa. (Bancária, Gestora Agência, 35 anos, 16 de banco)

Na visão dos trabalhadores entrevistados o "bom bancário" é aquele que deve se vestir bem, estar bem-humorado, não reclamar, não questionar, estar comprometido com o banco, ter iniciativa, ser dinâmico, ser focado no trabalho, suportar pressão e cumprir as metas de trabalho, ou, melhor, ultrapassá-las.

Sznelwar e Pereira (2011) ao analisarem a psicodinâmica do trabalho bancário e seus efeitos para a saúde dos trabalhadores afirmaram que predomina nestes ambientes:

A busca por ser eficaz em tudo, provar que está sempre pronto a se sobrepujar para cumprir ou, melhor ainda, bater as metas fixadas, com a perspectiva de que, caso seja considerado um trabalhador "bom", possa galgar postos na hierarquia do banco. (SZNELWAR; PEREIRA, 2011, p. 48, grifo nosso)

O "bom bancário" precisa demonstrar o resultado de seu trabalho no curto prazo.

Pro banco, tudo, tudo é resultado. Você pode ter CPA, você pode não ter CPA, se você bate o resultado, tá ótimo. Todos os supervisores tem essa visão e é realmente assim. Esse é o perfil que o banco quer. As pessoas batendo resultado, mesmo que esteja tudo ruim. Ok. Batendo resultado tá ótimo. Você tá se matando e o outro não chega nem no horário, não importa, se ele bate resultado. [...] as pessoas precisam disso pra sobreviver, então mesmo com sistema ruim, horário ruim, máquina ruim, a pessoa se vira pra bater o resultado, acabam conseguindo e pro gerente e acima dele tá tudo ótimo, porque conseguiu bater os resultados. Então tudo bem. (Operador de Teleatendimento, 24 anos, 03 anos de banco)

Esses aspectos mencionados pelos trabalhadores, quanto à importância de atingir resultados, se articulam diretamente aos programas de gestão que abordamos neste capítulo e nos levam a inferir que a despeito da relevância notada sobre as exigências comportamentais são os fatores objetivos relacionados ao cumprimento de metas de produtividade os essenciais na determinação do "bom bancário". Em nossa análise sobre a instituição pesquisada é o pragmatismo do resultado que define de fato a qualidade do trabalhador. Mesmo que haja comportamento adequado, isso não será o suficiente, se não houver resultado o trabalhador não serve à corporação. 


\subsection{Quando o trabalho na grande corporação bancária se torna um risco à saúde dos trabalhadores}

A questão central deste tópico está em analisar de que modo a relação entre a organização do trabalho e as respectivas formas de gestão interferem na qualidade de vida e saúde dos trabalhadores do setor bancário e em especial no Banco $\Delta$.

Concordando com Sznelwar (2011) e Maeno (2011a), as questões relativas à saúde do trabalhador não podem ser tratadas de forma apartada do modo pelo qual o trabalho se organiza e é gerido, pois aí estão as causas das doenças profissionais.

Maeno (2013) afirma que a "tendência do empregador ainda é atribuir o adoecimento a um fator externo ao trabalho". Diversos autores (MAENO, 2011b; BARRETO; HELOANI, 2011; SALVADOR; FILHO, 2011) manifestam sua preocupação em torno da subnotificação das doenças ocupacionais, ${ }^{162}$ reconhecidas pelo nexo causal derivado do trabalho por parte das empresas. Há ainda uma crítica direcionada aos órgãos de Estado pela leniência com as dificuldades de prazo e perícia dos adoecidos, sendo que essas inviabilizam o acesso ao benefício previdenciário e demais direitos.

Gaulejac (2007) chega a afirmar que a gestão de pessoal no interior das organizações pode ser entendida como uma "doença social". O autor destaca que os padrões ideológicos, vigentes no atual momento do capitalismo financeirizado, reforçam o poder gerencialista ao mesmo tempo em que o poder é despersonificado. Se antes o poder era centrado no proprietário, hoje são os acionistas que determinam seu ritmo e condições de trabalho. Nesse cenário, os trabalhadores cada vez mais têm enfrentado sofrimentos psíquicos e a sociedade tem colhido os sintomas da "gestão como doença social" refletidos na perda de sentido, perversão de valores, comunicação paradoxal, explosão de coletivos, pressão sobre os indivíduos em uma competição sem limites.

Soboll (2008) enfatiza que a violência no trabalho se efetiva pelas novas configurações da organização do trabalho que são:

Permeadas de controles simbólicos e psicológicos, de estratégias que estimulam a competitividade entre os iguais, em um tempo de curto prazo e em uma lógica de supervalorização dos resultados em

\footnotetext{
${ }^{162}$ Ao não emitir o Comunicado de Acidente de Trabalho - CAT o sistema de informações do INSS deixa de computar o número real de pessoas adoecidas em função do trabalho. Além disso, as "altas programadas" do INSS de acordo com Maeno (mimeo) contribuem ao lado da subnotificação para distorcer as estatísticas sobre adoecimento no Brasil, na medida em que se constitui como um obstáculo diante da burocracia que leva o trabalhador a uma exaustiva peregrinação para comprovar sua doença ou renovar o respectivo tratamento.
} 
detrimento dos processos. Esses parâmetros empurram para a fragilização dos vínculos e promovem a cisão do coletivo, instalando o isolamento. (SOBOLL, 2008, p. 14)

O sistema meritocrático no $\operatorname{Banco} \Delta$ considera o resultado do indivíduo no curto prazo, desprezando o histórico de médio e longo prazo. Além disso, desconsidera as tentativas, o empenho sem retorno, o contexto adverso em que o trabalhador pode se encontrar e os demais problemas operacionais são abstraídos das métricas contabilizadas pelo sistema de avaliação.

A meritocracia reproduz o processo de "seleção natural" no mundo corporativo desconsiderando, desprezando e descartando aqueles que não conseguem sobreviver à concorrência do próprio colega em seu meio.

Em nossa pesquisa analisamos como o refinamento da racionalização do trabalho bancário possibilitou ao longo das últimas décadas que o paradigma da gestão por resultados, amparada no sistema ideológico meritocrático, submetesse os trabalhadores à forte pressão. Os elementos a seguir recapitulam como se engendra esse processo no interior do $\operatorname{Banco} \Delta$ :

a) A expectativa de retorno financeiro dos acionistas exercida sobre os administradores e os altos executivos recai, em efeito cascata, pressionando gestores e consequentemente demais trabalhadores, sejam bancários ou terceirizados;

b) As formas de pressão são objetivas e subjetivas, ambas se viabilizam, sobretudo, com a implantação de controles informatizados de produtividade e de comportamento no ambiente de trabalho;

c) A implantação do sistema de avaliação (EixoX-EixoY) facilitou a comparação entre os trabalhadores aumentando a disputa entre si. O modelo, por regra, determina que sejam apontados os perfis com baixa produtividade ou em situação pouco eficiente;

d) A relação com o cliente é mediada pela obrigatoriedade de entrega de resultados, há um tensão entre as ofertas dos produtos e serviços feitas pelos trabalhadores e as necessidades dos clientes;

e) Os clientes exercem pressão direta sobre o trabalho e os trabalhadores, podendo inclusive atribuir notas de avaliação para os 
trabalhadores, individualizando um problema que pode ser derivado das condições de trabalho ou do sistema operacional da instituição; cumprimento de metas na medida em que há muito trabalho e poucas pessoas. Desse modo, qualquer atraso ou ausência que possa comprometer a entrega de resultados da área, ainda que seja para cuidar da saúde, pode ser gerador de mal-estar; O medo de perder o emprego reforça a todo o momento a insegurança sobre sua posição socioeconômica.

Desse modo, é possível concluir que se tornou banal viver nesses ambientes sob estresse, ansiedade, depressão, sintomas gástricos e síndrome do pânico, como foi relatado pelos entrevistados a seguir:

O estresse é altíssimo porque o volume de trabalho é alto e você lida com situações difíceis o tempo todo. Hoje um superintendente, com uns 30 anos de banco, ganha uns 20 mil reais, os mais novos ganham menos. Mas, o nível de estresse é muito elevado, o celular não para e ele descarrega isso para baixo. (Bancário, Analista Júnior, 29 anos, 04 de banco)

Eu identifiquei uma úlcera devido ao trabalho, ao estresse. Hoje ela cicatrizou, está ligada ao nervosismo que a gente passa. E isso abala o seu psicológico, eu nunca cheguei em uma fase crítica, mas o trabalho do banco é em suma muito estressante. A médica atribuiu a minha doença ao meu estilo de vida, por ser bancário, ela disse que vai muito bancário no consultório. Você não almoça direito, come nervoso, não mastiga. Depois vai pra o happy hour, uma forma de aliviar toda essa pressão que a gente está recebendo no dia e aí acaba extravasando de outras formas. Eu conheço gente que toma calmantes para dormir e pra suportar o trabalho, às vezes para ir para uma reunião. (Bancário, Gerente de Contas, 32 anos, 07 de banco)

Pra mim isso daí acaba sendo desumano, né? A forma como foram criados esses programas [de metas]. Os funcionários adoecem, adoecem por conta dessa pressão. É tudo tão profundo... porque assim, eu tenho relação com vários funcionários que estão hoje afastados por conta desse tipo de trabalho, realizado dessa forma. Se não existisse essa pressão, talvez o funcionário estivesse lá na agência executando e produzindo, dando até o resultado que o banco quer. Mas a pressão, a forma, a cobrança, acaba interferindo na saúde do trabalhador. Então, tenho várias colegas que estão afastadas. Inclusive tem uma que é muito próxima a mim que ela não pode nem entrar no banco nem pra receber o beneficio do INSS 
dela. Ela não consegue. Ela entra em pânico, a síndrome do pânico, né?! (Bancária, Gestora Agência, 35 anos, 16 de banco).

Eu tenho alguns amigos que trabalham em agência e têm problema de depressão, tem problema de não alcançar o resultado, a pessoa fica preocupada. Por isso que eu tenho muito medo de mudar de área, porque na minha área, querendo ou não, a gente tem a cobrança, mas eu sei como funciona, como que eu tenho que trabalhar, eu só tenho um produto. O cara que é gerente ele tem 50 produtos, 30 tipos de clientes, diversos problemas. Então o leque dele de problemas é muito maior. E nem tudo depende dele. (Operador de Teleatendimento, 24 anos, 03 anos de banco)

O uso de medicamentos para controlar os problemas de saúde derivados do trabalho foi citado por diversos entrevistados. Também, outras explicações que desencadeiam o adoecimento como a dificuldade para sair de férias e os assaltos nas agências fazem parte da vida dos bancários, conforme observamos a seguir:

Eu não tomo remédios, nunca tomei. Mas sei de várias pessoas que tomam, vários gerentes, tanto no sentido de pressão no trabalho quanto... Há problema de assalto que deixa a gente tenso, com medo, quem passa por isso acaba ficando com problema psicológico... Eu mesma já passei por assalto, mas foi há muitos anos, quando eu trabalhava em outro banco, eu fiquei um ano assim, com medo de sair na rua. Com medo de tudo, qualquer barulho você já acha que tá acabando o mundo, depois passou. E não passei por mais nenhum. (Bancária, Gestora Agência, 35 anos, 16 de banco)

Eu tenho essa gastrite, eu tomo medicamento de vez em quando. Tem gente que toma também por problema de estômago, depressão, problema muscular. Tem um pessoal que vai ao médico, saúde em primeiro lugar, mas tem um pessoal que pensa mais no trabalho... Hoje o banco não dá trinta dias de férias pra você. Só que você tem que tirar parcelado suas férias. Você também quer trabalhar, você também não quer sair. Porque, você trabalhou bateu sua meta em cinco meses aí você vai tirar aquele mês todo de férias, você não vai conseguir, ninguém vai fazer por você. (Bancário, Gerente de Contas, 25 anos, 04 de banco)

Soboll (2008), em sua análise sobre saúde e a organização do trabalho bancário, aponta que o trabalhador evita demonstrar que está doente para não ser prejudicado, afinal, se o seu papel é ser produtivo, adoecer significa perder aquilo que lhe atribui valor dentro da lógica organizacional. Nesse sentido, os trabalhadores podem vivenciar o que os pesquisadores denominam "presenteísmo" (SELIGMANN-SILVA, 2013; BARRETO, 2013). De acordo com Seligmann-Silva (2013, p. 53), “o presenteísmo é a presença no trabalho de pessoas adoecidas". 
Como explica Maeno (2011a), os trabalhadores bancários adiam a procura por auxílio médico e com isso tem dificuldades de diagnóstico precoce, pois há por parte desses um "forte senso ético", que os leva a não se afastarem do trabalho, devido às pressões econômicas e o medo de perder o emprego.

O adoecimento psíquico carrega consigo uma estigmatização dos envolvidos gerando nos trabalhadores resistência em aceitar a situação por receio de serem discriminados. A autora ainda registra que em sua atuação profissional como médica tem conhecimento de uso de psicotrópicos pelos bancários, medicamentos popularmente chamados de "tarja preta". ${ }^{163}$ Os entrevistados do Banco $\Delta$, a seguir, demonstraram por meio de seus relatos como os colegas "administram" sua saúde no ambiente corporativo:

As pessoas evitam procurar médico, porque você não quer se mostrar frágil diante de um ambiente tão duro, porque no mundo você não pode ser fraco. (Bancária, Analista Sênior, 30 anos, 11 de banco)

Vários escondem os problemas [psicológicos e físicos] nem procuram médico pra não correr o risco. Mas... sentem dor, mas não dão o devido valor. Eu acho que em alguns casos as pessoas são punidas por terem ficado afastadas. Se for problema ortopédico não, agora se for problema emocional, sim. Porque as pessoas acham que... Ah! Não aguentou o tranco, não vai aguentar... Ah! Espanou. Então, se você continuar apertando, não vai aguentar, vai adoecer ainda mais. Então não vale a pena, acham que tão fazendo um favor, e mandam embora logo. (Bancária, Gestora Regional Agências, 43 anos, 16 de banco)

As pessoas procuram o médico a fim de remediar a situação, mas como é irremediável, eles vão levando até onde podem. Já tomei medicamento por causa da LER. Conheço um monte de gente que toma medicamento continuo por causa do trabalho. Tem um monte de gerente que vai no médico, que tá com estresse, que tem problema de ansiedade, que tem depressão, que não quer mostrar pra os outros que não aguentou, que não tá aguentando, vai, passa no psiquiatra, toma remédio tarja preta, mas não fala nada pra ninguém. Vários assim. (Bancário, Gerente de Contas, 32 anos, 07 de banco)

Tem muita gente com LER/DORT, problema psicológico também, começa assim: dor de cabeça, começa toma novalgina, remédio para dor de cabeça, depois não sara a dor de cabeça, aí vai parar no psiquiatra e ele taca tarja preta, e ele vai escondido para o banco não saber, ele não comenta, ele não traz atestado. (Bancária, Analista Júnior, 57 anos, 12 de banco)

\footnotetext{
${ }^{163}$ A venda de calmantes subiu 42\% no Brasil em 2014. A consultoria IMS Health apurou que de 2009 a 2013 o número de psicotrópicos saltou de 12 milhões para 17 milhões. Segundo apurou a reportagem, dentre os usuários estavam aqueles que faziam o uso de medicamento para suportar o estresse no trabalho (Folha de S.Paulo em 27 fev. 2014).
} 
Segundo Maeno (2013), as grandes empresas propiciam soluções cosméticas como programas de qualidade de vida e ginástica laboral desconectadas da organização do trabalho. Por visarem apenas atenuar as consequências, tais iniciativas não são bemsucedidas porque desconsideram o fato gerador.

Os principais problemas de saúde relacionados ao trabalho bancário se situam nas estruturas musculoesqueléticas do corpo humano como tendinites, tenossinovites, fribromialgia, compressão do nervo periférico, bursite, síndrome complexa de dor regional, síndrome miofascial, entre outras que se enquadram nas LER/DORT (MAENO, 2011a). Além destas, predominam os transtornos psíquicos, como: estresse, ansiedade, depressão e síndrome do pânico.

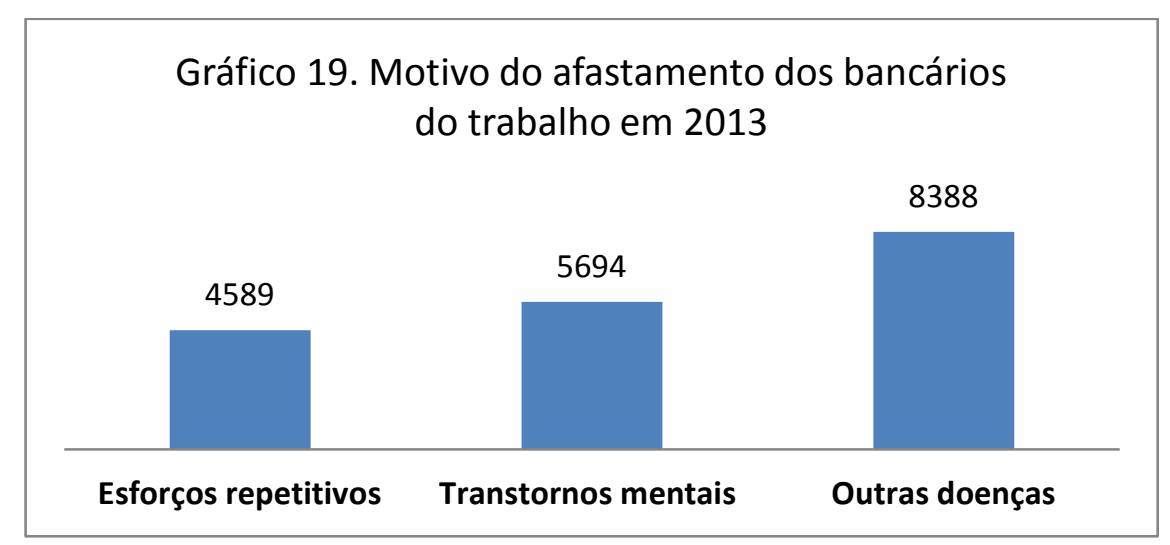

Fonte: INSS - Estatísticas: Segurança e saúde ocupacional - Previdência Social. Elaboração da Autora.

Segundo o INSS, em 2013, foi de 18.671 o número de pessoas afastadas na categoria bancária em nível nacional. Pela primeira vez as doenças relacionadas às lesões por esforços repetitivos não aparecem em primeiro lugar em volume de afastamentos. Assim, os transtornos mentais consolidaram-se entre as principais causas de adoecimento e afastamento que acometem os trabalhadores do setor, representando $24 \%$ do total de afastamentos, sendo que as LERs atingiram 20\%. É, portanto, contingente deduzir que os transtornos mentais atingiram uma participação maior devido às diversas formas de pressão que os trabalhadores são submetidos, como buscamos apontar ao longo desta tese.

Os estudos sobre o setor bancário são fartos em apontar a estreita relação entre a pressão, cargas de trabalho (metas), ritmo, escassez de trabalhadores com o adoecimento (PENELLA, 2000; CAMPELLO, 2004; SANTOS, 2009; GRISCI; SCALCO; KRUTER, 2011, MAENO, 2011a; SZNELWAR, 2011). 
A pesquisa coordenada por Rodrigues (2011) apurou a opinião dos trabalhadores bancários em São Paulo, captando elementos que nos auxiliam na análise sobre as condições de trabalho nos bancos e a relação com o adoecimento dos trabalhadores.

Quadro 10. Pesquisa: "Perfil do bancário e as condições de trabalho no setor financeiro na cidade de São Paulo"

\begin{tabular}{lc}
\hline Frase apresentada ao bancário(a): & $\%$ de \\
& concordância \\
\hline "A pressão no trabalho é muito intensa" & $61 \%$ \\
\hline "O trabalho é muito estressante" & $47 \%$ \\
\hline "Me senti exausto no trabalho todos os dias" & $31 \%$ \\
\hline
\end{tabular}

Fonte: Rodrigues (2011). Elaboração da autora.

Esses resultados apontam para uma relação de causa e efeito, pois como já havíamos abordado no Capítulo 3, a percepção sobre o processo de trabalho para o mesmo grupo de trabalhadores participantes da pesquisa citada alcançou percentuais elevados para as seguintes afirmativas: o ritmo é muito intenso, as metas não são compatíveis com a jornada de trabalho e a quantidade de funcionários não atende à demanda da empresa.

A experiência nas grandes corporações bancárias se estabelece de tal modo que é possível admitirmos uma coerência lógica ao ciclo que explica o adoecimento. Portanto, inferimos que os dados contidos no Gráfico 19 tratam das consequências da gestão por resultados, que se refletem na pressão, estresse e cansaço sentidos pelos trabalhadores no setor.

Outra pesquisa realizada pelo sindicato dos bancários $(2011)^{164}$ trouxe dados específicos do Banco $\Delta$, os quais que reforçam os resultados obtidos na pesquisa sobre o setor coordenada por Rodrigues (2011), revelando as políticas homogêneas adotadas pelos bancos. Os respondentes manifestaram a seguinte percepção sobre aspectos que envolvem o processo de trabalho:

\begin{tabular}{|c|c|}
\hline $\begin{array}{r}\text { Quadro 11. Pesquisa: "O impacto da organização e do am } \\
\text { bancário na saúde física e mental da catego } \\
\text { Grupo Respondente: Trabalhadores Banco } \Delta\end{array}$ & rabalho \\
\hline Frase apresentada ao bancário(a): & $\begin{array}{c}\% \text { de } \\
\text { concordância }\end{array}$ \\
\hline "Sente dificuldade para relaxar/está sempre preocupado" & $57 \%$ \\
\hline "Sente-se estressado" & $66 \%$ \\
\hline "O ambiente e a organização do trabalho podem levar ao adoecimento" & $65 \%$ \\
\hline
\end{tabular}

Fonte: SEEB-SP (2011). Elaboração da Autora.

${ }^{164}$ O impacto da organização e do ambiente de trabalho bancário na saúde física e mental da categoria. São Paulo: SEEB-SP, 2011. 
As consequências sobre a vida do trabalhador envolvem ainda outros aspectos. A dor e o sofrimento não são visíveis a olho nu, o que pode acarretar em uma associação direta daqueles que, adquirindo LER ou doença psíquica, são estigmatizados como indivíduos que fazem "corpo mole". Há uma desconfiança em torno da pessoa adoecida que pode vir do chefe, colegas, médicos e até de amigos e familiares. Uma intolerância velada paira sobre os adoecidos e estes por sua vez vivenciam em decorrência da doença sentimento de culpa, perda, humilhação e restrição (SZNELWAR; PEREIRA, 2011).

Heloani (2011) argumenta que para conquistar e manter um emprego cada vez mais é necessário ser detentor não só de competências técnicas, mas também de um forte espírito competitivo e de agressividade. Essa situação leva à emergência de comportamentos violentos, abusivos e humilhantes no ambiente de trabalho. Em nome da competição interna e das metas a serem cumpridas, o relacionamento entre indivíduos torna-se desrespeitoso.

Esse clima permissivo, por parte das organizações, pode levar a práticas de assédio moral. O assédio moral de acordo com Heloani, Freitas e Barreto (2008, p. 37)

é uma conduta abusiva, intencional, frequente e repetida, que ocorre no ambiente de trabalho e que visa diminuir, humilhar, vexar, constranger, desqualificar e demolir psiquicamente um indivíduo ou um grupo, degradando as suas condições de trabalho, atingindo sua dignidade e colocando em risco a sua integridade pessoal e profissional.

O assédio moral é reconhecido como um tipo de violência psicológica no ambiente de trabalho. Autores (SOBOLL, 2008; HELOANI, 2011; MAENO, 2011a; SOARES; OLIVEIRA, 2012) em suas pesquisas captaram a percepção dos trabalhadores sobre o fenômeno e concluíram que ele está diretamente associado à forma de "gestão por pressão" focada nas metas de produção e na competitividade.

Rodrigues (2011), a respeito do assédio moral na categoria bancária, verificou em sua pesquisa que $26 \%$ concorda totalmente com a afirmação de que no trabalho "o assédio moral é muito frequente", sendo seguida da reposta de $36 \%$ que afirma que concorda parcialmente.

Ao contrário do que se possa imaginar, não são apenas questões econômicas que sintetizam as principais preocupações dos trabalhadores. Considerando o resultado do questionário aplicado por Ostronoff (2015) a um grupo de trabalhadores bancários sobre 
qual tema era mais importante na ação sindical entre os seguintes itens: salário/PLR; saúde/assédio moral; lazer/convênios; foi o tema saúde/assédio moral que se demonstrou para os respondentes como o mais relevante.

Vale ressaltar que grande parte dos casos de violência organizacional não ganha visibilidade, haja vista a insegurança daqueles que apesar de vivenciar tais problemas têm medo de represália. O isolamento do trabalhador, configurado nestas circunstâncias, o faz suportar por tempos prolongados o sofrimento psíquico ou físico.

No Banco $\Delta$ tanto a violência psicológica - ainda que não seja admitida pela instituição esta designação - como o adoecimento relacionado ao trabalho são reconhecidos "formalmente". Ao criar um canal para receber denúncias via "ouvidoria interna" sobre conflitos no ambiente de trabalho e ao declarar em seus relatórios gerencias informações sobre doenças ocupacionais, a instituição está admitindo a existência de ambos.

Os números divulgados nos relatórios gerenciais do $\operatorname{Banco} \Delta$ nos últimos quatro anos apontam para uma taxa média de $2 \%$ do volume total de trabalhadores com doenças ocupacionais, o que corresponde a aproximadamente 1.720 pessoas. No documento não há detalhamento sobre quais são os tipos de doença tabulados. $\mathrm{O}$ volume, relativamente baixo, dos casos registrados pode estar relacionado ao presenteísmo e a subnotificação tratados neste texto.

Sznelwar e Pereira (2011) explicam que os trabalhadores bancários ao viverem sob situações conflitantes entre si, no interior das organizações, ficam angustiados. Ao se empenharem e se submeterem ao modelo de gestão predominante alimentam um tipo de expectativa sobre sua carreira que com o tempo se frustram no ambiente competitivo e cheio de pressão, agravando-se por conviverem com aquilo que consideram injusto.

O conceito de "sofrimento ético" que foi introduzido por Dejours em 1998 e se tornou reconhecido e pesquisado em diversos setores demonstra a importância que o tema assumiu no mundo do trabalho (ROLO, 2011). A base do conceito está fundamentada no fato de que se tornou recorrente que trabalhadores tenham que se confrontar com prescrições e ordens que os constrangem, passando a agir contra suas convicções e sua ética profissional, o que certamente se faz com um custo pessoal muito elevado, comprometendo a saúde física e mental.

A experiência da grande corporação por nós estudada apontou para o constrangimento vivido pelos trabalhadores derivado do modelo de gestão por 
resultados, sendo que as metas de produtividade exigidas e avaliadas no curto prazo se constituem como fatores determinantes desta relação.

Dejours (2006), a partir de uma visão crítica sobre a tolerância ao sofrimento vivenciado no cotidiano do trabalho, analisa que o funcionamento das grandes corporações se viabiliza por homens e mulheres que nela atuam e que eles, no plano subjetivo ao consentirem as determinações postas pela cultura empresarial, dividem-se em dois grupos, um que é levado a padecer ao sofrimento e outro que inflige tal sofrimento ao primeiro.

Há uma normalização desse tipo de vivência, na qual a integração e adaptação conferem ao trabalhador uma forma de sobrevivência e antes de mais nada um forma de suportar o sofrimento causado pela pressão e pelo medo. Entretanto, quando estratégias defensivas não funcionam, há descompensações psicopatológicas como depressão, prostração e alcoolização (DEJOURS, 2006).

O estabelecimento das estratégias defensivas para suportar a pressão no trabalho consolidam práticas individualistas e hiperativas que passam pela negação ou minimização da realidade, possibilitando assim uma "salvaguarda" do seu equilíbrio psicológico (ROLO, 2011).

Segundo Rolo (2011), diversas pesquisas sob diferentes áreas no setor de serviços apontam que a mentira e a manipulação se tornaram uma prescrição no trabalho, generalizadas a ponto de estarem integradas ao modo operacional. $\mathrm{O}$ autor relaciona tais praticas à multiplicação de formas específicas de sofrimento no trabalho, e ao analisar os efeitos das estratégias defensivas dos trabalhadores adverte, assim como Dejours (2006), que elas em si são problemáticas, pois contribuem com o "aumento da tolerância ante a situações de injustiça e atos imorais" (ROLO, 2011, p. 84).

\subsection{Formas de enfrentamento às pressões no ambiente de trabalho}

Nossa pesquisa apreendeu uma baixa capacidade de reação individual por parte dos bancários submetidos à forte pressão no sentido de alterar a configuração da realidade no ambiente de trabalho. Como mencionamos anteriormente, quando em plena atuação profissional os trabalhadores convivem e assumem a "não conformidade" dos procedimentos de trabalho, apesar de não ser de forma explícita, esta nos parece uma das formas que encontram para lidar com o ambiente hostil e com o risco de perdas iminentes. 
E é certo que não o fazem sem "constrangimento", mas, como Dejours (2006) sugere, o trabalhador constrói defesas contra o tipo de sofrimento que essa circunstância cria. Ainda que assim ocorra para alguns como uma forma de resistência não reconhecidamente elaborada, não exclui os riscos postos à saúde mental e física, como é o caso dos trabalhadores bancários.

Os reflexos negativos decorrentes da pressão no ambiente de trabalho, como é o caso do assédio moral, tem chamado a atenção de diversos agentes sociais, dentre eles citamos: sindicatos dos trabalhadores, pesquisadores, profissionais da área de saúde e Ministério Público do Trabalho (MPT).

O MPT patrocinou uma campanha com o título "MPT contra o Assédio Moral"165 em veículos de comunicação de grande porte, TV aberta, para esclarecer o conceito de assédio moral no trabalho e estimular a denúncia da prática, que segundo o próprio texto da mensagem é "mais comum do que se imagina". A pressão por cumprimento de metas aparece como a principal razão para criar um ambiente favorável ao assédio.

No vídeo que faz parte da campanha é retratado o ambiente de trabalho em um escritório. Na cena um gestor reúne todos os trabalhadores da área para anunciar o “incompetente do mês". Em uma situação humilhante, dirige as seguintes palavras a um trabalhador: "continue assim sem cumprir as metas que você vai longe, você vai bem longe, você vai para o olho da rua”.

O combate às práticas de abuso de poder, humilhações e conflitos no ambiente de trabalho sempre fez parte da ação sindical bancária que passou, desde a década de 2000, a canalizar maiores esforços no sentido de combater o que se tornou conhecido por assédio moral no trabalho (FONTES; MACEDO; SANCHES, 2013).

De acordo com os trabalhadores entrevistados por Ostronoff (2015, p. 143), sobre o tema da saúde bancária, "o sindicato nos últimos anos tem tido a função de refrear a pressão sobre os trabalhadores, tanto nas metas, quanto na manutenção do emprego".

Os instrumentos de comunicação do Sindicato dos Bancários de SP, como jornais sindicais, panfletos, programas audiovisuais e site, têm estampado com frequência os problemas vividos pelos trabalhadores nos locais de trabalho, fazendo esclarecimentos sobre as origens e consequências dos problemas relacionados à saúde nos bancos em função do processo de trabalho. A entidade de classe dispõe de médicos

165 A campanha circulou na TV em julho de 2015 e também na internet. Disponível em: https://www.youtube.com/watch?v=ZSBY9mPhMw4. Acesso em: jul. 2015. 
e assistência jurídica especializada em saúde ocupacional, que prestam atendimento aos bancários e assessoram a diretoria sindical visando estabelecer políticas de combate ao adoecimento. Soma-se a estas práticas as atividades frequentes de protesto realizadas em frente dos locais de trabalho após apuradas as denúncias vindas de sua base de representação, e, a interlocução intermitente com os agentes reguladores e fiscalizadores do mundo do trabalho na cena pública. ${ }^{166}$

O sindicato tem buscado atingir as causas das diversas formas de violência organizacional intervindo nos processos geradores de adoecimento. Contudo, no mais das vezes, consegue remediar as consequências dadas. Por ser uma categoria profissional com ampla experiência negocial, o tema da saúde do trabalhador perpassou pelas negociações mais importantes que existem no setor. Há inclusive uma mesa temática que reúne ao longo das últimas décadas representantes dos empregados e empregadores do setor para tratar especificamente do tema da saúde ocupacional. Analisando a CCT 2014, observamos que 20\% das cláusulas tratam diretamente da saúde dos trabalhadores.

Destacamos como um marco desse processo que envolve ação sindical direta e processo negocial a inclusão da cláusula na CCT do "Protocolo para prevenção de conflitos no ambiente de trabalho (adesão voluntária)". Tanto sindicatos como bancos podem fazer a adesão voluntária a tal protocolo que em síntese viabiliza um Acordo Coletivo aditivo à CCT, pelo qual os sindicatos recebem as denúncias de assédio moral e após realizarem apuração nos locais de trabalho repassam-nas aos canais formalizados nas instituições financeiras que também vão apurar e dar retorno às entidades de classe. O nome dos denunciantes é mantido sob sigilo e as instituições tem o prazo de 45 dias para dar retorno.

A cláusula do assédio moral é considerada uma conquista por grande parte dos sindicatos que fizeram a adesão voluntária ao Acordo Aditivo, sobretudo por ser vista como um importante instrumento para a prevenção da prática à medida que dá visibilidade ao problema colocando-o em debate permanentemente e fomentando a insubordinação dos trabalhadores para que não aceitem as formas de violência organizacional. O canal para recebimento de denúncias ${ }^{167}$ proporcionou uma sistematização de dados e informações que apontam a intensidade do problema de

\footnotetext{
${ }^{166}$ Conforme pesquisa em materiais sindicais: Folha Bancária (diversas edições) e material de campanha "Menos metas mais saúde" (SEEB, 2012).

${ }^{167}$ Explicamos que além dos Sindicatos poderem fazer seu controle estatístico, a própria FENABAN possui os dados consolidados para o setor. Na ocasião do balanço semestral do Acordo entre as partes envolvidas, os dados são apresentados.
} 
acordo com o banco e locais mais vulneráveis, os quais acabam reforçando a tese dos sindicalistas sobre as principais causas geradoras do assédio serem institucionais/organizacionais.

Tem havido por parte das entidades de classe uma busca incessante em melhorar os termos do Acordo, ${ }^{168}$ que trata do combate ao assédio moral, principalmente no tocante ao tempo de apuração e solução de problemas existentes.

Do ponto de vista das causas geradoras do adoecimento, é impossível não associá-las ao processo de trabalho. Os bancários, quando se referem à rotina a que são submetidos, deixam claro nas entrevistas que o problema não é ter metas, mas sim ter metas inalcançáveis, advertindo que alguns indicadores crescem à revelia do que havia sido planejado no curtíssimo prazo, ou seja, no curso de um mês para outro a meta pode ser redefinida para maior.

Soma-se a estas circunstâncias a possibilidade de baixa aceitação dos clientes e de uma conjuntura econômica desfavorável. Tudo isso, quando levado às últimas consequências, quando relacionado à permanência ou não no emprego, altera as relações sociais e deteriora a experiência no trabalho vivida na corporação, sobretudo para o indivíduo mais vulnerável nessa relação tensa e ameaçadora.

Os sindicatos de representação dos bancários são catalisadores destas demandas que envolvem a pressão no cotidiano bancário e vêm interagindo há vários anos sobre os aspectos negativos causados pela gestão por resultados, em especial combatendo as "metas abusivas".

Pode-se em resumo dizer que esta atuação tem duas frentes de luta distintas: uma que questiona, denuncia e busca reorientar o modo como o trabalho está organizado e outra que visa articular o agrupamento de aliados nas mais diversas entidades, inclusive as de defesa do consumidor, sobretudo por considerar que os prejuízos deste modelo de gestão se expandem para todos.

As várias iniciativas que compõem o mosaico de lutas sindicais foram permeadas pela relação estabelecida entre condições de trabalho, saúde do trabalhador e atendimento aos clientes. As campanhas sindicais ${ }^{169}$ pela saúde do trabalhador visaram atacar as causas geradoras do adoecimento, como esteve expresso nos seguintes motes: “diminuição do ritmo de trabalho", "fim das metas abusivas" e "fim do assédio moral".

\footnotetext{
${ }^{168}$ Conforme matéria publicada no site da CONTRAF/CUT - Confederação Nacional dos Trabalhadores do Ramo Financeiro. Disponível em: http://www.contrafcut.org.br/noticias.asp?CodNoticia=42451

${ }^{169}$ Fontes, Macedo e Sanches (2013).
} 
Tem constado na pauta de reivindicações dos empregados a "regulamentação" das metas de trabalho. ${ }^{170}$ Trata-se de uma proposta que visa, em linhas gerais, possibilitar aos trabalhadores intervir nas decisões sobre o processo de trabalho, por exemplo, determinando as metas conjuntamente, controlando o volume de trabalhadores que atuam em determinada tarefa de forma que não haja sobrecarga, incluindo limites à cobrança, com metodologias que preservem a saúde física e mental dos participantes.

No setor bancário o "controle social da produção" ainda que frágil e discreto exercido pelas entidades de representação sindical conseguiu proibir as práticas de publicização de rankings e cobranças via celulares, via mensagem de texto e similares ${ }^{171}$ por parte dos gestores dos bancos. Fruto das campanhas, negociações e da ação sindical direta dos bancários, essas condutas que eram caracterizadas pelo "abuso" da gestão por resultados foram "regulamentadas" entre as partes.

A pressão para atingir resultados nas corporações bancárias não se limita ao território nacional. Em 2010, a United Networks International - UNI Finanças ${ }^{172}$ lançou uma campanha sobre a "Venta responsable de productos financieros". ${ }^{173}$ Seus protagonistas questionam as práticas operativas internas relacionando-as com a responsabilidade social das instituições financeiras.

El sector financiero desempeña um papel importante em la economia, que va mucho más allá de la estabilidad de las propias instituciones financieras. El sector es responsable de garantizar la existencia de mercados estables y de apoyar a la economia real [...] Las prácticas operativas internas de uma empresa deben ser propicias para esto y facultar a los empleados para actuar de um modo que respalde el desarrollo sostenible (UNI Finanzas Global Union, 2010, grifo nosso)

Em 2012, a campanha "Venda Responsável: de produtos e serviços financeiros", que se espelhou na campanha da UNI Finanças, foi lançada no Brasil pelo Sindicato dos Bancários de SP em parceria com o Instituto Brasileiro de Defesa do Consumidor IDEC. Uma cartilha foi desenvolvida para explicar os direitos dos consumidores e dos trabalhadores. Reproduzimos a seguir um trecho do texto de abertura:

\footnotetext{
${ }^{170}$ De acordo com a Folha Bancária de 28 mar. 13

${ }^{171}$ A CCT possui uma cláusula denominada "monitoramento de Resultados", que proíbe os bancos monitorar resultados expondo os trabalhadores por meio de ranking individual. Também veda a cobrança de cumprimento de resultados por mensagens de texto no celular particular do trabalhador.

${ }^{172}$ A UNI Finanças é sediada em Nyon - Suiça. A entidade integra a UNI, que é uma rede global de sindicatos do setor de serviços com 900 entidades filiadas em 150 países.

173 Carta modelo sobre La venta responsable de prodcutos financieros. Disponível em: http://www.uniglobalunion.org/es/sectors/finance. Acesso em: abr. 2012.
} 
No Brasil, consumidores e trabalhadores bancários vivenciam dois lados de um mesmo problema. Por um deles, os bancos estabelecem metas abusivas de venda de serviços financeiros aos seus funcionários. Pelo outro, levam parte dos consumidores a adquirir produtos que não são necessários ou apropriados ao seu perfil. $\mathrm{O}$ resultado - fruto da forma de gestão dos bancos - não poderia ser outro: muitas reclamações de consumidores e bancários adoecidos em função da pressão pela venda desses produtos (SEEB-SP e IDEC, 2012, grifo nosso)

Como é possível notar, a campanha toca na principal causa geradora de problemas, qual seja: a forma de gestão dos bancos. A campanha coloca em evidência o mal-estar entre a obrigação de cumprir metas elevadas de vendas quando ao mesmo tempo as instituições buscam disseminar a sua "responsabilidade social". O sindicato denuncia que as fortes pressões, a redução do quadro de funcionários e as más condições de trabalho induzem ao erro sendo que os clientes precisam receber atenção suficiente para conhecer e adquirir um produto financeiro que deve envolver suas reais necessidades e considerar o próprio risco de endividamento.

No material da campanha "Menos Metas Mais Saúde", realizada em 2012, consta a seguinte lista de propostas sindicais: as metas devem ser estabelecidas coletivamente e os mecanismos de acompanhamento devem ser definidos com a participação direta e ativa dos envolvidos e dos sindicatos; proibição da competição entre trabalhadores; não tornar a avaliação pública, assim como não pode haver rankings e outras formas de cobrança por meios eletrônicos.

De acordo com o Sindicato dos Bancários de SP, a pressão por resultados é ainda responsável pela onda de demissões por "justa causa" que vem acontecendo em um dos maiores bancos privados brasileiros (Folha Bancária, jul. 2015). A “justa causa” tem sido aplicada em circunstâncias que o trabalhador foge às regras internas e ao Código de Ética.

Cohn, Fehr e Maréchal (2014), economistas na Universidade de Zurich, realizaram a pesquisa intitulada "Business culture and dishonesty in the banking industry”. Os resultados apontaram que os funcionários dos bancos não são mais desonestos do que os trabalhadores de outras empresas. Entretanto, concluíram que a cultura empresarial no setor, implicitamente, favorece comportamentos desonestos, o que tem contribuído para manchar a imagem dos bancos.

A pesquisa nos dá mais um indício de que questões similares estão sendo questionadas em nível internacional, sendo difícil desconsiderar que há um problema 
colocado não apenas para os trabalhadores, mas para a toda a sociedade quando as pressões competitivas contemporâneas sinalizam chegar a um grau insustentável.

Assim, no seio deste debate acerca das interações que envolvem condições de trabalho, saúde do trabalhador e atendimento aos clientes, há outro ponto que os interliga: a qualidade nos serviços prestados.

Metas elevadas podem implicar em queda de qualidade do atendimento aos clientes, sobretudo aqueles com menor grau de instrução e mais vulneráveis, levando-os ao agravamento dos seus problemas financeiros, sobretudo por comprarem produtos e serviços inadequados para o seu perfil. Segundo os trabalhadores entrevistados, os clientes com idade mais avançada são os principais alvos das vendas.

Os indicadores sobre a qualidade dos produtos e serviços prestados tornaram-se relevantes do ponto de vista da gestão. As empresas podem obter um lucro elevado no curto prazo lançando mão de práticas “indesejáveis”, contudo, se há um alto nível de reclamações dos clientes podem ser sinalizados prejuízos ao próprio negócio no médio ou longo prazo.

Os órgãos de defesa do consumidor como PROCON e IDEC sistematizam reclamações listando as principais empresas envolvidas. Os bancos estiveram entre os primeiros reclamados durante a última década. ${ }^{174}$ Constam como relevantes as reclamações, por exemplo, de débitos não autorizados na conta corrente relativos a serviços não contratados ou solicitados pelos clientes.

Além dos problemas com as vendas de produtos e serviços, vamos ilustrar a partir da narrativa de um entrevistado como a cobrança por metas no processo de trabalho pode interferir na qualidade de atendimento fornecido remotamente, via telefone. Uma das metas para este tipo de atividade realizada nos bancos é o TMA - Tempo Médio de Atendimento, que se refere ao respeito ao tempo estabelecido para atender um cliente, caso o trabalhador o ultrapasse o período delimitado pelo Bancos, a meta não é cumprida.

$\mathrm{O}$ trabalhador explica que na maior parte das vezes, quando os clientes entram em contato, é porque não conseguiram resolver algum problema nos demais canais disponíveis, o que, consequentemente, resulta em questões mais complexas, e, portanto necessitam de mais tempo para poderem ser esclarecidas e o cliente se sentir satisfeito.

\footnotetext{
${ }^{174}$ Fonte: Cadastro de reclamações fundamentadas - 2013 Fundação PROCON - SP; Dados, Rankings e Comentários Diretoria de Atendimento e Orientação ao Consumidor Procon - SP, março de 2014; Cartilha "Venda responsável: de produtos e serviços financeiros", Sindicato dos Bancários de SP e IDEC, 2012 e matérias publicadas em veículos da grande imprensa: "Setor financeiro é líder de reclamações nos Procons em 2012”. Disponível em: http://www.valor.com.br/brasil/2972276/setor-financeiro-e-lider-dereclamacoes-nos-procons-em-2012\#ixzz2RI4jZVSB. Acesso em: jul. 2014.
} 
Mas, ainda de acordo com o trabalhador entrevistado, "muitos lá [refere-se aos operadores de teleatendimento] derrubam a ligação de propósito para não estourar o tempo e o cliente é obrigado a ligar novamente" (bancário, operador de teleatendimento). Esse é um exemplo singular de como a gestão por resultados é complexa e pode ser até desastrosa.

Falamos, portanto, de um modo de trabalho que desafia a saúde física e mental das trabalhadoras e dos trabalhadores por toda a carga da pressão exercida, seja ela dada pelo mercado financeiro, controles informatizados, gestores, colegas, clientes ou pela própria ameaça de perder o emprego quando se coloca em risco os compromissos assumidos com a família e a necessidade de sobrevivência.

Podemos associar a gestão por resultados aos efeitos colaterais sentidos pelos trabalhadores, mas entendemos que tais efeitos não se restringem apenas a esses. Como vimos, o modelo que serve à lógica do curto prazo pode forjar relações sociais e econômicas deterioradas que extrapolam o ambiente estudado e atingem diretamente os clientes.

As corporações buscam a todo o momento reforçar valores orientados para o bem comum, relacionados à perspectiva de atuar na construção de um mundo melhor. Buscam, ainda, consolidar uma visão encantadora e adocicada sobre a experiência de trabalho em seu interior, como foi possível observar em nossa análise. Isso se faz como objeto de "marketing social" ou "falsas promessas aos trabalhadores". Deste modo, é altamente pertinente compreender, questionar e ainda propor novos métodos de atuação sob aspectos que permeiam a vida coletiva dentro e fora das empresas, superando os limites estreitos dos interesses particulares de altos executivos e acionistas. 


\section{Considerações finais}

Visamos no texto discorrido aprofundar a análise sobre o processo produtivo e as relações entre os agentes, situando os relatos que dispúnhamos, confrontando-os com as narrativas que vieram das mais diversas bases, ou seja, literatura sobre o setor, documentos produzidos por um grande banco privado nacional, materiais de consultorias de $\mathrm{RH}$, resultados de pesquisas secundárias sobre os temas tratados e a análise sobre o ambiente pesquisado. Nesta trajetória reunimos os elementos que mais poderiam nos ajudar nesta investigação sobre "como" se estabelece o processo de trabalho bancário, inclusive não deixando de perceber as ambiguidades que essa experiência complexa enseja no campo subjetivo.

Seria para nós possível descrever extensivamente os problemas relacionados ao cotidiano de trabalho, mas percebemos que outros trabalhos acadêmicos já contemplaram essa abordagem de algum modo. Assim, apesar de não ter como escapar em parte a esta tarefa, pois tais problemas emergem na pesquisa e são estruturantes para compreensão da realidade dos trabalhadores, buscamos olhar com maior profundidade para os meandros do processo de trabalho relacionando micro e macro espaço destacando outras singularidades.

No detalhamento das estratégias miúdas, postas no cotidiano do trabalho, se revela como as molas propulsoras da engrenagem produção de serviços bancários se movimentam para atender às prioridades dos interesses particulares de grupos estreitamente definidos, quais sejam: os administradores do capital e acionistas. Enquanto, os trabalhadores, clientes e sociedade de forma mais geral se submetem à dinâmica por eles e para eles orientadas.

Nessa incursão, elegemos como fio condutor de nossa análise a lógica cultural do curto prazo aplicada aos processos de trabalho. A partir desse pressuposto foi possível verificar em quais bases se estabelecem as interações sociais entre diversos atores envolvidos e quais seus significados.

Os representantes do "capital impaciente", como se refere Sennett (2011), ao se transformarem em acionistas das empresas, estabeleceram uma expectativa de retorno que fosse suficientemente interessante para não apostar recursos em outros investimentos financeiros ou "papéis" mais rentáveis. A partir deste nível de comparação e competição intercapitalista se estabeleceu um determinado padrão de produtividade no interior das grandes corporações. 
Há uma estreita relação entre aspectos economicamente orientados e as práticas culturais, sociais e políticas vivenciadas no cotidiano de uma grande corporação bancária. As pressões por rentabilidades elevadas e o retorno aos acionistas no curto prazo vão se refletir no modelo de gestão e organização do trabalho que melhor atende a estes propósitos. Como salientaram Dias e Zilbovícius (2006), as "boas práticas de governança corporativa" valorizadas nos procedimentos internos da grande empresa são reflexo das "boas práticas" adotadas no mercado financeiro - liquidez, volatilidade e flexibilidade.

A análise microssociológica nos dá a possibilidade de observar como os acontecimentos localmente situados estão sincronizados com os movimentos globalizados do capitalismo hegemonizado pelas finanças. Mas, para além de compreender essa dinâmica, o que mais pode nos contar a experiência local? O que pode nos contar as pessoas que vivenciam tais experiências no setor bancário? Considerando que o agente é portador de sentido, o que orienta suas ações em contextos adversos e competitivos no interior das grandes corporações bancárias?

Para captar como as relações entre os agentes se constroem, ou se destroem neste cenário, buscamos nos aprofundar escolhendo uma empresa que é referência e símbolo econômico de seu tempo no setor pesquisado, o Banco $\Delta$. A atuação em rede, o valor da marca e a presença difusa na sociedade, cristalizada em projetos sociais por ela empreendidos, são formas de contar sobre sua influência e, consequentemente, sobre seu poder.

O poder da grande corporação bancária influencia não apenas os trabalhadores e clientes, ele perpassa por vários níveis simbólicos interagindo com toda a sociedade. Por ser referência, acaba ditando modelos de gestão e organização no trabalho, ao mesmo tempo em que dissipa valores de convivência por ela eleitos. As consultorias de RH, nesse sentido, e as publicações especializadas em carreira e negócios reforçam esse ambiente cultural que se articula com um nível mais amplo de funcionamento do próprio modelo político-econômico predominante.

A pesquisa demonstrou que as estratégias de negócios do setor bancário obedeceram a ajustes de estrutura que viabilizaram um novo patamar de competição intercapitalista. Os pilares desta reestruturação se fundaram: a) nas fusões e privatizações que permitiram maior concentração de capitais; b) atuação em rede que viabilizaram novas alavancagens no negócio; c) na reorganização do processo de trabalho, baseada na terceirização e nas mudanças administrativas que buscaram novas 
formas de racionalizar a ação dos trabalhadores nesses ambientes; d) nas inovações tecnológicas que foram fundamentais para alicerçar todas essas transformações.

As terceirizações apresentaram tendência de crescimento intermitente ao longo das últimas décadas e em especial a partir dos anos 2000 com o modelo dos Correspondentes Bancários. O resultado deste processo foi uma nova divisão do trabalho no setor que possibilitou com que os custos antes fixos se tornassem flexíveis, haja vista os contratos com as empresas prestadoras de serviço se firmarem por temporalidades definidas e de acordo com a demanda. Verificou-se, por consequência, que a terceirização, além de precarizar as relações de trabalho, fragmenta ainda mais a organização dos trabalhadores, criando novas segmentações entre si que dificultam uma identificação comum baseada na categoria profissional, fortalecendo aspectos discriminatórios no ambiente de trabalho.

Os processos de terceirização envolvem, principalmente, as funções que se encontram na base da pirâmide hierárquica dos bancos, basicamente composta por tarefas mais simplificadas. As comparações trazidas à tona apontaram o aumento das jornadas de trabalho e perdas na composição da remuneração e também nos demais direitos dos trabalhadores que se fragmentaram em categorias profissionais distintas.

Determinadas tarefas com maior requisito técnico envolvido, caso exemplar dos profissionais vinculados às TIs, também se apresentam fortemente terceirizadas. Contudo, para esses casos há variações nas modalidades de contratação que buscam disfarçar o assalariamento e a subordinação com a empresa principal. Pela análise empreendida por nós, há controvérsias sobre o fato de esses segmentos obterem uma condição mais vantajosa que aqueles que executam tarefas mais simplificadas, pois com o passar do tempo as condições negativas no tocante aos aspectos econômicos, políticos e sociais prevalecem.

As possibilidades criadas com os avanços derivados das tecnologias da informação e telecomunicações são centrais para compreender os acontecimentos recentes no setor. Foi por meio delas que o tempo e espaço puderam ser comprimidos e as operações bancárias tornaram-se possíveis de serem realizadas no sistema "24 horas por 7 dias da semana", interferindo diretamente no processo de trabalho e na interação com os clientes.

Desse rearranjo na forma de atuar no mercado, o Banco $\Delta$ modificou a composição dos cargos existentes, sendo alguns eliminados totalmente e outros em fase de extinção, como Escriturários, Tesoureiros e Chefe de Serviço. Paralelamente, novas 
ocupações ganharam espaço como é o caso dos Gerentes de Contas, Assistentes de Gerência, Operadores de Teleatendimento, Atendentes de Caixa Eletrônico e Analistas de Processos.

Ainda que tenha havido alterações na pirâmide de cargos e salários do Banco $\Delta$ combinado a estratégias organizacionais que primaram pela horizontalização do ambiente corporativo, as relações internas são pautadas pelo respeito à hierarquia funcional. As mudanças de nomenclatura e a própria disposição dos gestores - antigos chefes -, que passaram a se sentar na mesma bancada de trabalho que seus subordinados, não são suficientes para comprovar que a atuação dos trabalhadores é marcada por mais autonomia como pressupõem alguns analistas das novas formas de gestão pós-fordistas.

O modelo de gestão organizacional em vigor admite um caráter híbrido, por adotar traços tayloristas-fordistas e também do modelo toyotista ou flexível. Encontramos no Banco $\Delta$ formas renovadas e mais sofisticadas de aumentar a produtividade dos trabalhadores. A forte relação entre inovações tecnológicas e ampliação dos controles de tempo e produção é um elemento-chave para apontar a continuidade do padrão taylorista-fordista em novas bases, aspectos esses que se somam à permanência de um trabalho prescrito para a maior parte dos trabalhadores.

O processo de trabalho se adaptou no sentido de tornar os custos relacionados à produção cada vez mais maleáveis de forma que, a exemplo da flexibilidade e volatilidade de movimentação dos "capitais impacientes", fossem removidas as travas políticas e sociais que poderiam colocar limites indesejáveis aos resultados econômicos esperados.

A flexibilização tem sido considerada um dos elementos centrais do paradigma de produção que emergiu nos anos 1990 no Brasil. Observando os processos de trabalho nos bancos, verificamos que a flexibilidade está presente de diversas formas. Desde os locais onde o trabalho é executado, passando pela distribuição da jornada de trabalho, composição da remuneração e até mesmo por ter se tornado uma característica comportamental requerida dos trabalhadores.

Houve uma diversificação dos locais onde podem ser executadas as atividades bancárias. É o que se pode verificar nas práticas predominantes de terceirização que, ao subcontratar e externalizar parte das atividades que compunham a rotina de uma instituição, pulverizam os locais de trabalho. A flexibilidade do local físico da produção também envolve o trabalho remoto, não presencial, realizado à distância do cliente. A 
modalidade, que já se manifestava no trabalho das centrais de teleatendimento, tem crescido nos últimos anos e recentemente passou a contar com as "agências digitais". Soma-se ainda a essas experiências o home office. Em fase de testes em algumas das organizações do sistema bancário brasileiro, aponta para uma nova estratégia na busca de maior produtividade e redução de custos fixos atrelados ao posto tradicional, situado dentro do espaço físico do empregador.

A percepção dos trabalhadores revela que a maior conexão estabelecida a partir dos meios informatizados levou à intensificação do ritmo de trabalho, pois novas etapas e tarefas foram agregadas ao fazer diário, acompanhando a velocidade pela qual as informações podem circular nos meios disponíveis. Smartphones, notebooks, e-mails, comunicadores instantâneos e principalmente os softwares "intuitivos" agilizaram as conexões no ambiente de trabalho reduzindo o intervalo entre uma tarefa e outra, impondo-se simultaneidade às atividades antes realizadas em compassos distintos.

O uso dos novos dispositivos tecnológicos não implicou necessariamente em um trabalho mais complexo ou que para exercê-lo fosse exigida mais qualificação dos trabalhadores, sendo que em determinadas funções as tarefas até foram simplificadas. A reorganização de funções e cargos na composição do quadro de funcionários aponta para a tendência de redução daqueles que executam tarefas mais simplificadas. As exigências de outros requisitos técnicos para atuar na profissão como são as certificações CPA 10 e 20 fortalecem a ideia de que as funções predominantes no futuro se tornarão mais especializadas, voltadas para aquilo que os executivos do setor chamam de consultoria financeira.

Ainda relevante é destacar o papel atribuído às novas tecnologias no tocante à organização do trabalho no interior da grande corporação. Por meio dos softwares foi possível evitar o retrabalho, agilizar, atribuir, distribuir e controlar tarefas com maior precisão. O tempo nessas circunstancias pode ser verificado em fração de segundos. Relatórios minuciosos explicitam o nível de produtividade em tempo real. Desse modo, o fluxo de produção das rotinas que se estabelecem na burocracia bancária pode ser monitorado a distância e a qualquer tempo.

Com essa sofisticação nos controles possibilitada pelas TIs, o papel dos gestores foi redimensionado. Os softwares acabam por cumprir boa parte de suas antigas atribuições chegando inclusive a monitorar o treinamento e a leitura de conteúdos normativos da instituição. 
Os gestores ainda exercem um papel coercitivo e tem em suas mãos o maior peso no processo de avaliação de desempenho dos trabalhadores. Eles dividem entre essas atribuições a função de incentivar suas equipes de subordinados a cumprir as metas estabelecidas.

Observamos que existem outras formas de controle vivenciadas pelos trabalhadores, como aquele exercido pelos próprios colegas de trabalho, pelos clientes e, até mesmo, pelos acionistas.

À medida que as metas por equipe são exigidas, a ausência ou resultado insuficiente de alguém pode determinar o não cumprimento das metas de produção, levando o próprio grupo a sinalizar o descontentamento com o trabalhador ausente ou menos produtivo. Os clientes também podem avaliar e reclamar do atendimento recebido dos trabalhadores, haja vista a facilidade de canais para tal finalidade e estímulo dado pelas organizações.

Os acionistas, por sua vez, exercem um controle difuso. Ao monitorar de longe os acontecimentos na empresa do qual são cotistas, exigem a adoção das práticas de "boa" governança corporativa que ensejam a transparência dos atos administrativos e financeiros das empresas publicizados em períodos trimestrais, semestrais e anuais.

A ação disciplinar no $\operatorname{Banco} \Delta$ está calcada no controle do tempo e no cumprimento de metas de trabalho. Os manuais, as circulares internas e mais recentemente os Códigos de Ética prescrevem a rotina da atividade a ser realizada demonstrando o caráter circunscrito do trabalho bancário, submetido a rígidas burocracias e controles internos e externos. Os trabalhadores neste universo precisam dar vista a todas as normas, inclusive confirmando a leitura por meio de sua assinatura eletrônica e posteriormente respondendo a testes aplicados pelo banco sobre os conteúdos abordados.

Há ainda outros modos de disciplinar os trabalhadores na grande corporação analisada. Por meio de todas as formas de comunicação disponíveis - portal de informações, TVs corporativas, banners, revistas impressas -, são repassadas orientações sobre comportamento dentro da organização abrangendo valores, condutas pessoais e até modo de se vestir, além de normas de segurança, dicas para a execução do trabalho e incentivo moral para cumprimento de metas.

$\mathrm{O}$ medo de ficar à deriva exerce forte influência sobre a disciplina dos trabalhadores. A falta de estabilidade no emprego na iniciativa privada coloca para os participantes, submetidos a processos de monitoramento de produtividade mais 
sofisticados e realizados em ciclos menores, maior apreensão consolidando a percepção de incerteza e a noção de viver sob risco constante.

Diante dos mecanismos de controle e disciplina descritos e ainda pelos relatos dos trabalhadores foram evidenciados os limites de um processo de trabalho que tem, de acordo com a perspectiva dos novos modelos de gestão pós-fordistas, características mais acentuadas relacionadas à autonomia e criatividade. As prescrições e normatizações são elementos fundamentais para questionar uma visão superficial sobre tais processos. Além disso, é forçoso relativizar determinadas iniciativas internas que conduzem à participação dos trabalhadores, sobretudo, quando estes são obrigados a dar ideias que contam em sua avaliação de desempenho podendo levar inclusive a punições caso não sejam ofertadas possibilidades de melhorar o processo de trabalho.

A transmissão de ideias é na verdade a apropriação de conhecimento tático e atualizado sobre os procedimentos que passam a ser socializados e reavaliados permanentemente com o objetivo de maximizar a produtividade, tanto é assim que propostas que envolvam, por exemplo, mais contratação de funcionários não têm passagem, pois trazem maiores custos e não propõem melhorar o trabalho com os recursos existentes. Pesa ainda o fato de que qualquer ideia apresentada pelos trabalhadores é submetida a mais de uma instância de decisão.

Outros elementos que permeiam os processos de trabalho no Banco $\Delta$ corroboram com uma política de atuação mais ágil e flexível espelhada na dinâmica dos próprios mercados financeiros, ou, em outros termos, pós-fordistas. Citamos por exemplo: as jornadas flexíveis de trabalho; a multifuncionalidade das ocupações; as carreiras de curto prazo na mesma empresa; os programas de gestão orientados pelos resultados e os ciclos voláteis de avaliação.

A jornada de trabalho flexível está articulada aos novos modos de atuação do setor bancário. O horário flexível permite rearranjar a jornada de trabalho quando o volume de tarefas é maior, implicando em um ajuste sazonal dos tempos e necessidades do empregador. As instituições, ao ampliarem os horários de atendimento aos clientes, sobretudo, por meio da criação de canais remotos, fizeram diversos trabalhadores passarem a contar com alterações na jornada de trabalho. Tais mudanças atingiram inclusive a jornada semanal de trabalho, tradicionalmente aplicada de segunda à sexta. Os dias e horários deixaram de ser rígidos. Passaram a acompanhar as tendências de mercado diversificando os horários de atendimento ao público à noite, madrugada, finais de semana e feriados. 
A multifuncionalidade no Banco $\Delta$ existe, mas é pouco difundida. As situações em que se verificou que um mesmo trabalhador tem conhecimento e autorização para executar diferentes tarefas que são atribuídas a outros cargos foram bem reduzidas. Prevalece neste ambiente a atribuição de tarefas por cargo.

A perspectiva de construir uma carreira de longo prazo na mesma empresa tem sido desconstruída pelas consultorias de $\mathrm{RH}$ e pela própria empresa pesquisada. $\mathrm{O}$ Banco $\Delta$ declarou no seu relatório gerencial em 2012 que sua rotatividade anual havia atingido a margem dos 16\%. A instituição enfatiza a meritocracia para justificar premiações e punições endossando a lógica cultural de curto prazo ao apostar em carreiras igualmente mais curtas, calcadas em esforços concentrados para atingir resultados elevados em menor espaço de tempo.

Apesar de as perspectivas apontarem para as carreiras de curto prazo, os jovens têm manifestado que tem apreço pela estabilidade. Os entrevistados conservam a expectativa de se manterem na instituição pesquisada alegando o objetivo de constituir reservas e garantias financeiras para poder no futuro se distanciar das formas de subordinação e pressão a que são expostos. Os relatos nos levaram a questionar a noção de que os jovens da nova geração são mais propensos ao risco e tem aversão de empregos nos moldes tradicionais fordistas, ficando claro que a condição econômica, política e social de cada indivíduo é o que coloca sob cada situação uma determinada escolha e percepção. Em geral, ao analisarem a possibilidade de atuar em uma grande corporação, diante dos prós e contras, a preferência tem sido pela permanência ainda que fossem verbalizados diversos problemas no ambiente.

A flexibilização das remunerações é outro aspecto central do novo paradigma de gestão e organização do trabalho. Desde a década de 1990, no setor bancário, a remuneração fixxa perdeu espaço para a variável. As políticas de RH vincularam os pagamentos feitos a título de remuneração variável ao cumprimento dos programas de metas. Contudo, pela experiência analisada no $\operatorname{Banco} \Delta$, com o passar dos anos os programas de metas espalharam-se por todas as áreas e atingiram praticamente todos os cargos dentro das instituições sem que necessariamente houvesse acréscimo de renda variável, servindo, portanto, como um meio efetivo de gerir o processo de trabalho.

Os programas de gestão por resultados, também conhecidos genericamente por programas de metas ou ainda por programas de remuneração variável, são a expressão mais acabada da lógica do curto prazo no ambiente corporativo bancário. Eles são a espinha dorsal do sistema meritocrático que desconsidera a valorização profissional por 
tempo de experiência. Nesses moldes é o resultado do indivíduo no curto prazo o que interessa, desprezando seu histórico de médio e longo prazo.

O processo de avaliação formal, nesse âmbito, foi um instrumento relevante para auxiliar a gestão da força de trabalho. A objetividade na busca de resultados esteve presente na rotina dos bancários que tiveram que se submeter a controles de tempo até mesmo em situações em que existia a interação direta com o cliente. Outro aspecto que nos chamou a atenção é que o comportamento, um indicador subjetivo, se tornou quantificável numericamente. Pelo sistema de avaliação é possível pontuar o nível de aderência do trabalhador com relação aos princípios da instituição.

Nesse ambiente de superação constante vivido pelos trabalhadores, com premiações para poucos e punições para os menos produtivos, sabe-se que os resultados de ontem não valem para hoje. Sob essas condições, o individualismo prevalece e se torna ao mesmo tempo um empecilho à colaboração entre os agentes no processo de trabalho, ou seja, tendem a minar o trabalho em equipe tão almejado pelos administradores.

A "cultura corporativa" se reflete na construção do universo simbólico que permeia as organizações e dá sustentação ao modo de trabalho que está associado à flexibilidade, agilidade e volatilidade. Nesse escopo é relevante o papel da "educação corporativa" na disseminação de valores que servem a esta causa, afinal os treinamentos não envolvem apenas formação técnica, mas destinam muita atenção ao comportamento.

As consultorias de RH e grandes corporações convidam o trabalhador a participar de uma experiência que reúne em torno de si adjetivos que remetem a um ambiente em que predomina a autonomia, criatividade, participação, flexibilidade e, sobretudo, o envolvimento em uma causa maior que extrapola os limites estabelecidos em uma jornada de trabalho ou em um contrato entre patrão e empregado.

O trabalhador é convidado a ser um "colaborador". Subjetivamente se constrói a noção de colaboração de classes, de parceria, como se houvesse simetria na relação entre tais agentes. Um elo maior busca unificar os distintos interesses e posições sociais. A grande corporação apresenta para a sociedade seu empenho para transformar o mundo em um lugar melhor, mais humanitário, que não se restrinja apenas aos seus interesses mesquinhos de lucro e rentabilidade.

Os trabalhadores manifestaram uma percepção ambivalente sobre as relações que permeiam o processo de trabalho na grande corporação bancária. Os relatos 
trouxeram à tona experiências heterogêneas que não possuíam, em sua maioria, uma narrativa que fosse "coerente" em si. Apontaram uma realidade contraditória.

Considerando que uma ação não é necessariamente orientada só por interesses econômicos, mas também pode ser carregada de um sentido maior para quem o faz, analisamos que os bancários trabalham imbuídos de uma racionalidade econômica movida pelos fins de sobrevivência e paralelamente encontram outros sentidos, explicações e razões que se constituem como cimento social que serve de base para desejaram sua permanência nas grandes corporações.

Em linhas gerais, os trabalhadores vivenciam a "cultura corporativa" adaptandose a ela, cientes das regras do jogo social entre capital e trabalho, assim como de suas punições e recompensas. Participam e interagem com a organização estabelecendo a todo o momento um cálculo de "custo-benefício" nesta relação colocada.

Assim, a experiência de trabalhar em uma grande corporação bancária é permeada de ambiguidades. Por um lado, os trabalhadores narram o aumento do ritmo de trabalho, as diversas formas de controle e pressões a que estão submetidos, além dos reflexos negativos à saúde que observam em decorrência deste processo. Por outro, trazem à tona elementos que valorizam e redimensionam sua passagem pela instituição à medida que sentem realização pessoal e ainda reconhecem haver reciprocidade, sobretudo na relação estabelecida com os clientes.

Admitir que seu trabalho, subjugado, pouco criativo e extremamente controlado, lhe traga realização pessoal e ainda confere posição de status social, é algo que não poderíamos deixar de trazer à tona. A literatura sobre o tema, consultada por nós, não capta este viés. Entendemos que são possíveis novas abordagens e verificações que envolvam a subjetividade dos agentes no sentido de aprofundar essas percepções e dimensioná-las.

O trabalho bancário, pelo que observamos, é ainda considerado uma atividade profissional que confere status social aos trabalhadores. Sendo a noção de status uma percepção socialmente construída, só é possível admitir certo prestígio atribuído a alguém a partir de uma relação social estabelecida. Assim, apesar da literatura consultada sobre o setor ter manifestado impressões diferentes sobre este aspecto, e, ainda que, esta posição também não tenha sido reconhecida à primeira vista pelos trabalhadores que participaram das entrevistas, é forçoso explicitar que todos foram unânimes em afirmar que a percepção de seus familiares e amigos em relação ao 
emprego que tinham na grande corporação bancária era fundamentada em orgulho e admiração.

As características que delineiam o perfil do trabalhador apto a atuar na grande corporação bancária passam pela sua formação escolar, técnica e principalmente pelo seu comportamento. As exigências em torno de níveis cada vez mais elevados de escolaridade são utilizadas como formas de refinar a triagem entre muitos candidatos e servem ao mesmo tempo para potencializar o efeito sobre os processos de trabalho. Contudo, observamos que os projetos que envolvem a "educação corporativa", treinamentos realizados no interior do $\operatorname{Banco} \Delta$, são ainda o principal meio para capacitar os trabalhadores para atuar nas rotinas estabelecidas, constituindo-se por excelência no lugar que o bancário é moldado e preparado para exercer seu ofício.

Nesse contexto onde os trabalhadores possuem alta escolaridade e atributos técnicos podem ser aprendidos internamente o principal diferencial se concentrou na importância atribuída às características comportamentais. Tornaram-se assim supervalorizadas, entre aqueles que circulam no universo corporativo, as seguintes características: flexibilidade, proatividade, capacidade de trabalhar em equipe e suportar pressão.

Há uma disjunção entre um determinado perfil comportamental generalizado pelas chamadas para o processo seletivo na grande corporação estudada e as situações de trabalho objetivamente dadas, marcadas pelo pragmatismo dos resultados.

O simbolismo dos anúncios, direcionados ao público jovem, evoca um ambiente pouco convencional, com possibilidades de ter uma atuação criativa, questionadora e transformadora. A chance de conseguir um emprego no Banco $\Delta$ é idealizada a partir da expectativa gerada pelas peças de marketing que envolvem as chamadas para preenchimento de vagas. Contudo, os selecionados para participar da experiência corporativa se deparam com o trabalho ainda fortemente prescrito, hierarquizado e burocratizado para a maior parte dos participantes.

Apesar de toda importância dada aos aspectos subjetivos e ao grau de adesão à cultura corporativa, observados nos processos de admissão e avaliação, o "bom bancário" na percepção dos trabalhadores entrevistados se define essencialmente pelo seu "bom" resultado objetivo. As atuações medianas em termos de produtividade, que tendem à queda, explicam a necessidade de trocas constantes e carreiras mais curtas, afinal, os acionistas não perdoam a ausência de valorização das suas ações. 
O modo pelo qual o processo de trabalho está estruturado leva ao adoecimento físico e mental dos trabalhadores. Com a ampliação dos números dos casos de transtornos mentais na categoria profissional bancária, representando $24 \%$ do total de afastamentos, pela primeira vez no ano de 2014, as lesões por esforços repetitivos, ainda elevadas, ficaram em segundo plano, representando 20\%. Esse resultado reflete as consequências de atuar sob um ritmo intenso e ainda de estar submetido às diversas formas de pressão, proporcionando um ambiente em que o assédio moral se torna uma prática comum.

O "sofrimento ético", em especial, passou a fazer parte do cotidiano dos trabalhadores quando a exigência por resultados, sobretudo relacionada a vendas de produtos e serviços, foi intensificada nas últimas décadas. O fundamento para essa afirmação se dá com base no fato recorrente dos trabalhadores terem que se confrontar com orientações veladas e práticas que os constrangem, passando a agir contra suas convicções e sua ética profissional para conseguir cumprir as metas de produtividade, atingindo diretamente a interação que mantêm com os clientes da instituição.

O sindicato de representação profissional dos trabalhadores tem criado formas de luta para combater os efeitos do modelo de gestão por resultados no curto prazo. Além disso, tem colocado no centro do debate a necessidade de intervir diretamente nas causas geradoras de um mal-estar que extrapola a experiência daqueles que atuam nos escritórios das grandes corporações bancárias.

As mudanças observadas no ambiente de trabalho resultaram em controles mais detalhados, intensificação do ritmo de trabalho, agravamento da subordinação e maior apropriação dos saberes dos trabalhadores. Concomitantemente a isso, forjou-se um sujeito marcado pela ação pragmática que pode colocar em xeque a sua própria ética profissional, pois é a sua performance mensurada em tempos reduzidos e orientada pelas regras da meritocracia que definirão se ele terá ou não o direito a ocupar a vaga de emprego na grande corporação, quando seu histórico de realizações passadas não tem valor algum.

Nesta interação política, econômica e social promovida em torno da grande corporação bancária, reunimos elementos para repensar os limites e brechas em torno do processo de trabalho, sobretudo quando há argumentos que apontam para a deterioração das relações sociais. Assim, não chamamos a atenção unicamente para questões de interesse restrito ao mundo do trabalho, falamos de um processo que também deteriora a 
qualidade do atendimento dos clientes e usuários dos serviços bancários em decorrência do vale-tudo para dar retorno aos acionistas. 


\section{Referências bibliográficas:}

ABECS. Anuário Brasileiro de Meios Eletrônicos de Pagamento 2009. São Paulo: ELAP, 2009.

ACCORSI, A. Automação: bancos e bancários. Dissertação (Mestrado em Administração). Departamento de Administração de Empresas da Universidade de São Paulo: São Paulo, 1990.

ALBUQUERQUE, L.G de.; OLIVEIRA, P.M. de. Competências ou cargos: uma análise das tendências das bases para o instrumental de recursos humanos. Caderno de Pesquisas em Administração, São Paulo, v. 08, nº 4, outubro/dezembro, 2001.

ALCADIPANI, R.; ALMEIDA, A. Organizações através de um estudo de caso sobre a implementação de um escritório aberto no Brasil. Organizações e sociedade. n. 19, set./dez., 2000.

ALCÂNTARA JÚNIOR, J. O conceito de sociabilidade em Georg Simmel. Ciências Humanas em Revista - São Luís, v. 3, n. 2, dez. 2005.

ALVES, D.A. de; OLIVERIA, S.R. de. Controle organizacional no processo capitalista de produção. In: PICCININI, V.C.; ALMEIDA, M.L.; OLIVEIRA, S.R. de. Sociologia e administração: relações sociais nas organizações. Rio de Janeiro: Elsevier, 2011.

ANDERSON, P. Balanço do neoliberalismo. In: SADER, E.; GENTILI.P. (Orgs.) Pósneoliberalismo: as políticas sociais e o Estado democrático. Rio de Janeiro: Paz e Terra, 1995.

ANGELO, I. Febraban: 40 anos de participação.São Paulo: DBA Artes Gráficas, 2007. ANTUNES, R. Os sentidos do trabalho: ensaio sobre a afirmação e a negação do trabalho. São Paulo: Boitempo, 2002.

O caracol e a sua concha: ensaios sobre a nova morfologia do trabalho. São Paulo: Boitempo, 2005.

ANTUNES, R.; BRAGA, R. (Orgs.) Infoproletários: degradação real do trabalho virtual. São Paulo: Boitempo, 2009.

APINFO. Pesquisa APinfo 2014. Disponível em: http://www.apinfo2.com/apinfo/informacao/p14sumario.cfm. Acesso em: out. 2015.

ARONI, F. Carreira: visão acadêmica e práticas do mercado de trabalho relatadas pela publicação Guia Você S/A Exame “As melhores empresas para você trabalhar”. Dissertação (Mestrado em Psicologia Social), USP, São Paulo, 2011.

BACEN. Relatório de Economia Bancária e Crédito, 2011. 
BARBOSA, L. Igualdade e meritocracia: a ética do desempenho nas sociedades modernas. Rio de Janeiro: Editora FGV, 2006.

BARBOSA, A.F. (Org.) Pesquisa sobre o uso das tecnologias da informação e comunicação no Brasil. São Paulo: Comitê Gestor da Internet no Brasil, 2014.

BARRETO, M.; HELOANI, R. Da violência moral no trabalho à rota das doenças e morte por suicídio In: Trabalho e saúde: a precarização do trabalho e a saúde do trabalhador no Século XXI. VIZZACCARO-AMARAL, A.L.; MOTA, D.P.; ALVES, G. (Orgs.) São Paulo: LTr, 2011.

BARRETO, M. Assédio moral: trabalho, doenças e morte In: Seminário Compreendendo o Assédio Moral no Ambiente de Trabalho: [anais] / coordenadoras: Cristiane Queiroz Barbeiro Lima, Juliana Andrade Oliveira, Maria Maeno. Ministério do Trabalho e Emprego/FUNDACENTRO. São Paulo: Fundacentro, 2013. Disponível em: http://www.fundacentro.gov.br. Acesso em: nov.2015.

BAUMAN, Z. Vida líquida. Rio de Janeiro: Jorge Zahar Ed., 2009.

BECKER, H. Métodos de pesquisa em ciências sociais. São Paulo: Hucitec, 1999.

BENOSSI, V.G. Atitudes de trainees frente às exigências das grandes corporações. Dissertação (Mestrado em Psicologia). Instituto de Psicologia, USP, São Paulo, 2010.

BLASS, L. Estamos em Greve! Imagens, gestos e palavras do movimento dos bancários. São Paulo: Hucitec; Sindicato dos Bancários de São Paulo, 1992.

BOLTANSKI, L.; CHIAPELLO, È. O novo espírito do capitalismo. São Paulo: Martins Fontes, 2009.

BORGES, L.O; VITULLO, G.E.; PONTE, J.R.T. DA. (Orgs.) Ser bancário: viver o esplendor social ou o trabalho precário? Curitiba: CRV, 2012.

BOURDIEU, P. Meditações pascalianas. Rio de Janeiro: Bertrand Brasil, 2001

BRAGA, R. A nostalgia do fordismo: modernização e crise na teoria da sociedade salarial. São Paulo: Xamã, 2003.

Uma sociologia da condição proletária contemporânea. Tempo Social. USP, v. 18, n. 1, pp. 133-152, 2006.

A vingança de Braverman: o infotaylorismo como contratempo In: ANTUNES,

R.; BRAGA, R. (Orgs.) Infoproletários: degradação real do trabalho virtual. São Paulo: Boitempo, 2009.

BRAVERMAN, H. Trabalho e capital monopolista: a degradação do trabalho no século XX. Rio de Janeiro: Editora Guanabara, 1987. 
BRESSER-PEREIRA, L.C. A crise financeira global e depois: um novo capitalismo? Novos estudos. CEBRAP, São Paulo, n. 86, pp. 51-72, mar. 2010.

Disponível em: <http://www.scielo.br/scielo.php?script=sci_arttext\&pid=S010133002010000100003\&lng=en\&nrm=iso>. Acesso em: jul. 2015.

CAMPELLO, J.C. Cargas de trabalho e evidências de seu impacto sobre a saúde de trabalhadores em bancos: estudo de caso em quatro instituições financeiras em Porto Alegre. Dissertação (Mestrado em Engenharia). Escola de Engenharia - UFRGS. Porto Alegre, 2004.

CANÊDO, L.B. O sindicalismo bancário em São Paulo. São Paulo: Símbolo, 1978. Bancários: movimento sindical e participação política. Campinas: Editora Unicamp, 1986.

CARNEIRO, R. Globalização e integração periférica. Texto para discussão. IE/UNICAMP n. 126, jul. 2007. Disponível em: www.eco.unicamp.br. Acesso em: nov. 2013.

CARNEIRO, R. Dinâmica e crise do capitalismo com dominância financeira. In: CARNEIRO, R.; MARCOLINO, L.C. (Orgs.) Sistema financeiro de desenvolvimento no Brasil: do Plano Real à crise financeira. São Paulo: Publisher/Atitude, 2010.

CARNEIRO, R.; MARCOLINO, L.C. (Orgs.) Sistema financeiro de desenvolvimento no Brasil: do Plano Real à crise financeira. São Paulo: Publisher/Atitude, 2010.

CASTELLS, M. A sociedade em rede. Rio de Janeiro: Paz e Terra, 2002.

A sociedade em rede: do Conhecimento à Política. Palestra proferida em Conferência promovida pela Presidência da República em Portugal em 4 e 5 de março de 2005. Disponível em: www.cies.iscte.pt. Acesso em: fev. 2014.

CASTILLO, J.J. O trabalho do conhecimento na sociedade da informação: a análise dos programadores de software. In: ANTUNES, R.; BRAGA, R. (Orgs.) Infoproletários: degradação real do trabalho virtual. São Paulo: Boitempo, 2009.

CHAVES, L.A. Trabalho, tecnologia e ação sindical. São Paulo: Annablume, 2005.

COHN, A.; FEHR, E.; MARÉCHAL, M. A. Cultura empresarial e desonestidade no setor bancário. 2014. Disponível em: http://www.nature.com/nature/journal/v516/n7529/full/nature13977.html. Acesso em: jul. 2015.

COLOMBI, A.P.F. Entre a fragmentação e a ação unificada: uma análise da atuação do Sindicato dos Bancários de São Paulo, Osasco e região durante os anos 2000. Dissertação (Mestrado em Economia). Campinas: UNICAMP, 2014. 
CORAL, E. Modelo de planejamento estratégico para a sustentabilidade empresarial. Tese (Doutorado em engenharia). UFSC-Programa de Pós-graduação em Engenharia de Produção, 2002.

COSSALTER, C.; VENCO, S. Centrais de atendimento nos bancos: uma comparação França e Brasil. In: BORGES, L.O; VITULLO, G.E.; PONTE, J.R.T. DA. (Orgs.) Ser bancário: Viver o esplendor social ou o trabalho precário? Curitiba: CRV, 2012.

CUT NACIONAL. Dossiê Terceirização e desenvolvimento: uma conta que não fecha. São Paulo, 2011.

DEJOURS, C. A banalização da injustiça social. Rio de Janeiro: Editora FGV, 2006.

DIAS, A.V.C.; ZILBOVICIUS, M. A produção face à financeirização: quais consequências para a organização da produção e do trabalho? Uma proposta de agenda de pesquisa para a Engenharia de Produção brasileira. XXVI ENEGEP - Fortaleza, CE, Brasil, 9 a 11 de out. de 2006 ENEGEP, 2006.

Trabalho e criação de valor: financeirização da produção e novas formas de organização do trabalho. In: MONDADORE, A.P. et al. (Orgs.) Sociologia econômica e das finanças: um projeto em construção. São Carlos: Edufscar, 2009.

DIEESE. Profissão Bancário: perfil da categoria. São Paulo: 1980.

Terceirização e reestruturação produtiva do setor bancário no Brasil. Estudos Setoriais. Espírito Santo, n. 2, 1994.

DIEESE; CONTRAF. Pesquisa de Emprego Bancário 2011. Disponível em www.contraf.cut.org.br. Acesso em: fev. 2014.

Pesquisa de Emprego Bancário 2013. Disponível em: www.contraf.cut.org.br.

Acesso em: fev. 2014.

DIEESE. Desempenho dos bancos. Rede bancários, 2014.

DONADONE, J.C. Lógica financeira e dinâmica organizacional nos anos 1990: novos donos, novos consultores, outros gerentes. In: MONDADORE, A.P et al. (Orgs.) Sociologia econômica e das finanças: um projeto em construção. São Carlos: Edufscar, 2009.

DRUCK, G. Terceirização: (Des)fordizando a fábrica - um estudo do complexo petroquímico. São Paulo: Boitempo/Edufba, 1999.

DUBAR, C. A construção de si pela atividade de trabalho: a socialização profissional. Caderno de Pesquisa. São Paulo. Vol. 42, n. 146, pp. 351-367, ago. 2012. Disponível em: http://www.scielo.br/scielo.php?script=sci_arttext\&pid=S010015742012000200003\&lng=en\&nrm=iso. Acesso em: jul. 2015. 
DULCI, L.B. Automação bancária no Brasil do século XXI: Febraban e Contraf-CUT. Dissertação (Mestrado em Sociologia). UFRJ - Programa de Pós Graduação em Sociologia e Antropologia, 2015.

DURAND, J.P. A refundação do trabalho no fluxo tensionado. Tempo Social. São Paulo: abril, 2003, pp.139-158.

DUTRA, J.S. A gestão de carreira In: FLEURY, M.T.L. (Org.) As pessoas na organização. São Paulo: Editora Gente, 2002.

EBOLI, M. Educação corporativa e desenvolvimento de competências. In: DUTRA, J.S.; FLEURY, M.T.L.; RUAS, R. (Orgs.) Competências: conceitos, métodos e experiências. São Paulo: Atlas, 2008.

FARIA, J.A.; PAULA, L.F.; MARINHO, A. Fusões e aquisições bancárias no Brasil: uma avaliação da eficiência técnica e de escala. (Texto para discussão, n. 1233). Rio de Janeiro: IPEA, nov., 2006.

FEBRABAN. Pesquisa FEBRABAN de tecnologia bancária 2014. Pesquisa FEBRABAN de tecnologia bancária 2013. Pesquisa FEBRABAN de tecnologia bancária 2012. Pesquisa FEBRABAN de tecnologia bancária 2011. Relatório Anual 2010. Relatório Anual 2011. . Relatório Anual 2014.

FERREIRA, M.A.G.R. A utilização de tecnologias self-service nos serviços bancários e o comportamento do consumidor final em Portugal. Dissertação (Mestrado em Marketing). Universidade do Porto, 2008.

FISCHER, A.L. Um resgate conceitual e histórico dos modelos de gestão de pessoas. In: As pessoas na organização. São Paulo: Editora Gente, 2002.

FISCHER, A.L.; FLEURY, M.T.L.; URBAN, T.P. Cultura e competência organizacional In: Dutra, J.S.; Fleury, M.T.L.; Ruas, R. (Orgs.) Competências: conceitos, métodos e experiências. São Paulo: Atlas, 2008.

FISCHER, A.L.; DUTRA, J.S.; AMORIM, W.A.C. (Orgs.) Gestão de Pessoas: desafios estratégicos da gestão contemporânea. São Paulo: Atlas, 2009.

FLEURY, M.T.L.; FISCHER, R.M. (Orgs.) Cultura e Poder nas Organizações. São Paulo: Atlas, 1989. 
FONTES, P.; MACEDO, F.; SANCHES, A.T. (Orgs.) 90 anos fortalecendo a democracia: Bancários de São Paulo-CUT (1923-2013). São Paulo: SEEB-SP/Editora Gráfica Atitude, 2013.

FORTUNA, E. Mercado Financeiro: produtos e serviços. Rio de Janeiro: Qualitymark, 2009.

FREITAS, M.C.P. O sistema bancário e o aparecimento da moeda eletrônica. Revista São Paulo em Perspectiva 12 (4): pp. 113-20, 1998.

FREITAS, M.C.P.; PRATES, D.M. Reestruturação do Sistema Financeiro Internacional e Países Periféricos. Revista de Economia Política, vol. 22, n. 2 (86), abr./jun., 2002.

FREITAS, M.E. Cultura organizacional: evolução e crítica. São Paulo: Thomson Learning, 2007.

FRIEDMANN, G. O trabalho em migalhas: especialização e lazeres. São Paulo: Perspectiva, 1972.

GAULEJAC, V. Gestão como doença social: ideologia, poder gerencialista e fragmentação social. São Paulo: Ideias e Letras, 2007.

GEHM, T.C. As transformações no sistema bancário e a hostilidade nas condições de trabalho: um olhar a partir do Banco do Brasil. Dissertação (Mestrado em Economia) UNICAMP. Instituto de Economia, 2013.

GONZALEZ, L. Crises Financeiras Recentes e Poupança Externa. Tese apresentada ao Curso de Pós-Graduação da FGV/EESP. Área de Concentração: Economia de Empresas, 2007.

GRINBLATT, M. e TITMAN, S. Mercados Financeiros: estratégia corporativa. Porto Alegre: Bookman, 2005.

GRISCI, C.L.I.; SCALCO, P.D.; KRUTER, G.E. Dilemas pessoais no trabalho imaterial bancário. Psicologia \& Sociedade, 23(3), pp. 564-573, 2011.

GRÜN, R. A produção de uma empresa moderna. Dissertação (Mestrado em Sociologia) PUC. São Paulo: 1985.

- Taylorismo e fordismo no trabalho bancário: agentes e cenários. Revista Brasileira de Ciências Sociais. São Paulo: v. 1, n. 2, out. 1986. Disponível em: http://www.anpocs.org.br/portal/publicacoes/rbcs_00_02/rbcs02_02.htm. Acesso em: jul. 2014.

A sociologia das finanças e a nova geografia do poder no Brasil. Revista Tempo Social. USP, v. 16, n. 2, pp. 151-176, nov. 2004a. 
A evolução recente do espaço financeiro no Brasil e alguns reflexos na cena política. DADOS - Revista de Ciências Sociais. Rio de Janeiro: v. 47, n. 1, 2004b.

Apagão Cognitivo: A Crise Energética e sua Sociologia. DADOS - Revista de Ciências Sociais. Rio de Janeiro, v. 48, n. 4, 2005.

A crise financeira, a guerra cultural e as transformações do espaço econômico brasileiro em 2009. DADOS - Revista de Ciências Sociais. Rio de Janeiro: v. 53, n. 2, pp. 255-297, 2010.

HARVEY, D. A Condição Pós-Moderna: uma pesquisa sobre as origens da mudança cultural. São Paulo: Loyola, 1992.

HELOANI, R.; FREITAS, M.E.; BARRETO, M.M.S. Assédio moral no trabalho. São Paulo: Cengage Leaning, 2008.

HELOANI, R. A dança da garrafa: assédio moral nas organizações. Revista GV Executivo. Especiais pressões e angústias no mundo corporativo, jan./jun., 2011.

HIPÓLITO, M.; REIS, G.G. A avaliação como instrumento de gestão. In: FLEURY, M.T.L. (Org.) As pessoas na organização. São Paulo: Editora Gente, 2002.

HIRATA, H. Da polarização das qualificações ao modelo de competências. In: FERRETTI, C.J. et al. (Orgs.) Novas tecnologias, trabalho e educação: um debate multidisciplinar. Petrópolis: Vozes, 1994.

HIRATA, H.; ZARIFIAN, P. Força e fragilidade do modelo japonês. Estudos avançados, São Paulo, v. 5, n. 12, pp. 173-185, ago. 1991. Disponível em: http://www.scielo.br/scielo.php?script=sci_arttext\&pid=S0103-

40141991000200011\&lng=en\&nrm=iso. Acesso em: abr. 2015.

HOBSBAWM, E. Era dos extremos: o breve século XX 1914-199, São Paulo: Companhia das Letras, 1995.

IBGE. Caderno Contas Nacionais n. 35: Contas Regionais do Brasil 2005-2009. Rio de Janeiro, 2011.

JINKINGS, N. O mister de fazer dinheiro: automatização e subjetividade no trabalho bancário. São Paulo: Sindicato dos Bancários de São Paulo/Boitempo, 1996.

Trabalho e resistência na "fonte misteriosa": os bancários no mundo da eletrônica e do dinheiro. Campinas: Editora Unicamp/Imprensa Oficial do Estado de São Paulo, 2002.

A reestruturação do trabalho nos bancos. In: ANTUNES, R. (Org.) Riqueza e miséria do trabalho no Brasil. São Paulo, Boitempo, 2006, pp. 189-205. 
As formas contemporâneas da exploração do trabalho nos bancos. In: ANTUNES, R. e SILVA, M.A. (Orgs.) O avesso do trabalho. São Paulo: Expressão popular, 2010.

KATZ, C. Pós-taylorismo. In: KATZ, C.; BRAGA, R.; COGGIOLA, O. Novas tecnologias: crítica da atual reestruturação produtiva. São Paulo: Xamã, 1995.

KAYO, E.K. et al. Ativos intangíveis, ciclo de vida e criação de valor. Rev. Adm. Contemp., Curitiba, v. 10, n. 3, pp. 73-90, set. 2006. Disponível em: http://www.scielo.br/scielo.php?script=sci_arttext\&pid=S1415$65552006000300005 \& \operatorname{lng}=e n \& n r m=i s o$. Acesso em: 18 out. 2015.

KREIN, J.D. O sistema de relações do trabalho no Brasil. In: Caderno Debate \& Reflexões.Escola Sindical São Paulo, n. 12, 2004.

Tendências recentes nas relações de emprego no Brasil: 1990-2005. Tese (Doutorado em Economia). UNICAMP - Instituto de Economia/Programa de PósGraduação em Desenvolvimento Econômico, Campinas, 2007.

LAHERA-SÁNCHEZ, A. Conquistando los corazones y las almas de lós trabajadores: El aseguramiento de la calidad total como nuevo dispositivo disciplinario. In: CASTILLO, J.J. El trabajo recobrado: una evaluación del trabajo realmente existente en España. Madrid-Buenos Aires, Miño y Dávila Editores, pp. 395-440, 2005. Disponível em: https://www.academia.edu/543215/Conquistando_los_corazones_y_las_almas_de_los_t rabajadores_La_participaci\%C3\%B3n_de_los_trabajadores_en_la_calidad_total_como_ nuevo_dispositivo_disciplinario Acesso em: mar. 2015.

LANCASTER, L.C.; STILLMAN, D. O Y da questão. São Paulo: Saraiva. 2011.

LAPYDA, I. A "financeirização" no capitalismo contemporâneo: uma discussão das teorias de François Chesnais e David Harvey. Dissertação (Mestrado em sociologia). FFLCH/Programa de Pós-Graduação em Sociologia - USP, São Paulo, 2011.

LARANGEIRA, S.M.G. Reestruturação produtiva no setor bancário e realidade nos anos 90. Educação e Sociedade, v. 18, n. 61, pp. 110-138, dez. 1997.

LEMOS, A.H. da C.; PINTO, M.C.S. Empregabilidade dos administradores: quais os perfis profissionais demandados pelas empresas? Cad. EBAPE.BR, Rio de Janeiro, v. 6, n. 4, pp. 01-15, dez. $2008 . \quad$ Disponível em: http://www.scielo.br/scielo.php?script=sci_arttext\&pid=S167939512008000400010\&lng=en\&nrm=iso. Acesso em: jul.2015. 
LIMA, J.C. Trabalho, família e mobilidade social: um estudo sobre sociabilidade operária Caderno CRH. Salvador: n. 24-25, pp. 123-153, jan./dez. 1996.

LODI, J.B.; LODI, E.P. Holding. São Paulo: Pioneira Thomson Learning, 2004.

LÓPEZ RUIZ, O.J. O "ethos" dos executivos das transnacionais e o espírito do capitalismo. Tese (Doutorado em Ciências Sociais) - Universidade Estadual de Campinas UNICAMP, Instituto de Filosofia e Ciências Humanas, 2004.

MAÇADA, A.C.G.; BECKER, J.L. O impacto da tecnologia de informação na estratégia dos bancos. RAE - Revista de Administração de Empresas/FGV-EAESP. out./dez. São Paulo: v. 41, n. 4, pp. 87-97, 2001.

MAENO, M. LER e transtornos psíquicos relacionados ao trabalho: faces de uma mesma moeda. In: SZNELWAR, L.I. (Org.) Saúde dos Bancários. São Paulo: Publisher/Editora Gráfica Atitude, 2011a.

Ser médico In: VIZZACCARO-AMARAL, A.L.; MOTA, D.P. e ALVES, G.

(Orgs.) Trabalho e saúde: a precarização do trabalho e a saúde do trabalhador no Século XXI.. São Paulo: LTr, 2011b.

Visão Abrangente: médica fala dos impactos da organização do trabalho nos adoecimentos. Entrevista. Revista Proteção, mar. 2013.

Por que conversamos ainda sobre LER/DORT? Mimeo, s.d.

MARTINS, J. S. O poder da imagem: o uso estratégico da imagem criando valor subjetivo para a marca. São Paulo: Intermeios, Comunicação e Marketing, 1992.

MARTINS, H.H.T. de S. Metodologia qualitativa de pesquisa. Educação e Pesquisa, São Paulo, v. 30, n. 2, pp. 289-300, mai./ago., 2004.

MARX, K. O Capital. Livro I. São Paulo: Nova Cultural, 1985.

MELLO E SILVA, L. Trabalho em grupo e sociabilidade privada. São Paulo: Editora 34, 2004.

MILLS, C.W. A nova classe média. Rio de Janeiro: Zahar Editores, 1969a.

MILLS, C.W. A imaginação sociológica. Rio de Janeiro: Zahar Editores, 1969b.

MILONE, M.C. de Mattos. Cálculo do valor de ativos intangíveis: uma metodologia alternativa para mensuração do valor de marcas. Tese (Doutorado) FEA USP, São Paulo, 2004.

MINELLA, A.C. Banqueiros: organização e poder político no Brasil. Rio de janeiro: Espaço e Tempo; São Paulo: ANPOCS, 1988. 
Construindo hegemonia: democracia e livre mercado (atuação do NED e do CIPE na América Latina). Caderno CRH. Salvador, v. 22, n. 55, pp. 13-40, jan./abr. 2009.

NOGUEIRA, A.J.F.M. Transformações e sentidos do trabalho no setor financeiro: uma contribuição aos estudos organizacionais críticos. Tese (Livre-Docência). São Paulo: Universidade de São Paulo, 2015.

OLIVEIRA, L.; VIEIRA, V.H. Nas tramas do discurso: sociabilidade comunicação cultura poder. Trabalho apresentado ao Grupo de Trabalho Comunicação e Sociabilidade do XXIII Encontro Anual da Compós, na Universidade Federal do Pará, Belém, de 27 a 30 de maio de 2014. Disponível em: www.compos.org.br. Acesso em: jul.2015.

OLIVEIRA, R.G. de. Terceirização e ação sindical no trabalho bancário: dilemas entre o discurso e a prática. Tese (Doutorado em sociologia). Rio de Janeiro: UFRJ/ IFCS/Programa de Pós-Graduação em Sociologia e Antropologia, 2014.

OSTRONOFF, L.J. Menos metas, Mais saúde: um estudo sobre o sindicato dos bancários de São Paulo. Tese (Doutorado em sociologia). Faculdade de Filosofia Letras e Ciências Humanas/Programa de Pós-Graduação em Sociologia USP, São Paulo, 2015. PAGÉS, M; BONETTI, M; GAULEJAC, V.; DESCENDRE, D. (Orgs.) O poder das organizações: a dominação das multinacionais sobre os indivíduos. São Paulo: Atlas, 1990.

PELAEZ, V.; SZMRECSÁNYI, T. Economia da inovação tecnológica. São Paulo: Hucitec, 2006.

PENELLA, I. LER: uma jornada de sofrimento no trabalho bancário. Dissertação (Mestrado em sociologia). São Paulo: Universidade de São Paulo, 2000.

POCHMANN, M. Proteção social na periferia do capitalismo: considerações sobre o Brasil. São Paulo em Perspectiva, vol. 18, n. 2, São Paulo, abr./jun. 2004.

QUEIROZ, M.I.P. Variações sobre a técnica de gravador no registro da informação viva. São Paulo: CERU/FFLCH/USP, 1983.

RAMALHO, J.R.; RODRIGUES, I.J. Trabalho, flexibilidade e terceirização: o caso da indústria automotiva. In: DAU, D.M.; RODRIGUES, I.J. e CONCEIÇÃO, J.J. da (Orgs.) Terceirização no Brasil. Do discurso da inovação à precarização do trabalho (atualização do debate e perspectivas). São Paulo: Annablume/CUT, 2009.

ROCHA, D.F. da. Estranhamento (Entfremdung) no trabalho: o Unibanco na virada dos anos 90. Dissertação (Mestrado em Sociologia). PUC: São Paulo, 2006. 
RODRIGUES, A.C. O emprego bancário no Brasil e a dinâmica setorial (1990 a 1997). Dissertação (Mestrado em Economia). PUC: São Paulo, 1999.

RODRIGUES, I.J. Comissão de fábrica e trabalhadores na indústria. São Paulo: Cortez; Rio de janeiro: FASE, 1990.

(Org.) Pesquisa Perfil do Bancário e as Condições de Trabalho no setor Financeiro na cidade de São Paulo. São Paulo: Centro de Pesquisa, 28 de Agosto, 2011.

RODRIGUES, I.J.; RODRIGUES, L.M. A greve dos nove dias (greve dos bancários de 1987) Relatório de Pesquisa, 1988.

RODRIGUES, L.C. Metáforas do Brasil: demissões voluntárias, crise e rupturas no Banco do Brasil. São Paulo: Annablume/Fapesp, 2004.

ROLO, D. Novas perspectivas sobre sofrimento ético no trabalho: o caso da mentira como prescrição. In: SZNELWAR, L.I (Org.) Saúde dos Bancários. São Paulo: Publisher/Editora Gráfica Atitude, 2011.

ROMANELLI, G. O provisório definitivo: trabalho e aspirações de bancários em São Paulo. Dissertação (Mestrado em antropologia). FFLCH/USP, São Paulo, 1978.

ROSENFIELD, C.L. A identidade no trabalho em call centers: a identidade provisória. In: Infoproletários: degradação real do trabalho virtual. ANTUNES, R.; BRAGA, R. (Orgs.) São Paulo: Boitempo, 2009.

SABOURIN, E. Teoria da reciprocidade e sócio-antropologia do desenvolvimento. Sociologias, Porto Alegre, v. 13, n. 27, pp. 24-51, ago. 2011. Disponível em: http://www.scielo.br/scielo.php?script=sci_arttext\&pid=S1517-

$45222011000200003 \& \operatorname{lng}=e n \& n r m=i s o>$. Acesso em: mai. 2015.

SALVADOR, L.; PAULO FILHO, O. Higidez física e mental - a efetividade das leis da infortunística como instrumento de dignificação do trabalhador: mens sana in corporesano. In: Trabalho e saúde: a precarização do trabalho e a saúde do trabalhador no Século XXI. VIZZACCARO-AMARAL,A.L.; MOTA, D.P.; ALVES,G. (Orgs.) São Paulo: LTr, 2011.

SANCHES, A.T. Terceirização e terceirizados no setor bancário: relações de emprego, condições de trabalho e ação sindical. Dissertação (Mestrado em sociologia). São Paulo: PUC, 2006.

Dimensões da difusão tecnológica no setor bancário, divisão do trabalho e ação sindical. Cadernos CERU/USP, vol. 23, n. 1, jun., 2012. Disponível em http://www.revistas.usp.br/ceru/index. Acesso em: jun. 2015. 
- Terceirização e ação sindical no setor bancário In: RAMALHO, J.R.; RODRIGUES, I.J. (Orgs.) Trabalho e ação sindical no Brasil Contemporâneo. São Paulo: Annablume, 2015.

SANDRONI, P. Novíssimo dicionário de economia. São Paulo: Best Seller, 1999.

SANTOS, A.L. dos. A geração Y nas organizações complexas: um estudo exploratório sobre a gestão de jovens nas empresas. Dissertação (Mestrado em Administração). USP, São Paulo, 2011.

SANTOS, M.A.F. Patologia da solidão: o suicídio de bancários no contexto da nova organização do trabalho. Dissertação (Mestrado em Administração). Brasília: UNB, 2009.

SANTOS, W.E.F. Entre a hegemonia e o despotismo: os programas de participação nos lucros ou resultados (PLR) no setor bancário. Dissertação (Mestrado em sociologia). FFLCH. USP, São Paulo, 2012.

SEEB-SP. O impacto da organização e do ambiente de trabalho bancário na saúde física e mental da categoria. Relatório Pesquisa. São Paulo: SEEB-SP, 2011.

Menos metas mais saúde. Cartilha. São Paulo: SEEB-SP, 2012.

SEEB-SP/DIEESE. Participação dos trabalhadores bancários nos Lucros $e$ Resultados: balanço e perspectivas (1995-2010). São Paulo: Sindicato dos Bancários de São Paulo, 2011.

SEEB-SP e IDEC. Venda responsável: de produtos e serviços financeiros. São Paulo, 2012.

SEGNINI, L. A liturgia do poder: trabalho e disciplina. São Paulo: Educ, 1988. Novas formas de relações empregatícias e qualificações requeridas em um contexto altamente informatizado: análise do sistema financeiro no Brasil. Projeto de pesquisa. Relatório I e II. Convênio CEDES/ UNICAMP, 1995/1997. Campinas, 1997. . Mulheres no trabalho bancário. São Paulo: Edusp/Fapesp: 1998.

- Reestruturação nos bancos no Brasil: desemprego, subcontratação e intensificação do trabalho. Educação e Sociedade, v. 20, n. 67, pp. 183-209, ago. 1999. SELIGMANN-SILVA, E. O assédio moral no trabalho. In: LIMA, C.Q.B.; OLIVEIRA, J.A.; MAENO, M. (Orgs.) Seminário Compreendendo o Assédio Moral no Ambiente de Trabalho: [anais]. Ministério do Trabalho e Emprego/FUNDACENTRO. São Paulo: Fundacentro - FUNDAÇÃO JORGE DUPRAT FIGUEIREDO DE SEGURANÇA E MEDICINA DO TRABALHO, 2013. Disponível em: http://www.fundacentro.gov.br. Acesso em: jul.2015. 
SENNETT, R. A corrosão do caráter - consequências pessoais do trabalho no novo capitalismo. Rio de Janeiro: Record, 2002.

A cultura do novo capitalismo. Rio de Janeiro: Record, 2011.

SHINYASHIKI, G. O processo de socialização organizacional. In: FLEURY, M.T.L. (Org.) As pessoas na organização. São Paulo: Editora Gente, 2002.

SOARES, A.; OLIVEIRA, J.A. Assédio moral no trabalho. Rev. Bras. Saúde Ocupacional. v. 37, n. 126, 2012, pp. 195-202. Disponível em: http://www.scielo.br/scielo.php?script=sci_arttext\&pid=S0303-

$76572012000200002 \& \operatorname{lng}=e n \& n r m=i s o$. Acesso em: nov. 2015.

SILVA JL; NAVARRO VL. Organização do trabalho e saúde de trabalhadores bancários. Rev. Latino-Am. Enfermagem. mar.-abr. 2012. Disponível em: http://rlae.eerp.usp.br/. Acesso em: ago. 2015.

SOARES, J.L. de O. Radiografia da Mobilização Bancária. Tese (Doutorado em sociologia). UFRJ/IFCS/Programa de Pós-Graduação em Sociologia e Antropologia, Rio de Janeiro, 2013.

SOBOLL, L.A. P. Assédio moral/organizacional: uma análise da organização do trabalho. São Paulo: Casa do Psicólogo, 2008.

SUPER, D.E. The psychology of careers: an introduction to vocational development. New York: Harper \& Brothers, 1957.

SZMRECSÁNYI, T. Keynes. São Paulo: Ática, 1984.

SZNELWAR, L.I. Prefácio. Saúde dos Bancários. São Paulo: Publisher/Editora Gráfica Atitude, 2011.

SZNELWAR, L.I.; PEREIRA, L. Trajetórias de trabalhadores bancários - entre o sonho e o real sofrimento patogênico. In: SZNELWAR, L.I (Org.) Saúde dos Bancários. São Paulo: Publisher/Editora Gráfica Atitude, 2011.

VARELLA, J.M. de C.; BORGES, L. de O. O processo de reestruturação produtiva nos bancos no século XXI, sob a ótica dos gerentes. In: Ser bancário: Viver o esplendor social ou o trabalho precário? Curitiba: CRV, 2012.

VASQUEZ, B.V.; CAVARZAN, G.M. Redução do emprego bancário no Brasil: ajuste conjuntural ou nova reestruturação produtiva? XIV Encontro Nacional da ABET. Campinas, 2015.

VENCO, S. B. Telemarketing nos bancos: o emprego que desemprega. Campinas: Editora da Unicamp, 2003. 
. Tempos moderníssimos nas engrenagens do telemarketing. Tese (Doutorado em educação) UNICAMP/Faculdade de Educação, Campinas, 2006.

. Centrais de Teleatividades: o surgimento dos colarinhos furta-cores? In: ANTUNES, R.; BRAGA, R. (Orgs.) Infoproletários: degradação real do trabalho virtual. São Paulo: Boitempo, 2009.

\section{Revistas:}

REVISTA BANCOA, 1995; abr. 2003; dez. 2006; mai. 2008; fev. 2009; mai. 2012; mar.; mai.; ago.2013; 2014; fev.; mar.; mai. 2015.

REVISTA CIAB. Febraban, 2014.

REVISTA EXAME, set. 2002; out. 2012 - Edição especial remuneração; fev. 2015.

REVISTA EXECUTIVOS FINANCEIROS, abr. 2013.

REVISTA FINANCEIRO, nov./dez. 2010.

REVISTA VOCÊ S.A., abr. 2011; 2013; jan./dez., 2014; jan./mar., 2015.

\section{Jornais:}

FOLHA BANCÁRIA, 2011; 2012; 2013; 2014; 2015.

JORNAL FOLHA DE S.PAULO, 28.11.11; Especial carreira. Jun., 2015.

JORNAL O ESTADO DE S. PAULO, 23.07.02; 23.09.02; 06.04.13; Caderno de economia e negócios, 24. 08.12; 16.03.14.

JORNAL CLARO! ECA USP; jul. 2011

\section{Documentos:}

Acordo coletivo Bancos, 2013.

Código de Ética Bancos.

Convenção Coletiva de Trabalho (Bancários), 2013-2014.

Declaração sobre a Venda Responsável de Produtos Financeiros-UNI, 2010.

Informativo Bimestral Banco $\Delta, 2008$.

Protocolo para prevenção de conflitos no ambiente de trabalho Banco $\Delta 2013$.

Relatórios Gerenciais BancoL, 2009; 2010; 2011; 2012; 2013; 2014. 
ANEXOS 


\begin{tabular}{|c|c|c|c|c|c|c|c|c|}
\hline \multicolumn{9}{|c|}{ Quadro 12 - Perfil dos Entrevistados } \\
\hline \multicolumn{9}{|c|}{ Bancários } \\
\hline SEXO & CARGO & IDADE & $\begin{array}{l}\text { TEMPO DE } \\
\text { BANCO }\end{array}$ & ESCOLARIDADE & CURSO & $\begin{array}{l}\text { ESTADO } \\
\text { CIVIL }\end{array}$ & FILHOS & $\begin{array}{l}\text { MORA COM } \\
\text { QUEM }\end{array}$ \\
\hline $\mathrm{F}$ & $\begin{array}{l}\text { Gestora regional } \\
\text { agências }\end{array}$ & 43 & 16 anos & $\begin{array}{l}\text { Superior completo pós- } \\
\text { graduação }\end{array}$ & Administração & Casada & 2 filhas & Marido e filhas \\
\hline M & Agente comercial & 29 & 7 anos & Superior completo & Administração & Casado & 2 filhos & Esposa e filhos \\
\hline $\mathrm{F}$ & Gerente de contas & 46 & 28 anos & Superior completo & Letras & Divorciada & 1 filho & Filho e sobrinha \\
\hline M & Gerente de contas & 25 & 4 anos & Superior completo & Administração & Solteiro & 0 filho & Sozinho \\
\hline $\mathrm{F}$ & Gestora agência & 35 & 16 anos & Pós-graduação & $\begin{array}{l}\text { Matemática. Pós em } \\
\text { Administração Financeira } \\
\text { e Controladoria }\end{array}$ & Solteira & 1 filho & Filho \\
\hline M & Analista Júnior & 42 & 12 anos & Superior incompleto & $\begin{array}{l}\text { Economia com ênfase em } \\
\text { comércio }\end{array}$ & Divorciado & 2 filhas & $\begin{array}{l}2 \text { filhas e } \\
\text { companheira }\end{array}$ \\
\hline $\mathrm{F}$ & Analista Sênior & 30 & 11 anos & Pós-graduação & $\begin{array}{l}\text { Letras. Pós em Ciências } \\
\text { Sociais }\end{array}$ & Solteira & 0 filho & Sozinha \\
\hline $\mathrm{M}$ & Gerente de contas & 32 & 10 anos & Superior completo & $\begin{array}{l}\text { Administração, História } \\
\text { (cursando) }\end{array}$ & Solteiro & 0 filho & Sozinho \\
\hline $\mathrm{F}$ & Analista Júnior & 57 & 12 anos & Superior completo & $\begin{array}{l}\text { Pedagogia e Psicologia da } \\
\text { Educação }\end{array}$ & Divorciada & 2 filhos & Sozinha \\
\hline
\end{tabular}




\begin{tabular}{|c|c|c|c|c|c|c|c|c|}
\hline $\mathrm{F}$ & Gerente de contas & 35 & 8 anos & Pós-graduação & $\begin{array}{l}\text { Publicidade e Propaganda. } \\
\text { Pós em Marketing }\end{array}$ & Solteira & 0 filho & Prima \\
\hline $\mathrm{M}$ & Analista Júnior & 29 & 4 anos & Superior completo & $\begin{array}{l}\text { Direito. Pós Especialista } \\
\text { em Relações } \\
\text { Internacionais, MBA FIA/ } \\
\text { USP - Gestão de } \\
\text { Negócios }\end{array}$ & Solteiro & 0 filho & Pai e mãe \\
\hline $\mathrm{M}$ & Estagiário & 23 & 5 meses & Superior incompleto & $\begin{array}{l}\text { Engenharia (Quinto ano } \\
\text { do instituto Mauá de } \\
\text { tecnologia) }\end{array}$ & Solteiro & 0 filho & Pai e mãe \\
\hline $\mathrm{F}$ & Estagiária & 19 & 1 ano & Superior incompleto & $\begin{array}{l}\text { Direito (Segundo ano da } \\
\text { faculdade de direito da } \\
\text { USP) }\end{array}$ & Solteira & 0 filho & Pai e mãe \\
\hline $\mathrm{M}$ & $\begin{array}{l}\text { Operador de } \\
\text { Teleatendimento }\end{array}$ & 24 & 3 anos & Superior incompleto & $\begin{array}{l}\text { Administração (Quinto } \\
\text { semestre) }\end{array}$ & Solteiro & 0 filho & Pai e mãe \\
\hline M & Coordenador* & 52 & 23 & Superior e pós & Contabilidade & Casado & 2 filhos & Esposa e filhos \\
\hline $\mathrm{M}$ & Gerente de área** & 48 & 22 & Superior e pós & Sem informações. & & & \\
\hline $\mathrm{F}$ & $\begin{array}{l}\text { Operadora de } \\
\text { Teleatendimento** }\end{array}$ & \multicolumn{7}{|c|}{ Sem informações } \\
\hline $\mathrm{M}$ & Analista Junior** & \multicolumn{7}{|c|}{ Sem informações } \\
\hline \multicolumn{9}{|c|}{ Consultores } \\
\hline $\mathrm{F}$ & $\begin{array}{l}02 \text { Consultoras } \\
\mathrm{RH}^{*}\end{array}$ & \multicolumn{7}{|c|}{ Empresa de Consultoria de RH Multinacional, prestadora de serviços para bancos. } \\
\hline $\mathrm{M}$ & 01 Consultor RH & \multicolumn{7}{|c|}{ Empresa de Consultoria de RH Nacional, prestadora de serviços para bancos. } \\
\hline
\end{tabular}




\section{Roteiro de entrevista com bancários}

Explicações sobre procedimentos:

O que visa a pesquisa, compromisso de sigilo, solicitação autorização para gravar, dar carta USP.

Idade:

Local nascimento:

Estado civil:

Quantidade de filhos:

Com quem mora:

Qual sua escolaridade?

Bancário desde quando?

Qual seu cargo no banco?

\section{TRANSFORMAÇÕES NA ORGANIZAÇÃO DO TRABALHO}

Quais são suas tarefas no cotidiano de trabalho dentro do banco?

Nos últimos anos houve mudanças com relação a cargos, funções e carreira no banco?

Favor descrever.

As mudanças tecnológicas alteraram sua rotina de trabalho (sistemas, equipamentos)?

O trabalho ficou mais fácil? Você trabalha menos?

Você acha que alguma etapa do seu trabalho pode ser automatizada?

Você considera que seu trabalho foi intensificado nos últimos anos? (aumentou volume e ritmo)

Quais formas de controle sobre seu trabalho que você identifica no seu dia a dia?

Você tem autonomia para realizar seu trabalho? Descreva.

Você cumpre sua jornada de trabalho?

Você realiza ou conhece alguém que realize trabalho remoto? (ou seja, fora do ambiente de trabalho propriamente dito) Como funciona?

O que você acha das metas colocadas para os trabalhadores no banco? As metas são atingíveis? Há pressão para cumprimento de metas?

Qual sua opinião sobre seu salário fixo, variável e demais direitos que você recebe como bancário?

Qual sua perspectiva com relação à carreira no banco?

Qual sua opinião sobre o sistema de avaliação que o banco faz?

Você conhece atividades que antes eram exercidas por bancários e passaram para terceirizados realizarem?

Como é a relação entre bancários e terceirizados que realizam atividades bancárias dentro do banco?

Qual é o tipo de perfil profissional exigido pelo banco nos dias atuais? (características físicas, técnica/escolaridade e comportamentais)

O que é preciso fazer para ser um bom bancário para o banco?

\section{ASPECTOS ORGANIZACIONAIS}

Você tem conhecimento de funcionários que atuam fora das regras ou do código de ética estipulado pelo banco? Como e por que isso acontece em sua opinião?

\section{SOCIABILIDADE NO TRABALHO}

Como você classifica o ambiente de trabalho (clima interno)?

Há trabalho em equipe? Funciona? É adequado?

Há pressão/competição entre colegas? Se sim, afeta as pessoas de algum modo? 
Você mantém uma boa relação com os colegas de trabalho? Em termos gerais como você classifica o banco para trabalhar?

O trabalho afeta a sua vida familiar? Sua convivência social?

O que você mais valoriza na sua condição de bancário?

Você se sente realizado trabalhando no banco? Você já pensou em sair do banco?

O que sua família e amigos pensam sobre seu trabalho?

SAÚDE E TRABALHO

Você já teve algum problema de saúde que pudesse ser relacionado ao trabalho?

Você toma medicamento de uso contínuo derivado de problemas no trabalho? Tem conhecimento de outra pessoa nesta situação?

Você acredita que muitos que apresentam problemas físicos ou psicológicos evitam procurar médico para não se expor diante do banco?

\section{ASPECTOS RELACIONADOS A GÊNERO}

Hoje o banco tem $58 \%$ de mulheres, por que você acha que é tão forte a presença feminina?

As mulheres conseguem ocupar os cargos mais altos no banco? Quais?

Você acha que as mulheres sofrem alguma discriminação no ambiente de trabalho?

Você considera que existe alguma desvantagem pelo fato de ser mulher e isso atrapalhe o deslanche da carreira delas dentro do banco quando comparada a situação dos homens?

Para você as mulheres e os homens têm igualmente as mesmas chances de construir carreira no banco?

\section{SENTIDO DO TRABALHO E VALORES}

Para você o que significa trabalhar no banco?

Quais os valores mais importantes em sua vida pessoal? Quais os valores mais importantes na sua vida profissional?

Muito Obrigada 


\section{Roteiro Entrevista - Consultores de RH}

Explicações sobre procedimentos:

O que visa a pesquisa, compromisso de sigilo, solicitação autorização para gravar, dar carta USP.

Você poderia comentar a frase: "A carreira não é mais um lugar onde se pode situar a experiência de uma vida inteira"?

Você percebe alguma mudança no perfil dos empregados exigido pelas corporações bancárias nos últimos anos? Se sim, isso se deve a que razões em sua opinião?

Qual o nível de escolaridade esperado? (Há preferência de faculdades de "primeira linha". Qual seria?)

Qual qualificação técnica é esperada?

Quais as características comportamentais mais requeridas?

O profissional que trabalha nas corporações bancárias precisa suportar pressão? O que significa ser resiliente no ambiente corporativo?

Características pessoais como idade, sexo, raça ou outro quesito tem algum peso?

O ambiente de trabalho marcado pela meritocracia em sua opinião interfere no trabalho em equipe?

O que você pensa da noção de "superação constante" como um atributo necessário para se manter empregado?

Ter comprometimento com a empresa ou estar alinhado com os interesses da empresa pode significar em algum momento negligenciar a vida pessoal? Não ter horário de trabalho definido? Colocando sempre que preciso a saúde, os amigos e até a família em segundo plano?

Muito Obrigada 